

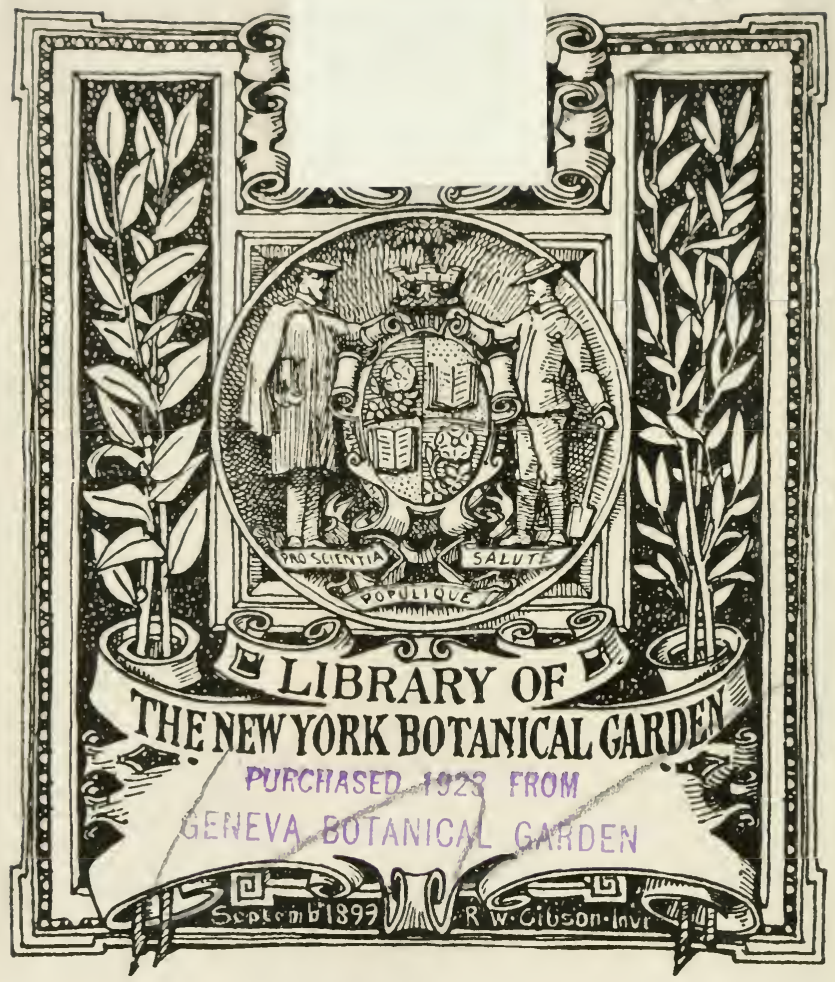




$$
F 282
$$





\section{FLORA OF JAMAICA}

VOL. I.

ORCHIDS OF JAMAICA 



\section{FLORA OF JAMAICA}

CONTAINING DESGRIPTIONS OF THE FLOWERING PLANTS KNOWN FROM THE, ISLAND

BY

WILLIAM FAWCETT, B.Sc., F.L.S.

Formerly Assistant, Department of Botaxy, British Museum

(Natural History)

Late Director of Public Gardens axd Plantations, Jamaica,

A.ND

ALFRED BARTON RENDLE, M.A., D.Sc., F.R.S., F.L.S.

Keeper of the Department of Botany, British Museum •

(Natural History)

WITH ILLUSTRATIONS

VOL. I.

ORCHIDACEA

WITH THIRTY-TWO PLATES AIT? $49 \mathrm{P}$

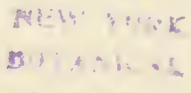

LONDON :

PRINTED BI ORDER OF THE TRUSTEES OF THE BRITISH MUSEUMI

$A N D$ SOLD BY

Longmans \& Co., 39, Paternoster Row, E.C.; B. Quaritch, i i, Graftox Street, New Bond Street, W. ; Dulau \& Čo., Ltd., 37, Soho Square, IV.; and at the

British Migeum (Natural History), Cromwell Road, S. W.

$$
\text { I } 9 \text { IO }
$$

(All rights reserved) 


$$
\begin{aligned}
& .58 \\
& v 1 . \\
& c .3
\end{aligned}
$$

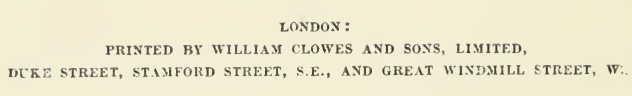




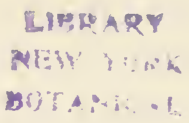

\section{P R E F A C E}

$(1+\cdots,=$

DurIsg his residence in Jamaica for twenty-one years as Director of Public Gardens and Plantations, Mr. William Fawcett gave attention to the botanical exploration of the Island. He was specially interested in the Orchids, and, with the assistance of Mr. William Harris, Superintendent of the Gardens and an excellent collector, a very fine collection illustrating the family was got together. A beautiful series of drawings from the living plants was also made under Mr. Fawcett's direction by Miss Helen Wood. During one of Mr. Fawcett's visits to England we agreed to collaborate in a monograph of the Jamaican Orchids, and in 1904 an account of the genus Lepanthes was published in the Transactions of the Linnean Society. The work, however, proceeded slowly until 1908, when Mr. Fawcett retired and came to England. The permission of the Trustees having been obtained for the publication of the work as a British Museum Catalogue, Mr. Fawcett was fortunately able to devote himself to the task, and I have given what time I could spare in the intervals of other work. Though Mr. Fawcett has done the larger part of the work of preparation, we have both been carefully through each species. Our work has been greatly facilitated by the loan of the Jamaican Herbarium, for which we are much indebted to the Government of Jamaica.

As Mr. Fawcett is able to continue his work at the Museum, it is proposed that the present volume shall form the first part of a complete "Flora of Jamaica."

\section{A. B. RENDLE.}

Departient of Botany,

British Migseum (Natural History), Cromwell Road, Lomdox, S.IV.

October, 1910. 



\section{INTRODUCTION}

Tre Island of Jamaica, the largest of the British West Indian Islands, is 144 miles long and 30 to 40 miles broad. It lies about 90 miles south of Cuba, and about 380 miles N.E. of Honduras, the nearest part of the mainland.

"Jamaica is remarkable for the limited area in which very many species are found, and for the wonderful contrasts in neighbouring districts in geological structure and soil, in elevation, in rainfall and in temperature.

"The Blue Mountains in the eastern end of the island attain the highest elevations, rising to $\tau, 423$ feet. The distance from the ridge to the coast on the north and south in a straight line is about 20 miles. On the Blue Mountains and north to the coast the north-east trade winds bring almost constant rain throughout the year, the rainfall varying from 150 to 200 inches annually. From the ridge to the south coast the rainfall decreases, and as the Blue Mountains run not directly west but inclined towards the north-west, and as the prevailing winds are from the north-east, the result is a decrease in the rainfall in travelling along the coast from Morant Point to Kingston; thus from Morant Point to Morant Bay there is a rainfall from 70 to 55 inches annually, then a belt 50 to 40 inches, and then for a considerable distance to Kingston and beyond, 35 to 30 inches. The slopes of the mountains are frequently precipitous, and there may be great differences in elevation, in moisture and temperature within short distances. For instance, one may pass from the southern slopes of the John Crow Peak of the Blue Mountains at about 5,500 feet, where xerophytic conditions sometimes occur and often cold nights with tempera ture down to $50^{\circ} \mathrm{F}$., round the shoulder to the north, and straight down 2000 feet to the Mabess River, where there is almost constant rain, continual moisture from a perennial stream, and a warm temperature at nights. The geological structure of 
the district eonsists chiefly of brittle shale, easily decomposing, with occasional masses of coral limestone, marble, granite, dee, interspersed.

"There is a range of mountains elose to the east ond, rumning in a northerly and southerly direction, and rising to an elevation of 2,100 feet. The coast in the neighhourhood is locky, and continues so for some distance to the west of Port Antonio. These mountains, known as the John Crow Mountains or Blake Mountains, are so wet, and the limestone rock is so difficult to travel over, that it is believed only one white man has ever crossed them. Nathaniel Wilson may have collected on the slopes of these mountains on the east side, or on the southerly slopes, some of the species that have not been found since. The limestone roek of these mountains occurs over the greater part of Jamaica, and in large districts it has disintegrated so as to form, as in the John Crow Mountains, such a series of precipitous cliffs that it is impossible to travel through it. The so-called 'Cockpit country' is of this nature, and it is in such places that new species of plants may naturally be looked for." (W. F. in Urban, Symbolie Antillane, vi. 86.)

The Orchids of Jamaica are of special interest from the large number of endemic forms which they include. The total number of genera is 61 , one of which, Homalopetalum, is endemic. The total number of species is 194 , of which 73 are confined to the Island. There are also some endemic varieties.

The most striking affinity of the Orchid flora is with that of Cuba, 82 species, out of a total of 121 , which are not endemic, occurring also in that island, and of these 14 are restricted to the two islands. The affinity with Hispaniola is apparently not so marked, there being only 29 species known from both islands, of which two, Epidendrum repens and Broughtonia domingensis, occur nowhere else. The difference is due no doubt to some extent to our greater knowledge of the botany of Cuba as compared with that of Hispaniola. With the much better explored island of Porto Rico, which lies further east beyond Hispaniola, the atfinity is apparently greater, there being 40 species common to Jamaica and this island, four of which are known elsewhere only in Cuba. Ten species are common to Jamaica and the Bahamas, and 15 to Jamaica and Florida, the relation of which to the West Indies is very close. Passing 
further east and south from Porto Rico, 38 species are common to Jamaica and one or more of the Lesser Antilles. Forty species occur both in Jamaica and Trinidad, of which nine are not recorded from the Lesser Antilles, but six of these are known from Cuba, and three from Cuba and Porto Rico. Epidendrum mutans has a somewhat remarkable distribution, being known only from Trinidad, Venezuela and Brazil, in addition to Jamaica.

The relationship with Central America is well marked; 3 species are common to Jamaica and some part of Central America, and if we include Mexico the number is raised to 44 . Of these 28 are also found in equatorial south America, of which sixteen represent an element widely distributed over the West Indian and tropical American area. Of the sixteen which do not occur in equatorial South America, four are confined to Jamaica and Central America and ten to Central America (with Mexico), Jamaica and Cuba.

The affinity with equatorial South America is also strongly marked, 48 species being known to occur in some portion of tropical South America and Jamaica. A number of these also represent a widely distributed tropical American element occurring more or less generally in the West Indies and Central America, some few being also known from Florida and the Bahamas. If we consider Trinidad as part of equatorial South America, six of these forty-eight species occur nowhere else in the IT est Indies except in Jamaica. These comprise three species of Epidendrum - E. verrucosum, known also only from Columbia, $E$. nutans from Trinidad, Venezuela and Brazil, and $\boldsymbol{E}$. imbricatum from Central America and Brazil - and Brassarola nodosa, Maxillaria rufescens and Cryptarrhena lunata from Central America and more or less widely distributed in equatorial South America.

These six species which do not otherwise occur in the West Indies, together with the Central American group already refer'ed to, probably represent an element of the Jamaican flora associated with two former extensions of the land surface between Cuba and Yucatan, and Jamaica and Honduras. The seabottom between Jamaica and Honduras comes within the 6000 fathom limit and contains large banks within the 600 fathom limit. If we include Jamaican species which occur also in the Greater Antilles, there are twenty-four common to these and 
equatorial south America which are not foland in the Lesser Antilles and may also be assoriated with the extensions of land already referred to. A south-eastern line of association with equatorial south America through Hispaniola and Porto Rico is: without doubt represented by the series of the Lesser Intilles and Trinidad: as we have mentioned above thirty-cight Jamaican species occur in the Lesser Antilles and forty in Trinidarl.

These facts of distribution are in accord with reological. evidence of a former linking up of Central America and Venezucla hy means of the line of the $\mathrm{IV}^{\mathrm{e}}$ est Indies.

. "The Antilles are formed by the summits of a mountain chain which separates the Caribbean sea from the Atlantic Ocean and the Gulf of Mexico. A second arc running from Honduras through Jamaica and the south-west of Haiti appears to join the principal chain. Even the great deeps which oceur in certain places, as, for instance, between Virgin Gorda and Anguilla, do not inter'upt the continuous course of the mountain chain."

"With the slopes of the Mexican plateau in the State of Oaxaca, says Seebach, the compact northern continent terminates. 'To the south and to the east of the isthmus of Tehuantepec,. Central America commences, which already belongs to the island world of the Antilles. "The mountain series of the Greater Antilles, which further to the east in Porto Pico and San Domingo-the eastern part of Haiti-forms a single main chain, divides in the middle of the latter island, giving rise to a southern branch which proceeds through the elongated peninsula of Jacmel towards Jamaica and Honduras, and a northern branch. which extends beyond Cuba towards Yucatan . . . Is it merely a remarkable accident that the Sierra Maestra, consisting of crystalline schists and massive rocks and situated in the southeast of Cuba (where the Greater Antilles reach their greatest elevation of 2,338 meters above the sea), should run through the Cayman group, the bank of Misteriosa, the Viciosas, and Swan Island to the depths of the gulf of Honduras, and that from the edge of this mountain ridges similarly constituted should rise abruptly and proceed with constant strike into the interior.'" -(Suess, "The Face of the Earth," Engl. Transl. i. 543.)

Our knowledge of the flora of Jamaica starts with the work of Sir Hans Sloane, who collected in the Island during a stay. 
of fifteen months in the years 1687-89, and published the results in his work on the Natural History of Jamaica (1707-25). s'loane's Jamaican plants occupy Vols. I. to VIII. of the S'loane Herbarium at the British Museum, and these volumes have been carefully gone through in connection with our work on the Orchids. The herbarium of Sir Joseph Banks, which became at his death the foundation of the Department of Botany, included collections from Jamaica by William Houstoun (1729-33), William Wright (1771-85), Poger Shakespear (1780-2), and Francis Masson (1781), and also a large number of specimens from Olof Swartz (1784-6), including types of many of the new species published in his "Prodromus" and elsewhere. Besides these and the later collections at the British Museum we have worked through the material in the Kew Herbarium, which includes the collections of James Macfadyen (1825-50), W. Purdie (1843, 4), Nathaniel Wilson (1846-58), R. C. Alexander Prior (1849, 50), W. T. March (185j, 8), and others.

We have to thank the Government of Jamaica for the loan of the whole of the material contained in the Jamaican Herbarium, the formation of which was begun by Sir Daniel Morris (1879-86) and was continued by one of us (1887-1908) with the very efficient help of Mr. William Harris as collector. In this connection special reference should be made to Mr. Harris's work as an indefatigable and successful plant-collector, to which is owed a considerable increase in knowledge of the flora of Jamaica. Our work has been greatly facilitated by the use of a fine series of drawings made at the Hope Gardens, Jamaica, from the living plants, under the supervision of one of us, by Miss Helen A. Wood; many of these have been reproduced in the plates at the end of the volume, for the large number of which we are grateful to the Trustees of the British Museum. We have also to thank Dr. N. L. Britton, Director of the New York Botanic Garden, for specimens and for the loan of a collection of Orchids made in Jamaica by Sir D. Morris. A number of private individuals resident in or visiting the Island have also contributed specimens; most of these are contained in the Jamaican Herbarium. By the kindness of Dr. Radlkofer of the Royal Botanical Museum, Munich, we have been able to work through the Orchids collected by H. R. Wullschlaegel (1847-9). As Wullschlaegel's specimens are cited by Grisebach 
in the "Flora of the British West Tndies", it has heen of interest to revise his determinations by comparison with the original collection. Prof. Tgnatius Urban of Berlin has generously entrusted to us the volume of Siwartz's "Fones Ineditie," and has allowed us to cite the drawings. During the preparation of our work Prof. Urban has given a detailed account of the botanical exploration of Jamaica since the publication of Grisebach's "Flora" in his "Symbola Antillane" (vi., pp. 70-131, 1909). To Prof. Cogniaux, who is elaborating the Orchids of the West Indies for the "Symbolre," we are indebted for the loan of specimens and helpful information.

Our descriptions of the genera have been drawn up with special reference to the species which occur in Jamaica. For measurements we have used the metric system, but for convenience of tourists we have added English measures for the height of the plant and the size of the flower. The figure below renders possible a ready comparison of the two systems, e.g. $2 \cdot 5 \mathrm{~cm}$. are equivalent to an inch, $2 \mathrm{~mm}$. to $\frac{1}{12}$ inch, and $1 \mathrm{dm}$. to about 4 inches.

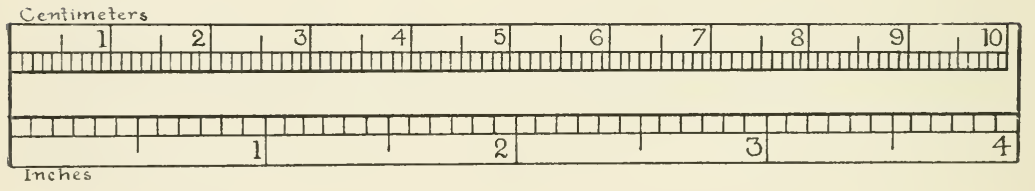

The J.P. (Jamaican Plants) numbers cited are those given by Sir D. Morris to the species in the Jamaican Herbarium; the numbers cited as Fl. Jam. (Flora Jamaicensis) are those attached to specimens, as collected, later.

The mark " !" indicates that we have seen a specimen.

In order to conform to the international rule, which requires that diagnoses of new species shall be published in Latin, descriptions of novelties have been inserted in the "Journal of Botany," and are quoted here from that work.

W. FAWCETT.

A. B. RENDLE. 


\section{LIST OF PLATES}

Plate 1. 1, Habenaria macroceratitis ; 2, 3, H. distans var. jamaicensis ; 4-7, H. alata ; 8-10, H. monorrhiza ; 11, Pogonia macrophylla.

Plate 2. 1-3, Habenaria Purdiei ; 4-7, H. socialis ; 8-12, H. troyana; 13-15, Pogonia gentianoides ; 16, Vanilla inodora ; 17, V. Wrightii ; 18, 19, V. claviculata ; 20, V. phæantha ; 21, 22, Pelexia setacea.

Plate 3. 1-5, Spiranthes tortilis; 6-9, S. Fawcettii; 10-14, S. elata ; 15, Erythrodes plantaginea; 16-19, E. hirtella; 20, E. jamaicensis ; 21, Stenorrhyncos squamulosus; 22, S. lanceolatus; 23, 24, Wullschlægelia aphylla.

Plate 4. Pseudocentrum minus.

Plate 5. 1-3, Cranichis pilosa; 4, Prescottia oligantha; 5, 6, Stenoptera ananassocomos ; 7-11, Ponthieva Harrisii ; 12, 13, P. pauciflora; 14, Corymborchis flava; 15 , Tropidia polystachya.

Plate 6. 1-5, Liparis Harrisii ; 6-10, L. Saundersiana ; 11-17, Malaxis integra ; 18-23, M. Grisebachiana.

Plate 7. 1-3, Galeandra Beyrichii ; 4, 5, Polystachya minuta; 6, 7, P. minor; 8-10, Cryptophoranthus atropurpureus; 11-14, Stelis ophioglossoides; $15-28$, S. micrantha.

Plate 8. 1-6, Pleurothallis trilobata; 7-10, P. brachypetala; 11-16, P. rotundifolia; 17-22, P. velaticaulis.

Plate 9. 1-4, Pleurothallis Morrisii; 5-7, P. confusa; 8, P. Wilsonii; 9-14, P. Helenæ ; 15-19, P. hirsutula.

Plate 10. Pleurothallis uncinata.

Plate 11. 1-7, Lepanthes arcuata; 8-11, L. Harrisii; 12-17, L. Woodiana; 18-21, L. elliptica ; 22, 23, L. brevipetala.

Plate 12. Brachionidium Sherringii.

Plate 13. 1-7, Cœlia triptera ; 8-13, Isochilus linearis.

Plate 14. 1-3, Seraphyta diffusa ; 4-9, Arpophyllum giganteum; 10-14, Broughtonia sanguinea; $15-19, \mathrm{~B}$. domingensis.

Plate 15. 1, Epidendrum angustilobum; 2, E. nocturnum ; 3, E. difforme ; 4, E. serrulatum ; 5, E. nutans ; 6, E. bifarium; 7, E. rivulare ; 8, E. Ottonis ; 9, E. imbricatum; 10, E. anceps ; 11, E. verrucosum; 12, E. ramosum.

Plate 16. 1-4, Epidendrum monticolum; 5-7, E. parvilobum; 8-10, E. belvederense.

Plate 17. 1-5, Hormidium tripterum ; 6-12, Lælia monophylla; 13-16, Octadesmia montana.

Plate 18. 1-6, Homalopetalum vomeriforme; 7-10, Tetramicra parviflora. 
Plate 19. 1-6, Schomburgkia Lyonsii ; 7-11, Brassavola cordata.

Plate 20. 1-7, Ellcanthus capitatus; 8-12, E. longibracteatus; 13-17, Phaius Tancarvillere; 18-22, Calanthe mexicana.

Plate 21. 1-7, Bletia purpurea; 8-11, B. florida.

Plate 22. 1-3, Govenia utriculata ; 4-8, Eulophia alta.

Plate 23. 1-3, Lycaste Barringtonix ; 4-7, Xylobium palmifolium ; 8-14, Bulbophyllum jamaicense ; 15, 16, B. pachyrrhachis; 17-19, Zygopetalum flabclliforme.

Plate 24. Neo-urbania adendrobium.

Plate 25. 1-6, Maxillaria alba; 7-12, M. sessilis; 13-16, M. rufesecns ; 17-19, M. rufescens var. minor.

Plate 26. 1-4, Ornithidium vestitum; 5-7, O. prolifcrum.

Plate 27. 1-3, Ionopsis satyrioides ; 4-6, I. utricularioides ; 7-10, Macradenia lutescens.

Plate 28. 1-6, Brassia maculata; 7-9, B. caudata ; 10-15, Comparettia falcata.

Plate 29. 1-3, Trichopilia jamaicensis ; 4-8, Oncidium pulchellum; $9-11$, O. luridum ; $12-17$, O. triquetrum; $18-21$, O. guttatum ; 22-25, O. sphacelatum.

Plate 30. 1-5, Leochilus labiatus; 6, 7, Cryptarrhena lunata; 8-12, Dichæa graminoides; $13-16$, D. glauca ; 17-21, D. trichocarpa ; $22-25$, D. muricata ; 26-30, D. echinocarpa ; 31-36, D. Morrisii.

Plate 31. 1-4, Campylocentrum Sullivanii ; 5-8, C. minus; 9-15, C. Barrettiæ ; 16-21, Harrisella porrecta.

Plate 32. 1-7, Dendrophylax funalis. 


\section{WORKS REFERRED TO IN THE TEXT}

(Where no date is given the work is in progress)

Ait. Hort. Kew.-Hortus Kewensis, ed. 2. W. T. Aiton. London. 1810-13. Ames Orch.-Orchidaceæ, Illustrations and Studies of the Family. Oakes Ames. Boston and New York.

Ames Orch. S. Fla. - Contribution... Orchid Flora of S. Florida. O. Ames. Cambridge, Mass. 1904.

Andrews Bot. Rep.-Botanists Repository. H. C. Andrews. London. $1797-1816$.

Ann. \& Mag. Nat. Hist.-Annals and Magazine of Natural History. London.

Ann. Sc. Nat.-Annales des Sciences Naturelles. Paris.

Aubl. Pl. Guian.-Histoire des Plantes de la Guiane Française. J. B. C. F. Aublet. London and Paris. 1775.

Bateman Orch. Mex. \& Guat.-The Orchidaceæ of Mexico and Guatemala. J. Bateman. London. 1837-43.

Bauer Ill. Orch.-Illustrations of Orchidaceous Plants. F. A. Bauer. London. 1830-38.

Beitr. Orch. Centr. Amer.-Beiträge zu einer Orchideenkunde Central Amerikas. H. G. Reichenbach fil. Hamburg. 1866.

Benth. \& Hook. f. Gen. Pl.-Genera Plantarum. G. Bentham and J. D. Hooker. 1862-83.

Ber. Deutsch. Bot. Ges.-Berichte der Deutschen Botanischen Gesellschaft. Berlin.

Bijdr. Flor. Ned. Ind.-Bijdragen tot de Flora van Nederlandsch Indië, K. L. Blume. Batavia. 1825-26.

Biol. Centr. Amer. Bot.-Biologia Centrali-Americana. F. D. Godman and O. Salvin. London. Botany by IV. B. Hemsley. 1879-88.

Bonpl.-Bonplandia. Ed. by W. E. G. Seemann and B. Seemann. Hanover. 1853-62.

Bot. Mag.-Botanical Magazine. Ed. by W. Curtis and others. London.

Bot. Reg.-The Botanical Register. London. 1815-47.

Bot. Zeit.-Botanische Zeitung. Berlin and Leipzig.

Browne Hist. Jam. - Civil and Natural History of Jamaica. P. Browne. London. 1756.

Bull. Sc. Acad. Pétersb.-Bulletin scientifique publié par l'Académie Impérial des Sciences de St. Pétersbourg. St. Petersburg. 1836-40.

Catesby Nat. Hist. Carol.-Natural History of Carolina, \&c. MI. Catesby. London. 1731-43.

Comp. Bot. Mag.-Companion to the Botanical Magazine. IV.J. Hooker. London. 1835-37.

Duperr. Voy. Coq. Bot.-L. I. Duperrey. Voyage autour du Monde sur La Coquille, 1822-25. Botanique par A. T. Brongniart. Paris. 1829.

Engl. \& Prantl Nat. Pflanzenf.-Die natürlichen Pflanzenfamilien. H. G. A. Engler and K. A. E. Prantl. Leipzig. Orchids by E. Pfitzer, (ii. pt. 6. 1889). 
Fawe. Fl. Pl. Jam.-List of the Flowering Plants of Jamaica. W. Fawcett. Kingston. 1893.

Fedde Repert.- Repertorium novarum specierum regni vegetabilis. F. Fedde. Berlin.

Fl. Bras.-Flora Brasiliensis. K. F. P. von Martius and A. W. Eichler, completed by I. Urban. Munich. 1340-1906.

Fl. Cub.-Flora cubana, \&c. R. de La Sagra. P'hanerogans by A. Richard. Paris. 1853.

Fl. Cub. Ic.-Icones plantarum in Flora Cuhana. R. de La Sagra. Phanerogams by A. Richard. Paris. 1863.

Flora-Flora. Regensburg.

Gard. Chron.-Gardeners' Chronicle. London.

Gard. Mag. Bot.-Gardeners' Magazine of Botany. 'T. Moore and W. P. Ayres. London. 1850-52.

Griseb. Cat. Cub.-Catalogus Plantarum Cubensium. A. H. R. Grisebach. Leipzig. 1866.

Griseb. Fl. Br. W. Ind.-Flora of the British West Indian Islands. A. H. R. Grisebach. London. 1859-64.

H. B. \& K. Nov. Gen. \& Sp.-Nova genera et species plantarum. Humboldt, Bonpland and Kunth. Paris. 1815-25.

Hamburg Gartenz.--Hamiurger Garten und Blumenzeitung. Hamburg.

Herb. Sloane-Sloane's Herbarium in the Department of Botany, British Museum.

Herm. Parad.-Paradisus Batavus. P. Hermannus. Ed. W. Sherard. Leyden. 1698.

Hook. Exot. Fl.-Exotic Flora. W. J. Hooker. London. 1823-27.

Hook Ic. Pl.-Icones Plantarum. W. J. Hooker and others. London.

Hook. Journ. Bot.-Journal of Botany. W. J. Hooker. 1834-42.

Ic. Fl. Germ.-Icones Floræ Germanicæ et Helveticæ. H. G. L. Reichenbach and others. Leipzig. Orchids by H. G. Reichenbach fil. xiii \& xiv, $(1850,1)$.

Jacq. Collect.-Collectanea. N. J. von Jacquin. Vienna. 1786-96.

Jacq. Enum. Pl. Carib.-Enumeratio Plantarum, quas in Insulis Caribæis, etc., detexit N. J. von Jacquin. Leyden. 1760.

Jacq. Ic. Pl. Rar.-Icones Plantarum rariorum. N. J. von Jacquin. Vienna. 1781-93.

Jacq. Sel. Stirp. Amer.-Selectarum Stirpium Americanarum Historia. N. J. von Jacquin. Mannheim. 1763. Ed. pict.-Edition with coloured plates. 1788 .

Journ. Bot.-Journal of Botany. J. Britten. London.

Journ. Linn. Soc.-Journal of the Linnean Society of London.

Kew Bulletin-Bulletin of Miscellaneous Information, Royal Botanic Gardens, Kew. London.

Kuntze Rev. Gen. Pl.-Revisio Generum Plantarum. C. E. O. Kuntze. Leipzig. 1891-8.

L. Sp. Pl.-Species Plantarum. C. Linnæus. Stockholm. 1753.

L. Syst.-Systema Naturæ. C. Linnæus. (Ed. 10. Stockholm. 1759.)

Lam. Encycl. Méth.-Encyclopédie Méthodique. Paris, \&c. Botany by J. B. Lamarck and others. 1789-1817.

L'Hérit. Sert. Angl.-Sertum Anglicum. C. L. L'Héritier. Paris. 1788-92.

Lindenia-Lindenia. Gand.

Lindl. Coll. Bot.-Collectanea Botanica. J. Lindley. London. 1821.

Lindl. Fol. Orch.-Folia Orchidacea. J. Lindley. London. 1852-59. 
Lindl. Gen. \& Sp. Orch.-Genera and Species of Orchidaceous Plants. J. Lindley. London. 1830-40.

Lindl. Orch. Scel.-Orchidearum Sceletos. T. Lindley. London. 1826. Linnæa-Linnæa. Berlin. 1826-82.

Llave \& Lex. Nov. Veg. Descr.-Novorum Vegetabilium Descriptiones. P. de La Llave and J. Lexarza. Mexico. 1824-25.

Lodd. Bot. Cab.-Botanical Cabinet. C. Loddiges. London. 1817-33.

Lour. Fl. Cochinch.-Flora Cochinchinensis. J. Loureiro. Lisbon. 1790.

Mém. Mus. Par.-Mémoires du Muséum d'Histoire Naturelle. Paris. 1815-32.

Mém. Soc. Phys. \& Hist. Nat. Genève.-Mémoires de la Société de Physique et d'Histoire Naturelle de Genève. Geneva. 1821-76.

Merian Pl. Ind.--Recueil des Plantes des Indes. MI. S. Merian. Paris. 1768.

Miller Gard. Dict.-Gardeners Dictionary. P. IHiller. (Ed. 8. London. 1768.)

Mus. Bot. Lugd.-Bat.-Museum Botanicum Lugduno-Batavum. K. L. Blume. Leyden. 1849-56.

Nederl. Kruidk. Arch.-Nederlandsch Kruidkundig Archief. Leyden and Amsterdam.

Nov. Act. Upsal.-Nova Acta Regiæ Societatis Scientiarum Upsaliensis. Upsala.

Nutt. Gen. Amer.-Genera of North American Plants. T. Nuttall. Philadelphia. 1818.

Orch. Rev.-Orchid Review. London.

Paxt. Fl. Gard.-Paxton's Flower Garden. J. Lindley and J. Paxton. London. 1850-84.

Pl. Hartw.-Plantæ Hartwegianæ. G. Bentham. London. 1839-57.

Pluk. Alm.-Almagestum Botanicum. L. Plukenet. London. 1696.

Plum. Cat.-Catalogus Plantarum Americanarum. C. Plumier. Paris. 1703.

Plum. Ic. ined.-Plumier's original drawings in the Department of Botany, British Museum.

Plum. Nov. Pl. Amer. Gen.-Nova Plantarum Americanarum Genera. C. Plumier. Paris, 1703.

Plum. Pl. Amer. (Burm.).-Plantarum Americanarum. C. Plumier. Ed.J. Burmann. Amsterdam. 1755-60.

Poepp. \& Endl. Nov. Gen. \& Spec.-Nova genera ac species plantarum. E. F. Poeppig and S. L. Endlicher. Leipzig. 1835-45.

Proc. Biol. Soc. Wash.- Proceedings of the Biological Society of Washington. Washington, D.C.

Redouté Liliacées-Les Liliacées, peintes par P. J. Redouté. Text by A. P. De Candolle and others. Paris. 1802-16.

Reichb. Fl. Exot.-Flora Exotica. H. G. L. Reichenbach. Leipzig $1834-6$.

Rep. Miss. Bot. Gard.-Report of the Missouri Botanical Garden. St. Louis.

Salisb. Ic. ined.-R. A. Salisbury's original Drawings and Mss. in bound volumes in the Department of Botany, British IIuseum.

Salisb. Prodr.--Prodromus stirpium in horto ad Chapel Allerton vigentium. R. A. Salisbury. London. 1796.

Saund. Ref. Bot.-Refugium Botanicum. W. W. Saunders. London. 1869-73.

Schrad. Journ.-Journal für die Botanik. H. A. Schrader. Gottingen. 1799-1803. 
Schum. \& lauterb. Nachtr. Fl. Deutsch. Sïdsee.-Nachtriige zur Flora der Dentschen Schutzgebiete in der Südsee. K. Schumann if $k$. Lauterbach. Leipzig. 1905.

Sert. Bot.-Sertum Botanicum. P. C. van Géel. Brusscls. 1828-36.

Sloane Cat.-Catalogus plantarum quae in Insula Jamaica sponte proveniunt....H. sloane. London. 1696.

Sloane Hist.- Toyage to... Jamaica, with the Natural History. Hans Sloane. London. 1707-25.

Sm. Ic. Pict.-Icones picta plantarum rariorum. J. E. Smith. London. 1790-93.

Small Fl. S. E. Un. St.-Flora of the South Eastern United States. J. K. Small. New York. 1903.

Smith Spicil.-Spicilegium botanicum. J. E. Smith. London. 179192.

Spreng. Syst.-Systema Vegetabilium. C. Linnæus. Ed. 16, C. spresgel. Gottingen. 1825-8.

Steud. Nom.-Nomenclator botanicus. E. G. Steudel. Ed. 2. Stuttgart and Tübingen. $1840-41$.

Sw. Adnot. Bot.-Adnotationes Botanicæ. O. Swartz. Ed. by J. E. Wikström. Stockholm. 1829.

Sw. Fl. Ind. Occ.-Flora Indiæ Occidentalis. O. Swartz. Erlangen. $1797-1806$

Sw. Icon. ined.-Descriptiones et Icones Plantarum incognitarum quas in India occidentali detexit atque delineavit O. Swartz. Lent by Prof. I. Urban. Berlin.

Sw. Obs. Bot.-Observationes Botanicæ. O. Swartz. Erlangen. 1791.

Sw. Prodr.-Nova Genera et Species Plantarum. O. Swartz. Stockholm. 1788.

Symb. Ant.-Symbolæ Antillanæ. I. Urban. Berlin. Orchids by A. Cogniaux.

Trans. Linn. Soc.-Transactions of the Linnean Society of London.

Vet. Handl. Stockh.-Kongl. Vetenskaps Academiens nya Handlingar. Stockholm.

Walp. Ann.-Aunales Botanices systematicæ. W. G. Walpers and others. Leipzig. 1848-68. Orchids by H. G. Reichenbach fil.

Willd.Sp. Pl.--Species Plantarum. C. Linnæus. Ed. 5. C. L. Willdenow. Berlin. 1797-1810.

Williams Orch. Alb.-The Orchid Album. R. Warner, B. S. Williams and others. London. 1882-96.

Xen. Orch.-Xenia Orchidacea. H. G. Reichenbach fil. Continued by F. Kraenzlin. Leipzig. 1858-1900. 
NAMES OF THE MORE IMPORTANT COLLECTORS AND CONTRIBUTORS WITH DATE OF COLLECTION

Baxcroft, E. N. 1811-42.

Barrett, Miss T. Moulton, $1887-$

Bertero, C. 1821.

Blake, Sir Henry and Lady, 1887-97.

Brittox, Dr. N. L. and Mrs. $1906-$

Browne, P. 1746-55.

Canpbell, E. 1894-6.

CraDWick, W. 1888-

Distin, H. 1830-40.

EgGers, H. vor. 1888.

FawCETt, W. 1887-1908.

Gosset, Miss B. 1909-

Harris, W. 1881-

HART, J. H. 1880-6.

Нiтснсоск, A. S. $1890-$

Houstoun, W. 1729-33.

JeNhax, G. S. 1873-9.

Loxgstaff, Dr. and Mrs. 1907.

Macfaydex, J. 1825-50.

March, W. T. $1857,8$.
Massox, F. 1781-

MCNAB， G. 1838-59.

Moore, A. 1883-

Morris, Sir Daniel. 1879-86.

Nicholds, C. N. 1891.

Nichols, G. E. 1903, 6.

Prior, R. C. Alexander, $1849,50$.

Purdie, W. 1843, 4.

Shakespear, R. 1780-2.

Slodne, Sir Hans. 168 i-9.

Suluivan, C. 1883-90.

Swartz, O. $1784,5,6$.

Sуме, G. 1879-84.

Thoupson, W. J. 1889-

Thomson, R. 1862-79.

Tomlinson, R. K. 1900-

WATERS, J. about 1826-30.

WАTT, D. E. $1890-$

WILES, J. 1793-1805.

Wilson, N. 1846-58.

Wright, W. 1771-7, 1782-5.

Wullschlategel, H. R. 1847-9. 



\section{ORCHIDS OF JAMAICA}

OrCHIDs are perennial herbs showing much variety in their habit. They are either terrestrial, growing in the soil, or more or less epiphytic, that is, growing on stems or branches of trees, on rocks, etc., often surrounded by a dense growth of moss. In the simplest form of growth, the stem continually produces new leaves at the apex, while the flowering shoots spring from the axils of older leaves. This method, known as the monopodial, occurs in some epiphytic orchids, as in Dichæa, where the internodes and leaves are both very short. In all terrestrial orchids and many epiphytic, growth of the main axis soon ceases, usually at the end of one season, while a lateral shoot continues the growth next season. The apparent main axis of the plant is then a sympodium, consisting of the basal scale-bearing portions of successive shoots, the upper parts of which are aërial and leafy. The shoots may end in an inflorescence, or flowers are borne on special lateral branches. The development of the sympodial rhizome governs the habit of the plant. If the basal portion of the yearly shoot is short, the successive aërial shoots are crowded and the habit is bushy or clustered, whereas if the basal portions are lengthened a creeping or climbing habit results.

In terrestrial orchids the basal portions of the annual shoots form a thin or fleshy root-bearing rhizome (as in Spiranthes), or a tuber is produced each year (as in Habenaria, Bletia). The aërial stem is slender, bearing one to many foliage-leaves and ending in a single flower or an inflorescence. The leaves are inserted along the stem (cauline) or are clustered at the base (radical).

The majority of epiphytic sympodial forms are pseudobulbous; that is, the stem is thickened to serve as a reservoir of food and water. The pseudobulb consists of only one internode and bears one or more leaves at its apex, or of several internodes and bears leaves throughout its length, or bears scales at the lower nodes and a terminal tuft of leaves. The 
pseudobulb is of very various shapes, sometimes globose, usually more or less clongated; its surface is generally smooth and shiny. In Pleurothallis and allied genera the shoots are not thickened to form a pseudobulb, and bear a single leaf which spreads at right angles to the axis or apparently forms il continuation of it.

The leaves are simple, generally sessile, and wither and recay on the stem, or, as in most epiphytic species, separate by a distinct joint. The margin is entire and the apex often denticulate or unequally cut; the venation is as a rule parallel. In some cases the blacle passes gradually into a stalk which has generally a sheathing base.

At the basal nodes of the shoots leaf-scales are borne, which pass gradually into foliage leaves, or the latter may start abruptly. 'The leaves are generally arranged in two ranks, one each side of the stem.

Leaves of epiphytic forms are generally thick and fleshy; and by a thick cuticle they are adapted for storage of water. A main root is never present; its place is taken by adrentitious roots which arise especially from the nodes and often show as regular an arrangement as the leaves. In terrestrial orchids the roots are sometimes thickened to form stores of reserve material. The air-roots of epiphytic orchids have a special development of the outer layers forming a sponge-like tissue (velamen), by which water is absorbed for the plant from the atmosphere. Three kinds of air-roots may be distinguished. Clinging roots which creep close to the substratum and are inseparable from it; absorptive roots, or branches of the former which grow into the humus which collects about the plant; and the fine aërial roots which hang down sometimes to a considerable length.

The flowers are hermaphrodite and irregular. The perianth consists of an outer whorl of three sepals and an inner whorl of three petals which alternate with the sepals. The odd or median sepal is normally on the lower side of the flower and furthest from the axis. The odd petal, which generally differs considerably in size and shape from the two lateral petals and is termed the lip, is normally on the upper side of the flower next the axis. This position is, however, generally reversed by a twist of the ovary so that the lip in the open flower is on the lower side. The sepals are usually smaller and less conspicuous than the petals, but in some genera (as Pleurothallis, Lepanthes and Brassia) they are much larger. They are free from each other or more or less coherent; in some genera, as Pelexia and Stenorrhyncos, the lateral sepals are united at the base to form a spur which in Pelexia encloses the elongated base of the lip. The petals show a great variety in form and colour; the lateral pair are generally smaller than the lip. The lip which is, as a 
rule, the most conspicuous feature of the flower, is often large and spreading, or has upwardly curving sides. It is simple (undivided) or two- three- or four-lobed and generally bears on the upper face thickened veins or swellings (calli), or fleshy warts, which are often, as in Oncidium, large and conspicuous. The lip is sometimes produced at the base into a sac or spur, which may arise partly from the axis of the flower.

The most characteristic feature of the flower is the development of the receptacle, which at an early stage becomes cup-shaped, and finally forms a hollow cylinder. The carpels (three in number) arise as outgrowths from the edge of the cup, on the interior of which the ovules are developed on three double placental lines alternating with the carpellary outgrowths. The perianth springs from the upper edge of the inferior ovary, where there is often also an expansion of the axis known as the foot. The lateral sepals are continued along the sides of the foot, from the tip of which the lip springs at a sharp angle, forming externally a chin, inside which at the base nectar is often secreted.

The stamens and stigmatic surfaces are raised above the perianth on an elongation of the floral axis known as the column; occasionally some of the other organs are raised up on the column, as in Ponthieva, where the petals and lip are carried up above the sepals. Comparative study of the orchid flowers among themselves, and especially with those of other families of Monocotyledons, suggests that the stamens are derived from two alternating whorls, each of three members, the members of the outer whorl alternating with the petals. The stamens are, however, much reduced, and are represented in the great majority of orchids by one anther, which is variously placed on or near the apex of the column, and represents the median stamen of the outer whorl, opposite the median sepal. There is generally no trace of the other members of this whorl, but they sometimes appear as small outgrowths on the side of the column; and the lateral pair of the inner whorl is also often similarly represented ; in Epidendrum Ottonis they are more or less fertile. The presence of a single fertile stamen characterises the great majority of the genera; in the genus Cypripedium, not found in Jamaica, the lateral stamens of the inner whorl are fertile, while the median stamen of the outer whorl is represented by a large staminode.

Cypripedium has three functional stigmas; but in Jamaican orchids only the lateral pair are functional, the third is sterile and forms the rostellum, which often plays an important part in transference of the pollen. The stigmas form a smooth, viscid, flat or cushion-like area on the inner face, or sometimes on the end of the column, or two distinct processes which in Habenaria are borne on projecting style-like structures. 
The form of the anther, its position on the column and the means by which the pollen is transferred, vary widely in the different genera. The anther contains two, four, or eight cells, each of which contains a mass of pollen. The pollen masses or pollinia are granular or powrlery, breaking up into grains on removal, as in Poyonia, Spirantles, Tanilla, ete.; or the grains are united into packets by an elastic web as in Habenuria; or waxy pollinia are produced by the formation of a strong common covering round each mass as in Epidendrum and allied genera.

The anther may stand erect and free on the top of the column, as in Habenaria where it is strongly united to the rostellum by its base, and does not separate from the column when the pollinia are removed. Usually, however, the anther is attached to the rostellum by its apex. In this case it may be erect and stand behind the stigma in such a way that the rostellum reaches its apex, as in Stenorrliyncos, and the filament is generally thin but strong enough to hold the anther in place after removal of the pollen. In most cases, however, the anther is not erect, but is placed horizontally or hangs on the inner face of the column; it usually separates so easily from the thin filament that it falls when the pollen is removed. It lies along the rostellum or is more or less enclosed within a special cavity of it (clinandrium), or is in contact with it only at the apex.

The removal of the pollinia is generally effected by the help of insects, which visit the flower for the sake of a sweet juice contained in the sac or spur-like development or in the various excrescences of the lip. Insects are attracted by the colour, form and smell of the flower, the lip of which often forms an effective landing-stage. The pollinia and stigma are so placed in reference to the position assumed by the insect as to favour the carrying off of the pollinia from one flower and its deposition upon the stigma of another of the same species.

To ensure its transference the pollinia are often attached to a stalk, which is associated with a sticky mass, the so-called "gland." Thus in Habenaria each anther-cell is procluced into a long process (anther-canal), the contents of which form stalks (caudicles), to which are attached above the numerous packets of grains forming the pollinia. Below, the caudicle is attached to a gland formed from the rostellum. The anthers split open longitudinally when mature, and the pollinia are drawn out by the adhesion of the gland to the head or proboscis of an insect visiting the flower. In other genera no definite gland is produced from the rostellum, but a quantity of viscid matter exudes from it when touched, and serves to glue the protruding tips of the caudicles to the retreating object. In many genera the pollinia are connected to the rostellar gland by a stalk (stipes or pedicel), which is not a development of the anther, but of the 
upper face of the rostellum (as in Maxillaria). In some cases short true caudicles are formed, by which the pollinia are attached to the pedicels.

The ovary is generally somewhat cylindrical-ellipsoidal or spindle-shaped, and often bears longitudinal lines, ridges, or wings, which become further developed in the fruit.

The fruit is a dry capsule, except in Vanilla, crowned by the withered remains of the flower, and opening usually by six longitudinal slits, forming three broad and three narrow valves, which remain united above and below; in Harrisella they are free above. In Pleurothallis there are only two slits. In Vanilla the fruit is fleshy and pod-like. The seeds are innumerable and minute, and contain a small rudimentary few-celled embryo enveloped by a thin loose membranous coat, which varies much in shape and colour. They are scattered by aid of hygroscopic hairs on the interior of the valves, and are carried by the wind.

The family falls into two groups, a small one, Diandræ, not represented in Jamaica, with two or rarely three fertile stamens, and a large one, Monandræ, with one fertile stamen.

The subdivision of the Monandræ was based by John Lindley (The Genera and Species of Orchidaceous Plants, 1840) solely on characters derived from the anther, the pollen, or the pollendistributing apparatus. Lindley recognised six tribes. E. Pfitzer, who more recently elaborated the family in Engler and Prantl's Pfanzenfamilien (ii. part 6, 1889), criticises this arrangement, which was practically followed by Bentham and Hooker in the Genera Plantarum (iii. 1883), as depending too much on the relation of the floral structure to insect visits for the purpose of pollination, and too little on a general study of the whole plant. He retains the Ophrydeæ which are characterised by the persistent terminal erect anther (to which belongs Habenaria), but subdivides the remainder into twenty-eight tribes, based on the terminal or lateral chatacter of the inflorescence, the development of the leaf and stem, and the form and relative size of the lip. We have followed the sequence of genera in Pfitzer's ar'rangement. 


\section{KEY TO GENERA.}

\section{Terrestrial Plants (growing in soll).}

Anther-cells distant, diverging, with the stalks of the pollinia in special tubes and each ending in a naked gland ................................ 1. Habenaria.

Anther-cells closely approximate.

i. Leaves membranous, not plaited. Pollinia granular (i.e. breaking up into granules on removal), 2 or 4 .

Anther deciduous, opercular, on the margin of the clinandrium. Pollinia 2. Leaves along the stem or wanting................2. Pogonia.

Anther persistent, parallel to the back of the long rostellum. Pollinia 2 or 4 . Leaves generally radical.

a. Lip on the lower side of the flower.

Lateral sepals combined into a spur.

Spur enclosing the elongated base

of the lip............................... 4. Pelexia.

Spur not enclosing base of lip.

Bracts coloured.................... 5. Stenorrhyncos.

Lateral sepals free.

Lip not spurred ....................6. Spiranthes.

Lip spurred ........................ 7. Erythrodes.

b. Lip on the upper side of the flower.

Lateral sepals forming a spur.

Spur short. Leaves wanting ..... 8. Wullschlegelia.

Spur very long. Leaves present... 9. Pseudocentrum.

Lateral sepals not forming a spur.

Lip inserted at base of column, free 10. Cranichis.

Lip inserted on the cup formed by the base of the sepals, which have grown together ..................... 12. Prescottia.

Lip and petals inserted on the long column ............................ 13. Ponthicva.

ii. Leaves membranous, not plaited. Pollinia waxy (not breaking up into granules), 4.

Column long, curved. Anther terminal, opercular, incumbent, deciduous ........ 17. Liparis.

Column short, erect. Anther enclosed by the clinandrium, persistent

16. Malaxis.

iii. Leaves papery, plaited.

Flowers small, in terminal and axillary panicles. Pollinia 2, granular.

Sepals cohering into a tube. Lip linear from base. Column long ............. 14. Corymborchis.

Sepals, lateral connate into a short chin.

Lip saccate at base. Column short... 15. Tropidia.

Flowers large, racemose on a scape. Pollinia 4 or 8 , waxy.

Pollinia 8.

[Lip continuous with base of column, spurred. Flowers white and brown... 39. Phaius.] 
Lip jointed with base of column, not spurred. Flowers purple or rose ..... 41. Bletia.

Claw of lip connate with column, forming a tube, spurred. Flowers white

40. Calanthe.

Pollinia 4.

Lip produced into a wide spur

18. Galeandra.

Lip forming a chin between the lateral sepals. Flowers greenish, with purple lip...................................

Lateral sepals forming a chin. Flowers white

42. Eulophia.

43. Govenia.

iv. Leaves fleshy, linear, semi-terete. Flowers small, pink; lip 3-lobed 36. Tetramicra.

II. Climbixg Plants with fleshy Frutt .............................. 3. Vanilla.

\section{Plants growixg ox Trees, Rocks or Stores, NOT IN THE SOIL.}

(Sometimes it may be difficult to decide whether a plant should be included under I. or III., as it may be growing amongst moss on rocky ground and apparently terrestrial, but unless it is actually growing in soil, it should be classed amongst the epiphytic orchids.)

i. Leaves plaited.

Pollinia 8.

Raceme from base of pseudobulb. Orary 3-winged. Pseusobulbs present ........ 27. Calia.

Flowers with large bracts in terminal heads or spikes. No pseudobulbs ..... 38. Elleanthus.

Pollinia 4.

Peduncles several, with one flower on each.

Flowers greenish. Pseudobults present 44. Lycaste.

Flowers whitish, with a blue variegated

lip. No pseudobulbs .................. 46. Zygopetalum.

Raceme with several flowers. Pseudobulbs 45. Xylobium.

ii. Leaves not plaited.

Lip on upper side of flower (see also some species of Epidendrum and Oncidium).

Plant very small. Flowers in head with large bracts ...........................

Plant not very small. Flowers in panicles,

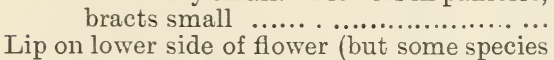

11. Stenoptera.

19. Polystachya. of Epidendrum and Oncidium have lip on upper side).

A. Pollinia 4.

a. Column with foot, with which the sepals more or less form a chin.

1. Lip free, jointed to foot of column.

Flowers small, several, on stalk from base of pseudobulb 
Flowers large, solitary, axillary to large leaves. With or without pseudobulbs 48. Maxillaria.

Flowers small, solitary, axillary to small two-ranked leaves. No pseudobulb.... 59. Dichcea.

Flowers small, in clusters, axillary in sheaths of large leaves. No pseudobulbs ... 49. Neo-urbania.

2. Lip not jointed to foot of column; erect.

Stem covered with imbricated sheaths in two ranks, with pseudobulbs here and there

Stem bearing short linear leaves in two ranks; no pseudobulbs

50. Ornithidium.

25. Isochilus.

b. Column without foot.

Claw of lip as long as column, with which it is connate into a cup. No pseudobulbs. Pollinia connected in pairs by a viscous substance which stretches elastically into two threads

28. Seraphyta.

Claw of lip shorter than column, with which it is connate into a cup. Pseudobulbs present. Pollinia connected by a viscous substance...................

Claw of lip erect, adpressed to column, and more or less connate with it into a tube, but sometimes quite free. Peduncle terminal, simple or branching. With or without pseudobulbs. Pollinia connected in pairs by a granularviscous linear appendage ...... Lip free from column, and embracing it at base, produced below into an adnate spur. Pseudobulbs present ............ Lip free from the column and continuous with its base, spreading, claw long and keeled - crested above. No

pseudobulb ......................
Lip free, subsessile, somewhat similar to sepals and petals ... 37. Homalopetalum.

B. Pollinia 8.

Without pseudobulbs.

Flowers numerous, mauve, in a long dense spike .................... 29. Arpophyllum.

Flowers greenish or whitish-yellow, corymbose ......................... 35. Brassavola.

Flowers creamy-white, racemose ... 26. Octadesmia. 
Flowers few, orange-coloured, racemose 33. Lelia.

With pseudobulbs.

Flowers purple-spotted, several, racemose .......................... 34. Schomburgkia.

c. Pollinia 6.

Sepals, petals and lip with long, tailed apices

24. Brachionidium.

D. Pollinia 2.

a. Without pseudobulbs.

1. Stem with one leaf at the apex.

Flowers opening only by a chink at the side............. 20. Cryptophoranthus.

Flowers opening normally.

Petals and lip free, much alike, and spreading ...... 21. Stelis.

Petals free, differing from the lip. Lip jointed with column .......................

Claw of petals and lip aanate to base of column .......... 23. Lepanthes.

2. Stem with two or more leaves or leafless.

Flowers with a short spur.

Lip longer than sepals; sepals forming the spur... 52. Ionopsis.

Lip not longer than the sepals; lip forming the spur.

Flowers numerous, on spikes. Capsule dehiscing in middle. Sometimes leafless ... 60. Campylocentrum.

Flowers few, on racemes. Capsule dehiscing from apex. Leafless ........ 61. Harrisella.

Flowers with a very long spur.

Stemless and leafless ....... 62. Dendrophylax.

b. With pseudobulbs.

Flowers not spurred ............ 56. Oncidium.

Flowers spurred

Flowers not spurred.

53. Comparettia.

Lip with large lateral lobes, em-

bracing the column.

51. Macradenia.

Lip more or less entire.

Flowers large, sepals long, narrow .................... 55. Brassic.

Flowers small.

Scape shorter than leaves ... 54. Trichomlia. Scape longer than leaves..... 57. Leochilus. 


\section{HABENARIA Willd.}

Terrestrial herls, with tubers or fleshy roots. Stem erect, simple, with a few leaves which are sheathing at their base. Flowers shortly stalked, in a raceme. Sepals unequal, free; median hooded; lateral spreading or deflexed. Petals smaller, 2-partite, or simple. Lip continuous with the column, spreading or pendulous, spurred, 3-partite, or simple. Column very short, without a foot; stigma produced into two papillose processes; anther-cells distant from one another; pollinia in each cell granular, with long stalks lying in the anther-canals and each ending in a naked gland. Capsule narrowly ellipsoidal.

There are about 500 known species, natives mainly of the warmer regions of both hemispheres.

$\S 1$. Petals 2-partite; lip 3-partite.

Stem leafy upwards.

Spur much longer than ovary

Spur not much longer, or shorter, than ovary.

Stem erect, with short roots 2. H. monorrhiza.

Stem creeping at base, with long roots 3. H. repens.

Stem leafy at base only

4. H. distans.

§2. Petals entire; lip simple.

Spur much longer than ovary

Spur not much longer, or shorter, than ovary.

Sepals and petals acute

5. H. Purdiei.

Sepals and petals obtuse.

Spur tapering towards apex 6. H. alata.

Spur thickened towards apex...

7. H. socialis.

8. H. troyana.

\section{$\S 1 . \quad$ Petals 2-partite; lip 3-partite.}

1. H. macroceratitis Willd. Sp. Pl. iv. 44 (1805); leaves reticulately many-nerved, oval to elliptical-oblong; spike fewflowered; spur much longer than ovary, curved.-Griseb. Fl. Br. W. Ind. 643 ; Cogn. in Symb. Ant. vi. 299 ; Ames Orch. iv. 222. H. macroceras Spreng. Syst. iii. 692 (1826); Hook. in Bot. Mag. t. 2947 ; Lindl. Gen. \& Sp. Orch. 308. Orchis habenaria L.* Syst. ed. 10, 1242 (1759) \& Herb. Linn. ; Sw. Obs. Bot, 319, t. 9. (Pl. 1, f. 1.)

On stony ground; in fl. Oct.-Jan.; Shakespear! Swartz! Bancroft! Waters! Alligator Pond, Purdie! Fairfield, Wullschlaegel, 1050! Mo:eague, Prior! March! Lady Blake! Red Hills, J.P. 467, Morris! Stony Hill, J.P. 2410, Syme! near Browns Town, Miss T. M. Barrett! Lacovia,

* The species name is generally spelt with a capital initial, Habenaria being the name of a genus. Linnæus, however, did not take the trivial name from a generic name, as Habenaria was founded much later by Willdenow (1805). As therefore the species name is not taken from a generic name (see International Rules of Botanical Nomenclature (1905) Rec. $\mathrm{x}$ ) it should begin with a small letter as in Linnæus's original description. 
Tomlinson! Red Hills, $800 \mathrm{ft}$; near Hope Mines, $800 \mathrm{ft}$; Long MIt., $900 \mathrm{ft}$. Harris! St. Ann, Miss Stennett! Fl. Jam. 6901, 7789, 9106, 10,404, 10,415, 10,416.-Cuba, Florida, Mexico, Guatemala, Costa Rica, B. Guiana, Surinam.

Plant 1-21 ft. high. Stem leafy, 2-5 dm. $1 ., 7 \mathrm{~mm}$. br. Leaves oval below ; elliptical-oblong in middle, $10-12 \cdot 5 \mathrm{~cm}$. $1 ., 2 \cdot 5-3 \cdot 5 \mathrm{~cm}$. br. ; ovateacuminate above. Racemes $10-15 \mathrm{~cm}$. 1., numerous-fld. Bracts oratelanceolate, acuminate, as long as the ovary, $3 \cdot 5-4 \cdot 5 \mathrm{~cm} .1 ., 1 \cdot 3 \mathrm{~cm}$. br. Flowers greenish-white. Sepals, median ovate-suborbicular, very obtuse, $1.5 \mathrm{~cm}$. 1., lateral ovate, obtuse, $1.6 \mathrm{~cm}$. 1. Petals, posterior segment oblong-falcate, acute to sub-acute, $1 \cdot 3 \mathrm{~cm}$. $1 ., 3 \mathrm{~mm}$. br., anterior linearsetaceous, curving upwards, $3.5 \mathrm{~cm}$. l. Lip 3-partite nearly to base, middle lobe linear-lingulate, ac. te, barely $2 \mathrm{~cm}$. l., about $2 \mathrm{~mm}$. br., lateral linear-setaceous, curved-spreading, $4 \mathrm{~cm}$. 1. Spur pendulous, curved, filiform, slightly clavate, apex acute $10 \mathrm{~cm} .1$. and more. Stigmatic processes short, obtuse; anther-canals longer, curved upwards.

2. H. monorrhiza Reichb. f. in Ber. Deutsch. Bot. Ges. iii. 274 (1885) ; leaves 3-nerved, lanceolate to orate-lanceolate; sheaths marked with purple spots and lines; lip with lateral lobes erect, longer than sepals.-Ames op. cit. it. 229. H. brachyceratitis Willd. op. cit. 44. H. brachyceras Spreng. op. cit. 692. H. maculosa Lindl. op. cit. 309 ; Griseb. op. cit. 643; Cogn. op. cit. 304. Orchis monorihiza Sw. Prodr. 118 (1788) \& Fl. Ind. Occ. 1391. (Pl. 1, f. 8-10.)

On damp clayey shady banks; in fl. Nov.-April; Swartz; Macfadyen! Hagley Gap, Purdie! Wilson! IIt. Diabolo, Prior! Fairfield, Wullschlaegel, 1049! March; MIt. Airy, J.P. 2052, Syme, and "common" Morris! Port Antonio \& Blue Mt. Peak, Hitchcock; Browns Town, Miss T. M. Barrett ! Cinchona, $5000 \mathrm{ft}$. ; Silver Hill Gap ; near Castleton ; Fawcett! Westphalia, 4000 ft.; Cinchona; Wallenford, 3500 ft. ; Harris! Fl. Jam. 7525, 7771, 7884, 10,407, 10,500 (partly).-Cuba, Porto Rico, St. Thomas, Guadeloupe, Dominica, Martinique, St. Lucia, St. Vincent, Grenada, Trinidad, Guatemala, Colombia, Ecuador, Peru, Venezuela, Brazil.

Plant to $2 \mathrm{ft}$. high. Stem leafy, $2 \cdot 5-5 \mathrm{dm}$. 1., to about $6 \mathrm{~mm}$. br. Leaves 4-8 cm. 1., 2-3 cm. br. Raceme 10-13 cm. 1., densely-fld. Bracts ovate-lanceolate, acute or shortly acuminate, about as long as the ovary, $1 \cdot 2-2 \cdot 2 \mathrm{~cm} .1 ., 4-5 \mathrm{~mm}$. br. Pedicels very short. Flowers white. Sepals reticulate-5-nerved, nerves prominent outside: median ovate or ovatesuborbicular, very obtuse, keeled, 7-8 mm. 1., 4-5.5 mm. br.; lateral ovate, obtuse, apiculate, $7-8 \mathrm{~mm}$. 1., 3-4 $\mathrm{mm}$. br. Petals posterior segments narrowly oblong, tapering to base and apex, apiculate, 2-3nerved, connivent or spreading, 6.5-7.5 mm. $1 ., 1 \cdot 8-2 \cdot 5 \mathrm{~mm}$. br. ; anterior segment linear, acuminate, generally about $4 \mathrm{~mm}$. l., erect, sometimes reduced to a short, descending process, about $1 \mathrm{~mm}$. l. Lip, lobes subequal ; middle lobe linear-ligulate, $7-8 \mathrm{~mm}$. 1., 1-2 mm. br. ; lateral filiform, 8-9 mm. 1., barely $5 \mathrm{~mm}$. br. Spur pendulous or curved anteriorly, filiform, apex acute, $1 \cdot 5-2 \mathrm{~cm}$. 1. Stigmatic processes short, fleshy; anther-canals much longer, ascending; rostellum small, triangular.

Cogniaux regards $O$. monorrhiza Sw. as distinct from $H$. maculosa Lindl. and identical with $H$. alata Hook., and describes the lip as undivided. Swartz, however, says "labio tripartito" Prodr. \& "Labium ad basin fere tripartitum" Flor., in which $H$. maculosa agrees, but $H$. alata differs.

3. H. repens Nutt. Gen. Amer. ii. 190 (1818); stem creeping at base; leaves 3-nerved, oblong-lanceolate; lip with lateral lobes pendulous, shorter than sepals.-Lindl. op. cit. 310 ; 
Rolfe in Hoets. In. Pl. t. 2686; Cogn. op. cit. 305; Ames Orch. i. 51, t. 14 \& iv. 216. H. tricuspis A. Rich. Fl. Cul. iii. 249 (1853).

In wet places; St. Ann, McNab! Worthy Park, I'rior!-Cuba, Porto Rico, Florida, Georgia, Carolina, Alabama, Louisiana, Guatemala, Nicaragua, B. Guiana, Vonezuela, Brazil.

Plant $\frac{1}{2}-2 \frac{1}{2} \mathrm{ft}$. high. Stem without tubers, $1 \cdot 5-7 \cdot 5 \mathrm{dm}$. I Leaves 1-3 dm. 1., -7 -2 om. br. Raceme $5-20 \mathrm{~cm}$. 1., dense, many-fld. Bracts linear-lanceolate, acuminate, lowest longer than flower, upper shorter than ovary, to $1 \cdot 5 \mathrm{~cm}$. 1. Pedicels 4-6 mm. 1. Flowers erect, yellowishgreen. Sepals, median broadly ovate, apiculate, $5 \mathrm{~mm}$. 1.; lateral ovate, apiculate, nearly $6 \mathrm{~mm}$. 1. Petals $4 \mathrm{~mm}$. 1., posterior segment falcate, lanceolate, acute; anterior segment linear-filiform, acute, about as long as the posterior. Lip 4-5 $\mathrm{mm}$. 1., lobes sub-equal, linear-filiform, median broader than lateral. Spur incurved, linear, $9 \mathrm{~mm}$. 1. Stigmatic processes oblong, thickish; anther-canals short, directed forwards. Capsule $10 \mathrm{~mm} .1$.

4. H. distans Griseb. Cat. Cub. 270 (1866); steam leafy at base only; leaves reticulate-many-nerved, broadly oblong or lanceolate, acute.-Cogn. op. cit. 300 ; Ames op. cit. 202.

On damp shady banks; in fl. Dec.; Moody's Gap, 3000 ft., Harris! Fl. Jam. 7768.-Cuba, Porto Rico, Florida.

Plant 8-16 in. high. Stem 2-4 dm. Leaves $8-16 \mathrm{~cm} .1 ., 2 \cdot 5-5 \mathrm{~cm}$. br. Raceme laxly 6-10-fld., 6-12 cm. 1. Bracts foliaceous, ovate-lanceolate, long-acuminate, $2-1 \cdot 5 \mathrm{~cm}$. 1. Flowers greenish. Sepals 3-nerved, median ovate-oblong, somewhat obtuse, 5-6 mm. 1.; lateral deflexed, oblong, acute, about $8 \mathrm{~mm}$. l. Petals, segments somewhat equal ; posterior linearligulate, abruptly acute, suberect, as long as the median sepal; anterior somewhat longer, filiform. Lip, middle lobe about equal to the lateral sepals, narrowly linear; lateral lobes generally longer, filiform, spreading. Spur incurved, filiform, gradually becoming spindle-shaped, somewhat acute, $1 \cdot 3-1 \cdot 6 \mathrm{~cm} .1$. Stigmatic processes extended, thickened, altogether free from the lip; anther-canals shorter, ascending.

Var. jamaicensis Cogn. loc. cit. (1909); plant smaller than the typical species; leaves roundish-oval to oblong-lanceolate. Habenaria jamaicensis Fawc. \& Rendle in Journ. Bot. xlvii. 126 (1909) ; Ames op. cit. iv. 204, t. 67. (Pl. 1, f. 2, 3.)

On rocky or clayey, shady banks; in fl. Dec.-March; below Guava Ridge, J.P. 483, Morris! MIt. Hybla, 4000 ft.; Clydesdale, 4000-4500 ft.; near Cinchona, 4500 ft.; Harris ! Fl. Jam. 7851, 7854, 10,499.-Hispaniola.

Plant $\frac{1}{2}-1 \mathrm{ft}$. high. Stem 1-2 dm. Leaves $3-9 \mathrm{~cm} .1 ., 1 \cdot 5-4 \cdot 5 \mathrm{~cm}$. br. Raceme laxly 4-12-fld., 4-15 cm. 1. Bracts membranous, ovate-lanceolate or lanceolate, acute or acuminate; sterile $2-4$, more or less distant, 5-2 cm. 1. ; floral about as long as the stalked ovary, 2.5-1.5 cm. 1. Pedicels about $5 \mathrm{~mm}$. 1. Sepals 3-nerved, median ovate-suborbicular, very obtuse, 6-7 mm. 1., 4.5-6 mm. br. ; lateral half-ovate, subfalcate, obtuse, apiculate, $6 \cdot 5-9 \mathrm{~mm}$. 1., 3.5-4 mm. br. Petals, segments equal or unequal; posterior oblong-lanceolate, falcate, acute, connivent, $5 \cdot 5-7 \mathrm{~mm}$. 1 ., 1.5-2 mm. br. ; anterior segment a little to many times shorter than the posterior, 1.5-4 mm. l. Lip, middle lobe linear-ligulate, $6 \cdot 5-10 \mathrm{~mm}$. 1 ., about $1 \mathrm{~mm}$. br.; lateral lobes filiform, erect, much longer than the petals, 9-12 mm. 1. Spur 1.3-1.6 cm. 1. Stigmatic processes short, truncate-rounäish; anther-canals about as long; somewhat curved; staminodes shortly triangular. 


\section{$\$ 2$. Petals entire; lip simple.}

5. H. Purdiei Fawc. \& Rendle in Journ. Bot. xlvii. 263 (1909); leaves lanceolate; bracts lanceolate, shorter than the stalked ovary ; sepals very obtuse; spur much longer than ovary.-Ames op. cit. iv. 270. (Pl. 2, f. 1-3.) Type in Herb. Kew.

Hollis's Savanna, Clarendon, Purdie!

Plant $1 \frac{1}{2}$ ft. high. Stem about $3 \mathrm{dm} .1 ., 3.5 \mathrm{~mm}$. br. Leaves thin, conspicuously reticulate-11-15-nerved, acute, to $8 \mathrm{~cm}$. 1 ., to $1.9 \mathrm{~cm}$. br. Raceme, about $12 \mathrm{~cm}$. l., somewhat laxly many-fld., oblong in outline. Bracts acuminate, lower $1.7 \mathrm{~cm}$. l. Pedicel about $5 \mathrm{~mm}$. l. Ovary $1-1.8$ cm. l. Flowers somewhat spreading. Sepals reticulate-3-nerved, nerves prominent outside; median suborbicular, margin minutely denticulate, $8.5 \mathrm{~mm}$. 1., $7 \cdot 7 \mathrm{~mm}$. br.; lateral oval-oblong-falcate, concave, about 11 $\mathrm{mm}$. l., about $5 \mathrm{~mm}$. br. Petals oblong, very obtuse, 2-nerved, $6 \mathrm{~mm}$. l., $2 \mathrm{~mm}$. br. Lip linear-ligulate, margin revolute, with a small tooth on each side above the base, pendulous, half as long again as the sepals, 13 $\mathrm{mm}$. l., nearly $2 \mathrm{~mm}$. br. Spur slender, compressed, tapering to apex, nearly $3 \mathrm{~cm}$. 1. Stigmatic processes thick and fleshy at apex, about $2 \mathrm{~mm}$. 1.; anther-canals nearly twice as long, about $3 \cdot 3 \mathrm{~mm}$. l., ascending; anther acutely crested (in the specimen examined).

Near H. obtusa Lindl., from Brazil and Surinam, but differs in the smaller lanceclate bracts and in other details.

6. H. alata Hook. in Exot. Fl. t. 169 (1827); bracts ovate to lanceolate, acuminate, apex shortly awned, about as long as the stalked ovary; sepals acute; petals acute, linear-lanceolate.Griseb. op. cit. 644; Ames op. cit. iv. 273. H. brachyceras Lindl. op. cit. 315 (1835), non Spreng. H. monorrhiza Cogn. op. cit. 307 excl. syn. (in part). (Pl. 1, f. 4-7.)

In damp clayey ground; in fl. Nov.-April; Macfadyen! Purdie! Prior! Golden Spring, J.P. 466, Morris! Farm Hill, Miss B. Gosset! Salt Hill Road; Westphalia, 4000 ft.; Halls Delight, 1000 ft.; below Cinchona, 4000 ft.; Harris! Fl. Jam. 7526, 7806, 10,470, 10,500.-Cuba, Porto Rico, St. Thomas, Antigua, St. Vincent, Grenada, Mexico, Guatemala, Costa Rica, Venezuela, Bolivia.

Plant reaching sometimes to $3 \frac{1}{2}$ feet. Stem leafy, covered by the leafsheaths, $2-5 \mathrm{dm} .1$. Leaves lanceolate, acute, passing from a sheath at the base into bracts above, 7-16 cm. l., 1-2.4 cm. br. Raceme somewhat laxly many-fld., $10-15 \mathrm{~cm}$. l. Bracts $2 \cdot 7-2 \mathrm{~cm} .1 ., 4-6 \mathrm{~mm}$. br. Flowers green. Sepals reticulate-7-nerved, keeled, median broadly ovate, 6-8 $\mathrm{mm}$. 1., 4.5-6 mm. br.; lateral ovate, acute, 7-9 mm. l., 3-4.5 mm. br. Petals reticulate-3-nerved, with a small projecting lobe on the anterior side near the base, $6-7 \cdot 5 \mathrm{~mm}$. 1., 1.75-2 mm. at greatest width. Lip linear-ligulate, margin revolute, with or without a small tooth on each side above the base, spreading or ascending, $6-8 \mathrm{~mm}$. 1., about $1 \mathrm{~mm}$. br. Spur pendulous, clavate, slightly shorter than the ovary, $1 \cdot 2-1 \cdot 4 \mathrm{~cm}$. l. Stigmatic processes short, compressed; anther-canals subequal, ascending. Capsule 6 -winged.

7. H. socialis Fawc. \& Rendle loc. cit.; bracts lanceolate, acuminate, about as long as the stalked ovary; lateral sepals 2-nerved, oblong, retuse, about $4.3 \mathrm{~mm}$. l., about $2 \mathrm{~mm}$. br.; petals oblong, apex emarginate, the nerves ending in two pro- 
jecting points, $3 \cdot j \mathrm{~mm}$. 1., about $1 \mathrm{~mm}$. br. ; spur tapering towards apex.-Ames op. cit. ir. 276. Type in Herb. Kew. (Pl. 2), f. 4-7.)

Growing with $H$. alata Hook. in marshy soil, near Mandeville, Purdie!

Plant 12 in. high, glabrous. Stem erect, leafy, covered by leaf-sheaths, about $2 \mathrm{dm}$. 1., $3 \mathrm{~mm}$. br. Leaves lanceolate, thin, 9-nerved, acute, passing into the bracts above, blade to $8.5 \mathrm{~cm}$. 1., to $2 \mathrm{~cm}$. br. Raceme somewhat laxly many-fld, about $10 \mathrm{~cm}$. 1 . Bracts, lower $1.3 \mathrm{~cm} .1$. Pedicel about $3 \mathrm{~mm}$. 1. Ovary about $1 \mathrm{~cm}$. l. Flowers green, erect. Sepals median, without nerves, suborbicular, very obtuse, apiculate, about $3.5 \mathrm{~mm}$. l. and br. Petals reticulate-2-nerved, with a projecting lobe on the anterior side near the base, $3.5 \mathrm{~mm}$. l., about $1 \mathrm{~mm}$. br. Lip linearligulate, with a small projecting lobe just above the narrow base, margin revolute, simple, about $5.5 \mathrm{~mm}$. 1., about $1.2 \mathrm{~mm}$. br. Spur slender, compressed, nearly as long as ovary, about $1 \mathrm{~cm}$. l. Stigmatic processes very short, capitate, glandular; anther-canals ascending, about twice as long as processes.

Differs from $H$. alata Hook. in the texture and venation of the leaves; in the flowers being about half the size; in the form of the sepals and petals, and the relatively longer lip. Differs from the Brazilian species, H. quadrata Lindl., in form of petals, length of spur, which is $1.5 \mathrm{~cm} .1$. in $H$. quadrata, and in other details.

8. H. troyana Fawc. \& Rendle op. cit. 264; bracts ovatelanceolate, subacuminate, like the leaves at base of raceme, lowest longer than flower, upper shorter than ovary; lateral sepals reticulate-nerved, falcately oblong-ovate, obtuse, the nerve on the lower face projecting as an apiculus just below the apex, $7 \mathrm{~mm}$. 1., $3 \cdot 5 \mathrm{~mm}$. br. ; petals oblong, retuse, oblique at base and rather broader there than at the apex; spur increasing in size upwards from a slender base-Ames op. cit. iv. 260. (Pl. 2, f. $8-12$.

In damp shady forest; in fl., Nov.; near Troy, 2500 ft., Harris! Fl. Jam. 10,432.

Plant somewhat robust, $2 \mathrm{ft}$. high. Stem leafy, $3 \mathrm{dm}$. 1. Leaves lanceolate, acute, reticulate-11-15-nerved, passing into bracts above, about $10 \mathrm{~cm}$. l., about $2.5 \mathrm{~cm}$. br. Raceme densely-fld., $30 \mathrm{~cm} .1$. Bracts $3 \cdot 5-1 \cdot 2 \mathrm{~cm} .1 ., 1 \cdot 3-\cdot 6 \mathrm{~cm}$. br. Pedicels short. Sepals reticulate-nerved, median ovate-suborbicular, very obtuse, $6 \mathrm{~mm}$. l., $5 \mathrm{~mm}$. br.; lateral spreading, $7 \mathrm{~mm}$. 1., $3.5 \mathrm{~mm}$. br. Petals with an obsolete lobe near base anteriorly, $5 \mathrm{~mm}$. l., $2 \cdot 3 \mathrm{~mm}$. br. Lip linear-ligulate, angled at the base, 7.5-8 mm. 1., 1.5-1.75 mm. br. near apex, 1.5-2 mm. br. near base. Spur pendulous, slightly curved, shorter than the stalked ovary, $9 \mathrm{~mm}$. 1 . Stigmatic processes short, compressed; anther-canals about as long, slightly projecting upwards.

Since the publication of $H$. troyana, we have had the opportunity, through the courtesy of Prof. I. Urban, of comparing flowers from the type specimen of $H$. eustachya Reichb. f. in Ber. Deutsch. Bot. Ges. iii. 274 (1885) from Porto Rico (Sintenis, no. 511b) ; this differs from $H$. troyana in being smaller, with thinner, non-clavate spur, and much smaller lip. When describing $H$. troyana we compared it with $H$. Sanbornii Ames, which we suggested might prove identical with $H$. eustachya. Mr. Oakes Ames now (op. cit. 257) refers H. Sanbornii to H. eustachya, and considers $H$. troyana as probably the same species. 


\section{POGONIA Juss.}

Terrestrial herbs, with fleshy roots or a tuber. Leaves wanting, or appearing on the stem with the flowers; stalk sheathing, blade broad. Flowers medium-sized or small, corymbose, erect. Sepals equal, free, erect. Petals similar to, and nearly as long as, the sepals, erect. Lip erect from the base of the column, free, not spurred, contracted below, narrowly embracing the column, 3-lobed, the face with 1-3 raised lines. Column elongate, at the apex slightly thicker, with a short rostellum ; stigma under the rostellum oblong or broad; clinandrium more or less elevated, entire or denticulate. Anther more or less incumbent, obtusely conical or semiglobose; pollinia two, thinly granular. Capsule ellipsoidal, erect.

Species about 90, widely dispersed over the world.

Stem leafy 1. P. macrophylla.

Stem leafless...

2. P. gentianoides.

1. P. macrophylla Lindl. in Ann. \& Mag. Nat. Hist. ser. 3, i. 335 (1858); stem leafy; flowers greenish.-Cogn. in Symb. Ant. vi.317. P. physurifolia Reichb. f. in Nederl. Kruidl. Arch. iv. 324 (1859); Griseb. Fl. Br. W. Ind. 637. (Pl. 1, f. 11.)

In damp shady places; probably in fl. all the year, our specimens were collected in Feb., April, June \& Dec.; woods above Dunrobin Castle, St. Thomas in East, Purdie! J.P. 2090, Morris! Mabess River, 2500 ft., G. Nichols! Vinegar Hill, St. George, $4000 \mathrm{ft}$; ; ridge below Vinegar Hill, $3800 \mathrm{ft}$.; near MLabess River, 3500 ft.; Harris! Fl. Jam. 6252, 7840, 9013, 10,097.-Cuba, Hispaniola, Porto Rico, Guadeloupe, Dominica, St. Lucia, St. Vincent, Grenada, Venezuela, Guiana, Colombia.

Plant 9-12 in. high, glabrous. Stem often prostrate at the base and rooting at the nodes, erect above, purple, $1-3 \mathrm{dm}$. 1. Leaves, blade ovate, acute or obtuse, at the base rounded, sometimes somewhat cordate and clasping, green above, deep purple beneath, conspicuously 3-nerved, 3-7 cm. 1., 2-3 cm. br. Racemes 1-several, with numerous broad bracts, short or becoming long, with 1-6 flowers open at one time at the apex, $2-13 \mathrm{~cm}$. l. Flowers, perianth $\frac{1}{2}$ in. or more 1. Bracts, floral broadly ovate, obtuse, clasping, much shorter than the ovary, 5-1 cm. 1. Pedicels $4 \mathrm{~mm}$. 1., elongating often to $5.5 \mathrm{~mm}$. in fruit. Ovary slender with thin longitudinal ridges, 11 or $12 \mathrm{~mm}$. 1. Sepals oblanceolate, 3-nerved, margins somerwhat involute, strongly' keeled, keel ending in a pointed tip, about $1.5 \mathrm{~cm}$. $1 ., 3.5 \mathrm{~mm}$. br., lateral falcate. Petals oblanceolate, acute or somewhat obtuse, 3 -nerved, about $1.4 \mathrm{~cm}$. $1 ., 2 \cdot 2 \mathrm{~mm}$. br. Lip in outline obovate, a little shorter than the petals (by $1 \mathrm{~mm}$.), nearly $5 \mathrm{~mm}$. br. (including lobes), many-nerved, middle vein prominent, 3-lobed above; middle lobe much larger than the lateral, somewhat roundish-rhomboid, margin somewhat eroded; lateral lobes oblong, obtuse, with a very narrow sinus. Column narrowly winged; clinandrium with 2 pointed lobes. Capsule nearly $2.5 \mathrm{~cm}$. 1 ., $7 \mathrm{~mm}$. br.

2. P. gentianoides Spreng. Syst. iii. 706 (1826); stem leafless; flowers dark purple.-Lindl. Gen. \& Sp. Orch. 413 ; Griseb. op. cit. 637 ; Cogn. op. cit. 315 . Limodorum gentianoides Sw. Prodr. 119 (1788). Arethusa gentianoides Sw. Fl. Ind. Occ. 1436 (1806) \& Ic. ined. t. 18. (Pl. 2, f. 13-15.) Type in Herb. Mus. Brit. 
In shady plaees; in fl. June; Morant Bay, Swartz! J.P. 4\$2, Morris!

Plant growing from a tuber, glabrous 5-15 ins. high. Scaje ereet, slender, with a few sheaths, 1-3 dm. 1., purplish. Sheaths about 5, clasping, rounded at the apex, dark- or reddish-green, 2-1 cm. 1. Filowers at the end of the scape "dark purple, glaueescent, like the calyx of Gentiana Amarella" (Sw.). Peduncles 6-12, somewhat crowded, very long, $2 \cdot 5-7 \cdot 5 \mathrm{~cm}$. 1., filiform, 1-fld., lax, red. Bracts ovate, acuminate, entire, eoneave, 3-nerved, grcen, 5-9 $\mathrm{mm}$. 1. Sepals 3.nerved, narrowly oblong, hooded at tip, connivent, ereet, dark purple, $9 \mathrm{~mm} .1 ., 1 \cdot 75 \mathrm{~mm}$. br. I'rtals nearly as long as the scpals, white, 3-nerved, lanceolate, obtuse, about $8 \mathrm{~mm}$. 1., $1.5 \mathrm{~mm}$. br. Lip narrow at the base, ereet, half-cmbracing the eolumn, nearly as long as the petals, 3-lobed; middle lobe larger than lateral, oblong, blunt; lateral ovate, cntire; 3 raised lines marked with green spots run from the base to the apex of the middle lobe. Column somewhat stout, semi-terete. Anther bluntly apiculate. Capsule with 6 shallow kecls, $1 \cdot 1 \mathrm{~cm} .1 ., \cdot 5 \mathrm{~cm}$. br.

\section{VANILLA Sw.}

Herbs ; strong, high-climbing, branching ; stems with or sometimes without leaves, emitting roots. Leaves leathery, papery, or membranous. Racemes or spikes axillary, generally short. Flowers large. Bracts ovate. Sepals about equal, free, spreading. Petals somewhat similar to the sepals. Lip, claw adnate to the column; limb broad, concave, embracing the column at the base. Column long, without a foot; stigma transverse under the short rostellum; clinandrium short or obliquely raised. Anther attached to the margin of the clinandrium, incumbent, convex, semiglobose or obtusely conical, with separate cells; pollinia powdery-granular, free, or at length sessile on the rostellum. Capsule generally long, fleshy, not dehiscing or only slightly later. Species about 20, widely dispersed throughout the tropics of the whole world.

Leaves, wanting on main stem, laneeolate-subulate on terminal shoot

1. V. claviculata. Stem leafy.

Bracts large, foliaceous. Leaves much longer than internodes

2. V. inodora.

Bracts small, not foliaceous. Leaves about as long as, or shorter than, internodes.

Leaves ovate, small, shorter than internodes ... 3. V. Wrightii.

Leaves oblong or elliptical, large, about as long as internodes.

Flowers $2 \frac{1}{4}-3 \frac{1}{4}$ in. 1 . Capsule thick.

Capsule rounded and somewhat flattish in section

[Capsule somewhat 3.cornered in section

[Flowers 2 in. 1. Capsule slender

4. V. phrantha. V. pompona.] V. planifolia.]

1. V. elaviculata Sw. in Nov. Act. Upsal. vi. 66, t. 5, fig. 1 (1799) (figure* bad); leaves wanting on main stem; on the

* This figure does not agree with deseription of Fl. Ind. Oce., but it may refer to $V$. Wrightii. 
terminal shoots lanceolate, acuminate, rigid, recurved at apex, concave, sessile, half-clasping at base.-Sv. Fl. Ind. Occ. 1515; Lindl. Gen. \& Sp. Orch. 434; Reichl. f. in Ber. Deutsch. Bot. Ges. iii. 275 ; Giseb. Fl. Br. W. Ind. 538 ; Rolfe in Journ. Linn. Soc. xxxii. 471 (1896); Cogn. in Syml. Ant. vi. 324. V. barbellata Reicht. $f$. in Flora xliii. 274 (1865). Cereo aftinis scandens planta dc. Sloane Hist. ii. 160, t. 224, fig. 3, 4. Cactus parasiticus L. Syst. ed. 10, 1054 (1759) (in part, i.e. so far as concerns reference to Sloane Jam.). Epidendrum claviculatum Sw. Prodr. 120 (1788). (Pl. 2, f. 18, 19.) Type in Herb. Mus. Brit.

Greenwithe.

On shrubs and trees, growing on limestone rocks; in fl. and fr. June; Angels, near Spanish Town, and on hills near, Sloane Herb. vii. 86! in very dry, calcareous mountainous places, Swartz! Retirement, St. Elizabeth, J.P. 460, Morris ! Stony Hill, J.P. 460 (2613) Syme! Constant Spring 650 ft., Stony Hill, 900 ft., Harris! Fl. Jam. 5827, 10,411 (March! in Hb. Kew.; owing to the unsatisfactory condition of the flower, which has apparently a glabrous lip, we have had some hesitation in referring it to this species).-Cuba, Hispaniola, Porto Rico, St. Thomas, Bahamas.

Stem leafless on main stem, thick, $1 \mathrm{~cm}$. or more br., shrivelling very much, to 5 or $6 \mathrm{~mm}$., when dry; internodes about $10 \mathrm{~cm}$. l.; adventitious roots often twisting spirally like tendrils. Leaves $3-8 \mathrm{~cm}$. l. Raceme with 8-12 sessile flowers, to $14 \mathrm{~cm}$. l. Bracts below like the leaves, but much smaller, above triangular, acuminate, $2-\cdot 5 \mathrm{~cm}$. 1 . Ovary $\frac{3}{4}$ as long as the sepals, cylindrical. Flowers fragrant, glaucous green sepals with a white and purplish lip, perianth nearly 2 ins. l., crowded towards apex of raceme. Sepals narrowly elliptical, obtuse, $4-4 \cdot 7 \mathrm{~cm}$. 1., 1-1.1 cm. br. Petals as long as sepals, keeled, $1 \cdot 3 \mathrm{~cm}$. br. Lip roundish, crenate and curled on upper margin, attached to column for two-thirds its length, with ramentaceous hairs inside along the central line, and at the sides below, $5 \mathrm{~cm}$. l., about $4.5 \mathrm{~cm}$. br. when flattened out. Column $3 \mathrm{~cm}$. l. Capsule ellipsoidal-cylindrical, thickest in the upper part, narrowing gradually to the base, $10 \mathrm{~cm} .1 ., 1 \cdot 6 \mathrm{~cm}$. br.

Swartz says, "flores albi . . . odor fortis Orchidearum." Grisebach quotes Wright as saying "perigonium rufescenti-virens, labello rubromarginato et punctato, mediano intus barbato." We have not taken the species name from Linnæus's Cactus parasiticus owing to the great confusion in his references. In the s'ystema (1759) he describes $C$. parasiticus as "repens, teres, striatus, muticus," referring to (1) Sloan. Jam. 224, f. 3, 4, the specimen of which is in Herb. Sloane, and is Vanilla clariculata Sw.; (2) Plum. Ic. 197, f. 2, probably a species of Rhipsalis. In Species Plantarum, ed. 2, i. 668 (1762) he repeats the diagnosis from the Systema, but drops the reference to Sloane, citing instead Cactus parasiticus inermis \&c. Browne Jam. 238. In the Linnean Herbarium there is a specimen from Browne named Cactus parasiticus by Linnæus; this has no flower, and is either Dendrophylax funalis, or a leafless species of Campylocentrum.

2. V. inodora Schiede in Linnæa iv. 574 (1829); leaves much longer than the internodes, elliptical, shortly acuminate, membranous, very shortly stalked; bracts in two ranks, foliaceous, membranous, like the leaves but much reduced and varying in size.-Rolfe op. cit. 449 ; Cogn. op. cit. 320. Vanilla flore viride et albo, fructu nigrescente, Plum. Nov. Gen. Pl. Amer. 25, t. 28 
(1703) i Pl. Amer. (Burm.) 1\&3, t. 188 (1758). V. volubilis siliquosa Mexicana plantaginis folio Catesly Nat. Mist. Carol. App. t. 7 (1743). V.anaromatica Grisel, op. cit. 63\%. Epidendrum Vanilla, L. in H(erl. (Pl. 2, f. 16.)

On trees, in rocky woodland; in $\mathrm{fl}$. Dec., in fr. March-Aug. ; I'. Browne (in Herb. Linn.)! Nanchester, I'urdie! J.P. 461 (2614) S'yme! Claverty Cottage, J.P. 461, Hart! in Swift River course, near Hope Bay ; near'Troy, $2600 \mathrm{ft}$.; Ilarris! Middle Quarters, Farquharson! Pedro, St. Ann, Sir H. Blake! Fl. Jam. 8555, 8829.-Cuba, Hispaniola, Porto Rico, Guadeloupe, Dominica, Martinique, Grenada, Trinidad, Mexico, Nicaragua, B. Guiana, Surinam.

Stem leafy, somewhat thick, $8 \mathrm{~mm}$. br., shrivelling to 5 or $6 \mathrm{~mm}$. in drying; internodes $3.5-10 \mathrm{~cm}$. l. Leaves $10-20 \mathrm{~cm}$. 1., $5-10 \mathrm{~cm}$. br., nerves numerous, prominent in drying. Racemes axillary, with 6 or 7 sessile flowers, to $15 \mathrm{~cm} .1$. Bracts usually $1 \cdot 3-2.5 \mathrm{~cm}$. l., sometimes to $8 \mathrm{~cm} .1$. Ovary 3 as long as sepals, or nearly as long, cylindrical. Flowers greenish, with white lip with orange-yellow crest, perianth $13-2$ in. 1 . Sepals and petals lanceolate to lanceolate-oblong, somewhat obtuse, $5 \mathrm{~cm}$. 1., to 1.5 cm. br. Lip 3-lobed, nearly as long as sepals and petals, united to column only a short distance at base (about $5 \mathrm{~mm}$.) ; lateral lobes oblong, obtuse, median lobe spreading and then erect, ovate-oblong, subacute; disk 3 -keeled, without a tuft of hairs, $4.5 \mathrm{~cm}$. 1., about $3 \mathrm{~cm}$. br. (when flattened out). Column $2 \cdot 5-3 \mathrm{~cm}$. 1. Capsule slender, elongate-linear, slightly tapering at apex, not fragrant, $12-18 \mathrm{~cm} .1$.

3. V. Wrightii Reichb. f. in Flora xlviii. 273 (1865); leaves shorter than the internodes, ovate or elliptical, shortly acuminate, shortly stalked, papery.-Griseb. Cat. Cub. 267 ; Rolfe op. cit. 454 ; Cogn. op. cit. 321. V. claviculata Lindl. in Ann. \& Mag. Nat. Hist., ser. 3, i. 334 (1858), non Sw. Vanillas piperis arbori jamaicensis innascens Pluk. Alm. 381, t. 320, f. 4. (Pl. 2, f. 17.)

Climbing over trees; in fl. March, in fr. August; Mt. Airey, near Mt. Moses, 2300 ft., J.P. 2088, Syme! Bull Head, Hart! Tweedside; MIt. Moses, 2200 ft.; Harris! Fl. Jam. 7885.-Cuba, Trinidad, B. Guiana, Surinam.

Stem leafy, slender, 3-4 mm. br., shrivelling to $2 \mathrm{~mm}$. in drying; internodes $5-10 \mathrm{~cm} .1$. ; roots $2-4$ from the same node. Leaves, nerves numerous, prominent in drying; blade $4-7 \mathrm{~cm}$. 1., $2-3 \cdot 3 \mathrm{~cm}$. br., stalk $5-12 \mathrm{~mm}$. l. Racemes axillary, with 5, or more, sessile flowers, to $7 \mathrm{~cm}$. l. Bracts triangular, obtuse, half-clasping, 5-7 $\mathrm{mm}$. l. Ovary about $\frac{3}{4}$ as long as sepals,

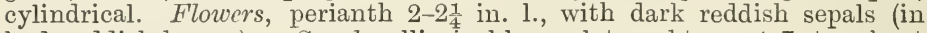
bud reddish-brown). Sepals elliptical-lanceolate, obtuse, $4 \cdot 7$ to about $5 \mathrm{~cm}$. 1., 8-9 mm. br. Petals keeled, $4.7 \mathrm{~cm}$. 1., $7 \mathrm{~mm}$. br. Lip entire, united to column about $2 \mathrm{~cm}$. above base, roundish-obovate, shortly acute, margin crenulate, with ramentaceous hairs on the disk especially along the central line, about as long as the sepals. Column $3 \cdot 7 \mathrm{~cm}$. l., hairy below the stigma, winged on each side of anther. Anther somewhat rectangular in outline. Capsule elongate, linear, somewhat flattened, slender, slightly tapering at apex, $12-14 \mathrm{~cm}$. 1., $4 \mathrm{~mm}$. br.

Reichenbach describes the lip as "apice bilobulo (disco lævi ?)"; Grisebach as " barba destituto," and Rolfe as "disco lævi." Wright, quoted by Lindley, says of his Cuban specimen (672) : "Flowers light dull red. Labellum light-yellow with a white margin. Column adhering to the labellum more than half its length, reddish towards the base." 
4. V. phæantha Reirhb.f.op. cit. 274 ; leaves about as long as the internodes, oblong, tapering to an acute apex, with very short stalk, clasping at the base, Heshy ; flowers $2 \frac{1}{4}-3 \frac{1}{4}$ in. 1. ; capsule linear-cylindrical, somewhat flattened, tapering to base.-Rolfe op. cit. 464. Cogit. op. cit. 323. V. planifolia, var. macrantha Griseb. loc. cit. (Pl. 2, f. 20.)

In fl. May; Askenish, 800 ft., near Dolphin Head, Harris! Fl. Jam. 10,489. - Cuba, Bahamas, St. Vincent, Trinidad.

Stem leafy, thick, 5-8 mm. br. when dry; internodes 13 to $14 \mathrm{~cm}$. 1 . Leaves several-nerved (when dry) $2 \cdot 5-3 \mathrm{~cm}$. br. Raceme with several flowers, 3-5 cm. l. Bracts ovate, acute, 6-14 mm. 1., 4-8 mm. br. Flowers fleshy, perianth $3 \frac{1}{4}$ in. l. Ovary cylindrical, slightly 2 -angled, $5 \mathrm{~cm}$. 1 , 6-7 mm. br. Sepals oblanceolate, about 11-veined; lateral somewhat acute, slightly falcate, $8 \cdot 2-8 \cdot 8 \mathrm{~cm}$. $1 ., 1 \cdot 6-1 \cdot 8 \mathrm{~cm}$. br.; median somewhat blunt, $8 \cdot 5-9 \cdot 1 \mathrm{~cm} .1 ., 1 \cdot 7 \mathrm{~cm}$. br. Petals about 10-nerved, aistinctly broadly keeled, $8 \cdot 1-8 \cdot 7 \mathrm{~cm}$. 1., 1 $2-1 \cdot 4 \mathrm{~cm}$. br. Lip attached to column almost to its apex, limb very broadly ovate, apex retuse, apiculate just below the apex on the back, distinctly keeled along the back, the keel ending in a long mucro at $5 \mathrm{~mm}$. below the apex, nerves prominent in the tube and on disk, with a tuft of transverse, flat, toothed crests pointing downwards opposite the column near the apex, margin somewhat curled and crenulate, 8.1-8.3 cm. l., about $4 \cdot 5 \mathrm{~cm}$. br. Column $6 \cdot 3 \mathrm{~cm}$. l., bearded below the stigma; in the specimen examined 3 anthers are present, in the lateral one cell incomplete. Capsule (unripe), $8 \mathrm{~cm} .1 ., 1 \cdot 2 \mathrm{~cm}$. br.

[V. planifolia Andrews Bot. Rep. viii. 538 (1808); leaves like those of $V$. phrantha; flowers 2 in. 1. ; capsule slender.Bauer Ill. Orch., Gen. tt. 10, 11 ; Lindl. Gen. \& Sp. Orch. 435; Griseb. Fl. Br. W. Ind. 638 ; Rolfe op. cit. 463 ; Cogn. op. cit. 322 ; Salisb. Ic. ined. vi. fol, 582, 591.

S.E. Mexico, Yucatan, B. Honduras, Guatemala, Costa Rica.

Stem leafy, somewhat thick, shrivelling to 5 or $6 \mathrm{~mm}$. in drying; internodes 8 or $9 \mathrm{~cm}$. 1 . Leaves longer than the internodes, with short thick stalks, oblong to subovate-oblong, acute or shortly acuminate, thick and fleshy, nerves obscure in fresh specimens; 10-18 cm. 1., 4-6 cm. br. ; stalks half-clasping, about $1 \mathrm{~cm}$. 1 . Pacemes axillary, many-flowered (to 14), 5-7 cm. 1. Bracts oblong, subacute or obtuse, 5-10 mm. 1 . Flowers greenish-yellow, perianth 2 in. l. Sepals and petals oblongoblanceolate, somewhat obtuse, about $5 \mathrm{~cm}$. l. Lip convolute, attached by its margins to the column almost to its apex, with longitudinal crenulate keels, and a hairy tuft in the tube pointing downwards ; somewhat 3-lobed above, apex retuse; with revolute margin, somewhat longer than the sepals. Column hairy anteriorly, about $3 \mathrm{~cm} .1$. Capsule long, linear, $15-25 \mathrm{~cm}$. 1 .

This species furnishes the best "vanilla beans" of commerce, and is cultivated to some extent in Jamaica. It may consequently occur here and there, in a naturalised state, producing perfect fruit, as it has done in Hope Gardens without being artificially pollinated, and on that account we have included it.

Miller's V. mexicana (Gard. Dict. ed. 8, 1768), as well as Swartz's $V$. aromatica (in Nov. Act. Upsal. vi. 66, 1799 \& in Schrad. Journ. ii. 208, t. 1, fig. 1b, 1799) was founded on Linnæus's 
Epidendrum Vunilla, and inclucled the vanilla beans of commerce and the leaves and flowers of another species.

The pots of both $V$. pompona sichiede and $V$. planifolia are used in eommerce, and as $V$. pompona is much more widely spread than $V$. planifolia, it is probable that its pods were more common in early times before cultivation was resorted to. $V$. pompona is not so much cultivated at present as $V$. planifolia, as its pods are not nearly so valuable commercially.

Judging from the habitat given by Miller for the plant cultivated by him, from the thickness of the pod ("scarce an inch broad "), and from the shape of the leaves "oblongo-ovatis," it seems more probable that his plant was $V$. pompona rather than V. planifolia.

$V$. inodora Schiede has much the same distribution on the mainland as $V$. pompona, and extends also to the West Indies. The stem and leaves of this species may have been sent to England as specimens of Vanilla, and certainly some of the old drawings suggest $V$. inodora rather than $\dot{V}$. pompona or V. planifolia, e.g. Catesby's plate (Nat. Hist. Carol., App. t. 7), which is quoted by Miller as his $V$. mexicana. Miller also states in his generic description that the lip "runs out into a long point," and this cannot apply to either $V$. pompona or $V$. planifolia, but may well refer to $V$. inodora.]

[V. pompona Schiede in Linnæa iv. 573 (1829); leaves and flowers like those of $V$. phæantha but larger; capsule thick, somewhat 3-cornered in section.-Rolfe op. cit. 465; Cogn. op. cit. 323. V. grandiflora Lindl. Gen. \& Sp. Orch. 435 (1840). Banille Merian Pl. Ind. t. 25 (1768).

Trinidad, Mexico, Nicaragua, Panama, Colombia, Venezuela, B. Guiana, Surinam, Cayenne.

Like $V$. planifolia but larger. Leaves ovate-oblong, 14-25 cm. 1., 5-11 cm. br. Racemes 6-8 fld., 2-5 cm. 1. Bracts broadly ellipticooblong, 10-18 mm. l. Flowers greenish-yellow, perianth $3 \frac{1}{4}$ in. l. Sepals and petals $8-8.5 \mathrm{~cm}$. 1., oblong-lanceolate, subspathulate. Lip $9-9 \cdot 5 \mathrm{~cm} .1$., adnate to the column almost to the middle, constricted for some distance below, limb obscurely 3-lobed, veins somewhat thick, with tuft pointing downwards, median lobe broadly rounded, apex emarginate and apiculate. Column hairy anteriorly, 6-7 cm. 1. Capsule linear-oblong, obtusely 3-cornered, 10-15 cm. 1 .

The description of this species, which is cultivated in the Hope Gardens, is inserted for comparison. $]$

\section{PELEXIA Lindl.}

Terrestrial herbs, with roots clustered. Leaves radical, long-stalked, at base of a simple stem, with several sheaths. Flowers of medium size, with very short stalks, in a somewhat lax spike. Bracts narrow or lanceolate. Sepals, median erect, connate with the petals; lateral linear, connate at the base into 
a long linear spur-like appendage, partly open on the upper side, adnate to ovary or half-free. Lip erect, concave, embracing the column above, involute below the column and attached at its base to the inside of the spur of the sepals. C'olumn short, without a foot; stigma broad, at the base of the erect, long, subulateacuminate rostellum; clinandrium short. Anther erect, behind the rostellum, oblong-linear, cells contiguous; pollinia narrow, powdery-granular, on the dehiscence of the anther pendulous from the apex of the rostellum. Capsule erect, ellipsoidal.

Species about 20, natives of tropical America, from the West Indies and Central America to Brazil.

Sepals acute. Spur adnate ................ 1. P. adnata.

Sepals produced into a long, awn-like apex.

Spur half-free ............................. 2. P. setacea.

1. P. adnata Spreng. Syst. iii. 704 (1826); flowers barely $\frac{1}{2}$ in. l. from apex of sepals to point of spur ; sepals acute; spur adnate to ovary almost to apex; lip tubular below, terminal lobe large, kidney-shaped._Cogn. in Symb. Ant. vi. 329. P. spiranthoides Lindl. Bot. Reg. t. 985 (1826) \& Gen. \& Sp. Orch. 481 ; Griseb. Fl. Br W. Ind. 642. Satyrium adnatum Sw. Prodr. 118 (1788). Neottia adnata Š. Fl. Ind. Occ. 1409 (1805); Salist. Ic. ined. fol. 587.

In shady woods; in fl. May; Masson! Bahamas, Cuba, Hispaniola, Porto Rico, Guadeloupe, St. Vincent, Grenada, Margarita.

Plant $1 \frac{1}{2} \mathrm{ft}$. high. Stem downy above, glabrous below, about $3 \mathrm{dm}$. 1 . Leaves 2 or 3 , oval, acute, blade about $10 \mathrm{~cm} .1 ., 5 \mathrm{~cm}$. br.; stalks red, $14 \mathrm{~cm}$. l., sheathing at the base. Sheaths coloured, shortly tubular below, free part lanceolate, $4 \cdot 5-2 \mathrm{~cm} .1$. Spike downy, many-flowered, somewhat lax. Bracts linear-lanceolate, as long as the ovary, 10-17 mm. l. Flowers more or less erect, green or whitish. Sepals, lateral linear, somewhat spreading, acute, 1-nerved, green outside, white inside, spotted, from attachment at base of column about $6 \mathrm{~mm}$. l., about $1 \mathrm{~mm}$. br.; median elliptical, obtuse, very concave, 3-nerved, pale green, about $6 \mathrm{~mm}$. l., (with the attached petals) about $3.5 \mathrm{~mm}$. br. Petals linear, white, closely attached to the median sepal, and nearly as long as it. Lip white, about $5.3 \mathrm{~mm}$. l. from base of column, terminal lobe $2 \mathrm{~mm}$. $1 ., 3.6 \mathrm{~mm}$. br. Capsule 6-keeled, $1 \cdot 5 \mathrm{~cm}$. $1 ., \cdot 5 \mathrm{~cm}$. br.

2. P. setacea Lindl. Gen. \& Sp. Orch. 482 (1840); flowers $1 \frac{1}{2}-2$ in. 1. from apex of sepals to point of spur; sepals produced into a long awn-like apex; spur half-ftee trom ovary ; lip oblong, broadening upwards, terminal lobe lanceolate, fimbriate below, with awn-like apex.-Griseb. op. cit. 642 ; Cogn. op. cit. 327. P. setacea var. glabra Cogn. in Fedde Repert. vii. 123 (1909). Neottia calcarata Hook. in Bot. Mag. t. 3403 (1835). (Pl. 2, f. 21, 22.)

In stony land in shade or woodland; in fl. and fr. Dec., Jan.; MIts. above Negril, Purdie! Moneague, Prior! Jenman! Stony Hill, J.P. 470, Morris! \& Syme! near Halls Delight, $1000 \mathrm{ft}$; Knapdale, near Browns Town; Stony Hill, 1000 ft.; Harris! Fl. Jam. 7077 (partly) 7863.- 
Cayman Brac, Bahamas, Cuba, Hispaniola, Porto Rico, Trinidad, Colombia, Brazil.

Plant 15-18 in. high. Stem somewhat stout, downy above, glabrous below, $3 \mathrm{dm}$. and over. Leaves 1 or 2, oval, acute, blade $11-15 \mathrm{~cm}$. 1 ., $3-5 \mathrm{~cm}$. br.; stalks $12-18 \mathrm{~cm} .1$. Sheaths 1 or 2, radical, below the leaves, scarious, $2-5 \mathrm{~cm}$. l. ; cauline tubular below, free part triangular, acuminate, 2-3 cm. l. Spilie downy, lax, with several flowers, $3-15 \mathrm{~cm} .1$. Iracts ovate, apex acuminate, awn-like, 5-nerved, longer than the ovary, $2-2.5 \mathrm{~cm}$. 1., abc $\cdot 2 t \cdot 5 \mathrm{~cm}$. br. Ovary spindle-shaped (with stalk) $2 \mathrm{~cm}$. 1 . Flowers greenish-white. Sepals linear-lanceolate, 7-nerved below (from point of attachment at base of column) $2.8 \mathrm{~cm}$. l., barely $2 \mathrm{~mm}$. br., median $2.5 \mathrm{~mm}$. br.; spur tapering, obtuse. P'etals similar to scpals, attached throughout their length to the median sepal, nearly $2 \mathrm{~cm} .1$, $1.4 \mathrm{~mm}$. br. Lip white, many-nerved. Column (below stigma) $3 \mathrm{~mm}$. l., from base of column to apex of anther $9 \mathrm{~mm}$. 1. Capsule broadly ellipsoidal, with six shallow keels, dehiscing at some little distance below the apex, $2 \mathrm{~cm} .1 ., 8 \mathrm{~mm}$. br.

Var. glabra Cogn. is based on Harris Fl. Jam. 7863, the author says "scapus usque ad apicem glaberrimus," but all the specimens which we have seen bear the usual pubescence.

\section{STENORRHYNCOS Spreng.}

Terrestrial herbs, root fibres generally fleshy, clustered, with radical leaves, or flowering stems leafless. Leaves elliptical to ligulate, radical, tapering at base into long stalks which are flattish, concave, sheathing at base. Flowers medium size to small, in a spike. Sepals free, subequal ; median ereet, cohering with the petals; lateral obliquely affixed at the apex of the ovary, and decurrent with the column, produced at the base into a chin or distinct spur, erect. Lip sessile or clawed, erect, concave, embracing the column and sometimes adherent to it, spreading at the apex, entire or inclistinctly 3-lobed, without calli. Column terete, at the base with a long foot; stigma broad under the erect, long rostellum; clinandrium posteriorly short, margins sometimes raised and continuous with the rostellum. Anther erect, oblong-lanceolate, 2-celled ; pollinia powdery-granular, pendulous from a gland of the rostellum. Capsule obovoid or ellipsoidal, 3-keeled.

Species about 25, natives of tropical America.

Leaves, several, elliptical

Leaves, 1 or 2 , or wanting during flowering season.

Plant with glandular-pubescent hairs. Perianth

$\frac{1}{2}-\frac{3}{4}$ in. 1. Spur about $\frac{1}{2}$ length of ovary .....2. S. lanceolatus.

Plant scurfy with white scales. Perianth $1-1 \frac{1}{4}$

in. l. Spur about $\frac{2}{3}$ length of ovary ........... 3. S. squamulosus.

1. S. speciosus Lindl. Gen. \& Sp. Orch. 477 (1840); plant glabrous; leaves several, elliptical ; bracts crimson or rosy-pink, elliptical, acuminate, nerves 3, lateral branching, nearly as long as or longer than the flower; perianth crimson or rosy-pink, $\frac{2}{3}-\frac{3}{4}$ in. l.; sepals forming a short chin.-Griseb. Fl. Br. W. 
Ind. 642. Cardamomum minus pseudo-asphodeli foliis Sloane Cat. 61 \& Hist. i. 166, t. 103, f. 3. Neottia speciosa Jacq. Collect. iii. 174 (1789) \& Ic. Pl. Rar. iii. t. 600 (1786-1793) ; Sw. Fl. Ind. Occ. 1400 ; Hook. Exot. Fl.tt. 3 \& 4 ; Salisb. Ic. ined. fol. 586,587 .

On banks and in rocky places in damp woods; in fl. Oct.-Feb.; Guanaboa, Sloane, Herb. iii. 38, iv. 115*! Shatespear! Bancroft! Browns Town, Purdie! Fairfield, Wullschlaegel, 1075! MIt. Moses, 2500 ft., J.P. 2059, Syme! Clydesdale, Moore! Cinchona, $5000 \mathrm{ft}$.; Holly Mount, Mt. Diabolo, 2600 ft.; Harris! Fl. Jam. 7632, 7640, 7757, 8572, 9593.Cuba, Porto Rico, Mexico, Guatemala, Costa Rica, Panama, Colombia, Venezuela.

Plant 9 in. to nearly $2 \mathrm{ft}$. high, with thick, clustered roots. Scape erect, somewhat stout, $2 \cdot 5-6 \mathrm{dm}$. 1. Leaves acute, with several nerves, 6-17 cm.1., 3 $5-6 \mathrm{~cm}$. br., stalks 3-5-10 cm. 1. (incl. sheath). Sheaths several at base, 5-7 above, membranous, lax; free portion lanceolate, acuminate; upper red; 4-8 cm. 1. Spike erect, dense, somewhat one-sided, generally short, 4-11 cm. 1. Bracts $3 \cdot 5-2 \mathrm{~cm}$. 1. Ovary oblong, tapering to base, oblique at apex, 3-ribbed, purplish. Flowers numerous. Sepals slightly spreading at apex, nerves 3, sometimes branching; lateral oblong-lanceolate to narrowly lanceolate, acute to acuminate, $1 \cdot 6-2 \mathrm{~cm}$. 1., about $4 \cdot 5 \mathrm{~mm}$. br. ; median oblong, subacuminate, to triangular-lanceolate, concave, $1 \cdot 25-1 \cdot 5$ cm. 1., about $4.5 \mathrm{~mm}$. br. Petals 3-nerved, oblong tapering to an acute apex, or linear-lanceolate, slightly falcate, oblique at base and there attached both io median and lateral sepals, $1 \cdot 25-1 \cdot 5 \mathrm{~cm}$. $1 ., 2 \cdot 5-3 \mathrm{~mm}$. br. Lip 7-nerved, pubescent on the disk, shortly pubescent on the lower face, somewhat rhomboidal, with a recurved oblong acute or lanceolate apex, concave, slightly saccate at each side at base, $1.25-1.85 \mathrm{~cm}$. 1., about $5 \mathrm{~cm}$. br. Column $3 \cdot 5 \mathrm{~mm}$. 1. from junction with lip to attachment of anther, $1.1 \mathrm{~cm}$. to apex of rostellum; rostellum obovate, with a long beaked apex (beak $3 \cdot 5 \mathrm{~mm}$. 1.), pubescent below the stigma, 2 -winged below, wings united with stalk of anther. Anther 5-6 mm. 1., ovate-lanceolate, shortly stalked.

2. S. lanceolatus Griseb. loc. cit.; plant with glandularpubescent hairs; leaves glabrous, 1 or 2 , ligulate or ellipticallanceolate, often disappearing before flowering; bracts lanceolate to linear-lanceolate, long acuminate, nerves 3, lateral branching, about as long as the ovary; perianth dirty yellow, between $\frac{1}{2}$ and $\frac{3}{4}$ in. l. ; spur not more than half as long as ovary, bluntly oblong, apex obtuse, almost wholly adnate to ovary, not more than about $1 \mathrm{~mm}$. free.—S. orchioides Lindl.op. cit. 477 (in part). Helleborine purpurea \&c. Plum. Pl. Amer. (Burm.) 176, t. 181, f. 2. Limodorum lanceolatum Aubl. Pl. Guian. ii. 821 (1775). Satyrium Orchioides Sw. Prodr. 118 (1788). Neottia Orchioides Sw. Fl. Ind. Occ. 1411, t. 28, fig. a. b. (1806). (Pl. 3, f. 22.)

On banks amongst grass; in fl. and fr., March and Apri]; Macfadyen! Distin! Port Royal IIts., Purdie! Fairfield, Wullschlaegel, 1382 (in part)! IIt. Moses, 2500 ft., J.P. 2400, Syme! below Vinegar Hill, Portland, 3000 ft.; Mt. Airy, 2000 ft.; Harris! Fl. Jam. 7876.-Cuba, Bahamas, Hispaniola, Antigua, Guadeloupe, Dominica, Nartinique, St. Lucia, St. Vincent, Barbados, Grenada, Trinidad, Mexico, Guatemala, Colombia, Brazil, Argentine, Paraguay. 
Plant $1 \mathrm{ft} .-2 \mathrm{ft} .4 \mathrm{in}$. high, with thick, clustered roots. Scape erect, somewhat stout, glandular-pubescent above, glabrescent below, $2 \cdot 5 \cdot 6 \cdot 5$ dm. l. Leaves acute, entire, with several nerves and reticulate veins, $7-20$ cm. l., 1·8-2.3 cm. br. ; stalk 1-5 cm. l. (including sheath). Sheaths screral at base, 5 or 6 above; free portion ovate, acute, below, to acuminate, above; glabrous, $2-35 \mathrm{~cm}$. l. Spike erect, short or elongate, glandularpubescent, $4-8 \mathrm{~cm} \mathrm{1.} \mathrm{Bracts} \mathrm{9-13} \mathrm{mm}$. l., to $2.75 \mathrm{~mm}$. br., sparsely glandular-pubescent, and sometimes margin ciliolate. Ovary obovateoblong, very oblique at the apex, slightly glandular-pubescent, or gla brescent. Flowers close together. Sepuls glandular-pubescent outside; lateral 5-nerved, lanceolate, acute, grcatest length about $1.5 \mathrm{~cm}$. 1., length anteriorly about $1 \mathrm{~cm}$. $1 ., 2 \cdot 5-3 \mathrm{~mm}$. br.; median 7-nerved, triangularlanceolate, acute, about $1 \mathrm{~cm} .1 ., 3 \cdot 2-4 \cdot 2 \mathrm{~mm}$. br. Petals 7-nerved, oblong, tapering above middle to apex, subacute, somewhat falcate, about as long as the median sepal, $2 \cdot 2-2 \cdot 75 \mathrm{~mm}$. br. Lip several-nerved, dilated and saccate about the middle; oblong, acute above, below convolute, slightly tapering to base; pubescent below the middle on inside, and on outside on margin, lighter in colour than sepals and petals, $12-14 \mathrm{~mm} .1 ., 3 \cdot 2-4 \cdot 5 \mathrm{~mm}$. br. in middle, $2 \cdot 5 \mathrm{~mm}$. br. in lower portion. Column 6-7 mm. to apex of rostellum; beak of rostellum about $4 \mathrm{~mm}$. 1. Anther sessile at base of column, about $4 \mathrm{~mm}$. 1. Capsule with a few scattered hairs, 1-1.2 cm. 1 , $5 \mathrm{~mm}$. br.

3. S. squamulosus comb. nov. ; plant scurfy with white scales ; leaves wanting during flowering, according to Macfadyen (fide Trisebach) "serotinous, long, broadly lanceolate, pointed"; bracts lanceolate to linear-lanceolate, acuminate, somewhat longer than the ovary, 3-5-nerved with reticulate veins; perianth brick-red colour, $1-1 \frac{1}{4}$ in. l. ; spur about $\frac{2}{3}$ as long as ovary, ovate, apex obtuse, free from ovary near apex, 2-3 mm. free.-S. orchioides Lindl. loc. cit. (in part); Griseb. loc. cit. Neottia squamulosa H. B. \& K. Nov. Gen. \& Sp. i. 332, t. 71 (1815). N. orchioides Sims Bot. Mag. t. 1036 (1807), non Su.; Bot. Reg. t. 701 ; Salisl. Ic. ined. fol. 585. (Pl. 3, f. 21.)

On dry banks; in fl. and fr. April, May; St. Mary; Pedro, St. Ann.; Port Royal Mts.; Purdie! Shepherd! Wilson! Fairfield, Wullschlaegel 1382 (in part)! Liguanea Plain, J.P. 8, Morris! Campbell! Chapelton, Faucett! Cinchona, Harris! Fl. Jam. 10,395, 10,396, 10,410, 10,496.Cuba, Colombia.

Plant 1-2 ft. high, with clustered thick fleshy roots. Scape erect, somewhat stout, scurfy with white scales, $3-6 \mathrm{dm}$. 1. Sheaths several at the base, $5-8$ above, free portion ovate, acute below, acuminate above, sometimes scurfy, $2 \cdot 5-4 \cdot 5 \mathrm{~cm}$. l. Spike erect, long, scurfy, 6-14 cm. l. Bracts scurfy, sometimes with ciliolate margin, 16-23 mm. 1., 3.5-6 mm. br. Ovary oblong, tapering to base and apex, oblique at apex, scurfy. Flowers shortly stalked, crowded towards the apex of the spike. Sepals scurfy outside; lateral 5-nerved, lanceolate, long acuminate, very oblique and decurrent at the base, greatest length $2-2 \cdot 35 \mathrm{~cm} .1 ., 3-3 \cdot 5 \mathrm{~mm}$. br.;

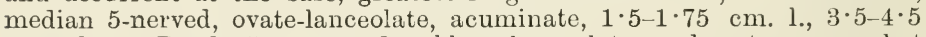
mm. br. Petals 5-7 nerved, oblong-lanceolate, subacute, somewhat falcate, about as long as the median sepal, 2.5-3 mm. br. Lip severalnerved, dilated and saccate about the middle, lanceolate, acumivate, above; below convolute, linear; pubescent below the middle on inside and on outside on margin, $2-2 \cdot 35 \mathrm{~cm}$. $1 ., 5-6 \mathrm{~mm}$. br. in middle. Column about $11 \mathrm{~mm}$. to apex of rostellum. Capsule scurfy, 1·1$1.3 \mathrm{~cm} .1$. 


\section{SPIRANTHES L. C. Rich.}

Terrestrial herbs, roots fibrous or tuberous, stems leafy or the flowering leatless. Leaves linear, ovate or elliptical. Flowers small, secund, in often twisted spikes. Sepals free, subequal, median erect, cohering wich the petals; lateral gibbous at the base. Lip sessile or clawed, erect, concave, embracing the column and often adherent to it, spreading at the apex, entire or 3-lobed, base concave, sometimes with calli inside. Column short, terete, base generally decurrent on the ovary; stigma broad under the rostellum, which is erect, obtuse, or elongate; clinandrium short, margins sometimes raised and continuous with the rostellum. Anther erect, ovate or oblong, 2 celled; pollinia powdery-granular, pendulous from a gland of the rostellum. Capsule ellipsoidal, erect.

Species about 85, widely dispersed! through the north temperate zone and tropical Asia and America to Chile.

Leaves linear or linear-lanceolate, generally decaying before flowering ............ 1. S. tortilis.

Leaves ovate or elliptical, present during flowering.

Leaves all radical ........................2. S. elata.

Leaves radical and along the stem ... 3. S. Fawcettii.

1. S. tortilis L. C. Rich. in Mém. Mus. Par. iv. 59 (1817) (in part, excl. S. quadridentata) ; leaves radical, generally decaying before flowering, linear or linear-lanceolate, erect, clasping at base, elongate; lip shortly clawed, ovate-elliptical, scarcely 3-lobed, slightly cordate at base, emarginate at apex, margin of upper half curled, crenulate, with numerous nerves, median nerve prominent below, with two conical calli at base, green shaded off into white at margin.-Lindl. Gen. \& Sp. Orch. 468; Griseb. Fl. Br. W. Ind. 640 ; Cogn. in Symb. Ant. vi. 342. S. apiculata Lindl. op. cit. 474. Satyrium spirale Sw. Prodr. 118 (1788). Neottia tortilis Sw. in Vet. Handl. Stockh. 1800, 226, d Fl. Ind. Occ. iii. 1406, t. 28, f. g, h. (Pl. 3, f. 1-5.)

On damp shady banks and in pastures; in fl. and fr. March-June; Hollis Savanna, Clarendon; Guy's Hill, St. Mary; Purdie! Fairfield, Wullschlaegel, 1067! Hanover, J.P. 2312, Morris! Cinchona, 4900 ft., Moore! Castleton, $490 \mathrm{ft} .$, Fawcett! Harris! Farm Hill, Miss B. Gosset! below Vinegar Hill, Portland, 3000 ft.; between Cinchona and Morse's Gap, 4900 ft.; Harris! Fl. Jam. 7314, 7853, 9553, 10,495.-Louisiana, Florida, Bermuda, Bahamas, Cuba, Hispaniola, Porto Rico, St. Thomas, Antigua, Guadeloupe, Dominica, Martinique, St. Lucia, Grenada, Trinidad.

Plant $1-1 \frac{1}{2} \mathrm{ft}$. high. Scape erect, slender, sparsely pubescent near apex, glabrous below, 2-4 dm. Leaves striate, smooth, to $3 \mathrm{dm}$. Sheaths 6 or 7 , tubular below, free portion lanceolate, acute, 3-1 cm. 1. Spike erect, 
spirally twisted, somewhat dense, pulerulous, 8-13 $\mathrm{cm}$. l. Fleneers on one side of spike, nodding, white, perianth $\frac{1}{5}-\frac{1}{4}$ in. l. Bracts puberulous, ovate, subacuminate, as long as, or longer than, the ovary, $6-7 \mathrm{~mm} .1$. Orary pubescent, broader above. Sipals slightly pulserulous, white, 3-nerved, lateral oblique at base, oblong tapering to an obtuse apex, $5 \mathrm{~mm}$. 1., ncarly $2 \mathrm{~mm}$. br. ; median elliptical, obtusc, $4.56 \mathrm{~mm} .1 ., 2 \mathrm{~mm}$. br. Petals 3-nerved, oblong, apex rounded, slightly tapering to base, as long as the median sepal, white. Lip $5.5 \mathrm{~mm}$. 1., $3.75 \mathrm{~mm}$. br. Column very short, green; rostellum and clinandrium connected by broad wings, rostcllum on removal of linear gland with pollinia, 2-dentate. Anther ovate, cordate, somewhat acute, sessile, brown. Capsule 4-6 mm. 1., 3-4 $\mathrm{mm}$. br.

2. S. elata L. C. Rich. loc. cit.; leaves glabrous, radical, long stalked, oval, elliptical or oblong, erect, somewhat abruptly acute, tapering somewhat abruptly into the stalks, which are rather Hattish-concare, dilated and clasping at base; lip, lower half somewhat fiddle-shaped with rounded corners, 5-nerved, abruptly contracted above into a neck and then expanding into a roundish or transversely elliptical apical lobe, minutely curled and crenulate, rather broader than the lower half, base slightly saccate with a pair of short calli, white, faintly tinged with pink or with faint tinge of brown at apex and striped with green about middle.-Lindl. op. cit. 470 ; Griseb. op. cit. 641 ; Cogn. op. cit. 336 (excl. syn. Sloane and Browne) \& under S. bicolor Lindl. (as regards Jamaican spec.). Satyrium elatum Sw. Prodr. 119 (1788). Neottia elata Sw. in Vet. Handl. Stockh. 1800, 226 \& Fl. Ind. Occ. 1403 ; Bot. Mag. t. 2026. P. spiranthoides Griseb. Cat. Cub. 269 (1866) (non Lindl. nec Griseb. Fl.). (Pl. 3, f. 10-14.) Type in Herb. Mus. Brit.

On stone walls, on rocky banks and in peaty soil in woodland; in fl. and fr. Feb.-April; Macfayden! Distin! Manchester and St. Ann, Purdie! Bethabara, Wullschlaegel, 1073, 1074! Prior! near Cinchona J.P. 36 ; Portland Gap, 5550 ft. J.P. 235 (somewhat abnormal) ; Mt. MIoses, 2500 ft. J.P. 2191 ; lowlands, J.P. 472; Morris! near Browns Town, Miss T. M. Barrett! Green River, Sullivan! Knapdale, near Browns Town, $1000 \mathrm{ft}$; near Mabess River, $4000 \mathrm{ft}$; near Tweedside, south St. Andrew, $2500 \mathrm{ft}$.; near John Crow Peak, $5500 \mathrm{ft}$; Wallenford, $2500 \mathrm{ft}$; Holly Mount, MIt. Diabolo, $2400 \mathrm{ft}$; Newhaven Gap, 5600 ft. ; between Cinchona and Morse's Gap, $4900 \mathrm{ft}$; ; near Morse's Gap, $4500 \mathrm{ft}$. ; Iron Face, Chester Vale, 3500 ft. ; Harris! Fl. Jam. 7077 (partly), 7631, 7845, 7856, 7857, 7882, 8910, 10,458, 10,492, 10,497.-Bahamas, Cula (Wright 624, 3293 in Herb. Mus. Brit.), Hispaniola, Porto Rico, St. Thomas, St. Croix, Tortola, St. Martin, Antigua, Guadeloupe, Dominica, Grenada, Trinidad, Venezuela, B. Guiana, Brazil, Argentine.

Plant 6 in. to $2 \mathrm{ft}$. high, with clustered, thick, fleshy root-fibres. Scape erect, somewhat slender, pubescent above, glabrate below, $1 \cdot 5-4 \mathrm{dm}$. 1 . Leaves 2-6; blade $3-13 \mathrm{~cm} .1 ., 1 \cdot 5-5 \cdot 5 \mathrm{~cm}$. br. ; stalks $2-7 \mathrm{~cm}$. 1. Sheaths 5-7, free portion oblong-lanceolate, acute or acuminate, $7-1 \mathrm{~cm}$. 1. Spike erect, loosely spirally twisted, sometimes somewhat secund, puberulous, 2-18 cm. 1. F'lowers very shortly stalked, nodding, perianth $\frac{1}{4}-\frac{1}{5} \mathrm{in}$. 1., green or brownish-green. Bracts glabrate, dotted, oblong-lanceolate, acuminate, longer than the ovary, $8-12 \mathrm{~mm}$. l., about $2 \mathrm{~mm}$. br. Ovary 
sparsely puberulous, cylindrical. Sepals green or brownish-green, puberulous, dotted, 1-nerved, slightly gibbous at base; lateral linear-oblong, dilated and oblique at base, slightly falcate, tapering to a somewhat obtuse apex, $5-7 \mathrm{~mm}$. 1., $\cdot 75-1 \cdot 3 \mathrm{~mm}$. br., expanding to $1.5-1.8$ at base; median oblong, tapering to a somewhat obtuse apex, 4.75-6 mm. $1 ., 1 \cdot 3-1 \cdot 5 \mathrm{~mm}$. br. Petals brownish-green or green with pinkish tips, dotted, 1-nerved, oblanceolate with rounded apex, shorter than median sepal, 4-5 $5 \mathrm{~mm}$. 1., $\cdot 6-\cdot 75 \mathrm{~mm}$. br. Lip 5-6.3 mm. 1., 1·6-2.5 mm. br. below; neck about $1 \mathrm{~mm}$. l. and $1 \mathrm{~mm}$. br. Column pubescent on the upper half anteriorly, to base of anther $1-1.4 \mathrm{~mm}$. 1., to apex of rostellum $3 \cdot 2-3 \cdot 6 \mathrm{~mm}$. 1 . Anther ovate-elliptical, subsessile. Capsule 8-9 mm. 1., 4 mm. br.

3. S. Faweettii Cogn. in Fedde Repert. vii. 123 (1909); leaves conspicuousiy 3 -nerved with ascending connecting branches, ovate, sometimes subcordate, obtuse to subacute, long-stalked, glabrous, stalks long, flattish-concave, sheathing at the base ; lip 3-nerved, lateral nerves with 1 or 2 branches, oblong, suddenly contracting near apex and with somewhat square corners there, pilose inside about the middle of oblong part, apical lobe rounded-kidneyshaped, with small crenulations on margin, striped with green.Sauroglossum tenue Lindl. in Ann. \& Mag. Nat. Hist. (1858) 334 ; Griseb. op. cit. 642. (Pl. 3, f. 6-9.)

In shade, in leaf-mould in woods and amongst mosses on rocky banks; in fl. and fr. April ; Pedro, St. Ann, Purdie! near Mabess River, 3500 ft.; Cascade, $3000 \mathrm{ft} ., 2500 \mathrm{ft}$; ; between Cinchona and Morse's Gap, $4900 \mathrm{ft}$. ; Harris! Fl. Jam. 7877, 7879, 10,493.-Cuba, Porto Rico.

Plant $2 \frac{1}{2}-8 \frac{1}{2}$ in. high, leafy in the lower portion, with few sheaths, and tuberous roots. Scape erect, somewhat weak, pubescent above, glabrous below, 4-16 cm. 1. Leares, blade 1.5-3.5 cm. 1., 1-2 cm. br.; stalks $1.5-4$ $\mathrm{cm}$. 1. Sterile sheathing bracts generally $3(2-4)$, loose, free part lanceolate, acuminate, $2-2 \cdot 5 \mathrm{~cm}$. 1. Spike erect, short, pubescent, $1-3 \mathrm{~cm}$. l. Flowers sessile, erect or spreading, perianth about $\frac{1}{3}$ in. 1., greenish-white. Bracts oblong-subulate, 1-nerved, glabrous, dotted, as long as, or a little longer than the ovary, the lower $1.2 \mathrm{~cm}$. l., nearly $3 \mathrm{~mm}$. br. Ovary linearoblong, slightly pubescent towards the apex, $7 \mathrm{~mm}$. l. Sepals pubescent at the base, greenish-white; lateral linear, spathulate, with one nerve which is slightly prominent on the outside, oblique and somewhat gibbous at the base, free, dotted, about $8 \mathrm{~mm}$. l., about $1 \mathrm{~mm}$. br., $1.4 \mathrm{~mm}$. near apex; median oblong, with obtuse apex, 1-nerved, dotted, about $8 \mathrm{~mm} .1$., $1.6 \mathrm{~mm}$. br. Petals linear-spathulate, dilated at base, acute, with margin slightly denticulate near apex, somewhat shorter than median sepal, striped with brown, nearly $8 \mathrm{~mm}$. $1 ., 5 \mathrm{~mm}$. br., $\cdot 75 \mathrm{~mm}$. br. near apex. Lip about $9 \mathrm{~mm}$. 1., $2 \mathrm{~mm}$. br., apical lobe nearly $4 \mathrm{~mm}$. br. Column long, about $4 \mathrm{~mm}$. 1. to junction of anther, about $6 \mathrm{~mm}$. to apex of rostellum; rostellum with 2 acuminate membranous lobes. Anther subsessile. Capsule about $1 \mathrm{~cm} .1$.

\section{ERYTHRODES Blume.}

Terrestrial leafy herbs. Roots thickish, clustered at base of stem and from the nodes in the lower part of the stem. Stem ascending or erect, simple, sometimes prostrate and rooting in the lower portion, often pubescent above. Leaves stalked, ovate 
ol lanceolate, membranous, with many converging nerves with nettel veins. Flowers small or minute, subsessile, in a lax or dense terminal spike which is often elongate. Sepals subequal, free, erect or somewhat spreading. Petals cohering with the median concave sepal. Lip erect from the base of the column which it embraces, produced beiow into a descending obtuse spur. Column short; stimma at the base of the erect rostellum. Anther erect, slrortly acuminate, cells contiguous, distinct; pollinia granular, pendulous from an oblong gland of the rostellum, which is deeply 2-fid on the fall of the pollinia. Capsule oblong or ellipsoidlal.

Species about 60, natives of the warmer regions of America and Asia.

The name Erythrodes (Blume Bijdr. Flor. Ned. Ind. 410, t. 72, 18:5) must be adopted for this genus,-Physurus (I. C. Rich. in Mém. Mus. Par. iv. 55, 1818) being a nomen nudum. WVe cannot follow Schlechter (Schum. \& Lauterb. Nachtr. Fl. Deutsch. Südsee, 87) in separating as Erythrodes the Old World species as a distinct genus from the species of the New World. His distinction rests on the bilobed character of the spur in the Old World species, which in our opinion is insufficient. The habit of the species from both hemispheres is similar, and the general structure of the flowers also closely corresponds. In the West Indian species, $\boldsymbol{E}$. plantaginea, the spur sometimes shows an indication of lobing in a slight median depression.

Perianth, including spur, about $\frac{1}{3} \mathrm{in.} 1$.

Perianth, including spur, abcut $\frac{1}{5}$ in. 1 .

Plant more or less hairy (except leaves).

Lip with a lunate apical lobe..........2. 2. E. hirtella.

Plant glabrous. Lip with a roundish $3-$

lobed apex, the middle lobe long and

narrow...................................... 3. E. jamaicensis.

1. E. plantaginea comb. nov.; stem trailing along the ground, attaining a length of $6 \mathrm{ft}$. and emitting roots at the nodes like Vanilla, stout, leafy and glabrous below, slender, hairy, and with a few scales above; leaves glabrous, oval-elliptical, shortly acuminate, tapering into the stalk, sometimes the uppermost leaf much smaller in transition to the sheaths; lip oblong, concave, enclosing the column, with an apical, ovate, often crenulate lobe (but the lip appears to be sometimes undivided), $\tilde{5}-\bar{\tau}$-nerved.-Physurus plantagineus Lindl. Gen. \& Sp. Orch. 503 (1840); Griseb. Fl. Br. W. Ind. 643; Cogn. in Symb. Ant. ri. 346. Orchis elatior ic. Sloane Cat. 119 it Hist. i. 250. t. 147, f. 2. Satyrium plantagineum L. Syst. ed. 10, 1244 (1759); Sw. Obs. Bot. 320 ; Salisb. Ic. ined. fol. 585. Orchis plantaginea Sw. in Vet. Handl. Stockil. xxi. 207 (1800). (Pl. 3, f. 15.) 
In damp soil in woods; in fl. and fr. Nov.-April ; Mt. Diabolo, Sloane Herb. iv.116! Hector's River, Manchester, Purdie! Fairfield, Wullschlaegel, 1072 ! Mt. Moses, 2500 ft. J.P. 2034, Syme! John Crow Peak, Moore! IIt. Diabolo, Fawcett \& Harris! near Mabess River, 3000 ft.; Moody's Gap, 3000 ft. ; near Woodcutter's Gap, 4000 ft. ; Morse's Gap. 5000 ft. ; near Hardware Gap, 4200 ft. ; Harris! Fl. Jam. 7175, 7573, 7837, 7875, 7886, 9794, 10,101, 10,129. - Cuba, Porto Rico, Saba, St. Eustatius, St. Kitts, Guadaloupe, Dominica, Martinique, St. Vincent, Grenada, Trinidad.

Plant, erect portion 1 to $2 \mathrm{ft}$. high. Stem, erect portion $3-6 \mathrm{dm} .1$. Leaves, blade 6-12 cm. 1., 3-5.5 cm. br. Sheaths tubular below, free part triangular, shortly acuminate, 3-nerved, glabrous, $2 \cdot 5-1 \mathrm{~cm}$. 1. Spike hairy, with numerous flowers, cylindrical, 5-17 cm. l. Bracts triangular, acuminate, hairy, 1-nerved, concave, lower $1 \mathrm{~cm}$. 1.; becoming smaller upwards. Flowers white (including spur), about $\frac{1}{3}$ in. 1 . Ovary tapering downwards, shcrtly stalked, very hairy, (with stalk) 6.5-8 mm. 1. Sepals oblong to oblong-lanceolate, obtuse, 1-nerved, hairy; lateral slightly oblique, $6-7 \cdot 5 \mathrm{~mm}$. 1., 1.6-1.9 mm. br. ; median 6-7 mm. $1 ., 2 \cdot 5 \mathrm{~mm}$. br. Petals oblanceolate-linear, obtuse or acute, slightly oblique, rounded at base, 1-nerved, as long as the median sepal, maximum breadth $1.5 \mathrm{~mm}$. Lip about $5.5 \mathrm{~mm}$. 1., $2 \mathrm{~mm}$. br. Spur ellipsoidal, not as long as ovary, 3.5-5 mm. 1., 1.6-2 mm. br. Column (including rostellum) about $4 \cdot 5$ mm. l. Capsule ellipsoidal, with 6 shallow keels, $8 \mathrm{~mm}$. 1., $3 \mathrm{~mm}$. br.

2. E. hirtella comb. nor.; stem somewhat sparsely pilose, with several leaves crowded at the base; leaves glabrous, ovate to lanceolate, tapering into the stalk, the leaves near the middle the largest, those above and below smaller; lip oblong, with an apical lunate lobe, apex mucronate.-Physurus hirtellus Lindl. op. cit. 501 (1840); Griseb. op. cit. 642; Cogn. in Symb. Ant. vi. 347. Satyrium hirtellum Sw. Prodr. 118 (1788). Orchis hirtella Sw. in Vet. Handl. Stockh. xxi. 207 (1800) \& Fl. Ind. Occ. iii. 1394 (1805). (Pl. 3, f. 16-19.)

In damp places in woodland; in A. and fr. April ; Macfadyen! March! Mit. Moses, 2500 ft., J.P. 2107, Syme! near Mabess River, 3000 ft., Harris ! Fl. Jam. 8110 (fide Cogn.) 9010.-Cuba, Porto Rico, St. Eustatius, Guadeloupe, Dominica, Iartinique, St. Lucia, St. Vincent, Grenada, Trinidad.

Plant 9-12 in. high. Stem 2-2.5 dm. 1. Leaves 5-6 cnı. 1., 1.5-2.5 $\mathrm{mm}$. br. Sheaths 2-3, tubular below, free part oblong, acute, 1-2 cm. l., glabrous. Spike hairy, many-flowered, less than $4 \mathrm{~cm}$. l., elongating in fruit to $15 \mathrm{~cm}$. Flowers white, shortly stalked, erect-spreading, (including spur) about $\frac{1}{5}$ in. 1 . Bracts lanceolate, acuminate, $4-6.5 \mathrm{~mm}$. l. Ovary somewhat clavate, hairy, including stalk $6 \mathrm{~mm}$. l. Sepals 1-nerved, ovateoblong, obtuse, sparsely hairy, green tipped with white, $3.5 \mathrm{~mm}$. l. ; lateral $1 \mathrm{~mm}$. br., median broader. Petals linear-oblanceolate, obtuse, 1-nerved, $3 \mathrm{~mm}$. l., about $75 \mathrm{~mm}$. br. Lip about $3 \mathrm{~mm}$. 1. Spur oblong, $1.5 \mathrm{~mm}$. 1 . Capsule oblong, tapering to base, 6-keeled, sparsely hairy, $8 \mathrm{~mm}$. 1., $2 \cdot 5-3 \mathrm{~mm}$. br.

3. E. jamaicensis comb. nov.; stem glabrous, leafy nearly to apex ; leaves lanceolate, acute, stalked, highest leaf quite small, succeeded by one or two scarious bract-like sheaths ; lip 3-nerved, constricted below the middle, upper portion broadly roundish in outline, 3-lobed, lateral lobes somewhat semicircular, middle lobe 
subulate, lower portion somewhat ovate, very eoncave, somewhat cordate at base. - Physurus jamaicensis Fance d: Rendle in Journ. Bot. xlvii. $26+$ (1909). (I'1. :3, f. 20.)

In shady woods; in 11. Oct.; Olive River, near Christiana, 3000 ft., Harris! Fl. Jam. 10,472.

Plunt glabrous, about 8 in. high. Stem about $1 \frac{1}{2} \mathrm{dm} .1$. Leaves, blade 3.5-5 cm. 1., 11-16 mm. br. ; stalk with sheath 7-17 mm. 1. ; highest leaf, blade $1 \cdot 2-1 \cdot 7 \mathrm{~cm} .1$. Spitie many-flowered, cylindrical, about $4 \mathrm{~cm}$. 1 . Bracts ovate-triangular, acuminate, 1-nerved, as long as the ovary, 6-4 mm. l. Ovary slender. Flowers spreading, (with the spur) about 1 in. 1. Sepals spotted, 1-nerved; median lanceolate, obtuse, margin undulate above the middle, concave, $3.2 \mathrm{~mm}$. $1 ., 1 \mathrm{~mm}$. br.; lateral oblong-elliptical, obtuse, slightly falcate, $3 \cdot 4 \mathrm{~mm}$. 1., 1-1.1 mm. br. Petals spotted, 1-nerved, linear-lanceolate, margin undulate, $3.1 \mathrm{~mm}$. $1 ., 75 \mathrm{~mm}$. br. Lip, middle portion about $1.4 \mathrm{~mm}$. l., $1.6 \mathrm{~mm}$. br., middle lobe $.75 \mathrm{~mm}$. l., lower portion about $1 \mathrm{~mm}$. l. Spur roundish-elliptical, about half as long as ovary, $1.6-1.8 \mathrm{~mm}$. l., $1-1.3 \mathrm{~mm}$. br.

\section{WULLSCHLÆGELIA Reichb. f.}

Terrestrial leafless herb, with clustered fibrous roots slightly thickened. Stem simple, very slencler, with a few small scales. Flowers very small, subsessile in a lax spike. Bracts very small. Sepals thin, erect, connivent ; median free ; lateral a little broader, united at the base into a saccate chin. Petals similar to the median sepal, but smaller. Lip on the upper side of the flower, sessile at the base of the column, erect, broad, concave, undivided, produced at the base into a sac within the chin of the sepals. Column very short; stigma entire, beneath the short broad erect rostellum; clinandrium short. Anther erect, sessile, ovate, scarcely acuminate, with distinct cells ; pollinia powderygranular, affixed to a small gland of the rostellum. Capsule small, ovoid, erect.

Species 3, natives of the West Indies and Brazil.

W. aphylla Reichb. f. in Bot. Zeit. (1863) 131 ; Griseb. Fl. Br. W. Ind. 639 ; Cogn. in Fl. Bras. iii. pt. 4, 242, t. 57, f. 1 ; \& in Symb. Aut. vi. 351.-Cranichis aphylla Sw. Prodr. 120 (1788), \& Fl. Ind. Occ. iii. 1421, t. 29, f. 1, \& Ic. ined. t. 21 ; Lindl. Gen. \& Sp. Orch. 450. (Pl. 3, f. 23, 24.) Type in Herb. Mus. Brit.

In damp deep-shady woods ; in fl. Sept., Oct.; mountains of Clarendon, Swartz! Bethabara, Wullschlaegel, 1071! St. Ann, Purdie!-Cuba, Dominica, Brazil, Paraguay.

Plant 8-14 in. high, with numerous, very long roots, thickened near base. Stem erect, slender, leafless, puberulous, 16-24 cm. l., with numerous minute scales. Scales triangular-lanceolate, acuminate, half-clasping, 4-5 mm. 1. Raceme somewhat long, many-flowered, 4.5-13 cm. 1. (in fruit). Pedicels $2 \mathrm{~mm}$. to $3 \mathrm{~mm}$. l. (in fruit). Bracts similar to the scales, 
$3 \mathrm{~mm}$. l. Flowers very small, pale white, erect, somewhat spreading. Ovary 3-1 mm. 1., thicker upwards, puberulous, hairs bifurcate, composed of 3 cells, one of which is the stalk, the other two, forming the fork, are clarate. Sepals sparsely puberulous, median oblong, concave, 1.75 $\mathrm{mm}$. 1.; lateral transversely elongated, oblate, with subacute apex, asymmetrical, greatest length about $3.5 \mathrm{~mm}$., 1.5 mm. br. Petals oblong, obtuse, $1.75 \mathrm{~mm}$. 1. Lip incumbent, oblong, conduplicate-concave, $3 \mathrm{~mm}$. 1. Column with a long foot; clinandrium cup-shaped. Capsule 5-7 mm. 1., 3-3.5 mm. br.

\section{PSEUDOCENTRUM Lindl.}

Terrestrial, tall herbs; rhizome short with clustered fleshy roots. Stems leafy, simple, erect. Leaves several, radical, longstalked, membranous; a few on the stem, reduced above to sheaths. Flowers of medium size, numerous, almost sessile on a long spike. Bracts membranous. Sepals, median free, narrow, incurved; lateral shorter, broader, connate at the base and produced into a very long cylindrical ascending spur. Petals narrow, free. Lip turned upwards, adnate to the base of the column, produced anteriorly into a long narrow channelled process, inclosed in the sepaline spur with apex inflexed and saccate, auriculate with two erect lobes near the column. Column very short; rostellum erect, broadly membranous, acuminate in the middle, with the deeply-hollowed stigma at the base; clinandrium short, membranous-dilated, the margins continuous with the rostellum. Anther erect on the margin of the clinandrium, ovate, with contiguous cells; pollinia oblong, powdery-granular, pendulous from a terminal gland of the rostellum. Capsule ellipsoidal.

Species 5, natives of Jamaica, Central America, and the Andes of South America.

P. minus Benth. in Hook. Ic. Pl. xiv. 63, t. 1382 (1882); Cogn. in Symb. Ant. vi. 352. (Pl. 4.) Type in Herb. Kew.

In shady places; in fl. Sept.-Oct., in fr. Feb.; Portland Gap, $5400 \mathrm{ft}$., J.P. 228, Morris! Morse's Gap; near John Crow Peak, 5000 ft.; between Newhaven Gap and Vinegar Hill, 5500 ft.; Harris! Fl. Jam. 6058, 7756, 10,088 .

Plant 1-2 ft. high. Stem stout, glabrous, 3-4 dm. 1. Leaves radical, elliptical to lanceolate-oblong, tapering to an acute or shortly acuminate apex, glabrous, blade 10-14 cm. l., 3-6 cm. br., one or two higher up much smaller. Spike dense, $8-21 \mathrm{~cm}$. 1. Bracts 1-3-nerved, ovate-lanceolate, acuminate, glabrous, $1-1.5 \mathrm{~cm}$. l. Ovary narrowly cylindrical, somewhat densely covered with several jointed pellucid hairs, $10-12 \mathrm{~mm}$. 1 . Sepals sparsely pilose on the outside, median oblong-lanceolate, 5.5-6 mm. 1., $1.5 \mathrm{~mm}$. br.; lateral, spur somewhat longer than the ovary, $15 \mathrm{~mm}$. l., the limb connate half way, each sepal semicircular, with an obtuse apex. Petals oblanceolate-oblong, apex acute, half as long as the median sepal. Column $1 \mathrm{~mm}$. l. Capsule $1.5 \mathrm{~cm}$. 1 . 


\section{CRANICHIS Niw.}

Terrestrial herls, with roots somewhat clustererl. Leaves radical, broad, spreading, membranous, many-nerverl, reticulately veined, with long stalks, flattish, sheathing at hase. Ficape gencrally slender, simple, with a fow sheaths. Flowers small, in a spike. Bracts short or narrow. Sepals free, subequal, more or less connivent. Petals a little shorter than the sepals, and less than half as broad, spreading, free from the column. Lip on the upper side of the flower, sessile or shortly clawed at the base of the column, erect, concave, embracing the column, undividerl. Column short; rostellum anıple, erect, often longer than the column, posteriorly (towards the anther) concave and 2-winged; stigma anterior, near the apex; clinandrium short. Anther on the margin of the clinandrium, sessile or stalked, erect, parallel to the rostellum and somewhat shorter than it, with distinct cells; pollinia powdery-granular, acuminate, pendulous from a gland of the rostellum. Capsule erect, ovoid or oblong.

Species about 30, natives of the West Indies, Mexico, and the Andes of tropical America.

Sheaths foliaceous on scape, leaves 4-6 ....... 1. C. muscosa. Sheaths not foliaceous, leaves 1 or 2 .

Leaves ovate, cordate: petal glabrous ...2. C. diphylla.

Leaves roundish-ovate, sub-cordate; petals hairy on margin ................... 3. C. pilosa.

1. C. muscosa Siv. Prodr. $12 n$ (1788); glabrous; sheaths foliaceous, passing into lracts above; leaves few (4-6), and often one just above base, oval, oval-roundish, elliptical or ovate, acute or obtuse; petals narrowly linear-lanceolate, obtuse to subacute, glabrous, white.-Sw. Fl. Ind. Occ. 1429, t. 29, f. 3, \& Ic. ined. t. 25 ; Lindl. Gen. \& Sp. Orch. 451 ; Griseb. Fl. Brit. W. Ind. 639 ; Cogn. in Symb. Ant. vi. 354 ; Ames Orch. S. Fla. 14, t. 3. Type in Herb. MIus. Brit.

On damp shady banks, in fl. Nov.-Feb.; Shakespear! Swartz! Wiles! Bancroft! ITacfayden! IIcNab! Ponds, St. Elizabeth; Woodside, St. Mary; Hectors River, Manchester, Purdie! Wilson! Fairfield, Wullschlaegel 1070! Prior! J.P. 2068, Morris! Mt. Moses, J.P. 2068, Syme! below Whitfield Hall Works, Sullivan! near Morse's Gap, $4500 \mathrm{ft}$; near Vinegar Hill, $4500 \mathrm{ft}$., $3950 \mathrm{ft}$.; Tweedside, $3000 \mathrm{ft}$.; Silver Hill Gap, 3800 ft. ; Moody's Gap, 3000 ft.; Troy, 2000 ft.; Harris! Fl. Jam. 7469, 7551, 7563, 7800, 10,093, 10,660.-Florida, Cuba, Porto Rico, St. Kitts, Dominica, Martinique, St. Vincent, Grenada, Trinidad.

Plant $\frac{1}{2}-1 \mathrm{ft}$. high. Scape $15-30 \mathrm{~cm}$. 1. Leaves, blade $4-7 \mathrm{~cm}$. 1 ., $2 \cdot 5-3 \cdot 5 \mathrm{~cm}$. br.; stalks $2-6 \mathrm{~cm}$. 1. Sheaths, blade roundish-oval, obtuse, near base of stem, to lanceolate, acuminate, above, $3 \cdot 5-\cdot 75 \mathrm{~cm}$. 1 . Spite dense-flowered, $3-5 \mathrm{~cm}$. 1. Flowers white, perianth about $\frac{1}{10} \mathrm{in} .1$. Bracts triangular-ovate or lanceolate, acute or acuminate, 1-nerved, shorter than the ovary, $4 \mathrm{~mm}$. l. Ovary $5 \mathrm{~mm}$. l. Sepáls, median narrowly ovate-oblong, obtuse, 1-nerved, $2 \cdot 6 \mathrm{~mm}$. 1., $1.3 \mathrm{~mm}$. br.; lateral broadly semi-ovate, somewhat acute or obtuse, 2-nerved, 2.7- 
$3 \mathrm{~mm}$. 1., $1.6 \mathrm{~mm}$. b. Lip sessile, roundish in outline, obtuse, with two lateral folds near the base, $2 \cdot 6-2 \cdot 8 \mathrm{~mm}$. l., white, spotted with green. Column (including rostellum) $1.5 \mathrm{~mm}$. l., dilated above, towards the anther concave and broadly 4-winged, wings broader above, apex of rostellum obtusely pointed; stigma somewhat roundish. Anther stalked, nearly as high as apex of rostellum. Capsule ellipsoidal, with six shallow keels, 7-8 mm. 1., 3-4 mm. br.

2. C. diphylla Sw. Prodr. 120 (1788); glandular-pubescent above; leaves generally 2 , sometimes 1 or 3 , one smaller, ovate, cordate, shortiy acuminate or acute; petals oblanceolate, obtuse, glabrous, white.-Sw. Fl. Ind. Occ. 1423 ; Lindl. Gen. \& Sp. Orch. 450 ; Griseb. op. cit. 639 ; Cogn. in Symb. Ant. vi. 357. Type in Herb. Mus. Brit.

In peaty soil on damp shady banks; in fl. and fr. Dec.-Feb.; Swartz! MIt. Moses, 3000 ft., J.P. 2440, Syme! Morse's Gap; Stony Hill, J.P. 477; Morris! Morse's Gap, 5000 ft., C. Nicholls! Fawcett! Morse's Gap; near Mabess River, 4000 ft.; Clydesdale, 4000 ft. ; Harris! Fl. Jam. 7555, 7557, $7855,9797,10,080$.

Plant 4-14 in. high. Scape slender, 10-40 cm. 1., about $1 \mathrm{~mm}$. br. Leaves, blade $2 \cdot 5-6 \cdot 5 \mathrm{~cm}$. 1., 1-3 cm. br.; stalk, 1-3 cm. 1. Sheaths several (4 or 5), linear-lanceolate, shortly acuminate, $2 \cdot 5-1 \mathrm{~cm}$. 1 . Spike lax-flowered, glandular-pubescent, $1-6 \cdot 5 \mathrm{~cm}$. l. Flowers greenish-white or green, perianth about $\frac{1}{10}$ in. l. Bracts ovate, acuminate, 1-nerved, with a few glandular hairs, much shorter than the ovary, $3-4 \mathrm{~mm}$. l. Ovary spindle-shaped, glabrous or with occasional glandular hairs, $5.5 \mathrm{~mm}$. 1 . Sepals oval, obtuse, 1-nerved, $2.5 \mathrm{~mm}$. 1., 1.3 mm. br.; lateral slightly shorter and broader than the median. Petals a little shorter than the median sepal, $\cdot 6 \mathrm{~mm}$. br. Lip very slightly keeled posteriorly, sessile, roundish in outline, obtuse, 3-nerved, with 2 lateral folds near the base, about $2 \mathrm{~mm}$. 1., greenish-white spotted with green. Column (including rostellum) $1.5 \mathrm{~mm}$. l., on the posterior side towards the anther concave and winged, with a long acuminate apex to the rostellum; stigma roundish. Anther stalked, slightly shorter than the rostellum. Capsule ellipsoidal, slightly 3-keeled, 6-7.5 mm. l., $3 \mathrm{~mm}$. br.

3. C. pilosa Fawc. \& Rendle in Journ. Bot. xlvii. 265 (1909); glandular-pubescent above; leaves 1 or 2 , roundish-ovate or roundish, subcordate, acute; petals linear, acute, margins pilose, light pink with white hairs or pale reddish-brown. (Pl. 5, f. 1-3.) Type in Herb. Mus. Brit.

In damp shady places; in fl. Nov., April; John Crow Peak, 5500 ft., J.P. 240, Syme! Morse's Gap, 5000 ft.; Vinegar Hill, Portland, 3000 ft.; Cascade, $3000 \mathrm{ft}$; near John Crow Peak, $5800 \mathrm{ft}$; between Cinchona and Morse's Gap, 4900 ft.; Harris! Fl. Jam. 7749, 10,503.

Plant 4-10 in. high. Scape 10-25 cm. l. Leaves, blade $4-10 \mathrm{~cm} .1 .$, $2 \cdot 5-7 \cdot 5 \mathrm{~cm}$. br.; stalks $1 \cdot 5-3 \mathrm{~cm}$. 1. Sheaths $(1$ or 2$)$ scarious, below the leaves, and several (5 to 9) loose, elliptical, shortly acuminate, $3-1 \mathrm{~cm} .1$. Spike dense-flowered, glandular-pubescent, 1-2 cm. l. Flowers greenish tinted with pink, perianth about $\frac{1}{8}$ in. 1 . Bracts as long as, or shorter than, the ovary, 4-7 mm. l., ovate, acuminate, 3-nerved, with short lateral nerves, glabrous, green or white. Ovary spindle-shaped, broadest below the middle, glabrous, greenish or white, 6-7 mm. 1 . Sepals 3-nerved, oval, very shortly acuminate, greenish below, flesh-coloured in the upper half, 
or greenish tinted with umber; median $3 \cdot 5-4 \mathrm{~mm}$. 1., 1.5-2 $\mathrm{mm}$. br.; lateral $3 \cdot 2-3 \cdot 5 \mathrm{~mm} .1 ., 1 \cdot 5-2 \mathrm{~mm}$. br. Lip shortly and broadly clawed, broadly ovate, strongly 3-nerved, the lateral nerves with descending branches on the outer side, with a narrow triangular apex, $2 \cdot 6-2 \cdot 8 \mathrm{~mm} .1$, $2 \mathrm{~mm}$. br., white tinted with green outside and pink inside, or white with reddish markings. Column white, tinted, $1.5 \mathrm{~mm}$. l., on the posterior side towards the anther winged at the base, wings broadest below, with small wings on the sides at the base, with a rather long capitate rostellum; stigma roundish. Anther very shortly stalked. Capsule (not ripe) spindleshaped, about $1 \mathrm{~cm} .1$.

\section{STENOPTERA Presl.}

Epiphytic herb; rhizome short with clustered fleshy roots. Stem leafy, simple, with a sheath above the leaves. Leaves crowded at the base of the stem, tapering into a short clasping stalk. Flowers very small in a dense ovoid bracteate spike. Perianth united below to form a tube, which is attached to back of the column. Sepals free above, incurved, somewhat erect, median shorter. Petals shorter than the sepals. Lip on the upper side of the flower, erect from the tube. Column straight, grooved anteriorly, not winged ; rostellum erect, ample, conical, with a broad stigma at the base; clinandrium with membranous sides which are connate with the margins of the rostellum into a cup. Anther erect on the margin of the clinandrium, roundish-ovate, cells contiguous ; pollinia powdery-granular, on the dehiscence of the anther remaining attached to the apex of the rostellum. Capsule oblong, erect.

Species 8 or 9 , natives of the mountains in tropical America from the West Indies to Brazil and Peru.

S. ananassocomos Reichb. f. in Bot. Zeit. xxi. 131 (1863); Griseb. Fl. Br. W. Ind. 640 ; Cogn. in Fl. Bras. iii. pt. 4, 254, \& in Symb. Ant. vi. 358. (Pl. 5, f. 5, 6.)

On trees, pendent; in fl. March ; Beaufort, Wullschlaegel, 1077 ! Prior ! Iron River, Golden Spring, 900-2500 ft., J.P. 2283, Syme!-Cuba, Brazil, Venezuela.

Plant very small, about $1 \frac{1}{2}$ in. 1 . Leaves elliptical, acute, ciliate, with 3 branching nerves, fleshy, semi-transparent, waxy, 1.5-2.5 c.m. 1., 7-11 mm. br. Scape erect, densely clothed with short hairs, as long as the leaves. Spike very short, capitate, many-flowered (5-11 or more), 6-10 mm. 1. Bracts ovate, acuminate, glabrous, margin ciliate or fimbriate, longer than the flowers, $8-10 \mathrm{~mm}$. l., about $5 \mathrm{~mm}$. br. Sepals lanceolate, 1-nerved, with short hairs at apex and at back, lateral $5 \mathrm{~mm}$.1., median shorter. Pctals oblanceolate, adhering to, and shorter than, the median sepal. Lip similar to petals, shorter than lateral sepals. Column $3.5 \mathrm{~mm}$. 1 . 


\section{PRESCOTTIA Lindl.}

Terrestrial herbs, roots clustered on a rhizome, fibrous, sometimes fleshy; stem leafy, slender or tall, simple, with several sheaths above the leaves. Leaves crowded at the base of the stalk or radical, sessile or with long stalks, small or ample, membranous. Flowers small, sometimes very small, numerous in a thick or slender spike, subsessile. Bracts shorter than the flower. Sepals membranous, connate at the base in a short cup or a somewhat long tube, at the apex spreading or generally revolute. Petals narrow, thin, adnate to the sepaline cup just above the median sepal. Lip on the upper side of the flower ; claw adnate to the sepaline cup, blade erect, broad, somewhat fleshy, very concare, arched, hooded or almost closed, at the base 2-auriculate, often enclosing the column. Column very short, adnate to the sepaline cup; stigmatic surface beneath the broad, membranous, retuse rostellum; clinandrium erect, acuminate or produced, as it were, into a filament, margins connate with rostellum. Anther erect on the margin or point of the clinandrium, generally short, with cells diverging; pollinia powdery-granular. Capsule small, erect, ovoid or oblong.

Species about 32, natives of tropical America from the West Indies and Mexico to Brazil and Ecuador.

Flowers green; sepals revolute; lip $4 \mathrm{~mm}$. 1. ..... 1. P. stachyodes. Flowers white or rosy, minute; sepals connivent;

lip $1 \mathrm{~mm} .1$.

2. P. oligantha.

1. P. stachyodes Lindl. in Bot. Reg. sub. t. 1915 (err. typ. 1916) (1836) ; leaves large, long-stalked ; flowers green, changing to a tawny yellow ; sepals revolute, narrowly oblong; lip long, $4 \mathrm{~mm}$. 1.-Lindl. Gen. \& Sp. Orch. 454 . P. myosurus Reichb. $f$. in Griseb. Fl. Br. W. Ind. 639 (1864); Cogn. in Mart. Fl. Bras. iii. pt. 4, 258, t. 61, \& in Symb. Ant. vi. 359. Cranichis stachyodes Sw. Prodr. 120 (1788), Fl. Ind. Occ. 1427, t. 29, f. 4, \& Ic. ined. t. 24. Type in Herb. MIus. Brit.

On stony ground or peaty soil in damp shady places ; in fl. and fr. Nov.Feb.; Blue MIts., Swartz! Macfadyen! Christiana Woods, Manchester, Purdie! Tiddenham, St. Ann, Prior! Blue Mts., J.P. 234, Morris! Morse's Gap, $4900 \mathrm{ft} .$, Fawcett! Moore! Harris! near Mabess River, 3000-4000 ft.; near John Crow Peak, $5800 \mathrm{ft}$. ; ridge below Vinegar Hill, $3800 \mathrm{ft}$. ; road to Vinegar Hill, 4500 ft.; Harris! Fl. Jam. 7553, 7556, 7572, 7750, 7769, $7846,10,094$ (partly), 10,096, 10,408, 10,480, 10,481.-Cuba, Hispaniola, Porto Rico, St. Eustatius, Guadeloupe, Dominica, Martinique, St. Vincent, Trinidad, Costa Rica, Guatemala, Colombia, Brazil.

Plant 1-2 ft. high. Stem slender or stout, with several radical leaves, invested by numerous, membranous sheaths, $2-6 \mathrm{dm}$. l. Leaves broadly oval, ovate or elliptical, shortly acuminate, base sometimes subcordate, tapering into the stalk, entire or minutely crenulate, veins slightly prominent on the under surface, blade $7-14 \mathrm{~cm}$. $1 ., 3 \cdot 5-8 \mathrm{~cm}$. br.; stalks 
slender, narrowly winged, $2-17 \mathrm{~cm}$. l. Sheaths at base of stem, few, scarions, loose, and soon decaying. Cauline sheaths loose, tubular below, free part triangular, acuminate, with several nerves and branching veins, 4.5-1.5 cm. 1. Spike long, crowded with flowers, to 10 or $12 \mathrm{~cm}$. 1 . Bracts elliptical, acuminate, 1-nerved, glabrous, as long as, or longer than, the ovary, $6 \cdot 5-8 \mathrm{~mm}$. 1., 1.7-2.5 mm. br. Ovary obovoid-oblong, glabrous. Sepals obtuse, 1-nerved; lateral slightly falcate, free part 3.1-3.4 mm. 1., 1-1.3 $\mathrm{mm}$. br.; median, free part $2 \cdot 5-2.9 \mathrm{~mm}$. l., $1 \mathrm{~mm}$. br. Petals revolute, narrowly linear, obtuse, 1-nerved, as long as the median sepal, $.4 \mathrm{~mm}$. br. Lip projecting much beyond the revolute sepals, upper margin rolled in; nerves 7 , branching; $3 \cdot 2 \mathrm{~mm}$. br.; auricles linear, about $\cdot 5 \mathrm{~mm}$. br. Capsule ellipsoidal, with six shallow keels, about $1 \mathrm{~cm} .1$., $3.5 \mathrm{~mm}$. br.

2. P. oligantha Lindl. Gen. \& Sp. Orch. 454 (1840); leaves small, short-stalked; flowers white or rosy; sepals erect, roundish; lip short, $1 \mathrm{~mm}$. 1.-Cogn. in. Symb. Ant. vi. 360. Cranichis oligantha Sw. Prodr. 120 (1788), Fl. Ind. Occ. 1425, t. 29, f. 2 \& Ic. ined. t. 23. Prescottia myosurus Reichb. $f$. in Griseb. Fl. Br. W. Ind. 640 (1864). (Pl. 5, f. 4.) Type in Herb. Mus. Brit.

On damp shady banks; in fl. and fr. March; Blue Mits., Swartz! Orange Bay, Hanover, Purdie! St. Ann, Prior! Stony Hill, J.P. 471 (2606) Syme! Mt. Moses, J.P. 2156, Morris! near Cinchona, 4500 ft.; Clydesdale $4000 \mathrm{ft}$. ; Tweedside, south St. Andrew; Morse's Gap $4900 \mathrm{ft}$; Harris! Fl. Jam. 7612, 7844, 7856A, 10,094 (partly).-Cuba, Porto Rico, St. Thomas, Guadeloupe, Dominica.

Plant 8-12 in. high. Stem slender, with a few radical leaves and many sheaths, 15-23 cm. l. Leaves elliptical or oval, obtuse or acute, tapering into the flattish membranous stalks, sheathing below; blade $2 \cdot 5-7 \cdot 5 \mathrm{~cm}$. 1., $1 \cdot 5-3 \mathrm{~cm}$. br.; stalk $1-3 \cdot 5 \mathrm{~cm}$. l. Sheaths tubular below, free part oblong, tapering into a shortly acuminate apex, $3-1 \mathrm{~cm}$. 1 . Spite densely crowded with numerous small flowers, $3-7 \mathrm{~cm} .1$. Bracts ovate, long-acuminate, 1-nerved, as long as, or a little longer than, the ovary, 3-2 $\mathrm{mm}$. l. Ovary obovoid, barely $2 \mathrm{~mm}$. 1. Sepals concave, 1-nerved, tinged with brownish-pink at the tips; lateral connivent; median spreading; free part about $1.3 \mathrm{~mm}$. l., nearly $1 \mathrm{~mm}$. br. Petals narrowly obovoid, very obtuse, 1 -nerved, recurving, barely $1 \mathrm{~mm}$. l., about $.5 \mathrm{~mm}$. br. Lip 3-nerved, 1-1.2 mm. 1.; auricles short, $\cdot 2 \mathrm{~mm} .1$. Column winged laterally at the apex. Capsule ellipsoidal, with six shallow keels, $4 \mathrm{~mm}$. 1., $2 \cdot 5 \mathrm{~mm}$. br.

\section{PONTHIEVA R. Br.}

Terrestrial herbs with fibrous roots. Leaves radical, ovate, oval or elliptical, membranous, many-nerved, reficulately veined; stalks long or short, flattish, membranous, sheathing below. Scape simple, slender with a few sheaths. Flower's small, shortly stalked, in a lax raceme generally glandularpubescent. Bracts narrow, generally small. Sepals free, spreading, either nearly equal or the lateral broader than the median. Petals raised on the column, spreading, very asymmetrical, triangular. Lip on the upper side of the flower; 
raised on the column, ascending; blade abruptly dilated, concave and more or less folded on itself. Column short, somewhat terete, dilated at the apex ; rostellum erect, dilated, posteriorly concave; stigma under the rostellum, broad, hollowed out; clinandrium short. Anther erect behind the rostellum and shorter than it, with cells contiguous ; pollinia 4, joined in pairs, powdery-granular, pendulous from a gland of the rostellum. Capsule erect, obovoid-ellipsoidal or ellipsoidal.

Species about 22, natives of the warmer regions of America from the southern United States to Chile, including the West Indies.

Petals, margin ciliate.

Lip roundish with linear apical lobe.................. 1. P. glandulose. Petals glabrous.

Lip obscurely 3-lobed at apex, with 2 minute erect lobes at base

Lip kidney-shaped with linear lobe at apex and

2 minute auricles at base .......................... 3. P. pauciflora.

Lip 3 -lobed at apex, saccate at base ................... 4. P. ventricosa.

1. P. glandulosa R. Br. in Ait. Hort. Kew. ed. 2. v. 200 (1813); sepals glandular-pubescent, median 3-nerved, lateral incompletely 4-nerved; petals, margin ciliate; lip clawed, very broadly roundish, almost transversely oval, with linear apical lobe, disc with linear median erest.-Lindl. Gen. \& Sp. Orch. 444 ; Griseb. Fl. Br. W. Ind. 638 ; Cogn. in Symb. Ant. vi. 363; Ames Orch. S. Fla. 14, t. 4. Neottia glandulosa Sims in Bot. Mag. t. 842 (1805).

On damp shady banks; in fl. and fr. Dec.-Feb.; Macfadyen! McNab! St. Ann, Purdie! Fairfield, Wullschlaegel, 1069! Prior! near Cinchona, J.P. 13, Morris! near Castleton, J.P. 2377, Syme! Browns Town, Miss T. M. Barrett! Cinchona, 5000 ft., Fawcett! Mt. Diabolo, $2300 \mathrm{ft}$., Fawcett \& Harris! Cinchona; Hall's Delight, $1000 \mathrm{ft}$; Clydesdale, $4000 \mathrm{ft}$; Harris! Bloxburgh, Blue Mts., Miss B. Gosset! Fl. Jam. 7549, 7861, 7862 (7266, 7532, 7562, 9787, fide Cogniaux).-Cuba, Hispaniola, Porto Rico, St. Thomas, St. Kitts, Guadeloupe, Dominica, St. Vincent, Grenada, Carolina, Georgia, Virginia, Florida, Mexico, Costa Rica, Ecuador.

Plant 1-2 ft. high, glandular-pubescent above. Scape glandularpubescent above, 2 to nearly $4 \mathrm{dm}$. 1 . Leaves broadly oval to oblanceolateelliptical and oblanceolate, obtuse or acute; blade $4-15 \mathrm{~cm} .1 ., 2-4 \mathrm{~cm}$. br. Sheaths (3-6), those near the base (1 or 2) generally foliaceous and passing into the oblong-lanceolate to lanceolate-acuminate sheaths above, glabrous at the lower part of the stem and glandular-pubescent above. Raceme 6-20 cm. l., glandular-pubescent, with few to many wide-spreading flowers. Bracts oval or elliptical, acuminate, 3-nerved, half as long as the stalked ovary, $10 \mathrm{~mm}$. l. or less, $2.7 \mathrm{~mm}$. br. Ovary densely glandular-pubescent, about $1-1.5 \mathrm{~cm}$. 1. Pedicel $3-4 \mathrm{~mm}$. 1. in flower, 7-8 mm. 1. in fruit. Flowers white, about $\frac{1}{4}$ in. $1 . \quad$ Sepals glandular-pubescent; median elliptical, obtuse, 5-7 mm. 1., 2-2.5 mm. br.; lateral obliquely ovate, obtuse, $5 \cdot 5-7 \mathrm{~mm} .1 ., 3 \cdot 3-4 \mathrm{~mm}$. br. Petals on the outer side dilated and semi-cordate, curved inwards, clawed, several nerves springing from claw and more or less branching; extreme length of blade $4-6 \mathrm{~mm}$. 1., 2.5-3.5 mm. br.; claw attached to column for about $1 \mathrm{~mm}$. above base. Lip 
folded on itself down the middle, each half somewhat round, 5-nerved; blade about 3-4 $\mathrm{mm}$. 1. to base of lobe $(1 \mathrm{~mm}$. 1.), 4-5 $\mathrm{mm}$. br.; claw $1.3 \mathrm{~mm}$. 1. above its attachment to tho column. Column (including rostellum) 4-4.5 mm. l., curved, rostellum long-pointed, winged posteriorly on the side of the anther, wing broadest at the middle; stigma oblong. Anther stalked, nearly reaching apex of rostellum. Capsule obovoidellipsoidal, tapering to base, narrowly 6 -kceled, $1 \cdot 3-1 \cdot 6 \mathrm{~cm}$. $1 ., 4-5$ mm. br.

2. P. Harrisii Cogn. in Fedde Repert. vi. 304 (1909); sepals, median glabrous, 5-7 nerved, lateral sparsely glandular-pubescent, 7 -nerved ; lip boat-shaped, obscurely 3 -lobed at apex, obtuse, with 2 minute, erect lobes near base, with a transverse callus near apex.-Cogr. in Symb. Ant. vi. 362. (Pl. 5, f. 7-11.)

In peaty soil in damp places in woodland; in fl. April, May; Greenhill Wood, $4000 \mathrm{ft}$. ; near Mabess River, $3000 \mathrm{ft}$. ; below Vinegar Hill ; Harris ! Fl. Jam. 7618, 7883.

Plant 14-24 in. high. Scape 3-5 dm. l., somewhat sparsely glandularpubescent. Leaves several (3-8), ovate-elliptical, acute, glabrous, margins slightly wavy; blade $6-11 \mathrm{~cm}$. $1 ., 3$ to about $5 \mathrm{~cm}$. br.; stalks with sheath to $6 \mathrm{~cm}$. l. Cauline leaf much smaller than the radical. Cauline sheaths, 2 or 3 , subfoliaceous, tubular below, passing into the bracts above, acute, glandular-pubescent. Raceme 9-10 cm. l., glandularpubescent, many flowered. Bracts elliptical, shortly acuminate, acute, sparsely glandular-pubescent, 3-nerved, about half as long as the stalked ovary, lower about $8.5 \mathrm{~mm}$. $1 ., 3.5 \mathrm{~mm}$. br. Pedicels $4-5 \mathrm{~mm}$. 1 . Ovary densely glandular-pubescent, 7-8 mm. l. Flowers erect-spreading, cream-colour or pale brick colour and lip marked with green. Sepals, median elliptical, shortly acuminate, 4-5 mm. 1., 1.5-2 mm. br. ; lateral subfalcately obovate-elliptical, obtuse, $5 \cdot 5-7 \mathrm{~mm}$. 1., 3-4 mm. br. Petals attached by a short claw to the column at $2 \cdot 7 \mathrm{~mm}$. above its base, narrowly triangular, on outer side dilated and scmi-auriculate, basal lobe obtuse, from apex to cnd of basal lobe $3 \mathrm{~mm}$. 1. Lip attached to column about $2 \mathrm{~mm}$. above base, 2.5-3 mm. 1., $1 \mathrm{~mm}$. br. Column (to apex of rostellum) 3-4 $\mathrm{mm}$. 1., the long pointed rostellum much thickened upwards, hollow and broadly winged towards anther; stigma round.

3. P. pauciflora comb. nov.; sepals glandular-pubescent, median 3-nerved, lateral incompletely 5-nerved; lip clawed, kidney-shaped, with a sinus above from which projects a short blunt linear lobe, and with very small auricles at base. Cranichis pauciflora Sw. Fl. Ind. Occ. 1431 ; Griseb. op. cit. 639 ; Cogn. in Symb. Ant. vi. 356. (Pl. 5, f. 12, 13.)

On damp shady banks, amongst mosses; in fl. and fr. Nov.-Jan.; Swartz ; Distin ! St. Mary, McNab ! J.P. 13, 476, Morris ! Cinchona, 5000 ft., C. Nicholls! Morse's Gap, 5000 ft., Harris! Fl. Jam. 7532, 7804, 97S7.Cuba.

Plant $\frac{1}{2}-1 \frac{1}{2} \mathrm{ft}$. high, glandular-pubescent above. Scape 1-3 dm. 1., glandular-pubescent above, glabrous below. Leaves few (about 3), oval or elliptical, obtuse, blade $1 \cdot 5-6 \cdot 5 \mathrm{~cm} .1 ., 1-2 \cdot 5 \mathrm{~cm}$. br., stalk $5-13 \mathrm{~mm}$. 1 . Sheaths few (about 3), tubular below, free portion ovate, obtuse near base of stem to ovate-lanceolate, acuminate, above, $1-2.5 \mathrm{~cm}$. 1. Raceme somewhat one-sided, few-flowered, glandular-pubescent, $2-10 \mathrm{~cm}$. I. Bracts broadly oval to obovate, shortly acuminatc, 3-nerved, with scattered 
glandular hairs, about half as long as the stalked ovary, $4-5.5 \mathrm{~mm}$. 1 , 2-2.5 mm. br. Pedicel $4 \mathrm{~mm}$. l., glabrescent. Ovary thicker above, glandular-pubescent, $7 \cdot 5-8 \mathrm{~mm}$. l. Flowers white, erect-spreading, about $\frac{1}{5}$ in. 1. Sepals white, slightly tinged with green outside; median elliptical or lanceolate-elliptical, very shortly acuminate, $5 \cdot 2-5 \cdot 5 \mathrm{~mm}$. l., 1.8-2 mm. br.; lateral ovate, slightly oblique, very shortly acuminate, 4.5-5.5 mm. 1., $2 \cdot 6-2 \cdot 7 \mathrm{~mm}$. br. Petals dilated on the outer side, slightly falcate, 2-4-nerved, 4 to nearly $5 \mathrm{~mm}$. 1., 1·6-2.5 mm. br., clawed, attached to column $5-1 \mathrm{~mm}$. above its base. Lip folded on itself, white with 2 green spots on either side, greenish where it joins the column, 3-nerved, very concave at base and thickened on outside, $2 \cdot 5-3.5 \mathrm{~mm}$. l. (without claw), 3.2-4 mm. br., terminal lobe $1 \mathrm{~mm}$. l.; claw thickened and broad above, rather more than $\cdot 5 \mathrm{~mm}$. l. Column (including rostellum), 2-2.5 $\mathrm{mm}$. l., the short pointed rostellum dilated above, concave and winged on the posterior side next the anther, wings forming a cup from the edge of which the anther springs; stigma large. Anther shortly stalked, about as high as apex of rostellum. Capsule (unripe) cylindrical-ellipsoidal, somewhat wider near apex.

We have transferred this and the following species to Ponthieva, as the petals and lip are raised on the column.

4. P. ventricosa comb. nov.; sepals glandular-pubescent, median 3-nerved, lateral 5-nerved; lip sessile, forming a very short saccate spur, 3-lobed above, lateral lobes rounded, median lobe narrow, blunt.-Cranichis ventricosa Griseb. loc. cit.; Cogn. loc. cit.

On rocky shady banks; in fl. and fr. Dec.; Fairfield, Wullschlaegel, 1068! Prior! Browns Town, Miss T. M. Barrett! Farm Hill; Tweedside, 2500 ft.; Guava Ridge Road, 2500 ft.; Harris! Anchovy, Cradwick! Fl. Jam. 5538, 6924, 7814, 10,403, 10,469.-Cuba, Hispaniola, Porto Rico.

Plant 7-15 in. high. Scape 1.5-3 dm. l., glabrate. Leaves 3 or 4, oblong, elliptical or obovate, often tapering into the stalks, $2-7 \mathrm{~cm}$. 1 ., $1-2.5 \mathrm{~cm}$. br.; sometimes the stalk of the upper leaf completely sheathing. Sheaths 3-6, lower sometimes a leaf-like blade, varying greatly in size; the others tubular below, free portion oblong, acute, 7-16 mm. l. Raceme glandular-pubescent, $3-7 \mathrm{~cm}$. l., lengthening in the fruit. Bracts ovate, acute, 3-nerved, glandular-pubescent, $5 \mathrm{~mm}$. 1. Ovary thicker above, tapering to base, glandular-pubescent, $1 \mathrm{~cm}$. l. Flowers white, few or several, small, erect-spreading, shortly stalked, nearly $\frac{1}{4}$ in. l. Sepals median oval, obtuse, tapering to apex and base, $5 \cdot 2 \mathrm{~mm}$. $1 ., 2 \cdot 2 \mathrm{~mm}$. br., lateral forming a chin round short spur of lip, broadly ovate, oblique on the side forming the chin, $6 \mathrm{~mm} .1 ., 3.5 \mathrm{~mm}$. br. Petals with 3-nerves branching, somewhat triangular, unequally 2-lobed, about $5 \mathrm{~mm}$. l., nearly $2.5 \mathrm{~mm}$. br. Lip attached to column shortly above the base, 5 -nerved, folded on itself, $4.5 \mathrm{~mm}$. l. Column thicker above, with a sharp pointed rostellum, $2.5 \mathrm{~mm}$. l., concave and slightly winged at base posteriorly towards the anther; stigma roundish. Anther stalked, exceeding the apex of the rostellum. Capsule ellipsoidal, tapering to base, $8 \mathrm{~mm}$. l., $3 \cdot 5-4 \mathrm{~mm}$. br. 


\section{CORYMBORCHIS Thou.*}

Terrestrial, high-growing herbs, leafy, sometimes branching, with thick, woody ronts clustered on the short rhizome. Sheaths decaying below, spathaceous or passing into leaves above. Leaves ample, plaited, chartaceous, petioles sheathing. Flower's mediumsized, subsessile, in short terminal or axillary sub-corymbose panicles. Bracts small, ovate. Sepals and petals oblong. Lip erect from the base of the column, ovate, channelled, with a recurved apical lobe. Column long, erect, at the apex thicker, terminated by two erect lobes or auricles; stigma at the base of an erect acuminate rostellum; clinandrium short. Anther erect, narrow, nearly as long as the rostellum, acuminate, cells contiguous; pollinia granular, attached to a subulate stalk which depends from a peltate gland of the rostellum; on the fall of the pollinia the rostellum remains 2-fid. Capsule cylindrical, subterete, crowned by the remains of the perianth.

Species about 13, widely dispersed through the tropical regions of the world, one in West Indies and Mexico.

C. flava Kuntze Rev. Gen. Pl. 658 (1891).- Serapias flava Sw. Prodr. 119 (1788); Neottia flava Sw. Fl. Ind. Occ. 1417 (1806). Chloidia flava Reichb. f. in Walp. Ann. Bot. vi. 644 (1863) \& Beitr. Orch. Centr. Amer. 5 ; Griseb. Fl. Br. W. Ind. 643. Corymbis flava Hemsl. in Biol. Centr. Amer. Bot. iii. 297 (1884). (Pl. 5, f. 14.)

In damp woods; in fl. Oct.-April; mountains of Clarendon, Swartz; Hector's River, Manchester, Purdie! Prior! Olive River, Christiana district, 3000 ft., Harris! Fl. Jam. 10,398.-Cuba, Hispaniola, Porto Rico, Guadeloupe, Mexico.

Plant to $6 \mathrm{ft}$. high. Stem about $6 \mathrm{dm}$. high, simple. Leaves oblonglanceolate, acuminate, about 7-nerved, blade 18-26 cm. 1., 4-6 cm. br. Panicle 4-5 cm. 1., with several lax flowers. Bracts, at base of branches oblong, acuminate, about $1 \mathrm{~cm}$. 1.; floral ovate, shortly acuminate, $4 \mathrm{~mm}$. l. Flowers yellow, about 2 in. 1., subsessile. Ovary cylindrical, about $8 \mathrm{~mm}$. 1 . Sepals 7 -nerved, oblong-linear, acute, nearly $1.5 \mathrm{~cm} .1 ., 2-2.5 \mathrm{~mm}$. br. Petals 5-nerved, oblong-elliptical, somewhat blunt, $1 \cdot 2-1 \cdot 3 \mathrm{~cm} .1$., about $3 \mathrm{~mm}$. br. Lip ovate, conduplicate below, ovate-oblong above, as long as the petals. Column (including anther) as long as petals.

\section{TROPIDIA Lindl.}

Like Corymborchis, except in the following particulars : Flowers small, not so lax, in few short dense spikes at the apex of the branches. Bracts linear-subulate. Sepals connivent, median oblong-lanceolate, lateral oblong, connate at the base

* Corymborchis is the generic name given by Thouars (Orch. Iles Afr. t. 37). Corymbis is a uninomial composed from the generic and specific names; it is, therefore, inadmissible to substitute Corymbis for the true generic appellation. 
under the lip into a short chin. Lip saccate at base, oblong. Column short.

Species about 15, natives of the East Indies, Malaya, China and Japan, and one in W. Indies and Florida.

T. polystachya Ames Orch. ii. 262 (1908).-T. Eatoni Ames Orch. S. Fla. 14, t. 5 (1904). Serapias polystachya Sw. Prodi. 119 (1788). Neottıa polystachya Sw. Fl. Ind. Occ. 1415 (1806). Chloidia vernalis Lindl. Gen. d Sp. Orch. 484 (1840). C. polystachya Reichb. f. in Walp. Ann. vi. 644 (1861), \& in Griseb. Fl. Br. W. Ind. 643. Polystachya membranacea A. Rich. Fl. Cub. ii. 248 (1853). Corymborchis polystachya Kuntze Rev. Gen. Pl. 658 (1891). (Pl. כ, f. 15.) Type in Herb. Mus. Brit.

In damp woods; in fl. in spring; mountains of Clarendon, Swartz! Manchester; Westmoreland; Purdie! Prior! Stony Hill, J.P. 469, Morris ! -Cuba, Florida.

Plant nearly $2 \mathrm{ft}$. high. Stem $4 \mathrm{dm}$. high, branching. Leaves oblonglanceolate, acuminate, about 7-nerved; blade 12-22 cm. 1., 3-5 cm. br. Panicle 10-15 cm. 1., with numerous lax flowers. Bracts linear-subulate; at base of branches 2.5-7 cm. l. ; floral 2-7 mm. l. Pedicels very short, 1-2 mm. 1. Flowers pale red, $\frac{1}{4}$ in. 1 . Ovary cylindrical, about $8 \mathrm{~mm}$. l. Sepals 5-nerved; lateral, acute, somewhat gibbous at base, erect, falcate $6 \mathrm{~mm}$. 1., $2 \mathrm{~mm}$. br.; median, with acute apex, concave, $7 \mathrm{~mm}$. 1., $2 \mathrm{~mm}$. br Petals 3-nerved, oblong, somewhat falcate, acute, $6 \mathrm{~mm} .1 ., 1.5 \mathrm{~mm}$. br. Lip very concave and embracing the column below, retuse and obscurely 3-lobed at apex, 2-lamellate on disk, as long as petals. Colımn 4.5 mm. l. Capsule $1 \mathrm{~cm}$. 1., $3 \mathrm{~mm}$. br.

\section{MALAXIS Solander ex Swartz.*}

Terrestrial herbs, base of stem generally pseudobulbous. Leaves 1 or 2, broad, not jointed with the sheathing petiole. Scape slender, elongated. Flowers small or minute in a terminal raceme, sometimes contracted and corymbose. Bracts small, narrow. Sepals nearly equal, free or lateral slightly connate at base, spreading. Petals equal to sepals or a little shorter, narrow. Lip sessile, entire or lobed, with auricles embracing the column, not extending as far as the sepals, but, including the auricles, longer than the sepals. Column very short, terete, hollowed at apex. Anther terminal, incumbent, two-celled. Pollinia 4, waxy, ovoid. Capsule small, ovoid or turbinate.

Species about 140, widely distributed, but mainly in Central America and Indo-Nalaya.

* Swartz adopted the name Malaxis from Solander and defined the genus in Prodr. 119 (1788), including therein the two Jamaican species $M$. spicata and $M$. umbelliflora. This name must therefore be retained for these and for the other species now included under Microstylis. The latter name is cited by Bentham \& Hooker (Gen. Pl. iii. 494) as of Nuttall (Gen. N. Amer. Pl. ii. 196), but Nuttall uses it only for a section of Malaxis. Microstylis was first used as a generic name by Lindley (Orch. Scelet. \& Gen. \& Sp. Orch.). 
Leaves two

Flowers corymbose................................ 1, M. umbelliflora.

Flowers racemose.

Lip with a distinct apical lobe............. 2. M. spicata.

Lip not lobed ................................ 3. M. integra.

Leaf one ............................................. 4. H. Grisebacticanu.

1. M. umbelliflora Sw. Prodr. 119 (1788); leaves two ; raceme umbellately corymbose, very short, not exceeding $1 \mathrm{~cm}$. but elongating in fruit; lip 3 -lobed above, middle lobe $2 \mathrm{~mm}$. l., with revolute margins, large, half the length of the lip, triangular, obtuse ; side lobes small, roundish, obtuse ; auricles short, rounded, obtuse.-Sw. Ic. ined. t. 20. M. umbellulata Sw. Fl. Ind. Occ. 1444, t. 28, fig. a, b, c (1806). Nicrostylis umbellulata Lindl. Gen. \& Sp. Orch. 19 (1830); Griseb. Fl. Br. W. Ind. 612; Ridl. in Journ. Linn. Soc. xxiv. 324. M. umbelliflora Hitchc. in Rep. Miss. Bot. Gard. iv. 132 (1893); Cogn. in Symb. Ant. vi. 371. Type in Herb. Mus. Brit.

Peaty soil in damp shady places; in fl. and fr. Sept.-Jan.; Macfadyen ! "Gap of St. Andrew's," Purdie! J.P. 2080, Morris! Moody's Gap and Second Breakfast Spring, J.P. 20S0, Syme! Moy Hall, Sullivan! Cinchona, 4850 ft., C. Nicholls! Fawcett! Near Vinegar Hill; Green Hill Wood, 3500 ft.; Morse's Gap, 4800 ft.; Mabess River, 3500 ft.; Woodcutters' Gap, 4350 ft. ; Harris! Fl. Jam. 7549, 7760, 7779, 7780, 9785, 9798, 10,482. -Cuba, St. Kitts, Guadeloupe, Dominica, St. Vincent, Trinidad, Mexico, Andes (Jameson), La Banca (10,000 ft., Pearce).

Plant 4-10 in. high. Stem pseudobulbous, with two sheaths; upper sheath $2 \cdot 5-4 \mathrm{~cm}$. Leaves, the lower larger, blade $5-10 \mathrm{~cm} .1 ., 3-6 \mathrm{~cm}$. br., ovate, shortly acuminate, petiole long-sheathing. Flowers pale green, numerous, small; pedicels long, to $12 \mathrm{~mm}$. Bracts $2-3 \mathrm{~mm}$. 1., lanceolate, acuminate, setaceous, much shorter than the lower pedicels. Sepals about $3 \mathrm{~mm}$. l., half as broad, median ovate-elliptical, lateral ovate-oblong with revolute margins. Petals $3 \mathrm{~mm} .1 ., \cdot 3 \mathrm{~mm}$. br., linear. Lip $4 \mathrm{~mm}$. l., 2.25 mm. br. Column $\cdot 75 \mathrm{~mm}$. 1. Capsule 8-9 mm. 1., ellipsoidal, tapering to base, with three angles.

2. M. spicata $S w$. Prodr. 119 (1788); leaves two; raceme somewhat lax; lip* broadly elliptical, with a prominent linearoblong obtuse apical lobe; auricles elliptical, obtuse.-Su. Fl. Ind. Occ. 1441 it Ic. ined. t. 19. Microstylis spicata Lindl. op. cit. 19 ; Griseb. op. cit. 612 ; Ridl. op. cit. 323 ; Cogn. in Symb. Ant. vi. 368. Type in Herb. Mus. Brit.

On damp shady banks and in woods; in fl. and fr. Sept.-Jan.; Westmoreland Mts., Purdie! J.P. 233, Morris! Stony Hill, J.P. 464,

* The lip is described and figured by Swartz as trilobed, but in all the Jamaican specimens examined by us, including Swartz's type, the lateral lobes are not evident. Swartz describes his figure as the flower of $M$. spicata or $M$. umbelliflora, and in his description of the latter omits the parts of the flower as being very similar to $M$. spicata. The drawing agrees best with $M$. umbelliflora, under which we have cited it. In his Icon. ined. tt. 19 \& 20, the flowers are represented as precisely similar, and we can only suggest that a flower of $M$. umbelliflora has been drawn for each plate. 
Syme! Moody's Gap, $3000 \mathrm{ft} . ;$ near Vinegar Hill, $4500 \mathrm{ft} . ;$ near Christiana, 3000 ft.; Harris! Trelawney, Miss T. M. Barrett! Fl. Jam. 7880, 10,471, 10,473.-Cuba, Hispaniola, Porto Rico, St. Eustatius, Martinique.

Plant 8-12 in. high. Stem thickened at the base, pseudobulbous in fruiting stage, with two sheaths at the base, upper sheath $2-3 \mathrm{~cm}$. 1., the outer smaller one often withering. Leaves distant, the lower larger, 6-10 cm. 1., 3-5 cm. br., ovate, ovate-elliptical or ovate-lanceolate, petiole long-sheathing. Raceme 3-8 cm. 1. Flowers numerous, small; pedicels 6-9 mm. Bracts 2-4 mm., lanceolate, setaceous, much shorter than the pedicels. Sepals about $3 \mathrm{~mm}$. 1., and half as broad; median ovate-lanceolate, acute; lateral shortly connate at base, lanceolate, obtuse, with revolute margins. Petals $2 \mathrm{~mm}$. 1., $5 \mathrm{~mm}$. br., linear, shorter. Lip 3.5-4 mm. 1., 2.5 mm. br. Capsule (unripe) $8 \mathrm{~mm}$. 1., ellipsoidal, slightly tapering to base.

3. M. integra comb. nov. ; leaves two ; raceme lax ; lip ovate, entire, obtuse, auricles roundish-elliptical.-Microstylis integra Favc. \& Rendle in Journ. Bot. xlvii. 7 (1909); Cogn. in Symb. Ant. vi. 370. (Pl. 6, f. 11-17.) Type in Herb. Mus. Brit.

On rocky shady banks; in fl. and fr. Nov.; Guava Ridge Road, $2500 \mathrm{ft}$. ; Mount Hybla, 4000 ft.; Harris! Fl. Jam. 7735, 7740, 7741.

Plant 6 to 12 in. high. Stem thickened at the base, 2-leaved below, with a sheath at the base; sheath $1.5 \mathrm{~cm}$. l. Leaves elliptical, obtuse or abruptly acute, petiole long-sheathing; lower leaf generally $3-5 \mathrm{~cm}$. 1 ., $2-2 \cdot 5 \mathrm{~cm}$. br. Raceme $3-8 \mathrm{~cm}$. Flowers very small, stalked; pedicels 4-5 $\mathrm{mm}$. Bracts $2 \mathrm{~mm}$., linear-lanceolate, much shorter than the pedicels. Sepals $2.2 \mathrm{~mm} .1 ., 1 \cdot 5 \mathrm{~mm}$. br., obtuse with revolute margins, median ovate, lateral broadly elliptical. Petals linear, scarcely as long as the sepals. Lip $2.5 \mathrm{~mm}$. 1., $2 \mathrm{~mm}$. br. Capsule $6 \mathrm{~mm}$. 1., ellipsoidal, slightly narrowed at the base.

4. M. Grisebachiana comb. nov. ; leaf solitary ; raceme oblong, with flowers crowded towards the apex; lip somewhat quadrate, 3 -lobed above, median lobe very short, tooth-like; auricles roundish-elliptical.-Microstylis Grisebachiana Fauc. \& Rendle in Journ. Bot. xlvii. 7 (1909) ; Cogn. in Symb. Ant. vi. 372. (Pl. 6, f. 18-23.) Types in Herb. Mus. Brit. \& Jam. Herb.

On damp clayey shady banks; in fl. and fr. Oct.-Dec.; Cinchona, 4920-5000 ft.; Morse's Gap, 4800 ft.; Harris! J.P. 230 (in part), MLorris! F1. Jam. 7530, 7743, 7744, 9790, 9792.

Plant 4-10 in. high. Stem 1.5-3 cm., swollen underground into a small spherical corm, 1-2 cm. br., with one leaf affixed below the middle or near the base, with one or two sheaths at the base. Leaf $2 \cdot 5-5 \mathrm{~cm}$. 1 ., 1.5-3 cm. br., elliptical to ovate-elliptical, obtuse, subcordate, with sheathing petiole. Raceme $3-4 \mathrm{~cm}$., oblong, with flowers crowded towards the apex. Flower's yellowish-green, very small, stalked. Bracts triangular, acuminate, much shorter than the pedicels. Sepals ovate-oblong, obtuse, with revolute margins, median about $2 \mathrm{~mm}$. $1 ., \cdot 6 \mathrm{~mm}$. br., lateral slightly shorter. Petals $1.5 \mathrm{~mm}$. l., linear shorter than the sepals. Lip $2.25 \mathrm{~mm}$. 1., $1.75 \mathrm{~mm}$. br., lateral lobes $6 \mathrm{~mm}$. 1., median $.25 \mathrm{~mm}$. 1., auricles $.5 \mathrm{~mm} .1$.

Near M. unifolia Michx., but distinguished by the auriculate, not cordate, lip, and the position of the leaf nearer the base of the stem. 


\section{LIPARIS L. C. Rich.}

Terrestrial herbs; stems leafy, short, thickened into a corm or narrow pseudolulb. Leaves one, two or few, springing either from the base of the corm or from the notes of the psendobulb, or from below it, with a sheathing leaf-stalk, membranous, conspicuously many-nerved. Flowers small or medium-sized, greenish or purple, in a terminal stalked raceme. Biracts small, narrow. Sepals free, spreading, about equal. Petals narrower. Lip attached to the base of the column, oblong or expancled into a broad spreading or reflexed blade, entire or emarginate. Column long, incurved, half-terete, without a foot, at the apex on both sides margined or appendiculate with a wing; clinandrium short. Anther terminal, opercular, incumbent; pollinia 4, waxy, ovoid, sometimes acuminate, segregated in pairs in the cells, each pair superposed. Capsule generally small, ellipsoridal or obovoid.

Species about 200, widely dispersed through the temperate and warmer regions of the globe.

Leaf one.

Leaf oblong or lanceolate. Corm present... 1. L. vexillifera.

Leaf roundish, cordate. Pseudobulb present 2. L. neuroglossa.

Leaves two.

Lip greenish, $\frac{1}{2}$ in. 1. Pseudobulb present... 3. L. Harrisii.

Lip purple, $\frac{1}{4}$ in. 1. Corm present ........... 4. L. Saundersiana.

Leaves three or more ................................. 5. L. elata.

1. L. vexillifera Cogn. in Fl. Bras. iii.pt. 4, 289 (1895); with corm; leaf one, oblong-elliptical to oblong-lanceolate, acute to subobtuse; lip pale yellow with reddish-brown veins, or altogether reddish-brown, 3-nerved, middle nerve prominent, lower half broadly roundish, conduplicate; upper half broadly oblongelliptical or roundish, recurved; at base sub-cordate, apex obtuse, somewhat apiculate.-Cogn. in Symb. Ant. vi. 377. L. elliptica Reichl. f. in Walp. Ann. vi. 218 (1861); Griseb. Fl. Br. W. Ind. 612 ; Ridl. in Journ. Linn. Soc. xxii. 265 . L. jamaicensis Lindl. ex Griseb. Cat. Cub. 261 (1866). Cymbidium vexilliferum Llave \& Lex. Nov. Veg. Deser. ii. 7 (1825).

On damp clayey banks; in fl. and fr. Nov.-Feb; Wiles; Macfadyen! Hollis Savanna, Clarendon, Purdie! below Cinchona, J.P. 237, Morris! 11t. Moses, $3000 \mathrm{ft}$., J.P. 2443, Syme! Clydesdale, $4500 \mathrm{ft}$. , Fawcett! Cinchona, C. Nicholls! Westphalia, 4000 ft.; Clydesdale; Mt. Hybla, $4000 \mathrm{ft}$.; Cinchona, 4800-5000 ft.; Harris! Fl. Jam. 7528, 7751, 7842, 9512, 9791, 9788.- Cuba, Porto Rico, Trinidad, Mexico, Guatemala, Colombia, Venezuela, B. Guiana, Ecuador, Argentine (var.), Bolivia.

Plant 4-11 in. high. Stem swollen below the ground into a spherical corm, covered by the sheathing leaf-stalks and one or two sheaths, upper sheath sometimes foliate above. Leaf blade $7-12 \mathrm{~cm} .1 ., 1 \cdot 5-3 \cdot 5 \mathrm{~cm}$. br.; stalk sheathing, sometimes very short. Scape $1-3 \mathrm{dm} .1$, angled or winged. 
Raceme 5-18 cm. l., somewhat lax. Flowers pale yellow, 12-30, perianth nearly 1 in. 1 . Bracts lanceolate, acuminate, $16 \mathrm{~mm}$. 1. below, to about $5 \mathrm{~mm}$. 1. at apex. Pedicels $5-8 \mathrm{~mm}$. l. (lengthening to about $1 \mathrm{~cm}$. in fruit). Ovary about $5 \mathrm{~mm}$. 1., 3-winged. Sepals 3-nerved, oblonglanceolate, apex somewhat obtuse; median $7.5 \mathrm{~mm}$. $1 ., 2 \cdot 3 \mathrm{~mm}$. br.; lateral attached at base to lip, 6.5-7 mm. 1., 2.3-2.6 mm. br. Petals 1-nerved, linear, obtuse, about $7 \mathrm{~mm}$. 1., $8 \mathrm{~mm}$. br. Lip 7-8 $\mathrm{mm}$. 1., 5-6 mm. br. Column erect, curved near apex, channelled anteriorly and angled, broadly winged at apex, $3.8 \mathrm{~mm}$. 1. Capsule narrowly obovoid, 3-keeled, about $1 \cdot 2 \mathrm{~cm}$. l., $4 \mathrm{~mm}$. br.

2. L. neuroglossa Reichb. f. Xen. Orch. iii. 26 (1900); with pseudobulb ; leaf one, roundish, acute, cordate, many-nerved, with long, sheathing leaf-stalk; lip greenish with five purple nerves, triangular-cuneate with a broad premorse-apiculate apex, the two upper corners præmorse and irregularly erose ; shortly 2-lobed, crimson callus at base--Ridl. op. cit. 280 . L. cardiophylla Ames Orch. iii. 92, t. 59 (1908). L. rotundifolia Cogn. in Fedde Repert. vi. 305 (1909), it in Symb. Ant. vi. 378.

In peat and decaying leaves or mosses, in damp shady places; in $\mathrm{fl}$. Nov., Dec., in fr. Feb.; near Cinchona, 5000 ft., Cradwick! Harris!; below John Crow Peak, 5500-6000 ft., J.P. 239, Sullivan! Harris! Fl. Jam. 7529, 7574, 7733, 9784, 9799.-Bolivia.

Plant $3-4 \frac{1}{2}$ in. high. Stem a creeping rhizome from which are given off at intervals secondary stems which become thickened and form pseudobulbs, 8-10 mm. l., covered by the sheathing leaf-stalk and sheaths. Sheaths, one at each node, papery, $\cdot 8-2 \mathrm{~cm}$. l. Leaf, blade 3-4 cm. 1., 2-4 cm. br.; stalk 2-3.5 cm. 1. Scape 5-10 cm. 1., angled. Raceme 1-4 cm. l., somewhat lax below, becoming crowded above. Flowers greenish, perianth $\frac{1}{6}$ in. 1. Bracts linear-lanceolate, 1-nerved, $2 \cdot 5-4 \mathrm{~mm} .1$. Pedicels $3 \mathrm{~mm}$. l. Ovary 6-angled, about $2 \mathrm{~mm}$. l. Sepals 1-nerved; lateral lanceolate, obtuse, about $4 \mathrm{~mm}$. 1., $1.4 \mathrm{~mm}$. br.; median oblong-lanceolate, about $4 \mathrm{~mm}$. 1., 1.2 mm. br. Petals 1-nerved, linear, 4.3-5 mm. 1., 5 mm. br. Lip 3.5 mm. 1., 3-3.5 mm. br. Column erect, curved towards apex, $2 \cdot 5 \mathrm{~mm}$. 1 . Capsule ellipsoidal, $5-6 \mathrm{~mm}$. 1 .

The flowers of the type from Bolivia are rather larger than those from Jamaica, but we fail to see any specific difference. The distribution of $L$. vexillifera and $L$. elata shows that we may look for the occurrence of $L$. neuroglossa at intermediate stations.

3. L. Harrisii Fawc. \& Rendle in Journ. Bot. xlvii. 7 (1909); with pseudobulb; leares two, oval-elliptical, abruptly acute, with a somewhat long, sheathing stalk; lip greenish, veined and tinged with purple or brown, elliptical, obtuse, cordate, veins prominent in the middle and at the base converging into two calli.-Cogn. in Symb. Ant. vi. 375. (Pl. 6, f. 1-5.) Type in Herb. Mus. Brit.

In spongy peat and vegetable mould or amongst mosses in damp shady places; in fl. and fr. Sept.-Dec. Cinchona 5000 ft., J.P. 229, Morris! Green Hill Wood, 4000 ft. ; near John Crow Peak, 5300-6000 ft.; Harris! Fl. Jam. 7732, 7737, 9786, 9795.

Plant 4 to 9 in. high. Stem at base slightly thickened and at length forming a pseudobulb $2.5 \mathrm{~cm}$. $1 ., 8 \mathrm{~mm}$. br., covered by the sheathing 
petioles and two loose papery sheaths, upper sheaths $3 \cdot 5-5 \mathrm{~cm}$. 1. Teares, blade of upper loaf $7-12 \mathrm{~cm} .1 ., 4-6.5 \mathrm{~cm}$. br. Scape 7-13 cm. 1., 3-winged. Raceme $2.5 .5 \mathrm{~cm}$, lax. Flowers large, greenish, usually from 15 to 10 , perianth nearly $\frac{1}{2}$ in. 1. Bracts $4-5 \mathrm{~mm}$. 1., lanceolate, 1-nerved. Pedicels, without ovary, 8-10 $\mathrm{mm}$. Sepals $9 \mathrm{~mm}$. 1., $2.5 \mathrm{~mm}$. br., greenish margined with purple, linear, acuminate. Pctals equal in length to sepals, purplish, filiform. Lip $13 \mathrm{~mm}$. 1., $8.5 \mathrm{~mm}$. br. Column $4.5 \mathrm{~mm}$. 1., greenish, slender, curved, enlarged at base and below the anther. Capsule $1 \cdot 3 \mathrm{~cm} .1$,, ellipsoidal, narrowed at base.

Allied to $L$. Saundersiana, but a larger plant with evident stem, and leaves and flowers twice as long.

4. L. Saundersiana Reichb. f. in Gard. Chron. 1872, 1003; with corm ; leaves two, the lower larger, roundish-ovate, cordate to oval, obtuse ; leaf-stalk sheathing, one-third to about one-half the length of the blade; lip purple, oval, cordate, apex rounded, sometimes minutely apiculate.-Ridl. op. cit. 274. (Pl. 6, f. 6-10.)

Damp shady banks amongst mosses; in fl. and fr. Nov.-Dec. ; Cinchona, 5000 ft., Watt! J.P. 5, 236, Morris! C. Nicholls! Harris! Fl. Jam. 7531, 7734, 7739, 9789.

Plant very variable in size, $1 \frac{1}{2}-4$ in. high. Stem swollen below the ground into a small spherical corm covered by the sheathing leaf-stalks and one or two sheaths, upper sheath 5 to $15 \mathrm{~mm}$. Leaves, lower blade very variable, $12 \times 11 \mathrm{~mm}$. to $30 \times 25 \mathrm{~mm}$., sometimes to $69 \times 40 \mathrm{~mm}$. Scape angled, edges scabrid. Raceme with many flowers, $18-45 \mathrm{~mm} .1$. Flowers green in bud, dark purple or sometimes crimson when expanded, dark purple when dried, perianth about $\frac{1}{5}$ in. 1 . Pedicels $4-7 \mathrm{~mm}$. Bracts 4-5 mm., thin, lanceolate, acuminate, 1-nerved. Sepals 4-5 mm. l., shorter than the lip, greenish in bud, colourless during flowering, lanceolate. Petals longer than the sepals, purple, narrower, linear, $6 \mathrm{~mm}$. l., -5 mm. br. Lip 5-6 mm. 1., 4.5-5 mm. br. Column curved, enlarged at base and apex. Capsule (unripe) $8 \mathrm{~mm}$. l., ellipsoidal, narrowed at base.

5. L. elata Lindl. in Bot. Reg. t. 1175 (1828), with pseudobulb; leaves few (3-5), erect, broadly elliptical, to lanceolateacute, tapering at the base into sheathing stalks, many-nerved; lip purple, very broadly spathulate, emarginate, with a lunate callus at base.-Lindl. Gen. \& Sp. Orch. 27 (excl. syn.); Griseb. Fl. Br. W. Ind. 612 ; Ridl. op. cit. 259 ; Cogn. in Fl. Bras. iii. pt. 4.286.

In shady places; in $\mathrm{fl}$. June-Dec., in fr. July-April; Macfadyen; Distin! Wilson! March! Near Castleton, J.P. 2395, Syme! Morris! Morse's Gap ; Silver Hill ; Cedar Hurst, 2000 ft. ; Harris! Fl. Jam. 7608, 7659, 7873.- Cuba, Hispaniola, Porto Rico, St. Thomas, Guadeloupe, Dominica, St. Vincent, Trinidad, Costa Rica, Colombia, Venezuela, Brazil, Paraguay, Ecuador, Bolivia, Peru.

Plant 12-15 in. high (sometimes only 6 in.). Stem forming a pseudobulb, 2-5 cm. l., 6-S mm. br., covered by the sheathing leaf-stalks and sheaths. Sheaths, 2 or more, passing into leaves. Leaves 1-3 dm. 1., 4-10 cm. br. Scape 2-3 dm. l., angled. Raceme 8-11 cm. l., somewhat lax. Flowers purple and green, 10-20, perianth nearly $\frac{1}{4}$ in. 1. Bracts lanceolate, 1-nerved, 5-8 $\mathrm{mm}$. 1. Pedicels 5 or $6 \mathrm{~mm}$. l. (somewhat longer in fruit). Ovary $8 \mathrm{~mm}$. l., narrowly 3-winged. Sepals greenish streaked with purple, 5-nerved, oval-elliptical, obtuse; median $5.5 \mathrm{~mm}$. 1., $2.5 \mathrm{~mm}$. 
br.; lateral shorter, nearly $5 \mathrm{~mm}$. 1., $2.5 \mathrm{~mm}$. br., slightly falcate. Petals greenish streaked with purple, 3-nerved, linear-oblanceolate, obtuse, as long as the median sepal, $5.5 \mathrm{~mm}$. l., about $1.5 \mathrm{~mm}$. br. Lip $4 \mathrm{~mm}$. 1 ., and nearly as broad. Column suberect, curved, channelled anteriorly and winged, $3.5 \mathrm{~mm}$. l. Capsule obovoid, $1.5 \mathrm{~cm}$. 1., 5-6 mm. br.

\section{GALEANDRA Lindl.}

Terrestrial herb. Raceme terminal. Sepals equal, free, spreading. Petals similar to sepals. Lip attached at base of column, orbicular, produced into a very short conical spur, erect, disk with longitudinal crests. Column short, without a foot. Anther terminal, opercular, incumbent, imperfectly 2-celled; pollinia 4, ovoid, waxy, on the dehiscence of the anther affixed to a gland of the rostellum.

Species about 25, natives of tropical America from Mexico and the West Indies to Brazil.

Galeandra Beyrichii Reichb.f. in Linnæa xxii. 854 (1849); Cogn. in Fl. Bras. iii. pt. 4, 308, t. 74 \& in Symb. Ant. vi. 380. (Pl. 7, f. 1-3.)

In dry woodland; in fl. and fr. Sept.; St. Ann, J.P. 531, Steer! Hopeton, Westmoreland, 1300 ft., Harris! Fl. Jam. 9780.-Cuba, Venezuela, Colombia, Brazil, Bolivia, Paraguay, Peru.

Plant terrestrial, to $4 \mathrm{ft}$. high. Stem robust, with thickened pseudobulb-like joints, including raceme $8-12 \mathrm{dm}$. l. with no leaves during flowering, but covered with sheaths and terminated by a raceme of greenish flowers. Rhizome short, stout, covered with scales, and bearing numerous roots. Sheaths, 12-15, large, loose, scarious, somewhat overlapping, free portion triangular-oblong, acute or shortly acuminate, 3-10 $\mathrm{cm}$. l., at the base of the stem small and embracing, generally tubular below, but becoming bract-like above. Leaves (not seen, but from figure and description in $\mathrm{Fl}$. Bras. loc. cit.) appearing after flowering, erect, large, elongate-lanceolate, very acute, with 3 thick nerves, $3 \mathrm{dm} .1 ., 3-3 \cdot 5 \mathrm{~cm}$. br., tapering insensibly below into a robust stalk about $1 \mathrm{dm}$. 1 . Raceme long, lax, several-flowered (10-12), a fruiting specimen measured $2.5 \mathrm{dm}$. 1 . Bracts oblong, tapering to an acute or shortly acuminate apex, about as long as the flower-stalks, 1-2 cm. l., 3-6 mm. br. Flowers greenish, erect-spreading, large, stalked, perianth nearly an inch l. Ovary terete, tapering gradually to base, about as long as sepals. Sepals linear-oblong, tapering to base and apex, keeled, 5-nerved, green, $2 \cdot 3 \mathrm{~cm}$. l., lateral rather broader than median $(6 \mathrm{~mm}$. br.), with a blunt apiculate apex; median $5 \mathrm{~mm}$. br., obtuse. Petals oblanceolate, abruptly acute, 5-7nerved, light green, a little shorter than the sepals but as broad as the lateral. Lip with numerous nerves, almost orbicular, shorter than the sepals, broader than long, about $2 \mathrm{~cm} .1 ., 2 \cdot 5 \mathrm{~cm}$. br. when flattened, green with lines of crimson, disk with 4 crests running from the base to the middle, pubescent between the crests, in the middle and along the nerves above the crests. Column barely $1 \mathrm{~cm}$. l., stout, thicker upwards, concave in front with short hairs on apex; anther with short hairs, shortly conical. Capsule reflexed, ellipsoidal, about $2.5 \mathrm{~cm} .1$. 


\section{POLYSTACHYA Hook.}

Epiphytic herbs. Stems leafy, short, sheathed at the base, sometimes thickened into slender pseudobulbs. Leaves few, in two ranks, oblong-ligulate, many-nerved but not plaiter, contracted at the base into sheaths and jointed with them. Perluncle terminal, with a few sheaths alove the leaf. Raceme terminal on the leafy stem, simple, or scveral short racemes along a common rachis forming a narrow lax panicle. Flowers small. Bracts small. Sepals connivent, merlian free, lateral broader, at the base attached to the foot of the column. Petals narrow. Lip on the upper side of the flower, jointed with the foot of the column, at the base contracted, incumbent, then erect; 3-lobed; lateral lobes but little prominent, erect, median spreading or recurved, undivided. Column very short, not winged, produced at the base into a foot; clinandrium short, truncate. Anther terminal, opercular, incumbent, very convex, 1-celled or imperfectly 2-celled; pollinia 4, waxy, broadly ovate, lightly adpressed in pairs, or connate into 2, not appendiculate, affixed to a short stalk or gland. Capsule oblong.

Species about 170, natives chiefly of tropical and south Africa, some of India and Malaya, a few of tropical America.

Flowers with very prominent chin ........ 1. P. minuta.

Flowers smaller, with chin not prominent 2. P. minor.

1. P. minuta Britton in Small Fl. S.E. Un. St. 328 (1903); lateral lobes of lip oblong, sometimes subfalcate, obtuse; sinus above middle of lip; callus extending along the median nerve from the base to the middle.-P. luteola Hook. Exot. Fl. t. 103 (1825); Lindl. Gen. \& Sp. Orch. 73 (in part, excl. syn. P. mauritiana); Griseb. Fl. Br. W. Ind. 628. P. extinctoria \& P. luteola Reichb.f. in Walp. Ann. Bot. vi. 638, 639 (1861). Helleborine ramosa dc. Plum. Pl. Amer. (Burm.) t. 185, f. 1. Epidendrum minutum Aubl. Pl. Guian. ii. 824 (1775). Dendrobium polystachyum Sw. in Vet. Handl. Stockh. xxi. 247 (1800); Lindl. Coll. Bot. t. 20 (non Thouars \& A. Rich.). Cranichis luteola Sw. Fl. Ind. Occ. 1433 (1806). (Pl. 7, f. 4, 5.)

On trees and rocks; in fl. and fr. Nov. to April; Wilson! Fairfield, Wullschlaegel 1055 (partly)! J.P. 21, 22, Morris! Moneague, Lady Blake! Content Road, Campbell! Mavis Bank, $2000 \mathrm{ft} ., 7765$, Harris!-Cuba, Hispaniola, Porto Rico, St. Thomas, St. Eustatius, Dominica, Martinique, St. Lucia, St. Vincent, Grenada, Trinidad, Florida, Mexico, Guatemala, Colombia, B. Guiana, Surinam, F. Guiana, Brazil, Peru.

Plant 8-14 in. high. Pseudobulb about $3 \mathrm{~cm}$. l. Leaves acute or somewhat obtuse, sometimes slightly oblique, 10-20 cm. 1., 12-28 mm. br. Panicle 1.5-3 dm. 1., generally longer than the leaves. Bracts triangular, acuminate, $2 \mathrm{~mm}$. 1. Flowers yellowish-green, perianth $\frac{1}{7} \mathrm{in}$. 1., and somewhat broader; buds very obliquely 3-cornered, apex somewhat acute. 
Ovary cylindrical, 4-5 mm. 1. Sepals 3-nerved, apiculate; median triangular-orate, $3 \mathrm{~mm}$. l., $2 \mathrm{~mm}$. br.; lateral deltoid, very oblique, $3.5 \mathrm{~mm}$. 1., $4 \mathrm{~mm}$. br.; chin obtuse. Petals linear-subspathulate, subobtuse, apiculate, $3 \mathrm{~mm}$. 1. Lip, apex of lateral lobes extending to or beyond middle of median lobe; median larger, roundish-elliptical, margin curled, apex rounded, emarginate, apiculate; disk with very short glandular hairs, and a callus extending along the median nerve from the base to the middle; $4 \mathrm{~mm}$. 1., $3.3 \mathrm{~mm}$. br. Column, incl. anther, $1 \mathrm{~mm}$. 1 . Capsule $1 \mathrm{~cm} .1$.

2. P. minor Fauc. \& Rendle in Journ. Bot. xlviii. 106 (1910); lateral lobes of lip small, rounded; sinus not above middle of lip ; callus basal, projecting, conical.--P. foliosa Griseb. loc. cit. (as regards spec. from Jamaica) non Reichb. $f$. (Pl. 7, f. 6, 7.)

On trees and walls; in fl. and fr. Sept.-Jan.; road to Guanaboa and Red Hills, Sloane Herb. vii. 86! Fairfield,. Wullschlaegel, 1055 (partly)! J.P. 523, Morris! near Browns Town, Miss T. M. Barrett! Claremont, $1700 \mathrm{ft} .$, Fawcett \& Harris! Lancaster, $2200 \mathrm{ft} ., 2500 \mathrm{ft} ., 3000 \mathrm{ft}$. ; Belvedere, Hanover, 500 ft. ; Harris! Ramble, Hanover; below Guava Ridge; Fawcett! Fl. Jam. 7568, 7777, 7805, 10,434, 10,457.-B. Guiana.

Plant 5-12 in. high. Pseudobulb $\cdot 5-2 \mathrm{~cm}$. 1. Leaves obliquely emarginate, 7-20 cm. 1., 11-25 mm. br. Panicle 1 to nearly $3 \mathrm{dm}$. l., generally shorter than the leaves. Bracts triangular, shortly acuminate, $1.5 \mathrm{~mm}$. 1. Flowers yellowish-white, perianth $\frac{1}{8}$ in. 1. Sepals 3-nerved, apiculate; median oblong-elliptical, $2 \cdot 5-2 \cdot 7 \mathrm{~mm} .1 ., 1.5 \mathrm{~mm}$. br.; lateral triangular-ovate, slightly oblique, $3 \mathrm{~mm}$. 1., $2 \mathrm{~mm}$. br.; chin rounded. Petals linear-subspathulate, acute, $2.5 \mathrm{~mm}$. 1. Lip, apex of lateral lobes scarcely extending beyond sinus; median much larger, roundish-elliptical, obscurely apiculate, margin curled; disk with very short, mealy hairs, about $3 \mathrm{~mm}$. l.; median lobe $2 \mathrm{~mm}$. br. Column, incl. anther, about $1 \mathrm{~cm} .1$. Capsule 6-8 mm. 1 .

Differs from $P$. foliosa Reichb. f. in being a larger plant, with larger flowers, also in other details, especially in petals and lip; the conical projecting callus at the base of the lip is characteristic.

\section{CRYPTOPHORANTHUS Barb. Rodr.}

Epiphytic herbs, with creeping rhizome without pseudobulbs. Stems with one leaf, short, with scarious sheaths. Leaf leathery or fleshy, more or less erect. Flowers rather small, shortly stalked, solitary, or sometimes a few clustered, at the base of the leaf. Sepals connate altogether, except for an open chink on each side between the median and the lateral sepals. Petals much smaller than the sepals. Lip free, a little longer than the petals, parallel with the column, very shortly clawed, jointed to the foot of the column, 3-lobed. Column erect, produced at the base into a rather long foot. Anther terminal, opercular, incumbent, hooded, 1-celled; pollinia 2, waxy, narrowly obovoid, compressed. Capsule broadly ellipsoidal.

Species 9, natives of IV. Indies and tropical America.

C. atropurpureus Rolfe in Gard. Chron. ii. 693 (1887). Specklinia atropurpurea Lindl, in Bot. Reg. under t. 1797 (1835). Pleurothallis atropurpurea Lindl. in Bot. Reg. xxviii. Misc. S1 
(1842). Masdevallial fenestrata Limll. ex Mook, in Bot. Mag. t. $416+(18+5) . \quad$ (Pl. 7, f. $8-10$.)

On trees, lanks and decaying logs; in fl. Aug.-Dec., in fr. Apr., Aug.; Purdic! J.I'. 484, Morris! Mansfield, noar Bath; Mabess River, 3000$4000 \mathrm{ft}$; Holly Mount, MIt. Diabolo, 2600-3000 ft.; Harris! Fl. Jam. 7580, 7626, 7817, 8911, 9014, 9891, 10,466.-Cuba.

Plant 3-6 in. high. Stem 3-5 cm. 1., 5-7-jointed, covered with sheaths; sheaths increasing in size from below upwards, $5-3 \mathrm{~cm}$. 1 , dilated at mouth, glabrous. Leaf obovate-elliptical, tapering into a short stalk $(1 \mathrm{~cm} .1$.) which is enclosed in the top sheath, $8-9 \mathrm{~cm} .1 ., 1 \cdot 5-3 \mathrm{~cm}$. br. Pedicel 2-jointed, $13 \mathrm{~mm}$. 1. Ovary 7-8 mm. 1., 12-winged. Bracts at each joint of pedicel, sheathing, one at upper joint 6-7 $\mathrm{mm}$. 1., with 3 or 4 smaller at base. Hlowers about $\frac{1}{2}$ in. 1., deep crimson. Sepals 14-15 mm. 1., $5 \mathrm{~mm}$. br., conduplicate; chink $5 \mathrm{~mm}$. from apex, $2 \mathrm{~mm}$. l., -6-.7 $\mathrm{mm}$. br. Petals nearly $4 \mathrm{~mm}$. 1., $2 \mathrm{~mm}$. br., oblong, truncate, 3-toothed at apex. Lip $4.5 \mathrm{~mm} .1 ., \cdot 75 \mathrm{~mm}$. br. at base, hastate, lateral lobes folded in front, a minute auricle at each side at the base. Column 2-2.5 mm. 1. ; clinandrium 2-toothed in front and 1-toothed behind.

\section{STELIS SW.}

Stems erect, clustered, simple, with one leaf at the apex, 2-jointed, with a sheath to each joint and small basal sheaths. Leaf leathery, contracted at the base into a short stalk, jointed near the base. Flowers very small, numerous on a long raceme springing from the base of the leaf, enclosed by a spathaceous bract and smaller inner bracts. Floral bracts small, sheathing below, about equalling the pedicel. Sepals generally subequal, lateral slightly oblique, spreading, shortly or deeply connate. Petals much shorter, broad, with thickened margins. Lip sessile at the base of the column, equal and somewhat similar to the petals. Column short, broad, generally thicker above; clinandrium with a lobe at each side, and a posterior lobe which is 3-lubulate; rostellum tongue-like. Anther terminal, opercular, incumbent, semiglobose, incompletely 2-celled; pollinia 2, waxy, pyriform, generally connected at the apex by slight viscum. Capsule small, ovoid or oblong, 3-cornered.

Species about 210, natives of tropical America, from the West Indies and Mexico to Brazil and Peru.

Closed flowers rounded; sepals elliptical ... 1. S. micrantha.

Closed flowers 3-cornered; sepals deltoid... 2. S. ophioglossoides.

1. S. micrantha Sw. in Schrad. Journ. Bot. ii. 240 (1799); racemes somewhat longer than leaf; closed flowers rounded; sepals elliptical-ovate, longer than broad, shortly connate at base, nerves slightly prominent below, the central nerve generally forming a keel in the lateral sepals. $S$ Sw. Fl. Ind. Occ. 1553 ; Smith Exot. Bot. t. 75 ; Hook. Exot. Fl.t. 158; Griseb. Fl. Br. W Ind. 611 ; Cogn. in Symb. Ant. vi. $386 . \quad$ Epidendrum micranthum Sw. Prodr. 125 (1788) \& Icon. ined. t. 50. Dendrobium 
micranthum Sw. in Nov. Act. Upsal. vi. 84 (1799). (Pl. 7, f. 15-28.) Type in Herb. Mus. Brit.

On trees and rocks; in $\mathrm{fl}$. all the year; Swartz! Macfadyen! Blue Mt. Peak, Prior! MIt. Moses, J.P. 23, Morris! Blue MIt. Peak, Fawcett! New Haven Gap, Moore! Morse's Gap, $5000 \mathrm{ft}$.; Woodcutters Gap near Newcastle, $4000 \mathrm{ft}$.; ridge from Newhaven Gap to Vinegar Hill, $4000 \mathrm{ft}$. ; Greenwich woodland, 4500 ft., Harris! Fl. Jam. 7537, 7815, 7835, 10,087, 10,141 .

Stem 7-12 cm. l., 1·5-2 mm. br., sometimes as short as 2 or $3 \mathrm{~cm}$, or as long as $15 \mathrm{~cm}$. Sheaths striate, apex truncate, apiculate, generally covering stem, scarious, soon decaying. Leaf lanceolate-oblong or ligulate, apex obtuse, sometimes minutely toothed, generally somewhat longer than stem, 11 or $12 \mathrm{~cm}$. 1., about $1.5 \mathrm{~cm}$. br., sometimes as short as $7 \mathrm{~cm}$., or as long as $16 \mathrm{~cm}$. Raceme solitary (rarely 2), many-flowered, 12-14 cm. l., rarely longer; spathaceous bract at base about $12 \mathrm{~mm}$. 1. Bracts sheathing at base, apex rounded, acute or apiculate to shortly acuminate, $1 \cdot 5-2 \mathrm{~m}$. 1 . Flowers: the size of the flower varies considerably: in Swartz's original specimen the median sepal is $2.3 \mathrm{~mm}$. $1 ., 1 \cdot 4-1.5 \mathrm{~mm}$. br., and the petal . $6 \mathrm{~mm}$. 1. and br.; in Fl.Jam. 7537 the median sepal is $2.5 \mathrm{~mm}$. 1 . and br., and the petal $.75 \mathrm{~mm}$. br.; in Fl. Jam. 7835 the median sepal is $3 \mathrm{~mm}$. l., $2.5 \mathrm{~mm}$. br., and the petal $1 \mathrm{~mm}$. br. Measurements of parts of the flower from dried specimens are somewhat misleading. In specimens put into spirit when collected (Fl. Jam. 10,087) the median sepal is $3 \cdot 75 \mathrm{~mm} .1$., $3 \mathrm{~mm}$. br., and the sepals are not distinctly keeled on back (petal $1.2 \mathrm{~mm}$. br.); sepals from the dried specimen (moistened in hot water) measure $3 \cdot 5 \mathrm{~mm}$. $1 ., 2 \cdot 4 \mathrm{~mm}$. br., and are obviously keeled. The flowers from the type specimen, and also from the MIarquis of Blandford's specimen figured by Sowerby (J. E. Smith, Exot. Bot. $t$. 75), are much smaller, but these are evidently not fully developed. Sepals pale green, 3-nerved, the central nerve in the median sepal sometimes forming a dorsal mucro just below apex, lateral nerves generally meeting the central nerve above in lateral sepals, but not always in the median sepal, lateral shorter but as broad or broader. Petals deep purple, sub-quadrangular, upper margin subdeltoid-lunate. Lip deep purple, somewhat like petals but broader above, upper surface semicircular with a narrowly elliptical median depression, with the upper margin lunate. Column deep purple.

2. S. ophioglossoides Sw. in Schrad. Journ. Bot. ii. 239 (1799) ; raceme much longer than leaf ; closed flowers 3-cornered ; sepals deltoid-ovate, broader than long, connate nearly to outer basal angle, nerves only slightly prominent below, angles at base and apex somewhat rectangular.-Sw. Fl. Ind. Occ. 1551 ; Lindl. Fol. Orch. Stelis, 7 (in part) not in Orch. Cub. Wright; Griseb. loc cit.; Cogn. op. cit. 387 (in part). S. polystachya Cogn. loc. cit. Ruscus? foliis ovatis petiolatis \&c. Plum. Pl. Amer. (Burm.) 172, t. 176 f. 3 (1758). Epidendrum ophioglossoides Jacq. Enum. Pl. Carib. 29 (1760) \& Sel. Stirp. 225, t. 133, f. 2, Ed. pict. t. 211 ; Sw. Obs. Bot. 331. E. trigonifiorum Sw. Prodr. 125 (1788) \& Icon. ined. t. 49. Dendrobium ophioglossoides Sw. in Nov. Act. Upsal.vi. 83 (1799). (Pl. 7, f. 11-14.) Type in Herb. Mus. Brit.

On trees and rocks; in fl. all the year; Swartz! J.P. 12, Morris! J.P. 2024, Syme! near Morse's Gap, 5000 ft., Fawcett! near Moy Hall, Sullivan! Greenhill, Moore! Mabess River, $3000 \mathrm{ft}$.; Cinchona, Harris! Fl. Jam. 7764a, 7764b. 
Similar to S. micrantha with the following differences: Stems $3-9 \mathrm{~cm} .1 .$, 1-2 mm. br. Leaf longer than tho stems, 5-11 cm. 1., $1-2 \mathrm{~cm}$. br. Racemes, 1-3, much longer than leaf, 12-22 cm. l. Bracts shortly acuminate, 2-3 $\mathrm{mm}$. 1. Scpals groenish-yellow with purplish tinge at base, apex obtuse, mucronate, 3-nerved, lateral nerves generally meeting the central nerve above in lateral sepals, but not always in median, median $2-2 \cdot 3 \mathrm{~mm}$. 1., $2 \cdot 5-2 \cdot 6 \mathrm{~mm}$. br., lateral $1 \cdot(j-2 \mathrm{~mm}$. $1 ., 2-2 \cdot 1 \mathrm{~mm}$. br. Petals deop purple, broadly roundish or obovate, upper margin lunate, with very thin points, $\cdot 7 \mathrm{~mm}$. 1., $\cdot 9-1 \cdot 1 \mathrm{~mm}$. br. Jip decp purple, angular-semicircular, $\cdot 75 \mathrm{~mm}$. 1., $1 \mathrm{~mm}$. br.

\section{PLEUROTHALLIS R. Br.}

Stems clustered or branches of a creeping stem or rhizome, simple, somewhat long, short or very short, with one leaf at the apex, sometimes with one to numerous sheaths below the leaf, not pseudobulbous. Racemes, one to numerous, at the base of the leaf, within the sheath or spathe, simple, with several flowers or laxly few-flowered, or in a few species shortened, 1-3-flowered, and densely crowded, or sometimes solitary. Flowers small, sometimes very small, or in a few species of medium size or rather large, generally on one side of the raceme. Bracts small, shortly tubular. Sepals about the same length, erect or spreading; the median free or very shortly connate with the lateral at the base; lateral connate at the base or higher into one, entire, 2 -fid or generally 2-partite, generally concave or slightly gibbous under the foot of the column. Petals shorter or narrower than the sepals, sometimes very small, more rarely about as long as the sepals. Lip shorter than the petals or more rarely a little longer, at the base generally contracted and jointed with the base of the column, 3-lobed; lateral lobes erect, embracing the column, or small, dentiform, or obsolete; the median somewhat spreading. Column as long as the lip or a little shorter, semiterete, the angles sometimes membranous-margined, not truly winged, at the base generally produced into a very short foot; clinandrium small or with a membranous extension, oblique, entire or shortly 3-lobed. Anther terminal or within the margin of the clinandrium, opercular, incumbent, 1-2-celled, pollinia 2, waxy, globose, ovoid or pyriform, free or cohering at the apex by a sparse viscid substance. Capsule sub-globose or ellipsoidal, 3-keeled or 3-cornered.

Species nearly 600 , natives of the mountains of tropical America from the West Indies and Mexico to Brazil and Bolivia.

I. Spathe at base of racemes large and leathery.

Racemes solitary, much longer than leaf.

Sepals yellow, acute

1. P. longissima.

Sepals purple, acuminate

2. P. racemiflora.

Racemes two or more, clustered, not longer than leaf.

Lip undivided; sepals white, gibbous........

Lip 3-lobed; sepals pale yellow.

3. P. gelida.

4. P. velaticaulis. 
II. Spathe inconspicuous, scarious.

A. Sheaths of the stem straight, adpressed, not ciliate.

1. Stem evident, leaf distant from base.

a. Racemes many-flowered, longer than the leaf or about as long.

Sepals yellowish-green, shortly acute, connivent ................

Sepals brownish-purple, obtuse, connivent .........................

Sepals deep purple, acuminate, divaricate ........................

5. P. alpestris.

6. P. multirostris.

7. P. laxa.

b. Flower-stalks with few flowers or only one, shorter than leaf.

Leaf 4 or 5 inches 1 . Flowerstalks very numerous, short, clustered

10. P. ruscifolia.

Leaf less than 4 inches 1 .

Basal sheaths hirsute .........

Basal sheaths glabrous, ovary smooth.

Petals not subulate.

Sepals greenish-yellow.

Leaf linear-lanceolate

Leaf elliptical-lanceolate.......................

Sepals dark purple....

8. P. hirsutula.

Petals subulate

9. P. pruinosa.

12. P. Wilsonii.

11. P. brachypetala.

Basal sheaths glabrous, ovary

8 or 9 inches 1 . Sepals

Leaf 8 or 9 inches 1 . Sepals

rough, about $\frac{2}{3}$ inch 1 . '........ 19. P. uncinata.

2. Stem very short, leaf close to the root.

Stems clustered.

Flower-stalk shorter than leafstalk. Capsule covered with

soft prickles......................
Flower-stalk shorter than leaf.

Capsule smooth ...............
Flower-stalks much longer than

18. P. tribuloides.

13. P. monophylla. leaf (or about as long in $P$. lanceola). Capsule smooth.

Leaf roundish

Leaf not roundish.

Flower-stalk with one flower; lateral sepals connate nearly to apex .............. 16. P. corniculata.

Flower - stalk few - flowered; lateral sepals free or not more than $\frac{1}{3}$-connate.

Flower-stalk much longer than leaf.

Sepals, apex obtuse ; flower-stalk zig-zag..... 21. P. delicatula. Sepals, apex tailed ......... 22. P. Helence.

Flower-stalk about as long as leaf

23. P. lanceola. 
Stems at intervals from creeping rhizome.

Leaf oval-roundish .................. 17. P. testifolia.

Lcaf lincar-spathulate ................. 24. 1'. sertularioides.

B. Sheaths (as in Lepanthes) with mouth

dilated, margiued, ciliate. Leaves

$\frac{1}{2}$ inch 1. or less.

Flower-stalk much shorter than leaf; stems much shorter than leaf....... 25.P.microlepanthes.

Flower-stalk longer than leaf; stem not shorter than leaf.

Stem with more than one leaf........... 26. P. foliata.

Stem with only one leaf ............... 27. P. trilobata.

In the sequence of the species wc have followed the arrangement adopted by Prof. Cogniaux in Urban's Symbolæ Antillanæ vi. 391-7.

1. P. longissima Lindl. Fol. Orch. Pleuroth. 31 (1559); raceme solitary, many-flowered, two or three times as long as leaf, enclosed by large leathery spathe; sepals greenish-yellow, acute, lateral connate almost to apex.-Griseb. Fl. Br. W. Ind. 607 ; Reichb. f. in Saund. Ref. Bot. t. 141 (1872); Cogn. in Symb. Ant. vi. 397. P. racemiflora Lodd. Bot. Cab. x. t. 949 (1824); Lindl. in Hook. Exot. Fl. t. 123 (1825), non in Fol. Orch. Type in Lindley's Herb. at Kew.

On trees and rocks; in fl. March-June; Bertero; Macfadyen! St. Mary, Purdie! McNab; Wilson! Fairfield, Wullschlaegel, 1383 ! St. Mary, J.P. 2331, Syme! St. Ann, Miss T. M. Barrett! Claverty Cottage, Moore! Back Woods, Portland Gap, Miss B. Gosset! Mt. Moses, $2000 \mathrm{ft}$., Harris! Fl. Jam. 9018, 10,424, 8118 (fide Cogn.).-Guatemala.

Plant 1-1 $\frac{1}{2} \mathrm{ft}$. high. Stems $4-17 \mathrm{~cm}$. l., shorter or a little longer than the leaves, clustered, clothed below with 2 or 3 adpressed acute sheaths. Leaf 9-14 cm. 1., 2-3 cm. br., sessile, oblong or oblong-elliptical, obtuse, tapering to base. Raceme to $35 \mathrm{~cm}$. 1., with 15-26 secund flowers; spathe 1-2 cm. l. Bracts 3-4 mm. l., slightly shorter than pedicels, scarious, sheathing, obliquely truncate and obtuse. Pedicels short, $5 \mathrm{~mm}$. 1. Flowers about $\frac{1}{3}$ in. l., greenish-yellow. Sepals $7-9 \cdot 5 \mathrm{~mm}$. 1., with mid-nerves prominent on back; lateral $4-4 \cdot 3 \mathrm{~mm}$. br., broadly ovately concave; median 3-3.3 mm. br., ovate, subacute, 3-nerved. Petals 6-8 mm. 1., $2 \cdot 1-2 \cdot 5 \mathrm{~mm}$. br., narrowly oval-oblong, broadest below the middle, to lanceolate, apex rounded, very minutely apiculate to acute, exceeding lip. Lip shorter than petals, when flattened barely exceeding $4 \mathrm{~mm}$. l., limb 3-3.5 mm. 1., 2-2.25 mm. br., with large basal auricles and short claw, roundish, 3-nerved, mid-nerve thickened in upper part. Column about $3 \mathrm{~mm}$. 1., slender; clinandrium membranous, ovate, blunt.

2. P. racemiflora Lindl. Fol. Orch. Pleuroth. 34 (1859); racemes usually more than one, but only one flowering, manyflowered, two or three times as long as leaf, enclosed by large leathery spathe; sepals purple, long acuminate, lateral $\frac{1}{2}$-connate. -Griseb. op. cit. 607; Cogn. op. cit. 398. P. oblongifolia Lindl. in Comp. Bot. Mag. ii. 355 (1837). Epidendrum racemiflorum S'w. Prodr. 125 (1788). Dendrobium racemi- 
florum Sw. in Nov. Act. Upsal. vi. 83 (1799) \& Fl. Ind. Occ. 1543. Type in Herb. Nus. Brit.

On trees and rocks; in fl. Aug.-Nov., in fr. throughout the year; Swartz! Macfadyen! Mit. Moses, 2500 ft., J.P. 2073 (in part), Syme! Blue Mits., J.P. 2073 (in part), Morris! John Crow Peak, Moore! Vinegar Hill, Sherring! Cinchona, 5000 ft. ; Morse's Gap; Old England ; Harris! Fl. Jam. 7685, 7818.-Cuba.

Plant 5 to $12 \mathrm{in.} \mathrm{high.} \mathrm{Stems} \mathrm{to} 10 \mathrm{~cm}$. 1., $2 \mathrm{~mm}$. br., with two developed internodes, clustered, terete at the base, compressed and angular above; sheaths, upper about $4 \mathrm{~cm}$. l., loose, brown, membranous, longitudinally striate, widening considerably towards the mouth. Leaf generally about as long as the stem, blade $5 \cdot 5-9 \mathrm{~cm}$. $1 ., 1 \cdot 5-2 \cdot 8 \mathrm{~cm}$. br.; ovaloblong, narrowed at the base into a short stalk $(1 \mathrm{~cm}$. or less). Racemes 14-24 cm. l., with 10-12 flowers in two rows, lax; spathe $1 \cdot 5-3 \mathrm{~cm}$. 1., compressed, obtuse. Bracts 4-7 mm. l., slightly shorter than the pedicels, scarious, ovate, obtuse, sheathing at base. Flowers about $\frac{3}{5}$ in. 1., magentacoloured. Sepals 7-10 mm. 1., connivent, concave, lanceolate, median $2 \mathrm{~mm}$. br., lateral $4.5 \mathrm{~mm}$. br. Petals $4 \mathrm{~mm}$. 1., $2 \mathrm{~mm}$. br., less than half as long as the sepals, oval, narrowed at the base, apex round, crenulate, 3-nerved. Lip longer than the petals, clawed, limb $4 \mathrm{~mm} .1 ., 1.5 \mathrm{~mm}$. br., concave, disk 3-keeled, elliptical, apex obtuse, triangular. Column scarcely equalling the petals; clinandrium shortly 3 -fid. Capsule $7-9 \mathrm{~mm}$. l., oblong.

3. P. gelida Lindl. in Bot. Reg. xxvii. Misc. 91 (1841); racemes two together, many-flowered, a little shorter than leaf, enclosed by large leathery spathe; sepals white, gibbous, lateral often $\frac{1}{2}$-connate; lip undivided.-Lindl. Fol. Orch. Pleuroth. 4 (1859); Griseb. op. cit. 607; Kränzl. in Yen. Orchid. iii. 116, t. 267, II. (1900). Cogn. op. cit. 399. P. univaginata Lindl. in Ann. \& Mag. Nat. Hist. ser. 3, i. 326 (1858) \& Fol. Orch. Pleuroth. 4 ; Griseb. loc. cit.; Cogn. op. cit. 398.

On trees in rocky woodland; in fl. Dec.; Manchester, Purdie! Iron Face, Chester Vale, 3500 ft., Harris! Fl. Jam. 7836.-Cuba, Porto Rico.

Plant often $1 \frac{1}{2} \mathrm{ft}$. high. Stems clustered, about $3 \mathrm{~mm}$. thick near the base; 2-jointed; sheath above the base of the stem somewhat compressed, membranous, blunt, to $8.5 \mathrm{~cm}$. 1. Leaf elliptical, $18-25 \mathrm{~cm}$. 1., including stalk (3-4 cm.), 4-5.5 cm. br. Racemes $12-14 \mathrm{~cm}$. l., with 16-20 secund flowers; spathe $1 \cdot 5-2 \mathrm{~cm}$. 1. Bracts barely $2 \mathrm{~mm}$. 1., short, obtuse. Flower's nearly $\frac{1}{3}$ in. 1., pale yellow. Sepals $7 \mathrm{~mm}$. 1., erect, forming a cup, subelliptic, obtuse, with short hairs on the inside. Petals $35 \mathrm{~mm}$. 1 ., subovate. Lip $2.5 \mathrm{~mm}$. l., widening above to a broad rounded apex, bearing two wing-like keels on the upper face which do not reach the apex, with two teeth in the middle of each side. Column less than $2 \mathrm{~mm}$. l., with a minute tooth on each side at the apex. Capsule ellipsoidal, 3-ribbed.

Lindley says of $P$. urivaginata, "very like the last" ( $P$. gelida), "but distinguished by the state of the sepals and form of the lip." Examination of the type specimens in Lindley's herbarium and of other available material leads to the conclusion that we are dealing with only one species. The degree of union of the lateral sepals varies somewhat, while the hairs to which Lindley refers in his description "sepalis intus pilosis," are present to a very slight extent in the type specimen; the form of the lip is the same in both, the two median wing-like keels being present, though Lindley says of univaginata, "labello ecarinato." 
Neither at Ker nor the British Museum are there any specimens named $P$. gelida, and Grisebach merely quotes Lindley's description, which was based on a cultivated plant ohtained by Messrs. Loddiges from Jamaica.

The figure in Yenia Orchidacea (iii. t. 267, II.) represents the flower more widely open than obtains in any specimens we have seen.

4. P. velaticaulis Reichb. f. in Linnxa xxii. 824 (1849): racemes 1-5, with numerous flowers, shorter than leaf, or about as long, enclosed by a large leathery spathe; ovary terete, smooth; sepals keeled, lateral subfree; lip 3-lobed, lateral lobes emarginate.-Lindl. Fol. Orch. Pleuroth. 29 (1859); Cogn. op. cit. 400 \& under. P. crassipes Lindl., so far as concerns Jamaican specimen Fl. Jam. 7745. (Pl. S, f. 17-2..)

On rocks and trees; in fl. Nov.; near Cinchona, $5000 \mathrm{ft}$. , Harris! Fl. Jam. 7745.-Cuba.

Plant a foot or more high. Stems $13-21 \mathrm{~cm}$. 1., clustered, long, slender, angular, of two internodes, with a long thin tubular sheath at each node, $5 \mathrm{~cm}$. 1., with a shorter outer one at the base. Leaf oblanceolate-oblong, tapering into a long stalk, shorter than the stem, 10-12 cm. 1., of which the stalk is about $2 \mathrm{~cm} .1 ., 2-2 \cdot 5 \mathrm{~cm}$. br. Racemes $6-10 \mathrm{~cm}$. 1 . Bracts tubular below, dilated upwards, truncate, apiculate, $3-3.5 \mathrm{~mm}$. 1 . Pedicels as long as the bracts. Ovary $3 \cdot 5-4 \mathrm{~mm}$. l., carrying the flower much above the bracts. Sepals, median ovate, subacute, 3-nerved, $4 \mathrm{~mm}$. 1., $2 \mathrm{~mm}$. br. ; lateral lanceolate, acute, 3-nerved, $4 \mathrm{~mm} ., 1 ., 1 \cdot 3 \mathrm{~mm}$. br. Petals linearoblong, blunt, obscurely apiculate, 1-nerved, a little over $2 \mathrm{~mm}$. 1., $.7 \mathrm{~mm}$. br. Lip broad, 3-lobed, 3-nerved, $1.7 \mathrm{~mm}$. 1., barely $1.5 \mathrm{~mm}$. br., inserted by a short broad claw, above which is a transverse ridge, middle lobe shortly ovate, blunt; lateral lobes much shorter than the middle lobe, rounded, emarginate. Column short, broad, about $1 \mathrm{~mm}$. 1., without a membranous margin.

Reichenbach's description differs in that the sepals are oblong, obtuse, and the petals cuneate. This species is very near $P$. crassipes Lindl.

5. P. alpestris Lindl. Gen. \& Sp. Orch. Pleuroth. 7 (1830); racemes, 1-several, with numerous flowers, not much longer than the small leaf, or about as long; sepals yellowish-green, shortly acute, connivent into a tube, the lateral connate nearly to apex. -Griseb. op. cit. 607 ; Cogn. op. cit. 401. P. nigroannulata Cogn. in Fedde Repert. vi. 306 (1909) in part (Fl. Jam. 7554) \& in Symb. Ant. vi. 417. Epidendrum alpestre Sw. Prodr. 125 (1788). Dendrobium alpestre Sw. in Nov. Act. Upsal. vi. 84 (1799) \& Fl. Ind. Occ. 1545. Type in Herb. Mus. Brit.

On trees; in fl. Nov.-Feb.; Blue Mts., Swartz! Clydesdale, $4000 \mathrm{ft}$., J.P. 29; 35 ; Morris! Cinchona, C. Nicholls! Mt. Hybla ; Silver Hill Woodland, $4000 \mathrm{ft}$. ; Hardware Gap; Woodeutters' Gap, $4000 \mathrm{ft}$. ; Holly Mount, Mt. Diabolo, 2600 ft.; near Cinchona, 4000 ft.; Harris! Fl. Jam. 7554, 7613, 7829, 8908, 10,502.

Plant 4 or 5 in. high. Stems $2-3 \mathrm{~cm} .1 ., 1 \mathrm{~mm}$. or less thick, clustered; somewhat compressed and angular when dry; a loose membranous sheath springs from a node just above the base and extends about half-way to the leaf. Leaf $3-4.5 \mathrm{~cm}$. 1., 7-13 mm. br., narrowly oval to oval-lanceolate, 
obtuse, sessile, at the base subacuminate. Racemes $3 \cdot 5-5 \cdot 5 \mathrm{~cm}$.l., filiform. Flowers $\frac{1}{3}$ in. l., yellowish-green, lax. Pedicels scarcely longer than the bracts. Bracts $2 \mathrm{~mm}$. l., small, acute, sheathing. Sepals $8 \mathrm{~mm}$. l., median 1.75 to $2.5 \mathrm{~mm}$. br., the united lateral 3 to $4 \mathrm{~mm}$. hr., erect, keeled, lanceolate. Petals yellowish-green tinged with purple at the base, $2 \cdot 5-2 \cdot 75 \mathrm{~mm}$. l., 75 to $1 \mathrm{~mm}$. br., subovate, acute, one-third as long as the sepals. Lip deep purple, very small, $2.5 \mathrm{~mm}$. l., shortly clawed, 2-keeled on the disk, keels running up near the apex, sub-panduriform with a blunt tooth on each side below middle, then constricted, and 2-auricled above the narrow claw. Column shorter than the petals, clinandrium crenulate, 2-denticulate, tinged with purple at the base. Capsule $8 \mathrm{~mm} .1 ., 2 \cdot 5 \mathrm{~mm}$. br., oblong, gibbous, with 6 muricate keels.

\section{P. multirostris Reichb. f. in Linnæa xli. 49 (1877);} raceme 1, with several flower's; sepals brownish-purple, curved, beak-lize, the lateral connate nearly to apex, apex obtuse.Cogn. in Symb. Ant. vi. 401.

\section{In fl. Sept.}

Stems clustered, about as long as the leaf, amply sheathed. Leaves oblong, acute, stalked. Raceme deflexed, with several flowers. Bracts minute, triangular. Pedicels about equalling the ovary. Flowers brownishpurple, curved, beak-like. Sepals linear-ligulate, lateral sepals connate nearly to apex, apex obtuse. Petals half as long as sepals, oblong, obtuse, minutely denticulate at apex, 3-nerved. Lip oblong, obtusely acute, obscurely 3-lobed at the middle, lateral lobes low, obtuse-angled and 3-nerved. Column thick, at apex membranous, denticulate.

We have not seem any specimen of this species, and it is solely on the authority of Reichenbach that it is included among the orchids of Jamaica.

7. P. laxa Lindl. Gen. \& Sp. Orch. 7 (1830); racemes 1-3, sometimes with as many as six flowers on each, longer than the leaf; sepals deep purple or greenish striped with purple, acuminate, divaricate, lateral $\frac{1}{2}$-connate.-Lindl. Fol. Orch. Pleuroth. 35 ; Griseb. op. cit. 607 ; Cogn. op. cit. 403. P. nigroannulata Cogn. in Fedde Repert. vi. 306 (1909) in part (Fl. Jam. 7536) \& in Symb. Ant. vi. 417. Epidendrum laxum Sw. Prodr. 125 (1788). Dendrobium laxum Sw. in Nov. Act. Upsal. vi. 84 (1799) \& Fl. Ind. Occ. 1547. Type in Herb. Mus. Brit.

On trees; in fl. Aug.-Nov.; in fr. Dec.; Swartz! Portland Gap, 5500 ft., J.P. 170; 2073 (in part); Morris! John Crow Peak, Fawcett! Pleasant Hill, $4500 \mathrm{ft}$; near Woodcutters' Gap, $4000 \mathrm{ft}$; Harris! Fl. Jam. 7536.

Plant 3 to 5 in. high. Stems clustered, 2-5 cm. l., barely reaching $1 \mathrm{~mm}$. in width, somewhat compressed and angular when dry, covered within $1 \mathrm{~cm}$. or less of the leaf by three loose membranous keeled sheaths. Leaf 3-4 cm. 1., 1-1.3 cm. br., oval-oblong. Racemes $5-7 \mathrm{~cm}$. 1. Bracts $2 \mathrm{~mm}$. l., clasping, acute. Flouers deep purple, $\frac{1}{3}$ in. l. Sepals $8 \mathrm{~mm} .1$., lateral narrowly lanceolate, median linear-lanceolate. Petals $4 \mathrm{~mm}$. l., purple or purple-streaked, narrowly lanceolate, half the length of the sepals. Lip slightly shorter than the petals, spotted with purple, shortly elawed, the lower part concave, obtusely lobed, the upper part ovate, recurved, with a pair of short, rounded erect lobes at base. 2-keeled on the disk. Column a little shorter than the petals, spotted with purple; clinandrium denticulate, anther-case dark purple. 
8. P. hirsutula Fruwe. \& Renille in Journ. Pot. xlvii. 3 (1909); basal sheaths with dark hrown stiff short hairs: racemes 1-5 together, generally not more than one flowering at a time, with four or five flowers, about one-third the length of the leaf. Cogn. in stymb. Aut. vi. 403. (Pl. 9, f. 15-19.) Type in Herb. Mus. Brit. \& Jam. Herb.

On trunks of trees; in fl. Aug.; Holly Mount, Mt. Diabolo, 2600-3000 ft., Harris! Fl. Jain. 6681, 9890.

I'lant $4 \frac{1}{2}-7$ in. high. Rhizome creeping, rooting. Stems $6-10 \mathrm{~cm} .1$., clustered, longer than the leaves, two-edged, edges furrowed; sheaths three, loose. Leaf $5-7 \cdot 5 \mathrm{~cm} .1 ., 1-1 \cdot 3 \mathrm{~cm}$. br., sessile, lanceolate, at the base clasping. Raceme $1 \cdot 2-2 \cdot 5 \mathrm{~cm} .1$. Bracts $2 \mathrm{~mm}$. 1., sheathing, truncate. Flowers about $\frac{1}{4}$ in. l., very dark red. Scpals more or less erect, 3 -nerved, somewhat fleshy; median $6.5 \mathrm{~mm}$. 1., lanceolate, somewhat acuminate, concave; lateral slightly shorter, narrowly triangular-lanceolate, acute, at the base connate, gibbous. Petals slightly exceeding $3 \mathrm{~mm}$. l. by $1.5 \mathrm{~mm}$. br., rhomboid, narrowed at the base, upper margins minutely toothed. Lip 2.75 mm. 1., 1.25 mm. br., ovate, shortly clawed, margin undulate. Column $2 \cdot 25 \mathrm{~mm}$. l., slender, curved.

9. P. pruinosa Lindl. in Bot. Reg. xxviii. Misc. 75 (1842) stem longer than leaf ; raceme one, with about six flowers, shorter than the leaf; leaf linear-lanceolate to narrowly oval; sepals greenish-white or pale yellow, lateral connate almost to apex; petals linear, somewhat acute-Lindl. Fol. Orch. Pleuroth. 26 ; Griseb. op. cit. 608 ; Cogn. op. cit. 404.

On trees; in fl. April; Irilson; Fairfield, Wullschlaegel, 1353! MIt. Moses, 2500 ft., J.P. 2125, Syme! near Mabess River, $3500 \mathrm{ft}$.; Cascade, 2500 ft.; Harris! Fl. Jam. 7997 \& 8111 (fide Cogniaux).-Hispaniola, Porto Rico, Guadeloupe, Martinique, Grenada, Trinidad, Guiana.

Plant 2 to $3 \mathrm{in}$. high. Stems to $5.5 \mathrm{~cm}$. l., clustered, subterete, thin, sheathed at the base, and with one close, glabrous, obliquely truncate sbeath below the middle. Leaf to $3.5 \mathrm{~cm}$. 1., $6 \mathrm{~mm}$. br., sessile. Spathe 5-7 mm. l., closely compressed, lanceolate, subacute. Bracts sheathing, truncate, obtuse, glabrous, a little shorter than the pedicels. Flowers $\frac{1}{8}$ in. l., pale yellow or greenish-white, minute, distant, very shortly stalked, cleistogamous (?). Sepals $3 \mathrm{~mm}$. l., equal, broadly ovate, slightly 2 -keeled; median ovate, subacute, slightly keeled. Petals a little shorter than the sepals. Lip half as long as sepals, erect, shortly clawed, limb triangular, somewhat acute, with 3 parallel keels on the disk. Column barely $1 \mathrm{~mm}$. 1., short, thick. Capsule $4 \mathrm{~mm}$. l., elliptical, crowned by the persistent calyx.

10. P. puscifolia R. Br. in Ait. Hort. Kew. ed. 2. v. 211 (1813) ; stem much longer than leaf ; flower-stalks very short, in dense clusters, each with one flower; leaf 4 or 5 in. 1.-Hook. Exot. Fl. t. 197 ; Griseb. op. cit. 608; Cogn. op. cit. 405. P. multicaulis Puepp. \& Endl. Nov. Gen. i. 47, t. 82 (1835). Ruscus foliis \&c. Plum. Pl. Ámer. (Burm.) t. 176, fig. 2 (1755). Epidendrum ruscifolium Jacq. Enum. Pl. Carib. 29 (1760), Select. Stirp. Amer. 226. t. 133, fig. 3 (1763) \& Ed. pict. t. 212 ; Sw. Obs. Bot. 331 (1791). Dendrobium ruscifolium Sw. in Nor. Act. Upsal. vi. 84 (1799). 
On trees; in fl. July, Aug. ; in fr. Aug. ; Swartz! Moody's Gap, J.P. 2071, Syme! Mabess River, $2000 \mathrm{ft} .$, C. Nicholls! G. Nichols! Harris!-Cuba, Hispaniola, Porto Rico, Martinique, Dominica, St. Vincent, Grenada, Trinidad, Margarita, B. Guiana, Ecuador, Peru, Bolivia.

Plant 7 to 13 in. 1 . Rhizome creeping, $1-1 \cdot 5 \mathrm{~mm}$. thick, with a dense covering of slender root fibres and from the upper surface a number of erect slender rounded clustered stems from 4 to $20 \mathrm{~cm}$. l., with a slender adpressed cylindrical truncate bract (about $2 \mathrm{~cm}$. 1.) about or rather below the middle. Leaf, blade $11 \mathrm{~cm} .1 ., 2.5 \mathrm{~cm}$. br., erect or suberect, stiff, many-nerved, glabrous, oblong-Ianceolate, apex more or less acuminate, stalk about $1.5 \mathrm{~cm}$. l. A dense cluster of inflorescences springs from the short conduplicate bract $(6-7 \mathrm{~mm}$. 1.) ; each inflorescence contains several stalked flowers (stalks 5-6 mm. 1.), the base of each stalk is surrounded by a thin hyaline bract. Sepals $7 \mathrm{~mm}$. l., lanceolate, acuminate, lateral connate. Petals $3.5 \mathrm{~mm}$. l., linear, acuminate, erect. Lip $1.25-1.5 \mathrm{~mm}$. 1 , -75-1 mm. br., lower portion nearly square in outline with raised convex sides and a broad central channel, apex bluntly triangular with a much thickened callus on the midrib. Column less than $1 \mathrm{~mm}$. 1., including the short rounded anther-cell. Ovary $2 \mathrm{~mm}$. l. Capsule green, narrowly club-shaped, about $1 \mathrm{~cm}$. 1 .

11. P. brachypetala Griseb. in Cat. Cub. 25: (1866); stems nearly as long as leaf; racemes 2-4 together, with two to five flowers, one-third to one-fourth the length of the leaf; leaf oval; sepals dark purple, lateral $\frac{2}{3}$-connate; petals cuneate, apiculate.-Cogn. op. cit. 406. (Pl.8, f. 7-10.) Type: Cuba, Wright, 3349 .

On trunks of trees amongst lichen and moss; in fl. Nov.-April; Mt. Moses, 3500 ft., J.P. 2277, Syme! above Mabess River, 3500-4000 ft.; Lancaster, 2500 ft.; near Cinchona, 4500 ft.; Harris! Fl. Jam. 7641, 7852, 9012, 10,501.-Cuba, Porto Rico.

Plant 2 to 3 in. high. Stems $2-3 \mathrm{~cm}$. 1., clustered, compressed, nearly covered with rather loose sheaths, the upper keeled, acute, the others blunt. Leaf $3-4 \mathrm{~cm}$. l., 10-14 mm. br., sessile, oval to narrowly elliptical, base clasping. Racemes to $1 \mathrm{~cm}$. l., with a prominent sheathing bract at base. Flowers dark purple. Bracts $2 \mathrm{~mm}$. l., sheathing, loose, shortly acute. Sepals $4 \mathrm{~mm}$. l., gibbous; median ovate, obtuse; lateral ovate-lanceolate, shortly acute. Petals half as long as sepals, $\cdot 8 \mathrm{~mm}$. br. Lip shortly clawed, with two short lobes below the middle, elliptical above, apex rounded, incurved towards the column below, recurving above the middle. Column as long as petals, clavate, winged, with a distinct foot.

Specimens from Jamaica agree with Wright No. 3349 in Herb. Kew, which unfortunately has no flowers. Grisebach's description differs from our plant in petals being ovate and lip obovate.

12. P. Wilsonii Lindl. in Ann. \& Mag. Nat. Hist. ser. 3, i. 326 (1858) (in part); stem longer than the small ellipticallanceolate leaf; peduncles, one or (rarely) two or three, with one flower (or rarely two) on each, much shorter than leaf ; petals oblanceolate, shortly acute.-Lindl. Fol. Orch. Pleuroth. 17 (in part); Griseb. Fl. Br. W. Ind. 608; Cogn. op. cit. 407. (Pl. 9, f. 8.) Type in Lindley's Herb. at Kew.

On trees and rocks; in fl. Aug.-Nov.; in fr. Dec.-May (fide Cogniaux); Bethabara, Wilson! and Wullschlaegel, 1079 !-Porto Rico and Guadeloupe (fide Cogniaux). 
Plunt $2 \frac{1}{2}$ in. high, with crecping rhimome. Secondary stem $1.54 \mathrm{~cm}$. l., slender, the lower half loosely shenthed. Iseaf $1 \cdot 5-3 \cdot 3$ em. 1., 5-8 mm. br., sessile, margined. Peduncles $3-5 \mathrm{~mm}$. l. Jracts about $1 \mathrm{~mm} .1$., sherthing, truncate, obtuse. Flowers greenish-ycllow, striped violet inside (fide Cogniaux), about $\frac{1}{6}$ in. l. Sepals about 4 mm. l., 3-nerved; median narrow, triangular, acute, coneave, $1.2 \mathrm{~mm}$. l)r. ; latcral triangular, falcate, slightly narrower. l'etals $2 \mathrm{~mm}$. l., $5 \mathrm{~nm}$. br. lip, lower portion somewhat broadly ovate above a short broad claw, indistinetly 3-lobed, middlc lobe narrow, oblong, blunt, about $2 \mathrm{~mm}$. l.; lower portion about twothirds of whole length; margin papillose. Capsule obovoid, narrowly 3-kceled, 8-9 mm. 1 .

Lindley included two plants in his description of $P$. Wilsonii-one from Cuba (Wright, No.668), and the other from Jamaiea, eolleeted by Wilson. The two plants differ remarkably in the conformation of the lip, and must be regarded as distinet species. We retain the name $P$. Wilsonii for the Jamaican plant, as Lindley's deseription of the lip evidently refers to it, and not to the Cuban plant, which we have described, in Journ. Bot. xlvii. 129 (1909), under the name P. confusa. The lip only of $P$. Wilsonii is represented in Pl. 9, f. 8. A portion of the plant $P$. confusa is shown in f. 5 , a petal in f. 6 , and the lip in f. 7 .

Cogniaux's description of Porto Rico and Guadeloupe specimens differs somewhat from ours, e.g., the median sepal is oblong-subspathulate, obtuse, the petals are narrowly ovate, $1 \cdot 5-1 \cdot 75 \mathrm{~mm}$. $1 ., \cdot 75 \mathrm{~mm}$. br., the peduneles are $6-14 \mathrm{~mm} .1$.

13. P. monophylla comb. nov.; stem shorter than the leaf; racemes, two or three together (only one flowering), with two flowers, shorter than the leaf; leaf elliptical-lanceolate; ovary warty; sepals pale-green, lateral united near base and somewhat gibbous; petals lanceolate, acute.-P. emarginata Lindl. Fol. Orch. Pleuroth. 25 (1859); Griseb.op. cit. 608 ; Cogn. op. cit. 408. Epidendrum (?) monophyllum Hook. Exot. Fl. t. 109 (1825).

Without loeality, Wiles.

Plant about 2 in. high. Stems abnut $2 \mathrm{~cm}$. 1., clustered, ereet, slender, covered for the most part by sheathing bracts. Leaf $3-4 \mathrm{~cm} .1 ., 1 \cdot 2 \mathrm{em}$. br., obtuse. Pedicels about one-third as long as sepals, rather swollen upwards. Bract searcely exceeding the pedicel, sheathing, with ovate acute mouth. Sepals 7 or $8 \mathrm{~mm}$. 1., 1-nerved, slightly keeled, lanceolate, acute. Petals minute, about one-third as long as sepals, whitish with a red central line, 1-nerved. Lip small, about as long as the petals, pink or deep purple, lanceolate, parallel with the petals and enclosed by them, nearly plane, slightly serrated at the margin, near the base above having two indistinct tubercles. Column shorter than the petals, straight, semicylindrical at the base, above at the base of the anther expanding into a sort of hood formed by the concave broadly winged and toothed margin, the base deep purple. Ovary very short, purple.

No specimen seen; deseribed from figure and deseription in Hooker's Exotic Flora.

14. P. Morrisii Fawc. \& Rendle in Journ. Bot. xlvii. 3 (1909); stem about as long as the narrowly lanceolate, somewhat falcate, subacuminate sessile leaf; peduncles two together, 1-flowered, very short ; petals subulate ; lip entire.-Cogn. op. cit. 408. (PI. 9, f. 1-4.) Type in Herb. Mus. Brit. and Jam. Herb. 
Without locality, Morris, 28 !

Plant 3 or 4 in. high. Stems $3-5 \mathrm{~cm}$. 1., filiform, clustered, terete, with two dark-brown, adpressed sheaths at the base, the upper sheath 7-9 mm. 1. Leaf 4-5 cm. 1., 5-8 mm. br. Sepals $3.5 \mathrm{~mm}$. 1., broadly elliptical; median $2 \mathrm{~mm}$. br., 3-nerved; lateral somewhat broader, connate, 2-nerved, at apex 2-toothed. Petals $2.5 \mathrm{~mm}$. 1. Lip $2.4 \mathrm{~mm} .1 ., 1 \cdot 6 \mathrm{~mm}$. br., shortly clawed, articulated to foot of column, obtuse, concave, with a thickened margin. Column $1.5 \mathrm{~mm}$. 1., short; clinandrium with a long narrow process in front.

The species is named after Sir Daniel Morris, formerly Director of Public Gardens and Plantations in Jamaica.

15. P. rotundifolia Rolfe in Kew Bulletin, 1895, 191 ; stems almost none, clustered; peduncle much longer than the roundish leaf, solitary, few-flowered ; sepals straw-coloured, lateral connate nearly to apex.-Cogn. op. cit. 409. (Pl. 8, f. 11-16.) Type in Herb. Kew.

Without locality, Morris!

Plant very small, $1 \frac{1}{2}-2$ in. high, acaulescent. Leaves roundish-obovate, marginate, fleshy, 6-S mm. l., 5-7 mm. br.; petiole short, 2-4 mm. l. Scape slender, with about six flowers, $4-5 \mathrm{~cm}$. l. Bracts tubular at the base, triangular-ovate, acute, small, $1 \mathrm{~mm}$. 1. Pedicels $2 \mathrm{~mm}$. l. Flowers strawcoloured, about $\frac{1}{6}$ in. 1. Sepals oval; median acute, concave, 3-nerved, $4 \mathrm{~mm}$. 1., $1.8 \mathrm{~mm}$. br., with light red-purple nerves; lateral 2-nerved, $4.5 \mathrm{~mm}$. 1., $2.5 \mathrm{~mm}$. br. Petals spathulate-oblong, subobtuse, $1.4 \mathrm{~mm}$. 1., straw-coloured with mid-nerve purple-red. Lip subrecurved, undivided, oblong, obtuse, 3-nerved, 1.7 mm. $1 ., \cdot 7 \mathrm{~mm}$. br., basal three-fourths purplered, upper fourth straw-coloured. Column winged, with acute apex, $1.25 \mathrm{~mm}$. 1 .

16. P. corniculata Lindl. in Bot. Rey. xxviii. Misc. 83 (1842) (excl. syn.) ; stems very short, clustered; peduncle longer than the oval-oblong leaf, solitary, with only one flower; lateral sepals connate almost to apex.-Lindl. Fol. Oich. Pleuroth. 42 ; Griseb. op. cit. 609; Cogn. op. cit. 412. Epidendrum corniculatum Sw. Prodr. 123 (1788). Dendrobium corniculatum Sw. in Nov. Act. Upsal. vi. 83 (1799) \& Fl. Ind. Occ. 1537. Type in Herb. Mus. Brit.

On trunks of trees; in fl. Sept.-April; Swartz! near Rodney Hall, Purdie! Beaufort, Wullschlaegel, 1081 (in part)! Prior! lowlands to 1000 ft.; St. Mary; J.P. 2403; Syme! Hopeton, Westmoreland, 1400 ft., Harris! Fl. Jam. 9781.-Cuba.

Plant $1 \frac{1}{2}-2$ in. high. Stems closely clustered, barely exceeding $\cdot 5 \mathrm{~cm}$. 1 ., enveloped in loose overlapping brown scarious blunt sheaths. Leaf 1-2 cm. 1., 5-7 mm. br., margined, with a short stalk (3-8 mm. 1.). Peduncle $2 \cdot 5-3.5 \mathrm{~cm}$. l., solitary, longer than the leaf, filiform, with one flower, with a scarious sheathing bract above the middle. Flower yellowish, not open (cleistogamous ?), about $\frac{1}{5}$ in., slightly curved. Sepals $5 \mathrm{~mm}$. 1., lanceolate-acuminate; median 3-nerved, median nerve keeled; lateral connate almost to the apex, 2-keeled, gibbous at the base. Petals $2.75 \mathrm{~mm}$. l., erect, suboblanceolate, 3-nerved, a little more than half as long as the sepals. Lip yellow, $2.5 \mathrm{~mm}$. l., subrhomboid, obtusely acuminate above, 3-nerved. Column, including the anther, $2 \mathrm{~mm}$. 1., erect, a little shorter than the petals; clinandrium, with a lateral tooth and prolonged anteriorly on both sides into a slightly curved tooth. Capsule $6 \mathrm{~mm}$. 1., oblong. 
17. P. testifolia Lindl. in Ann. \& Mag. Nat. Hist. ser. 3, i. 328 (1858) ; stems very short from a creeping rhizome; leaf oval or rounclish oval, 7 -9-nerved, sessile at the apex of the stalk-like stem, minutely 3-toothed at the obtuse apex; sepals purple, oblong, 3-neved, covered with white hairs, median obtuse and minutely apiculate, lateral connate above the middle, gibbous at base, connivent above over the lip and column, concave, narrowing to a shortly apiculate apex.-Lindl. Fol. Orch. Pleuroth. 43 ; Griseb. op. cit. 609 ; Cogn. op. cit. 414. Epidendrum testiefolium Sw. Prodr. 122 (1788). Cymbidium testafolium Sw. in Nov. Act. Upsal. vi. 71 (1799) \& Fl. Ind. Occ. 146.

In fl. Sept.-Feb.; Wilson! Purdie! March! Bethabara, Wullschlaegel, 1082 ! J.P. 2122, Syme! Dollwood; Lancaster, 2200-2500 ft.; near Mabess River, 4000 ft. ; near John Crow Peak; Harris! Fl. Jam. 7548, 7551, 7787, 10,484.-Cuba, Martinique, Venezuela.

Plant creeping, branch with leaf to $1 \frac{1}{4}$ in. 1. Rhizome long, creeping, rooting at the nodes, ringed, $1 \mathrm{~mm}$.- or a little more-thick; sheaths about equal to internodes, membranous, obtuse, keeled. Secondary stems reduced, distant along rhizome, usually at every third node, $1 \mathrm{~cm}$. or less apart, about $5 \mathrm{~mm}$. l., enveloped in a pair of overlapping truncate sheaths. Leaf 20-30 mm. 1., 10-20 mm. br. Flouer purple, nearly $\frac{1}{4}$ in. 1., single, subsessile, subtended by a sheath; sheath ultimately about $6 \mathrm{~mm}$. l., persistent, accrescent, conduplicate, with a lacerate-winged keel. Ovary covered with white hairs. Sepals, median $5.5 \mathrm{~mm}$. 1., $1.5 \mathrm{~mm}$. br., lateral $6 \mathrm{~mm}$. l. Petals 2.5-3 mm. l., erect, not quite half the length of the sepals, spathulate, crenulate at upper margin. Lip including the narrow claw ( $75 \mathrm{~mm}$. 1.), 2.75-3 mm. 1., broadly oblong-pandurate, shortly auriculate at the base, apex rounded, 3-nerved, margin with long hairs. Column slightly shorter than the petals; clinandrium membranous, curledcrenulate.

18. P. tribuloides Lindl. Gen. \& Sp. Orch. 6 (1830); stems very short, clustered; peduncle shorter than leaf-stalk, one or a few together, 1-flowered; capsule covered with soft prickles.Lindl. Fol. Orch. Pleuroth. 39 ; Griseb. op. cit. 609 ; Kränzl. in Xen. Orch. iii. 131, t. 275, f. III. \& 14-19; Cogn. op. cit. 415. Epidendrum tribuloides Sw. Prodr. 123 (1788). Dendrobium tribuloides Sw. in Nov. Act. Upsal. vi. 83 (1799), Fl. Ind. Occ. 1535 \& Adnot. Bot. t. 1, f. 4. Type in Herb. Mus. Brit.

On trees in moist woods; in fl. Aug.-Jan.; in fr. Oct.-Jan.; Swartz! Wilson! Macfadyen! St. Mary, Purdie! Beaufort, Wullschlaegel, 1080 ! St. Mary, $2000 \mathrm{ft}$., J.P. 2402, Syme! Mabess River, $2000 \mathrm{ft} .$, G. Nichols! Slope of John Crow Peak, $200 \mathrm{ft}$. above Mabess River, Fawcett! Union Hill, near Moneague, Lady Blake! Trelawney, Miss 'T. M. Barrett! Mt. Moses; Mabess River; Mt. Airy, 2000 ft.; Belvedere, Hanover, 500 ft.; near Christiana, 2600 ft.; Harris! Fl. Jam. 7546, 7648, 10,402.-Cuba, Costa Rica, Mexico.

Plant 1 or 2 in. high. Stems about $2 \mathrm{~mm}$. l., closely clustered on a short densely rooted rhizome, and enveloped in scarious sheaths. Leaf 3-5 cm. 1., 8-10 mm. br., narrowly elliptical to elliptical-oblong, tapering into a long stalk, minutely emarginate. Peduncle closely surrounded by short blunt scarious sheaths. Ovary densely covered with long papillæ. 
Flowers about $\frac{1}{4}$ in. 1., brownish-red. Sepals papillose, $6 \mathrm{~mm}$. 1.; median nearly $2 \mathrm{~mm}$. br. at base, broadly linear-tapering; lateral $2.5 \mathrm{~mm}$. br. together, 2 -nerved, about $\frac{1}{2}$-connate, free part acuminate. Petals about $2 \mathrm{~mm}$. 1., one-third as long as sepals, cval-oblong. Lip about as long as petals, short-clawed; limb narrowing from a broader base to a short linear recurved fleshy shortly pubescent tip. Column nearly as long as petals, narrowly margined, margins forming a slender tooth at each side near apex. Capsule about $\cdot 5 \mathrm{~cm} .1$., broadly ellipsoidal.

19. P. uncinata Favvc. in Journ. Bot. xxxiii. 12 (1895) ; stem about as long as the leaf; peduncles much shorter than the leaf, three or four together, l-flowered; leaf 8 or 9 in. l. ; sepals and ovary rough.-Cogn. op. cit. $416 . \quad$ (Pl. 10.)

On trees and peaty banks; in fl. Feb., June; fr. July; Greenhill, near Newcastle; Ridge below Vinegar Hill, 3900 ft.; Harris! Hardware Gap, $4000 \mathrm{ft} .$, G. Nichols! Fl. Jam. 10,092.

Plant about $15 \mathrm{in}$. high. Stems 12-24 cm. 1., clothed with 5-7 loose scarious flaccid sheaths, terete below, compressed and angular above, striate. Leaves 15-23 cm.1., 2·5-3 cm. br., oblong-lanceolate or lanceolate, with numerous prominent nerves. Peduncles $3-4 \mathrm{~cm} .1$, rough; pedicels about $6 \mathrm{~mm}$. 1.; floral bracts $1.3 \mathrm{~cm}$. l., reaching nearly to top of ovary, sheathing at the base, gradually tapering to an obtuse apiculate apex; spathaceous bract about $2 \mathrm{~cm}$. 1. at base of peduncles. Sepals purplish, surface rough on inner and outer sides, tomentose on outer side; median $1.7 \mathrm{~cm}$. 1., $5 \mathrm{~mm}$. br., oblong, tapering to a subacute apex, 5-nerved; lateral $1 \cdot 6 \mathrm{~cm}$. $1 ., \dot{5} \cdot 5 \mathrm{~mm}$. br., free or shortly connate at base, oblongelliptical, tapering to a subacute apex, 4-nerved. Petals about $8 \mathrm{~mm}$. 1 ., $2 \mathrm{~mm}$. br., half as long as the lateral sepals, oblanceolate, apex acute, 3-nerved, purplish above, orange-coloured at base. Lip slightly exceeding $7 \mathrm{~mm}$. l., nearly as long as the petals, about $3 \mathrm{~mm}$. br. above, purplish, indistinctly 3 -lobed, 3-nerved; middle lobe roundish, margin with minute denticulations ; lateral lobes conduplicate, uncinate, each forming a sharp curved hook pointing upwards, with a thickened margin above the hook. Column nearly $7 \mathrm{~mm}$. 1., narrowly winged in front, with a short foot. Ovary about $8 \mathrm{~mm}$. l., about $3.5 \mathrm{~mm}$. br. above, rough. Capsule $2.2 \mathrm{~cm}$. 1 ., $1 \cdot 1 \mathrm{~cm}$. br., ellipsoidal, surface rough and tomentose, with 6 furrows.

20. P. jamaicensis Rolfe in Journ. Bot. xlvii. 122 (1909); plant $1-1 \frac{1}{2}$ in. high; stems clustered, shorter than the leaf; peduncle one-half or one-third as long as the leaf, with one or a few flowers; sepals reddish-purple, lateral very shortly connate at base; petals linear-lanceolate, acuminate--Cogn. op. cit. 422.

Without locality, Morris! Flowered at Kew in Sept. 1886 and on subsequent occasions.

Plant 1-1 $\frac{1}{2}$ in. high. Secondary stems clustered, 1-2 cm. 1., shorter than the leaf; sheaths tubular, apiculate, veined. Leaf shortly stalked, elliptical, obtuse, leathery, $1 \cdot 5-2 \cdot 5 \mathrm{~cm}$. l. Racemes shortly stalked, with one or a few flowers, $1-1.5 \mathrm{~cm}$. l. Bracts sheathing, shortly acuminate, $2 \mathrm{~mm}$. l. Flowers light reddish-purple with a darker lip, scarcely $\frac{1}{3}$ in. 1 . Sepals somewhat spreading, ovate-lanceolate, acute, $7-8 \mathrm{~mm}$. l. Petals a little shorter than the sepals. Lip linear, obtuse, recurved, $2 \mathrm{~mm}$. 1 . Column slender, curved, $1 \mathrm{~mm}$. 1 .

21. P. delicatula Lindl. Fol. Orch. Pleuroth. 38 (1859); stems almost none, clustered; peduncle flexuose, generally much 
longer than leaf, one flower developed at a time, but pedicels of former flowers present (to 16); lateral sepals $\frac{1}{3}$-connate.Giriseb. op. cit. 608 ; Coyn. op. cit. 423.

On trees in moist woods; in fl. Oct.-April; Purdie! near Nabess River, 3500-4000 ft.; near Troy, $2500 \mathrm{ft}$; near Christiana, $3000 \mathrm{ft}$.; near John Crow I'eak; Harris! Ellen Aire, Moy Hall, Sullivan! slope of John Crow Peak, 100 ft. above Mabess River, Fawcett! Fl. Jain. 7617, 7826, 8869, $9007,10,399,10,476,10,478$.

Plant (without the raceme) $\frac{1}{2}-\frac{3}{4}$ in. high. Stens about $3 \mathrm{~mm}$. 1., very short, closely clustered, filiform, enveloped by the membranous sheath. Leaf 1-2 cm. 1., including the stalk, oblanceolate, margined, narrowed at the base into a slender stalk. Racemes $2 \cdot 5-4 \mathrm{~cm}$. 1., generally much longer than the leaf, but occasionally shorter, clustered, flowering solitary, filiform, flexuose, with several (to 16) flowers, laxly secund or in two ranks. Bracts about $1 \mathrm{~mm}$. l., short, half the length of the pedicels, sheathing, obtuse, shortly apiculate. Pedicels about $2 \mathrm{~mm}$. 1. F'lowers about $\frac{1}{6}$ in., greenish-yellow streaked with crimson or purple. Sepals $3.75 \mathrm{~mm}$. 1., suberect, acuminate above and somewhat thick, obtuse; lateral narrowly ovate, about $\frac{1}{3}$-connate; median oblong or lanceolate-oblong, keeled. Petals about $2 \mathrm{~mm}$. l., half as long as the sepals, cuneate, fimbriateserrulate above, acute. Lip about $3 \mathrm{~mm}$. l., a little shorter than the sepals, 3-lobed; middle lobe oblong or oblong-oblanceolate, somewhat thick; much exceeding the short broad incurved serrulate lateral lobes. Column a little shorter than the petals, upper margin dilated, serrulate; clinandrium 2 or 3-dentate. Capsule $6 \mathrm{~mm}$. 1., obovate-elliptical, glabrous.

22. P. Helenæ Fawc. \& Rendle in Journ. Bot. xivii. 4 (1909); stems very short, clustered; peduncle filiform, much longer than the leaf, few-flowered; sepals caudate, lateral free; lip nearly half as long as sepals.-Cogn. op. cit. 424. (Pl. 9, f. 9-14.) Type in Herb. N. York Bot. Gard. and in Herb. Mus. Brit.

On trunks of trees; in fl. July; in fr. Aug.; Mt. Moses, 3500 ft., J.P. 2279, Syme! Mabess River, $3500 \mathrm{ft} .$, Harris!

Plant $1 \frac{1}{4}-2$ in. high. Stems very short, clustered; sheaths tubular below, acute. Leaf, including stalk, $10-15 \mathrm{~mm}$. 1., 2-3 mm. br., oblanceolateelliptical or oblanceolate-linear, narrowed at the base into the stalk. Racemes 1.5-5 cm. 1., branched. Bracts sheathing, acute or apiculate. Flowers $\frac{1}{8}$ in. 1., pale green. Sepals about $3.25 \mathrm{~mm}$. 1., pale greenish, 1-nerved, spreading, caudate, glabrous; median ovate, $1 \mathrm{~mm}$. br.; lateral lanceolate, free, narrower than median. Petals two-thirds as long as sepals, $2.6 \mathrm{~mm}$. 1., $.75 \mathrm{~mm}$. br., pale greenish, ovate, fimbriate on the upper margin, caudate at the apex. Lip half as long as the sepals when spread out, $1.5 \mathrm{~mm}$. 1., $\cdot 75 \mathrm{~mm}$. br., pale greenish marked with crimson, 3-lobed, conduplicate, lateral lobes broadly rounded, fimbriate on the upper margin, middle lobe ovate, obtuse. Column lined with crimson, including the conical anther, as long as the lip, slender, thicker above; clinandrium 3-toothed. Capsule obovoid-ellipsoidal, 3-4 mm. l., $2 \mathrm{~mm}$. br.

The figures in the plate are from a detailed drawing by Miss H. A. Wood, after whom the plant is named.

23. P. lanceola Spreng. Syst. iii. 731 (1826); stems very short, clustered; peduncle about as long as the leaf, clustered, only one flowering at a time, 2-4-flowered; lateral sepals connate at base.-Lindl. Fol. Orch. Pleuroth. 40 ; Griseb. op. cit. 609; Cogn. op. cit. 425. Epidendrum lanceola Sw. Prodr. 123 (1788). 
Dendrobium lanceola Siv. in Nov. Act. Upsal. vi. 83 (1799), Fl. Ind. Occ. 1539 \& Adnot. Bot. t. 2, f. 5. Type in Herb. Mus. Brit.

On trees and stones; in fl. and fr. Oct.-Feb.; mountains, Swartz ! St. George, J.P. 171, 231, Morris! Mt. Moses, 3800 ft., J.P. 2091, Syme! St. George, Portland, $2500 \mathrm{ft}$; near Mabess River, 3000-4000 ft.; near John Crow Peak ; Harris! Fl. Jam. 7467, 7520, 7742, 10,479.

Plant $1 \frac{1}{2}$ to $2 \frac{1}{2}$ in. high. Stems generally $1-1 \frac{1}{2} \mathrm{~cm}$. 1., sometimes shorter, enveloped in scarious sheaths, filiform. Leaf 3-4 cm. 1., 3-3.5 $\mathrm{mm}$. br., narrowing gradually below into a distinct stalk, linear-lanceolate, shortly apiculate, margins revolute when dry, midrib prominent on the under side. Pedicels $5 \mathrm{~cm}$. 1. Bracts about $1.5 \mathrm{~mm}$. 1., sheathing, truncate. Flowers nearly $\frac{1}{4}$ in. 1., orange or scarlet. Sepals 5-6.5 $\mathrm{mm}$. l., lanceolate, obtuse, 3-nerved, keeled, spreading at apex, lateral connate at the base, gibbous. Petals $2.5 \mathrm{~mm}$. 1., nearly half as long as the sepals, oblong-spathulate, with 1-2 nerves, prominent. Lip, as long as the petals, oblanceolate, 3-nerved, reflexed about the middle, with undulate margin there. Column scarcely shorter than the petals, winged; clinandrium, margin crenulate. Capsule $5 \mathrm{~cm}$. 1., ellipsoidal to obovoid.

24. P. sertularioides Spreng. Syst. iii. 731 (1826); stems very short, from creeping rhizome; leaf narrowly oval, ovaloblong or linear-spathulate, narrowed into the stalk; sepals straw-coloured or greenish, membranous, lanceolate, acuminate, lateral shortly connate, slightly gibbous.-Lindl. Fol. Orch. Pleuroth. 42 ; Griseb. op. cit. 609 ; Cogn. op. cit. 426 . Epidendrum sertularioides Sw. Prodv. 122 (1788). Dendrobium sertularioides Sw. in Noc. Act. Upsal. vi. 83 (1799) \& Fl. Ind. Occ. 1541. Type in Herb. Mus. Brit.

On trees; in fl. and fr. Jan., Feb.; mountains, Swartz! Beaufort, Wullschlaegel, 1081 (in part)! below Vinegar Hill Gap, Portland, J.P. 2039, Campbell! near Mabess River, Fawcett! Belvedere, Hanover, 500 ft. ; Troy, 1600 ft. ; Harris! Walderston, Mrs. Longstaff! Fl. Jam. 7569, 10,446, 10,487.-Cuba, Trinidad.

Plant barely an inch high. Phizome less than $1 \mathrm{~mm}$. br., slender, creeping, ringed, rooting at the nodes, covered with membranous sheaths. Stems less than $5 \mathrm{~mm}$. 1., from 5 to $10 \mathrm{~mm}$. apart, generally springing from alternate nodes or every third node of the rhizome, enclosed by sheaths. Leaf $1 \cdot 5-2 \cdot 5 \mathrm{~cm}$. 1. Peduncles solitary, capillary, scarcely as long as the leaf, 1-rarely 2 -flowered, with a short, truncate, 2-dentate, spathaceous bract at the base and above the middle, sometimes with 3 bracts; occasionally the peduncles of two preceding flowering seasons persist. Bracts barely exceeding $1 \mathrm{~mm}$. l. Flowers about $\frac{1}{6}$ in. 1 , strawcoloured or light green. Sepals about $4 \mathrm{~mm} .1 ., 1 \mathrm{~mm}$. br., 1-nerved. Petals $3 \mathrm{~mm} .1 ., \cdot 7 \mathrm{~mm}$. br., linear-lanceolate, acuminate, 1-nerved. Lip 2.4-2.75 mm. 1., $\cdot 4-\cdot 75 \mathrm{~mm}$. br., sessile, with minute square auricles at base, linear-lanceolate, margin undulate, denticulate about midway, recurved above. Column $1.5 \mathrm{~mm}$. 1., with a membranous wing. Capsule ellipsoidal, 3-keeled, about $9 \mathrm{~mm}$. 1 .

25. P. mierolepanthes Griseb. op. cit. 610 ; plant not more than $\frac{1}{2}$ in. high; stems clustered, shorter than the leaf; sheaths with mouth dilated, margined and ciliate; peduncle half as long as leaf; sepals yellow in drying, lateral connate nearly to apex.-Cogn. op. cit. 430. 
On trees; in fl. Nov:; Macfadyen! Wilson! March! Mabess River, Harris. Fl. Jam. 7468 (fide Cogniaux).

Stems reduced, glabrous, $2-5 \mathrm{~mm}$. 1.; shoaths $2-3$, tubular, with a glabrate deltoid mouth. I Leaf margined, olliptical, or elliptical-roundish, somewhat pointed, tapering into the stalk, $8-6 \mathrm{~mm}$. $1 ., 4-6 \mathrm{~mm}$. br. Racemes stalked, clustered, with 2-5 flowers. Flowers ycllow and purple. Scpals ovate, acute, erect, scarcely $1 \mathrm{~mm}$. 1., yollow in drying; lateral connate nearly to apex. Petals minute, spathulate, half as long as the breadth of the sepals. Lip oblong, obtuse, a little shorter than the sopals.

26. P. foliata Griseb. op. cit. 610 ; stems clustered, with more than one leaf, much longer than leaf; sheath with mouth dilated, margined and ciliate; peduncle longer than leaf; sepals, lateral connate to apex; petals acute or acuminate; lip undivided.Cogn. op. cit. 431. Type in Herb. Kew.

Without locality, Wilson!-Cuba.

A small plant 2 to 3 in. high. Stems $3-7 \mathrm{~cm}$. 1., puberulous at the angles, often somewhat branched or distantly 2-several-leaved. Leaf margined, elliptical or obovate, apex somewhat rounded and sometimes minutely apiculate, narrowed into the stalk (2-3 $\mathrm{mm}$. 1.), $12-8 \mathrm{~mm}$. l., $5 \mathrm{~mm}$. br. Racemes stalked, one or sometimes two, distantly 4-8-flowered, 15-25 mm. 1. Pedicels 2-3 mm. 1. Bracts acuminate, 1-1.5 mm. 1 . Flowers yellowish. Sepals oblong-linceolate, erect, 2-3 mm. 1., yellow in drying. Petals ovate, acute, half as long as the sepals. Lip linear, obtuse, puberulous above, a little longer than the petals, dark purple at apex.

27. P. trilobata Fave. \& Rendle in Journ. Bot. xlvii. 4 (1909) ; stems clustered; about as long as leaf; sheaths with mouth dilated, margined and ciliate; peduncle much longer than leaf; sejals, lateral $\frac{1}{2}$-connate; petals very obtuse; lip 3-lobed.--Cogn. op. cit. 431. (Pl. 8, f. 1-6.) Types in Herb. Mus. Brit., in Jam. Herb. \& N. York Bot. Gard. Herb.

On trunks of ti'ees; in fl. Feb. and Sept.; in fr. Sept.; between Newhaven Gap and Vinegar Hill, $4000 \mathrm{ft}$., Harris! Fl. Jam. 10,084. John Crow Peak, Britton, 267 !

Plant minute, $\frac{1}{2}$ to $\frac{3}{4}$ in. high. Stem $7 \mathrm{~mm}$. 1. Leaf $7 \mathrm{~mm}$. 1., nearly $3 \mathrm{~mm}$. br., elliptical, narrowed at the base into a thin stalk. Sheaths 2 or 3 , covering the stem. Scape $2 \mathrm{~cm}$. l., one or few-flowered, solitary or two, filiform, flexuose. Bracts $6 \mathrm{~mm}$. l., spathaceous, lanceolate, acute. Sepals, median 4-4.3 mm. 1., 1.5 mm. br., lateral somewhat shorter and much narrower; median elliptical, apex caudate, 3-nerved, lateral 1-nerved. Petals $1.6 \mathrm{~mm}$. $1 ., \cdot 7 \mathrm{~mm}$. br., oblong, narrowed at the base, 1-nerved, about one-third as long as the sepals. Lip 1.5-1.7 mm.l., nearly as broad, 3-nerved, middle lobe oblong, sometimes crenulate at the apex, a little longer than the rounded lateral lobes. Column a little over $1 \mathrm{~mm}$. 1 .

\section{LEPANTHES SW.}

Small or dwarf epiphytic herbs. Stems clustered, thin, erect, covered throughout the length with sheaths, and bearing. 
at the apex a single leaf; sheaths tubular, enlarging towards the margined oblique mouth, and marked with several vertical ridges. Leaf sessile or subsessile, rigid, elliptical or roundish elliptical, margined, minutely 3 -toothed at the apex. Racemes axillary, solitary or clustered; flowers few or several, somewhat close together, in two ranks, generally minute. Sepals spreading or erect, more or less ovate, subequal, lateral more or less connate. Petals minute, the short claw adnate to the base of the column, the limb generally much wider than long. Lip adnate at the base or above the base of the column, 2-lobed, the lobes erect, parallel to the column, cuneate, with the upper edges thickened, forming flattened surfaces embracing the column; or sometimes simple, with or without two posterior lobes. Column short; anther terminal, opercular, generally obovate; pollinia 2, waxy, pear-shaped, pedicellate. Capsule obovoid.

Species about 50, on the mountains of tropical America and the West Indies.

§1. Diplocheilus. Lip dividing near the base into two erect, diverging lobes of which the upper edges thicken into more or less expanded lanceolate surfaces, embracing the column.

A. Breadth of petals shorter than length of sepals.

I. Breadth of petals longer than upper surfaces of lip.

a. Posterior lobe of petal subequal to anterior.

1. Sepals acuminate, lateral $\frac{1}{3}$-or less - connate.

Sepals ciliolate, lateral connate only at base .....................

Sepals glabrous, lateral $\frac{1}{3}$-connate

2. Sepals acuminate, glabrous, lateral $\frac{1}{2}$-connate; petals rhomboidal ......

3. Sepals acute or obtuse, $\frac{1}{2}-\frac{2}{3}$-connate.

Sepals ciliolate, lateral ${ }_{3}^{2}$-connate

Sepals glabrous, lateral $\frac{1}{2}$-connate. Petals deltoid or obversely deltoid.

Plants $1 \frac{1}{2}-2 \frac{1}{2}$ inches high, petals obversely deltoid.

Sepals acute, crimson ... Sepals obtuse, yellow .... Plants $4-7$ inches high; sepals acute, petals deltoid Petals lanceolate

1. L. pulchella.

7. L. divaricata.

9. L. obtusipetala.

2. L. sanguinea.

3. L. Wullschlaegelii.

4. L. Woodiana.

10. L. obtusa.

5. L. Loddigesiana.

4. Sepals connate nearly to apex .......

b. Posterior lobe of petal much larger

II. Breadth of petals shorter than upper surfaces of lip ................................ 11. L. arcuata.

B. Breadth of petals about as long as length of sepals 
\$2. Haplocheilus. Lip not dividing near the base, but expanding variously above the petals.

Lip simple in outline.

Petals 2-lobed

13. I. bilabiata.

Petals subulate .......................... 14. I. clliptica.

Petals small, rounded.

Sepals free nearly to base ........ 15. T. brevipetala.

Sepals $\frac{1}{2}$-connate ................. 16. I. Harrisii.

Lip prolonged posteriorly into 2 lobes.

Lip-lobes linear.

Anterior part of lip rounded ...... 17. I. tridentata.

Anterior part of lip square ......... 18. L. quadrata.

Lip-lobes triangular....................... 19. L. concolor.

$\S 1$. Diplocheilus. Lip dividing near the base into two erect diverging lobes, of which the upper edges thicken into more or less expanded lanceolate surfaces, embracing the column.

1. L. pulchella Sw. in Nov. Act. Upsal. vi. 86, t. 5, figs. 6, c, $d, e(1799)$; sepals yellow, lateral with a crimson spot at base, median crimson along midrib; ciliolate, caudate-acuminate, lateral connate only at base; posterior lobe of petal subequal to anterior, breadth of petals shorter than length of sepals, longer than upper surfaces of lip.-Sw. Fl. Ind. Occ. 1559 \& Adnot. Bot. t. 2, fig. 3 ; Griseb. Fl. Br. W. Ind. 610 ; Fawc. \& Rendle in Trans. Linn. Soc. vii. 7, t. I. f. 15 (1904). Epidendrum pulchellum Sw. Prodr. 125 (1788). Type in Herb. Mus. Brit.

In $\mathrm{fl}$. throughout the year; top of Catherine Peak, Swartz! Moody's Gap, J.P. 2031, Syme! Mabess River, 3000 ft. ; John Crow Peak; Nowhaven, $4000 \mathrm{ft}$.; Newhaven Gap, $5600 \mathrm{ft}$. ; Gap to Vinegar Hill, $4000 \mathrm{ft}$. ; Morse's Gap ; ridge above Morse's Gap, $5300 \mathrm{ft}$. ; Harris! John Crow Peak, Fawcett! Moy Hall, Sullivan! Fl. Jam. 7761, 7830, 10,085.

Plant less than an inch high. Stems $1 \mathrm{~cm}$. or less in length, about as long as the leaves; mouth of the sheaths acute, ciliolate, ridges glabrous. Leaves, including the short stalk, 10-14 mm. l., 5-6 mm. br., oval, acute. Racemes 1.5-2 cm. 1., exceeding the leaf, generally 2-5-clustered, rarely solitary. Flowers about $\frac{1}{4}$ in. l., several, three or four appearing at the same time. Sepals 6-8 mm. 1., 2-3 mm. br., ovate, long-acuminate, ciliolate, lateral connate only at the base. Petals crimson, inclining to yellow at the ciliolate margin; apex obscure, indicated by an inconspicuous notch or tooth; lobes subequal, subtriangular, varying somewhat in shape, especially in breadth, more or less bluntly and asymmetrically triangular, the outer edges of the two forming an almost continuous line, $2 \cdot 2-4 \mathrm{~mm}$. br. Lip crimson, minutely ciliolate, $1-1.5 \mathrm{~mm}$. br. Column to base of clinandrium $1 \mathrm{~mm}$. l., crimson; anther subglobose, emarginate. Capsule (unripe), $5 \mathrm{~mm}$. l., 6-keeled. (The flowers of some specimens are only about half the above measurement.)

Swartz's figure in Adnot. Bot. l. c. represents a larger plant than any that we have seen, having stems to $2 \mathrm{~cm}$. and leaves to nearly $2 \mathrm{~cm}$. l., $1.8 \mathrm{~mm}$. br.

2. L. sanguinea Hook. in Bot. Mag. 4112 (1844); sepals magenta-crimson, ciliolate, subacute, lateral $\frac{2}{3}$-connate; posterior 
lobe of petal subequal to anterior, breadth of petals shorter than length of sepals, longer than upper surfaces of lip.-Griseb. op. cit. 611 ; Fawc. \& Rendle op. cit. 9, t. I. f. 16, 17.

In fl. throughout the year; near Mabess River, $4000 \mathrm{ft}$; near John Crow Peak ; MIt. Diabolo, 2500 ft.; Harris! Fl. Jam. 7616, 7747, 7825.

Plant $\frac{1}{2}$ to 1 in. high. Stems $1 \mathrm{~cm}$. or less l., shorter than the leaves; mouth of the sheaths acute, ciliolate, ridges muriculate. Leaves $1 \cdot 2-1 \cdot 8$ cm. l., 5-8 mm. br., subsessile, oval to elliptical, shortly apiculate. Racemes 4-6 $\mathrm{mm}$. l., $\frac{1}{3}$ or $\frac{1}{4}$ as long as leaves, several clustered, fewflowered. Bracts acute, more or less hirsutulous on the dorsal nerve and margin. Sepals $4 \mathrm{~mm}$. l., ovate, median 2.5-3 mm. br. Petals $\cdot 7 \mathrm{~mm}$. l., 2.5-3 mm. br., rose-coloured and crimson, somewhat equally extended on both sides, lobes oblong or oblong-elliptical, ciliolate, apex forming an almost straight line or slightly retuse. Lip deep crimson, upper margins elliptical to elliptical-lanceolate. Column short, dilated above; anther obovately orbicular, emarginate.

3. L. Wullschlaegelii Fawc. \& Rendle in Journ. Bot. xlvii. 126 (1909); plant 1 $1 \frac{1}{2}-2 \frac{1}{2}$ in. high; leaves green; bracts ciliolate on keel and margins; sepals crimson, glabrous, acute, lateral $\frac{1}{2}$-connate; petals obrersely deltoid, apex abruptly apiculate, lobes subequal, glabrous, breadth of petals shorter than length of sepals, longer than upper surfaces of lip.-Type in Herb. Reg. Monac.

Beaufort, Wullschlaegel, 1078!

Plant $1 \frac{1}{2}-2 \frac{1}{2}$ in. high. Stem longer than leaf, $2 \cdot 5-6 \mathrm{~cm}$. 1., slender, sheaths long, slender, ciliolate on the ridges and at the ovate acuminate mouth. Leaves oval, shortly acuminate, $2-2 \cdot 5 \mathrm{~cm}$. 1 , about $1 \mathrm{~cm}$. br. Racemes shorter than the leaf; flowers many, in two ranks. Bracts clasping, broadly ovate, $1-1 \cdot 2 \mathrm{~mm}$. l. Sepals ovate, lateral, nearly $2 \mathrm{~mm}$. l., $1.75 \mathrm{~mm}$. br. ; median nearly $2 \mathrm{~mm}$. 1., $1.2 \mathrm{~mm}$. br. Petals 1.3-1.4 mm. br. Lip, upper surfaces lanceolate, $\cdot 6 \mathrm{~mm}$. l. Column long, $\cdot 8 \mathrm{~mm}$. 1 . Capsule small, obovoid, $2 \cdot 5 \mathrm{~mm}$. 1 .

Closely resembles $L$. divaricata in habit, but the structure of the flower brings it near to L. obtusa and L. Woodiana.

4. L. Woodiana Fawc. \& Rendle op. cit. 6 ; plant $1 \frac{1}{2}$ in. high ; bracts glabrous; sepals transparent yellow, glabrous, obtuse, lateral $\frac{1}{2}$-connate; petals obversely deltoid, apex short, obtuse, lobes subequal, glabrous, breadth of petals shorter than length of sepals, longer than upper surfaces of lip.-(Pl. 11, f. 12-17.)

On trunks of trees; in fl. Feb. ; Holly Mount, MIt. Diabolo, 2600 ft., Harris!

Stem to $3.5 \mathrm{~cm}$. 1., generally longer than the leaf; sheaths very acute, muriculate on the ridges. Leaf generally $8-14 \mathrm{~mm}$. l., elliptical, subsessile. Racemes several, clustered, shorter than the leaf. Bracts somewhat acute. Flowers $\frac{1}{12}$ in. 1., yellow, several. Sepals broadly ovate, median $2 \mathrm{~mm}$. l., lateral barely as long as median. Petals slightly over $1 \mathrm{~mm}$. br., a deeper shade of yellow than the sepals, shaded with crimson. Lip $\cdot 5 \mathrm{~mm}$. 1., crimson, upper margins elliptical to elliptical-lanceolate. Column deep pink, short, dilated above ; anther case white.

The specific name is given in honour of Miss $\mathrm{H}$. A. Wood. 
5. L. Loddigesiana Reichb. f. Xen. Orch. i. 145 (1856); sepals yellow and purple, glabrous, acute, lateral $\frac{1}{2}$-connate; petals lanceolate, downy, lobes subequal, anterior obtuse, posterior acute, breadth of petals shorter than length of sepals, longer than upper surfaces of lip.-Fawe. \& Rendle in T'rans. Limn. S'oc. vii. 8 (1904). L. tridentata Liull. Bot. Reg. t. 1762 (1835) (non Swartz); Griseb. op. cit. 610, "i form with reduced stems."

Highest parts of mountains.

Plant 1-3 in. high. Stems varying from $4 \mathrm{~mm}$. to $5 \mathrm{~cm}$. l., generally shorter than the leaves; sheaths smooth. Leaves $3.7 \mathrm{~cm}$. 1., oval, with shortly acute apex, tapering at the base into an obscure petiolo. Racemes about half as long again as the leaves, solitary,1-2-flowered. Sepals equal, ovato, median purple with a yellow edge, lateral yellow, slightly tinged with purple, the surface frosted with brilliantly glittering tubercles. Petals half as long as the sepals, deep purple. Lip downy, yellowish, lower part tinged with purple. Column short, with two small lateral horns.

We have not seen this plant. The description is compiled from the account and figure in the "Botanical Register," where it is assigned by Lindley to $L$. tridentata Sw. It differs widely from that species in the form of the petals and lip, which resemble somewhat those of L. pulchella.

6. L. rotundata Griseb. op. cit. 610 ; sepals, lateral connate nearly to apex; petals obversely deltoid, breadth of petals shorter than length of sepals, longer than upper surface of lip.Fawc. \& Rendle op. cit. 6.

Without locality, Macfadyen.

Plant about 2 in. high. Stems much longer than the leaf; sheaths with a subulate minutely ciliate limb. Leaf 12-16 mm. $1 ., 8 \mathrm{~mm}$. br., elliptical. Racemes clustered, sometimes solitary, longer than the leaf. Flowers about $\frac{1}{6}$ in. 1. Sepals deltoid, lateral cohering below the 2 dentate apex. Petals much smaller than the sepals. Lip, lobes diverging, spathulate, adnate to the middle of the column.

We have not seen this plant.

7. L. divaricata Fawc. \& Rendle op. cit. 11, t. II. 27-29; sepals light yellow shaded with crimson down the centre, glabrous, acuminate, lateral $\frac{1}{3}$-connate; posterior lobe of petals subequal to anterior, breadth of petals shorter than length of sepals, longer than upper surfaces of lip.

In fl. Aug.-April ; Blue Mt. Peak, J.P. 14 (in part) ; Cinchona, J.I'. 16 (in part); Morris! Moy Hall, Sullivan! John Crow Peak, 5500 ft. ; Newhaven, $4000 \mathrm{ft}$. ; ridge from Newhaven Gap to Vinegar Hill, $4000 \mathrm{ft}$.; near Woodcutters' Gap, 4000 ft. ; ridge above Morse's Gap, 5300 ft. ; Hardware Gap, 4500 ft.; Blue Mt. Peak, 7000 ft.; Harris! Fortland Gap; Morse's Gap, 4800 ft.; John Crow Peak ; Fawcett! Retreat, J.P. 2031, Miss T. M. Barrett! Fl. Jam. 7758, 7832, 7833, 10,082, 10,127, 10,459.

Plant 3-8 in. high. Stems $2.5 \mathrm{~cm}$. 1., rarely longer (to $15 \mathrm{~cm}$.), much longer than the leaves; mouth and ridges of the sheaths minutely ciliolate. Leaves, including the short stalk, generally $2-3 \mathrm{~cm}$., rarely to $4 \mathrm{~cm}$. 1., 8-13 mm. br., often purple beneath, elliptical, acuminate. Racemes $2-3.5 \mathrm{~cm}$. l., several, clustered, sometimes shorter, sometimes longer than the leaves; flowers several, close together. Sepals very 
variable in size, $4-6 \mathrm{~mm}$. 1., $2-4 \mathrm{~mm}$. br., ovate, acuminate; lateral $\frac{1}{3}$-connate, apices diverging. Petals $2 \cdot 5-3 \cdot 5 \mathrm{~mm}$. br., apex obscure, extended nearly equally on both sides; lobes $\cdot 75-1.5 \mathrm{~mm}$. br., linear to linearoblong, obtuse; anterior half orange, posterior half crimson, the crimson colour sometimes extending nearly to the edge. Lip crimson, with more or less orange shading, upper surfaces lanceolate, anterior acute, posterior obtuse. Column crimson; anther light-purplish. Capsules $5 \mathrm{~mm}$. 1., $4 \mathrm{~mm}$. br., obovoid, with 6 ridges.

The colour of the sepals varies with age; when the flower opens, it is a transparent light yellow slightly shaded with crimson down the centre; as the flower grows older the crimson shading extends almost to the edges showing very little of the yellow. When the flower opens, the tips of both lobes of the petals overlap, then they straighten, but in the old flower converge again; when the lobe-tips converge, the apex of the petal appears distinctly acute, but when the petals are straight, the apex is not evident.

Var. minor Fuwc. å Rendle loc. cit.

In fl. Sept., Moy Hall, Sullivan!

Plant smaller. Stems to $3 \mathrm{~cm}$. 1. Leaves broadly elliptical, very shortly acuminate, rarely exceeding $1.5 \mathrm{~cm} .1 ., 1 \mathrm{~cm}$. br. Racemes to $2 \mathrm{~cm}$. 1., slightly longer than the leaf. Sepal, median $3 \mathrm{~mm}$. l., barely $2 \mathrm{~mm}$. br.; lateral $3.2 \mathrm{~mm}$. 1. Petals less than $.5 \mathrm{~mm}$. $1 ., 2.5 \mathrm{~mm}$. br. Upper surfaces of lip-lobes lanceolate, acute, a little over $2 \mathrm{~mm}$. 1 .

8. L. ovalis comb. nov.; stem many times (3-5) longer than leaf; leaf $4-7 \mathrm{~cm} .1$. ; sepals tawny yellow, sometimes flushed with crimson, deltoid, acute, lateral $\frac{1}{2}$-connate; petals, posterior lobe much larger, elliptical, obtuse, anterior lanceolate, acute; breadth of petals shorter than length of sepals, longer than upper surfaces of lip; lip, upper surfaces scarcely longer than the anterior lobes of the petals, lanceolate-subulate, apex pointing abruptly upwards.-L. concinna Sw. in Nov. Act. Upsal. vi. 85 (1799); Fl. Ind. Occ. 1557 \& Adnot. Bot. t. 2, f. 4 ; Griseb. op. cit. 611 ; Fawc. \& Rendle op. cit. 10, t. II.f. 22-25. Epidendrum orale Sw. Prodr. 125 (1788).

In fl. Oct.-Feb.; summits of the mountains, Swartz! Cinchona, J.P. 16 (in part), Morris! MIt. Moses, J.P. 2268, Syme! Green Hill Wood, $3500 \mathrm{ft}$; M Mabess River, 3500-4000 ft.; John Crow Peak; north side below John Crow Peak, 5000 ft.; below Vinegar Hill, 3900 ft.; Morse's Gap, $4800 \mathrm{ft}$., and ridge above the Gap, $5500 \mathrm{ft}$. ; Holly Mount, Mt. Diabolo, $2600 \mathrm{ft}$., $3000 \mathrm{ft}$; Harris! John Crow Peak, Fawcett! Greenhill, $3000 \mathrm{ft}$. Moore! Fl. Jam. 7755, 7767, 7782, 8909, 9782, 9892. 10,091._Cuba.

Plant sometimes as much as 10 in. high. Rhizome short, woody. Secondary stems, sometimes as much as $20 \mathrm{~cm}$. l., barely $1 \mathrm{~mm}$. br., slender, wiry, erect or suberect; sheaths thin, minutely ciliolate on the acute mouth and ridges; by the perishing of the sheaths, the older stems often become bare, exposing the cylindrical internodes, which often have a reddish tinge. Leaves, generally $4-7 \mathrm{~cm} .1 ., 1 \cdot 5-2 \cdot 8 \mathrm{~cm}$. br., elliptical, acuminate, shortly stalked. Racemes to $5 \mathrm{~cm}$. 1., shorter than the leaves ; besides the flowering peduncle, a number (sometimes as many as 15) of dried peduncies of former flowering seasons often form a dense cluster in the leaf-axil. Bracts glabrous, slightly acuminate. Flowers 8-16, in two close ranks in the upper 6-12 mm. Sepals deltoid, acute, 2.5-4 mm. l.; median 2.5-3.75 mm. br. ; lateral 3-4.5 mm. br. Petals $2.5-3 \mathrm{~mm}$ br., 
posterior lobes $1.5-1.6 \mathrm{~mm} . \times 1-1.3 \mathrm{~mm}$. ; orange, shaded on the inner side with erimson or purple; anterior lobes $1 \cdot 4-1.5 \times \cdot 75 \mathrm{~mm}$., yellow. Lip crimson or purple; upper surfaces $\cdot 75-1 \cdot 1 \mathrm{~mm}$. 1 . Column short, crimson, dilated above; anther obovate, apex retuse. Capsule $4 \mathrm{~mm}$. 1., $3 \mathrm{~mm}$. br., obovate, gibbous at the apex, the pedicel elongating considerably in the fruit ( $7 \mathrm{~mm}$. in our specimen).

9. L. obtusipetala $s p$. nov.; plant 4-7 in. high; stem many times (2-3) longer than leaves; leaf $3-5 \mathrm{~cm}$. 1. ; bracts glabrous; sepals deltoid, acuminate, lateral $\frac{1}{2}$-connate; petals rhomboidal, apex mucronate, lobes subequal, somewhat square, breadth of petals shorter than length of sepals, longer than upper surfaces of lip ; lip, upper surfaces longer than anterior lobes of petals, narrowly oblanceolate, tapering both anteriorly and posteriorly to an acute point.-L. concinna Sw. var. obtusipetala Fawc. \& Rendle op. cit. 11 (1904). Types in Herb. Mus. Brit. and Jam. Herb.

In fl. June ; J.P. 14 (in part) Morris! Portland Gap, 5550 ft., Fawcett!

Plant much like $L$. ovalis, differing in some details given above, and also as follows : 4-7 in. high. Stems $7-14 \mathrm{~cm}$. 1. Leaves 1.3-2 cm. br. Racemes 1-2 cm. 1., much shorter than the leaves, few (3-5) in a cluster, and most of them with one flower open at the same time, pedicels of $2-4$ older flowers remaining on each peduncle. Sepals, median 4.5-5 mm. l., $3 \cdot 7-4 \mathrm{~mm}$. br., lateral $5 \mathrm{~mm}$. l., together $4.5 \mathrm{~mm}$. br. Petals $1.2 \mathrm{~mm}$. l., 2.3-2.5 mm. br., posterior lobe a little larger than the anterior. Lip, upper surfaces of lobes $1 \cdot 5-2 \mathrm{~mm}$. l. (The flowers on some specimens measure scarcely more than half the above.)

On reconsideration, we are inclined to regard this as a distinct species.

10. L. obtusa Faroc. \& Rendle op. cit. 11, t. II. f. 26 ; plant $4-5$ in. high ; stems ( $1 \frac{1}{2}-2$ times) longer than leaves; leaf $3 \cdot 5-$ $5 \cdot 5 \mathrm{~cm}$. 1. ; bracts glabrescent; sepals crimson, glabrous, deltoid, acute, lateral $\frac{1}{2}$-connate; petals somewhat deltoid, apex obtuse, surface minutely pubescent, lobes subequal, posterior somewhat rhomboidal, anterior obtusely triangular, breadth of petals shorter than length of sepals, longer than upper surfaces of lip; lip, upper surfaces a little longer than the anterior lobes of petals, posterior half oblong, anterior tapering to an acute apex.

In fl. Nov.-April; Blue Mt. Peak, J.P. 14 (in part), Morris! Greenhill, $3000 \mathrm{ft} .$, Moore! Portland Gap Road, Fawcett! Newhaven Gap, $4000 \mathrm{ft}$.; between Morse's Gap and Vinegar Hill, 4000 ft.; Newhaven, $4000 \mathrm{ft}$; ridge from Newhaven Gap to Vinegar Hill, 4000 ft.; Harris! Fl. Jam. $7834,10,081$.

Plant much like L. ovalis but smaller. Stems slender, 10-12 cm. 1., much longer than the leaves. Leaves $1 \cdot 2-2 \mathrm{~cm}$. br., narrowly elliptical, acuminate, bright violet on lower side. Racemes $2 \mathrm{~cm}$. l., scarcely half as long as the leaves, few (3-6) in a cluster, of which two or three have one (sometimes two) flowers open at same time. Bracts sheathing, shortly acuminate, about $2 \mathrm{~mm}$. 1. Sepals, median 5-6 mm. 1. and br.; lateral, 
5.5-6 mm. 1., 6.3-6.5 mm. br. below the point of union. Petals $3 \cdot 5 \mathrm{~mm}$. br., crimson. Lip crimson. Column short, dilated above. Capsule $5 \mathrm{~mm}$. 1., broadly obovoid. (The flowers on some specimens scarcely measure more than half the measurements given above.)

11. L. areuata Fawc. \& Rendle in Journ. Bot. xlviii. 6 (1909); sepals magenta-crimson, lateral $\frac{1}{3}$-connate; breadth of petals shorter than length of sepals, and shorter than upper surfaces of lip.-(Pl. 11, f. 1-7.) Types in Herb. Mus. Brit. and Jam. Herb.

On trunks of trees; in fl. and fr., Feb.; Holly Mount, Mt. Diabolo, $2600 \mathrm{ft} .$, Harris!

Plant 1 to $1 \frac{1}{2}$ in. high. Stem $1 \cdot 5-2 \cdot 5 \mathrm{~cm}$. 1., longer than the leaf; sheaths ciliolate on the mouth and ridges. Leaf $1 \cdot 2-1 \cdot 7 \mathrm{~cm}$. 1., narrowlyelliptical to roundish-elliptical. Racemes with several flowers, clustered, shorter than the leaf. Bract shortly acute, glabrescent. Flowers about $\frac{1}{10}$ in. l. Sepals, median $2.3 \mathrm{~mm}$. 1., ovate-lanceolate, acuminate ; lateral $2 \mathrm{~mm}$. 1., broadly ovate, acuminate, 1-nerved. Petals brick-orange-yellow, barely $1 \mathrm{~mm}$. br., 3-lobed, lobes subequal, obtusely triangular. Lip brickorange-yellow tinged with crimson, $1.5 \mathrm{~mm}$. l., upper surfaces of lateral lobes much longer than the petals and column, $1 \mathrm{~mm}$. l., linear-lanceolate, subfalcate. Column short, $\cdot 6 \mathrm{~mm}$. l., of a rather lighter shade of magentacrimson than the sepals; anther white.

This species is near $L$. tridentata in appearance, but differs in the lip, the short column, and in other respects. Petals in breadth barely $1 \mathrm{~mm}$., while those of $L$. tridentata are $1.5 \mathrm{~mm}$. broad. Lip $1.5 \mathrm{~mm}$. l., the lateral lobes nearly twice as long as the column, being $1 \mathrm{~mm}$. l., whereas the lip of L. tridentata is just over $1 \mathrm{~mm}$. l., the lateral lobes being barely $1 \mathrm{~mm}$. l. The column is $6 \mathrm{~mm}$. l. as contrasted with that of L. tridentata, which is $1 \mathrm{~mm}$. $\mathrm{l}$.

12. L. cochlearifolia Siv. in Nov. Act. Upsal. vi. 86, t. 丂, figs. $6, a, b(1799)$; stem much longer than leaf ; leaf roundish, $1 \cdot 5-$ $2.5 \mathrm{~cm}$. l.; sepals purple, lateral $\frac{1}{3}$-connate; breadth of petals about as long as length of sepals.-Sw. Fl. Ind. Occ. 1563 \& Adnot. Bot. t. 2, fig. 1; Griseb. op. cit. 611 ; Fawc. \& Rendle in Trans. Linn. Soc. vii. 9, t. II. f. 18-21. Epidendrum cochlearifolium Sw. Prodr. 126 (1788). Type in Herb. Mus. Brit.

In fl. Sept.-April; summits of the Blue MIts., Swartz! Swift River, J.P. 463 (2679); MIt. Moses, 3500 ft., J.P. 2373; Syme! Browns Town, Miss T. M. Barrett! John Crow Peak, slopes of spur, 100 to $300 \mathrm{ft}$. above Mabess River, Fawcett! near Mabess River, 3500-4000 ft.; near John Crow Peak; Harris! Fl. Jam. 7788, 7828, 9015.

Plant less than 3 in. high. Stems 2-6 cm.1.; mouth of the sheath broadly open, apex acute; margin and ridges covered with numerous stiffish white hairs. Leaves $1-1.8 \mathrm{~cm}$. br., sometimes tinged with purple, varying in shape from orbicular to broadly elliptical, shortly apiculate, narrowing at the base into a short stalk, the marginal and three principal veins uniting below the apex. Racemes generally less than $1 \mathrm{~cm}$. 1., less than half as long as the leaves, generally several clustered, lax, with few flowers. Sepals 5-6 mm. 1., 3-3.5 mm. br., ovate, acuminate. Petals brick-orange-yellow, tinged with crimson towards the centre, with a short blunt apex and a short rhomboidal body $\cdot 65 \mathrm{~mm}$. 1 ., shortly toothed at the lower corners and drawn out at the upper into longer tapering upcurving 
horus; 6 mm. br., including the horns. Lip purplish-crimson; upper surfaces lanceolate. Column short, dilated under the apex; anther obovately rectangular, emarginate.

§ 2. Haplocheilus. Lip not dividing near the base, but expanding variously above the petals.

13. L. bilabiata Fawc. of Rendle op. cit. 4, t. I. f. 1-4; sepals, median dark crimson-purple, lateral reddish, $\frac{2}{3}$-comnate; petals 2 -lobed ; lip suborbicular, cordate.

In fl. Sept.-Feb., above Mabess River, 3000 and $4000 \mathrm{ft}$., Fawcett! Harris! near Hardware Gap, $4300 \mathrm{ft}$; ridge below Vinegar Hill, $3800 \mathrm{ft}$. ; Harris! F1. Jam. 7786, 10,095.

Plant $\frac{3}{4}$ to $1 \frac{1}{2}$ in. high. Stems $1-2 \cdot 5 \mathrm{~cm}$. 1., rarely shorter, thin, usually exceeding the leaf; sheaths with acuminate mouth ciliolate, ridges muriculate. Leaf narrowly elliptical, narrowing at the base into a short stalk 2-3 mm. 1., blade 10-17 mm. 1., 4-7 mm. br., obscurely apiculate. Racemes often several clustered, half as long as the leaf, lax, with a few flowers. Bracts subacute, almost glabrous. Sepals, median $3 \mathrm{~mm}$. l. and br., concave and shaped like an open basket, mucronate; lateral $2.5 \mathrm{~mm}$. 1., forming an anterior bifid lip, like the dorsal but scarcely as wide, apices acute. Petals about $3 \mathrm{~mm}$. br., apex obscure, the anterior lobe whitish-yellow, shortly subulate; the posterior lobe larger, dark crimson-purple. Lip about $2 \mathrm{~mm}$. 1., and somewhat broader when flattened; whitish-yellow, concave, 2- or 3-denticulate at apex, enclosing the coluinn. Column short, dilated above; anther obovate, deeply emarginate. Capsule subglobose, gibbous, with six conspicuous keels, markedly asymmetrical.

14. L. elliptica Fauc. \& Rendle in Journ. Bot. xlviii. 5 (1909) ; sepals crimson, latera] $\frac{1}{3}$-connate; petals subulate; lip elliptical, apiculate.-(Pl. 11, f. 18-21.)

On trunks of trees; in fl. Sept.; Holly Mount, Mt. Diabolo, $2700 \mathrm{ft}$. Harris! Fl. Jam. 9895a.

Plant 1 to $1 \frac{1}{2}$ in. high. Stem $1-3 \mathrm{~cm}$. l., exceeding the leaf; the large spreading hirsute sheaths and stems are much like those of $L$. cochlearifolia. Leaf $1-2 \mathrm{~cm} .1 ., \cdot 5-1 \cdot 1 \mathrm{~cm}$. br., sessile, elliptical, narrowing at the base. Racemes 2-several clustered or solitary, shorter than the leaf, with few flowers, bracteoles ciliolate at length glabrate. Flowers about $\frac{1}{7}$ in. 1., crimson. Sepals $3.5 \mathrm{~mm}$. 1., the median slightly over $2 \mathrm{~mm}$. br., triangular-ovate, shortly acuminate, lateral similar to median. Petals only developed anteriorly into a subulate lobe reaching in bud to about the top of the anther. Lip small, simple, springing from the column. Column (without anther) $1 \mathrm{~mm}$. 1 .

15. L. brevipetala Fauc. \& Rendle loc. cit.; sepals crimson, lateral shortly connate; petals very short, roundish-ovate, obtuse ; lip large, sinıple, semi-circular, cordate-(Pl. 11, f. 22, 23.) Types in Herb. Mus. Brit. and in Jam. Herb.

On trees; in fl. and fr. Dec.; J.P. 17, Morris! Silver Hill, Woodland, $4000 \mathrm{ft}$., Harris! Fl. Jam. 7539.

Plant 2 to $3 \frac{1}{2}$ in. high. Stem $3-7 \mathrm{~cm}$. 1., robust for the genus, exceeding the leaf; sheaths large, spreading, much like those of $L$. coch- 
learifolia, ferruginous-hirsute, mouth broadly open with acute apex. Leaves 2.5-4 cm. 1., $\cdot 7-1 \mathrm{~cm}$. br., narrowly elliptical, obtuse. Racemes generally several clustered, often a little longer than the leaf. Flowers very small, $\frac{1}{18}$ in. l., crimson, several. Sepals, median $1.4 \mathrm{~mm}$. 1., broadly ovate, obtuse, concave; lateral $1.2 \mathrm{~mm}$. 1., subacute. Petals - $3 \mathrm{~mm}$. l., simple. Lip $1 \mathrm{~mm}$. l:, a little more than $1 \mathrm{~mm}$. br., concave, strongly 3-nerved. Column short, about $.5 \mathrm{~mm}$. 1. Capsule $4 \mathrm{~mm}$. l., ellipsoidal, with three narrow wings.

16. L. Harrisii Fawc. \& Rendle loc. cit. ; sepals dark crimsonpurple, lateral $\frac{1}{2}$-connate ; petals short, shortly elliptical, rounded at apex; lip ovate-roundish, subcordate, rounded at apex.- $(\mathrm{Pl}$. 11, f. 8-11.)

On trees; in fl. and fr. Feb.; Holly Mount, MIt. Diabolo, $2600 \mathrm{ft}$, Harris !

Plant about $1 \frac{1}{2}$ in. high. Stem 3-4 cm. l., longer than the leaf; sheaths robust, ferruginous-hirtellous on the broad mouth and ridges. Leaf, blade 1·5-2 cm. 1., 7-9 mm. br., elliptical. Racemes few-flowered, longer than the leaf; bracts acute, glabrous. Flouers $\frac{1}{10}$ in. 1., dark crimson-purple, less caducous than usual. Sepals $2.5 \mathrm{~mm}$. 1., median long-ovate, 3-nerved; lateral lanceolate, 1-nerved. Petals $\cdot 7 \mathrm{~mm}$. l., like those of $L$. brevipetala, but twice as long. Lip $1.3 \mathrm{~mm}$. l., strongly 3-nerved. Column short, $\cdot 5 \mathrm{~mm}$. 1. Capsule ellipsoidal, 6-keeled.

17. L. tridentata Sw. in Nor. Act. Upsal. vi. 86 (1799); sepals yellowish, lateral $\frac{1}{2}$-connate; petals subrhomboid but extended transversely, truncate at the base, with the upper margins slightly concave, the posterior lobes embracing the column and meeting behind it; lip anteriorly rounded and suddenly mucronate, posteriorly with two erect awl-shaped lobes lying close to the column and of equal length to it.- $S w$. Fl. Ind. Occ. iii. 1561 \& Adnot. Bot. t. 2, f. 2 ; Griseb op. cit. 610, excl. syn.; Fauc. \& Rendle in Trans. Linn. Soc. vii. 6, t. I. f. 8-11. Epidendrum tridentatum Sı. Prodr. 125 (1788). Type in Herb. Mus. Brit.

In fl. throughout the year; Blue Mits., Swartz! near Mabess River, 4000 ft.; Morse's Gap, 5000 ft. ; near John Crow Peak, 5200 ft. ; Harris ! near John Crow Peak; near Newhaven Gap; Fawcett! Moy Hall, Sullivan!-Cuba.

Plant $1 \frac{1}{2}-3$ in. high. Stems $2-7 \mathrm{~cm}$. 1., very much longer than the leaves; sheath margins ciliolate, ridges muriculate. Leaves somewhat elliptical, and tapering at base and apex, 1.5-2.4 cm. 1., 5-7 mm. br. Racemes a little shorter than the leaf, 2-4-clustered, rarely solitary. Flowers numerous, in two ranks, closely crowded in the upper half or third of the raceme. Sepals $2.5 \mathrm{~mm}$. l., ovate-acuminate; median $1 \mathrm{~mm}$. br.; lateral $1.5 \mathrm{~mm}$. br. at the point of union. Petals yellowish, suberect. Lip crimson. Column $1 \mathrm{~mm}$. l., pink, scarcely dilated at the apex; anther white, roundly obcordate. Capsule $5 \mathrm{~mm}$. l., subglobose, with prominent deep-purple keels.

Swartz describes the flower as purple-yellow.

18. L. quadrata Favc. \& Rendle op. cit. 7, t. I. f. 12-14; sepals purplish-crimson, lateral $\frac{1}{3}$-connate; petals with a short 
blunt apex, the lobes of equal length, posterior oblanceolate, converging, anterior linear; lip eonsisting of a large anterior subquadrate portion attached by a very short insertion on the column-base, with a shallowly notched hroadly rounded apex, and produced behind into a pair of bluntly tapering narrow lobes about equal in length to the anterior portion.

In fl. Nov.-April ; near John Crow Peak ; near Mabess River, 3500 ft., 4000 ft.; Holly MLount, MIt. Diabolo, 2700 ft. ; Harris! Fl. Jam. 7746, 7824, 7827, 9016, 9893.

Plant about $1 \frac{1}{2} \mathrm{in}$. high. Stems to $2.5 \mathrm{~cm}$. l., longer than the leaves; mouth of the sheaths spreading, minutely ciliolate; ridges muriculate. Leaves 1-1.6 cm. 1., 4-9 mm. br., oval to elliptical. Racemes generally several clustered, sometimes solitary, not half as long as the leaves. Bracts glabrous. Flowers few, distant. Sepals $3 \mathrm{~mm} .1$. , ovate-acuminate, ventricose, margin and nerves ciliolate, lateral a little smaller. Petals $1.5 \mathrm{~mm}$. br. Column short, dilated above; anther ovoid, rectangular, emarginate. Capsule obovoid.

19. L. concolor Fawc. \& Rendle op. cit. 5, t. I. f. 5-7 ; sepals pale yellow, lateral $\frac{1}{2}$-connate; petals obversely deltoid, at the apex unequally concave; lip anteriorly shallowly retuse with a short apiculus, lobes thick, extended backwards and embracing the column.

In fl. Aug.-Feb.; Moy Hall, Sullivan! Morse's Gap and Blue Mountains ridge, Fawcett! ridge above Morse's Gap, $5400 \mathrm{ft}$. ; Newhaven Gap, $5600 \mathrm{ft}$.; Rose Hill, $4000 \mathrm{ft}$; Newhaven, $4000 \mathrm{ft}$; ridge from Newhaven Gap to Vinegar Hill, 4000 ft.; John Crow Peak; above Mabess River; Harris! Fl. Jam. 7831, 10,083, 10,465, 10,468.

Plant $\frac{1}{2}-1 \frac{1}{2}$ in. high. Stems generally $2-3 \mathrm{~cm}$. 1., much longer than the leaf; sheaths conspicuously ridged, the mouth (sharply acute) and the ridges minutely ciliolate. Leaf, blade generally 1 to $1.5 \mathrm{~cm} .1 ., 5-8 \mathrm{~mm}$. br., oval to roundish oval. Racemes 6-8 mm. l., generally shorter than the leaf, 1-3-clustered, lax, with a few flowers, one or two open at a time. Bracts glabrate. Flowers about $\frac{1}{8}$ in. 1., pale yellow. Sepals $3 \mathrm{~mm}$. 1., ovate, glabrous, lateral each barely $1.5 \mathrm{~mm}$. br. at union, median $2.5 \mathrm{~mm}$. br. Petals a little over $1 \mathrm{~mm}$. l. and slightly broader, pale yellow. Lip $1.5 \mathrm{~mm}$. br., lobes $1 \mathrm{~mm}$. 1. Column short, dilated above. Capsule $4 \mathrm{~mm}$. l., $3 \mathrm{~mm}$. br., obliquely obovoid, 6-keeled.

The plant from Rose Hill differs from the other specimens in having the racemes longer than the leaf; they reach nearly $2 \mathrm{~cm}$. The flowers, however, resemble those of specimens from other localities.

\section{BRACHIONIDIUM Lindl.}

Epiphytic herbs, forming a long prostrate rhizome, which often branches, and is more or less covered with scarious sheaths. Secondary stems with a solitary leaf, very short below the leaf, covered by one or two scarious sheaths. Leaf somewhat leathery, rather small, contracted at the base into a short petiole. Peduncle solitary, enclosed with the petiole in a scarious sheath with one flower and generally also an aborted bract. Sepals produced at 
the apex into long tails, lateral connate nearly to apex. Petals similar to sepals. Lip small, jointed to foot of column. Column short, broad, erect, with a foot; clinandrium 3-lobed. Anther opercular, incumbent, somewhat flat, cordate, indistinctly 2-celled; pollinia 6, elongated, clavate, in two bundles. Capsule obovoid.

Species 5 or 6 , natives of the Andes of Bolivia and Colombia, of Mt. Roraima in British Guiana, and of the West Indies.

B. Sherringii Rolfe in Kew Bulletin, 1893, 4.-B. parvum Cogn. in Fedde Repert. vi. 307 (1909), as regards the Jamaican plant. (Pl. 12.)

Amongst mosses on banks, or on trees; in fl. Oct.-Dec.; below Mount Moses, 3000 ft., J.P. 2361 Syme! Harris! Regale, below Hardware Gap, A. Moore! Fl. Jam. 7802, 10,474.-Grenada, Martinique, St. Kitts. -

Plant 1-1 $\frac{1}{2}$ in. high from the creeping or climbing rhizome. Secondary stem very short, 6-12 mm. l., enclosed by scarious truncate apiculate sheaths. Leaf oblanceolate, or oblong-lanceolate, narrowed into the petiole, 3-denticulate at apex, 7-nerved; blade 1.5-3 cm. 1., 4-12 mm. br. Peduncle slender, longer than the leaf, $1 \cdot 5-3 \cdot 5 \mathrm{~cm}$., springing from a scarious bract, bearing an acuminate sheathing bract at or below the middle, 3-4.5 mm. 1., and a third at the apex, $2-3 \mathrm{~mm}$. 1., tubular, spreading, enclosing the short thick pedicel of the flower and a slender pedicel $4 \mathrm{~mm}$. l., bearing an aborted bract. Flowers claret-coloured, sometimes tinged with tawny-yellow on the sepals, perianth 1 in. 1 . Sepals, median oval, acuminate, caudate, $1 \cdot 2 \mathrm{~cm}$. l. without tail, $3-4 \mathrm{~mm}$. br.; tail reaching nearly $2 \mathrm{~cm}$. 1. ; lateral connate, tail 2 -fid at apex, similar to median but broader, 4-5 mm. br., tail $1 \cdot 5 \mathrm{~cm}$. 1 . Petals as long as the sepals, subfalcate, ovate, caudate, margin minutely ciliolate, $1-1 \cdot 1 \mathrm{~cm} .1$, 2.5-4 mm. br., tail $1.5 \mathrm{~cm}$. 1. Lip, in the fresh flower, apparently simple, horseshoe-shaped, embracing the column, attached by a rather broad claw to the foot of the column, purple; when spread out under the microscope, it is evidently 3-lobed, with a short, slender claw, $1.5 \mathrm{~mm}$. l., middle lobe transversely oblong-elliptical, at apex mucronate, 3-nerved, $1 \mathrm{~mm}$. br., lateral lobes oblong, incurved over the disk; breadth of lip at lobes $3 \mathrm{~mm}$. Column broad, a little over $1 \mathrm{~mm}$. 1 .

\section{ISOCHILUS R. Br.}

Stems erect from a creeping rhizome, covered with the sheaths of leaves, no pseudobulbs. Leaves in two ranks, spreading, linear or lanceolate, somewhat rigidly herbaceous, generally obtuse or retuse. Flowers medium-sized, rose-coloured, lakemagenta or crimson, in a terminal dense one-sided raceme, with very short stalks. Bracts concave, much shorter than the flower. Sepals equal, erect, keeled-concave, at the base somewhat saccate. Petals slightly shorter than the sepals, flat. Lip equal to the petals, and with them attached to the base of the column, contracted below the middle, and slightly sigmoid-flexuose, dilated towards the middle. Column erect, somewhat long, semiterete, not winged, at the apex at the sides of the stigma produced into two erect points, with a short foot ; clinandrium little prominent, 
with a short posterior tooth, bearing the anther. Anther terminal, opercular, convex, distinctly 2-cellerl; cells dividerl again into two cells by an imperfect longiturlinal septum; pollinia 4, waxy, two in each cell, equal, oroid-oblong, compressed parallel, erect, the appendage granular-viserus, laminiform, ascending from the base, incumbent on the pollinia. Capsule globose or ovoid, ribs only slightly prominent.

Species about 1:3, natives of warmer America from the West Indies and Mexico to Brazil and Peru.

I. linearis R. Br. in Ait. Hort. Kew. ed. 2, v. 209 (1813); Bot. Reg. t. 745 ; Lindl. Gen. \& Sp. Orch. 112 ; Griseb. Fl. Br. W. Ind. 623. Helleborine tenuifolia repens Plum. Pl. Amer. (Burm.) t. 182, f. 1. Epidendrum lineare Jacq. Stirp. Amer. 221, t. 131, f. 1 (1763), Ed. jict. t. 201. Cymbidium lineare Sw. in Nov. Act. Upsal. vi. 72 (1799). (Pl. 13, f. 8-13.)

On trees and rocks; in fl. Sept.-March, in fr. Nov.-March; Shakespear! Swartz! Macfadyen! Petersfield, St. Mary, McNab! Radnor, Purdie! Fairfield, Wullschlaegel, 1063! March! Prior! Blue Mts. J.P. 32, Morris! Catherine Peak, Eggers, 3527; near Browns Town, Miss T. M. Barrett! Unity Valley, St. Ann, Miss A. Roper! Cinchona, 4500 ft., Fawcett! Harris! Tweedside, south St. Andrew, Harris! Fl. Jam. 7752, 7843, 10,460.-Cuba, Hispaniola, Porto Rico, St. Vincent, Guadeloupe, Dominica, Martinique, Trinidad, Costa Rica, Nicaragua, Guatemala, Mexico, Venezuela, Colombia, B. Guiana, Brazil, Argentine, Bolivia, Peru.

Plant $1 \mathrm{ft.}-2 \mathrm{ft} .4$ in. high. Stems $2-6 \mathrm{dm}$. 1. Leaves $35-6.5 \mathrm{~cm} .1$, 3- $6 \mathrm{~mm}$. br.; sheaths $1-2.5 \mathrm{~cm}$. 1. Racemes $1 \cdot 5-3 \cdot 5 \mathrm{~cm}$. 1. Bracts coloured like the flowers, obovate, $7-10 \mathrm{~mm}$. l. Flowers about $\frac{1}{3}$ in. 1 . Ovary 2-winged. Sepals 2-3 nerves on each side of median curve, lateral with a strong keel, which is decurrent on ovary, and forms a mucro at apex, oblong, tapering near apex, shortly connate at base, about $10 \mathrm{~mm}$. 1 ., $3 \mathrm{~mm}$. br.; median not keeled, oblong, abruptly acute, a little shorter and broader than the lateral. Petals 5-nerved, oblanceolate-elliptical, apex obtuse, somewhat oblique at base, a little shorter and narrower than the median sepal. Lip 7-nerved, oblong, expanding in middle, tapering near the apex, and slightly tapering to base, curved from base inwards to embrace column and then outwards, 8-10 mm.1., 1-1.25 mm.br. Column $\cdot 5 \mathrm{~cm}$. 1. Capsule 6-ribbed, two ribs prominent above, 7-9 $\mathrm{mm}$. 1., about $3 \mathrm{~mm}$. br.

\section{OCTADESMIA Benth.}

Epiphytic herbs, with simple leafy stems. Leaves linearoblong or broadly lanceolate, in two ranks, somewhat rigid but not fleshy, with numerous fine prominent nerves, jointed with, and deciduous from, the sheath. Peduncle terminal, simple, or slightly branched, the branches laxly few-flowered. Flowers medium-sized, shortly stalked. Bracts short, sheathing at the base. Sepals, all of about the same length, somewhat spreading, lateral somewhat falcate, connected under the lip into a slightly prominent chin. Petals somewhat like the lateral sepals. Lip suberect from the base of the column, free, oblong or roundish, 
3-lobed, lateral lobes slightly prominent. Column somewhat long, slightly incurved, concave anteriorly, with a short foot; clinandrium obscurely 3-lobed. Anther terminal, opercular, incumbent, semi-globose, with two cells which are divided again. Pollinia 8 , four in each cell, connected at the apices by a small amount of viscid substance. Capsule oblong or elongate, spindle-shaped, contracted into a short beak.

Species 2, natives of West Indies and Brazil.

Plant 1-2 ft. high ........................ 1. O. montana.

Plant reaching to $6 \mathrm{ft}$. high................. 2. O. elata.

1. 0. montana Benth. in Journ. Linn. Soc. xviii. 311 (1881) \& in Benth. \& Hook. f. Gen. Pl. iii. 525 ; leaves oblong-lanceolate; lip about as broad as long.-Cogn. in Fl. Bras. iii. pt. 5, 19 \& in Symb. Ant. iv. 172. Epidendrum montanum Sw. Prodr. 121 (1788). Cymbidium montanum Sw. in Nov. Act. Upsal. vi. 72 (1799) \& Fl. Ind. Occ. 1469. Octomeria serratifolia Hook. in Bot. Mag. t. 2823 (1828). Bletia montana Reichb. f. in Walp. Ann. Bot. vi. 445 (1862). Tetramicra montana Griseb. Fl. Brit. W. Ind. 622 (1864). (Pl. 17, f. 13-16.) Type in Herb. Mus. Brit.

On trees and rocky banks; in fl. Nov.-March; Blue MIts., Swartz! Wiles! Macfadyen! Wilson! Jenman! Blue IIts., 5000-5500 ft., J.P. 27, Morris! near Gordon Town, Watt! Morse's Gap, 5000 ft., Fawcett! Harris! Ridge from Newhaven Gap to Vinegar Hill, $4000 \mathrm{ft.;}$; Hardware Gap, 4000 ft.; below Sir John's Peak, 6000 ft. ; Harris! Fl. Jam. 7550, 10,090, 10,128, 10,436.-Hispaniola, Porto Rico.

Plant 15-24 in. high. Stem 2-6 dm. 1., covered below with sheaths, leafy above. Sheaths striate and with brown spots and minute warts, 2.5-3 cm. 1., free portion short. Leaves 4-11 cm. 1., 7-20 mm. br. Panicle (sometimes a raceme) 4-20 cm. 1. Bracts minutely spotted and warty, free portion triangular, acute or acuminate; sterile 1-1.7 cm. l. ; floral .5-1 cm. l. Ovary and pedicel each $4.5 \mathrm{~mm} .1$. Flowers creamy-white, with a delicate scent of violets, perianth over $\frac{1}{2}$ in. 1 . Sepals 5-nerved, oblonglanceolate, median $1.4-1 \cdot 8 \mathrm{~cm} .1 ., 4 \cdot 5 \mathrm{~mm}$. br., apex obtuse; lateral rather shorter, apex thickened and shortly apiculate. Petals 3-nerved, linearoblong, tapering to apiculate apex, $1 \cdot 2-1.5 \mathrm{~cm} .1 ., 2 \cdot 5-3.5 \mathrm{~mm}$. br. Lip very shortly clawed, 5-nerved with numerous lateral nerves branching off, roundish in outline, disk 2 -lamellate below, with minute warty calli along the three nerves of the terminal lobe, lamellæ 2-lobed; lateral lobes short, obtuse; terminal lobe much larger, minutely crenulate, apiculate, 9-10 mm. l., and about as broad. Column narrowly 2-winged, 6-6.5 mm. 1 . Capsule ellipsoidal, $2.5 \mathrm{~cm}$. 1 .

2. 0. elata Benth. \& Hook. f. Gen. Pl. iii. 525 (1883); leaves broadly lanceolate; lip longer than broad.-Type in Herb. Kew.

On trees, in rocky soil, and in peaty mould in forest; in fl. March; Mt. Moses, 3500-4000 ft., Syme! Harris!

Plant robust, erect, upright, reaching to $6 \mathrm{ft}$. high. Stem 15 or $16 \mathrm{dm} .1$., below bearing the fibrous remains of the leaf-sheaths, leafy above. Leaves, passing above into spathaceous bracts, blade $8-11 \mathrm{~cm} .1 ., 2-3 \mathrm{~cm}$. br. Panicle $2 \mathrm{dm}$. 1. Bracts, sterile $4-2 \mathrm{~cm}$. l., floral about $1 \mathrm{~cm} .1$. Ovary (fertilised) and pedicel, each generally about $1 \mathrm{~cm} .1$. Flowers, perianth over $\frac{1}{2}$ in.l. Sepals 7 -nerved, narrowly oblong, slightly apiculate; 
median $1.75 \mathrm{~cm} .1 ., 4 \mathrm{~mm}$. br. ; lateral keeled and slightly hooded towards apex, about $1.5 \mathrm{~cm}$. 1., barely $4 \mathrm{~mm}$. br. J'etals 5 -nerved, narrowly oblong, slightly keeled and hooded, $1.5 \mathrm{~cm} .1 ., 3.5 \mathrm{~mm}$. br. Lip sessile, 7 -nerved with lateral nerves, obovate-oblong in outline, $1 \mathrm{~cm}$. $1 ., 7 \mathrm{~mm}$. br., disk 2-lamellate below, lamellie and prominent middle nerve extending as prominent lines towards apex, lateral lobes rounded, terminal lobe much larger, at apex 3-lobulate, apiculate. Column about $7 \mathrm{~mm} .1$.

\section{CELLIA Lindl.}

Epiphytic herbs. Stems with several leaves, increasing at the base to form fleshy pseudobulbs. Leaves long, narrow, plaited, veiny. Scapes at the base of the pseudobulbs, short, simple, with imbricate subspathaceous sheaths at the base. Flowers medium-sized, densely racemose, shortly pedicellate. Bracts membranous or paleaceous, narrow, longer than the flowers. Sepals, all of about the same length, erect from the base, spreading above; median free, concave; lateral broader, connate at the base with the foot of the column, forming a short or long chin. Petals somewhat similar to the median sepal. Lip jointed at foot of column, narrow, incumbent at the base, spreading above, undivided, contracted into a flexuose claw. Column short, rather broad, acute, margined, produced at the base into a foot. Anther terminal, opercular, incumbent, semiglobose, perfectly 2-celled; pollinia 8, waxy, four in each cell, ovoid, cohering at the apex by a sparse viscid substance. Capsule prominently winged.

Species about 6, natives of the West Indies, Central America and Mexico.

C. triptera G. Don ex Steud. Nom. ed. 2, i. 394 (1840).Griseb. Fl. Br. W. Ind. 629. C. Bauerana Lindl. Gen. \& Sp. Orch. 36 (1830), in Bauer Ill. Oich. Pl. Gen. t. 3 \& Bot. Reg. xxviii. t. 36 (1842). Epidendrum tripterum Sm. Ic. Pict. t. 14 (1793). Cymbidium tripterum Sw. in Nov. Act. Upsal. vi. 70 (1799). Salisb. Ic. ined. vi. fol. 571. (Pl. 13, f. 1-7.) Type in Herb. Smith in Linn. Soc.

On rocky banks ; in fl. Jan.-Feb., in fr. March; J.P. 486, Morris! near Browns Town, Miss T. M. Barrett! Chester Vale, 3000 ft.; Silver Hill Woodland; Harris! Fl. Jam. 7614.-Cuba, Mexico.

Plant $1 \mathrm{ft}$. and more high. Pseudobulbs ovate-oblong, 3-5 cm. 1 . Leaves 3 or 4 from apex of pseudobulb, linear-lanceolate, long-tapering to base where they are articulated with closed sheaths, $2-4 \mathrm{dm}$. 1. (incl. sheath), 1-2 cm. br. Scape 10-14 cm. 1. Bracts linear-lanceolate, long-acuminate, $2-2.5 \mathrm{~cm}$. l. Flowers white, perianth a little over $\frac{1}{4}$ in. 1 . Ovary with nine wings, three very broad, about $1 \mathrm{~cm}$. 1 . Sepals 5-nerved, ovate, obtuse, about $7.5 \mathrm{~mm}$. 1., and $3 \mathrm{~mm}$. br. Petals oblong, concave, obtuse, about $7 \mathrm{~mm}$. l., nearly $2 \mathrm{~mm}$. br. Lip with seven branching veins, oblong below, expanding to form an obscure lobe on each side about the middle, tapering to an obtuse apex, with a callus along the upper margin as far as the lobes, about $6 \mathrm{~mm}$. l., more than $3 \mathrm{~mm}$. br. at lobes. Column scarcely $2 \mathrm{~mm} .1$. Capsule ellipsoidal, about $1 \mathrm{~cm} .1$. 


\section{SERAPHYTA Fisch. \& Mey.}

Epiphytic herb. Stems leafy, sheathed at the base, scarcely fleshy. Leaves leathery, elliptical, oblong or lanceolate, in two ranks along the stem, with sheaths tightly adpressed. Panicle terminal, laxly and thinly branched, with small stalked flowers laxly racemose along the branches. Bracts minute. Sepals nearly equal, free, acute, somewhat spreading. Petals narrowly linear, nearly as long as the sepals, spreading. Claw of the lip as long as the column, with which it is connate forming a cup; limb broadly ovate-cordate, undivided, spreading; disc with a callus at the mouth of the cup. Column short, the wings forming a cup with the claw of the lip, foot wanting; clinandrium short, lateral lobes roundish, median obsolete. Anther terminal between the lateral lobes, opercular, incumbent, subglobose, thick and fleshy at the back, as if appendaged, 2-celled anteriorly, each cell divided again into two cells; pollinia 4, waxy, ovoidglobose, distinct, without an appendage, connected in pairs by a somewhat copious viscid substance elastically extensible into two threads, and often attached to the rostellum. Capsule broadly ellipsoidal, somewhat beaked, the ribs scarcely prominent.

Species 1, native of the West Indies, Mexico, Colombia and Surinam.

S. diffusa Pfitz. in Engl. \& Prantl Nat. Pflanzenf. ii. 6, 142 (1889).- S. multiflora Fisch. \& Mey. in Bull. Sc. Acad. Petersb. vii. 24 (1840). Epidendrum diffusum Sw. Prodr. 121 (1788) \& Fl. Ind. Occ. 1503 ; Lindl. Gen. \& Sp. Orch. 102 \& Fol. Orch. Epidendr. 88; Hook. in Bot. Mag. t. 3565 ; Griseb. Fl. Br. W. Ind. 619. (Pl. 14, f. 1-3.)

On trees; in fl. Sept.-Jan., in fr. Dec., Jan., July; Swartz! Macfadyen! Manchester and St. Mary, Purdie! Fairfield, Wullschlaegel, 1052! March! Moneague, Prior! Blue Mits., 2000-5000 ft. J.P. 30, Morris! Blue Mts., Mrs. Maclaverty! near Browns Town, Miss T. M. Barrett! Cinchona, Plaxton! Arntully, Miss Sabonadiere! Ramble, Hanover; near Gordon Town; Fawcett! Ramble, Claremont, Fawcett \& Harris! Walderston, Mrs. Longstaff! Cold Spring; Belvedere, Hanover, $500 \mathrm{ft}$. ; Lancaster ; Clydesdale, $3500 \mathrm{ft}$; Maryland; Troy, $1600 \mathrm{ft}$; Harris! Lyndhurst, near Green Vale, Harris \& Britton! Fl. Jam. 7625, 7656, 7770, 10,394, 10,447, 10,623.-Cuba, Mexico, Colombia, Surinam.

Plant 7-27 in. high. Stem 3-30 cm. 1. Leaves 3-6 cm. 1., 1.5-3.5 cm. br. Panicle $1-3.5 \mathrm{~cm}$. 1. Bracts deltoid, acute, 1-2 $\mathrm{mm}$. 1. Pedicels 1-3 mm. l. Flowers yellowish-green, drying red, perianth about $\frac{1}{3}$ in. 1 . Sepals 3-nerved, linear-lanceolate, subacute, $7 \cdot 5 \mathrm{~mm}$. l., lateral somewhat oblique, $2.25 \mathrm{~mm}$. br., median $1.75 \mathrm{~mm}$. br. Petals 1-nerved, obtuse, $7 \mathrm{~mm}$. 1., $65 \mathrm{~mm}$. br. Lip as long as lateral sepals, median nerve prominent below and forming a mucro at apex, limb about $5 \mathrm{~mm} .1 ., 3 \cdot 5 \mathrm{~mm}$. br. Column 2.5 mm. 1. Capsule 13-18 mm. 1 . 


\section{ARPOPHYLLUM Llav. \& Lex.}

Epiphytic herb. Stems erect from a creeping rhizome, with one leaf at the apex, and covered below the leaf with ample sheaths. Leaf leathery, very long, folded together at the base, but not closed into a sheath. Peduncle terminal with one or two sheaths above the leaf; spike long, dense, cylindrical, with numerous merlium-sized shortly stalked or stalkless flowers. Bracts rery small. Sepals of nearly equal length, free among themselves, spreading, the lateral a little broader than the median, concave at the base, adnate to the foot of the column. Lip attached to the foot of the column, concave and somewhat saccate quite at the base, above the swelling contracted and incumbent, then erect; crenulate on the margin above. Column erect, slightly bent, not winged, produced at the base into a short foot; clinandrium little dilated, rostellum shorter. Anther opercular, incumbent, subglobose, 2-celled; pollinia 8, four in each cell, obovoid, acute or shortly acuminate, cohering into two groups by a sparse viscid substance. Capsule ellipsoidal, 3-keeled, 3 -ribbed.

Species 5, natives of Jamaica, Mexico and Guatemala.

A. giganteum Hartweg ex Lindl. in Ann. \& Mag. Nat. Hist. iv. 384 (1840); Reichenb. f. in Walp. Ann. vi. 448. (Pl. 14, f. 4-9)

On rocks; in fl. March-May; Old England, 4000 ft., J.P. 26, Morris ! Harris! Fl. Jam. 7652.-Mexico, Guatemala.

Plant $2 \mathrm{ft}$. high and over. Rhizome about $8 \mathrm{~mm}$. thick, covered with sheaths, sending out very long stout roots. Stem $14-25 \mathrm{~cm}$. 1., compressed, of three or four long joints; sheaths short at base, increasing above to $11 \mathrm{~cm} .1$. Leaves ligulate, flat above, keeled, $4-5 \mathrm{dm}$. $1 ., 2$ to nearly $3 \mathrm{~cm}$. br. Peduncle $10-15 \mathrm{~cm}$. l. to base of spike; spathe at base 9-13 cm. l. Spike 14-15 cm. 1. Bracts triangular, acuminate, sterle, lowest clasping, 13-15 $\mathrm{mm}$. 1., higher $2 \cdot 5-5 \mathrm{~mm}$. 1., floral $1.5 \mathrm{~mm}$. 1. Flowers light purple, stalkless, perianth $\frac{1}{5}$ in. 1. Sepals, lateral with 3 nerves branching from base, ovate-oblong, obtuse, slightly oblique, $6 \mathrm{~mm}$. l., about $3 \mathrm{~mm}$. br. at base; median 3-nerved, oblong, obtuse, $5.5 \mathrm{~mm}$. 1., $2 \mathrm{~mm}$. br. Petals, 1 median nerve with a few pinnate nerves, oblanceolate-linear, apex rounded, margin erose above, about $5.5 \mathrm{~mm}$. $1 ., 1.6 \mathrm{~mm}$. br. Lip about $5.5 \mathrm{~mm}$. 1., 7-nerved, not divided, hooded and erose above. Column 3.5-4 mm. l. Capsule 7-8 mm. l.

\section{EPIDENDRUM Sw.}

Epiphytic herbs. Stems leafy, sometimes fleshy, or at length thickened into a pseudobulb, sometimes thinner, sometimes branching. Leaves leathery or more rarely grass-like. Peduncle terminal on a leafy stem, simple or paniculate. Flowers mediumsized or somewhat small, racemose on a simple rachis or the branches of a panicle, shortly stalked, with small or narrow bracts, more rarely crowded on a very short, sessile raceme with 
imbricate bracts. Sepals free, equal, spreading or reflexed, or more rarely somewhat erect. Petals somewhat similar to the sepals, or more rarely much narrower. Claw of the lip erect, adpressed to the column and more or less connate with it into a tube; lateral lobes obsolete or more rarely dilated embracing the column; blade spreading, undivided or 3-fid; disc with various calli. Column generally narrow, connate with the claw of the lip even to the apex, sometimes free, semiterete or more rarely 2-winged or 2-auriculate; clinandrium generally short. Anther terminal, opercular, incumbent, convex or semiglobose, distinctly 2-celled, each cell again divided longitudinally ; pollinia 4, waxy, ovate or broad, equal, compressed from the side, in one series, connected in each cell by a granular-viscous appendage. Capsule ovoid or oblong, the ribs often very prominent, or sometimes winged.

Species about 750, widely dispersed through tropical America, a few extending to the southern States of North America.

I. Column connate with lip beyond its middle or even as far as the apex (but only to about the middle in E. cochleatum and E. spondiadum).

1. With pseudobulbs.

Lip 3-lobed, with fringed lobes

Lip entire.

Lip greenish-white with purple streaks ... Lip purple

Lip indistinctly 2 -Jobed, cream-colour blotched with reddish-purple

2. Without pseudobulbs.

a. Floral bracts inconspicuous, much shorter than the flowers.

Sterile bracts none, or a few similar to floral bracts.

Flowers more than $1 \frac{1}{2}$ inch 1., apparently solitary.

Lateral lobes of lip semi-ovate .........

Lateral lobes of lip linear..................

Flowers less than $\frac{3}{4}$ inch 1 .

Flowers umbellate

Flowers in a raceme or panicle.

Lip undivided ...........................

Lip 3-lobed with terminal lobe 2-partite.

Lip longer than sepals, lateral lobes oblong, apex of lobes eroded...

Lip not longer than sepals, lateral lobes rounded, apex of lobes entire

Sterile bracts spathaceous.

Lateral lobes of lip entire.

Flowers in a panicle; lateral lobes of

lip trapezoid-roundish

Flowers in a crowded raceme, almost

like a head; lateral lobes of lip

roundish, almost obsolete...

Lateral lobes of lip fringed
1. E. ciliare.

2. E. fragrans.

3. E. cochleatum.

4. E. spondiadum.
5. E. nocturnum.

6. E. angustilobum.

7. E. difforme.

8. E. jamaicense.

9. E. verrucosum.

10. E. patens.

11. E. nutans.

12. E. anceps.

13. E. rivulare. 
b. Floral bracts large, broad, concave, spathe-

like, enclosing the ovary or even the flower.

Lip undivided.

Leaves small, not more than 4 inches 1 .

Leaves oblong-elliptical, 2 inches 1 .;

spike longer than loaves.............. 14. E. rigidum.

Leaves linear-ligulate or linear-lanceolate.

Spike with few flowers.

Leaves linear, 3-4 inches 1 . Flowers $\frac{1}{4}$ inch 1 .

Leaves linear-lanceolate, $\frac{3}{4}$ inch 1 .

Flowers $\frac{1}{6}$ inch l................. 16. E. strobilifer

Flowers solitary ....................... 17. E. repens.

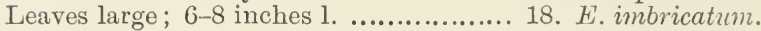

Lip 3-lobed .................................. 19. E. bifarium.

II. Column free, or only connate below the middle with the lip (connate about half-way in $E$. teretifolium).

1. With pseudobulb.

a. Lip undivided.

Flowers solitary ............................20. E. polybulbon.

Flowers racemose or paniculate.

Lip somewhat similar to sepals and petals 21. E. Ottonis.

Lip long-clawed, broadly ovate............. 22. E. subaquilum.

Lip very short-clawed, elliptical, acute, ventricose-concave .................... 23. E. bletioides.

b. Lip 3-lobed.

Lip quite free.

Lateral lobes rounded, median lobe rounded and not larger ................

Lateral lobes narrow, middle lobe differing in form, and much larger.

Ovary rugose.

25. E. monticolum.

Ovary smooth

26. E. belvederense.

Lip attached to column about one-third of its length

24. E. parvilobum.

. Without pseudobulb.

Stem with one leaf.

Flower-stalk longer than leaf, with one flower.

Leaf serrulate, spike of flowers shorter than

leaf .......................................

27. E. angustifolium.

Stem short with a few minute flowers clustered at apex.

Stem long with one flower at apex............ 31. E. teretifolium.

1. E. ciliare L. Syst. ed. 10, 1246 (1759); pseudobulbs long, thicker above, of several joints, 2-leaved; lip white, 3-lobed, lateral lobes with long fringes, median lobe subulate-filiform; column connate with lip as far as apex-Jacq. Sel. Stirp. Amer. 224, t. 179, f. 89, Ed. pict. t. 209; Bot. Reg. t. 784; Lindl. Fol. Orch. Epid. 29 ; Griseb. Fl. Br. W. Ind. 615; Cogn. in Fl. Bras. iii. pt. 5, 70 ; Salisb. Ic. ined. vi. fol. 574. Helleborine graminea \&c. Plum. Pl. Amer. (Burm.) t. 179, f. 2, \& Ic. ined. iii. t. 143. 
On trees; in fl. July-Dec.; Shepherd in Herb. Kew!-Porto Rico, S. Thomas, Tortola, St. Cruz, St. Martin, St. Bartholomew, Saba, St. Eustatius, St. Kitts, Antigua, Guadeloupe, Dominica, Martinique, St. Lucia, St. Vincent, Bequia, Barbados, Grenada, Trinidad, Venezuela, B. Guiana, French Guiana, Colombia, Brazil, Guatemala, Costa Rica, Mexico, B. Honduras.

Plant $1 \frac{1}{2} \mathrm{ft}$. high and more. Pseudobulbs 1-2 dm. 1. Leaves leathery, oblong-ligulate to elliptical-oblong, obtuse, 1-2 dm. $1 ., 2 \cdot 5-4 \cdot 5 \mathrm{~cm}$. br. Raceme with few or many flowers above, as long as the leaves, sometimes longer, clothed below with compressed keeled sterile bracts $(2 \cdot 5-5 \mathrm{~cm}$. 1.). Bracts, floral large, spreading, broadly lanceolate, acute, $2 \cdot 5-5 \mathrm{~cm}$. 1 . Pedicels about $1 \mathrm{~cm}$. 1. Flowers large, sweet-smelling, pale yellowishgreen with white lip. Sepals narrowly linear-lanceolate, long acuminate, many-nerved, $4-5 \cdot 5 \mathrm{~cm}$. 1., 3-5 mm. br. Petals like the sepals but slightly smaller, and somewhat falcate. Lip, lateral lobes 1-2 cm. 1., 2-3 mm. br., median lobe $3-3.5 \mathrm{~cm}$. 1. Column white, dilated above, 13-15 mm. l. Capsule oblong-spindle-shaped, 4-5 cm. 1., 1.5-2 cm. br.; beak $2-2.5 \mathrm{~cm}$. 1 .

The sole authority for including this species rests on a specimen from Shepherd "from Jamaica" in the Kew Herbarium. If truly native, it is remarkable that so striking a plant should have escaped the notice of so many collectors from Swartz onwards.

2. E. fragrans $S w$. Prodr. 123 (1788); pseudobulb spindleshaped or ovoidl-lanceolate, 1-leaved; lip creamy-white with purple lines, on upper side of flower, undivided, ovate-roundish, acuninate; column connate with lip beyond the middle.-Sw. Fl. Ind. Occ. 1487 \& Ic. ined. t. 46 ; Andrews Bot. Rep. x. t. 645; Bot. Mag. t. 1669 ; Lindl. Fol. Orch. Epid. 39 ; Griseb. op. cit. 615 ; Cogn. op. cit. 83 \& in Symb. Ant. iv. 174 ; Salisb. Ic. ined. vi. fol. 575 .

On trees and rocks; in $\mathrm{fl}$. all the year; Swartz! Bertero, Distin! Lane! Fairfield, Wullschlaegel, 1066! Moneague, Prior! J.P. 11, Morris ! Ramble, Hanover; Bath; Fawcett! Silver Hill, $4000 \mathrm{ft}$.; Dolphin Head, $1600 \mathrm{ft}$.; Harris! near Radnor,-Miss B. Gosset! Fl. Jam. 7859, 10,441.Cuba, Florida, Hispaniola, Dominica, Martinique, St. Vincent, Grenada, Trinidad, Venezuela, B. Guiana, Surinam, Brazil, Panama, Colombia, Ecuador, Nicaragua, Guatemala.

Plant 12-18 in. high. Pseudobulb 6-13 cm. l., with a few, rather large scarious sheaths, soon decaying. Leaves leathery, ligulate-oblong, obtuse, 2-3.5 dm. 1., 2-4 cm. br. Raceme 6-10 cm. 1., with few or several flowers, much shorter than the leaf; spathe at base broadly ovate, compressed, about $4 \mathrm{~cm}$. l. (3-6). Bracts minute, triangular or triangular-lanceolate, acute or shortly acuminate, 3-6 mm. 1. Flowers fragrant, shortly stalked, perianth 1 in. or more 1. Sepals lanceolate, long-acuminate, 5-7 nerved, yellowish-white with greenish tint outside, 25-35 mm. 1., 3.5-5 mm. br. Petals oval-lanceolate, long acuminate, 7-nerved, yellowish-white, 22$28 \mathrm{~mm}$. 1., 7-10 mm. br. Lip 11-13-nerved, 16-18 mm. 1. (to junction with column), 10-13 mm. br. Colımn greenish-white, short, 5-8 mm. l., thicker above, at the apex three obtuse lobes with a long tooth on the inner side of the median lobe; anther indistinctly 2-lobed above. Capsule ellipsoidal, $2 \cdot 5-3 \mathrm{~cm}$. 1 .

3. E. cochleatum L. Sp. Pl. ed. 2, 1351 (1763), excl. syn. Sloane; pseudobulb with one to three small joints at base and apex, ovoid-lanceolate or cylindrical, with two or sometimes 
three leaves: lip purple, whitish round column, with conspicuous purple radiating veins, rarely yellow, on the upper side of flower, undivided, shell-shaped, cordate, broadly roundish, apiculate, with two ealli at base; column connate with lip to about the middle.-Jarq. Ic. Pl. Rar. iii. t. 605; Andrews liot. Rep. t. 13 : Bot. Mug. t. 57.2; Griseb. op). cit. 616 ; Coym. in Symb. Ant. iv. 175. Viscum caryophylloides de. Catesby Nat. Hist. Curol. ii. is t. 88. Helleborine cochleato tlore Plum. Pl. Amer. (Burm.) 9, t. 18.), f. 2.

On trees and rocks; in fl. throughout year; Swartz! Fairfield, Wullschlaegel, 1064 bis! Newcastle Road, Prior! St. Ann (lip yellow), Stcer! J.P. 10, 2153, Morris! Syme! Green River, G. Nichols! Silver Hill ; Chester Vale, 3000 ft. ; Vinegar Hill, 4000 ft. ; Harris ! near Radnor, Miss B. Gosset! Mloneague, Mrs. Balston! Fl. Jam. 7676, 8000, 10,461. -Cuba, Bahamas, Florida, Hispaniola, Porto Rico, Costa Iica, Nicaragua, B. Honduras, Guatemala, Mexico, Venezuela.

Plant 1-2 ft. high. Pseudobulb 9-16 cm. l., with a few rather large scarious sheaths, soon decaying. Leaves oblong-lanceolate, acute, 2-3 dm. 1., 2-3.5 cm. br. Raceme 2-5 dm. 1., with few or several flowers, longer than the leaf; spathe at base $7-14 \mathrm{~cm}$. l. Bracts small, triangularlanceolate, acuminate, 5-12 mm. l. Flowers stalked, perianth $1 \mathrm{in}$. and more 1., lip about $\frac{1}{2}$ in. 1. Pedicels $1-2 \mathrm{~cm}$. 1 . Ovary 3 -cornered, about $1 \mathrm{~cm} .1$. Sepals linear-lanceolate from a broad base, acute or acuminate, pale green or greenish-white with one or two purple spots at base, pendulous, $2 \cdot 5-4 \cdot 2 \mathrm{~cm}$. 1., 3-5 mm. br. Petals narrowly oblanceolate, otherwise like sepals, but shorter and narrower. Lip 12-20 mm. 1 . Column purple below, white above, short, about $6 \mathrm{~mm}$. l., thicker above; clinandrium with three obtuse lobes. Capsule ellipsoidal, with three broad wings, recurved, about $4 \mathrm{~cm} .1$.

4. E. spondiadum Reichb. f. in Bot. Zeit. x. 731 (1852); pseudobulb with one or two small joints at base, cylindrical, sometimes slightly larger at base, with one leaf; lip reddishpurple with cream-coloured or yellowish-green margin, on the upper side of flower, cordate, broadly ovate with obscure lateral lobes, apex apiculate, two calli at base running up to a circular callus on the lower part of the disk, and level with top of column ; column connate with lip to about the middle.-Hook. $f$. in Bot. Mag. t. 7273. E. variegatum Hart in Gard. Chron. xxri. 11 (1886) (non Hook.).

On trees and rocks; in fl. and fr. Nov.-Feb.; Coldspring; Whitfield Hall: J.P. 245 ; Morris! Clydesdale, Harris! Fl. Jam. 7866.-Costa Rica.

Plant 12-16 in. high. Pseudobulbs clustered along a creeping rhizome, 10-17 cm. l., with two somewhat large scarious sheaths, soon decaying. Leaves ligulate, obtuse, 2-3 dm.1., 3-3.5 cm. br. Raceme $8-11 \mathrm{~cm}$. 1., with a few or several flowers, much shorter than the leaf, spathe at base $3 \cdot 5$ $4.5 \mathrm{~cm}$. l. Bracts small, triangular, obtuse, $3-4 \mathrm{~mm}$. 1. Flowers shortly stalked, perianth more than $\frac{1}{2}$ in. l., lip about $\frac{1}{2}$ in. br., but not so long. Pedicels 4-6 mm. 1. Ovary 3̈-winged, about $1 \mathrm{~cm}$. l. Sepals somewhat fleshy, oblong, with an acute apex, creamy-white or greenish-yellow tinted with reddish-purple, $13-15 \mathrm{~mm}$. 1., 3·5-4 mm. br. Petals 7-nerved, somewhat fleshy, oblanceolate, acute, creamy-white or greenish-yellow with a reddish-purple blotch in the centre, 11-15 $\mathrm{mm}$. 1., 4-4.5 mm. br. Lip about $11 \mathrm{~mm}$. l. from junction with column. Column short, about $5 \mathrm{~mm}$. 
1.; clinandrium with three lobes, lateral lobes obtuse, retuse or slightly 2-lobed, median lobe denticulate. Capsule ellipsoidal, with three broad wings, recurved, $3 \cdot 5-4 \cdot 5 \mathrm{~cm} .1$.

5. E. nocturnum Jacq. Enum. Pl. Carib. 29 (1760); without pseudobulbs; bracts very much shorter than flowers; flowers solitary, perianth $1 \frac{3}{4}$ in. l. ; ovary about $5 \mathrm{~cm}$. l.; lip deeply 3-lobed, lateral lobes semi-ovate, obtuse, entire, about $2 \mathrm{~cm}$. l., 5-7 mm. br., the median lobe about $2.5 \mathrm{~cm}$. l., $1 \mathrm{~mm}$. br., resembling petals; column connate with lip nearly to apex.Jacq. Sel. Stirp. Amer. 225, t. 139, Ed. pict. t. 210; Sw. Oss. Bot. 327 ; Lindl. Gen. \& S'p. Orch. 105 \& Fol. Orch. Epid. 81; Hook. in Bot. Mag. t. 3298; Griseb. op. cit. 619 ; Cogn. in Fl. Bras. iii. pt. 5, 134, t. 37 ; Ames Orch. S. Fla. 16, t. 7. (Pl. 15, f. 2.)

On trees, stones and rocky land; in fl. Aug.-Nov., in fr. Sept.-Dec. ; Macfadyen! Moneague, Prior! March ! J.P. 3, Morris! Moody's Gap, J.P. 2005, Syme! St. Ann and Trelawney, Miss T. M. Barrett! Cedar Valley, Moore! Lancaster, $2500 \mathrm{ft}$., Harris! Fl. Jam. 7565.-Cuba, Bahamas, Florida, Porto Rico, Guadeloupe, Dominica, Martinique, St. Lucia, St. Vincent, Grenada, Trinidad, Nicaragua, Honduras, Guatemala, Mexico, Venezuela, B. Guiana, Surinam, Brazil, Peru.

Plant 14-15 in. high. Rhizome short, with numerous stout roots. Stems 10-40 cm. 1., 4-5 mm. br., several, erect, long, stout, covered with the leaf-sheaths, the blades of which are fallen below, compressed and leafy above. Leaves $7-12 \mathrm{~cm}$. l., generally from $2-3 \mathrm{~cm}$. br., in two ranks, leathery, linear-oblong to oblong, apex rounded or slightly emarginate, at the base clasping and sheathing; sheaths slightly keeled. Bracts 3-7 mm. 1., broadly ovate, acute, at base clasping. Flowers greenishwhite or cream-coloured, sessile, five or six or more, in a terminal panicle, the rachis of which is scarcely developed, and generally remains enclosed by the leaf-sheaths, only one or two flowers generally appearing at a time. Ovary about $5 \mathrm{~cm}$. l., as long as, or longer than, perianth. Sepals 4-4.5 cm. l., greenish-white or cream-coloured, narrowly lanceolate, acuminate, many-nerved, lateral $5 \mathrm{~mm}$. br., slightly oblique, median slightly narrower. Petals as long as the sepals, 1-1.5 mm. br., whitish or cream-coloured, linear, long-acuminate. Lip as long as, or a little shorter than, the petals; disk with two long broad parallel lamellæ. Column 15-18 mm. l., much dilated above, clinandrium dentate. Capsule $6 \mathrm{~cm} .1$. , about $1.5 \mathrm{~cm}$. br., oblong, spindle-shaped, much attenuated above and at the base.

6. E. angustilobum Fawc. \& Rendle in Journ. Bot. xlvii. 124 (1909); without pseudobulbs; bracts very much shorter than flowers: tiowers solitary, large, perianth $1 \frac{3}{4}$ in. l. ; ovary very long, $12.5 \mathrm{~cm}$. 1.; lip deeply 3-lobed, lateral lobes linear, acuminate, $7 \mathrm{~mm}$. l., barely $1 \mathrm{~mm}$. br., the median lobes three times as long, linear, long-acuminate, $2 \cdot 2 \mathrm{~cm} .1 ., 1 \mathrm{~mm}$. br. ; column auricled, connate above the middle with the lip, about three-quarters of its length. (Pl. 15, f. 1.)

In fl. Oct. ; Rose Hill, 4000 ft., Harris! Fl. Jam. 10,485.

Plant over $2 \mathrm{ft}$. high. Stem high, erect, stout, terete at the base, bare above the base, compressed above, covered with the sheaths of the leaves, 
with two leaves at the apex, 5 dn1. 1., 4-10 $\mathrm{mm}$. br. Ifeaves oval or ellipticaloblong, leathery, obtuse, many-nerved, at the base clasping and longsheathing, blude about 11 cm. $1 ., 4-5 \mathrm{~cm}$. br., sheaths compressed, slightly keeled. Panicle, rachis scarcely protruded and covered by sheaths. Bracts sheathing at the base, ovate-oblong, acute or somewhat acuminate, 7-s mni. l. Flower cream-coloured. Sepals narrowly oblanceolate, acuminate, many-nerved, $4 \cdot 2-4 \cdot 3 \mathrm{~cm}$. l. Petals as long as the sepals, linear, long-acumiuate. Lip a little shorter than the sepals; disk with two narrow parallel lamellie at the base. Column $2 \mathrm{~cm}$. 1 ,, above very dilated; clinandrium with three posterior ovate acuminate lobes, and three anterior, the middle acuminate, and the lateral obtuse; anther purplish.

7. E. difforme Jacq. Enum. Pl. Carib. 29 (1760); without pseudobulbs; bracts much shorter than flowers; Howers umbellate, perianth about $\frac{1}{2}$ in. 1. ; lip kiclney-shaped, emarginate, margin undulate, with two calli on disk at base; column connate with lip to apex.-Jacq. Sel. Stirp. Amer. 223, t. 136, Ed. pict. t. 206 ; Cogn. in Fl. Bras. iii. pt. 5, 139 . E. umbellatum Sw. Prodr. 121 (1788) \& Fl. Ind. Occ. 1501; Bot. Mag. t. 2030; Lindl. Fol. Oich. Epid. 79 ; Griseb. op. cit. 618. (Pl. 15, f. 3.) Type in Herb. Mus. Brit.

On trees; in fl. Aug.-April; mountains, Swartz! Purdie! Nazareth, Wullschlaegel, 1395 ! Prior! Eggers; J.P. 18, 1516, Norris! lowlands, J.P. 524, Syme! Cedar Hurst, Fawcett! Cinchona, Isaacs! Harris! Keith Hill, $2200 \mathrm{ft}$., Thompson! Clydesdale, $4000 \mathrm{ft}$.; Lancaster $3000 \mathrm{ft}$; Belvedere, Hanover, $500 \mathrm{ft}$; Silver Hill, $4000 \mathrm{ft}$; Harris! Mahogany Vale Ridge, Miss B. Gosset! Fl. Jam. 7629, 7651, 7865, 9022, 10,455, 10,498.-Cuba, Florida, Hispaniola, Porto Rico, St. Eustatius, St. Kitts, Guadeloupe, Dominica, Martinique, St. Lucia, St. Vincent, Grenada, Trinidad, Guatemala, Mlexico, Costa Rica, Venezuela, B. Guiana, Surinam, Brazil.

Plant 2-10 in. high. Stems 4-20 cm. l., few or several, clustered, covered with leaf-sheaths. Leaves leathery, elliptical-oblong or ligulate, obtuse, obliquely retuse, clasping at base, blade $2 \cdot 5-7 \cdot 5 \mathrm{~cm} .1 ., 1-2 \cdot 5 \mathrm{~cm}$. br. Bracts linear, 7-12 mm. l. Flowers pale green or whitish. Pedicels $1-2.5 \mathrm{~cm} .1$. Ovary $1-2.5 \mathrm{~cm}$. 1 . Sepals with seven incomplete nerves prominent on inside, elliptical, median apex thickened, subacute, $15 \mathrm{~mm}$. 1., about $5.5 \mathrm{~mm}$. br.; lateral somewhat oblique, apex keeled at back, keel forming an acute point, $15-16 \mathrm{~mm}$. 1., $6 \mathrm{~mm}$. br. Petals 3-nerved, linear-lanceolate, $14 \mathrm{~mm}$. 1., $2 \cdot 5 \mathrm{~mm}$. br. Lip with numerous nerres, 13-14 mm. l., about $18 \mathrm{~mm}$. br. Column short, about $1 \mathrm{~cm}$. l. (to apex of clinandrium), thicker above; clinandrium with denticulate margin. Capsule ellipsoidal, shortly and thickly beaked, $2 \cdot 5 \mathrm{~cm} .1 ., 1 \cdot 5 \mathrm{~cm}$. br.

8. E. jamaicense Lindl. Fol. Orch. Epid. 82 (1853); without pseudobulbs; bracts shorter than flowers; flowers in a raceme, perianth $\frac{2}{3}$ in. l. ; lip undivided, roundish or broader than long, undulate, subentire, inconspicuously mucronate, two calli on disk at base ; column connate with lip to apex._Griseb. op. cit. 618 .

On trees; in fl. Sept.; Manchester, Dunrobin Castle, Purdie! Cedar Hurst, Rose Hill, J.P. 481, Syme! near Cedar Hurst, 2409, Morris! near Bath, Harris! 
Plant to $1 \mathrm{ft}$. high. Stem 2-3 dm. 1., covered with leaf-sheaths, leafy above. Leaves oblong-lanceolate, very acute, longer than the raceme, blade 4-11 cm. 1., 1-2 cm. br. Bracts triangular-lanceolate, acuminate, keeled, $12-5 \mathrm{~mm}$. 1. Pedicels 11-12 mm. l. Ovary rather longer than pedicel. Sepals oblanceolate, $12-16 \mathrm{~mm}$. l. Petals narrowly linear, slightly shorter than sepals. Lip, limb $8 \mathrm{~mm}$. 1., $12 \mathrm{~mm}$. br. Column short, branching upwards, $9 \mathrm{~mm}$. 1. ; clinandrium hooded, undivided.

9. E. verrucosum Sis. in Nov. Act. Upsal. vi. 68 (1799); without pseudobulbs; bracts much shorter than flowers; flowers in a diffuse panicle, sepals and petals $\frac{1}{3}$ in. 1.; lip much longer than sepals, 3-lobed with median lobe 2-lobed, lateral lobes and median lobes somewhat oblong with upper margins more or less eroded, three calli on disk at base; column connate with lip to apex.-Su. Fl. Ind. Occ. 1497; Lindl. Fol. Orch. Epid. 92. (Pl. 15, f. 11.)

On trees, rocks and dry banks; in fl. Dec., Jan.; S'wartz! Wright! Bancroft! Christiana, Purdie! Lane! March! Fairfield, Wullschlaegel, 1059! Manchester, J.P., 2008, 2040, Syme! Morris! Blue MIts., J.P. 2048, Iorris! Cinchona; Clydesdale; Harris! Fl. Jam. 7542, 7819.-Colombia.

Plant 1-4 ft. high. Stems 1-6 dm. 1., covered with leaf-sheaths. Leaves lanceolate or linear-lanceolate, acute, blade 8-14 cm. 1., 13-30 $\mathrm{mm}$. br.; sheaths covered with minute warts. Bracts triangular, acuminate, $2 \cdot 5-4 \mathrm{~mm}$. 1. Flowers creamy-white or light yellow. Pedicels about $1 \mathrm{~cm}$. 1 . Ovary about $1 \mathrm{~cm} .1$. Sépals with seren to nine nerves, prominent on inside, elliptical, apex thickened, obtuse, $9 \mathrm{~mm}$. 1., $4 \mathrm{~mm}$. br., lateral rather narrower and slightly oblique. Petals with three to five branching nerves, linear-oblanceolate, $9 \mathrm{~mm}$. $1 ., 2 \cdot 25 \mathrm{~mm}$. br. Lip with numerous fine nerves, about $12 \mathrm{~mm}$. 1. Column short, about $5 \mathrm{~mm}$. 1. (to apex of clinandrium); clinandrium with four broad truncate lobes; anther slightly 2-lobed above. Capsule spindle-shaped, beaked, $2.5 \mathrm{~cm} .1$.

10. E. patens Sw. in Nov. Act. Upsal. vi. 68 (1799); without pseudobulbs; bracts much shorter than flowers; flowers in a panicle; perianth nearly $\frac{1}{2}$ in. 1.; lip as long as median sepal, 3-lobed with median lobe -lobed, lateral lobes roundish, median lobes oblong, margins of lobes entire, three calli at base of median lobe ; column connate with lip to apex.-Su. Fl. Ind. Occ. 1495 ; non Lindl. in Paxt. Flou. Gard. ii. Glean. 119, f. 198, nec Fol. Orch. Epid. 75 ; Griseb. op. cit. 617 (in part).

Stems $20-30 \mathrm{~cm} .1$. Leaves, blade $5-10 \mathrm{~cm}$. 1., oblong or oblong-lanceolate; sheaths smooth. Bracts linear-lanceolate. Flowers pale yellow, shortly stalked. Sepals oblanceolate-oblong, acute, median $1-1 \cdot 1 \mathrm{~cm} .1$,, lateral $\cdot 9-1 \mathrm{~cm}$. 1 . Petals oblanceolate to elliptical, $1 \mathrm{~cm}$. 1. Lip 1-1.1 cm. 1. Column stout, concave in front, widening upwards, with a dorsal keel; clinandrium 3-lobed, median lobe broad, truncate, crenulate.

We have not seen any specimen from Jamaica, but a specimen in Herb. IIus. Brit. labelled in Solander's hand "Epidendrum patens fl. ind. occid., Barthol." agrees with Swartz's description. Swartz assigns the species to Jamaica and the Carribean Islands and cites Fahlberg as the collector. Samuel Fahlberg, a Swede, visited St. Bartholomew in 1785. The specimens referred by Lindley to this species, belong to the section Amphiglottum, characterised by a closely sheathed peduncle, and have flowers $1 \frac{1}{2}$ in. across. 
11. E. nutans Sw. Prod. 121 (17ss); without pseudobulbs; floral bracts much shorter than the flowers; panicle sheathed at base by two large spathaceous bracts: lip cordate, 3-lobed, median lobe :-lobed, lateral lobes subrotund or subrhomboid, disk with three limellar, the lateral forming at the base two auriculate calli; column comnate with lip to apex.-Sw. F\%. Ind. Oce. 1499); Bot. Rey. t. 17 ; Hook. Lixot. Fl. i. t. 50 ; Lindl. Fol. Orch. Epid.56; Griseb. op. cit. 616. (Pl. 15, f. 5.) Type in Herl. Mus. Brit.

On rocks and trees; in 11 . Aug.-Feb.; Swartz! Springficld, Wullschlargel, 1090! Moneague, Prior! Macfayden! Jenman! J.P. 2007, Syme! J.P. 527, Morris! Cedar Hurst, Fawcett! Trelawney, Miss T. M. Barrett! WValderston, Mis. Longstaff! Mt. Moses; Woodeutters' Gap, $4000 \mathrm{ft}$.; Chester Vale, $3000 \mathrm{ft}$.; Wallenford, $2000 \mathrm{ft}$.; Hoilymount, near Ewarton, 2500 ft., Harris! Fl. Jam. 7624, 7864, 8907.-Trinidad, Venezucla, Brazil.

Plant $1 \frac{1}{2}-2 \mathrm{ft}$. high. Stem 4-5 dm. 1., $710 \mathrm{~mm}$. br., erect, stout, covered with leaf sheaths, leafy above. Leaves leathery, oblong to oblonglanceolate, acute to subobtuse, clasping and sheathing, blade $12-20 \mathrm{~cm}$. 1., $3-5.5 \mathrm{~cm}$. br. Panicle terminal, large, longer than the leaves, lax, many flowered, subnutant; spathaceous bracts much smaller than the leaves and passing above into the floral bracts, lower floral bracts linear, decreasing upwards, the uppermost 3-4 $\mathrm{mm}$. 1., triangular, acuminate, very much shorter than the pedicels. Flowers between $\frac{1}{2}$ and $\frac{3}{t}$ in. 1., greenish, or whitish-green, pedicels long; ovary and pedicel together $2-3 \mathrm{~cm} .1$. Scpals 1.5-1.8 cm. 1., 3-5 mm. br., oblanceolate, distinctly 5-nerved, median obtuse, lateral acute, rather broader and longer. Petals a little shorter than the sepals, 3-nerved, subspathulate-linear, obtuse. Lip as long as or longer than the sepals. Column 1.2-1.3 cm. 1., erect, thick, club-shaped; clinandrium with a tooth on each side anteriorly.

Var. tridentatum var. nov. ; E. tridentatum Fawc. in Journ. Bot. axxiii. 12 (1895); leaves narrower and more acute, sterile bract small or none, middle lobe of lip with three triangular lobules.

In fl. April, Blue MIts., Harris!

Var. obtusifolium var. nov.; stems reaching to $4 \frac{1}{2} \mathrm{ft}$. in length; leaves oblong to oblong-elliptical, obtuse, broader than in type; flowers smaller, generally dark-purple lip and column and the same colour on back of sepals; sepals broader than in type, 1'3 cm. l. or less, $5-6 \mathrm{~mm}$. br. ; petals same length, barely $2 \mathrm{~mm}$. br.; lip as long as the sepals, and as broad as long.

On rocks in woodlands, in fl. Oct.-Dec., Nandeville, Lady Blake! Near Browns Town, Miss T. M. Barrett! near Chapelton, Craig! Troy, 2000 ft., Harris! Fl. Jam. 10,420; Walderston, Mrs. Longstaff !

12. E. anceps Jacq. Sel. Stirp. Amer. 224, t. 138 (1763), $E d$. pict. t. 208; without pseudobulbs; sheaths on long flower-stalk below, flowers crowded above almost into a head; floral bracts much shorter than the flowers; lip broadly kidney-shaped-cordate, 2-lobed at apex; column connate with lip nearly to apex.-E. fuscatum Smith Spicil. 21, t. 23 (1791); 
Bot. Mag.t. 2844 ; Lindl. Fol. Orch. Epid. 65 ; Griseb. op. cit. 617 ; Salisb. Ic. ined. vi. fol. 57t. (Pl. 15, f. 10.)

On trees and rocks; in fl. March-Nov.; Bancroft! Moneague, Prior! March! J.P. 19, 2401, Morris! Syme! Trelawney, Griffith! Bath, G. Nichols! Iron River, $1500 \mathrm{ft}$.; Cascade, $3000 \mathrm{ft}$; Holly Nount, IIt. Diabolo, 2800 ft.; Harris! Fl. Jam. 9021, 10,425.-Cuba, Florida, Hispaniola, Porto Rico, St. Martin, Saba, St. Eustatius, St. Kitts, Antigua, Guadeloupe, Dominica, Martinique, St. Lucia, St. Vincent, Barbados, Grenada, Trinidad, Mexico, Honduras, Nicaragua, Colombia, Venezuela, B. Guiana, Surinam, Brazil.

Plant $1 \frac{1}{2}$ to $3 \mathrm{ft}$. high. Stem to $8 \mathrm{dm}$. 1., compressed. Leaves oblongelliptical or sometimes oblong-lanceolate, obtuse, sometimes subacute, sessile, sheathing at base; limb 7-17 cm. 1., 2.5-4.5 cm. br. Peduncle 2-5 dm. l.; sheaths compressed, keeled, oblong-triangular above, imbricating, 2-6 cm. l. ; raceme short, dense, sometimes branching, 1.5 sometimes to $7 \mathrm{~cm}$. 1. Bracts lanceolate, acuminate, $3-6 \mathrm{~mm}$. 1. Flowers fleshy, light-brown, greenish-brown, or tawny yellow. Ovary slender, with pedicel about $1 \mathrm{~cm}$. 1. Sepals obovate-elliptical, somewhat acute, light brown, lateral slightly broader, 6-8 $\mathrm{mm}$. 1., 3-4 $\mathrm{mm}$. br. ; when dry, with 3-5 prominent nerves. Petals spathulate-linear, light brown, 1-nerved when dry, 5.5-6.5 mm. 1., 1-15 mm. br. Lip greenish-brown, with numerous veins when dry; limb 5-6.5 mm. 1., 6-9 $\mathrm{mm}$. br. Column $4 \mathrm{~mm}$. l., greenish brown.

13. E. rivulare Lindl. Ann. \& Mag. Nat. Hist. ser. 3, i. 330 (1858); without pseudobulbs ; stems long, slender ; leaves linearlanceolate; base of peduncle clothed with closely-sheathing, subfoliaceous sterile bracts; flowers few above, long-stalked, lax, somewhat corymbose; floral bracts much shorter than the flowers; lip 3-lobed, lateral lobes large, fringed; median lobe linear, 3-toothed at dilated apex; disk with two calli at base; column connate with lip to apex.-Griseb. op. cit. 616. (Pl. 15, f. 7.)

On trees; in fl. Aug.-Narch; Dolphin Head, Purdie! Green River, J.P. 485, Morris! near Browns Town, Miss T. H. Barrett! Christiana, Tomlinson! St. Ann, Stewart! between Cinchona and Old England; Holly Mount, MIt. Diabolo; Harris! Fl. Jam. 10,421, 10,429, 10,449.Cuba, Hispaniola.

Plant $1 \frac{1}{2}-2 \mathrm{ft}$. and over. Stem to $6 \mathrm{dm}$. and over, covered by the leaf-sheaths. Leaves 6-12 cm. 1., 8-11 mm. br. Peduncle 7-12 cm. 1., sterile bracts in two rows, compressed, tapering upwards, keeled above, imbricating, to $5 \mathrm{~cm}$. 1. Raceme short, rarely branching, $2-3 \mathrm{~cm}$. 1 . Bracts lanceolate, acute, 10-4 mm. 1. Flowers yellowish-green speckled with red, lip white or light yellow, column tipped with red, perianth nearly $\frac{3}{4}$ in. l. Ovary slender, $12-13 \mathrm{~mm}$. l. Pedicel about $15 \mathrm{~mm}$. 1 . Sepals with 7-nerves prominent on outside, oblong-lanceolate, acute, $1 \cdot 5-1 \cdot 6 \mathrm{~cm} .1 ., 3 \cdot 5 \mathrm{~mm}$. br. Petals 1 -nerved, linear, as long as sepals. Lip about $1 \mathrm{~cm}$. l. abuve attachment to column. Column thicker above, 7-8 mm. l.; clinandrium with two shallow lobes at edch side. Capsule ellipsoidal, tapering to base, and forming a beak at apex, about $3 \mathrm{~cm} .1$., $1 \mathrm{~cm}$. br.

14. E. rigidum Jacq. Enum. Pl. Carib. 29 (1760); without pseudobulbs; stems erect from a creeping rhizome, compressed; 
leaves leathery, ligulate-oblong or oblong-elliptical, obtuse, bracts ample, lroally triangular, obtuse, keeled, keel decurrent, clasping, as long as ovary and enclosing it; lip on the upper side of the flower, leathery, a little longer than the sepals, undivided, roundish-ovate, corclate, apex obtuse, disk with two calli at base ; column connate with lip to apex.-Jucq. Sol. Stirp. Amer. 222, t. 134. Ed. pict. t. 204; Sw. Prodr. 121 \& Fl. Ind Occ. 1507; Hook. Ic. Pl. t. 31t; Lindl. Fol. Orch. Epid. 66 ; Griseb. op. cit. 618 ; Cogn. in Fl. Bras. iii.pt. 5, 171.

On trees; in fl. Aug.-Nov., in fr. Nov.-Jan.; Macfadyen! St. Thomas in Vale, Purdie! New Carmel, Wullschlaegel, 1086! March! St. Mary, J.P. 2013, Syme! Morris! Trelawney, Miss T. M. Barrett! Ramble, St. Ann, Faucett \& Harris! Belvedere, Hanover; near Cinchona; Jarris! Fl. Jam. 7246, 7623, 7754.-Cuba, Florida, Hispaniola, Porto Rico, Guadeloupe, Dominica, Mtartinique, St. Lucia, St. Vincent, Grenada, Tobago, Trinidad, Costa Rica, B. Honduras, Mexico, Venezuela, B. Guiana, French Guiana, Surinam, Brazil, Colombia, Bolivia.

Plant 4-10 in. high. Stems somerwhat stout, simple, covered by the leaf-sheaths, $5-14 \mathrm{~cm}$. 1. Leaves, blade $2-6 \cdot 5 \mathrm{~cm} .1 ., 1 \cdot 2-2 \mathrm{~cm}$. br. ; sheaths 1-2 cm. 1. Spike 3-11 cm. l., longer than the leaves, simple, very compressed, with two winged edges. Bracts 10-15 $\mathrm{mm}$. l. F'lowers few or several, green, perianth about $\frac{1}{4}$ in. 1. Sepals 6-7-nerved, leathery, oval, apex with thickened margin, somewhat acute, $6 \mathrm{~mm}$. l., $3 \mathrm{~mm}$. br., lateral slightly oblique. Petals 3-nerved, linear, obtuse, as long as the sepals, $1 \mathrm{~mm}$. br. Column short, thick, $3 \mathrm{~mm}$. 1.; clinandrium denticulate on margin. Capsule ellipsoidal, with a short and thick beak, $16-20 \mathrm{~mm} .1$, 8-9 mm. br.

15. E. ramosum Jacq. Enum. Pl. Carib. 29 (1760); without pseudobulbs; spike with few flowers; bracts ample, ellipticalovate, obtuse, sometimes acute, slightly keeled at apex, hooded, as long as, or scarcely longer than the ovary and enclosing it; leaves leathery, linear-ligulate, apex obliquely emarginate; lip on the lower side of the flower, slightly shorter than the sepals, leathery, with numerous nerves, undivided, ovate, cordate, acute, with two calli at base of disk which unite above and form a rib running to apex; column connate with lip nearly to apex.-Jacq. Sel. Stirp. Amer. 221, t. 132, Ed. pict. t. 202 ; Sw. Prodr. 120 \& Fl. Ind. Occ. 1505 ; Lindl. Fol. Orch. Epid. 76 ; Griseb. op. cit. 618 ; Cogn. in. Fl. Bras. iii. pt. 5, 172. (Pl. 15, f. 12.)

On trees and rocks; in fl. Nov.-NIarch; mountains, Swartz! Bancroft! Macfadyen! St. Ann, McNab! Portland Gap, Purdic! Bethabara, Wullschlaegel, 1054! March! mountains, J.P. 28; lowlands, 400-800 ft. J.P. 2012, Morris! MIt. Moses, 2500 ft. J.P. 526, Syme! Cinchona, Clute! Newcastle, Hart! Belle Vue, Port Royal Mts., Miss B. Gosset! Cinchona, 5000 ft.; Moody's Gap, 3000 ft.; Clydesdale, 4500 ft.; above Mabess River, $3500 \mathrm{ft}$.; Newhaven Gap to Vinegar Hill, $4000 \mathrm{ft}$; Harris! Fl. Jam. 7535, 7799, 7881, 9897, 10,089.-Cuba, Hispaniola, Porto Rico, Guadeloupe, Dominica, Martinique, St. Lucia, St. Vincent, Grenada, Trinidad, Mexico, Guatemala, Costa Rica, Ecuador, Peru, Venezuela, B. Guiana, Surinam, French Guiana, Brazil.

Plant 1-3 ft. long. Stems to $1 \mathrm{~m} .1 .$, much branched. Leaves sheath- 
ing at the base, 2-9 cm. 1., 3-13 mm. br. Spite terminal on the branches, shorter than the leaves, or as long, laxly few- or several-flowered, $2-3 \mathrm{~cm}$. 1 . Bracts becoming scarious and white, 9-11 mm. 1. Ovary with a cavity above, within its walls, below the lip. Flowers greenish, perianth about $\frac{1}{4}$ in. 1. Sepals 5-9-nerved, lateral ovate-oblong, slightly oblique at base, keeled outside near apex, point of keel 3-denticulate, acute, $8 \mathrm{~mm}$. 1., $2.75 \mathrm{~mm}$. br.; median oblong, slightly keeled outside at apex, keel ending in a small tooth, $8 \mathrm{~mm}$. 1., 2.25 $\mathrm{mm}$. br. Petals 5-nerved, linear, somewhat acute or obtuse, shorter than the sepals, $7-8 \mathrm{~mm}$. $1 ., 1 \mathrm{~mm}$. br. Lip $3.5 \mathrm{~mm}$. br. Column 2-2.5 mm. 1., short, thick, thicker upwards; clinandrium, lateral lobes very broadly ovate, median lobe very short, 2-denticulate. Capsule ellipsoidal-ovoid, with a short, thick beak, 10-12 mm. 1., 6-8 mm. br.

16. E. strobiliferum Reichb. $f$. in Nederl. Kruidl. Arch. iv. 333 (1859) ; without pseudobulbs; spike with few flowers ; bracts ample, somewhat leathery, scarious, strongly nerved, plicatehooded, broadly ovate, obtuse, keeled, clasping, nearly as long as the flowers, somewhat densely imbricate in two ranks; leaves in two ranks, fleshy-leathery, small, shortly ligulate-oblong or linearlanceolate, at the apex obtuse, or subtruncate or sometimes obliquely emarginate, at the base half-clasping and shortly sheathing; lip on the upper side of the flower, leathery, about as long as the sepals, undivided, broadly ovate-cordate, acute, subacuminate, dise with several, somewhat prominent nerves ; column connate with lip nearly to apex.-Griseb. op. cit. 618 ; Cogn. op. cit. $174, t .25, f .2$; Ames Orch. $i .37, t .10$.

On trees; in fl. towards end of year, in fr. Jan.; Swartz! Masson! New Carmel, Wullschlaegel, 1085! Wag Water and Ginger Rivers, J.P. 2014 (in part), Syme! Belvedere, Hanover; Ramble, St. Ann ; Fawcett ! Harris! Fl. Jam. 7245a, 7519, 7543.-Florida, Cuba, St. Cruz, Saba, Dominica, Martinique, St. Vincent, Grenada, Trinidad, Venezuela, B. Guiana, French Guiana, Dutch Guiana, Brazil.

Plant 1-6 in. high. Stems clustered, branching, generally leafy to the base, $3-15 \mathrm{~cm}$. 1. Leaves, blade 1.5-2 cm. l., 4-6 mm. br.; sheaths 5-9 $\mathrm{mm}$. 1. Spike very short, 5-8 $\mathrm{mm}$. 1., shorter than the leaves, with 3-6 flowers. Bracts 5-6 $\mathrm{mm}$. 1. Ovary with a cavity below the lip. Flowers, perianth about $\frac{1}{6}$ in. 1 . Sepals with seven or eight prominent nerves, lateral oblong-lanceolate, acute, about $4 \mathrm{~mm}$. 1., $1.75 \mathrm{~mm}$. br.; median oblong, tapering slightly to a somewhat blunt point, as long as the lateral, $1 \cdot 25 \mathrm{~mm}$. br. Petals with three to five prominent nerves, linear, a little shorter than the sepals, $5 \mathrm{~mm}$. br. Column $1.5 \mathrm{~mm}$. 1., short, thick, thicker about the middle; clinandrium with two teeth on each side, one long and one short, and two short teeth behind. Capsule ellipsoidal, with short thick beak, $8-9 \mathrm{~mm}$. 1., 5-6 mm. br.

17. E. repens Cogn. in Fedde Repert. vii. 122 (1909); without pseudobulbs ; bracts two or three, with a solitary flower, ample, triangular-ovate to roundish, obtuse, slightly keeled, overlapping, clasping, as long as or longer than ovary and enclosing it; leaves somewhat rigid, small, narrowly ligulate-oblong, apex rounded and obliquely and slightly emarginate, at the base roundish-subcordate and shortly sheathing; lip erect on the 
upper side of the flower, slightly shorter thim the sepuls, leathery, with numeroms norves prominent on the outside and sometimes slightly on the inside, undivided, ovate, cordate, acute; column commate with lip nearly to apex.

On trees and rocks; in fl. Dec.-Feb.; Mucfudyen! Neweastle, J.P. 2014 (in part), Morris! near Woodeutters' Gap; near Neweastle, $4000 \mathrm{ft}$; ridge from Newhaven Gap to Vincgar Hill, 4000 ft.; Ilarrs! Morse's Gap, G. Nichols! Fl. Jam. 7561, 10,086.-Hispaniola.

Plant $1-1 \frac{1}{2} \mathrm{ft}$. long or longer. Stems long, crecping, slender, much and irregularly branched, with many leaves even to the base, 3-4 din. 1 . or longer. Leares, blade $1 \cdot 5-2 \mathrm{~cm}$. 1., 4-6 mm. br.; sheaths $6-8 \mathrm{~mm}$. 1 . Bracts 5-6 mm. 1. Ovary with a cavity above, within its walls, bclow the lip. Flowers terminal at the apex of branches, solitary ; perianth scarcely $\frac{1}{3}$ in. l. Sepals leathery, with seven to nine prominent ucrves, ligulatelanceolate, shortly acuminate, 7-8 mm. l., $2 \mathrm{~mm}$. br., median sepal slightly longer. Petals 3-5-nerved, narrowly linear, very acute, a little shorter than latcral sepals, about $.7 \mathrm{~mm}$. br. Column $2.5 \mathrm{~mm}$. 1., very short, thick, thicker upwards; clinandrium 3-lobed, lateral lobes triangular, acute, longer than median. Capsule erect, ovoid-subglobose, with short beak, 11-12 mm. l., 7-8 mm. br.

18. E. imbricatum Lindl. Gen. \& Sp. Orch. 110 (1831); without pseudobulbs ; bracts ample, spathe-like, leathery, broadly ovate, obtuse, concealing the flower in bud, keeled above; leaves large, leathery, ligulate-oblong, obtuse ; lip undivided, leathery, ovate, obtuse, obsoletely apiculate, cordate, strongly 1-ribbed; column connate with lip to apex.-Lindl. Fol. Orch. Epid. 78 ; Cogn. in Fl. Bras. iii. pt. 5, 170, t. 14, f. 2. (Pl. 15, f. 9.)

On trees; in fl. and fr. Nov.-April; Macfadyen! below Morse's Gap, J.P. 244, Morris! near Nabess River, 4000 ft ; near Vinegar Hill, Portland, $3500 \mathrm{ft}$; Catherine Peak, 5000 ft.; Thomson's Gap; Harris! Fl. Jam. 6540, 7577, 7807, 7867, 9092.-Brazil, Costa Rica.

Plant $15 \mathrm{in}$. high and more. Stem $40 \mathrm{~cm}$. l. and more, long, stout, branching, covered even to the apex with truncate, adpressed, sheathing bases, from which in the lower part the blades have dropped, succeeded near the base by simple sheaths. Leaves, blade 9-18 cm. 1., 1-2 cm. br. Spikes several-flowered, much shorter than the leaves. Bracts 2.1-2.5 cm. 1. Flowers white, sessile, about $\frac{1}{2}$ in. l. Sepals $12-14 \mathrm{~mm}$. l., $3.5 \mathrm{~mm}$. br., leathery, equal, narrowly oblong, subacute to acute, keeled above. Petals 11-13 mm. 1., 2-2.5 mm. br., a little shorter and much narrower than the sepals, linear-lanceolate to oblanceolate, acute. Lip a little shorter than the petals, $8-10 \mathrm{~mm}$. l., $6 \mathrm{~mm}$. br. Column 4-5 mm. l., short, thick; clinandrium obtusely auricled. Capsule $2.5 \mathrm{~cm} .1 ., 12 \mathrm{~mm}$. br., ovoid, constricted at apex, slightly 6-ribbed.

19. E. bifarium Sw. in Nov. Act. Upsal. vi. 68 (1799); without pseudobulbs ; spike long, 2-edged, many-flowered ; bracts ample, spathe-like, compressed, keeled, triangular, sheathing, acute, about as long as the ovary; flowers pale greenish shaded with reddish-brown; petals setaceous, white ; lip 3-lobed ; column connate with lip nearly to apex.-Sw. Fl. Ind. Occ. 1509 \& Ic. ined. t. 42 ; Lindl. Fol. Orch. Elid. 78; Griseb. op. cit. 618. 
E. anceps $S w$. Prodr. 121 (1788) (non $J a c q$.$) . (Pl. 15, f. 6.) Type$ in Herb. Mus. Brit.

On trees; in fl. Nov.-April ; mountains, Swartz! Macfadyen! March! J.P. 150, Morris! Clydesdale, $4000 \mathrm{ft}$; Cedar Hurst, $2000 \mathrm{ft}$; ; Wallenford, $3000 \mathrm{ft}$.; ridge below Vinegar Hill, 3800 ft.; Harris! Fl. Jam. 7558, 7753, $9024,10,095$ a.

Plant 6-13 in. high. Stem 5-15 cm. 1., leafy, covered with leaf-sheaths, sometimes decayed below, branching below, throwing out very long slender roots. Leaves fleshy, linear-lanceolate, cordate, clasping, somewhat falcate, 3-6 cm. 1., 4-8 mm. br. Spikes much longer than the leaves, $10-25 \mathrm{~cm} .1$. Bracts 5-10 mm. l. Flowers, perianth about $\frac{1}{4}$ in. 1. Sepals 3-nerved, oblong-elliptical, tapering to the keeled apex, lateral slightly falcate, 6-7 mm. 1., $3 \mathrm{~mm}$. br.; median as long, but a little narrower. Petals $5 \mathrm{~mm}$. l. Lip 5-6 mm. br., greenish-yellow, lobes somewhat equal, broader than long, lateral somewhat roundish, with undulate margin, median 2-lobed, apiculate; disk with two calli at base. Column short, thick, laterally compressed, thicker upwards, $3-4 \mathrm{~mm}$. 1.; clinandrium, margin undulate. Capsule spindle-shaped, long-tapering at base and apex.

20. E. polybulbon Sw. Prodr. 124 (1788); growing in masses with long creeping rhizome bearing many pseudobulbs each with two leaves and one white or pale yellow flower; lip undivided; column free.-Siv. Fl. Ind. Occ. 1491 ; Hook. Exot. Fl. t. 112 ; Bot. Mag. t. 4067. Dinema polybulbon Lindl. Gen. \& Sp. Orch. 111 (1831). Type in Herb. Mus. Brit.

On trees and rocks; in fl. Oct.-Feb.; mountains, Swartz! Macfadyen! Manchester, Purdie! Bethabara, Wullschlaegel, 1083! March! Mt. Moses, $3000 \mathrm{ft}$. J.P. 2060, Syme! Bath, Fawcett! Silver Hill, $4000 \mathrm{ft}$.; Lancaster, $2500 \mathrm{ft}$. ; Holly Mount, Mt. Diabolo, $2400 \mathrm{ft}$. ; above Mabess River, $3000 \mathrm{ft}$.; below Vinegar Hill, $3800 \mathrm{ft}$; near Christiana, $3000 \mathrm{ft}$; Harris! Fl. Jam. 7538, 7838, 8870, 9796, 10,098, 10,400, 10,401; near Belle Vue, Port Royal Mts., Miss B. Gosset!-Cuba, Mexico, Guatemala.

Plant 2 or 3 in. high. Rhizome jointed, covered with remains of decayed sheaths. Pseudobulb ellipsoidal to cylindrical, with a short joint at apex, rising directly from the rhizome or on branches of it, $1 \cdot 5-2 \cdot 5 \mathrm{~cm}$. l., covered at first with two scarious sheaths which soon decay. Leaves linear-oblong to oblong-elliptical, obtuse, obliquely emarginate, with numerous nerves, half-clasping at base, 2-5 cm. 1., 7-14 mm. br. Ovary cylindrical, with stalk about $3 \mathrm{~cm} .1$. ; stalk with 3 bracts. Bracts sheathing below, shortly acuminate, about $1 \mathrm{~cm} . \mathrm{l}$. Flowers, perianth a little more than $\frac{1}{2}$ in. l. Sepals 5-nerved, lanceolate-linear, very acute, spreading, 15-17 mm. 1., 2.5 mm. br. Petals like the sepals but narrower. Lip white, subroundish-cordate, clawed, as long as the sepals, $10-11 \mathrm{~mm}$. br. Column short, 2-angled and with two projecting teeth in front, and two long, subulate, erect teeth, one on each side, $4-5 \mathrm{~mm}$. 1 . Capsule cylindrical, narrow.

21. E. Ottonis Peichb.f. in Hamburg. Gartenz. xiv. 213 (1858); pseudobulbs with one long narrow leaf and flowering stalk nearly as long as leaf; flowers cream-coloured; lip undivided, somewhat similar to sepals and petals; column quite free.-Griseb. op. cit. 613 ; Cogn. in Symb. Ant. iv. 173. (Pl. 15, f. 8.)

On trees; in fl. and fr. Jan.; Belvedere, Hanover, 500 ft., Harris! Fl. Jam. 7540, 7678. - Cuba, Porto Rico, Trinidad, Venezuela. 
Plant 6-8 in. high. Pseudobulbs on short many-jointed clustered branches of a creeping rhizome, covered with three or four scarious sheaths, of which one is longer than pseudobulb, ellipsoidal, $2-2.5 \mathrm{~cm} .1$. Leaves linear-ligulate, obtuse, mucronatc, 9-15 cm. $1 ., 6-9 \mathrm{~mm}$. br. Peduncle many-jointed, covored with bracts, $7-10 \mathrm{~cm}$. l. Bracts, sterile and floral similar, folded together and compressed, linear-lanccolate, acuminate, 1.2 $15 \mathrm{~mm}$. 1. Ovary smooth, 8-10 mm. 1. I'edicel $2 \mathrm{~mm}$. 1. Flowers, perianth about $\frac{1}{3}$ in. 1 . Sepals 5 -nerved, lanceolate, shortly acuminate, 8-9 mm. 1., 2-3 mm. br., lateral slightly falcato. I'etals oblanceolato, acute, 3-nerved, 6-6.5 mm. 1., 2-2.5 mm. br. Lip, margin undulate, nearly as long as petals, $5 \cdot 5-6 \mathrm{~mm}$. 1., $2 \mathrm{~mm}$. br. Column $4 \mathrm{~mm}$. l., thickor upwards, slightly winged at tho sides; clinandrium 5 -toothed; anthers 3 , the lateral anthers apparently somewhat aborted, obtuse at apex and sides. Capsule narrowly ellipsoidal, with three shallow keels, very shortly beaked, 14-15 mm. 1., $5 \mathrm{~mm}$. br.

2.2. E. subaquilum Lindl. in Bot.Reg. xxxii.sub. t. 64 (1846); pseudobulbs with one leaf and panicle longer than, or about equal to, leaf ; lip undivided, broadly ovate abovo claw ; column almost free.-Lindl. Fol. Orch. Epid. 5. E. Harrisii Fawc. in Syml. Ant. i. 291 (1899).

On trees; in fl. Jan., Feb., in fr. March; near Bath, J.P. 4, Morris ! Bridge Hill, above Gordon Town, 1500 ft., Harris! Fl. Jam. 5583, 7645, 7858, 10,422.-Mexico or Guatemala.

Plant 8-12 in. high. Pseudobulbs densely clustered, with three or four scarious sheaths, soon splitting into ribbons, of which two are longer than the pseudobulb, ovoid, $2-2.5 \mathrm{~cm}$. 1., about $1 \mathrm{~cm}$. br. Leaves linearligulate, obtuse, obliquely emarginate, 8-19 cm. 1., 3.5-6 mm. br. Scape slender, paniculate, $16-27 \mathrm{~cm}$. 1. Bracts sterile, small, few, distant, sheathing, adpressed, triangular, acute or obtuse, 4-6 $\mathrm{mm}$. 1.; floral smaller, spreading, subulate. Ovary about as long as the pedicel, about $4 \mathrm{~mm}$. 1. Flowers greenish-yellow striped with reddish-brown, perianth $\frac{1}{4}-\frac{1}{3}$ in. 1. Sepals 3-nerved, linear-lanceolate, somewhat acute, 8-9 mm. 1., $2 \mathrm{~mm}$. br., median slightly narrower. Petals 1-nerved, linear, 7-8 mm. l., less than $1 \mathrm{~mm}$. br. Lip embracing the column, disk with three calli, as long as the sepals. Column 4-5 mm. 1., slightly thicker above, 2-edged; clinandrium with two short rounded lobes. Capsule ellipsoidal, 10-11 mm. 1., 5-6 mm. br.

23. E. bletioides Griseb. Fl. Br. W. Ind. 615 (1864); pseudobulbs with two (?) leaves and a scape longer than leaf; lip undivided, concave, elliptical, pointed, with two linear crests below the middle, claw very short; column free. Kew.)!

Hanover, Purdie! near Browns Town, Miss T. M. Barrett (in Herb.

Plant 1-1 $\frac{1}{2} \mathrm{ft}$. high. Pseudobulbs ovate-lanceolate, $3 \cdot 5 \mathrm{~cm} .1$. Leaves fleshy, oblong, apex rounded, $12-15 \mathrm{~cm}$. l., about $2 \cdot 5 \mathrm{~cm}$. br. Scape with flowers distant in a spreading panicle, or racemose. Bracts, sterile distant, short, adpressed-sheathing, blunt, about $1 \mathrm{~cm}$. 1.; floral short, broadly clasping, acute, much shorter than the pedicel, $3 \mathrm{~mm}$. l. or less. Flowers, perianth $\frac{1}{2}$ in. l. Sepals oblong-lanceolate, acute, $12-13 \mathrm{~mm}$. 1 . Petals oblong to slightly oblanceolate, acute, as long as sepals. Column obovate, sharply 3-dentate at the broad summit, $7 \mathrm{~mm}$. 1. Capsule (immature) spindle-shaped, keeled, $2.5 \mathrm{~cm} .1$. 
24. E. parvilobum Fawc. \& Rendle in Journ. Bot. xlvii. 123 (1909); pseudobulbs with one leaf and panicle much longer than leaf ; lip 3-lobed, lateral lobes obovate, somewhat roundish, middle lobe small, semicircular, minutely apiculate, disk with three thick raised lines and near the base a large callus ; column quite free. $-(\mathrm{Pl} .16$, f. $5-7$.

On trees; in fl. May; Dolphin Head, 1600 ft., Harris! Fl. Jam. 10,439.

Plant $2 \mathrm{ft}$. high. Pseudobulbs $3-5 \mathrm{~cm}$. 1., lanceolate-ovate, covered by two scarious sheaths. Leaf linear-ligulate, obtuse, conduplicate at base, with many prominent nerves, $22 \mathrm{~cm} .1 ., 1 \cdot 5-2 \mathrm{~cm}$. br. Panicle laxly fewflowered. Bracts, sterile sheathing, small, obtuse, 5-10 mm. 1.; floral deltoid, half-clasping, shortly acute, $1 \cdot 5-2 \mathrm{~mm}$. 1. Pedicels $7 \mathrm{~mm}$. 1 . Sepals 5-nerved, oval, obtuse; median $10 \mathrm{~mm} .1 ., 4 \mathrm{~mm}$. br.; lateral $8 \mathrm{~mm}$. l., $4 \mathrm{~mm}$. br. Petals reticulate-3-nerved, oblanceolate-oblong, $8 \mathrm{~mm}$. 1., $2.5 \mathrm{~mm}$. br. Lip $8 \mathrm{~mm}$. 1., $10 \mathrm{~mm}$. br. Column small, $3 \mathrm{~mm}$. 1., wider at apex, winged; clinandrium with minute teeth.

25. E. monticolum Fawc. \& Rendle op. cit. 124 ; pseudobulbs with one leaf or sometimes two, and scape as long as, or shorter than, the leaf : ovary rugose; lip shortly and broadly clawed, deeply 3-lobed, lateral lobes oblong, somewhat obtuse, median lobe much larger, roundish-rhomboidal, broadly clawed, somewhat apiculate at the apex, margin slightly curled below, veins raised, branching, diverging, disk with two thick calli; column quite free. (Pl. 16, f. 1-4.)

In fl. Feb.; Holly Mount, MIt. Diabolo, Harris! Fl. Jam. 10,467.

Plant 7-9 in. high. Pseudobulbs $1 \cdot 5-2 \mathrm{~cm}$. 1., ovoid, covered by scarious sheaths. Leaves linear-ligulate, obtuse, conduplicate at the base, with many nerves scarcely prominent, 12-22 cm. 1., 7-10 mm. br. Scape laxly few-flowered, rugulose. Bracts, sterile sheathing, small, somewhat acute, $8 \mathrm{~mm}$. 1.; floral half-clasping, somewhat acute, $2-3 \mathrm{~mm}$. 1 . Ovary and pedicel covered with minute warts, $1 \cdot 5-1 \cdot 7 \mathrm{~cm}$. 1 . (apparently fertilised). Pedicels $1 \mathrm{~cm}$. 1. Sepals reticulate-6-7-nerved, lanceolate-oblong, somewhat acute, somewhat thick, dark green, $1 \mathrm{~cm} .1 ., 3 \mathrm{~mm}$. br. Petals reticulate-3-4-nerved, oblanceolate-oval, obtuse, green, $9 \mathrm{~mm}$. $1 ., 3 \mathrm{~mm}$. br. Lip brownish-yellow, $9 \mathrm{~mm}$. l. ; median lobe, $6 \mathrm{~mm}$. 1., 5-6 mm. br.; veins raised. Column $5 \mathrm{~mm}$. l., stout, winged, at the apex auriculate.

26. E. belvederense Fawc. \& Rendle op. cit. 123; pseudobulbs with two leaves and panicle much longer than leaf; ovary smooth; lip reticulate-nerved, the three median nerves thick, prominent, especially on the disk, 3-lobed, lateral lobes short, obtusely triangular, much smaller than the median, median deltoid or triangular-ovate, shortly apiculate; column quite free. (Pl. 16, f. 8-10.)

On trees; in fr. Dec.-Jan.; Belvedere, Hanover, 500 ft.; Lancaster, 2500 ft.; Harris! Fl. Jam. 7541, 7620; between IIandeville and Black River, J.P. 532, Syme!

Plant $1 \frac{1}{2} \mathrm{ft}$. high. Pseudobulbs about $4 \mathrm{~cm}$. 1., about $1 \mathrm{~cm}$. br., lanceolate-ovoid, covered by scarious sheaths. Leaves linear-ligulate, obtuse, conduplicate at base, with many prominent nerves, $16-18 \mathrm{~cm} .1 ., 15-18$ mm. br. Panicle laxly few-flowered. Bracts, sterile sheathing, small, 
obtuse, 7-8 mm. 1.; floral deltoid, half-clasping, shortly acute, $2-3 \mathrm{~mm}$. 1 . Pedicels $1 \mathrm{~cm} .1$. Sepals 5-7-nerved, oblong-lanceolate, sulacute, $1 \cdot 3 \mathrm{~cm} .1$; lateral slightly keoled below the apex, $3.5 \mathrm{~mm}$. br.; median $3 \mathrm{~mm}$. br. Petals reticulate-8-nerved, oblanceolate, $1.3 \mathrm{~cm}$. $1 ., 3 \mathrm{~mm}$. br. Lip $1 \cdot 2$ cm. 1., $9 \mathrm{~mm}$. br.; lateral lobe $2 \mathrm{~mm}$. 1. Column stout, flattish anteriorly, $7.5 \mathrm{~mm}$. 1. (including anther); clinandrium 3-toothed, auriculate anteriorly. Capsule spindle-shaped, $3 \mathrm{~cm} .1 ., 1 \mathrm{~cm}$. br.

27. E. angustifolium Sw. Prodr. 123 (17\&8); pseurlobulbs with one grass-like leaf, and panicle much longer than leaf; lip 3-lobed, lobes subequal, lateral half-round, middle ovate; column connate with lip for one-third of its length.-Sw. Fl. Inrl. Occ. 1512 ; Griseb. op. cit. 613 .

On trees and rocks; Dolphin Head, Purdie! Dolphin Head, $1600 \mathrm{ft}$., Harris! Fl. Jam. 10,440.

Plant 8 in. to $1 \mathrm{ft}$. high. Pseudobulbs clustered, $1.5 \mathrm{~cm}$. 1., 6-7 mm. br., ovoid, acuminate. Leaf $12-22 \mathrm{~cm} .1 ., 2 \mathrm{~mm}$. br., linear, exceeded by the scape. Scape about $3 \mathrm{dm}$. l., filiform, naked. Bracts $2 \cdot 3-1 \mathrm{~mm}$. 1., minute, pointed. Raceme lax, branched at the base. Pedicels $4 \mathrm{~mm}$. l., as long as the ovary. Flowers, perianth less than $\frac{1}{4}$ in. 1. Sepals about $5 \mathrm{~mm}$. 1., about $1.5 \mathrm{~mm}$. br., oblong-lanceolate, 3-nerved. Petals about as long as the sepals, linear-lanceolate, 1-nerved. Lip about as long as the sepals. Column nearly as long as the lip, auricled below the clinandrium.

28. E. brachyglossum Cogn. in Fedde Repert. vii. 121 (1909); stem without pseudobulb, with one leaf at apex and an erect slender peduncle twice as long as leaf with solitary flower; column shortly connate with lip above base. 7783.

On trees; in fl. Sept.; Green Hill Wood, 4000 ft., Harris ! Fl. Jam.

Plant 3-12 in. high, with brown spots on sheaths, bracts and peduncle. Stem 4-7 cm. 1., 1.5-2 mm. br., with sheaths below. Leaf sessile, somewhat leathery, linear-ligulate, tapering downwards shortly above the base, apex somewhat obtuse and obliquely emarginate, with numerous nerves prominent beneath, especially the middle nerve, 6-10 cm. 1 ., 6-9 mm. br. Sheaths three, scarious, free portion short, triangular, obtuse, uppermost 2-3 cm. l., lowest $1-1 \cdot 3 \mathrm{~cm}$. l. Bracts $3-5$, closely sheathing, free portion short, triangular, obtuse; floral bract shortly spathaceous, shorter than the ovary. Pedicels about $5 \mathrm{~mm}$. 1. Flowers orange-scarlet, $\frac{3}{4}-1$ in. l., solitary, erect, thinly membranous. Ovary cylindrical, smooth, with pedicel nearly $3 \mathrm{~cm}$. 1. Sepals 7-nerved; lateral oblong-elliptical, apex somewhat obtuse and conduplicate, margin slightly undulate, $1 \cdot 8-2 \cdot 3 \mathrm{~cm}$. $1 ., 7-8 \mathrm{~mm}$. br. ; median elliptical, apex rounded, $1 \cdot 7-2 \mathrm{~cm} .1$, 8-9 mm. br. Petals a little oblique, 5-6-nerved, elliptical, tapering to base, apex rounded, shorter than the sepals, $1.9 \mathrm{~cm}$. 1., $9 \mathrm{~mm}$. br. Lip very short, not half as long as petals, $9 \mathrm{~mm}$. $1 ., 7 \mathrm{~mm}$. br., embracing column, 3-lobed, lateral lobes rounded, median lobe somewhat smaller than lateral, indistınctly 3-lobed; disk with two broad longitudinal lamellæ and warty protuberances above them. Column as long as the lip, broader above than below, winged; clinandrium with two large auricles, apex toothed. Capsule (not ripe) narrowly spindle-shaped, 3-angled, 3-keeled, keels 2-edged, $2 \cdot 4 \mathrm{~cm}$. 1 .

29. E. serpulatum Sw. Prodr. 121 (1788); stem without pseudobulbs, with one leaf at apex and a spike shorter than leaf; 
column shortly connate with lip above base.-Sw. Ic. ined. t. 43 ; Griseb. op. cit. 615. Cymbidium serrulatum Sw. in Nov. Act. Upsal. vi. 72 (1799) \& Fl. Ind. Occ. 1465. (Pl. 15, f. 4.) Type in Herb. Mus. Brit.

On trees; in fl. and fr. throughout year; summit of Blue Mountains, Swartz! Macfadyen! Blue Mt. Peak, Purdie! Blue Mountains, 60007300 ft., J.P. 20, Morris! Jenman! near Cinchona, 5000 ft. ; Morse's Gap, 5000 ft.; Sir John Peak, 6000 ft.; Blue IIt. Peak, 7420 ft. ; Harris! F'. Jam. 7860, 10,452; summit of Sir John's Peak, Mrs. E. G. Britton, 3878!

Plant 1-4 in. high. Stem $\cdot 5-3 \mathrm{~cm} .1$., covered with sheaths. Leaf linear, tapering below, sessile, apex acute, serrulate, 2-7 cm. 1., 3-5 mm. br., turning blackish in drying. Sheaths one longer than stem, somewhat spathaceous above, and one or two smaller and scarious below. Bracts ovate-triangular, acute, half-clasping, 3-4 mm. 1. Flowers greenish, sometimes yellowish above, changing to reddish-yellow, sessile or subsessile, perianth $\frac{1}{6}$ in. l. Ovary thicker above. Sepals fleshy, lanceolate, obtuse, keeled, $5 \mathrm{~mm}$. l. Petals 3 -nerved, narrowly oblong, obtuse, $4 \mathrm{~mm}$. l. Lip indistinctly 3 -lobed, lateral lobes rounded, median lobe triangular, disk with three prominent nerves, $4 \mathrm{~mm}$. $1 ., 3 \mathrm{~mm}$. br. Column very short. Capsule ellipsoidal, 10-11 mm. 1.

30. E. globosum Jacq. Enum. Pl. Carib. 29 (1760); stem short, simple, without pseudobulbs, with a few linear leaves, and a few minute flowers (rarely one) with very short stalks clustered at apex; column free.-Jacq. Sel. Stirp. Amer. 222, t. 133, f. 1, Ed. pict. t. 203; Sw. Prodr. 121 ; Griseb. op. cit. 619 ; Reichb. f. in Saund. Ref. Bot. ii. t. 140 ; Cogn. in Fl. Bras. iii. pt. 5, 43, t. 9, f. 1 \& in Symb. Ant. iv. 173. Cymbidium globosum Sw. in Nov. Act. Upsal. vi. 72 (1799) \& Fl. Ind. Occ. 1467. Isochilus globosum Lindl. Gen. \& Sp. Orch. 112 (1831).

On trees; in fl. and fr. throughout year; Macfadyen! Imray; Purdie! Moneague, Prior! New Carmel, Wullschlaegel, 1092! Wag Water River, J.P. 2333, Syme! Troy, 1600 ft., Harris! Fl. Jam. 10,445, 10,486.Cuba, Porto Rico, Saba, St. Eustatius, St. Kitts, Guadeloupe, Dominica, Martinique, St. Vincent, Grenada, Trinidad, Nicaragua, B. Honduras, Mexico, B. Guiana, Brazil.

Plant 1-6 in. high. Stems 2.5-14 cm. 1., numerous, clustered, slender, many-juinted, covered with sheaths. Leaves short, fleshy, rigid, linear, semiterete, flattened when dried, obtuse, jointed to the sheath, 1-2 cm. 1., 1.5-2 mm. br. Peduncles one-flowered, 1-2 mm. 1. Flowers yellow, red-variegated, perianth $\frac{1}{8}$ in. 1 . Bracts sheathing at the base, 1-1.5 mm. 1. Sepals fleshy, elliptical-ovate, obtusely acute, $3 \mathrm{~mm}$. 1., median slightly broader, $2 \mathrm{~mm}$. br., lateral very shortly connate at base, $1.5 \mathrm{~mm}$. br. Petals yellow, fleshy, ovate-subrhomboid, obtusely angled, apex somewhat acute, a little shorter than the sepals. Lip fleshy, slightly shorter than the sepals, undivided, obovate-rhomboid, apex obtuse, slightly gibbous. Column short, thick, $1 \frac{1}{2} \mathrm{~mm}$. 1. Capsule nodding, ellipsoidalovoid, apex shortly beaked, $4 \mathrm{~mm}$. 1., $3 \mathrm{~mm}$. br.

31. E. teretifolium $S w$. Prodr. 121 (1788); stem long, simple, without pseudobulbs, with a few linear fleshy leaves, and one flower at apex ; column connate with lip about half its length.Sw. Ic. ined. t. 44 ; Griseb. op. cit. 619 . Cymbidium teretifolium 
Sw. in Nor. Act. Upsal. vi. 72 (1799) \& Fl. Ind. Occ. 1463. Isochilus teretifolium Limal. Gen. \& $S_{p}$. Orch. 112 (1831). Type in Herb. Mus. Brit.

On trees and rocks; in fl. Aug., in fr. Oct., Nov.; mountains, Swartz! J.P. 2054, Morris ! near Chester Vale, Watt! Cinchona, $5000 \mathrm{ft}$; MIt. Moses, 3000 ft.; Greenwich, 4500 ft.; Harris! Fl. Jam. 7627, 7778, 10,142.-Cuba.

Plant 6-11 in. high. Stems $15-28 \mathrm{~cm}$. 1., numerous, clustered, somewhat robust, many-jointed, covered with sheaths below, naked above and somewhat compressed. Leaves rigid, semiterete, obtuse, jointed to the sheath, $2-4.5 \mathrm{~cm}$. l., on lower half or two-thirds of stem, one leaf with very much abbreviated sheath at apex. Peduncle solitary, terminal, shori, one-flowered, $7 \mathrm{~mm}$. l. Bracts at base of peduncle, four spathaceous bracts outside and two sheathing bracts inside, about $8 \mathrm{~mm} .1$. Flower yellowishgreen, perianth about $\frac{1}{2}$ in. 1 . Sepals $12 \mathrm{~mm}$. $1 ., 1.6 \mathrm{~mm}$. br., fleshy, linear, tapering towards the thickened obtusely acute apex, somewhat convex. Petals half as long as sepals, 6-7 mm.1., 1.5 mm. br., stalked, elliptical, thickened at the rounded apex, 3-nerved, with the median nerve forming a keel, green. Lip shorter than sepals, from junction with column $8 \mathrm{~mm}$. l., about $2 \mathrm{~mm}$. br., clawed, lower half of limb broadening upwards, concave, disk 3-nerved with a median keel at base, above 3-edged and thickened. Column shorter than petals, $5 \mathrm{~mm}$. 1., 2-winged at apex. Capsule ellipsoidal-spindle-shaped.

\section{BROUGHTONIA R. Br.}

Epiphytic herbs, with ovoid or globose pseudobulbs, which are covered with a few sheaths, and have one or two leaves at the apex. Leaves leathery or fleshy, oblong or elongate. Peduncles terminal, with adpressed sheaths. Raceme lax, simple or sparingly branched. Flowers medium-sized or rather large, shortly stalked. Bracts small, scale-like. Sepals equal, free, somewhat spreading. Petals larger than the sepals. Lip sessile at the base of the column, free from it, erect, broad, embracing the column. Spur adnate to ovary, long, slender. Column several times shorter than the sepals, erect, broadly 2-winged; clinandrium with short teeth. Anther terminal, opercular, incumbent, convex, 4-celled ; pollinia 4, waxy, in two pairs, ovate, equal, compressed from the side, connected by a granular-viscous appendage. Capsule ovoid, beaked with the neck of the ovary.

Species 2, natives of the West Indies.

Flowers crimson, $\frac{1}{2}$-nearly 1 inch $1 . . . . . . .1$. B. sanguinea.

Flowers lilac, 1-1 $1 \frac{1}{4}$ inch l. ................. 2. B. domingensis.

1. B. sanguinea R. Br. in Ait. Hort. Kew. ed. 2, v. 217 (1813); flowers crimson, $\frac{1}{2}$ to nearly $1 \mathrm{in.}$. .; lip cordate at base, glabrous on disk.-Lindl. Gen. \& Sp. Orch. 118; Hook. in Bot. Mag. t. 30 T6. B. coccinea Hook. in Bot. Mag. t. 3536 (1836). Viscum radice bulbosa minus dc. Sloane Cat. 119 \& Hist. i. 250, t. 121, f. 2. Epidendrum sanguineum Sw. Prodr. 124 (1788). 
E. nodosum var. $\beta$ L. Sp. Pl. 953 (1753). E. cochleatum L. Sp. Pl. ed. 2, 1351 (in part) (1763). Dendrobium sanguineum Sw in Nov. Act. Upsal. vi. 82 (1799) \& Fl. Ind. Occ. 1529 (Pl. 14, f. 10-14.) Type in Herb. Mus. Brit.

On trees; in fl. Nov.-April; Spanish town and neighbourhood, Sloane Herb. iv. 118! Swartz! Bancroft! Distin! Westmoreland, Purdie! Lane! Wilson! Prior! Manchester, Tíullschlaegel, 1059! lowlands up to $500 \mathrm{ft}$., Morris! Syme! Content Road, Moore! NIanchester, Bassett-Key! Halberstadt, $2000 \mathrm{ft}$., Miss B. Gossett! near Tweedside, $2500 \mathrm{ft}$.; Great Goat Island, $100 \mathrm{ft}$; Harris! Fl. Jam. 9020, 9209._Cuba.

Plant 12-15 in. high. Pseudobulbs $2 \cdot 5-5 \mathrm{~cm}$. 1., 1.5-2.5 cm. br., varying in shape from somewhat globular to nearly cylindrical, clustered, with two leaves and peduncle much longer than leaves. Leaves leathery, oblong, somewhat acute, with numerous nerves visible when dry, 8-20 cm. 1., 1.5-4.5 cm. br. Sheaths 2 or $3,3-6 \mathrm{~cm}$. l. Peduncle long, 2-4 dm. l., sometimes branched with lax raceme (7-8 cm. l.) at apex. Bracts sterile, short, sheathing, adpressed, triangular, somewhat obtuse, few, distant, 5-6 cm. 1. ; floral minute. Pedicels 1-1.5 cm. l. Flowers 5-12. Sepals oblong-lanceolate, $1 \cdot 5-2 \cdot 4 \mathrm{~cm}$. 1., 4-5 mm. br., lateral broader and slightly falcate. Petals roundish-elliptical, tapering to base and to apex, which is either acute or obtuse, as long as sepals, $7 \mathrm{~mm}$. br. Lip nearly as long as sepals and petals, and broader than long, roundish, truncate, margin eroded, yellow at base with purplish reins. Column about $9 \mathrm{~mm}$. l., slightly curved, thicker and winged above.

2. B. domingensis Rolfe in Gard. Chron. v. 491 (1889); flowers rosy-lilac, $1-1 \frac{1}{4}$ in. 1 ; ; lip hairy on the central veins. B. lilacina Henfr. in Gard. Mag. Bot. iii. 201 (1851). Cattleya domingensis Lindl. Gen. \& Sp. Orch. 118 (1831). Laliopsis domingensis Lindl. in Paxt. Fl. Gard. iii. 155, t. 105 (1852, 53). (Pl. 14, f. 15-19.)

On trees; Westmoreland, Purdie! Edwards! Tomlinson!-Hispaniola.

Plant 1-2 ft. high. Pseudobulb 2-5 cm. 1., 1·5-2.5 cm. br., ellipsoidal to globose, with two leaves (rarely one), and peduncle much longer than leaves. Leaves leathery, oblong-ligulate, apex oblique, mucronate, with numerous nerves apparent only when dry, 6-20 cm. 1., 8-30 mm. br. Sheaths 2 or $3,2 \cdot 5-5 \mathrm{~cm}$. l. Peduncle very long, $3-5 \mathrm{dm}$. l., rarely branching, with a lax raceme $(5 \mathrm{~cm}$. l.) at apex. Bracts sterile, short, sheathing, adpressed, triangular, somewhat obtuse, very few, distant, $6 \mathrm{~mm}$. 1.; floral minute, triangular. Flowers 8-14. Sepals linear-lanceolate, somewhat acute, 2 to nearly $3 \mathrm{~cm}$. $1 ., 4-6 \mathrm{~mm}$. br. Petals elliptical tapering to base and to somewhat acute apex, about as long, or a little longer, and twice as broad as sepals. Lip a little longer than sepals, broadly emarginate, margin wavy, denticulate. Column about $7 \mathrm{~mm} .1$. Capsule (unripe) ellipsoidal, beaked.

\section{HORMIDIUM Lindl.}

Small epiphytic herbs, with small pseudobulbs crowded along the creeping rhizome, with two or three membranous sheaths and two leaves at the apex. Leaves small, shortly sheathing at base, and jointed with sheath. Flower's small, stalked, in a terminal cluster, the cluster sometimes reduced to a single flower. Sepals, all of equal length, suberect or at 
length spreading, the median free, the lateral broader, at the base adnate to the columnar cup. Petals similar to the median sepal, but narrower. Lip connate at the base with the column into a cup, the blade erect-spreading, 3-loberl. Column short, with the dilated margins connate with the lip into a cup; clinandrium short. Anther terminal, opercular, incumbent, with four parallel cells; pollinia 4, waxy, ovoid, distinct, without an appendage, on the dehiscence of the anther connected at the apex by a sparse viscid substance. Capsule ovoid or subglobose, not beaked, the ribs winged.

Species 7 , natives of tropical America from the West Indies and Mexico to Brazil.

Hormidium tripterum Cogn. in Fl. Bras. iii. pt. 5, 29, t. 8 , f. 2 (1898); Ames Orch. ii. 7, t. 20. Cœlogyne triptera Brongn. in Duperr. Voy. Coq. Bot. 201, t. 42 A (1829).-Epidendrum pygmeum Hook. in Bot. Mag. t. 3233 (1833) \& Journ. Bot. i. 49, t. 118 (1834); Lindl. Fol. Orch. Epid. 27 ; Griseb. op. cit. 615. Hormidium pygmæum Hemsl. in Gard. Chron. xix. 700 (1883). (Pl. 17, f. 1-5.)

On rocks covered with peat and moss in shade; in fl. and fr. Oct.-Feb.; Manchester, Purdie! Springfield, Wullschlaegel 1084! J.P. 2011, Syme! Morris! Clydesdale, Cradwick! Cascade, Watt! Bridge Hill, 1500 ft.; Chester Vale, $3000 \mathrm{ft}$. and $3500 \mathrm{ft}$; Harris! Fl. Jam. 7103, 7535, 7823. Mabess River, G. Nichols!-Cuba, Porto Rico, Trinidad, Mexico, B. Guiana, Brazil, Peru.

Plant rising 3 or 4 in. from the long, creeping rhizome. Pseudobulbs 2-3 cm. 1., ovoid-oblong or narrowly spindle-shaped. Leaves narrowly elliptical or oval, obtuse, minutely apiculate, shortly sheathing at the base and jointed with sheath, blade $3-5 \mathrm{~cm} .1 ., 1-1.5 \mathrm{~cm}$. br. Bracts somewhat longer than the pedicels, 6 or $7 \mathrm{~mm}$. l. Flowers yellowish-white, perianth $\frac{1}{5}$ in. 1. Sepals elliptical, acuminate, shallowly keeled, 5-6 $\mathrm{mm}$. 1., $2 \mathrm{~mm}$. br. ; lateral shortly connate at base. Petals linear, acuminate, 4-4.5 mm. 1. Lip extending about half as long as sepals, $4 \cdot 5-5 \mathrm{~mm}$. br., median lobe triangular, acuminate, much smaller than the roundish lateral lobes. Column half as long as lip. Capsule about $1.3 \mathrm{~cm} .1$.

\section{LÆLIA Lindl.}

Epiphytic herbs, with fleshy generally oblong pseudobulbs, not, however, present in the Jamaican species, which have a few sheaths, and at the apex one or two leaves. Leaves somewhat leathery, not plaited. Peduncles terminal, almost always only one-flowered, with a few sheaths at intervals. Bracts like the sheaths, the uppermost spathaceous. Sepals almost equal, free, spreading. Petals wider than the sepals. Lip erect at the base of the column; lateral lobes enclosing the column; the median lobe spreading. Column rather long, narrowly 2-winged; clinandrium crenulate. Anther attached to a posterior tooth, opercular, incumbent, convex, distinctly 2-celled, each cell 
imperfectly divided again into two cells by a longitudinal partition; pollinia 8, four in each cell, all compressed in the same direction, the ascending portion of the inferior pair connected with the descending portion of the upper pair in each cell by a linear granular appendage.

Species about 39, natives of the warmer parts of America from the West Indies and Mexico to Brazil.

L. monophylla N. E. Brown in Gard. Chron. xviii. 782 (1882); Hook. f. in Bot. Mag. t. 6683. Trigonidium monophyllum Griseb. Fl. Br. W. Ind. 629 (1864). Octadesmia monophylla Benth. in Benth. \& Hook. f. Gen. Pl. iii. 526 (1883). (Pl. 17, f. 6-12.)

On trees; in fl. Aug.-Nov.; Bancroft! Mt. Moses, J.P. 2405, Syme! Morris! Greenwich Woods, Fawcett! Tweedside; Green Hill Woods, 4000 ft. ; Harris! Fl. Jam. 7783, 7996.

Plant 4-8 (sometimes 12) in. high. Stem slender, 2-9 cm. l., covered with three speckled cylindrical sheaths springing from the nodes, and with one leaf at apex. Leaf linear-oblong, obtuse, 5-10 cm. 1., 7-10 $\mathrm{mm}$. br. Peduncle with 4-6 bracts like the sheaths, $5-22 \mathrm{~cm}$. 1. Flowers vivid orange-scarlet, except the anther-cap which is purple, about $\frac{3}{4} \mathrm{in} .1$. Sepals, lateral elliptical, obtuse, $17-22 \mathrm{~mm}$. $1 ., 5 \cdot 5-7 \cdot 5 \mathrm{~mm}$. br.; median ovoid-elliptical, 16-19 mm. 1., 6.5-7.5 mm. br. Petals obovate-elliptical, 14-17 mm. l., 6-9 mm. br. Lip oboroid in outline, 7-9 $\mathrm{mm}$. l., continuous with wings of column below, 3-lobed near apex, lateral lobes rounded, median lobe semicircular, somewhat apiculate, disk papillose, with a sac-like outgrowth along the median line. Column 6.5-8.5 mm. 1., winged; clinandrium broadly winged, crenulate on the dorsal margin.

\section{SCHOMBURGKIA Lindl.}

Epiphytic herbs; pseudobulbs with several scarious sheaths, 2-leaved at the apex. Leaves oblong, elongated, thick, leathery. Raceme simple on a terminal elongated sheathed peduncle, flowers stalked. Bracts persistent, rigidly membranous. Sepals almost equal, free, spreading, more or less undulate. Petals similar and equal to the sepals. Lip very shortly connate quite at the base with the column, erect; the sides at first loosely embracing the column; the upper margin undulate. Column straight or incurved, winged; clinandrium lobed. Anther attached to the apex of the median tooth, incumbent; imperfectly 8 -celled; pollinia 8 , waxy, superposed in pairs, broadly ovate, compressed, connected by a slender granular appendage. Capsule ovoid.

Species about 13, natives of tropical America, including the West Indies.

S. Lyonsii Lindl. in Gard. Chron. 1853, 615; Hook. in Bot. Mag. t. 5172. S. carinata Griseb. Fl. Br. W. Ind. 621 (1864). (Pl. 19, f. 1-6.)

On rocks and trees; in fl. Aug.-Nov., in fr. Dec.; St. Ann, Purdie! St. Ann, Prior! Castleton, J.P. 535, Morris! Radnor, Cradwick! Ramble, 
Hanover, $600 \mathrm{ft}$., Fawcett! Content Road, $3000 \mathrm{ft}$., IIarris! Savanna-laNar, Lister Clark. Fl. Jam. 10,391, 10,427.

Plant rising to $3 \mathrm{ft}$. high and more. Pseudobulb narrowly spindleshaped, compressed, of several joints, 12-35 cm. 1., 2.5-3 cm. br. Sheaths 8-13 cm. l., reduced to $2 \mathrm{~cm}$. l. at base. Jueaves $1-3 \mathrm{dm} .1 ., 4-6 \mathrm{~cm}$. br. Peduncle 6-9 dm., with sheaths which become spathaceous and crowded and spreading at base of raceme; sheaths $5-6.5 \mathrm{~cm}$. l., acute, sometimes with purplish-brown spot. Raceme $7-12 \mathrm{~cm}$. l. Bracts linear-lanceolate, acuminate, reflexed, $5 \cdot 5-7 \cdot 7 \mathrm{~cm}$. l., to $6 \mathrm{~mm}$. br. Flowers white spotted with purple, perianth about 1 in. 1 . Pedicels $5-5.5 \mathrm{~cm}$. l., slender. Ovary a little over $1 \mathrm{~cm}$. 1. Sepals 7-nerved, ovate-oblong, obtuse, very shortly apiculate, with undulate, crispate margin, $2 \cdot 2-2 \cdot 3 \mathrm{~cm}$. $1 ., 9-10$ $\mathrm{mm}$. br., lateral somewhat falcate and broader than median. Petals 5-nerved, similar to sepals but longer and slightly broader, apex rounded, $2.6 \mathrm{~cm}$. l., $11 \mathrm{~mm}$. br. Lip 5-nerved, outer nerves branching, nerves prominent, sometimes lamellate; with yellowish edge, otherwise somewhat the same colouring as the sepals and petals, sometimes dull violet with crimson ribs, shorter than sepals, entire, ovate, very shortly clawed, with undulate crispate margin, apex bluntish, $1 \cdot 6 \mathrm{~cm}$. l., about $12 \mathrm{~mm}$. br. (flattened). Column curved, about $1 \mathrm{~cm}$. 1.; lateral lobes of clinandrium somewhat larger than median. Anther with 2 horn-like processes on the top. Capsule $3-4 \mathrm{~cm} . \mathrm{l}$, and 1.7-1.8 $\mathrm{cm}$. br.

\section{BRASSAVOLA R. Br.}

Epiphytic herbs. Stems scarcely thickened, sympodial, springing from the contracted base of the next older stem, with one or two sheaths covering the contracted base, with a few lax ash-coloured scarious sheaths above, and one leaf. Leaves thick and fleshy, conduplicate, almost half cylindrical, linear, tapering to a subulate apex. Flowers terminal, on an elongated peduncle, racemose, stalked. Bracts short. Ovary very slender. Sepals free, equal, spreading, long, linear, acuminate. Petals similar to the sepals, but slightly shorter and narrower, narrowly linearlanceolate. Lip with a long involute serrate claw; blade roundish, acuminate, entire. Column very short, clinandrium 3-lobed, the median toothed at the apex. Anther attached to the median lobe of the clinandrium, opercular, incumbent, with two distinct cells, each cell divided into two smaller cells by a longitudinal partition; pollinia 8 , four in each cell, broadly ovate and compressed in the same direction, connected by a granular, linear or blade-shaped appendage. Capsule large, ellipsoidal, 3-keeled, beaked.

Species about 22, natives of tropical America from the West Indies and Mexico to Argentine.

Flowers few, perianth 2-3 inches 1 .............. 1. B. nodosa.

Flowers many, perianth $1 \frac{1}{4}-1 \frac{3}{4}$ inch long......... 2. B. cordata.

1. B. nodosa Lindl. Gen. \& Sp. Orch. 114 (1831); flowers few ; sepals longer than ovary with pedicel, $5-7 \cdot 5 \mathrm{~cm}$. 1 . ; blade of lip roundish, 3-5 cm. l., claw 17-25 mm. 1.-Lindl. in Bot. Reg. 
t. 1465 ; Griseb. Fl. Br. W. Ind. 621 ; Rolfe in Orch. Rev. x. 65. B. grandiflora Lindl. in Bot. Reg. xxv. Misc. 16 (1839). B. venosa Lindl. in Bot. Reg. xxvi.t. 39 (1840); Hook. in Bot. Mag. t. 4021. Epidendron curassavicum \&c. Herm. Parad. 207 (errore 187). Viscum arboreum \&c. Pluk. Alm. 390, t. 117, f.6. Epidendrum nodosum L. Sp. Pl. 953 (1753) (excl. reference to Sloane \& var. B.); Jacq. Sel. Stirp. Amer. 226, t. 140, Ed. pict. 109, t. 213.

On rocks and trees; in fl. Aug., Sept.; Wright! Dickson! March! Cedar Valley, Moore !-Mexico, Honduras, Guatemala, Panama, Venezuela, Colombia, Peru.

Plant 8-13 in. high. Stem 6-7 cm. l., with two long joints, each covered with a sheath. Sheaths increasing in size from base $(4 \mathrm{~cm}$. l.), the topmost triangular, acute, $3 \cdot 5-5 \cdot 5 \mathrm{~cm}$. 1 . Leaf $14-22 \mathrm{~cm}$. 1., $8-18 \mathrm{~mm}$. br. Peduncle with three sterile joints below, followed by the few-flowered raceme, $10-27 \mathrm{~cm}$. 1. Bracts, sterile sheathing, 7-10 mm. l.; floral triangular, acute, $4-7 \mathrm{~mm}$. 1. Ovary with pedicel $3 \cdot 5-4 \cdot 5 \mathrm{~cm}$. 1 . Flowers large, spreading, perianth 2-3 in. 1. Sepals and petals pale green. Lip white. Column about $9 \mathrm{~mm}$. 1 . Capsule about $5 \mathrm{~cm} .1$.

2. B. cordata Lindl. in Bot. Reg. 1914, t. 1913 (1836); flowers many ; sepals as long as ovary with pedicel, $3 \cdot 5-4 \cdot 5 \mathrm{~cm}$. 1.; blade of lip subcordate-roundish, 1.8-2 cm. l., claw 12-16 mm. l. Hook. in Bot. Mag. t. 3782 ; Griseb. op. cit. 620 . B. nodosa Hook. in Bot. Mag. t. 3229 (1833). B. subulifolia Rolfe in Orch. Rev. x. 66 (1902); Griseb. loc. cit. (in part). Viscum delphinii dc. Sloane Cat. 120 \& Hist. i. 251, t. 121, f. 3. (Pl. 19, f. 7-11.)

On trees; in fl. June, Sept., Jan. ; Spanish Town, Sloane Herb. iv. 120 ! Wright! Bancroft! Macfadyen! St. Thomas in Vale, McNab! St. John, Purdie! Parke! White River, Cowan! Fairfield, Wullschlaegel, 1065 ! lowlands, J.P. 2398, Syme! Mandeville, Lady Blake! Lacovia, Tomlinson! Belvedere, Hanover, $500 \mathrm{ft}$; Halls Delight, $900 \mathrm{ft}$. ; near Troy, $2000 \mathrm{ft}$., $1600 \mathrm{ft}$.; Harris! Walderston, Mrs. Longstaff! near Mandeville, Harris \& Britton! Fl. Jam. 7661, 10,412, 10,448, 10,450, 10,451, 10,626.

B. subulifolia Lindl. Gen. \& Sp. Orch. 114 was described from a plant from Nevis. Lindley says "species distinctissima." We have not seen a specimen.

Plant 8-21 in. high. Stem 12-18 cm. 1., with three or four long joints, each covered with a sheath. Sheaths increasing in size from base $(2 \mathrm{~cm} .1$.$) ,$ the topmost becoming spathaceous, free portion oblong, tapering to an acute apex, or oblong-lanceolate, $5 \cdot 5-8 \mathrm{~cm}$. l. Leaf $20-35 \mathrm{~cm}$. 1., 7-12 mm. br. Peduncle one or two sterile joints below, followed by the many-flowered raceme, somewhat crowded above, $8-20 \mathrm{~cm}$. 1 . Bracts sterile, sheathing, free portion triangular, acute, 7-10 mm. 1.; floral lanceolate, acuminate, 6-9 mm. l. Ovary with pedicel $3 \cdot 5-4 \cdot 5 \mathrm{~cm}$. 1 . Flowers of medium size, spreading, perianth $1 \frac{1}{4}-1 \frac{3}{4}$ in. 1 . Sepals and petals pale green or greenish-yellow. Lip white, with a long involute serrate claw. Column about $7 \mathrm{~mm}$. 1., thicker upwards. Capsule $3.2 \mathrm{~cm}$. 1. , $1 \cdot 6 \mathrm{~cm}$. br.

\section{TETRAMICRA Lindil.}

Terrestrial herbs. Stems leafy, scarcely thickened, no pseudobulbs. Leaves from the rhizome within overlapping sheaths at the base of the scape, 1-3, linear, fleshy, semiterete, short and 
thick. Peduncle terminal, elongate, thin, rigid, with membranous adpressed sheaths at intervals. Raceme simple, lax, with small stalked flowers. Bracts minute. Siepals somewhat equal, free, spreading. Petals similar to the sepals but narrower. Lip attached at the base of the column, free, spreading from base; lateral lobez distinct on a short claw, ample, spreading; median broad, entire, contracted at the base. Column erect, broadly 2 -winged above; lateral lobes or teeth of the clinandrium often membranous, median small. Anther terminal, upercular, incumbent, convex, with two distinct cells, which are imperfectly divided into two smaller cells; pollinia perfect, 4, waxy, segregated in pairs in the cells, compressed in the same direction, connected by appendages. Capsule oblong, not beaked.

Species 7 , natives of tropical America from the West Indies to Brazil.

T. parviflora Lindl. ex Reicltb. $f$. in Walp. Ann. vi. 439 (1861); Griseb. Fl. Br. W. Ind. 622. Bletia parviflora Reichb. $f$. loc. cit. (Pl. 18, f. 7-10.)

In dry rocky ground; in fl. Feb.-April; Stony Hill, 1000 ft., J.P. 2033, Morris! Syme! near constant Spring, 600-1000 ft., Campbell! Le Ray! Harris! Fawcett! Fl. Jam. 7655, 10,409.-Bahamas.

Plant $7-15$ in. high. Stem very short, $2-4 \mathrm{~mm}$. 1., with two or three small leaves and a long peduncle. Leaves $1-4 \mathrm{~cm}$. 1., $3-6 \mathrm{~mm}$. br. Peduncle $18-38 \mathrm{~cm}$. l., very slender, with a lax raceme $(4-10 \mathrm{~cm}$. 1.) at apex. Bracts, sterile sheathing, free part very short, acute, $3 \cdot 5-5 \mathrm{~mm}$. l. ; floral half-clasping, ovate, very acute, $2-2.5 \mathrm{~mm}$. l. Flowers small, different shades of pink, sometimes white with a tinge of pink at the top of the column, perianth less than $\frac{1}{5}$ in. 1. Sepals green, sometimes striped inside with fine lines of purplish-brown, 5-nerved, oblong, apex acute to obtuse, 4.5-5 mm. 1., 1·6-2.1 mm. br. Petals 3-nerved, linear-lanceolate, sumewhat obtuse, 4-5 $\mathrm{mm}$. 1., ·75-.9 mm. br. Lip 5-6 mm. l., 3-lobed, lateral lobes broadly elliptical-ovate; median obovate, 5 -nerved, $3 \cdot 5 \mathrm{~mm}$. br. Column $2.5 \mathrm{~mm}$. 1 .

\section{HOMALOPETALUM Rolfe.}

Epiphytic herb, with a creeping rhizome, giving off 1-leaved pseudobulbs at intervals. Leaves sessile, fleshy. Peduncle solitary from apex of pseudobulb, longer than leaf, with one flower. Bracts few, small, distant. Sepals equal, free, connivent. Petals similar to sepals. Lip nearly similar to petals, free, undivided. Column thicker upwards, semiterete, incurved, with a falcate-oblong auricle at each side of the base, without a foot; clinandrium margined; rostellum ovate-oblong, descending. Anther terminal, opercular, convex; cells two, distinct, imperfectly divided by a longitudinal division; pollinia, perfect 4, waxy, in pairs in the cells, with linear granular-viscous appendiculie, at the apex of which are small imperfect pollinia.

Species 1, known only from Jamaica. 
H. vomeriforme* comb. nov.--H. jamaicense Rolfe in Hook. Ic. Pl. t. 2461 (1896). Epidendrum vomiforme Sw. Prodr. (1788) \& Ic. ined. t. 48 . E. vomeriforme Sw. Fl. Ind. Occ. 1511 (1806); Reichb. f. in Walp. Ann. vi. 416. Brassavola vomeriformis Reicltb. f. ex Griseb. Fl. Br. W. Ind. 621 (1864). (Pl. 18, f. 1-6.) Type in Herb. Mus. Brit.

On trees: in fl. Dec.-April; mountains, Swartz! Colthirst's Run, St. George, J.P. 238, Morris! Abbey Green, Blue MIts., 4000-5000 ft; near Cinchona, 5000 ft.; Harris! Fl. Jam. 6107, 7658, 7816, 9783, 10,494 (in part).

Plant $1 \frac{1}{2}-4$ in. high. Pseudobulbs cylindrical, ellipsoidal or somewhat globose, 4-6 mm. 1. Leaves ovate-oblong to oblong, shrivelling on drying, keeled, somewhat obtuse, 1-2 cm. 1., 4-5 mm. br. Peduncle filiform, 1-6.5 cm. l. Bracts, sterile sheathing, distant, 2-3 mm. 1. ; floral somewhat spathaceous, $3-3.5 \mathrm{~mm}$. 1. Flowers sessile, perianth $\frac{1}{2}-\frac{3}{t}$ in. 1 . Sepals 1.4-2 cm. 1., linear-lanceolate, acuminate. Petals similar, but shorter by about $2 \mathrm{~mm}$. and narrower. Lip as long as the petals, elliptical (when flattened), shortly acuminate, disk smooth. Column $4 \mathrm{~mm}$. l., slender below; clinandrium with one tooth behind and two in front, and a rounded lobe on each side. Capsule (unripe) ellipsoidal with a very short beak, $11 \mathrm{~mm}$. 1 .

\section{ELLEANTHUS Presl.}

Terrestrial herbs, tall, simple or branched, leafy. Leaves sessile above a sheath, plaited, lanceolate, nerves somewhat prominent below, highest leaf bract-like. Flowers sometimes dense in the form of a head or in a dense two-ranked spike. Sepals almost equal, free, erect, somewhat rigid. Petals as long as the sepals, generally narrower. Lip attached at the base of the column, erect, as long as the sepals or longer, generally enclosing the column, concave at the very base, with two prominent calli in the hollow, generally slightly constricted above the hollow, above roundish or inconspicuously trilobed, margin entire or denticulate. Column erect, semiterete or winged, without a foot. Anther attached to the median tooth, opercular, somewhat convex, slightly incumbent, afterwards erect, distinctly 2-celled, the cells not divided; pollinia 4 in each cell, waxy, ovoid, hardly superposed in pairs, connected at the apex by a sparse viscid substance or by a small granular appendage. Capsule shortly cylindrical, erect or spreading.

Species 45, natives of tropical America from the West Indies and Central America to Brazil and Peru.

Flowers in a head

1. E. capitatus.

Flowers in a spike

2. E. longibracteatus.

1. E. capitatus Reichb. f. in Walp. Ann. Bot. vi. 475 (1861); flowers in a head.-Cogn. in Fl. Bras. iii. pt. 5. 325. Bletia

* The original spelling was vomiforme, an error in orthography, subsequently corrected by Swartz. 
capitata R. Br. in Ait. Hort. Kev. ed. 2, v. 206 (1813) ; Lindl. Gen. \& Sp. Orch. 123. Evelyna capitata Poepp. \& Endl. Nov. Gen. d Sp. i. 32, t. 56 (1835); Griseb. Fl. Br. W. Ind. 622. (Pl. 20, f. 1-7.) Type in Herb. Mus. Brit.

On trees; in fl.July, Aug.; Masson! Wiles! Macfadyen! March! J.P. 232, Morris! near Claverty Cottage, Blue Mts., Moore! Vinegar Hill, St. (xeorge, Harris! Fl. Jam. 7717.-Guadeloupe, Nartinique, Grenada, Trinidad, Guatemala, Mexico, Venezuela, Ecuador, Peru.

Plant rising to $4 \mathrm{ft}$. and over. Stem to $12 \mathrm{dm}$. 1., 3-5 mm. br., simple, somewhat stout, erect, covered with leaf sheaths. Leaves papery, 7-9 nerved, 1-2 dm. 1., 2-5 cm. br.; sheaths 5-6 cm. 1., smaller near apex. Head dense, many-flowered, hemispherical, 2:5-5 cm. br. Bracts, outer without flowers, closely overlapping, ovate-triangular, acuminate, $2 \cdot 5-4$ cm. 1., 1-1.5 cm. br.; inver bracts subtending the flowers half as short and two or three times narrower. Flowers rosy-purple, perianth $\frac{1}{2} \mathrm{in}$. 1., lip $\frac{3}{4}$ ir. 1. Sepals 3-5-nerved, ligulate, shortly tapering to an acute apex, 12-13 mm. 1., 3-3.5 mm. br., lateral united and gibbous at base. Petals similar to sepals. Lip longer than the sepals, roundish with a narrower base, enclosing the column, saccate at base, apex broadly emarginate, margin denticulate-ciliate, with two large, subglobose calli at base. Column 9-10 mm. 1., thicker above, with a projecting, obtuse process on the anterior side below the stigma.

2. E. longibracteatus Fawc. Fl. Pl. Jam. 38 (1893); flowers in a spike.-Evelyna longibracteata Lindl. èx Griseb. loc. cit. (1864). (Pl. 20, f. 8-12.) Type in Herb. Lindl. at Kew.

On peaty banks and rocks; in fl. March-May; Wright! Macfadyen! March! J.P. 528, Syme! Greenwich, Moore! Fairfield, Oehler! Lancaster, $2500 \mathrm{ft}$; ; near Troy, $1400 \mathrm{ft}$; Cinchona, 10,414 ft.; Harris!-Dominica, Colombia, Ecuador.

Plant 2-3 ft. high. Stem 4.5-8 dm. 1., 2-4 mm. br., simple, erect, nearly covered with leaf-sheaths. Leaves papery, 5-nerved, $8-17 \mathrm{~cm}$. 1., 1-2 cm. br.; sheaths $1 \cdot 5-3 \cdot 5 \mathrm{~cm}$. 1. Spike somewhat dense, $4-8 \mathrm{~cm}$. l., several-flowered. Bracts ovate, acuminate, spathe-like, longer than the flower, $1 \cdot 5-2 \cdot 5 \mathrm{~cm}$. 1. Flowers cream-colour or pale yellow, perianth $\frac{1}{3}$ in. 1., lip longer. Sepals 9-nerved, lateral oblong-triangular, mucronate, saccate and gibbous at base, $7 \cdot 5-8 \cdot 5 \mathrm{~mm} .1 ., 4-5 \mathrm{~mm}$. br. at base; median oblong, apex rounded, mucronate, $7 \mathrm{~mm}$. $1 ., 4 \mathrm{~mm}$. br. Petals 6-nerved, ligulate, obtuse, nearly $7 \mathrm{~mm} .1 ., 2 \cdot 3 \mathrm{~mm}$. br. Lip not exserted beyond the sepals, saccate, enclosing the column, indistinctly 3-lobed, upper margin denticulate, somewhat eroded, curled, lobes rounded, nearly equal, with two large ovate calli at base, and two transverse linear calli at base of lobes, nearly as long as the lateral sepals. Column $6 \mathrm{~mm}$. l., winged; clinandrium with a spreading lobe at each side. Capsule cylindrical, slightly puberulous, $8 \mathrm{~mm}$. 1 .

\section{[39. PHAIUS Lour.]}

[Terrestrial herbs, rather tall, with stems crowded on a caudex. Leaves elongate, plaited, at the base narrowed or contracted into a long stalk, with sheaths generally striate. Scape springing from the caudex. Flowers in a raceme, several, stalked. Bracts sometimes small, linear, sometimes rather large, membranous or herbaceous. Sepals free, almost equal, spreading 
or somewhat erect. Petals similar to the sepals, but narrower. Lip erect, concave, produced at the base into a short spur, continuous with the base of the column; lateral lobes ample, erect, enclosing the column; median lobe expanded, generally short and broad, spreading or recurved. Column somewhat long, subterete, 2-angled or 2-winged, thicker upwards, without a foot; clinandrium short, oblique, sinuate on the margin. Anther attached near the margin of the clinandrium, opercular, incumbent, convex, distinctly 2-celled, cells divided imperfectly into four smaller cells; pollinia 8, obovate or oblong, compressed from the side, applied by the faces in pairs, the lower pair of each cell generally longer than the upper, connected at the apex by a granular appendage almost filling the cells in the younger anther. Capsule oblong, without a beak, ribs very prominent.

Species 50, natives of tropical Asia, but spreading to tropical Africa, the Mascarene Islands, Australia, the islands of the Pacific Ocean, China and Japan.

P. Tancarvilleæ Blume (Tankervillii) IIus. Bot. Lugd.-Bat.ii. 177 (1856). P. grandifolius Lour. Fl. Cochinch. 529 (1790); Lindl. Gen. \& Sp. Orch. 126 ; Griseb. Fl. Br. W. Ind. 622; Salisb. Ic. ined. vi. fol. 573 Limodorum Tancarvilleæ Banks ex L'Hérit. Sert. Angl. 28 (1788). L. Tankervilliæ Dryand. in Ait. Hort. Kev. iii. 302, t. 12 (1789). Bletia Tankervilliæ R. Br. in Ait. Hort. Kew. ed. 2, v. 205 (1813) ; Bot. Mag. t. 1924. (Pl. 20, f. $13-17$.)

In damp shady places; in fl. throughout year; Bethany, Wullschlaegel, 1061 ! Prior! Blue Mts., J.P. 7, Morris! Vinegar Hill, Moore! Clydesdale, near Cinchona, Fawcett! Farm Hill, Miss B. Gosset! near Catadupa, 1800 ft.; Wallenford, 3000 ft.; Harris! Fl. Jam. 7637, 9183.-China, Australia, N. Caledonia, Rarotonga.

Plant $1 \frac{1}{2}-3$ ft. high. Stem tuberous. Leaves, blade oblong-lanceolate to lanceolate, acute, 3-5 dm. 1., 7-10 cm. br.; stalks 5-15 cm. l. Scape 5-9 dm. Flowers chocolate-brown and white, $1 \frac{1}{2}$ in. 1. Bracts large, spathe-like, obtuse, about $3.5 \mathrm{~cm}$. l. Sepals 7-nerved, oblong-lanceolate, 4-5.5 cm. 1., 11-14 mm. br. Lip embracing the column, indistinctly 3 -lobed above, median lobe slightly reflexed with margin curled; disk with two parallel keels, $3 \cdot 5-4 \mathrm{~cm}$. 1. Spur slightly curved, $5 \mathrm{~mm}$. 1 . Column 1.5-2 cm. 1 .

This species cannot be considered indigenous, but it is so completely naturalised and so common in some parts of Jamaica, that a full description has been included. It is also recorded from Cuba.]

\section{CALANTHE R. Br.}

Terrestrial herbs; stem very short, rhizomatous. Leaves few, large, broad, veins prominent, contracted into a sheathing petiole. Scape tall. Raceme simple, lax-flowered. Bracts very long, narrow. Sepals nearly equal, free, spreading. Petals somewhat similar, smaller. Lip clawed, claw connate with the column forming a tube, produced at the base into a short spur; 
blade entire. Column short, erect, broadly winged at the apex above the tube. Anther subterminal, incumbent, 2-celled. Pollinia \&, waxy, narrowly pyriform. Capsule ellipsoidal, large.

Species about 138 , widely distributed in tropics of the old world, especially Asia, one or two in tropical America.

C. mexicana Reichb. $f$. in Limner xviii. 406 (1844), Ic. Fl. Germ. xiii. d xiv. t. 355, f. 5, 6, 7, \& Xen. Orch. i. 205, t. 79, i. 1-3. Ghiesbreghtia calanthoides A. Rich. \& Gal. in Ann. Sc. Nat. ser. 3, iii. 28 (1845). (Pl. 20, f. 18-22.)

Damp shady places; in fl. June-Nov.; near Cinchona, $4800 \mathrm{ft}$., Craduich! Watt! John Crow Peak, 5600 ft., Faucett! Morse's Gap, 4800-5000 ft.; Nabess River, 3500 ft.; Harris! Fl. Jam. 7790, 10,437.Cuba, Mexico.

Plant more than a foot high. Stem with abundant roots and two sheaths; upper sheath 9 or $10 \mathrm{~cm}$. Leaves two, oblong to oval, acute, 25-40 cm. 1., 7-11 cm. br. Scape 40-50 cm. Raceme 6-8 cm. Flowers white, ten or more, perianth $\frac{1}{2}$ in. l., all parts downy. Pedicels $3-5 \mathrm{~mm}$. Bracts 13-30 mm. 1., linear, acuminate. Sepals 11-12 mm. 1., 5-4 mm. br., oblong, shortly acute, 5-nerved, median rather shorter and broader than the lateral. Petals $8 \mathrm{~mm}$. l., $3 \mathrm{~mm}$. br., obovate-lanceolate, obtuse, 3-nerved. Lip (measuring from junction with tube) $6 \mathrm{~mm}$. l., $4 \mathrm{~mm}$. br., subrotund, shortly apiculate, entire (thus differing from the 3-lobed form generally characteristic of the genus). Capsule $2-2.5 \mathrm{~cm} .1$.

\section{BLETIA Ruiz \& Pavon.}

Terrestrial, erect herbs. Leaves springing from the top of a corm, few, very long, lanceolate, contracted into a sheathing petiole. Scape rising from the side of the corm, leafless with sheathing sterile bracts. Flowers numerous, stalked, somewhat large, in a terminal generally branched raceme. Bracts small. Sepals free, converging or somewhat spreading, subequal. Petals similar to the sepals, but broader. Lip attached to base of the column, free, erect, middle lobe spreading, broad, emarginate; lateral lobes somewhat broad, converging over the column; disc with five to seven crests. Column long, semiterete, 2 -winged, incurved, auricled at the base, without a foot. Anther incumbent, two-celled. Pollinia 8, waxy, obovate. Capsule oblong, erect.

Species about 45, mostly in tropical America.

Flowers rosy-purple or purplish-crimson; lateral lobes of lip broader below than above, and with narrow apex.

Flowers dark purple; lateral lobesi of lip rounded above and narrowing towards the base

1. B. purpurea.

2. B. florida.

1. B. purpurea DC. in Mém. Soc. Phys. \& Hist. Nat. Genève, ix. pt. 1, 100 (1841); flowers rosy-purple or purplish-crimson; lip with seven crests, only five of which pass into the middle 
lobe, lateral lobes with a bluntly triangular apex above the sinus and increasing in breadth towards the base, middle lobe roundish.-Griseb. Fl. Br. W. Ind. 622. B. verecunda, R. Br. in Ait. Hort. Kew. ed. 2, v. 206 (1813) ; Griseb. loc. cit.; Salisb. Ic. ined. vi. fol. 572, 573. B. acutipetala Hook. in Bot. Mag. $t$. 3217 (1833). B. alta Hitcheock in Rep. Miss. Bot. Gard. iv. 132 (1893). Limodorum purpureum Lam. Encycl. Méth. iii. 515 (1789); Redouté Liliacées i. 83. L. tuberosum Jacq. Coll. iv. 108 (1790), non L.* L.altum Jacq. Ic. Rar. iii. 17, t. 602 (1786-93), non $L . *$ L. verecundum Salisb. Prodr. 9 (1796). Cymbidium verecundum Sw. in Nov. Act. Upsal. vi. 75 (1799). (Pl. 21, f. 1-7.)

Dry stony banks, rocky land, on rocks in moist woods, 600-5000 ft.; in fl. and fr. Oct.-May; Houstoun! Fairfield, 1059, Wullschlaegel! J.P. 9, Morris! Cinchona, $5000 \mathrm{ft}$ ! Fawcett! G. Nichols! Farm Hill, C. Nicholls! Hanover, Tomlinson! Silver Hill, 3500 ft., Harris!-Cuba, Bahamas, Florida, Central America.

Plant $1 \frac{1}{2}-2 \frac{1}{2} \mathrm{ft}$. high; leaves $1 \frac{1}{2} \mathrm{ft}$. long. Corm $2 \mathrm{~cm}$., globose. Leares 30-50 cm. 1., 1-2 cm. br., narrowly lanceolate, long-tapering at base and apex, narrowing into a basal sheath. Flowers, perianth $\frac{1}{2}-\frac{3}{4}$ in. l. Bracts, sterile $1-1.3 \mathrm{~cm}$. 1., ovate, blunt, adpressed, sheathing at the base; floral 4-5 mm. 1., broadly ovate, acuminate, somewhat clasping. Pedicels (including ovary) $1-1 \cdot 5 \mathrm{~cm}$, of fruit about half as long. Sepals 15-18 mm. l., 5-7 mm. br.; median ovate-lanceolate, acute; lateral ovate, acute, slightly gibbous. Petals broader and sligbtly shorter than the sepals. Lip shorter than the petals, veins numerous and branching, middle lobe emarginate, crenate, curled. Column winged. Capsule $2 \cdot 7 \mathrm{~cm}$. 1 ., cylindrical, erect.

2. B. florida R. Br. in Ait. Hort. Kev. ed. 2, $v .206$ (1813); flowers dark purple, sometimes rosy with white lip; lip with five crests, of which only three generally stretch far into the middle lobe, lateral lobes rounded above, narrowing gradually to the base, middle lobe generally cuneate in form.-Griseb. op. cit. 621. B. Shepherdii Hook. in Bot. Mag. 3319 (1834); Griseb. loc. cit. B. verecunda $D C$. loc. cit. non $R$. Br. Limodorum floridum Salisb. Prodr. 9 (1796) \& Ic. ined. vi. fol. 572. L. altum Sims in Bot. Mag.t. 930 (1806). (Pl. 21, f. 8-11.)

Dry stony banks 1000-5000 ft.; in fl. and fr. Oct.-May; Sloane Herb. iv. 117 ! St. Anns Bay, Prior! J.P. 2145, Morris! Lane! Bryans Hill, Sullivan! Silver Hill, 3500 ft.; Wallenford, 2500 ft.; Constant Spring; Green Valley; Harris! Fl. Jam. 7622, 7653, 7682.-Cuba.

Plant $2-3 \frac{1}{2} \mathrm{ft}$. with leaves $1 \frac{1}{2}$ to $2 \mathrm{ft}$. long. Corm $1 \cdot 5-2 \cdot 5 \mathrm{~cm}$., ovateglobose. Leaves $20-50 \mathrm{~cm}$. 1., 2-9 cm. br., narrowly lanceolate to broadly lanceolate or oblanceolate, acuminate, narrowing into a basal sheath which persists after the fall of the leaf, many-nerved. Flowers, perianth less than an inch to $1 \frac{1}{2}$ in. long. Bracts, sterile $1-2 \cdot 5 \mathrm{~cm}$. l., ovate, blunt, adpressed, sheathing at the base; floral 3-10 $\mathrm{mm}$. l., ovate,

* Limodorum tuberosum L. Sp. Pl. 950 is Calopogon pulchellus R. Br. L. altum L. Syst. ed. 12, ii. 594 is Eulophia alta. 
acuminate, somowhat clasping. Pedicels (including ovary) about $2 \mathrm{~cm}$., of fruit less than $1 \mathrm{~cm}$. Sepals 2-2.5 cm. 1., 7-9 mm. br.; median oblong, apiculate; lateral ovate-elliptical. Petals about the same length as the sepals but broador, oval. $L_{i}$ p shortor than the petals, middle lobe cmarginate, crenate, curled. Column about 3 length of lip, winged. Capsule $4 \mathrm{~cm}$. l. narrowly oblong, erect.

Limodorum floridum was founded by Salisbury on a spccimen sent "from Jamaica by Wm. Shakespeare." The original specimen is not extant, but among Salisbury's drawings and Mss in the Department of Botany are comparative descriptions and sketches of parts of the flower of this species and of $L$. verecundum; the drawing of the lip of $L$. floridum is reproduced in our plate. Brown followed Salisbury in regarding the two species as distinct, but there are no specimens of Bletia florida authenticated by him. In our opinion $B$. florida is identical with the plant subsequently described by Hooker as B. Shepherdii.

42. EULOPHIA R. Br.

Terrestrial herbs, with rhizome thickened into a tuber-like pseudobulb, and stem with a few leaves. Leaves long, plaited, many-veined, contracted into the stalk. Scapes erect from the rhizome, tall, leafless, with several sheaths. Raceme simple; flowers medium-sized, shortly stalked. Bracts linear or lanceolate. Sepals free from each other, almost equal, the lateral broader at the base and more or less decurrent into the foot of the column. Petals somewhat similar to the median sepal, but a little broader and shorter. Lip attached at the apex of the foot of the column, forming a gibbous sac or spur between the lateral sepals, 3-lobed, lateral lobes embracing the column, the median rounded, spreading, with curled margin. Column erect, produced at the base into a foot, semiterete, with acute scarcely winged angles; clinandrium oblique, entire. Anther terminal, opercular, incumbent, obtusely conical, with a 2-lobed appendage, imperfectly 2-celled. Pollinia 2 or 4 , more or less connate in pairs, broadly ovoid or globose, waxy, without appendage, attached to a gland of the rostellum, which is broad, generally membranous, or produced into a short thick stalk. Capsule ellipsoidal, pendulous, without a beak, ribs thick and prominent.

Species about 180, widely diffused through the Tropics, most numerous in Africa, and rare in Malaya, Polynesia, Australia and Tropical America.

E. alta comb. nov.-E. Woodfordii Rolfe in Fl. Trop. Afr. vii. 68 (1897) ; Ames Orch. S. Fla. 19. Limodorum altum L. Syst. ed. 12, ii. 594 (1767). Limodorum foliis nervosis lanceolatis \&c. Plum. Pl. Amer. (Burm.) t. 189 \& Ic. ined. iii. t. 192. Satyrium foliis liratis \&c. Browne Hist. Jam. 325. Dendrobium longifolium H. B. \& K. Nov. Gen. \& Sp. i. 360 (1815). Cyrtopodium Woodfordii Sims in Bot. Mag. t. 1814 (1816); Lindl. in Bot. Reg. t. 1508. Cyrtopera Woodfordii Lindl. Gen. \& Sp. Orch. 183 
(1833); Griseb. op. cit. 630. C. longifolia Cogn. in Fl. Bras. iii. pt. 5, 354, t. 76. (Pl. 22, f. 4-8.) Type in Herb. Linn.

Ground Coco, Wild Coco.

In wet clayey soil in shady places; in fl. \& fr. Nov.-Feb.; P. Browne! Purdie; Bethabara, Wullschlaegel, 1057 bis! St. MIary, J.P. 2397, Syme! Brokenhurst, Wynne! Clydesdale, Fawcett! Wallenford; near Castleton; Harris! Christiana, Tomlinson! Fl. Jam. 7638, 10,435.-Cuba, Florida, Hispaniola, Porto Rico, Guadeloupe, Dominica, MIartinique, St. Vincent, Trinidad, Venezuela, Brazil, Colombia, Peru, West Africa.

Plant 2-4 ft. high. Leaves appearing after the flowers, three or four at a time, very long, lanceolate, acuminate, below tapering into a long sheath, 7-9-nerved, plaited, 3-5 dm. 1., 3-10 cm. br. Scape $\frac{1}{2}-1 \mathrm{~m} .1$. and sometimes more, much longer than the leaves. Sheaths long; free portion triangular, obtuse or somewhat acute. Raceme somewhat laxly manyflowered. Bracts linear-lanceolate or linear-subulate, acuminate, much shorter than the stalked ovary, 8-13 mm. l. Pedicels about $5 \mathrm{~mm}$. l. Ovary about $1 \mathrm{~cm}$. l. Flowers green with brownish-green lip; perianth $\frac{3-1}{4} \mathrm{in} .1$. Sepals 5-nerved, outer nerve branching, oblong to oblong-oblanceolate, apex bluntish; lateral oblique at apex, about $2 \mathrm{~cm}$. $1 ., 5.5 \mathrm{~mm}$. br.; median about $1 \cdot 6 \mathrm{~cm} .1 ., 4 \cdot 5 \mathrm{~mm}$. br. Petals with seven branching nerves, oblong, broadening slightly upwards, obtuse, about $1.4 \mathrm{~cm} .1 ., 6 \mathrm{~mm}$. br. Lip brownish-green, shaded and veined inside with purple, about $1.8 \mathrm{~cm} .1$., with several branching nerves; lateral lobes short, rounded; disk with warty calli on nerves. Column about $9 \mathrm{~mm} .1$. to base, about $13 \mathrm{~mm} .1$. from apex to end of foot. Capsule $4 \cdot 5 \mathrm{~cm} .1 ., 1 \cdot 8 \mathrm{~cm}$. br., pendulous.

\section{GOVENIA Lindl.}

Terrestrial herbs, with a rhizome sometimes thickened into tuber-like pseudobulbs. Stems erect, with few leaves and some stalked sheaths at the base, of which one is often inflated and utricle-like. Leaves ample, plaited, with many veins, with a long sheathing base. Raceme terminal on a leafy stem, simple; peduncle with a few sheaths near the base. Flowers mediumsized, crowded, or at length distant, very shortly stalked. Bracts small, ovate or narrow, a little shorter than the ovary. Sepals almost equal, connivent; median incurved, erect; lateral falcate or decurved, at the base forming a short chin with the foot of the column. Petals somewhat similar to the sepals. Lip attached at the foot of the column, jointed, incumbent at the base, concave, spreading at the apex, undivided. Column incurved, broadly semiterete, winged, produced into a short foot at the base; clinandrium truncate. Anther terminal, opercular, incumbent, very convex, sometimes crested on the back, 1-celled; pollinia 4, waxy, broadly ovate, compressed, without an appendage, on the dehiscence of the anther attached by an oblong or broad stalk, gland small or dilated. Capsule oblong, without a beak.

Species about 17, natives of tropical America from the West Indies and Mexico to Brazil and Bolivia.

G. utriculata Lindl. in Bot. Reg. xxv. Misc. 47, under no. 66 (1839) ; Hook. in Bot. Mag. t. 4151 ; Griseb. Fl. Br. W. Ind. 628. 
Limodorum utriculatum Sw. Prodr. 119 (1788). Cymbidium utriculatum Sw. in Nov. Act. Upsal. vi. 75 (1799) \& Fl. Ind. Occ. 1477. (Pl. 22, f. 1-3.) Type in Herb. Mus. Brit.

In damp woods; in fl. Sept.-Dec.; Swartz! Macfadyen! Manchester, Purdie! Fairfield, Wullschlaegel, 1056! Prior! near Cinchona, J.P. 33; Morris! Red Hills, J.P. 2413, Syme! Trelawney, Miss T. M. Barrett! Hamilton Town, Moore! above Mt. Hybla; above Bridge Hill; Fawcett ! Old England; near Ewarton, 1000 ft.; Harris! Fl. Jam. 6719, 10,433.Cuba, Hispaniola, Porto Rico, Mexico, Venezuela.

Plant $1 \frac{1}{2}-2 \mathrm{ft}$. high. Stem 3-4.5 dm. Sheaths inflated, one $10-20 \mathrm{~cm} .1 .$, 2 or $3 \mathrm{~cm}$. br., outer $4-8 \mathrm{~cm}$. 1. ; cauline, free-portion oblong-ovate, obtuse, $2 \cdot 5-5 \mathrm{~cm}$. 1. Leaves one or two, blade elliptical, tapering to base and apex, 15-25 cm. l., 5-9 cm. br.; the tubular sheathing base $13-18 \mathrm{~cm} .1$. Raceme 6-14 cm. l., laxly few- to many-flowered. Bracts linear-lanceolate, lower floral, 1·5-2 cm. l., upper shorter. Flowers rather more than $\frac{1}{2} \mathrm{in.}$., cream-coloured. Sepals 5-nerved; lateral lanceolate, $12 \mathrm{~mm}$. 1., $3 \mathrm{~mm}$. br.; median oblong, shortly acuminate, about $15 \mathrm{~mm}$. 1., $2.75 \mathrm{~mm}$. br. Petals 6-nerved, outer nerves branching, broadly oblanceolate, acute, broader than sepals, $14 \mathrm{~mm}$. 1., $5 \mathrm{~mm}$. br. Lip 5-nerved, nerves branching, ovate, acute, very shortly clawed, $9 \mathrm{~mm}$. 1., $4 \cdot 3 \mathrm{~mm}$. br. Column $6 \mathrm{~mm}$. 1 . Capsule $2 \cdot 5 \mathrm{~cm} .1$.

\section{LYCASTE Lindl.}

Epiphytic herbs. Stem short, with few leaves, sheathed at the base, becoming thickened into fleshy pseudobulbs. Leaves ample, plaited, many-veined. Scapes erect at the sides of the pseudobulbs, closely sheathed, with one flower, rarely two or three. Flowers large, nodding. Sepals nearly equal, erect-spreading, the lateral broader, forming a chin. Petals similar to the sepals but smaller. Lip attached at the foot of the column, shorter than the sepals ; lateral lobes erect ; the median spreading. Colunn rather long, curved, semi-terete, produced at the base into a foot; clinandrium short. Anther terminal, opercular, incumbent, very convex, 1-celled; pollinia 4, oblong or ovoid, without an appendage, attached by a long linear stalk, gland small. Capsule oblong or spindle-shaped, erect.

Species about 40, natives of tropical America from the West Indies and Mexico to Peru.

L. Barringtoniæ Lindl. in Bot. Reg. xxx. Misc. 43 (1844); Griseb. Fl. Br. W. Ind. 627. Epidendrum Barringtoniæ Smith Ic. pict. t. 15 (1793) ; Salisb. Ic. ined. fol. 579. Dendrobium Barringtoniæ Sw. Nov. Act. Upsal. vi. 82 (1799); Hook. Exot. Fl. t. 119. Maxillaria ciliata Lindl. in Bot. Reg. t. 1206 (1829). M. Barringtoniæ Lodd. Bot. Cab.t. 1824 (1832); Lindl. Gen. d Sp. Orch. 147. Type in Herb. Smith. in Linn. Soc. (Pl. 23, f. 1-3.)

On rocks and trees; in fl. April-June; Macfayden! Purdie! Beaufort, Wullschlaegel, $1062 !$ Mt. Moses, J.P. 2328, Syme! near Radnor, Miss B. Gosset! Content Road; Silver Hill Woodland ; Harris! Fl. Jam. 10,392.Cuba. 
Plant 1-2 ft. high. Pseudobulb ellipsoidal with two or three leaves at apex, about 8 or $9 \mathrm{~cm}$. 1., $5 \mathrm{~cm}$. br. Leaves long-elliptical, tapering to a short stalk and to apex, 3-5 dm. $1 ., 5-12 \mathrm{~cm}$. br. Scapes 8-12 cm. l. Bracts 4-6, sheathing, loose, ovate, obtuse, uppermost nearly as long as stalked ovary, $1 \cdot 5-3 \mathrm{~cm}$. l. Flowers drooping, nearly 2 in. l., olive-green. Stalked ovary about $3 \mathrm{~mm}$. 1. Sepals $4-4.5 \mathrm{~cm}$. l., about $1.7 \mathrm{~cm}$. br., oblong-ovate, lateral cohering and forming a bluntly conical chin, median narrower. Petals similar to sepals but smaller. Lip light buff in colour, about $3 \cdot 5-4 \cdot 5 \mathrm{~cm}$. l., with a long claw broadening upwards, lateral lobes at apex of claw, narrowly falcate; median ovate-oblong, blunt, with fimbriate margin, and terminating abruptly by a broad deeply furrowed callus. Column bordered, thicker upwards, about $2 \mathrm{~cm}$. l. (to end of foot over $3 \mathrm{~cm}$. 1.).

\section{XYLOBIUM Lindl.}

Epiphytic herbs. Stems short, with several sheaths, becoming thickened into flesby pseudobulbs with one or two leaves. Leaves ample or elongate, plaited, many-veined, contracted into the stalk. Scapes at the base of pseudobulbs, erect, simple. Flowers in racemes, medium-sized, very shortly stalked. Bracts linear, generally rather long. Sepals nearly equal, erect, at length somewhat spreading; lateral broader than the median, adnate at the base to the foot of the column, forming a chin. Petals similar to the median sepal but smaller. Lip somewhat jointed with the foot of the column, sessile or contracted at the base and incumbent, then erect; lateral lobes or sides erect, embracing the column; the median lobe or upper portion short, broad, spreading; the face lamellate or callose. Column erect, semi-terete, anteriorly concave or narrowly 2 -winged, produced at the base into a foot; clinandrium obliquely truncate. Anther terminal, opercular, incumbent, very convex, 1-celled; pollinia 4, ovoid, without an appendage, on the dehiscence of the anther attached to a stalk which is sometimes rather long; gland transverse, scale-like. Capsule oblong, erect.

Species about 12, natives of tropical America.

Pseudobulb with one leaf ................ 1. X. palmifolium.

Pseudobulb with two leaves .............. 2. X. stachyobiorum.

1. X. palmifolium Fawc. Fl. Pl. Jam. 39 (1893); flowers about $\frac{3}{4}$ in. l., lateral sepals only slightly keeled at back, lip entire.-Epidendrum palmifolium Sw. Prodr. 123 (1788). Dendrobium palmifolium Sw. in Nov. Act. Upsal. vi. 82 (1799) \& Fl. Ind. Occ. 1527. Maxillaria decolor Lindl. in Bot. Reg. t. 1549 (1832); Hook. in Bot. Mag. t. 3981. M. palmifolia Lindl. Gen. \& Sp. Orch. 148 (1832); Griseb. op. cit. 627. (Pl. 23, f. 4-7.) Type in Herb. Mus. Brit.

On trees and rocks; in fl. Sept. ; Swartz! MIt. Moses, 2500 ft., J.P. 2315, Syme! Trelawney, Miss T. M. Barrett.-Cuba.

Plant over $1 \mathrm{ft}$. high. Pseudobulb cylindrical-ovate, $5 \cdot 5-7 \cdot 5 \mathrm{~cm}$. 1 , with one leaf. Leaves (generally) broadly lanceolate, blade $26-42 \mathrm{~cm}$. l., 
2.7-8 cm. br. Scape laxly few-flowered, about $10 \mathrm{~cm} .1$. Bracts, sterile sheathing, ovate-oblong, acute or acuminate, $3-3.5 \mathrm{~cm}$. 1.; floral linear, acuminate, $2 \cdot 5-3 \mathrm{~cm}$. l. Flowers yellowish-white, sweet-scented. Pedicels about $\cdot 5 \mathrm{~cm} .1$. Ovary about $1 \cdot 3 \mathrm{~cm}$. 1 . Sepals 7 -nerved; median oblong, tapering towards an acute apex, $1.8 \mathrm{~cm} .1 ., 5 \mathrm{~mm}$. br.; lateral very oblique and broad at base, falcately triangular-lanceolate, $2 \cdot 2 \mathrm{~cm}$. $1 ., 9 \mathrm{~mm}$. br. Petals 5-nerved, linear-oblong, tapering to apex, about $1.4 \mathrm{~cm}$. 1., about $3.5 \mathrm{~mm}$. br. Lip white, about 15-nerved, outline obovate-oblong, about $1.6 \mathrm{~cm}$. l., about $9 \mathrm{~mm}$. br.; terminal portion fleshy, warty, retuse, $4 \mathrm{~mm}$. l., $7 \mathrm{~mm}$. br. ; sides incurved above, margin crisped; disk with four or five median nerves thickened, extending beyond the middle of the disk. Column (from apex to end of foot) $1.4 \mathrm{~cm} .1$.

2. X. stachyobiorum Hemsl. in Biol. Centr. Amer. Bot. iii. 252 (1883) ; flowers rather more than $\frac{1}{2}$ in. l., lateral sepals with broad keel extending beyond apex, lip 3-lobed above.-Maxillaria stachyobiorum Reichb. f. in Bot. Zeit. x. 735 (1852).

On peaty banks; in fl. Jan.-March; near Castleton, Fawcett! Silver Hill, $3500 \mathrm{ft} .$, Harris!-Nicaragua, Panama.

Plant over $1 \mathrm{ft}$. high. Pseudobulb large, ovate, compressed, $5 \cdot 5-6 \mathrm{~cm}$. 1., with two leaves. Leaves lanceolate to oblanceolate, acute or acuminate, narrowed into the stalk, 30-45 cm. l., 5-6 cm. br. Scape laxly manyflowered, 14-17 cm. l. Bracts, sterile sheathing, ovate-oblong, acute or acuminate, about $3 \mathrm{~cm}$. l. ; floral subulate, about $1 \cdot 5 \mathrm{~cm}$. 1 . Flowers creamcoloured, irregularly speckled with brown. Pedicels $4-5 \mathrm{~mm}$. l. Ovary about $1 \mathrm{~cm} .1$. Sepals 5-nerved with less well-marked intermediate nerves, median oblong-ovate, shortly acuminate, $14 \mathrm{~mm}$. l., about $4 \mathrm{~mm}$. br.; lateral oblong-ovate, tapering and keeled towards apex, $15 \mathrm{~mm} .1 ., 5 \cdot 5 \mathrm{~mm}$. br. Petals 5-nerved, oblong-lanceolate, apex somewhat acute and fleshy, falcate, $11 \mathrm{~mm}$. 1., $3.5 \mathrm{~mm}$. br. Lip with seven branching nerves, broadly oblong, $11 \mathrm{~mm}$. 1., $7 \mathrm{~mm}$. br., shallowly 3-lobed above, lateral lobes rounded, terminal fleshy, broader than long, rounded, larger than lateral lobes; disk with the three or five median nerves elevated. Column (from apex to end of foot) nearly $1 \mathrm{~cm}$. 1 . Capsule $2 \cdot 5 \mathrm{~cm} .1$.

\section{ZYGOPETALUM Hook.}

Epiphytic herbs, stemless, leafy. Leaves membranous, with numerous prominent veins, plaited. Scapes 1-flowered. Sepals nearly equal, spreading, free or scarcely very shortly connected at the base, lateral attached to the short foot of the column. Petals similar to the sepals. Lip attached to the foot of the column, forming with it a very short chin ; lateral lobes erect, embracing the column; median lobe generally broad; disk with a transverse crest generally very prominent, fteshy. Column incurved, semiterete, produced at the base into a short foot; clinandrium oblique, entire, or membranous and hooded with fimbriate. margin. Anther opercular, incumbent, 2-celled; pollinia 4, obovoid, segregated in pairs in the cells, without an appendage. Capsule ovoid or oblong, without a beak.

Species about 90, natives of warmer America from the West Indies and Central America to Brazil. 
Z. flabelliforme Reichb. f. in Walp. Ann. vi. 652 (1861).Z. cochleare Lindl. in Bot. Reg. t. 1857 (1836); Hook. in Bot. Mag. t. 3585 ; Griseb. Fl. Br. W. Ind. 629 (excl. distr.). Epidendrum flabelliforme Sw. Prodr. 123 (1788) \& Ic. ined. t. 45. Cymbidium flabelliforme $S w$. in Nov. Act. Upsal. vi. 73 (1799) \& Fl. Ind. Occ. 1471. (Pl. 23, f. 17-19.) Type in Herb. Mus. Brit.

On trees; in fl. Oct.-March; mountains, Swartz! Manchester, Purdie! St. Andrew and St. Mary, J.P. 2099, Morris! Spanish River, Watt! St. Ann, Miss T. M. Barrett! Cedar Hurst, Moore! Clydesdale, $3500 \mathrm{ft}$.; Dollwood; Silver Hill Woodland; Catherine's Peak, 5000 ft.; Noody's Gap, 3000 ft.; above Hope Mines, 900 ft.; Harris! Fl. Jam. 7576, 7736, 7808.

Plant 8-12 in. high. Leaves oblanceolate to narrowly oblong, abruptly acute, tapering below into a sheathing stalk with which the blade is jointed, $12-30 \mathrm{~cm}$. 1., $2 \cdot 5-4 \cdot 2 \mathrm{~cm}$. br. Sheaths below leaves, $3-6 \mathrm{~cm}$. 1 . Scape from the axils of the outer leaves, erect, $3-10 \mathrm{~cm}$. 1 . Bracts several at and just above base of scape, and two at base of flower, spathe-like, 1-2 cm. 1. Ovary white, curved, $2-3 \mathrm{~cm}$. 1. (pedicel forming about onethird). Flowers white with blue lip, with fragrance like lily-of-the-valley, perianth $1-1 \frac{1}{4}$ in. 1. Sepals oblong or oblong-lanceolate, greenish-white, 3-3.5 cm. 1., 9-10 mm. br. Petals similar and slightly smaller. Lip very large, somewhat square in outline when flattened, with a small short claw, at base broad, cordate, ventricose, margin involute and curled, apex emarginate; at the base within is a large lunate fleshy depressed crest, lobed and crenated, marked with purple lines continued into disk; $2 \cdot 5-3$ $\mathrm{cm}$. l. and br. Column short, with two small wings above, white streaked with red in front, $1 \mathrm{~cm}$. 1. Capsule cylindrical, 4-5 cm. 1., 10-13 mm. br.

\section{BULBOPHYLLUM Thou.}

Epiphytic herbs. Stem more or less covered with scarious sheaths. Pseudobulbs sessile at the axils of the sheaths, bearing one or two leaves at the apex. Flowering scapes at the sides of the pseudobulbs, leafless, simple, with numerous sheaths at intervals. Flowers minute, numerous on a terminal spike. Bracts small. Median sepal free, erect or spreading, about as long as the lateral; lateral at the base obliquely dilated, and adnate to the foot of the column, above spreading, free, or connate somewhat high up. Petals shorter than the sepals. Lip on the upper side of flower, contracted at the base, jointed with the foot of the column, or mobile, incumbent on the foot ; entire or plumose-ciliate, recurved, often variously thickened. Column erect, generally short, produced at the base into a rather long foot, 2-winged above; clinandrium short, posteriorly often produced into a tooth which bears the anther, anteriorly 2 -armed, 2-toothed or 2-angled, and sometimes the wings of the column below the arms appendaged on both sides with a somewhat small tooth. Anther terminal, opercular, incumbent, flattish-hemispherical or obtusely conical, generally 2-celled; pollinia waxy, normally four, segregated in pairs in the cells, 
sometimes one pair very small or wanting, without an appendage, or more rarely cohering by a small, subgranular viscid hody. Capsule globose, oroid or oblong, not beaked.

Species about 550, scattered for the most part through the tropical regions of Africa and Asia, very few in West Indies, South America or Australia, one in New Kealand.

Flower-stalk not swollen, petals ciliate....... 1. B. jamaicense.

Flower-stalk swollen, petals glabrous ......... 2. B. pachyrrhachis.

1. B. jamaicense Cogn. in Fedde Repert. vii. 122 (1909); with flowering-stalk not swollen, petals ciliate, lip pilose below. (Pl. 23, f. 8-14.)

On trees; in fl. and fr. March; near Tweedside, south St. Andrew, $2500 \mathrm{ft} .$, Harris! Fl. Jam. 7998.

Plant 4 in. high. Pseudobulbs small, densely clustered, globose, 1-leaved, 6-8 mm. 1. Leaves leathery, oblong-lanceolate, acute, 1-31 $\mathrm{cm}$. 1., 4-8 mm. br. Scape 6-10 cm. l., much longer than the leaf, very slender, with a few short (5-6 mm. 1.) obtuse sheaths at intervals; the upper portion $(2-3 \mathrm{~cm}$. 1.) a spike with slender rachis. Flowers reddish, few (4-10), lax, small, $\frac{1}{6}-\frac{1}{5}$ in. 1. Bracts ovate, acute, $2-3 \mathrm{~mm}$. 1., about as long as ovary. Sepals 3-nerved ; median concave, ovate, acute, 4.5-5 mm. l., $2 \mathrm{~mm}$. br.; lateral connate nearly to apex, elliptical, $5 \mathrm{~mm}$. 1., $3 \mathrm{~mm}$. br. Petals 1-nerved, linear, tapering to an acute apex, ciliate, $3-4 \mathrm{~mm}$. 1 , -7-1 mm. br. Lip shortly clawed, somewhat thick, oblong-elliptical, with sides recurved, obtuse, papillose, pilose below, $3 \mathrm{~mm}$. l. Column very short, $.5 \mathrm{~mm}$. 1., posterior tooth short, bristle-like, lateral subulate, erect, as long as column, branching at apex. Capsule obovoid, 5-6 mm. 1 .

2. B. pachyprhachis Griseb. Fl. Br. W. Ind. 613 (1864); flowering-stalk swollen, petals and lip glabrous.-Cogn. in Symb. Ant. iv. 179. Pleurothallis? pachyrachis A. Rich. Fl. Cub. ii. 234 (1853), Ic. t. 74 (1863). Bolbophyllaria pachyrrhachis Reichb. f. in Walp. Ann. vi. 241 (1861). (Pl. 23, f. 15, 16.)

On trees; in fl. and fr. Jan. ; St. Elizabeth, J.P. 525, Syme! Belvedere, Hanover, Harris! Fl. Jam. 7634.-Cuba, Porto Rico, Trinidad.

Plant 4-18 in. high. Pseudobulbs with two or more scarious sheaths, on a creeping rhizome, ovoid-conical, 4-winged, 2-leaved, 5-2 cm. 1 . Leaves somewhat leathery, ligulate, obtuse, 7-19 cm. 1., 8-23 mm. br. Scape 10-45 cm. 1., much longer than the leaves, with short $(8-10 \mathrm{~mm}$. 1.) obtuse sheaths at intervals; the upper portion $(5-30 \mathrm{~cm}$. 1.) a spike with more or less swollen and fleshy rachis. Flowers many, lax, small, $\frac{1}{6}-\frac{1}{5}$ in. 1. Bracts very broad at the clasping base, triangular, obtuse, 3-4 mm. l., a little shorter than the flower; two, ovate, acute, at apex of ovary, $1 \mathrm{~mm}$. l. Sepals 3-nerved, median concave, ovate, very acute, 4.5-5 $\mathrm{mm}$. 1.; lateral connate at base, ovate, acuminate, 4.3-5 mm. l., 1.5-2 mm. br. Petals 1-nerved, oblong-elliptical, obtuse, 1.75-2 mm. l., -9-1.2 mm. br. Lip thick and fleshy, 3-angled in section, undivided, with a very thick, 3-angled claw, disk at right angles to claw, oblongelliptical, obtuse, margin entire and glabrous, slightly keeled at back but not serrate, disk with a longitudinal furrow in the middle; claw about $1 \mathrm{~mm}$. l., disk 2-2.4 mm. l. Column short, posterior tooth small, lateral teeth longer, subulate, slightly incurved, shorter than the petals, 1.5-1.75 mm. 1. Capsule ellipsoidal, with six broad keels, $8 \mathrm{~mm}$. 1., $5 \mathrm{~mm}$. br. 
48. MAXILLARIA Ruiz \& Pavon.

Epiphytic herbs. Stems sometimes very short on the rhizome becoming thickened into a fleshy pseudobulb with one or two leaves, sometimes elongated at the apex of the rhizome with the leaves close together in two ranks. Leaves leathery, thin or somewhat fleshy, veins thin except the central nerve. Scapes or peduncles at the base of the pseudobulbs or in axils of the leaves, solitary, with two to numerous sheaths, always 1-flowered. Flowers large or medium-sized. Sepals nearly equal, free amongst themselves, lateral adnate at the base to the foot of the column, generally forming a chin, not very prominent, spreading or more rarely somewhat erect. Petals similar to the sepals or sometimes smaller. Lip concave, erect at the apex of the foot of the column with a very short inflexed claw; lateral lobes erect, median ovate-oblong spreading, shorter than the sepals; disk with a tubercle or naked. Column with a short foot, erect, often slightly incurved, thick, semiterete, not winged, anteriorly concave ; clinandrium somewhat thick, concave, entire. Anther terminal, opercular, incumbent, conical or semiglobose, 1-celled or imperfectly 2-celled, often pubescent; pollinia 4, ovate, compressed, without an appendage, on the dehiscence of the anther attached by a flat, short stalk, with a scale-like gland. Capsule ovoid or obovoid-oblong, erect, not beaked.

Species about 240, natives of tropical America from the West Indies and Mexico to Brazil.

Pseudobulbs conspicuous.

Pseudobulbs clustered, ovoid-cylindrical, with membranous sheaths ........................... 1. M. rufescens.

Pseudobulbs distant, ellipsoidal-compressed, with hard bases of foliaceous sheaths 2. M. alba.

Pseudobulbs poorly developed and inconspicuous, bases of leaves thickened 3. M. sessilis.

1. M. rufescens Lindl. in Bot. Reg. under t. 1802 (1835) \& $t$. 1848; pseudobulbs clustered, ovoid-cylindrical, with membranous sheaths; lip yellow with numerous purple spots, distinctly 3-lobed, lateral lobes springing from a little below middle of lip, triangular-falcate, subacute, terminal lobe much larger, broadly oblong, emarginate, disk with an oblong callus half length of lip.-Reichb. f. in Saund. Ref. Bot. ii. under $t .79$ \& t. 133 ; Griseb. Fl. Br. W. Ind. 626 ; Cogn. in Fl. Bras. iii. pt. 6, 12. (Pl. 25, f. 13-16.)

On trees; in fl. May; cult. in Hope Gardens from plant collected at Lancaster, Harris, drawing by Miss H. Wood!-Trinidad, Costa Rica, Colombia, Venezuela, B. Guiana, Brazil.

Plant 6-8 in. high. Stem, primary almost obsolete. Pseudobulbs 
$3-3.5 \mathrm{~cm} .1 ., 1 \cdot 5 \mathrm{~cm}$. br., at first covered with three or more scarious membranous sheaths (to $3 \mathrm{~cm}$. 1.) with one leaf at apex. Leaves ligulate, shortly complicate at base, apex somewhat abruptly acute, $14-18 \mathrm{~cm}$. l., $2 \mathrm{~cm}$. br. Peduncles 2-3 cm. 1., several, 1-flowered, with scarious sheaths at base; pedicel shorter than peduncle or ovary, with one sheathing bract $(18 \mathrm{~mm}$. 1.). Flowers creamy-yellow, perianth nearly 1 in. l. Ovary and pedicel together $3 \mathrm{~cm}$. 1. Sepals oblong, about $2 \mathrm{~cm}$. l., lateral spreading. Petals somewhat oblong, nearly as long as median sepal. Lip nearly as long as sepals.

Var. minor Fawc. \& Rendle in Journ. Bot. xlviii. 108 (1910); flowers about half the size; disk of lip with a linear-tapering deep crimson callus $\frac{3}{4}$ length of lip, and two nerves on each side. (Pl. 25, f. 17-19.)

On trees and rocks; in fl. Aug.-Nov.; Mt. Moses, 2500 ft., J.P. 2009, Syme! Mabess River, 3000 ft., Havis! Fl. Jam. 7615.-Cuba, tropical America.

Pedicel with one sheathing bract $(7-8 \mathrm{~mm}$. 1.). Flowers, perianth $\frac{2}{5}$ in. 1 . Sepals $1-1 \cdot 3 \mathrm{~cm}$. $1 ., 4 \cdot 5 \mathrm{~mm}$. br.

2. M. alba Lindl. Gen. \& Sp. Orch. 143 (1832); pseudobulbs distant, ellipsoidal, compressed, with hard bases of foliaceous sheaths; lip somewhat fleshy, elliptical, indistinctly 3-lober, terminal lobe oblong-ovate, slightly hooded and thickened at apex, callus extending from base to beyond the middle.Griseb. op. rit. 626. Dendrobium album Hook. Exot. Fl. t. 142 (1823-1827). (Pl. 25, f. 1-6.)

On trees and banks; in fl. Aug.-March; Sloane Herb. iv. 116* \& Ic! Wiles! March! near Cedarhurst; Mt. Moses; J.P. 465; Morris! Trelawney, Miss T. M. Barrett! Lancaster, 2500 ft., Harris! Fl. Jam. 7209.-Cuba, Trinidad, Guatemala, B. Guiana, Surinam, Brazil.

Stem stout, $7 \mathrm{~cm}$. and more long. Pseudobulbs to 4 or $5 \mathrm{~cm}$. 1 ., covered at first with several sheaths, with one leaf at apex. Sheaths in two ranks, imbricate, the outer triangular, acute, short, the inner becoming gradually foliaceous. Leaves ligulate, obliquely and slightly emarginate, to $2 \cdot 5 \mathrm{dm}$. and more, $1 \cdot 5-2 \mathrm{~cm}$. br. Peduncles several, solitary in the axil of a sheath, 1-flowered, bearing several two-ranked scarious narrow acuminate bracts. Flowers, perianth rather more than $\frac{3}{4}$ in. l., white. Ovary with pedicel (if any) $2-3 \mathrm{~cm}$. 1. Sepals somewhat leathery, 9-nerved, oblong-ligulate, acuminate, about $2 \mathrm{~cm}$. l., nearly $5 \mathrm{~mm}$. br. Petals 9-nerved, oblong-elliptical, somewhat acute, $1 \cdot 6 \mathrm{~cm}$. $1 ., 4 \mathrm{~mm}$. br. Lip 1.1-1.2 cm. 1., 4.5 mm. br. Column $8.5 \mathrm{~mm}$. 1. Capsule cylindricaltapering, $3 \mathrm{~cm}$. 1., bearing the hard persistent column.

3. M. sessilis comb. nov.; pseudobulbs poorly developed and inconspicuous, bases of leaves thickened; lip somewhat fleshy, elliptical, with a narrow terminal portion, obtuse, and with a broad thickened margin, disk with a broad densely tomentose band along the central line to the apex.-M. crassifolia Reichb. $f$. Bonpl. ii. 16 (1854); Griseb. op. cit. 626 . Epidendrum sessile $S w$. Prodr. 122 (1788). Heterotaxis crassifolia Lindl. in Bot. Reg. 
t. 1028 (1826); Lodd. Bot. Cab. t. 1651. Dicrypta Baueri Lindl. Gen. \& Sp. Orch. 44 \& 152 (1830 \& 1832); Bauer \& Lindl. Ill. Orch., Gen. t. 5. (Pl. 25, f. 7-12.) Type in Herb. Mus. Brit.

On rocks and trees; in fl. Aug.-March; Swartz! McNab! Petersfield, St. Mary, Purdie! Springfield, Wullschlaegel, 1087a! Wag Water R., J.P. 2 \& 2399, Morris! \& Syme! Trelawney, Miss T. M. Barrett! Belvedere, Hanover, $500 \mathrm{ft}$; Newcastle Road, $1500 \mathrm{ft}$. ; Tweedside, south St. Andrew, 2500 ft.; Harris! Fl. Jam. 7681, 7841, 9006.-Cuba, Costa Rica, Mexico, Venezuela, Brazil.

Plant 10-14 in. high. Stem very short, almost obsolete, buds springing from base of old plant. Pseudobulbs oblong, much compressed, with one leaf at apex, $2 \cdot 5 \mathrm{~cm} .1 ., 1 \cdot 5 \mathrm{~cm}$. br. Leares radical (except one at apex of pseudobulb), in two ranks, 3-edged, complicate below, sheathing and much thickened at base, jointed above the sheath, the outer lower leaves with very shortly developed blade; blade of inner leaves ligulate, oblique at apex and with a very short curved apiculus, keeled, 18-29 cm. 1., 17-26 mm. br. Peduncles 8 or $9 \mathrm{~mm}$. l., several, two or three in a cluster from the axil of each leaf and enclosed by its sheath, each cluster enclosed by three or four scarious bracts, about $1.5 \mathrm{~cm}$. 1.; each peduncle with three sheathing bracts from base; pedicel as long as peduncle, solitary, 1-flowered, with one sheathing bract. Sepals leathery, oblong, tapering to a thickened and slightly hooded apex; lateral $1.5 \mathrm{~cm}$. 1., $5 \mathrm{~mm}$. br.; median concave, $1.4 \mathrm{~cm}$. $1 ., 5 \mathrm{~mm}$. br. Petals somewhat fleshy, oblanceolate, somewhat acute, $1.25 \mathrm{~cm}$. 1 , about $3 \mathrm{~mm}$. br. Lip $1.2 \mathrm{~cm}$. $1 ., 4.5 \mathrm{~mm}$. br. Column $8 \mathrm{~mm}$. 1. Capsule ellipsoidal with six broad keels and furrows, $2 \cdot 3 \mathrm{~cm}$. 1 .

49. NEO-URBANIA Fawc. \& Rendle.

Herb, on trees or procumbent on shady stony banks, with long leafy branching stems, the lower internodes rooting. Leaves alternate, narrow, with persistent tightly adpressed sheathing stalks. Flowers stalked, rather small, few, clustered in the axils of the leaves. Sepals nearly equal in length and breadth, connivent, median free, lateral adnate to the foot of the column, forming a chin under the lip. Petals similar to the sepals. Lip 3-lobed, jointed to the foot of the column, and incumbent on it, the lateral lobes above the base curved in towards the column, the blade oval, recurved-spreading. Column very short, erect, not winged, produced at the base into a long foot; clinandrium slightly concave, entire, the median line raised, and ending in the slightly pointed rostellum; anther terminal, opercular, incumbent, hooded, 2-celled; pollinia 4, waxy, pyriform, equal, compresser laterally, collateral in pairs in the cells, not appendiculate, free. Capsule long, oblong, shortly beaked.

Differs from Ponera in its free simple pollinia and axillary flowers; from Pleuranthium in the lip, which is free from and attached to the foot of the column, and in the pollinia; from Camaridium in habit, in character of the pollinia (absence of gland and stipes), and in the connivent perianth. 
Dedicated to Prof. Dr. Ignatius Urban in recognition especially of his work on the botany of the West Indies.

Species 1, a native of Jamaica and Cuba.

N. adendrobium Fawc. \& Rendle in Journ. Bot.xlvii. 125 (1909). Ponera adendrobium Reichb. f. in Flora xlviii. 278 (1865); under Pleuranthium Benth. \& Hook.f. Gen. Pl. iii. 526 (1883); Camaridium parviflorum Fawc. in Symb. Ant. i.472 (1900). (Pl. 24.)

In fl. and fr. Sept.-March; near Cedar Hursé (high up on trees), J.P. 480, Morris! Lancaster, $2500 \mathrm{ft}$. (on stony banks under shade) ; Harris ! F1. Jam. 7650, 7696, 7874.-Cuba.

Plant several feet in length; internodes $2-4 \mathrm{~cm} .1$. Leaves linearlanceolate, subacuminate, $12-15 \mathrm{~cm} .1 ., 2 \mathrm{~cm}$. br. Peduncle $7 \mathrm{~mm}$. 1 . Pedicel $7.5 \mathrm{~mm}$. 1. Bracts scarious, the one subtending the cluster, $1.1 \mathrm{~cm} .1$; that at the base of the peduncle $1 \mathrm{~cm} .1$; that at the base of the pedicel $8 \mathrm{~mm}$. l.; bracteole below the ovary $1.3 \mathrm{~mm}$. l. Ovary $8 \mathrm{~mm}$. 1 . Flouers white, perianth about $\frac{1}{5}$ in. 1 . Sepals $5.5 \mathrm{~mm}$. l., subacuminate, median oblong, lateral oblong-elliptical. Petals $5 \mathrm{~mm}$. l., oblong, acuminate, 3-nerved. Lip middle lobe, $3 \mathrm{~mm}$. l., nearly $3 \mathrm{~mm}$. br., margin undulate, apex emarginate; disk at the base with two calli, 1-nerved, at the back 3-nerved, callose at the base, and with a thick apiculus below the apex. Column $2 \mathrm{~mm}$. l. ; foot $2 \mathrm{~mm}$. l. Capsule (unripe) $1.6 \mathrm{~cm} .1$., with slightly prominent ribs.

\section{ORNITHIDIUM Salisb.}

Epiphytic herbs. Stems leafy, covered with overlapping sheaths in two ranks, and emitting here and there lateral or sublateral 1-2-leaved pseudobulbs. Leaves thinly leathery, in $O$. vestitum only from pseudobulb, elongate, in $O$. proliferum short, those from stem, in two ranks, jointed with the sheath. Peauncles 1-flowered, clustered at the axils. Flowers small. Sepals about equal, free, erect or spreading, acute, the lateral scarcely forming at the base a very short chin. Petals similar to the sepals but smaller. Lip sometimes erect from the base of the columin with which it is continuous or very shortly connate, sometimes attached at the apex of the very short foot, erect from a claw which is very shortly horizontal; lateral lobes erect, parallel, often embracing the column, the median spreading, undivided. Column short or a little elongated, thick, without a foot or with a very short foot, not winged ; clinandrium obliquely truncate. Anther terminal, opercular, incumbent, helmet-like, imperfectly 2-celled; pollinia 4, waxy, ovoid, sometimes free, sometimes attached to a linear stalk, with a small gland. Capsule oblong-ellipsoidal.

Species about 44, natives of tropical America from the West Indies and Mexico to Brazil.

Leaves, one on each pseudobulb, none on stem .......... 1. O. vestitum.

Leaves, two on each pseudobulb, in two ranks on stem 2. O.proliferum.

1. 0. vestitum Reichb. f. in Walp. Ann. Bot. vi. 491 (1863); Griseb. Fl. Br.W.Ind. 625 ; Cogn. in Fl. Bras. iii.pt. 6, 95 (in part). 
Epidendrum vestitum Sw. Prodr. 124 (1788). Cymbidium vestitum Sw. in Nov. Act. Ups. vi. 70 (1779) \& Fl. Ind. Occ. 1448 ; Lindl. Gen. \& Sp. Orch. 168. (Pl. 26, f. 1-4.)

On trees, and rocks among peat; in fl. and fr. Aug.-March; "Jamaicæ temperatioris," Swartz! Radnor, Purdie! Springfield, Wullschlaegel, 1088! J.P. 24, Morris! Trelawney, Miss T. M. Barrett! Moneague, Lady Blake! Eillen Aire, Moy Hall, Sullivan! Cold Spring, Moore! Shooters Hill, Manchester, Scharschmidt! Cinchona, $5000 \mathrm{ft}$.; Lancaster, $2500 \mathrm{ft}$. ; Mabess River, 3900 ft.; Vinegar Hill, 3900 ft.; Harris! Fl. Jam. 7210, 7567, 7654, 7839, 9008, 9552, 10,100.-Cuba, Venezuela, Surinam, Brazil, Peru.

Stem to $3 \mathrm{dm}$. l., branching, decumbent and rooting, covered with scales, which are triangular-ovate, acute, sheathing at base, imbricaring, dry and becoming scarious, $1-1.5 \mathrm{~cm}$. 1. Pseudobulbs oblong-ellipsoidal, compressed, 1-leaved, 2 to nearly $3 \mathrm{~cm}$. 1 . Leaves lanceolate-ligulate, apex acute or obtuse, shortly attenuated at the base, middle nerve prominent below, 1-2 dm. 1., 1.5-2 cm. br. Peduncles clustered in the sheathing scales of the stem just below each pseudobulb, many-jointed, with a sheathing, spathaceous bract at each node. Sepals, lateral 5-nerved, broadly elliptical, apex acute, thickened, $5 \mathrm{~mm}$. 1., $3 \mathrm{~mm}$. br.; median 7-nerved, elliptical, apex with a thickened apiculus, $5 \cdot 5 \mathrm{~mm}$. $1 ., 2 \cdot 4 \mathrm{~mm}$. br. Petals 5-nerved, broadly lanceolate, acute, $4.5 \mathrm{~mm} .1 ., 1.8 \mathrm{~mm}$. br. Lip broadly 3-lobed, clawed, lateral lobes rounded, median larger than lateral, shortly ovate, thickened at the apex with a dorsal apiculus, $4 \mathrm{~mm}$. l. Column 1.75 mm. 1. Capsule smooth, $1 \mathrm{~cm} .1$.

2. 0. proliferum comb. nov. Epidendrum proliferum $S w$. Prodr. 124 (1788) \& Ic. ined. $t$. 47. Cymbidium proliferum Sw. in Nov. Act. Upsal. vi. 71 (1799) \& Fl. Ind. Occ. 1450. Isochilus prolifer R. Br. in Ait. Hort. Kew. v. 209 (1813), non. Lindl. in Bot. Reg. t. 825 (Scaphyglottis prolifera Cogn.). (Pl. 26, f. 5-7.) Type in Herb. Mus. Brit.

On rocks and trees, amongst moss; in fl. and fr. Dec.; "mont. Liguan. nov.," Swartz! near Cedar Hurst, J.P. 2121, Syme! Harris! Lancaster, Yarris! Fl. Jam. 7566.

Stem $\cdot 5-2 \mathrm{dm}$. 1., decumbent and rooting below. Pserdobulbs obovateellipsoidal, compressed, 2-leaved, $1 \cdot 5-2 \mathrm{~cm}$. 1. Leaves lanceolate-oblong or oblong, apex obliquely emarginate, apiculate, middle nerve prominent below, those on pseudobulbs narrowed at base, those on stems jointed to strongly compressed sheath, $1 \cdot 5-2 \cdot 5 \mathrm{~cm} .1 ., 4-7 \mathrm{~mm}$. br. Sheaths slightly keeled. Peduncles $7 \mathrm{~mm}$. l., 1-flowered, with three sterile bracts at base; pedicel very short, with one floral bract. Flowers purple, perianth $\frac{1}{3} \mathrm{in}$. 1. Ovary cylindrical, 6-furrowed, very long. Sepals with three strong nerves and four faintly indicated, slightly keeled, obtuse, $8 \mathrm{~mm}$. l., $3 \mathrm{~mm}$. br.; lateral ovate-oblong; median elliptical. Petals 3-nerved, elliptical-oblong, obtuse, $7 \mathrm{~mm}$. l., $2 \mathrm{~mm}$. br. Lip similar to jetals, erect, purple. Column with a short foot, $5 \mathrm{~mm}$. l. Capsule elongate, half-concealed by the sheaths, narrowly spindle-shaped, 6 -furrowed, $1.5 \mathrm{~cm} .1$.

O. coccineum Salisb. is quoted by Grisebach as coming from Jamaica on the authority of Swartz, but we have seen no specimen from Swartz nor any citation of it by him.

51. MACRADENIA R. Br.

Small herbs. Pseudobulbs with one leaf at apex and scarious sheaths at base. Leaves flat, fleshy or leathery. Peduncles short, from base of pseudobulb. Racemes nodding or reflexed, lax. 
Flowers medium-sized. Bracts small. Sepals equal, free, somewhat spreading. Petals a little smaller. Lip continuous with the base of the column, erect; lateral lobes broad, erect, embracing the column, the median spreading. Column erect, not winged, without a foot, furrowed in front, terminated by a thin erect or slightly inclined rostellum; clinandrium behind the rostellum. Anther erect in the bottom of the clinandrium, oblong, produced into a long membranous appendage embracing the rostellum; pollinia 2, waxy, ovoid, distinct, without an appendage, attached to the dilated apex of a long, very narrow stipes, gland small, ovate. Capsule ellipsoidal, tapering to base, shortly beaked.

Species 13, natives of the West Indies, Florida, Guatemala and Surinam.

M. lutescens R. Br. in Bot. Reg. t. 612 (1822); Lindl. Gen. \& Sp. Orch. 195 ; Reichb. Fl. Exot. t. 117 ; Griseb. Fl. Br. W. Ind. 635; Rolfe in Orch. Rev. iv. 357 (excl. syn.) ; Cogn. in Fl. Bras. iii. pt. 6, 111; Ames Orch. S. Fla. 20, t. 11. Rhyncadenia cubensis A. Rich. Fl. Cub. t. 85 (1853). (Pl. 27, f. 7-10.)

On trees; in fl. Nov.-Jan., in fr. Jan.; near Castleton, J.P. 1, 2388, Morris! Syme! Campbell! Blue Mts. Mrs. Maclaverty! Belvedere, Hanover, Harris! Fl. Jam. 7679.-Cuba, Florida, Trinidad, Colombia, Venezuela.

Plant 5-8 in. high. Pseudobulbs slender, narrowly ovoid-cylindrical, 2-5 cm. 1., 5-10 mm. br. Leaf oblong-lanceolate, acute, slightly tapering at base, 10-15 cm. 1., 1.5-3 cm. br. Peduncle shorter than the leaf, sometimes drooping, with a few sheathing acuminate bracts below (1 cm. 1.). Pedicels with ovary 1.5-2 cm. 1., of fruit $\cdot 8-1 \mathrm{~cm} .1$. Bracts triangular, acute, much shorter than ovary, 3-5 mm. 1. Flowers 4-9, dingy yellow with brown or purplish blotches on the inside, shortly stalked, perianth nearly $\frac{1}{2}$ in. l.,, sometimes longer. Sepals membranous, lateral 5-6-nerved, elliptical-lanceolate, acute, somewhat falcate, $1 \mathrm{~cm} .1$,, $3 \mathrm{~mm}$. br.; median 7-nerved, very concave, elliptical, acute, $1.1 \mathrm{~cm}$. 1 . Petals similar to sepals, but 5-7-nerved, elliptical-oblong, acute, somewhat falcate, $9 \mathrm{~mm}$. l., nearly $3 \mathrm{~mm}$. br. Lip roundish-obovate in outline below, $5 \mathrm{~mm}$. l., $6 \mathrm{~mm}$. br., with a narrow reflexed, terminal lobe; disk with three keels along centre as far as base of terminal lobe, and four nerves on each side; terminal lobe linear-lanceolate, 3-nerved, narrower at base than above, margin revolute, $4 \mathrm{~mm} .1 ., 1.5 \mathrm{~mm}$. br. Column thicker above, $4.5 \mathrm{~mm}$. 1., $2 \mathrm{~mm}$. br. above; rostellum linear, about $1.2 \mathrm{~mm}$. 1.; clinandrium membranous, cup-shaped, with the margin irregularly toothed. Anther shortly and imperfectly 2-celled.

\section{IONOPSIS H. B. \& K.}

Epiphytic herbs. Stems leafy, very short, without pseudobulbs. Leaves few, narrow, leathery; sheaths persistent, overlapping, in two ranks. Peduncles 1-3, lateral or subterminal, elongated, thin, rigid, with few sheaths. Racemes slender, lax, simple or branching. Flowers medium-sized, with somewhat 
long stalks. Bracts very small. Sepals of nearly equal length, erect or spreading at the apex; median free, the lateral quite at the base under the lip connate into a short sac. Petals similar to the median sepal but wider. Lip attached to the base of the column, large, expanded, clawed, the claw bearing two pairs of flat calli, broadening above. Column short, erect, thick, anteriorly concave, not winged, without a foot; clinandrium short, truncate. Anther terminal, opercular, incumbent, semiglobose, 1-celled or imperfectly 2-celled, anteriorly shortly produced; pollinia 2, waxy, obovoid-subglobose, without an appendage, attached to a linear stalk, gland scale-like. Capsule oblong or ovoid, without a beak or with only a short one.

Species 9, natives of tropical America from the West Indies and Mexico to Brazil and Peru.

Lip 2-lobed, much longer than the sepals; leaves flat

Lip entire, scarcely longer than sepals; leaves terete ..................................

1. I. utricularioides.

2. I. satyrioides.

1. I. utricularioides Lindl. Coll. Bot. t. 39 A. (1825); leaves flat, linear-ligulate; lip twice as long as sepals.-Lindl. Fol. Orch. Ionops. 2 ; Griseb. Fl. Br. W. Ind. 636 ; Cogn. in Symb. Ant. iv. 180. I. tenera Lindl. in Bot. Reg.t. 1904 (1836), in Paxt. Fl. Gard. ii. 13, f. 14, \& Fol. Orch. Ionops. 2. Epidendrum utricularioides Sw. Prodr. 122 (1788). Dendrobium utricularioides Sw. in Nov. Act. Upsal. vi. 83 (1799) \& Fl. Ind. Occ. 1531. (Pl. 27, f. 4-6.) Type in Herb. Mlus. Brit.

On trees; in fl. Jan.-June; Swartz! Wright! Shakespear! Masson ! Wag Water River, St. Mary, J.P. 2284, Morris! Syme! Manchester ; Mona, St. Andrew, 700 ft.; Belvedere, Hanover, 500 ft.; Harris! Fl. Jam. 7635.-Cuba, Hispaniola, Porto Rico, Martinique, St. Vincent, Trinidad, Guatemala, Mexico, Brazil, Peru.

Plant 7 in. to nearly $2 \mathrm{ft}$. high, occasionally with minute pseudobulbs. Leaves leathery, jointed to the sheathing base, 5-12 cm. l., 5-12 mm. br., with a few scarious sheaths on the rhizome below the leaves. Panicle 20-50 cm. l., much longer than the leaf, with a few distant adpressed sheaths (5-7 $\mathrm{mm}$. 1.). Bracts minute, triangular, acute, 1.5-2 mm. 1. Flower's white or pale rose-colour, variegated or with purple veins; perianth about $\frac{1}{4}$ in. 1., lip over $\frac{1}{2}$ in. l. Sepals 3 -nerved; lateral broadly lanceolate, acute, united at base into a very short simple obtuse sac, $6 \mathrm{~mm}$. l., $2 \mathrm{~mm}$. br.; median oblong, obtuse, $4.5 \mathrm{~mm}$. 1., $2 \mathrm{~mm}$. br. Petals 3-nerved, oblong, obtuse, very shortly apiculate, $4.5 \mathrm{~mm}$. 1 ., $2 \mathrm{~mm}$. br. Lip 2-lobed above, tapering below to base, with 2 pairs of wing-like calli on the narrow base opposite the column, the lower pair larger and less fleshy than the upper, $10-13 \mathrm{~mm}$. l., and as broad or broader. Column very short, $2 \mathrm{~mm}$. 1. Capsule ellipsoidal, beaked, $2 \mathrm{~cm}$. l., $7 \mathrm{~mm}$. br.

2. I. satyrioides Reichb. f. in Walp. Ann. vi. 683 (1861); leaves terete, subulate; lip a little longer than sepals. I. testiculata Lindl. Gen. \& Sp. Orch. 193 (1833) \& Fol. Orch. 
Ionops. 1 ; Griseb. loc. cit. I. teres Lindl. in Bot. Reg. xxiv. Misc. 181 (1838), \& Fol. Orch. Ionops. 2. Epidendrum satyrioides Sw. Prodr. 123 (1788). Dendrobium testiculatum Sw. in Nov. Act. Upsal. vi. 83 (1799) \& Fl. Ind. Occ. 1533. (Pl. 27, f. 1-3.) Type in Herb. Mus. Brit.

On trees; in fl. April-Oct., in fr. April-Jan.; Swartz! Chepstow, J.P. 462, Morris! Spanish Town, Hay! near Hope Bay, Moore! Swift River, $500 \mathrm{ft}$; Belvedere, Hanover, $500 \mathrm{ft}$; Troy, $1500 \mathrm{ft} . ;$ Harris! Fl. Jam. $7621,8666,10,456,10,463$.- Hispaniola, Trinidad.

Plant 2 in. to a foot high, varying much in size. Leaves $3-14 \mathrm{~cm}$. 1., 2-3 $\mathrm{mm}$. br. Raceme or panicle, $3-15 \mathrm{~cm}$. l., generally longer than the leaf, with a few distant lanceolate acute or acuminate adpressed sheaths (2-8 $\mathrm{mm}$. 1.), and sometimes with a few small leaves. Bracts small, triangular, acute, half-clasping, concave, $1 \cdot 5-3.5 \mathrm{~mm}$. 1 . Flowers creamywhite, perianth $\frac{1}{4}$ in. 1. Sepals, lateral 3-nerved, oblong-lanceolate, acute, united (for about $2 \mathrm{~mm}$.) at the base and forming a 2-lobed sac, $7 \mathrm{~mm}$. 1., $2 \mathrm{~mm}$. br. ; median, 5-nerved, ovate-lanceolate, acute, a little shorter than the lateral, $2 \cdot 3 \mathrm{~mm}$. br. Petals 5 -nerved, ovate-oblong, margin slightly undulate and curled, apex obtuse, $7 \mathrm{~mm}$. l., nearly $3 \mathrm{~mm}$. br. Lip $8.5 \mathrm{~mm}$. 1., obovate, long-tapering to base, with 5 nerves branching above, margin slightly undulate, apex obtuse, undulate and curled and so it may appear to be either 2-lobed or 3-lobed, with two minute calli at the outer edge of the base, and on the disk two lamellate calli which extend to about $2 \mathrm{~mm}$. from base. Column short, $2 \mathrm{~mm}$. l., thicker above. Capsule ellipsoidal, tapering to base, $13-16 \mathrm{~mm}$. 1., $5 \mathrm{~mm}$. br.

\section{COMPARETtia Popp. \& Endl.}

Epiphytic herbs. Stem very short with two or three sheaths, becoming thickened into a small fleshy pseudobulb with one leaf. Leaf leathery. Scapes at the base of the pseudobulbs, erect, elongate, simple. Flowers laxly racemose, distinctly stalked. Bracts small. Sepals, all of equal length, erectspreading, median free, lateral connate and produced at the base into a long spur free from the petals. Petals as long as the sepals but broader. Lip continuous with the base of the column, produced at the base into two long linear spurs, included within the spur of the sepals; spreading, much longer than the sepals, very broad, emarginate, clawed, the claw broadening below into a rounded base. Column erect, somewhat thick, semiterete, furrowed anteriorly, not winged, without a foot; clinandrium short, oblique, posteriorly somewhat acute. Anther terminal, opercular, incumbent, very convex, 1-celled; pollinia 2, waxy, broadly ovoid, furrowed, without an appenaiage, attached to a linear wedge-shaped stalk, gland ovate. Capsule ovoid or oblong, acute-angled, beaked.

Species 6, natives of the West Indies and the Andes, from Central America to Peru.

C. falcata Poepp. \& Endl. Nov. Gen. \& Spec. i. 42, t. 73 (1836); Hook. in Bot. Mag. t. 4980 ; Griseb. Fl. Br. W. Ind. 636 ; 
Lindenia iv. 41, t. 163 ; Williams Orch. Alb. viii. t. 359; Cogn. in Symb. Ant. iv. 181 \& in Fl. Bras. iii. pt. 6, 181, t. 42, f. 2. (Pl. 28, f. 10-15.)

On trees; in fl. Nov.-March; Manchester, Purdie! St. Ann, Prior! J.P. 25, 2015 (partly), Morris! Syme! Greenhill Wood, Moore! Greenwich, Watt! Mt. Diabolo, 2300 ft.: Lancaster, 2500 ft.; Harris! Fl. Jam. 9009. - Cuba, Porto Rico, Costa Rica, Guatemala, Colombia, Venezuela, Ecuador, Bolivia, Peru.

Plant 6-15 in. high. Pseudobulbs small, slender, $1 \cdot 5-2 \cdot 5 \mathrm{~cm} .1$, 4-5 mm. br.; sheaths triangular-lanceolate, $2 \cdot 5-4 \cdot 5 \mathrm{~cm}$. l. Leaf somewhat leathery, oblong-elliptical to oblong-ligulate, obtuse, apiculate, $5-18 \mathrm{~cm} .1 ., 1 \cdot 2-3 \cdot 8 \mathrm{~cm}$. br. Scape 1-3 dm. 1., much longer than the leaf, simple or occasionally branching, with a few distant adpressed triangular acuminate or obtuse sheaths $(4-10 \mathrm{~mm}$. 1.). Pedicels with ovary 1-1.5 cm. 1 . Bracts triangular, acute, clasping, 3-4 mm. l. Flowers bright pink or light crimson, lip $\frac{1}{2}$ in. 1 . Sepals concave, $10 \mathrm{~mm}$. 1., lateral connate, oblong, tapering to an obtuse apex, 5-nerved; median oblong, acuminate, 5-nerved; spur $13 \mathrm{~mm}$. 1. Petals 7-nerved, obovate-elliptical, abruptly acute, 8-10 $\mathrm{mm} .1 ., 5 \mathrm{~mm}$. br. Lip half as long again as the sepals, $15 \mathrm{~mm}$. 1., and nearly as broad, mid-vein forming a wing-like callus in the lower half of the claw. Column $5 \mathrm{~mm}$. 1 .

\section{TRICHOPILIA Lindl.}

Epiphytic herbs, pseudobulbs with one leaf. Leaf fleshy, erect, at the base folded upon itself. Scape short, leafless, with few sheaths. Sepals subequal, free, narrow, somewhat erect. Petals somewhat similar to sepals. Lip adnate to base of column, spreading. Clinandrium hooded, large, membranous. Anther within the clinandrium, opercular, incumbent, 1-celled; pollinia 2, obovoid-oblong, without appendage, but affixed by a strap-shaped stipes with a small gland. Capsule ovoid-ellipsoidal.

Species about 27 , natives of warmer parts of America, chiefly in Colombia, Central America and Mexico, with two species in the West Indies.

T. jamaicensis Fawc. \& Rendle in Journ. Bot. xlviii. 107 (1910). (Pl. 29, f. 1-3.) Type in Herb. Mus. Brit. \& Jam. Herb.

On trees; in fl. Sept.; Mansfield, near Bath, Harris! Fl. Jam. 7697.

Plant 6 or 7 in. high. Pseudobulb narrowly cylindrical, scarcely swollen, 1-2 cm. l., about $2 \mathrm{~mm}$. br. Leaf linear, subterete and tapering above, 11-17 cm. 1., about $4 \mathrm{~mm}$. br. Scape about $2.5 \mathrm{~cm}$. 1.; sheath nearly $2 \mathrm{~cm} .1$. Bracts elliptical-oblong, acuminate, $10-14 \mathrm{~mm}$. 1., about $4 \mathrm{~mm}$. br. Pedicel and ovary $1 \mathrm{~cm} .1$.; pedicel of $\mathrm{fr} . \cdot 5 \mathrm{~cm} .1$. Flowers, perianth nearly $\frac{3}{4}$ in. l. Sepals 3-nerved, with a few undulating pinnate nerves; lateral, linear-lanceolate, slightly folded on itself, forming a keel which extends separately as an acute projection beyond the apex, $19 \mathrm{~mm}$. l., barely $2.5 \mathrm{~mm}$. br.; median 4-nerved, slightly reticulate-nerved, ligulate, acuminate, $17 \mathrm{~mm}$. 1., $2.5 \mathrm{~mm}$. br. Petals with nerves as in lateral sepals, similar to median sepal, but a little shorter and broader, $16 \mathrm{~mm} .1 ., 3 \mathrm{~mm}$. br. Lip, general outline bruadly oval-elliptical, somewhat spoon-shaped, obscurely 3-lobed, apex abruptly acute, saccate below, margin denticulate- 
eroded, 15-17-nerved, nerves branching, at baso on inside 3 nerves prominent and eallose, forming the imner walls of two shallow pockets, $14 \mathrm{~mm}$. 1., about $10 \mathrm{~mm}$. br. Column $5 \mathrm{~mm}$. l., thicker upwards, with a small tooth on each side at the base of the clinandrium ; clinandrium $2.5 \mathrm{~mm}$. 1 ., with upper margin truucate and eroded; stigma deeply sunk, margin rounded. Capsule (umripe), 1.5 cm. 1., 5-6 mm. br.

\section{BRASSIA R. Br.}

Epiphytic herbs. Stems short, terminated by a pseudobulb with one or two leaves. Leaves under the pseudobulb few or reduced to sheaths, leathery. Peduncles from under the pseudobulb simple. Racemes lax, generally few-flowered. Flowers rather large. Bracts short or spathe-like. Sepals free, spreading, narrow, acuminate or tailed, the lateral longer. Petals similar to the median sepal or smaller. Lip sessile at the base of the column, spreading, flat, undivided, shorter than the sepals, at the base 2-lamellate. Column short, erect, not winged, without a foot; clinandrium hardly prominent, truncate. Anther terminal, opercular, incumbent, very convex or semiglobose, 1-celled; pollinia 2, waxy, obovoid, without an appendage, attached to a flat oblong or linear stalk.

Species 40, natives of tropical America, from the West Indies and Mexico to Brazil and Peru.

Lip about $1 \frac{1}{2}$ in. 1.; lateral sepals twice as long

1. B. maculata.

Lip about 1 in. 1.; lateral sepals 4 or 5 times as long 2. B. caudata.

1. B. maculata R. Br. in Ait. Hort. Kew. ed. 2, v. 215 (1813); lateral sepals twice as long as the lip ; lip broadly ovate-roundish, acute, contracted into an oblong base; lamellæ tooth-like at apex, hairy at base.-Bot. MIag. t. 1691 ; Lindl. Fol. Orch. Brass. 1 ; Griseb. Fl. Br. W. Ind. 633 ; Salisb. Ic. ined. vi. fol. 580. B. guttata Lindl. in Pl. Hartw. 94 (1842). B. Wrayæ Hook. in Bot. Mag. t. 4003 (1843). (Pl. 28, f. 1-6.)

On rocks and trees; in fl. April-June, Oct.; Old England, St. Andrew, Purdie! Fairfield, Wullschlaegel, 1884 bis! Oehler! near Gordon Town, J.P. 6, Morris! Sullivan! Harris! Greenwich, Moore! near Radnor, Miss B. Gosset! Dolphin Head, Harris! Fl. Jam. 10,442.-Cuba, Guatemala.

Plant $1 \frac{1}{2}-2 \mathrm{ft}$. high. Pseudobulbs large, oblong, sometimes contracted below, compressed, 2-edged, 6-10 cm. 1., 2.5-3.5 cm. br. Leaves leathery, broadly ligulate, acute, tapering to base, $10-40 \mathrm{~cm}$. 1., $3-5 \mathrm{~cm}$. br. Peduncle stout, longer than the leaves, with a few distant sheathing bracts, 3.5-6 dm. 1., with 7-14 flowers. Bracts, sterile sheathing, obtuse, distant, 12-20 mm. 1. ; floral triangular, acute, much shorter than ovary, 6-10 mm. l. Flowers large, yellowish-green with brown or purple spots; lip, yellowish-white, $1 \frac{1}{4}-1 \frac{1}{2}$ in. 1., sepals $2-3$ in. 1 . Sepals narrowly linearlanceolate, $4 \cdot 5-7 \cdot 5 \mathrm{~cm}$. 1., 4-6 mm. br. Petals similar to sepals $3-4 \mathrm{~cm}$. l., 4-5 mm. br. Lip 3.5-4 cm. 1., 2.5-3 cm. br.; lamellæ yellow, 5-6 mm. l. Column 5-6 mm. 1., green. 
2. B. eaudata Lindl, in Bot. Reg. t. 832 (1824); lateral sepals very long, very acuminate, generally four or five times as long as lip; lip obovate-oblong, abruptly acuminate, lamellæ thickish, pubescent, with free tooth-like points and two teeth above distinct from the lamellæ.-Lindl. Fol. Orch. Brass. 3 ; Hook. Exot. Fl. t. 179 \& in Bot. Mag. t. 3451; Reichb. Fl. Exot. t. 267 ; Griseb. loc. cit.; Cogn. in Fl. Bras. iii. pt. 6, 257, t. 58. Helleborine ramosissima \&c. Plum. Nov. Pl. Amer. Gen. Cat. 9 (1703) \& Pl. Amer. (Burm.) t. 177. Epidendrum caudatum L. Sp. Pl. ed. 2. 1349 (1763). (Pl. 28, f. 7-9.)

On trees; in fl. May-Aug.; Macfadyen! Iron River, Golden Spring, J.P. 2281, Syme! St. George, Watt! Clarendon, Tomlinson! Fl. Jam. 10,419.-Cuba, Guatemala, Mexico, Surinam.

Plant 10-15 in. high. Pseudobulbs large, oblong, compressed, 2-edged, 9-12 cm. 1., 2.5-3 cm. br.; at apex 2-leaved. Leaves leathery, broadly ligulate, abruptly acute, tapering towards base, $18-30 \mathrm{~cm} .1 ., 4-5 \cdot 5 \mathrm{~cm}$. br. Peduncle stout, a little longer than the leaves, with a few distant sheathing bracts below, $2 \cdot 5-3 \cdot 5 \mathrm{dm}$. 1., with 9-15 flowers. Bracts oblong-triangular, obtuse, shorter than the ovary, $8-10 \mathrm{~mm}$.1. Flowers large, shortly stalked, greenish-yellow, with brown or purplish spots, lip about 1 in. 1., lateral sepals 2 to 4 or 5 in. l. Sepals linear-lanceolate, very long, very acuminate, 5-6 mm. br., lateral 5-11 cm. l., median 4-5 cm. 1. Petals lanceolate, longacuminate, $2-2 \cdot 5 \mathrm{~cm}$. 1., 4-6 mm. br. Lip $2 \cdot 5-3 \mathrm{~cm}$. 1., 10-12 mm. br. Column 4 mm. 1 .

The floral parts vary much in size. In a living plant brought from Jamaica by IIrs. Longstaff, which flowered at Highlands, Putney, the measurements were as follows: sepals $6 \mathrm{~mm}$. br., lateral $13 \cdot 3 \mathrm{~cm}$. 1 ., median $5.2 \mathrm{~cm}$. 1 ; ; petals $2.3 \mathrm{~cm}$. $1 ., 4.5 \mathrm{~mm}$. br.; lip $2.8 \mathrm{~cm}$. $1 ., 1.2$ $\mathrm{cm}$. br.; column, including anther, $5 \mathrm{~mm} .1$.

\section{ONCIDIUM SW.}

Epiphytic herbs. Stems leafy, generally short or very short, with or without a pseudobulb. Leaves 3 -edged or flat. Peduncles lateral, generally elongated and branching. Racemes lax. Bracts small. Sepals generally almost equal, spreading or reflexed, free or lateral connate nearly to apex. Petals similar to the median sepal or larger. Lip attached to the base of the column, continuous, median lobe spreading, very broad, emarginate or 2-fid ; disk at the apex of the claw remarkably crested or tuberculate. Column short, thick, furnished with petaloid wings, without a foot; clinandrium sometimes very short, truncate, sometimes orate, obliquely erect, entire or anteriorly shortly 2-dentate. Anther terminal, opercular, incumbent, very convex, semiglobose or hooded, 1-celled or imperfectly 2-celled; pollinia 2, waxy, obovoid, without an appendage, attached to a flat stalk, narrow and elongated or broad and very short. Capsule almost always ovoid, oblong or spindle-shaped, more or less beaked. 
Species over 400, natives of tropical America, from the West Indies, Florida and Mexico to Brazil and Bolivia.

Leaves 3-edged, keeled, linear-ligulate; 110 pseudo-

bulb; lateral sopals comnate nearly to apex.

Lip, middle lobe clawed ............................

Lip, middle lobe not clawed.

Middle lobe entire

1. O. guttatum.

Viddle lobe 2-lobed .............................

2. O. triquetrum.

3. O. mulchellum.

Loaves flat; lateral sepals free.

Pseudobulbs wanting, or, if present, small;

leaves very broad, oblong .......................

Pseudobulbs present, leaves ]igulate ..............

4. O. luridum.

5. O. leucochilum.

1. 0. guttatum comb. nox.; leaves 3-edged, kneled, linearligulate; no pseudobulbs; lateral sepals connate nearly to apex ; lip 3-lobed, basilar lobes small, obovate-oblong, terminal lobe many-nerved, kidney-shaped-2-lobed, broadly emarginate, apiculate, clawed, crest with three erect lobes, two behind parallel, the third concave in front.-O. quadripetalum Sw. Vet. Handl. Stockih. xxi. 240 (1800). O. tetrapetalum Willd. Sp. P'l. iv. 112 (1805); Lindl. Gen. \& Sp. Orch. 198 \& Fol. Orch. Oncid. 12 ; Griseb. Fl. Br. W. Ind.631. O. tricolor Hork. in Bot. Mag. t. 4130 (1844). Ophrys bulbis filiformibus ite. Plum. Amer. (Burm.) 177, t. 182, f. 2. Viscum, delphinii flore albo guttato, minus, radice fibrosa Sloane Cat. 120 \& Hist. i. 251, t. 148, f. 2. Epidendrum guttatum L. Sp. Pl. 953 (1753). E. tetrapetalum Jacq. Sel. Stirp. Amer. 230, t. 142 (1763), Ed. pict. t. 216 ; Sw. Fl. Ind. Occ. 1484. Cymbidium tetrapetalum Su. in Nov. Act. Upsal. vi. 74 (1799). C. guttatum Willd. Sp. Pl. ix. 102 (1805). (Pl. 29, f. 18-21.)

On trees; in fl. Sept., Oct., March, April, in fr. March, April; Spanish Town, Sloane, Herb. iv. 122, $123 !$ Nacfadyen! Purdie! Luidas Vale, St. Thomas in Vale, Prior! Mile Gully, J.P. 246, Morris! Chapelton, Fawcett! Mona, $1000 \mathrm{ft}$.; Great Goat Is., $150 \mathrm{ft}$; Harris! Fl. Jam. 7S73, 9017, 10,438. - Cuba, Hispaniola, Porto Rico, St. Thomas, St. Martin, Saba, St. Eustatius, Mexico, Colombia.

Plant 9 in. to $2 \mathrm{ft}$. high. Leaves, margin entire to somewhat serrulate, 5-20 cm. 1., 3-6 mm. br. Peduncle erect, simple or slightly branched above, much longer than the leaves, with a few distant short acute sheaths below (5-9 mm.l.), many-flowered above, 3-6 dm. l. Pedicels with ovary $1 \cdot 3-2 \mathrm{~cm} .1$. Bracts triangular, acute, much shorter than ovary, $3-5 \mathrm{~mm}$. 1 . Flowers variable in colour, lip white tinted with pink, sepals and petals brownish with purplish markings, or flowers dingy-brown with rose-coloured markings, or brilliantly coloured white, green and crimson; lip over $\frac{1}{2}$ in. $1 ., \frac{3}{4}$ in. br. Sepals spathulate, keeled, apex acute, $7 \cdot 5-8 \mathrm{~mm}$. 1.; lateral 5-nerved; median 3-nerved, $3 \mathrm{~mm}$. br. Pctals 3-nerved, in general outline broadly elliptical, broadly clawed, more or less indistinctly 3-lobed, lateral lobes rounded, median love broadly triangular-ovate, apex shortly acute, $7 \cdot 5-8 \mathrm{~mm}$. l., $4 \cdot 5-5 \mathrm{~mm}$. br. Lip varying in size, $10-13 \mathrm{~mm}$. 1., $8 \cdot 5-16 \mathrm{~mm}$. br., lobes $2.5 \mathrm{~mm}$. 1. Colum short, $3.5 \mathrm{~mm}$. 1., with a broad square wing in front of lower half; upper wings falcately ovate, acute, $3 \mathrm{~mm}$. 1 .

O. variegatum Sw., from Hispaniola, differs in its obtuse sepals and emarginate petals. Although this species and $O$. sylvestre Lindl. are quoted by Grisebach from Jamaica wo have not seen any authoritative specimens. 
2. 0. triquetrum $R . B r$. in Ait. Hort. Kev. ed. 2, r. 216 (1813); leaves 3-edged, keeled, linear-ligulate; no pseudobulb; lateral sepals connate nearly to apex; lip 3-lobed, lateral lobes rounded, median lobe much larger, somewhat deltoid, with an apiculate apex, callus at base in front smooth, rounded, behind united with column.-Lindl. Gen. \& Sp. Orch. 205 \& Fol. Orch. Oncid. 11; Hook. in Bot. Mag. t. 3393 ; Griseb. op. cit 631. Epidendrum triquetrum Sw. Prodr. 122 (1788). Cymbidium triquetrum Siv. in Nor. Act. Upsal. vi. 74 (1799) \& Fl. Ind. Occ. 1475. (Pl. 29, f. 12-17.) Type in Herb. Mus. Brit.

On trees; in fl. Jan., Feb., June, in fr. Jan.; Swartz! Bligh ; Macfadyen! Iron River, Golden Spring, J.P. 2286, Syme! near Castleton, Campbell! Spaldings, Sullivan! near Browns Town, 1000 ft.; Belvedere, Hanover, $500 \mathrm{ft.;} \mathrm{Harris!} \mathrm{Fl.} \mathrm{Jam.} 7647$.

Plant 4-8 in. high. Leaves 3-19 cm. 1., 5-10 mm. br. Peduncle erect, simple or slightly branched above, shorter or longer than the leares, with a few distant triangular acute keeled sheaths below $(4 \cdot 5-6 \mathrm{~mm}$. 1.), few-flowered above, $7-18 \mathrm{~cm}$. l. Pedicel with ovary $11-15 \mathrm{~mm}$. 1., of fruit $8 \mathrm{~mm}$. 1. Bracts triangular, acuminate, much shorter than orary, 2-4 mm. l., sterile longer. Flowers variable in colour, white and densely purple-spotted, or rose bordered with white and deeply stained and spotted with crimson, lip nearly $\frac{1}{2}$ in. 1. Sepals slightly concave, oblanceolate, apex acute, 9-10 mm. 1., $4 \mathrm{~mm}$. br. Petals triangular-orate, clawed, apiculate, as long as sepals, 5.5-6 $\mathrm{mm}$. br. Lip a little over $10 \mathrm{~mm}$. l. and nearly as broad. Column very short, $3-4 \mathrm{~mm}$. l., wings somewhat triangular with an acute apex.

3. 0. pulchellum Hook. in Bot. Mag. t. 2773 (1827); leaves 3-edged, keeled, linear-ligulate; no pseudobulbs ; 'ateral sepals connate nearly to apex; lip, median lobe 2-lobed, broader than long, lateral lobes large, rounded, varying from considerably smaller to almost the size of half the median lobe, crest at base of disk consisting of three narrow calli free at apex.-Lindl. Gen. \& Sp. Orch. 206, Fol. Orch. Oncid. 12 \& in Bot. Reg.t. 1787; Griseb. op. cit. 631 ; Cogn. in Fl. Bras. iii. pt. 6, 434. (Pl. 29, f. $4-8$.)

On trees; in fl. April-July; Bancroft! Macfadyen; Blue Mts., 20003000 ft., J.P. 2385, Morris! MIt. Moses, 3500-4000 ft., J.P. 2385, Syme! Browns Town, Levy! Trelawney, Woollett! Noy Hall, Clark! near Troy, $1400 \mathrm{ft}$; Mabess River, 3000 ft.; Harris! Fl. Jam. 7362, 8656._Cuba, B. Guiana.

Plant 1-2 ft. high. Leaves 7-20 cm. 1., 7-15 mm. br. Peduncle erect, simple or occasionally branched, much longer than the leaves, with a very few distant short acute sheaths below (7-12 mm. 1.), many-flowered above, 3-6 dm. 1. Pedicels with ovary 1:5-2 cm. l. Bracts triangular, acute, much shorter than ovary, 3-5 mm. l. Flowers white with rosy tinge, not large, but varying very much in size; lip $\frac{1}{2}-1$ in. 1 . Sepals boat-shaped, lateral, 2-nerved, oblong or oblong-elliptical, tapering to base, 6-10 $\mathrm{mm}$. 1., 3.5-4 mm. br.; median 3-nerved, concave, obovate-cuneate, acute, 5.5-9 mm. 1., 2.5-3 mm. br. Petals 6-10 mm. 1.: 4·5-7 mm. br., roundish-elliptical or obovate, tapering to base, 3-nerved, apex rounded or apiculaie, margin undulate. Lip 1.3-2.5 cm. l., median lobe 1.2-3 cm. br. Column very 
short, $2 \mathrm{~mm}$. 1., wings somewhat oblong-triangular with rounded corners, about $3 \mathrm{~mm}$. 1., $4 \mathrm{~mm}$. br.

4. 0. luridum Lindl. in Bot. Rey. t. 727 (1823); leaves large, leathery, broadly ligulate-oblong; pseudobulbs wanting or occasionally occurring and quite small ; lateral sepals free; lip much narrower at base than above, at base cordate, lateral lobes small, semi-elliptical, margin revolute; median lobe large, shortly clawed, kidney-sliaped, at apex emarginate, sinus between the lobes roundish, rather broad, disk at the base with a thick fleshy crest composed in the lower half of two swollen calli uniting below where there is sometimes a small tubercle on each side, a third thin callus rises between these calli and is continued above with a 2-lobed tubercle on each side.-Lindl. Gen. is Sp. Orch. 201 (excl. syn. L. \& Willd.), Fol. Orch. Oncirl. 41 (excl. syn. L. \& Willd.); Hook. in Bot. Mag. t. 3603 ; Griseb. op. cit. 632. O. luridum var. guttatum Lindl. in Bot. Reg. xxv. t. 16 (1839); Ames Orch. S. Fla. 21. O. carthaginense Sw. in Vet. Handl. Stockh. xxi. 240 (1800) \& Fl. Ind. Occ. 1479 non Auct. O. guttatum Reichl. f. in Walp. Ann. Bot. vi. 782 (1863); Cogn. in Fl. Bras. iii. pt. 6,411. Viscum radice bulbosa majus \&c. Sloane Cat. $119 \&$ Hist. i. 250, t. 148, f. 1. Epidendrum undulatum Sw. Prodr. 122 (1788), non Sims in Bot. Mag. t. 777. (Pl. 29, f. 9-11.)

On trees and rocks; in fl. April-Sept.; near Spanish town, Sloane Herb. iv. 177! Wright! Poore! Masson! Bancroft! Macfadyen! Wag Water River, Purdie! Fairfield, Wullschlaegel, 1095a! March! common, 200-3500 ft., J.P. 2396 Morris! Bog Walk, 300 ft., Lehmann! Cedar Hurst, Watt! Moore! Trelawney (yellow without spots), Miss Jeffrey Smith! Mansfield, Bath, 1000 ft.; Tyre, near Troy, $1500 \mathrm{ft}$. ; Harris! Fl. Jam. 8646.-Cuba, Florida, Dominica, Martinique, St. Lucia, St. Vincent, Grenada, Trinidad, Margarita, Venezuela, Colombia, B. Guiana, Peru, Mexico.

Roots numerous, densely-clustered, long. Sheaths triangular-ovate, acute, 1-12 cm. 1. Leaves 3-5 dm. 1., 6-9 cm. br. Panicle 9-18 dm. l., much longer than the leaves, with several very short adpressed distant sheaths (to $1.5 \mathrm{~cm}$. 1.). Bracts very short, $3-5 \mathrm{~mm}$. 1., triangular, acute. Flowers rather large, long-stalked, segments spreading, margin curledwavy, yellow colour spotted more or less with cinnamon-brown, rarely yellow without any spots, lip about $\frac{3}{4}$ in. 1., and nearly an inch br. Sepals with 3-5 branching nerves of about equal length, rounded at the apex, median obovate-roundish or obovate-oblong, at the base abruptly long and narrowly clawed, 1·4-1.7 cm. 1. (claw 4-5 mm. 1.), 8·5-10 mm. br. ; lateral narrower, broadly elliptical, at the base long tapering into a claw, 1.4-1.7 cm. 1., 7-8 mm. br. Petals with four or five branching nerves, obovate-roundish, or obovate-oblong at the base abruptly, rather broadly, shortly clawed, about as long as sepals or slightly shorter, $1 \cdot 5-1 \cdot 6 \mathrm{~cm}$. 1., 9-10 mm. br. Lip 1.5-2 cm. 1., 1·6-2 $3 \mathrm{~cm}$. br., at base about $8 \mathrm{~mm}$. br. Column short, 4-5 mm. l., wings 2-lobed, anterior lobe hatchet-shaped, posterior small rounded. Capsule very large, obovoid-ellipsoidal, tapering to base, $5 \mathrm{~cm} .1 ., 2 \mathrm{~cm}$. br.

5. 0. leueochilum Bateman ex Lindl. in Bot. Reg. under t. 1920 (1837); leaves large, leathery, ligulate, acute; pseudo- 
bulbs ovoid-oblong, furrowed, compressed, with two leaves; lateral sepals free; lip 3-lobed, lateral lobes small, oblong-obtuse; middle lobe broadly kidney-shaped, emarginate or retuse; crest with two long lobes on each side, and an erect recurved one in the middle.-Bateman Orch. Mex. \& Guat. t. I. (1837); Lindl. Foì. Orch. Oncid. 48 \& in Paxt. Mag. Bot. vii. 241 with plate.

On trees in the Blue Mts.; Monklands, Moore! near Newcastle, Walker!-Mexico, Guatemala.

Roots numerous, long, branching. Pseudobulbs 5-10 cm. 1. Leaves 2-4 dm. 1., 2.5-4 cm. br. Panicle 10-20 dm. 1., much longer than the leaves, laxly-flowered, with several adpressed distant sheaths (about $1 \mathrm{~cm}$. 1.). Bracts triangular, acute, 5-7 $\mathrm{mm}$. 1. Flowers rather large, longstalked; sepals and petals nearly equal, about $\frac{3}{4}$ in. l., greenish-brown barred with light yellow-green; lip white, about same length. Sepals and petals similar, elliptical-oblong, acute, spreading, about $2 \mathrm{~cm} .1$. Column short, about $5 \mathrm{~mm}$. l.; wings somewhat hatchet-shaped, acute or obtuse above, rounded below.

O. altissimum $S w$. is credited to Jamaica by Swartz (Prodr. 123 \& Fl. Ind. Occ. 1481). We have seen no specimen nor any other record of the species for Jamaica. Swartz's citation may have been due to the fact that Jacquin, in his first description of the species (Epidendrum altissimum Pl. Ins. Carib. 30, 1760), cited Sloane's figure (Hist. Jam. i. t. 148, f. 1), which, as we have seen, represents $O$. luridum. The species is known from Guadeloupe, Dominica, Martinique, St. Vincent, Mexico, Panama, Colombia, British Guiana, and Surinam.

A very closely allied species, $O$. sphacelatum Lindl., from Florida and Central America, has been grown under the name of $O$. altissimum in the Jamaica Botanic Gardens, and a flower is figured on $\mathrm{Pl}$. 29, f. 22-25, but there is no satisfactory evidence that it is native in Jamaica.

\section{LEOCHILUS Knowles \& Westc.*}

Small epiphytic herbs. Stems very short, terminated by a pseudobulb with one leaf, covered by membranous scarious sheaths or a few leaves under the pseudobulb. Leaves oblong or elliptical, flat, contracted into the stalk. Scapes under the pseudobulb, thin, simple or more rarely somewhat branched. Racemes lax, with small tender flowers, distinctly stalked. Bracts about as long as the stalks or shorter, narrow, acute. Sepals about equal, spreading, free or the lateral shortly connate at the base. Petals similar to the sepals or a little broader. Lip attached at the base of the column, continuous, spreading,

* We have retained the original spelling for this genus. Bentham and Hooker f., Gen. Pl. iii. 564 (1883), on etymological grounds, wrote Leiochilus, overlooking the fact that a genus of Rubiacere established by Hooker in an earlier volume of the same work, ii. 116 (1873), bears the same name. 
oblong, undivided, sometimes longer than the sepals, the disk fleshy or callose. Columm short, erect, without a foot, not winged but 2-anricled below the stigna ; clinandrium trum cate; rostellum elongated. Anther terminal, opercular, incuntient, 1-celled, anteriorly produced beyond the eell into a membranous hooded appendage; pollinia 2, waxy, globose, without an appendage, attached to a narrow elongated stalk, sland ovate. Capsule ellipsoidal, beaked.

Species $T$, natives of the $T^{\top}$ est Indies, Mexico, and Central America.

L. labiatus Kuntze Rev. Gen. 656 (1891).-Cogn. in Symb. Aut. ii. 18:. L. cochlearis Lindl. in Bot. Ley. xxriii. Misc. 23 (1842); Griseb. Fl. Br. W. Ind. 634. Epidendrum labiatum Sw. Prodr. 12t (1788), Fl. Ind. Occ. 1493 \& Admot. Bot.t. 2, f. 6. Oncidium labiatum Reichb.f. in Walp. Amn. vi. 741 (1861). (Pl. 30, f. 1-5.)

On trees; in fl. March-June; $M c N a b$; St. Mary; St. Ann; Purdie! Beaufort, Wullschlaegel, 1091! Castleton, on river banks, J.P. 2324, Syme! near Gordon Town; near Hope Bay; Moore! near Browns Town, Miss T. M. Barrett! Christiana, Tomlinson! Castleton; Troy, $1500 \mathrm{ft}$; Harris ! Fl. Jam. 10,423, 10,426, 10,462.-Cuba, Hispaniola, Guadeloupe, Dominica, St. Vincent, Trinidad.

Plant 2-9 in. high. Roots numerous, very long. Pseudobulb somewhat globose, 7-15 mm. 1. Leaves, from apex of the pseudobulb and from its base, somewhat leathery, $2-7 \mathrm{~cm}$. 1., $\cdot 5-1 \cdot 5 \mathrm{~cm}$. br. Scape with a few distant lanceolate keeled acute sheaths below $(5-9 \mathrm{~mm}$. 1.), and a few flowers above. Pedicels about equalling ovary, together $8 \mathrm{~mm}$. l. Bracts triangular, acute, 2-3 mm. l. Sepals green, spotted with dark reddishbrown, 3-nerved; lateral oblong, obtuse, united at a distance of 1.5-3 mm. from base, 4-4.5 mm. 1., 1.3-1.5 mm. br. each at point of union; median ellip tical, very shortly acuminate, 3.5 to nearly $4 \mathrm{~mm}$. $1 ., 1.5$ to nearly $2 \mathrm{~mm}$. br. Petals green, spotted with dark reddish-brown, elliptical-oblong, apex conduplicate, shortly acute, $3 \cdot 25-3 \cdot 5 \mathrm{~mm}$. 1., 1.5-1.75 mm. br. Lip yellow, streaked with dark reddish-brown at base, elliptical-oblong, contracted above the base, where there is a fleshy callus, and very concave at the base, apex generally emarginate, about $5 \mathrm{~mm} .1 ., 2.5 \mathrm{~mm}$. br. Column $1.5 \mathrm{~mm}$. l. Capsule 14-15 mm. 1., $7 \mathrm{~mm}$. br.

58. CRYPTARRHENA R. Br.

Small epiphytic herbs. Stems leafy, very short, without pseudobulbs. Leaves several, crowded, membranous-leathery, with leathery sheaths overlapping in two ranks. Peduncles axillary, erect, longer than the leaves, simple. Flowers small, laxly racemose. Bracts narrow, about equalling the pedicels. Sepals almost equal, free, spreading, acute. Petals somewhat like the sepals. Lip continuous with the base of the column, spreading, claw long, keeled-crested above; lateral lobes at the apex of the claw narrow, spreading or recurved ; median shorter, broader, divided. Column short, thickened above, not winged, without a foot; clinandrium elevated, hooded, with small teeth 
on the margin. Anther within the clinandrium, opercular, incumbent, convex, shortly acuminate, imperfectly 2-celled ; pollinia 4, waxy, incumbent in pairs without appendage, affixed by the dilated apex of a linear stipes, with a small gland. Capsule ovoid or oblong.

Species 2, one extending through the West Indies and Central America to Peru and Guiana, the other growing in Surinam.

C. lunata R. Br. in Bot. Reg. t. 153 (1816). C. pallidiflora Reichb.f. in Bot. Zeit. x. 766 (1852). (Pl. 30, f. 6, 7.)

On trees; in fl. Aug.-Sept., in fr. Oct.-Feb.; J.P. 2406, Morris! St. Ann, Miss T. M. Barrett! Cedar Hurst; Spanish River; Moore! Holly Mount, MIt. Diabolo, Harris! Fl. Jam. 8912, 10,390, 10,397, 10,430, $10,431$. - Costa Rica, Mexico, Trinidad, B. Guiana, Peru.

Plant 4-10 in. high. Leaves linear-oblanceolate, acute, jointed to the sheathing base, 6-14 cm. 1., 7-13 mm. br. Peduncle 10-18 cm. 1. Pedicel and ovary 4-6 mm. l. Bracts lanceolate, acuminate, 2.5-5 mm. 1. Sepals elliptical, tapering to an apiculate apex; lateral $3.5 \mathrm{~mm}$. l., nearly $2 \mathrm{~mm}$. br.; median $3.25 \mathrm{~mm}$. l., $1.5 \mathrm{~mm}$. br. Petals obovate-oblong, apex rounded, upper margin minutely eroded, about $3 \mathrm{~mm} .1 ., 1.5 \mathrm{~mm}$. br. Lip about $4 \mathrm{~mm}$. l., lateral lobes linear-subulate, curved backwards, more than $2 \mathrm{~mm}$. l., terminal lobe 2-fid, upper margin slightly irregularly eroded, $1 \mathrm{~mm}$. 1., $2 \mathrm{~mm}$. br. Column about $2 \mathrm{~mm}$. 1. Capsule cylindrical, tapering abruptly at base into the stalk, 6-8 $\mathrm{mm}$. $1 ., 3 \mathrm{~mm}$. br.

\section{DICHÆA Lindl.}

Epiphytic herbs. Stems leafy, elongated, often pendulous, covered with the leaf-sheaths and leaves. Leaves in two ranks, somewhat membranous, spreading, short. Peduncles axillary, solitary, each with one small flower, with two or three scarious ample bracts, one above the other, near the base, the upper one acute, the lower obtuse, and bracteoles generally two at apex below the flower, the lower broadly roundish, apiculate, the upper linear, sometimes wanting. Sepals subequal, free, spreading, lateral, slightly oblique, forming at the base with the foot of the column a scarcely prominent chin. Petals similar to the sepals, but smaller. Lip fleshy, fixed to the base of the column, sometimes with a short claw; blade sometimes broadening upwards with angles produced sometimes into lobes or teeth, concave, uıdivided. Column erect, semiterete, very stout, at the base produced into a short or very short foot ; clinandrium oblique, short, entire, rather broad. Anther terminal, opercular, incumbent, very convex, imperfectly 2-celled; pollinia 4, waxy, oroid, closely incumbent in pairs on themselves, without appendage, affixed by a flat stipes, with a small gland. Capsule ovoid or oblong, muricate or smooth, ribs only slightly prominent. 
Species about 35, natives of tropical Americal, chiefly the West Indies, Central America and Mexico.

Leaves persistent, not jointed below; capsule densely covered with long bristles.

Leaves oblong, tapering to an acute apex with a long tip, inclined slightly towards the end of the shoot

1. D. echinocarpa.

Leaves elliptical-oblong with a roumded ayex with a short tip, inclined slightly away frow end of shoot

Leaves linear, inclined slightly away from end of shoot
2. D. muricata.
3. D. trichocarpa.

Leaves jointed above the sheath, limb falling; capsule smooth.

Leaves oblong-linear, with a long tip at apex, spreading .........................................

Leaves oblong, with a very short tip, inclined towards end of shoot

4. D. graminoides.

5. D. glauca.

Leaves jointed above the sheath, limb falling; capsule densely covered with long bristles.

Leaves oblong or oblong-ligulate, with a short or long tip, ciliate at apex, spreading

\section{D. Morrisii.}

1. D. echinocarpa Lindl. Gen. \& Sp. Orch. 208 (1833) (in part) ; leaves persistent, not jointed below, oblong, tapering to an acute apex with a long tip, inclined slightly towards the end of the shoot; lip white, variegated with blue, very shortly clawed, somewhat quadrangular-oblong, cuneate towards base, angles not produced into lobes, apex apiculate ; capsule densely covered with long bristles which are swollen at the base.Griseb. $\mathrm{Fl}$. Br. W. Ind. 624. Epiclendrum echinocarpon Sw. Prorlr. 124 (1788). Cymbidium echinocarpon Sw. in Nor. Act. Upsal. vi. 71 (1799) it Fl. Ind. Occ. 1452. (Pl. 30, f. 26-30.) Type in Herb. Mus. Brit.

Amongst mosses on trees and rocks; in fl. Aug.-Nov., in fr. Oct.-April ; mountains, Swartz! Wiles! Macfayden! MLarch! J.P. 2036, Morris! MIt. Moses, $3000 \mathrm{ft}$; Dollwood; Cinchona, $5000 \mathrm{ft}$.; Clydesdale, $4500 \mathrm{ft}$; Harris! Fl. Jam. 7527, 7994, 9023.-Cuba, Porto Rico.

Plant to $1 \frac{1}{2} \mathrm{ft} .1$. Stem to $5 \mathrm{dm}$. l., simple or sometimes branched, decumbent, pendulous, emitting roots, somewhat slender, compressed, $1.5 \mathrm{~mm}$. br. Leaves, limb 12-25 mm. 1., 5-8 mm. br., the long apical tip readily rubbing off, median nerve very prominent below, forming a slight keel, 5-7 nerves on each side; sheaths 12-15 mm. l., compressed, keeled. Peduncles about $15 \mathrm{~mm}$. l.; basal bracts, lower 2-4 $\mathrm{mm}$. l., upper $5 \mathrm{~mm}$. l.; bracteoles about $3 \mathrm{~mm}$. l. Flowers pale yellow. Sepals 5-nerved, outside muriculate; lateral oblong, elliptical, tapering to a shortly acuminate apex, $9.2 \mathrm{~mm}$. l., $4 \mathrm{~mm}$. br.; median obovate-oblong, tapering to a shortly acuminate apex, 8-9 mm. 1., $3 \cdot 25 \mathrm{~mm}$. br. Petals outside muriculate, oblanceolate-oblong, somewhat falcate, tapering to a shortly acuminate apex, nearly $8 \mathrm{~mm}$. l., $2.5 \mathrm{~mm}$. br. Lip $6 \mathrm{~mm}$. l., about $4 \mathrm{~mm}$. br. Column barely $2.5 \mathrm{~mm}$. 1., short and thick, hooded, stigmatic lip absent. Capsule ellipsoidal, somewhat tapering to base, 12-15 mm. 1., 6-8 mm. br. 
Lindley included two species under his D. echinocarpa, viz. Limodorum. pendulum Aubl. Guian. t. 322, and Epidendrum echinocarpon Sw. Prodr. 124; in this he is followed by Cogniaux in Symb. Ant. iv. 182 (1903) and in Fl. Bras. iii. pt. 6, 487, under the name D. pendula. Swartz described the lip as entire, and the Jamaican specimens agree with this. Aublet's figure shows a trilobed lip, which accords better with Lindley's description of the lip as sagittate. Aublet's species should therefore bear the name $D$. pendula, while D. echinocarpa should be reserved for the Jamaican plant.

2. D. muricata Lindl. Gen. \& Sp. Orch. 209 (1833); leaves persistent, not jointed below, elliptical-oblong, with a rounder apex with a short tip, inclined slightly away from end of shoot; lip blue, 7 -nerved, shortly clawed, obovate-rhomboid, the outer angles with a recurved, long, acuminate lobe, apex tapering, long-mucronate; capsule densely covered with long bristles which are only slightly swollen just at the base.-Griseb. op. cit. 624 ; Cogn. in Symb. Ant. iv. 183 (in part) \& in Fl. Bras. iii. pt. 6, 487 (in part). Cymbidium muricatum Sw. in Nov. Act. Upsal. vi. 71 (1799) \& Fl. Ind. Occ. 1454. (Pl. 30, f. 22-25.)

On trees; in fl. Dec.-Jan., in fr. Jan.; Morse's Gap, Purdie! Wilson! Plue Its., Prior! Bethabara, Wullschlaegel, 1212! Cedar Hurst; near ILabess River, 4000 ft.; Harris! Fl. Jam. 7649.-Cuba, Dominica, Martinique, St. Vincent, Grenada, Guatemala.

Plant to $1 \frac{1}{2} \mathrm{ft} .1$. Stems to $5 \mathrm{dm}$. l., simple, somewhat erect, emitting roots, slender, compressed, $1 \mathrm{~mm}$. br. Leaves, limb 10-20 mm. 1., 5-7 $\mathrm{mm}$. br., median nerve prominent below or sometimes forming a slight keel, 5-8 nerves on each side; sheaths 7-10 $\mathrm{mm}$. l., compressed, keeled. Peduncles about $2 \mathrm{~cm}$. 1. ; bracts, lower $1.5-3.5 \mathrm{~mm}$. 1., upper $4.5 \mathrm{~mm}$. 1. ; bracteoles $2 \cdot 5-3 \mathrm{~mm}$. 1. Sepals incompletely 5-nerved, elliptical, acuminate, $7 \cdot 5 \mathrm{~mm} .1 ., 2 \cdot 5 \mathrm{~mm}$. br. Petals incompletely 5-nerved, lanceolate-elliptical, shortly acuminate, spotted with blue, $7 \mathrm{~mm}$. 1., $2 \cdot 1 \mathrm{~mm}$. br. Lip 7 -nerved, $6 \mathrm{~mm}$. 1., $3 \cdot 25 \mathrm{~mm}$. br. (just above the lobes). Column 2.5-3 mm. 1., stigmatic lip depressed; clinandrium hooded. Capsule obovate, tapering to base, 14-17 $\mathrm{mm}$ l., $5 \mathrm{~mm}$. br.

Cogniaux has included this species in Fl. Bras. as a native of tropical $\mathrm{S}$. America, but as there seems to have been some confusion between the W. Indian and S. American species of Dichcea, we have cited only those localities from which we have seen specimens.

3. D. trichocarpa Lindl. Gen. \& Sp. Orch. 209 (1833); leaves. persistent, not joiuted below, linear, acute, inclined slightly away from end of shoot; lip sessile, broadly oblong, with a triangular lobe on each sicle above, just above the base cuneate, apex truncate with a blunt mucro projecting at the back, with calluslike thickening at the apex on each side of the central line; capsule densely covered with long bristles, which are swollen nearly throughout their length.-Griseb. op. cit. 624 . Epidendrum trichocarpon $S w$. Prodr. 12t (1788). Cymbidium trichocarpon Sw. in Nov. Act. Upsal. ri. 71 (1799) \& $\mathrm{Fl}$. Ind. Oce. 1455. (Pl. 30, f. 17-21.) Type in Herb. Mus. Brit.

On trees; in fl. Aug., in fr. Dec.-April; mountains, Swartz! $R$. Thomson! Abbey Green; MIt. Moses; J.P. 2049, Morris! Syme! Mabess 
River, C. Nichols! near Woodeutter's Crap, $4000 \mathrm{ft}$; Clydesdale, $4500 \mathrm{ft}$; near Cinchona, 5000 ft. ; Harris! Fl. Jam. 7578, 7995, 9019.—Cuba.

Plant to $2 \mathrm{ft} .1$. Stems to $6 \mathrm{dm}$. l., generally branching, pendulous, emitting roots, slender, tercte, a little over $1 \mathrm{~mm}$. br. Leares, limb 9-15 mm. 1., 1-2.5 mm. br., slightly fleshy, median nerve of the younger leaves in drying more or less prominent below, two or three nerves on each side sometimes evident; shcaths, 5-7 mm. 1., slightly compressed, sometimes slightly keeled. Peduncles about $8 \mathrm{~mm}$. 1.; bracts, lower $1.5-2.5 \mathrm{~mm}$. l., upper about $5.5 \mathrm{~mm}$. 1., attached about $1 \mathrm{~mm}$. above base; bracteoles 2.5-3 mm.l. Scpals 3-nerved; lateral oblong-elliptical, tapering to an acute point, nearly $7 \mathrm{~mm} .1 ., 2.5 \mathrm{~mm}$. br.; median ovate-elliptical, tapering to a somewhat obtuse point, nearly $6 \mathrm{~mm}$. $1 ., 2.5 \mathrm{~mm}$. br. Petals 3-nerved, oblanceolate-oblong, apex somewhat obtuse, slightly apiculate, $5 \mathrm{~mm}$. l., 1.75 mm. br. Lip $4.5 \mathrm{~mm}$. l., $4 \mathrm{~mm}$. br. (incl. lobes). Column $2.5 \mathrm{~mm}$. 1., $2 \mathrm{~mm}$. br., short, thick, slightly hooded above stigma, stigmatic lip obscurely 2-lobulate. Capsule narrowly obovate, $\cdot 8 \mathrm{~cm} .1$. , $4 \mathrm{~mm}$. br.

4. D. graminoides Lindl. Gen. \& Sp. Orch. 209 (1833); leaves deciduous, jointed above the sheath, oblong-linear, with a long tip at apex, spreading; lip 5-nerved above, upper portion deltoid, auriculate, shortly acuminate, auricles rounded, lower portion roundish, with a longitudinal callus along central nerve at the base; capsule smooth.-D. graminea Griseb. Fl. Br. W. Ind. 625 (1864). Epidendrum graminoides Sw. Prodr. 125 (1788). Cymbidium graminoides Sw. in Nov. Act. Upsal. vi. 71 (1799), Fl. Ind. Occ. 1459 \& Adnot. Bot. t. 1, f. 1. (Pl. 30, f. 8-12.) Type in Herb. Mus. Brit.

On trees, decaying logs and rocks ; in fl.Aug.-Dec. ; mountains, Swartz ! Morse's Gap, Purdie! Bethabara, Wullschlaegel, 1212! Mt. Moses; Cinchona ; J.P.2070, Morris! Moody's Gap, Syme. Mabess River, G. Nichols! Cinchona, $5000 \mathrm{ft}$; below Vinegar Hill, $3500 \mathrm{ft}$; Harris! Fl. Jam. 7464, 7524, 7766, 9899 .

Plants 4-12 in. high. Stems 1-3 dm. l., simple or branching a little from base, somewhat erect, emitting roots, somewhat slender, compressed, $2 \mathrm{~mm}$. br. Leaves, limb 3-4 cm. l., 3-5 mm. br., six to eight nerves on each side of the median, slightly prominent; sheaths $10-16 \mathrm{~mm}$. l., compressed, slightly keeled. Peduncles about $2 \mathrm{~cm} .1$. ; bracts, lower 2.5 $\mathrm{mm}$. 1., upper about $6 \mathrm{~mm}$. l., attached about $3 \mathrm{~mm}$. above base; bracteoles about $2.5 \mathrm{~mm}$. l. Flowers whitish. Sepals incompletely 5 -nerved, elliptical, tapering to an acute apex, lateral $6 \mathrm{~mm}$. 1., $2 \cdot 3 \mathrm{~mm}$. br.; median slightly shorter. Petals incompletely 5 -nerved, ovate, apex acute, ncarly $5 \mathrm{~mm}$. l., $2.2 \mathrm{~mm}$. br. Lip $4.5 \mathrm{~mm}$. l., $3.2 \mathrm{~mm}$. br. (at lobes), $2 \mathrm{~mm}$. br. at lower portion. Column about $2 \mathrm{~mm}$. l., 1.2 $\mathrm{mm}$. br., stigmatic lip forming a triangular obtuse lobe; anther broad, emarginate, apiculate, with acutely-pointed sides.

We have not seen any specimens elsewhere than from Jamaica that appear to agree with the description of the species.

5. D. glauea Lindl. Gen. \& Sp. Orch. 209 (1833); leaves deciduous, jointed above the sheath, oblong, with a very short tip, inclined towards the end of the shoot; lip 7 -nerved, with a thick short claw, broadly cuneate, with each lateral angle produced into a short ligulate lobe, apex retuse, at base a 
roundish callus; capsule smooth.-Griseb. op. cit. 625. Epidendrum glaucum Siv. Prodr. 124 (1788). Cymbidium glaucum Sw. in Nov. Act. Upsal. vi. 71 (1799) \& Fl. Ind. Occ. 145\%. (Pl. 30, f. 13-16.) Type in Herb. Mus. Brit.

On trees; in fl. July, Aug.; Blue MIts., Swartz! Wiles! Macfadyen! R. Thomson! J.P. 31, Mlorris! John Crow Peak, G. Nichols! near Portland Gap, Capper! near Cinchona, Miss R. Capper! Pleasant Hill, Harris! Fl.. Jam. 7361.-Cuba, Mexico.

Plant to $1 \frac{1}{2} \mathrm{ft}$. Stems to $4.5 \mathrm{dm}$., simple, clustered, erect, somewhat stout, compressed, about $3 \mathrm{~mm}$. br. Leaves of a glaucous colour, limb $3-5.5 \mathrm{~cm}$. 1., 9-13 mm. br., median nerve prominent or slightly keeled below, lateral nerves 13-19 on each side, very thin ; sheaths $1 \cdot 3-1 \cdot 8 \mathrm{~cm} .1$, compressed, keeled. Peduncle about $2 \mathrm{~cm}$. 1.; bracts 5.5-6 mm. 1., upper about $4 \mathrm{~mm}$. from base; bracteole about $1.5 \mathrm{~mm}$. 1., broadly roundish, apiculate. Flowers whitish. Sepais 3-nerved; lateral oblong-ovate, tapering to an acuminate apex, about $8 \mathrm{~mm} .1 ., 3.5 \mathrm{~mm}$. br.; median oval, tapering to an acuminate apex, $7 \cdot 5 \mathrm{~mm} \cdot 1 ., 3 \cdot 25 \mathrm{~mm}$. br. Petals 3-nerved, lanceolate-elliptical, acute, $7 \mathrm{~mm} .1 ., 2 \cdot 75 \mathrm{~mm}$. br. Lip nearly $6 \mathrm{~mm}$. 1., about $5 \mathrm{~mm}$. br. (exclusive of lobes). Column about $2.5 \mathrm{~mm}$. $1 ., 1.5 \mathrm{~mm}$. br., short, thick, slightly hooded abore stigma, apiculate, stigmatic lip triangular with a ligulate lobule at apex. Capsule obovate-ellipsoidal, tapering to base, $2 \mathrm{~cm} .1 ., 6 \mathrm{~mm}$. br.

6. D. Morrisii Fawc. \& Rendle in Journ. Bot. xlviii. 107 (1910); leaves jointed above the sheath, deciduous, oblong or oblong-ligulate, at apex rounded with a short or long tip, margin ciliate above, spreading; lip below linear-oblong, above dilated, anchor-shaped, margin minutely ciliate, apex apiculate, lateral lobes long, curved towards the base, subulate; capsule densely covered with long bristles, which are swollen at the base. (Pl. 30, f. 31-36.) Types in Herb. Mus. Brit., Bot. Gard. N. York \& Yale Univ.

On trees; in fl. July ; MIt. MIoses, 3500 ft., J.P. 2269, Morris! Hardware Gap, G. Nichols!

Plant to $1 \frac{1}{2} \mathrm{ft}$. 1. Stems to $4.5 \mathrm{dm}$. 1., few, simple, stout, compressed, $4 \mathrm{~mm}$. br. Leaves, limb $3 \cdot 5-5 \mathrm{~cm}$. 1., 10-13 mm. br., median nerve prominent or slightly keeled below, lateral nerves 20-30 on each side, very thin; sheaths about $25 \mathrm{~mm}$. l., compressed, keeled. Peduncle about $8 \mathrm{~mm}$. l., bracts at the base about $1 \mathrm{~cm}$. l. Sepals, margin ciliate; lateral 7-nerved, ovate, shortly acuminate, 11-13 mm. l., 5.5-7 mm. br.; median 9-nerved, oblong, tapering to an acute apex, as long as but narrower than lateral. Petals 7-nerved, like the median sepal, $10 \mathrm{~mm}$. $1 ., 3.5 \mathrm{~mm}$. br. Lip white barred with brownish-red colour below, fleshy, about $9 \mathrm{~mm}$. 1 . Column very short, thick, winged, $4 \mathrm{~mm}$. 1. Capsule about $15 \mathrm{~mm}$. 1., $10 \mathrm{~mm}$. br.

This species is named after Sir D. Morris, who discorered it. Since printing our description in the Journal of Botany we have seen better material kindly lent by MIr. G. E. Nichols, and have made a few emendations.

\section{CAMPYLOCENTRUM Benth.}

Epiphytic herbs; with leafy stems, or stemless and leafless; with clustered roots. Leaves oblong, in two ranks. Flowers minute, in two ranks, crowded, in spikes, radical or lateral. Bracts 
small, persistent. Sepals free, subequal, erect, comnivent. Petals as long as the sepals, but narrower. Lip as long as the sepals, sessile at base of columu, produced at the base into a more or less clavate spur, often recurved; the blade somewhat quadrate below, with convolute margins, produced upwards into a triangular lobe. Column very short, without a foot; anther terminal, opereular, incumbent, convex, 2)-celled; pollinia "2, globose, waxy, with filiform stalks. Capsule small, narrowly oblong, dehiscing in the middle by three valves.

species 30 in number, natives of tropical America from Brazil to the West Indies and Mexico.
Leafy plants.
Leaves deeply 2-lobed at apex. Capsule smooth.
Lip $4.5 \mathrm{~mm}$. 1., terminal lobe about half length of lip.
Lip about $3 \mathrm{~mm}$. l., terminal lobe
less than half length of lip ........2. C. jamaicense.
Leaves entire or only slightly lobed at apex. Capsule ribbed .................. 3. C. minus.
Leafless and stemless plants.
Bracts large, hooded, serrate ........ 4. C. pachyrrhizum.
Bracts small, entire .................. 5. C. Sullivanii.

1. C. Barrettiæ Fawe. \& Rendle in Journ. Bot. xlvii. 127 (1909); leaves deeply 2-lobed at apex; spikes opposite to, and much shorter than, the leaves, solitary or sometimes geminate, densely flowered, $1-2 \cdot 7 \mathrm{~cm}$. 1.; lip $4.5 \mathrm{~mm}$. $1 ., 5$-nerved above, 7 -nerved at base, obsoletely 3-lobed, as long as the sepals, $2 \mathrm{~mm}$. br., middle lobe linear-lanceolate, acute; lateral lobes bluntly rounded, not developed anteriorly, middle lobe about half length of the lip, $2 \mathrm{~mm}$. l., nearly $1 \mathrm{~mm}$. br. at base; spur linear, narrowly clavate, slightly constricted at the origin, $2 \mathrm{~mm}$. l., nearly $1 \mathrm{~mm}$. br., much shorter than the sepals, straight or slightly curved in flower, spreading in fruit; capsule smooth. (Pl. 31, f. 9-15.)

On trees; in fl. Oct.-Jan.; 27, Purdie! New Part, St. Mary, Wilson! Iron River, Water Valley, St. Mary, J.P. 2325, Syme! near Browns Town, Miss T. M. Barrett! Angust Town, Moore! Charlemont, near Ewarton, $1000 \mathrm{ft}$; near Gordon Town; Green Vale, $2000 \mathrm{ft}$. ; near Browns Town, $1200 \mathrm{ft.}$; Harris! Albany, St. George, Watt! Fl. Jam. 6580, 7172, 7801, $10,405,10,406$.

Plant 2-9 in. high. Roots somewhat slender, long, flexuose, canescent, simple, 1-3 dm. 1., 1-2 mm. br. Stem somewhat stout, slightly compressed, emitting roots, siniple, covered by the leaf-sheaths, becoming bare below, 5-26 cm. 1., 2-3 mm. br. Lieaves, blade rather large, somewhat leathery, oblong to ligulate, tapering to the base, at the apex very obliquely 2 -lohed, lobes rounded at the apex, in two ranks, numerous, caducous at the base of the stem, 3-7 cm. 1., 8-15 mm. br., middle nerve prominent below, canaliculate above, lateral nerves numerous; sheaths closely adpressed, with numerous ribs, $6-15 \mathrm{~mm}$. 1. Bracts triangular, acute, $1 \mathrm{~mm}$. 1. . Flowers sessile. Sepals ligulate, apex subacute, slightly apiculate, concave, 3-nerved, 4-5 mm. l., a little over $1 \mathrm{~mm}$. br. ; lateral, at the base slightly 
oblique and not constricted. Petals linear-lanceolate, acute, 3-nerved, with involute margins, $4 \mathrm{~mm}$. 1., $1 \mathrm{~mm}$. br. Capsule (not ripe) elongated, narrowly oblong, straight, $1 \mathrm{~cm}$. $]$.

2. C. jamaicense Favc. Fl. Pl. Jam. 40 (1893); leaves deeply -2-lobed; spikes opposite to, and very much shorter than, the leaves, solitary, about $1 \mathrm{~cm}$. l.; bracts triangular, acute, barely $1 \mathrm{~mm}$. 1. ; lip 5-nerved above, 7 -nerved at base, subquadrate with an oblong shortly apiculate lobe, about $3 \mathrm{~mm}$. $1 ., 1 \cdot 75 \mathrm{~mm}$. br.; apical portion less than half the length of the lip, a little over $1 \mathrm{~mm} .1 ., \cdot 6 \mathrm{~mm}$. br.; spur cylindrical, less than $2 \mathrm{~mm}$. l., shorter than the sepals; capsule smooth.-Aeranthus jamaicensis Reichb.f. \& Wullschl. in Walp. Ann. vi. 901 (1861). Aeranthes micrantha Griseb. Fl. Br. W. Ind. 625 (1864) (in part), non Reichb. $f$.

Fairfield, 1053, Wullschlaegel!

Plant 4 in. high. Leaves elliptical, at apex very obliquely 2-lobed, lobes rounded at the apex, in two ranks, numerous, caducous at the base of the stem, 2.5-3 cm. 1., 1-1.3 cm. br.; middle nerve prominent below, canaliculate above, lateral nerves numerous; sheaths tubular, closely adpressed, with numerous ribs, 5-10 mm. l. Sepals ligulate, apex obtuse, shortly apiculate, concave, 3-nerved, about $3 \mathrm{~mm}$. 1., less than $1 \mathrm{~mm}$. br. Petals similar to sepals. Capsule (not ripe) spindle-shaped, $8 \mathrm{~mm} .1$.

3. C. minus Fawc. \& Rendle loc. cit.; leaves, apex obtuse, occasionally slightiy 2-lobed, obliquely or not; spikes opposite to the leaves and about as long or longer, 2 -4-clustered, densely flowered, to $4 \mathrm{~cm}$. 1.; lip without nerves, obsoletely 3-lobed, middle lobe triangular, acute, with involute margins; lateral lobes rounded, projecting very slightly anteriorly; $2.5 \mathrm{~mm}$. l., at lobes barely $2 \mathrm{~mm}$. br. : middle lobe about $1 \mathrm{~mm}$. l., less than half the length of the lip; spur ellipsoidal, much constricted at origin, $1.5 \mathrm{~mm} .1 ., \cdot 7 \mathrm{~mm}$. br., much shorter than the sepals, spreading; capsule 6 -ribbed. (Pl. 31, f. 5-8.)

On trees; in fl. Dec., in fr. Jan.; Cedar Hurst, Harris!

Plant to 5 or 6 in. high. Roots slender, long, flexuose, canescent, simple, to $2 \mathrm{dm}$. 1., 1-1.5 mm. br. Stem slightly compressed, emitting roots, simple, covered by the leaf-sheaths, to $16 \mathrm{~cm}$. l., about $2 \mathrm{~mm}$. br. Leaves, blade somewhat membranous, elliptical, in two ranks, numerous, caducous near the base of the stem, 3-4 cm. 1., 7-12 mm. br., middle nerve prominent below, canaliculate above, lateral nerves numerous; sheaths closely adpressed, with numerous ribs, $6-8 \mathrm{~mm}$. l. Bracts triangular, acute, apiculate, keeled, $2 \mathrm{~mm}$. l., more than $2 \mathrm{~mm}$. br Flowers sessile. Sepals without nerves, median linear-lanceolate, acute, shorter than the lateral, $2 \cdot 3 \mathrm{~mm}$. l., barely $1 \mathrm{~mm}$. br. at base, $\cdot 7 \mathrm{~mm}$. higher up; lateral linear-lanceolate, acute, $2 \cdot 6 \mathrm{~mm} .1 ., \cdot 7 \mathrm{~mm}$. br. Petals linear-lanceolate, acute, without nerves, $2 \mathrm{~mm}$. $1 ., \cdot 6 \mathrm{~mm}$. br. Capsule (not ripe) oblanceolate, $6 \mathrm{~mm} . \mathrm{l}$.

4. C. pachyrrhizum Rolfe in Orch. Rev.xi. 246 (1903) ; leafless; bracts spathaceous, roundish, acuminate, cordate, margin minutely eroded, reddish-brown, 3-4 mm. 1.-Aeranthus pachyr- 
rhizus Reichb. f. in Flora xlriii. $279(1865)$; A. spathaceus Griseb. Cat. Pl. ('ub. $26+(1866)$.

On trees; Castleton; Cedar Hurst; J.P. 2326, Syme! Belvedere, Hanover, $500 \mathrm{ft}$., Harris! Fl. Jam. 7570.-Cuba, Trinidad, Guiana.

Plant less than $1 \mathrm{in}$. to $1 \frac{1}{2}$ in. high. Airial roots hanging free or sometimes attaching themselves to the bark of trees, broad and flat, flexuose, simple, to $3 \mathrm{dm}$. l., to $4 \mathrm{~mm}$. br. Stem reduced to a knob from which the aërial roots and the racemes spring. Theares wanting. Spilies radical, several, 3-many-clustered, with numerous flowers; peduncle puberulous. Flouers sessile. Sepals, median narrowly triangular, 3-nerved, abruptly acute, $4.6 \mathrm{~mm}$. 1., about $1 \mathrm{~mm}$. br.; lateral laneeolate, slightly oblique, 1-nerved, 5.2 mm. 1., 1.2 mm. br. Petals subulate, 3 -nerved, $4.5 \mathrm{~mm}$. 1., $1 \mathrm{~mm}$. br. Lip, lower lalf suborbicular, upper triangular, acuminate; $4 \mathrm{~mm}$. l., lower part about $2 \mathrm{~mm}$. br., upper $1 \mathrm{~mm}$. br.; 9-nerved below, 5-nerved above. Spur narrowly ellipsoidal, slightly constricted at the origin, about $2.5 \mathrm{~mm}$. $1 ., \cdot 7 \mathrm{~mm}$. br., spreading. Capsule ellipsoidal, 6-ribbed, about $8 \mathrm{~mm}$. l.

5. C. Sullivanii Fauce \& Rendle op. cit. 128 ; leafless ; bracts ovate, acute, clasping, $1.7 \mathrm{~mm} .1 ., 1 \cdot 3 \mathrm{~mm}$. br. Aeranthes filiformis Griseb. Fl. Br. W. Ind. 625 (1864) (in part, excl. syn.). (Pl. 31, f. 1-14.)

On trees; in fl. Jan.-March; Negril; Woodside, St. Mary; Purdie! Manchester Mts., Wilson! J.P. 34, Morris! Spaldings, Sullivan! Monklands, Roberts! Alexandria, Ramble, Mrs. Rankine! Belvedere, Hanover, 500 ft., Harris! near Hope Bay, Moore! Fl. Jam. 7523, 10,464.

Ylant, raceme 1-2 in. high. Aërial roots hanging free or sometimes attaching themselves to the bark of trees, somewhat slender, long, flexuose, canescent, simple, to $3 \mathrm{dm}$. 1., 1.5-2 mm. br. Stem reduced to a knob, from which the aërial roots and the racemes spring. Leaves wanting. Spikes radieal, several, 4-7-clustered, with numerous flowers in two ranks, 3-6 $\mathrm{cm}$. 1., rachis minutely puberulous. Pedicels short, about $7 \mathrm{~mm}$. 1 . Ovary obovoid, $1.5-2 \mathrm{~mm}$. 1., nearly $1 \mathrm{~mm}$. br. Flowers brownishwhite. Sepals 1-nerved; median ovate, acute, apiculate, 1.4-1.7 mm. 1., - $8 \mathrm{~mm}$. br.; lateral ovate-lanceolate, apiculate, 1.7-1.8 $\mathrm{mm}$. 1., ·-7-.8 $\mathrm{mm}$. br. Petals 1-nerved, oval or ovate-elliptical, subacute, $1.25 \mathrm{~mm} .1$., -6-. $7 \mathrm{~mm}$. br. Lip 3-lobed, 7 -nerved, 1.3 mm. 1., 1.3 mm. br., middle lobe triangular, acute, apieulate, $\cdot 25 \mathrm{~mm}$. l. ; lateral rounded ; spur linear, slightly clavate, 1.1-1.2 mm. l. Column green. Capsule broadly ellipsoidal, 9-ribbed, $4 \mathrm{~mm}$. 1., 2-3 $\mathrm{mm}$. br.

C. filiforme Rolfe (Epidendrum filiforme Sw.; type in Herb. Mus. Brit. from S. Domingo) differs from this species in the lip, the capitate spur, and the obtuse sepals and petals.

\section{HARRISELLA Fawc. \& Rendle.}

Epiphytic herbs, stemless and leaflless; roots clustered. Flowers minute, in two ranks, in lax few-flowered radical racemes, jointed on a short pedicel which is swollen above. Bracts small, persistent. Sepals free, subequal, erect, slightly spreading above. Petals similar to, and as long as the sepals, but narrower. Lip slightly longer than the sepals, sessile at base of column, produced at the base into a spur, globose from a very constricted base; the blade somewhat globose, embracing the column, and 
hooded over it. Column very short, without a foot; anther terminal, opercular, incumbent, rather flat, indistinctly 2-celled; pollinia 2, globose, waxy, with short filiform stalks. Capsule small, shortly ellipsoidal, dehiscing from the apex by six valves which are alternately broad and narrow.

Species, only one known, native of Jamaica and Cuba.

The genus is very near to Campylocentrum, in which it has been included, but differs in the inflorescence, the lip, the form of the anther, and the form and dehiscence of the capsule.

It is dedicated to Mr. Wil iam Harris, F.L.S., Superintendent of Public Gardens, Jamaica, and an indefatigable collector, who has added much to our knowledge of the Jamaican Flora.

H. porrecta Fawc. \& Rendle in Journ. Bot. xliii. 266 (1909). - Aeranthus porrectus Reichb. f. in Flora xlviii. 279 (1865); Griseb. Cat. Pl. Cub. 265. Campylocentrum porrectum Rolfe in Orch. Rev. xi. 247 (1903); Ames Orch. i. 15, t. 4. (Pl. 31, f. $16-21$.)

On trees; in fl. and fr. in Nov.; Manchester, Purdie! above Hope Mines, Harris! Fl. Jam. 7762.-Cuba, Porto Rico, Florida, Yucatan.

Plant $1 \frac{1}{2}-2$ in. high. Aërial roots hanging free or sometimes attaching themselves to the bark of trees, very slender, flexuose, white, canescent, simple, to $1 \mathrm{dm}$. 1., $5 \mathrm{~mm}$. br. Racemes several, clustered, zig-zag at each node, 4-5 cm. 1. Bracts tubular below, obtuse, $1.3 \mathrm{~mm} .1$. Pedicels slightly exceeding the bracts, thicker upwards than the base of ovary. Flowers about $\frac{1}{12}$ in. long, yellow-green. Ovary attenuated below, glandular along six vertical lines, $2 \cdot 7 \mathrm{~mm}$. 1. Sepals reticulate-nervulose, slightly keeled, a little over $2 \mathrm{~mm}$. l., median $.8 \mathrm{~mm}$. br.; lateral $1 \mathrm{~mm}$. br.; dorsal oval-elliptical, obtuse: lateral oval, oblique, acute. Petals a little over $2 \mathrm{~mm}$. 1., $\cdot 7 \mathrm{~mm}$. br., linear, obtuse, apiculate, 1-nerved. Lip $2.5 \mathrm{~mm}$. l., obtusely apiculate. Spur $\cdot 7 \mathrm{~mm}$. Column terete; clinandrium 2-lobed anteriorly; anther-case, somewhat deltoid. Capsule $6 \mathrm{~mm}$. 1., $5 \mathrm{~mm}$. br.

\section{DENDROPHYLAX Reichb. f.}

Epipliytic leafless herbs, with the roots densely clustered, a very short stem and no pseudobulb. Scapes thin, simple, with small distant bracts. Flowers solitary on the scape or a few in a raceme, very large, medium-sized or small. Sepals about equal, free, spreading. Petals somewhat similar to the sepals. Lip sessile at the base of the column, produced at the base into a long spur much dilated towards the mouth, continuous with the column, erect; limb entire or 2-lobed. Column very short, broad, without a foot. Anther terminal, opercular, incumbent, indistinctly -celled; pollinia 2, somewhat globose, waxy, each with a stalk, which is simple or flat and 2-partite. Capsule oblong or elongated.

Species about 5, natives of West Indies.

Sepals about $\frac{3}{4}$ inch 1 . 1. D. funalis.

Sepals about $\frac{1}{4}$ inch 1 . 2. D. Barrettia. 
1. D. funalis Fanc. Fl. Pl. Jam. 40 (1893); lip very large, broad, with two rounded lobes, united by a short claw to the wide mouth of the spur, reticulate-9-veined, to apex of lateral lobe $1 \cdot 7 \mathrm{~cm}$. $1 ., 2 \cdot 2 \mathrm{~cm}$. br.; spur filiform. tapering towards apex, nearly three times as long as the sepals, about $5 \cdot 5 \mathrm{~cm} .1$. - Epidendrum funale Sw. Prodr. 126 (1788). Limodorum funale Sw. in Nor. Act. Upsal. ri. 79 (1799) \& Fl. Occ. Ind. iii. 1521. Eeceoclades funalis Lindl. Gen. if Sp. Orch. 237 (1833). Angraecum funale Lindl. in Bot. Reg. xxvi. under t. 68 (1840); Hook. in Bot. Mag. t. 4295. Aeranthus funalis Reiclll. f. in Walp. Amn. vi. 902 (1861). Aeranthes funalis Grisel. $\mathrm{Fl}$. $\mathrm{Br}$. II. Ind. 625 (1864). Polyrrhiza funalis Pfitz. in Engl. \& Prantl Nat. Pflanzenf ii. pt. 6, 209 \& 215 (1889). (Pl. 32.) Type in Herb. Mus. Brit.

On trees; in fl. Nov.-March; Swartz! Wag Water River, J.P. 2330, Syme! near Browns Town, Miss T. M. Barrett! H. Levy! near Christiana, MIrs. Sewell! Blue Mts., Moore! near Gordon Town; Hope Mines ; Harris ! Fl. Jam. 5655, 7763, 9005.

Plant 5 or 6 in. high. Roots to $3 \mathrm{dm}$. or more l., slender, compressed, flexuose, canescent, simple, occasionally branched, repeatedly forming new growths from the tips of the old roots. Stem very much reduced, extending occasionally to scarcely $2 \mathrm{~cm}$., covered with brown sheathing scales, leafless, bearing long slender woody stolons. Scape simple, fewflowered, $5-10 \mathrm{~cm}$. 1. Bracts sheathing, wide at mouth, acute or acuminate, brown, 4-5 mm. 1. Pedicel (of fruit) 1 to nearly $2 \mathrm{~cm}$. l. Sepals elliptical, obtuse, reticulate-7-veined; median spreading, about $2 \mathrm{~cm} .1 ., 7 \mathrm{~mm}$. br.; lateral deflexed, about $2 \cdot 2 \mathrm{~cm}$. 1., $6 \mathrm{~mm}$. br. Petals oblong-elliptical, subacute, reticulate-7-veined, spreading, about $2 \mathrm{~cm}$. 1., 5-6 $\mathrm{mm}$. br. Column short, with two broad wings produced anteriorly. Anther subhemispherical, cells not divided, but indicated by an almost obsolete wall and by a longitudinal depression outside; pollinia on a ribbon-like process of the flat stalk. Capsule elongated, cylindrical, 6-angled, $7 \mathrm{~cm}$. 1., about $\cdot 5 \mathrm{~cm}$. br.

2. D. Barrettiæ Fawc. \& Rendle in Journ. Bot. xlvii. 266 (1909); lip undivided, saccate, above broadly ovate, shortly acuminate, extending about as far as lateral sepals; spur spreading, $2.3 \mathrm{~cm}$. 1., increasing in thickness from the middle towards the apex. Types in Herb. Kew. and in Herb. Mus. Brit.

On trees; in fl. in Aug.; near Browns Town, Miss T. M. Barrett! Holly Mount, Mt. Diabolo, $2600 \mathrm{ft}$., Harris !

A small stemless, leafless plant, about an inch high. Roots very slender, flexuose, simple, to $12 \mathrm{~cm}$. 1. Scapes several, clustered, simple, to $2 \cdot 5 \mathrm{~cm}$. 1. Bracts few (three), tubular below, free part ovate, apiculate, $1.5 \mathrm{~mm}$. 1 . Flowers small, one flower appearing at a time, greenish-white, the spur rather lighter in colour. Sepals spreading, 3-nerved, linear-lanceolate, subacute to acute, 5-6 mm. 1., 1.3-1.5 mm. br. Petals erect, 3-nerved, similar to sepals, linear-ligulate, acute, nearly $5 \mathrm{~mm}$. l., $1 \mathrm{~mm}$. br. Column very short, auriculate at apex as in $D$. funalis, auricles toothed on upper margin; anther-cells somewhat ovate-rectangular in outline; pollinia with a simple stalk. 


\title{
INDEX OF GENERA AND SPECIES
}

\author{
(Synonyms in italics)
}

\begin{tabular}{|c|c|c|c|c|}
\hline Aeranthes filiformis Griset & & $\begin{array}{r}\text { PAGE } \\
. \quad 142\end{array}$ & & $\begin{array}{r}\text { PAGE } \\
117\end{array}$ \\
\hline 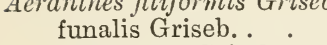 & & $\cdot \begin{array}{l}142 \\
\cdot \quad 144\end{array}$ & $\begin{array}{l}\text { BULBOPHYLLUM } \\
\text { jamaicense Cogn. }\end{array}$ & . 118 \\
\hline micrantha Griseb. . & & . 141 & pachyrrhachis Griseb. & 118 \\
\hline $\begin{array}{l}\text { eranthus funalis Reichb. } \\
\text { jamaicensis Reichb. } f \text {. }\end{array}$ & & 144 & & \\
\hline $\begin{array}{l}\text { jamaicensis Reichb. } f \text {. } \\
\text { pachyrrhizus Reichb. }\end{array}$ & & . 141 & & \\
\hline $\begin{array}{l}\text { pachyrrhizus Reichb. } \\
\text { spathaceus Griseb.. }\end{array}$ & & . 141 & Cactus parasiticus $I$. & 17 \\
\hline $\begin{array}{l}\text { spathaceus Griseb.. } \\
\text { Angrecum funale Lindl. }\end{array}$ & & . 142 & Calanthe & 109 \\
\hline $\begin{array}{l}\text { Angracum frinale Lindl. } \\
\text { Arethusa gentianoides Sw. }\end{array}$ & & 144 & mexicana Reichb. f. & 110 \\
\hline $\begin{array}{l}\text { Arethusa gentianoides } S w \text {. } \\
\text { ARPOPHYLUU . }\end{array}$ & & 15 & Calopogon pulchellus $R$. Br. & 111 \\
\hline $\begin{array}{l}\text { ARPOPHYLLUM } \\
\text { giganteum Hartw. }\end{array}$ & & 82 & Camaridium parviflorum & \\
\hline giganteum Hartw. & & 82 & $\begin{array}{c}\text { Fawc. } \\
\text { CAMPYLOCENTRUA }\end{array}$ & \\
\hline LETIA & - & 110 & Barrettiæ Fawc. \& Rendl & 140 \\
\hline acutipetala Hook. & . & 111 & filiforme Rolfe . & 142 \\
\hline alta Hitchcock. & . & 111 & jamaicense Fawc. . . & 41 \\
\hline capitata $R . B r$. & . & 107 & minus Fawc. \& Rendle & 141 \\
\hline florida R. Br. & & 111 & pachyrrhizum Rolfe . & 141 \\
\hline montana Reichb. $f$. & 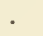 & 79 & porrectum Rolfe & 143 \\
\hline parviflora Reichb. $f$. & . & 106 & Sullivanii Fawc. \& Rendl & 142 \\
\hline ea DC. & . & 110 & Cattleya domingensis Lindl. & 101 \\
\hline Shepherdii Hook. & . & . 111 & Chloidia flava Reichb. $f$. . & 40 \\
\hline Tankervilliae R. $\mathrm{Br}$. & . & . 109 & polystachya Reichb. $f$. . & \\
\hline nda $D C .$. & & . 111 & vernalis Lindl.. . . & 41 \\
\hline verecunda $R . B r$. & & . 111 & CEELIA & 0 \\
\hline Bolbophyllaria pachyrrho & ach & & Bauerana Lindl. & \\
\hline Reichb.f.. . . & . & 118 & triptera G. Don & 80 \\
\hline RACHIONIDIUM . & . & 76 & Calogyne triptera Brongn. & 102 \\
\hline Cogn & . & 77 & Comparettia $\cdot{ }^{\circ}$. & 126 \\
\hline Sherringii Rolfe & & 77 & falcata Pœpp. \& Endl. & 126 \\
\hline Brassa & & 104 & Corymbis flava Hemsl. . . & 40 \\
\hline ata Lindl. . . & . & . 105 & CORYMBORCHIS . . • & 0 \\
\hline grandiflora Lindl. & - & - 105 & flava Kuntze · · & \\
\hline nodosa Lindl. . & . & - 104 & polystachya Kuntze & $\frac{1}{9}$ \\
\hline $\begin{array}{l}\text { nodosa Hook. } \\
\text { subulifolia Lindl. }\end{array}$ & & $\begin{array}{r}105 \\
-\quad 105\end{array}$ & CRANICHIS $\dot{S} \cdot$ & $\begin{array}{l}32 \\
30\end{array}$ \\
\hline $\begin{array}{l}\text { subulifolia Lindl. . } \\
\text { subulifolia Rolfe. }\end{array}$ & • & $\begin{array}{l}105 \\
. \quad 105\end{array}$ & $\begin{array}{l}\text { aphylla Sw. } \\
\text { diphylla Sw. }\end{array}$ & 33 \\
\hline $\begin{array}{l}\text { subulifolia Rolfe } \\
\text { venosa Lindl. }\end{array}$ & . & . 10 & $\begin{array}{l}\text { diphylla Sw. } \\
\text { luteola } S w . .\end{array}$ & 48 \\
\hline vomeriformis Reichb. & & 107 & muscosa Sw. & 32 \\
\hline RASSIA $\cdot \dot{T^{\prime}} \cdot$ & - & 128 & oligantha Sw. & . \\
\hline caudata Lindl. . & . & 129 & pauciflora $S w$. & \\
\hline guttata Lindl. . & . & . 128 & pilosa Fawc. \& Rendle & \\
\hline maculata R. Br. & . & - 12 & stachyodes Sw.. & \\
\hline a Hook. . & . & - 128 & ventricosa Griseb. . & 39 \\
\hline ROUGHTONIA . & - & - 100 & CRYPTARRHENA. & 134 \\
\hline coccinea Hook. . & ${ }^{\circ}$ & - 100 & lunata R. Br. . & 135 \\
\hline domingensis Rolfe. & ${ }^{\circ}$ & . $10 \mathrm{~L}$ & pallidiflora Reichb. $f$. . & - \\
\hline ra Henfr.. & 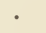 & . 10 & CRYPTOPHORANTHUS & ${ }^{\circ}$ \\
\hline sanguinea R. Br. . & & . 100 & atropurpureus Rolfe & \\
\hline
\end{tabular}




\begin{tabular}{|c|c|c|c|}
\hline & & & \\
\hline ymbrarum echrnocarp & & & \\
\hline num Sw. & & & \\
\hline globosum Sw. & • & & \\
\hline guttatum Willd. & . & . & \\
\hline graminoides Sw. & . & . & \\
\hline lineare $S w$. & . & . & \\
\hline montanum $S w .$. & . & . & \\
\hline muricatum Su. & . & . & \\
\hline proliferum Sw.. & & . & \\
\hline serrilatum $S w$. & - & . & \\
\hline teretifolium $S w$. & & & \\
\hline testafolium Sw. & & & \\
\hline tetrapetalum Sw. & & & \\
\hline trichocarpon Sw. & & & \\
\hline tripterum $S w$. & & & \\
\hline triquetrum $S w$. & & & \\
\hline utriculatum Sw. & & & \\
\hline verecundum Sw. & & & \\
\hline vestitum $S w$. & & & \\
\hline & & & \\
\hline folia $\mathrm{Co}$ & $\operatorname{og} n$ & & \\
\hline & & & \\
\hline topodium Woodford & & & \\
\hline
\end{tabular}

Dendrobium album Hook. . . 120 alpestre Sw. . . . . 56

Barringtonia S'w. . . . 114 comiculatum Su. . . 61 lanceola Sw. . . . . 65 laxum Sw. . . . . 57 longifolium H. B. \& k. . 112 micranthum Sw. . . . 50 ophioglossoides Sw. . . 51 palmifolium Sw. . . . 115 polystachyum Sw. . . . 48 racemiflorum $S w$. . . . 54 ruscifolium Sw. . . 58 sanguineum Sw. . . . 101 sertularioides Sw. . . . 65 testiculatum Sw. . . . 126 tribuloides Sw.. . . 62 utricularioides Sw. . . 125

DeNDRophylax . . . . 143 Barrettiæ Fawc. \& Rendle 144 funalis Fawc. . . . . 144

DiсHÆA . . . . . . 135 echinocarpa Lindl. . . 136 glauca Lindl. . . . . 138 graminea Griseb. . . . 138 graminoides Lindl. . . 135 Morrisii Fawc. \& Rendle. 139 muricata Lindl. . . . 137 pendula Cogn. . . . . 137 trichocarpa Lindl. . . 137 Dicrypta Baueri Lindl. . . 121 Dinema polybulbon Lindl. $\quad 95$
T'AGE:

Elleantuius . . . . 107 capitatus Reichb. f. . . 107 longibracteatus Fawc. . 108 EPIDENDRUM . . . . . 82 alpestre Sw. . . . . 56 altissimum Jacq. . . . 133 anceps Jacq. . . . . 90 anceps Sw. . . . . 95 angustifolium sw. . . 98 angustilobum Fawc. \& Rendle . . . 87 Barringtonice Smith . . 114 belvederense Fawc. \& Rendle . . . . . 97 bifarium Sw. . . . . 94 bletioides Griseb. . . . 96 brachyglossum Cogn. . . 98 caudatum L. . . . . . 129 ciliare L. . . . . . 84 claviculatum Sw. . . . 17 cochlearifolium Sw. . . 73 cochleatum L. . . . 85, 101 corniculatum S'w. . . . 61 difforme Jacq. . . . 88 diffusum Sw. . . . . 81 echinocarpon Sw. . . . 136 filiforme Sw. . . . . 142 flabelliforme S'w. . . . 117 fragrans Sw. . . . . 85 funale Sw. . . . . 144 fuscatum Smiti . . . 90 glaucum Sw. . . . . 139 globosum Jacq. . . 99 graminoides Sw. . . . 138 guttatum L. . . . . 130 Harrisii Fawc. . . . 96 imbricatum Lindl. . . 94 jamaicense Lindl. . . . 88 labiatum Sw. . . . . 134 lanceola Sw. . . . . 64 laxum Sw. . . . . . 57 lineare Jacq. . . . 78 micranthum $S w$. . . 50 minutum Aubl. . . . 48 monophyllum Hooli. . . 60 montanum Sw. . . . 79 monticolum Fawc. \& Rendle . . . . 97 nocturnum Jacq. . . 87 nodosum L. . . . . 105 nodosum var. $\beta$. L. . . 101 nutans Sw. . . . . 90 ophioglossoides Jacq. . . 51 Ottonis Reichb. f. . . . 95 ovale Sw. . . . . 71 palmifolium Siw. . . . 115 parvilobum Fawc. \& Rendle . . . . 97 
EPIDENDRUn-continued.

PAGE patens Sw. . . . polybulbon Sw. proliferum $S w$ pulchellum Sw.

pygmaum Hook.

racemiflorum $S w$.

ramosum Jacq.

repens Cogn.

rigidum Jacq.

rivulare Lindl.

ruscifolium Jacq.

sanguineum Sw.

satyrioides $S w$.

serrulatum Sw.

sertularioides $S w$.

sessile Sw.

spondiadum Reichb. f.

strobiliferum Reichb. f.

subaquilum Lindl.

teretifolium Sw.

testafolium Sw.

tetrapetalum Jacq.

tribuloides Sw.

trichocarpon $S w$.

tridentatum Fawc.

tridentatum Sw.

trigoniflorum Sw.

tripterum Sm.

triquetrum Sw.

nmbellatum Sw.

undulatum Sw.

utricularioides $S u$.

Vanilla $L$.

variegatum Hart

verrucosum Sw.

vestitum $S w$.

vomeriforme $S w$.

vomiforme Sw. .

ERr

hirtella Fawc. \& Rendle .

jamaicensis Fawc. \&

Rendle . . . plantaginea Fawc. \&

Eulophia

Rendle. . .

alta Fawc. \& Rendle

Woodfordii Rolfe. .

Evelyna capitata Poepp. \& Endl.

longibracteata $\dot{L}_{i n d l}$.

Galeandra .

Beyrichii Reichb. f. $\cdot$.

Ghiesbreghtia calanthoides A. Pich. \& Gal.

Gorenia .

utriculata Lindi.

89

95

123

68

102

54

92

93

91

91

58

100

126

98

65

120

86

93

96

99

62

130

62

137

90

75

51

80

131

88

132

125

18

86

89

123

107

107

27

29

29

28

112

112

112

108

108

47

110

113
Greenwithe.

PAGE

113

Ground Coco

Habenaria . . . . . 10

alata Hook.. . . . 11, 13

brachyceras Spreng. . . 11

brachyceras Lindl. . . 13

brachyceratitis Willd.. . 11

distans Griseb.. . . . 12

eustachya Reichb. f. . . 14

jamaicensis Fawc. \& Rendle 12

macroceras Spreng. . . 10

macroceratitis Willd. . . 10

maculosa Lindl. . . . 11

monorrhiza Reichb. f. . 11

monor hiza Cogn. . . . 13

obtusa Lindl. . . . . 13

Purdiei Fawc. \& Rendle. 13

quadrata Lindl. . . . 14

repens Nutt. . . . . 11

Sanbornii Ames . . . 14

socialis Fawc. \& Rendle . 13

tricuspis A. Pich. . . . 12

troyana Fawc. \& Rendle. 14

HARRISElLA. . . . . 142 porrecta Favc. \& Rendle. 143

Heterotaxis crassifolia Lindl. . 120

Homalopetalum . . . . 106 jamaicense Rolfe . . . 107 vomeriforme Fawe. \&

Rendle . . . . . 107

HoRMIDIUM . . . . . . 101

pygmceum Hemsl. . . . 102

tripterum Cogn. . . . 102

Ioxopsis . . . . . . 124

satyrioides Reichb. f. . 125

tenera Lindl. . . . . 125

teres Lindl. . . . . . 126

testiculata Lindl. . . . . 125

utricularioides Lindl.. . 125

IsochILUS . . . . . 77

globosum Lindl. . . . 99

linearis R. Br. . . . . 78

prolifer R. Br. . . . . 123

teretifolium Lindl. . . 100

LÆLIA . . . . . . 102

monophyila N. E. Brown 103

Laliopsis domingensis Lindl.. 101

LEOCHILUS . . . . . . 133

cochlearis Lindl. . . . 134

labiatus Kuntze . . . 134

Lepanthes . . . . . . 66

arcuata Fawc. \& Rendle. 73

bilabiata Fawc. \& Rendle 74

brevipetala Fawc. \&

Rendle . . . . 74

cochlearifolia Sw. . . . 73 
LEPANTHES-continued.

concinna Sw.

concolor Fawc. \& Rendle divaricata Fawc. \& Rendle elliptica Fawc. \& Rendle. Harrisii Fawe. \& Rendle. Loddigesiana Reichb. f. . obtusa Fawc. \& Rendle . obtusipetala Fawc. \& Rendle \& \& ovalis Fawc. \& Rendle. pulchella Sw. \& \& Rendle rotundata Griseb. . . . sanguinea Hook. . . . tridentata Sw. . . . . tridentata Lindl. . . Woodiana Fawc. \& Rendle Wullschlaegelii Fawe. \& Rendle

Limodorum altum Jacq. . . 111 altum Sims . . . . 111 altum L. . . . . 111, 112 floridum Salisb. . . 111, 112 funale Sw. . . . . . 144 gentianoides Sw. . . . 15 lanceolatum Aubl. . . . 23 pendulum Aubl. . . . 136 purpureum Lam. . . . 111 Tancarvillece Banks . . 109 Tankervillia Dryand. . 109 tuberosum Jacq. . . . 111 tuberosum L. . . . . 111 utriculatum Sw. . . . 114 verecundum Salisb. . . 111

LIPARIS . . . . . 44 cardiophylla Ames. . . 45 elata Lindl.. . . . . 46 elliptica Reichb. $f_{. .}$. . 44 Harrisii Fawc. \& Rendle. 45 jamaicensis Lindl. . . 44 neuroglossa Reichb. f. . 45 rotundifolia Cogn.. . . 45 Saundersiana Reichb. f. . 46 vexillifera Cogn. . . . 44

LYCASTE . . . . . . 114 Barringtoniæ Lindl. . . 114

Macradenia. . . . . . 123 lutescens R. Br. . . . 124

Malaxis . . . . . . 41 Grisebachiana Fawc. \& Rendle integra Fawc. \& Rendle . spicata Sw. .

umbelliflora $\mathrm{Sw} \cdot \ldots$

umbellulata Sw. $: 42$ unifolia Michx, . . . 43
Masdevallia fenestrata Lindl. PAG

MAXILlaria . . . . . . 119

alba Lindl. . . . . . 120

Barringtonise Lodd. . . 114

ciliata Lindl. . . . . 114

crassifolia Rieichb. $f$. . . 120

decolor Lindl. . . . 115

palmifolia Lindl. . . . 115

rufescens Lindl. . . . 119

sessilis Fawc. \& Rendle . 120

stachyobiorum Reichb. f. . 116

Microstylis Grisebachiana

Fawc. \& Rendle . . . . 43

integra Fawc. \& Rendle . 43

spicata Lindl. . . . . 42

umbelliflora Hitchc. . . 42

umbellulata Lindl. 42

Neottia adnata Sw.. . . . 21

calcarata Hook. . . . 21

elata $S w . \quad . \quad . \quad . \quad 26$

flava Sw. . . . . . 40

glandulosa Sims . . . 37

Orchioides Sw. . . . . 23

orchioides Sims . . . 24

polystachya $S w$. . . . 41

speciosa Jacq. . . . . 23

squamulosa $H . B . \&$. $K . \quad 24$

tortilis Sw.... 25

Neo-Urbania . . . . . 121

adendrobium Fawc. \&

Rendle. . . . 122

Octadesmia . . . . 78

elata Benth. \& Hook. f. . 79

monophylla Benth. . . 103

montana Benth. . . . 79

Octomeria serratifolia Hool. . $\quad 79$

Eccoclades funalis Lindl.. . 144

ONCIDIUMI . . . . . . 129

altissimum Sw. . . . 133

Carthaginense Sw. . . 132

guttatum Fawc. \& Rendle 130

guttatum Reichb. $f$. . . 132

labiatum Reichb.f. . . 134

leucochilum Bateman . 132

luridum Lindl. . . . 132

pulchellum Hook. . . . 131

quadripetalum Sw. . . 130

sphacelatum Lindl. . . 133

sylvestre Lindl. . . . . 130

tetrapetalum Willd. . . 130

tricolor Hook. . . . . 130

triquetrum R. Br. . . . 131

variegatum Sw. . . . 130

Orchis habenaria L. . . . 10

hirtella Sw. $: . \quad 29$

monorrhiza Sw. . . . 11

plantaginea Sw. . . . 28 
ORxithidiux
coccineum Salisb.
proliferum Fawc. \& Rendle
vestitum Reichb. f.

Pelexia

adnata Spreng.. . . . 21

setacea Lindl. . . . . 21

spiranthoides Lindl.

spiranthoides Griseb. . . $\quad 26$

Phaies

grandifolius Lour.. • : 109

Tancarvilleæ Blume . . 109

Physurus hirtellus Lindl. . . 29 jamaicensis Fawc. \& Rendle 30 plantagineus Lindl. . . 28

PleURothallis _. . $\quad 52$

alpestris Lindl. . . . 56

atropurpurea Lindl. . . 49

brachypetala Griseb. . . 59

confusa Fawc. \& Rendle. 60

corniculata Lindl. . . 61

crassipes Lindl. . . . . 56

delicatula Lindl. . . . 63

emarginata Lindl. . . 60

foliata Griseb. . . . . 66

gelida Lindl. . . . . 55

Helenæ Fawc. \& Rendle. 64

hirsutula Fawc. \& Rendle 58

jamaicensis Rolfe . . . 63

lanceola Spreng. . . . 64

laxa Lindl. . . . . 57

longissima Lindl. . . . 54

microlepanthes Griseb. 65

monophylla Fawc. \&

Rendle

Morrisii Fawc. \& Rendle.

multicaulis Poepp. \& Endl. multirostris Reichb. f. nigroanmulata Cogn. . .56, oblongifolia Lindl.

pachyrachis A. Rich. .

pruinosa Lindl. racemiflora Lindl. . . 54

racemiflora Lodd. . . . 54

rotundifolia Rolfe . . . 61

ruscifolia R. Br. . . . 58

sertularioides Spreng. 65

testifolia Lindl. . . . 62

tribuloides Lindl. . . . $\quad 62$

trilobata Fawc. \& Rendle 66

uncinata Fawc. . . . 63

univaginata Lindl. . . 55

velaticaulis Reichb. f. $\quad$. 56

Wilsonii Lindl. . . . 59

Pogonia . . . . . 15

gentianoides Spreng. . . 15
Pogoxia-continued.

PAGE

macrcphylla Lindl. . . 15

physurifolia Reichb. $f . \quad$. 15

Polyrrhiza funalis Pfitz. . . 144

Polystachya . • . . 48

extinctoria Peichb. f. . . 48

foliosa Griseb. . . . . 49

foliosa Reichb. f. . . . 49

luteola Hook. . . . . 48

luteola Reichb. f. . . . 48

membranacea A. Rich. . 41

minor Fawc. \& Rendle . 49

minuta Britton . . 48

Ponera adendrobium Reicht. $\dot{f} .122$

Poxthieva . . . . . . 36

glandulosa R. Br. . . . 37

Harrisii Cogn. . . . . 38

pauciflora Fawc. \& Rendle 38

ventricosa Fawc.\& Rendle 39

Prescottia . . . . 35

myosurus Reichb. $f$. . . .35, 36

oligantha Lindl. . . . 36

stachyodes Lindl. . . . 35

Pseudocentrum . . . . 31

minus Benth. . . . . 31

Rhyncadenia cubensis A. Pich. 124

Satyrium adnatum Sw. . . 21

elatum Sw. . . . . . 26

hirtellum Sw. . . . . 29

Orchioides Sw. . . . 23

plantagineum $I_{\text {. }}$. . . 28

spirale Sw. . . . . 25

Sauroglossum tenue Lindl. $\quad$. $\quad 27$

Scaphyglottis prolifera Cogn.. 123

Schomburgkia . . . . . 103

carinata Griseb. . . . 103

Lyonsii Lindl. . . . . 103

SERAPHYTA . . . . . 81

diffusa Pfitz. . . . . 81

multiflora Fisch. \& Mey. . 81

Serapias flava Sw. . . . . 40 polystachya $S w . \quad$. . . 41

Speckliniaatropurpurea Lindi. 49

Spiranthes . • • • . . 25 apiculata Lindl. . . . $\quad 25$

bicolor Lindl. . . . . 203

elata L. U. Rich. . . . 26

Fawcettii Cogn. • . 27

quadridentata L.C. Rich. 25

tortilis L. C. Rich. . . 25

Stelis . . . . . 50

micrantha Sw. . . . 50

ophioglossoides Sw. . . 51

polystachya Cogn. . . . 51

Stenoptera Presl . . . . 34

ananassocornos Reichb. f. 34 


\begin{tabular}{|c|c|c|c|c|}
\hline & & & & PAGI: \\
\hline TTEXORRHYXCOS & & 22 & VaNiLla-continued. & \\
\hline lanceolatus friseb. & $\cdot$ & 23 & culata Sw.. & 16 \\
\hline orchioides Lindl. . & . & $.23,24$ & clariculata Lindl. . & 18 \\
\hline speciosus Lindl. . & . & 22 & grandiflora Lindl. . & 20 \\
\hline squamulosus Fawc. & & $\&$ & inodora Schiede. & 17 \\
\hline Rendle. & & 24 & mexicana Willer & 19 \\
\hline & & & Reichb. $\mathrm{f}$. & 19 \\
\hline FTRAMICRA . & . & 105 & planifolia Androws & 19 \\
\hline montana Griseb. & . & 79 & ona Schiede. & 20 \\
\hline parviflora Lindl. & . & 106 & Wrightii Reichb.f. & 18 \\
\hline TRICHOPILIA . . & . & 127 & & \\
\hline jamaicensis & & $\&$ & Wild Coco & 113 \\
\hline Rendle & & 127 & WULLSCHLAG ELIA & 30 \\
\hline $\begin{array}{c}\text { Trigonidium } \\
\text { Griseb. . }\end{array}$ & lllum & & aphylla Reichb. 1 . & 30 \\
\hline Tropidia : : & . & 40 & T'YTRUTU & \\
\hline Eatoni Ames . . & • & 41. & $\begin{array}{l}\text { AYLOBIUA } \\
\text { palmifolium Faiwc. }\end{array}$ & \\
\hline polystachya Ames. & & & stachyobiorum Hemsi. & - 116 \\
\hline ANILLA . & ${ }^{\circ}$ & 1 & & \\
\hline anaromatica Griseb. & - & & Zygopetaleir & 116 \\
\hline aromatica Su & . & & e Lindl. & . 1 \\
\hline ellata Rie & & & Habelliforme R & 117 \\
\hline
\end{tabular}


PLATES 



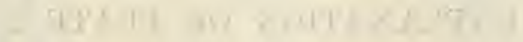

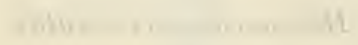

$$
\begin{aligned}
& -1,+1+1
\end{aligned}
$$

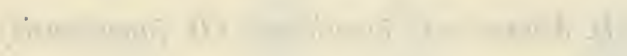

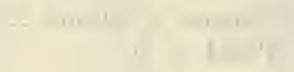

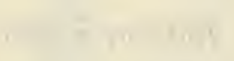

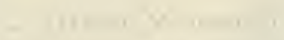

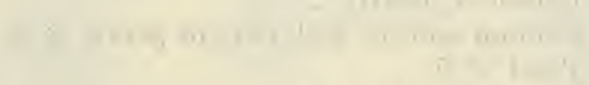

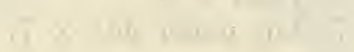

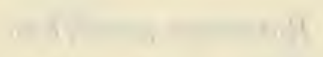

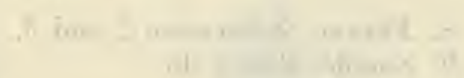

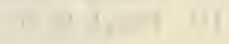

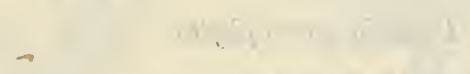

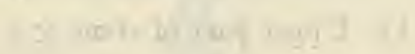




\section{EXPLANATION OF PLATE 1}

\section{Habenaria marroceratitis}

1. Flower, natural size.

H. distans var. jamaicensis (H. jamaicensis)

2. Flower $\times$ about 2 .

3. Petal $\times 5$.

\section{Habenaria alata}

4. Flower $\times$ nearly 2 .

5. Column and lip with part of petals $\times 4$.

6. Petal $\times 5$.

7. Lip, under side $\times 7$.

Habenaria monorrhiza

8. Flower $x$ between 2 and 3 .

9. Smaller flower do.

10. Petal $\times 5$.

Pogonia macrophylla

11. Upper part of stem $\times \frac{2}{3}$. 


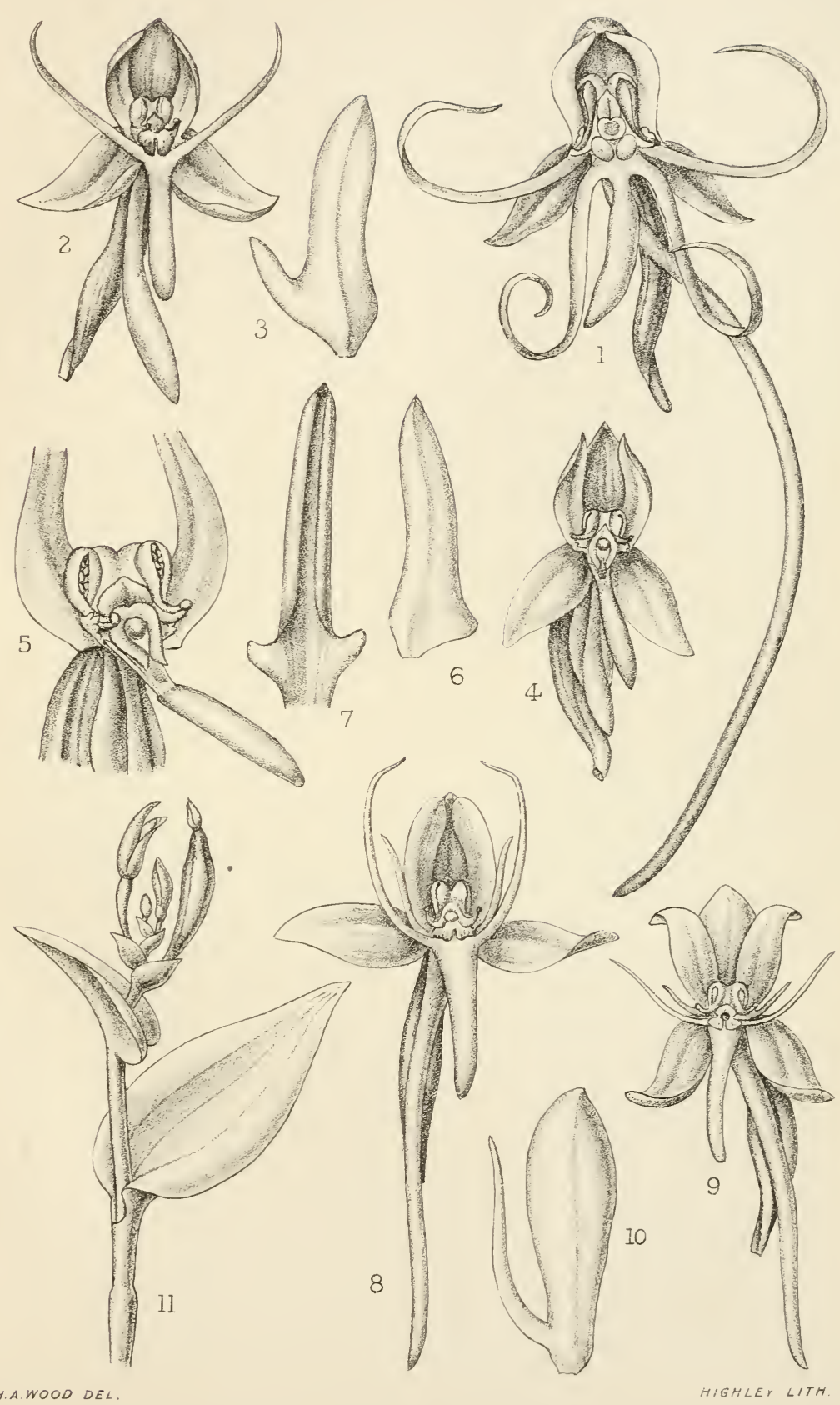

1 Habenaria macroceratitis ; 2,3 Hidistans var.; 4-7 H. alata; 8-10 H monorrhiza; ll Pogonia macrophylla. 


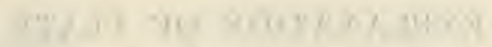

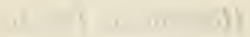

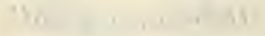

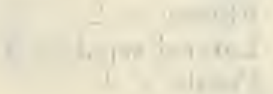

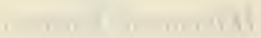

$$
\begin{aligned}
& +1 \\
& \text { inh wh }
\end{aligned}
$$

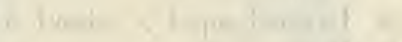

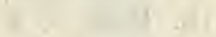

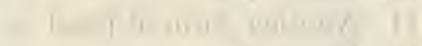

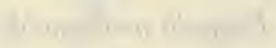

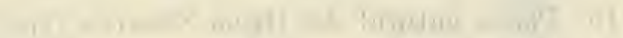

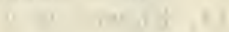

$$
\begin{aligned}
& \text { nin } 1 \text { y } \\
& \text { ing atho it }
\end{aligned}
$$

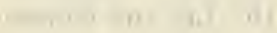

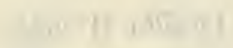

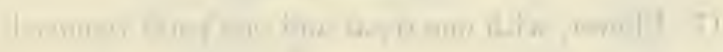

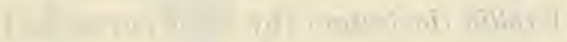

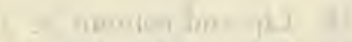

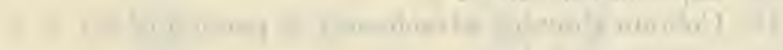

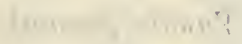

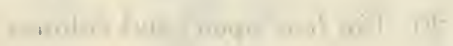

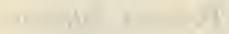

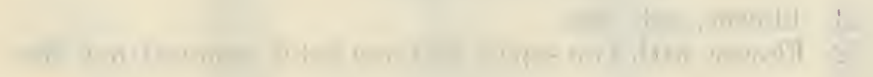


Habenaria Purdiei

1. Flower $\times 2$.

$\therefore$. Lateral sepal $\times$ :?.

3. Petal $\times 3$.

Habenaria socialis

4. Flower $\times 2$.

5. Lateral sepal $\times 4$.

6. Petals $\times 4$.

7. $\operatorname{Lip} \times t$.

Habenaria troyana

S. Flower $\times 2$.

9. Lateral sepal $\times$ about 5 .

10. Petal $\times 4$.

11. Another form of petal $\times 4$.

12. Lip $\times 4$.

\section{Pogonia gentianoides}

13. Plant, natural size (from Swartz's type).

14. Flower $\times 2$.

15. $\operatorname{Lip} \times 4$.

\section{Vanilla inodora}

16. Lip and column $\times \frac{1}{2}$.

\section{Vanilla Wrightii}

17. Flower, with one sepal and one petal removed, $\times \frac{1}{2}$.

Vanilla claviculata (by error parasitica)

18. Lip and column $\times \frac{1}{2}$.

19. Column showing attachment of portion of lip $\times \frac{1}{2}$

\section{Vanilla pliæantha}

20. Lip (cut open) and column $\times \frac{1}{2}$.

\section{Pelexia setacea}

21. Flower, nat. size.

22. Flower, with two sepals and one petal removed, nat. size. 


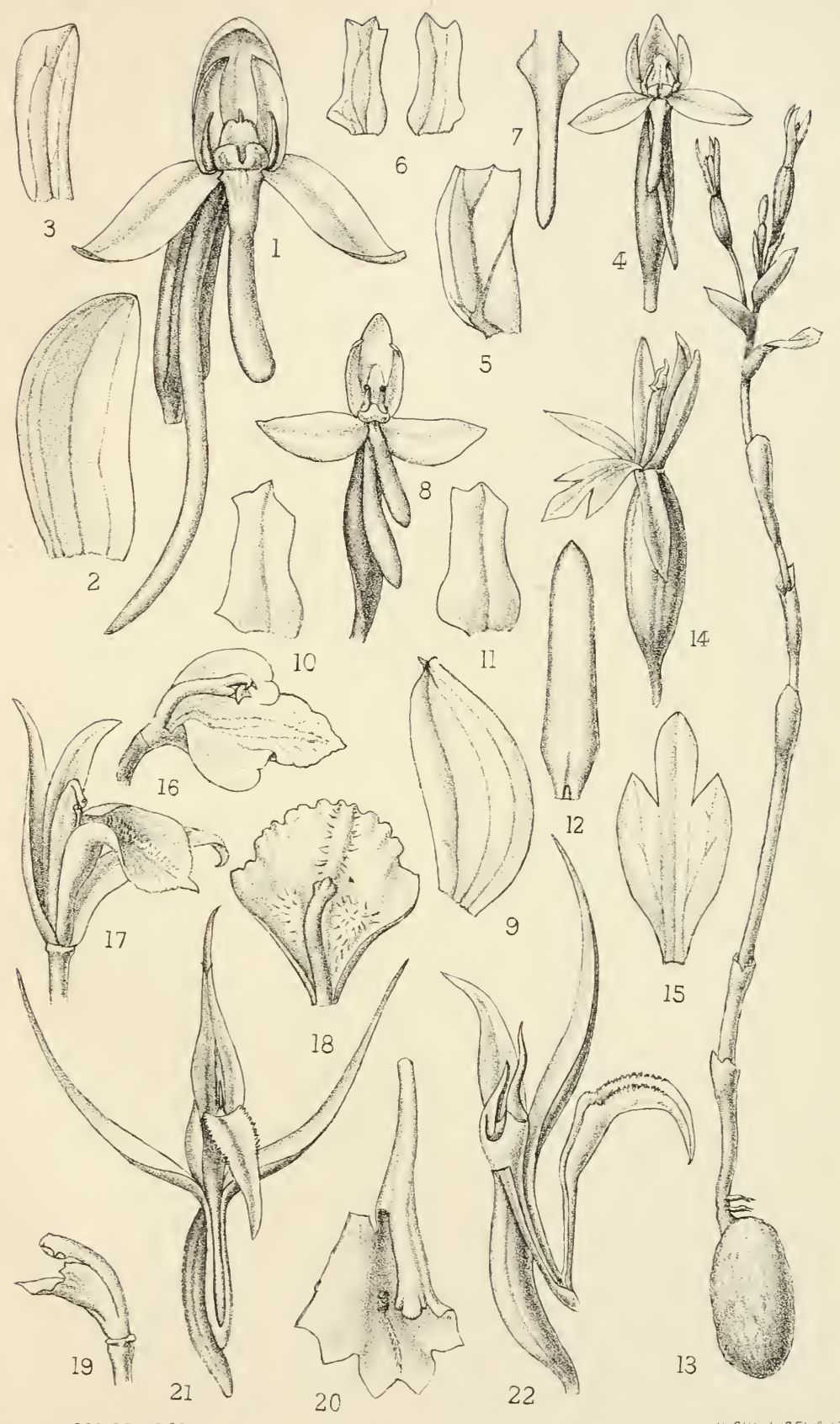

is i $W C O O D E_{L}, 16-22$

1-3 Habenarıa Purdiel; 4-7 H socialis: 8-12 H troyana; 13-15 Pogonia gentianoidés; 16 Vanilla inodora 17 V. Wrightil: 18-19 V parasitica; $20 \mathrm{~V}$. phæantha; 21.22 Pelexia setacea. 


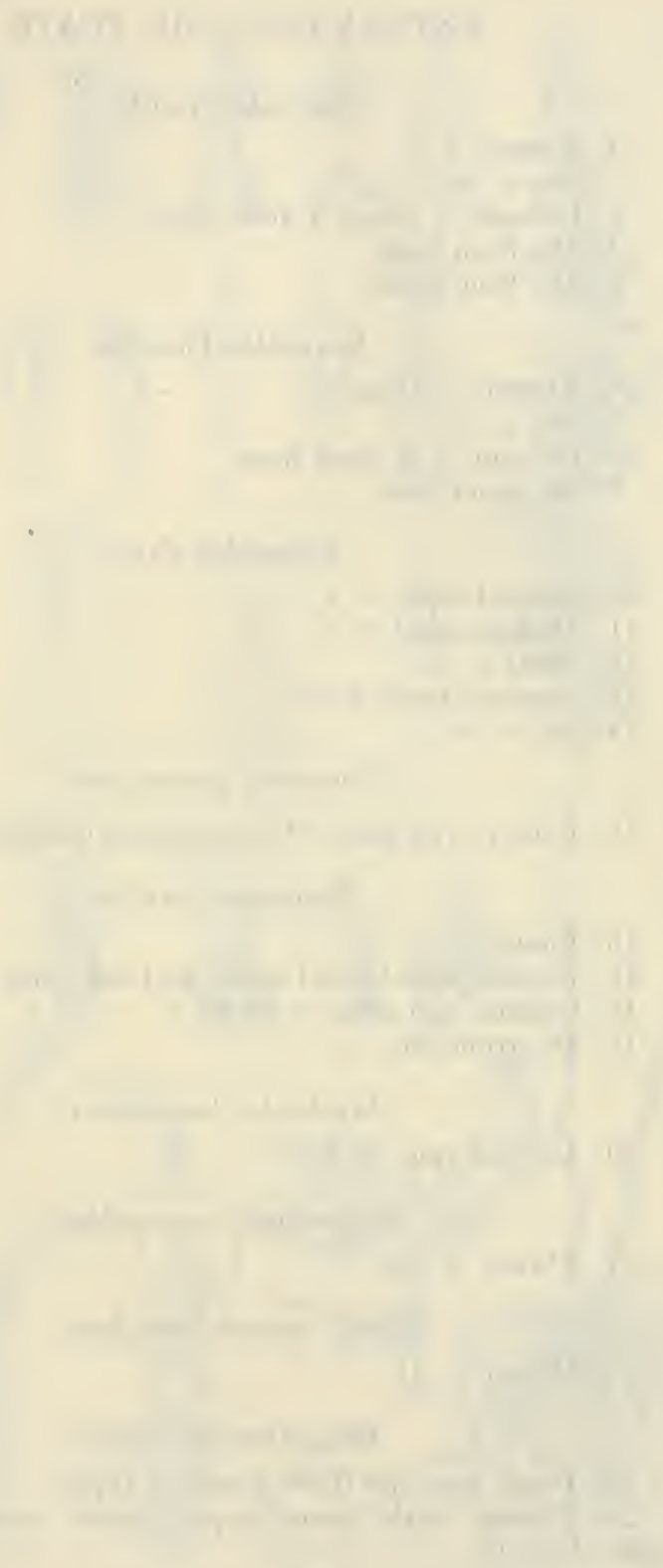
Spiranthes tortilis

1. Flower $x+$.

2. $\operatorname{Lip} \times 4$.

3. Column $\times$ about 5 , from side.

4. Do. from back.

j. Do. from front.

Spiranthes Fawrettii

6. Flower $\times$ about $2 \frac{1}{2}$.

7. Lip $\times 3$.

8. Column $\times 3$, from front.

9. Do. from back.

$$
\text { Spiranthes elata }
$$

10. Lateral sepal $\times 4$.

11. Median sepal $\times 4$.

12. Petal $\times 4$.

13. Another form of do.

14. $\operatorname{Lip} \times 4$.

\section{Erythrodes plantaginea}

15. Flower, with part of the sepals and one petal removed, $\times 3$.

$$
\text { Erythrodes livtella }
$$

16. Flower $\times 3$.

17. Flower, with lateral sepals and one petal removed, $\times 3$.

18. Column and spur $\times$ about 4 .

19. Do. from side.

Erythrodes jamaicensis

20. Lip and spur $\times 3$.

\section{Stenorrhyncos squamulosus}

21. Flower $\times 1 \frac{1}{2}$.

Stenorilyncos lanceolatus

22. Flower $\times 1 \frac{1}{2}$.

\section{Wullschlregelia apliylla}

23. Plant, nat. size (from Swartz's type).

24. Flower, with lateral sepal pulled down and a petal removed, $\times 6$. 


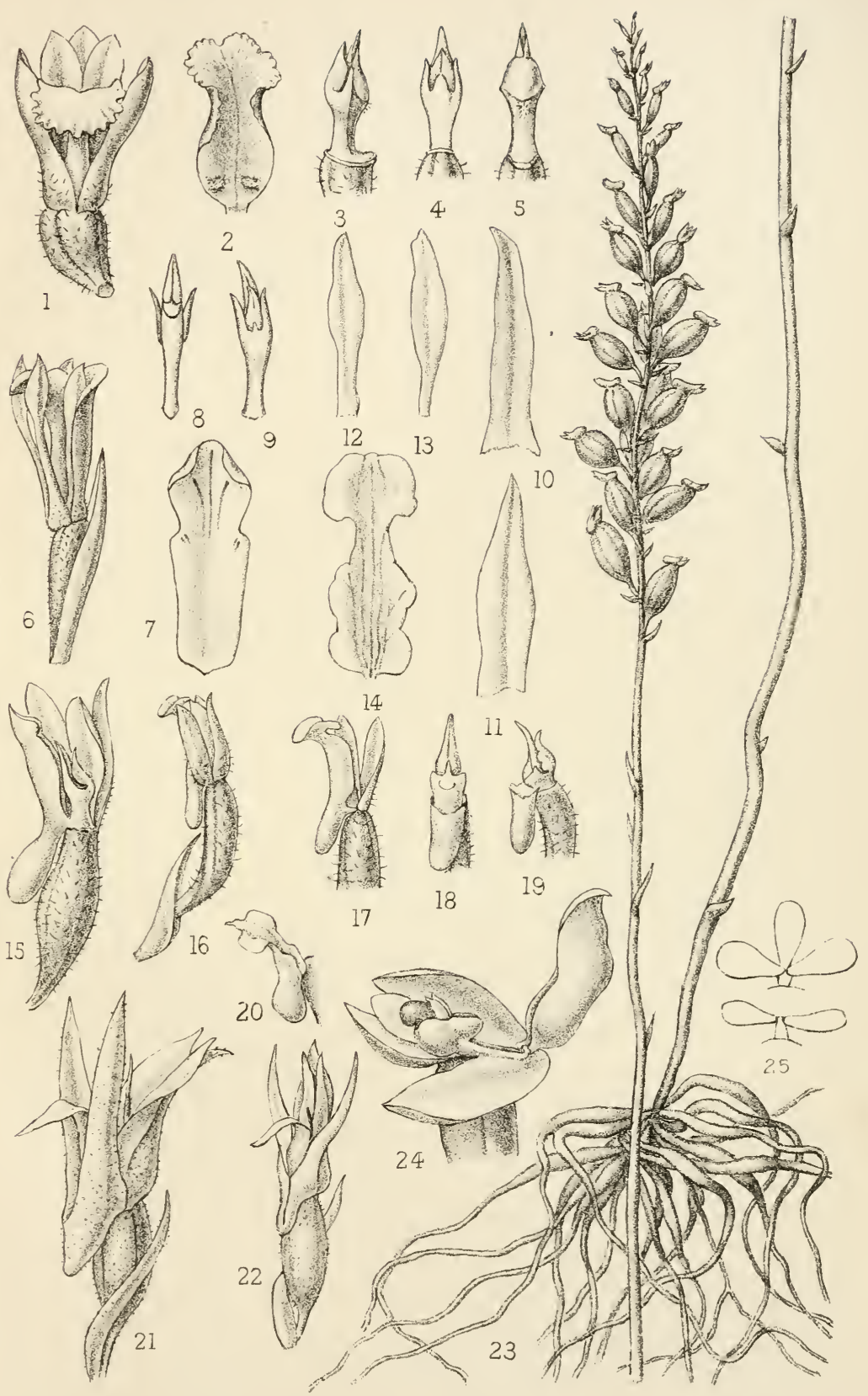

H. A WOOD DEL $1 \cdot 9,15-19,21,22$

1-5 Spiranthes tortilis; 6-9 S. Fawcetti1: 10-14 S.elata; 15 Erythrodes plantaginea; $16-19 \mathrm{E}$.hirtella; $20 \mathrm{E}$ jamaicensis; 21 Stenorrhyncos squa mulosus; 22 S lanceolatis; 



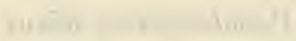

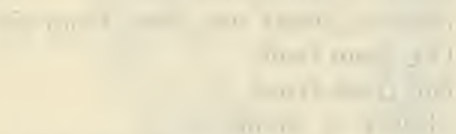$$
\text { - }
$$

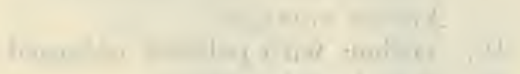




\section{EXPIANATION OF PLATE 4}

Pseudocentrum minus

1. Plant, half natural size.

2. Flower, about nat. size, from side

3. Do. from back.

4. Do. from front.

5. Flower $\times$ about 3 .

6. Section of flower $\times$ between 2 and 8 .

7. Column enlarged.

8. Column from side enlarged.

9. Anther enlarged.

10. Anther, with pollinia, enlarged.

11. Pollinia enlarged. 
Orchids of Jamaica

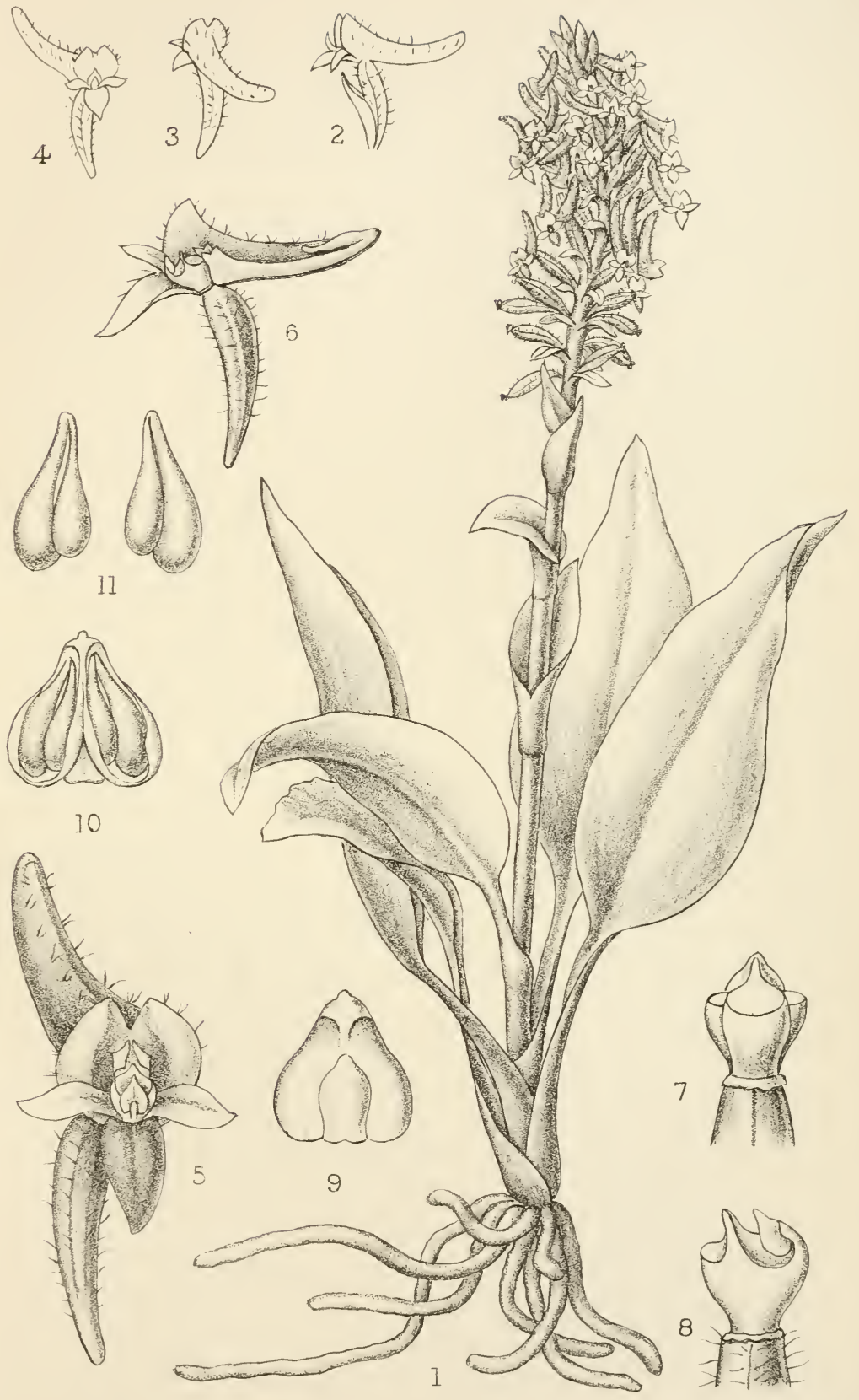

H.A. WOOD DEL 




\section{EXPLANATION OF PLATE 5}

\section{Craniclis pilosa}

1. Raceme, natural size.

2. Flower $\times$ about 41 .

3. Column, with lip thrown back, $x$ about 10 .

\section{Prescottia oligantha}

4. Flower, with one sepal and one half and one petal removed, $\times 16$.

\section{Stenoptera ananassocomos}

5. Plant, nat. size.

6 . Flower $\times 8$.

\section{Ponthieva Harrisii}

7. Raceme, nat. size.

8. Flower, with sepal thrown back, $\times$ about 3 .

9. Flower, with one sepal and one half and one petal removed, $\times$ about 6 .

10. Anther enlarged, from different points of view.

11. Pollinia enlarged.

\section{Ponthiera panciflora}

12. Flower, with one sepal and one petal removed, $x$ about 6 . 13. Lip $\times$ about 6 .

\section{Corymborchis flava}

14. Flower, with lip and lateral sepals spread out, nat. size.

\section{Tropidia polystachya}

15. Flower $\times 2$. 

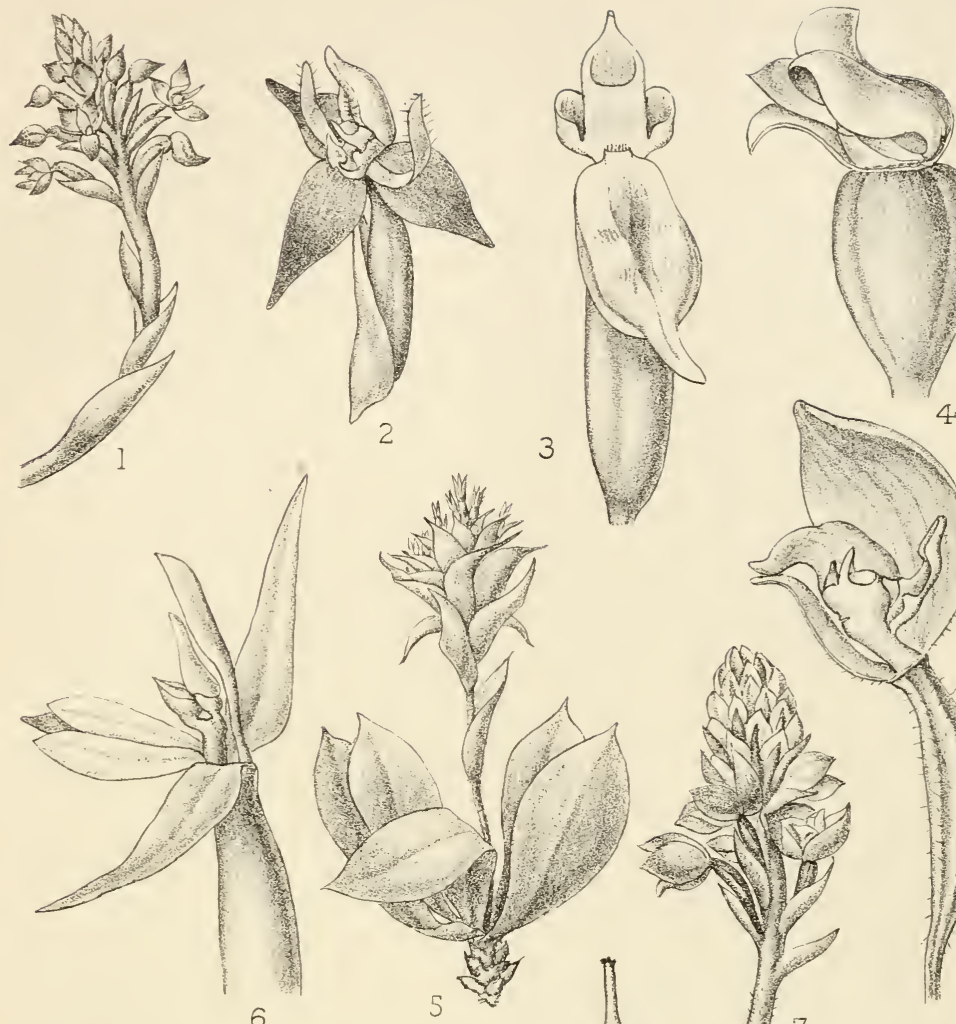

3
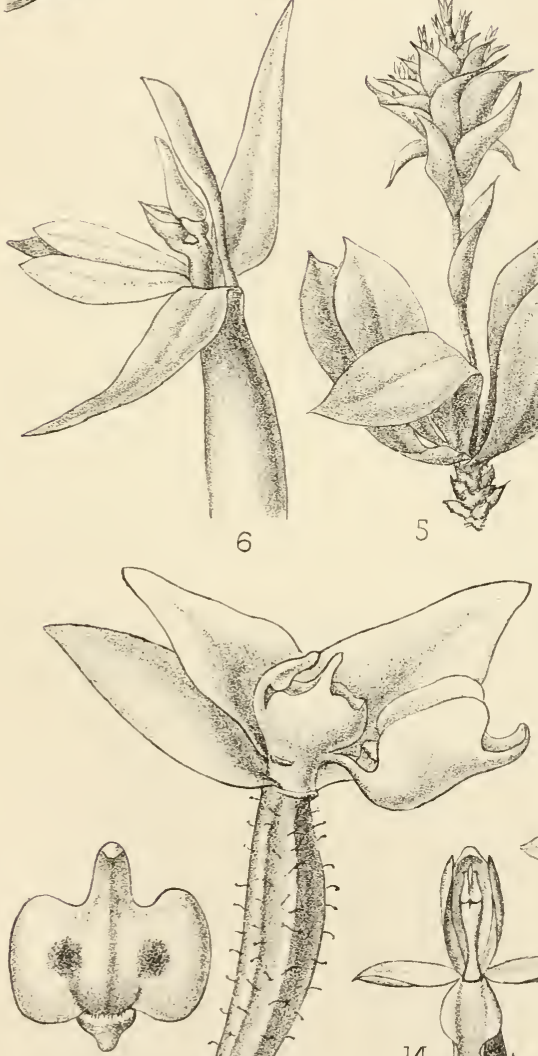

6
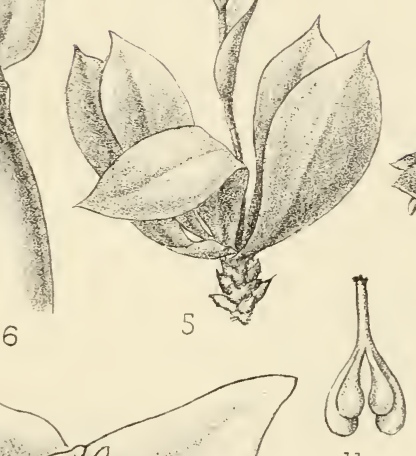

13

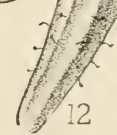

14.

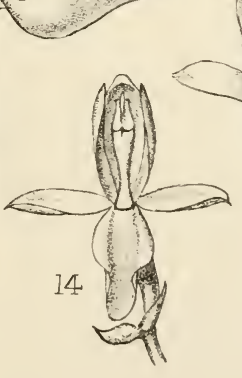

11
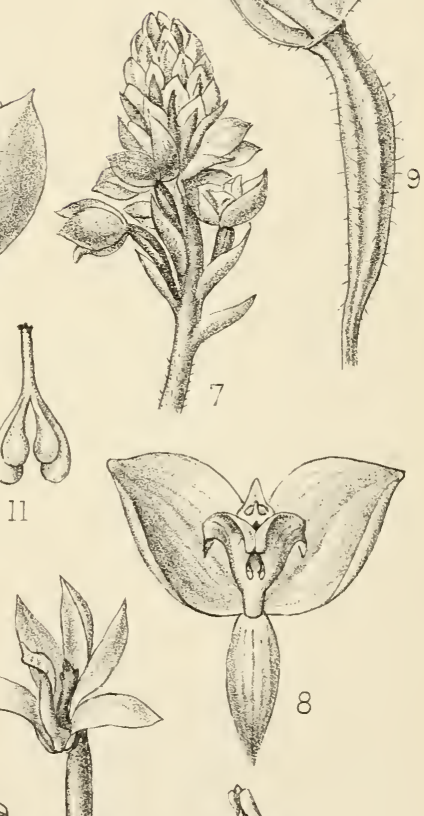

$-9$ 



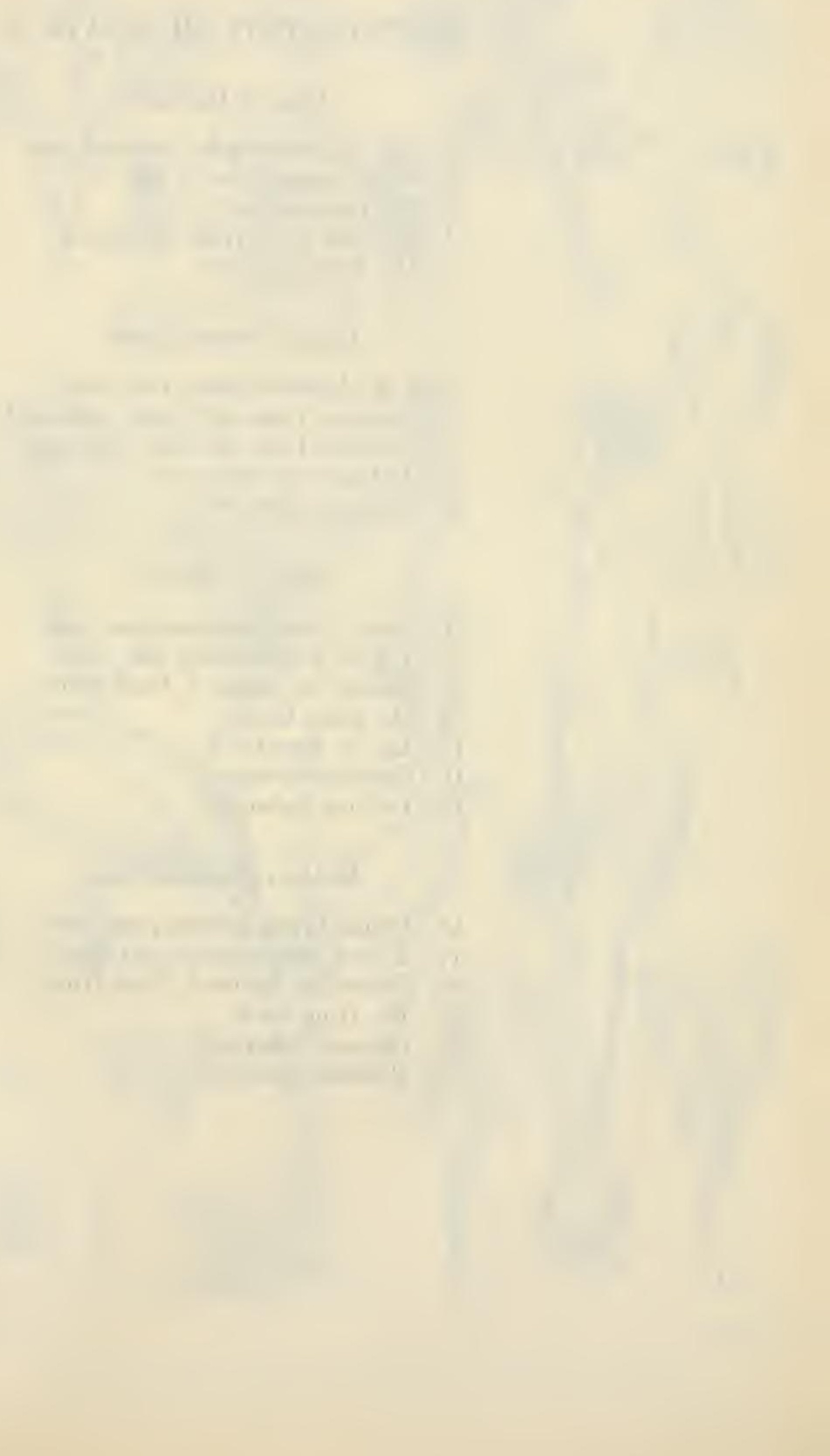


EXPLANATION OF PJATE 6

\section{Liparis Harrisii}

1. Top of flower-spike, natural size.

2. Sepal pressed flat $\times 2 \frac{1}{2}$.

3. Lip pressed flat $\times 3$.

4. Column $\times 5$, from the front.

5. Do. from the side.

\section{Liparis Saundersiana}

6. Top of fiower-spike, nat. size.

7. Column, from the front, enlarged

8. Column, from the side, enlarged.

9. Anther case enlarged.

10. Pollinia enlarged.

\section{Malaxis integra}

11. Plant, lower portion, nat. size.

12. Top of flower-spike, nat. size.

13. Flower $\times$ about 6 , from front.

14. Do. from back.

15. Lip $\times$ about 8 .

16. Column enlarged.

17. Pollinia enlarged.

\section{Malaxis Grisebachiana}

18. Plant, lower portion, nat. size.

19. Top of flower-spike, nat size.

20. Flower $x$ about 6 , from front.

21. Do. from back.

22. Column enlarged.

23. Pollinia enlarged. 


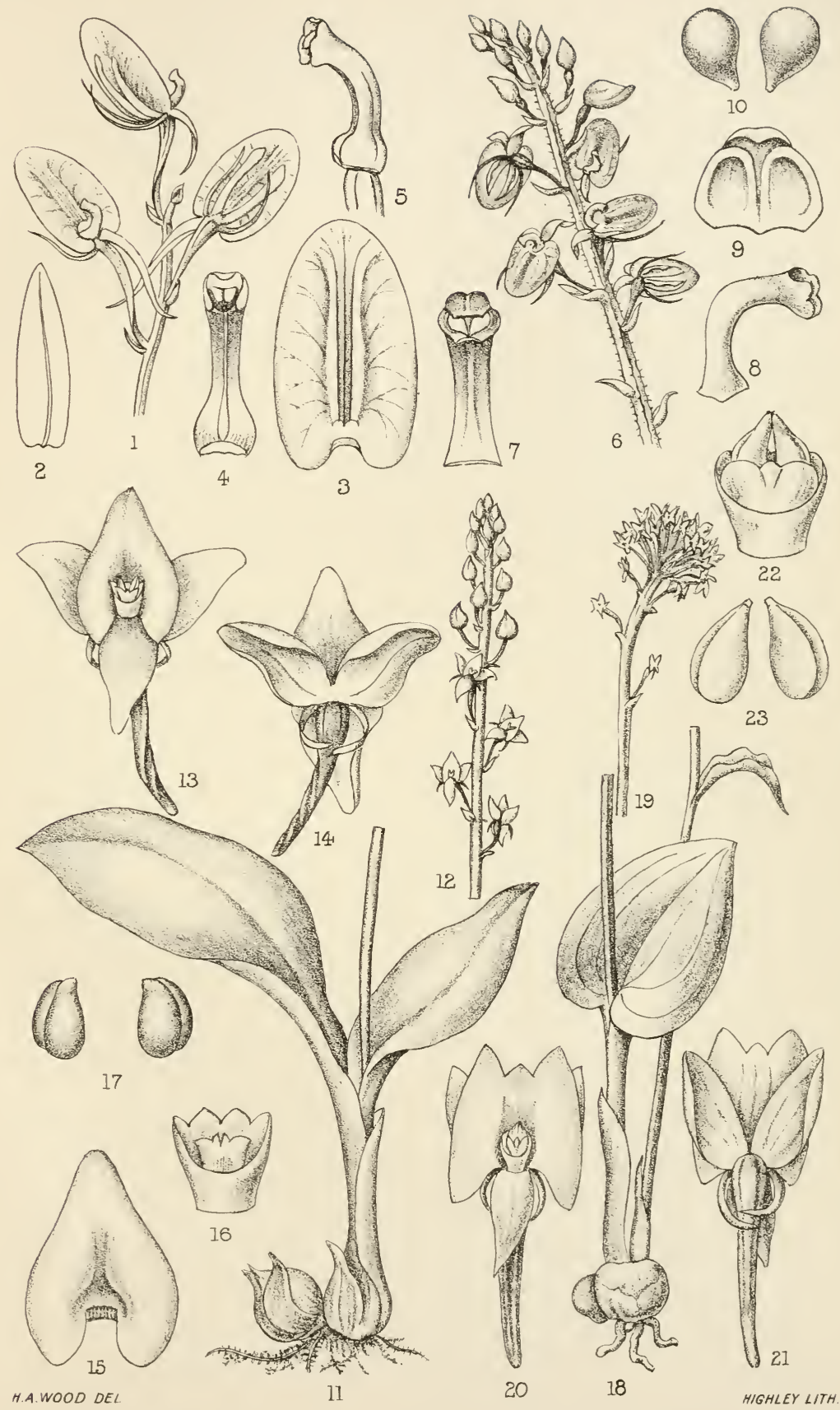






\section{EXPLANATION OF PLATE 7}

\section{Galeandra Beyrichii}

1. Part of peduncle with one flower, about natural size.

2. Lip tom away at base and flattened, with column, about nat. size.

3. Anther enlarged.

\section{Polystachya mimuta}

4. Flower, with one sepal and one half removed, and lip turned back, $x$ about 4 .

5. Lip spread out $\times$ about 5 .

\section{Polystacliya minor}

6. Flower, with one sepal and one balf and one petal removed, and lip turned back, $\times$ about 4 .

7. Lip spread out $\times$ about 5 .

\section{Cryptophoranthus atropurpureus}

8. Flower, nat. size.

9. Flower, with sepals removed and one petal turned back, $\times 3$.

10. $\operatorname{Lip} \times 3$.

\section{Stelis oplioglossoides}

11. Raceme and part of leaf, nat. size.

12. Flower $\times 5$.

13. Petals, lip and column $\times 16$.

14. Column viewed more from the anterior $\times 16$.

\section{Stelis micrantha}

15. Raceme and part of leaf, nat. size.

16. Flower (Fl. Jam. 10,08i $\times 5$.

17. Petals, lip and column of do. $\times 16$.

18. Column of do., viewed more from behind, $\times 16$.

19. Flower (Fl. Jam. 7835$) \times 5$.

20. Petals, lip and column of do. $\times 16$.

21. Petal of do. lying flatter $\times 16$.

22. Lip of do. lying flatter $\times 16$.

23. Bud of do. $\times 16$.

24. Column of do. $\times 16$.

25. Pollinia $\times 16$.

26. Flower of Sowerby's specimen $\times 5$.

27. Flower of Swartz's specimen $\times 5$.

28. Flower (J.P. 23) $\times 5$. 


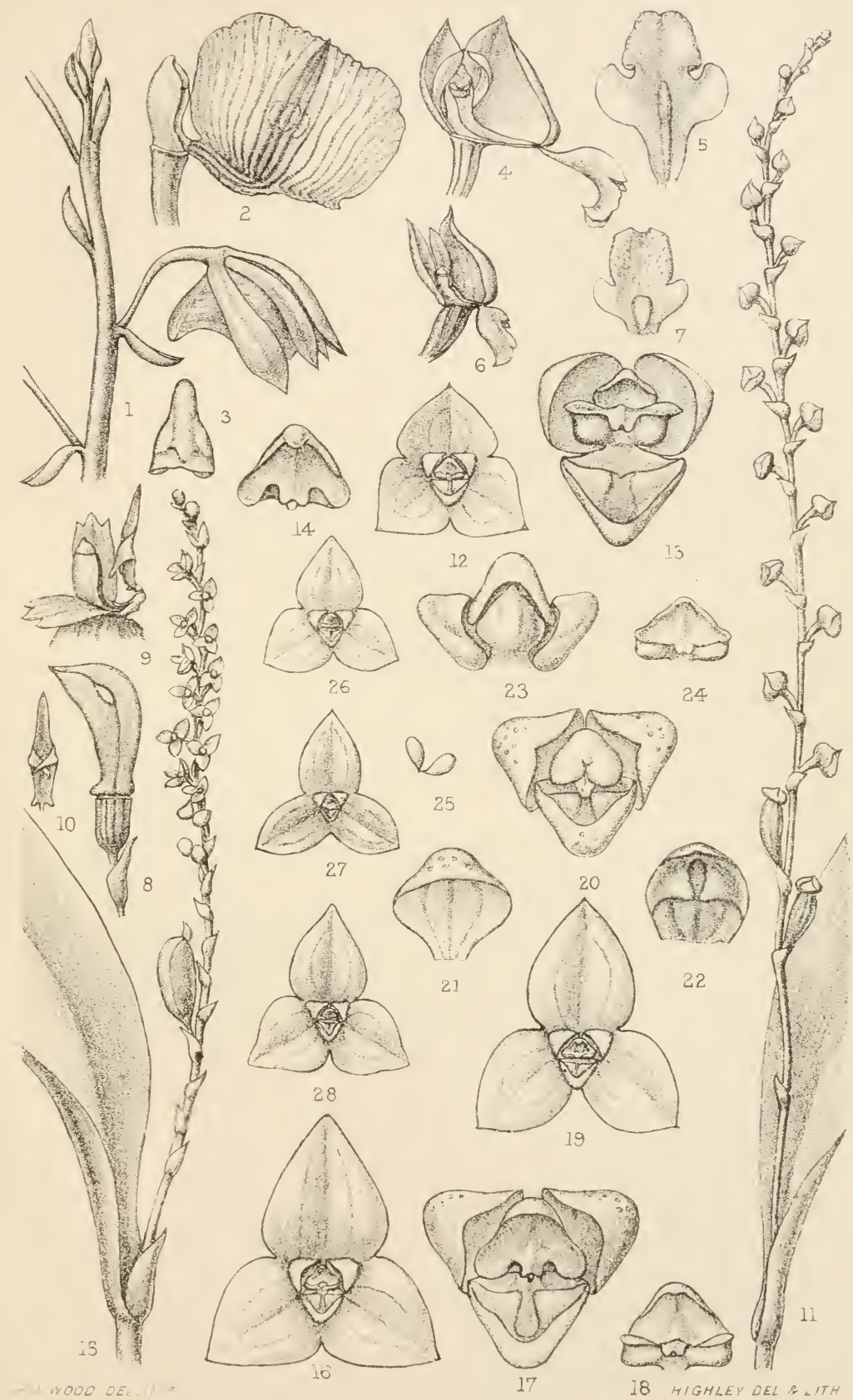

Galeandra Beyricnil; 4,5 Polvstachya mınuta, 67 P.minor,

8-il Cryptophoranthus atrop Irpureus; $11-14$ Stelis ophioglossoides; 



$$
\text { I. }
$$

$$
\text { (1, }
$$




\section{EXPLANATION OF PLATE 8}

\section{Pleurothallis trilobata}

1. Plant, natural size.

2. Flower $\times 5$.

3. Petal $\times 9$.

4. $\operatorname{Lip} \times 10$.

5. Column $\times 10$.

6. Pollinia enlarged.

\section{Pleurothallis brachypetala}

7. Plant, nat. size.

8. Flower with part of the sepals removed $\times 7$.

9. $\operatorname{Lip} \times 10$.

10. Lip spread out $\times 10$.

\section{Pleurothallis rotundifolia}

11. Plant, nat. size.

12. Flower $\times 4$.

13. Petal $\times \tau$.

14. $\operatorname{Lip} \times 6$.

15. Lip spread out $\times 6$.

16. Column $\times 7$.

\section{Pleurothallis relaticanlis}

17. Portion of stem with leaf and raceme, nat. size.

18. Flower $\times 5$.

19. Dorsal sepal $\times 5$.

20. Lateral sepal $\times 5$.

21. Petal $\times 8$.

22. $\operatorname{Lip} \times 7$. 

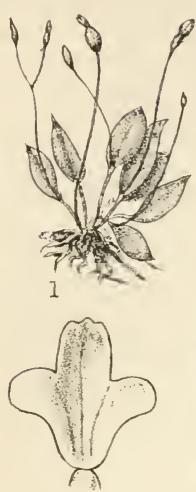

4

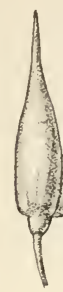

2

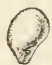

6
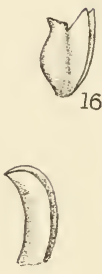

14
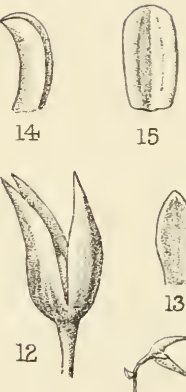

15

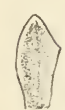

13

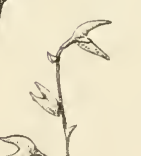

A
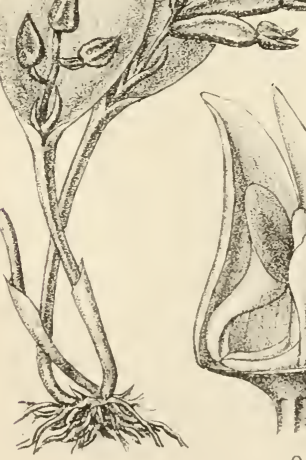

7

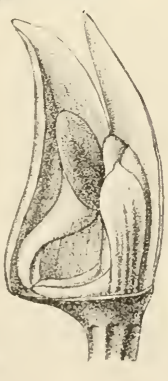

8

FAWCETT DEL $11 \cdot 16$

16 Pleurothallis trilobata 7-10 P brachypetala. 11-16 P. rotundifolia: 17-22 P. velaticaulis.

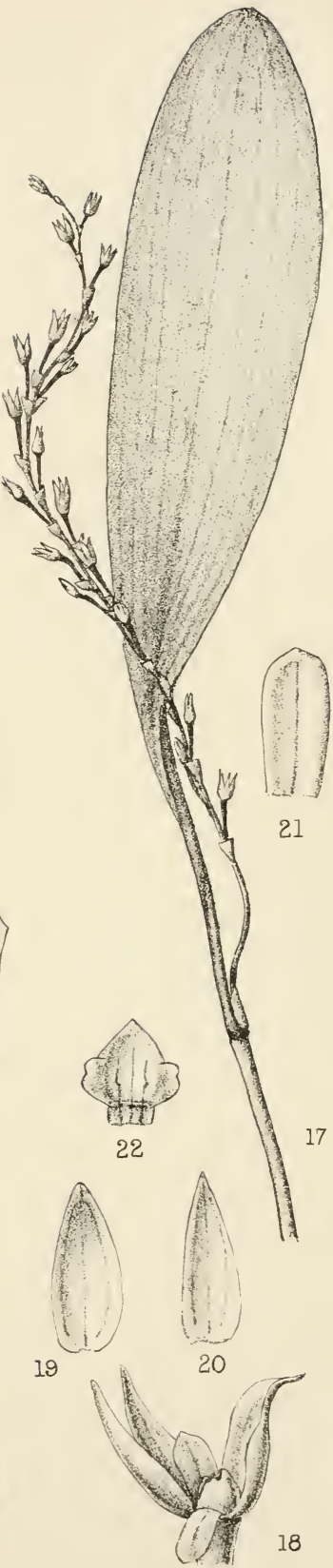

HIGHLEY DEL \& LITH 


EXPLANATION OF PLATE 9

Pleurothallis Morrisii

1. Plant, natural size.

2. Petal $\times 15$.

3. Lip $\times 15$.

4. Column $\times 15$.

Pleurothallis confusa

5. Portion of plant, nat. size.

6. Petal $\times 15$.

7. Lip $\times 9$.

\section{Pleurothallis Wilsonii}

8. $\operatorname{Lip} \times 9$.

\section{Pleurothallis Helenæ}

9. Plant, nat. size.

10. Flower spread out $\times 6$.

11. $\operatorname{Lip} \times 19$.

12. Ovary and column $\times 15$.

13. Anther case enlarged.

14. Pollinia enlarged.

\section{Pleurothallis hirsutula}

15. Portion of plant, nat. size.

16. Flower $\times 4$.

17. Petal $\times 5$.

18. $\operatorname{Lip} \times 6$.

19. Column $\times 7$. 

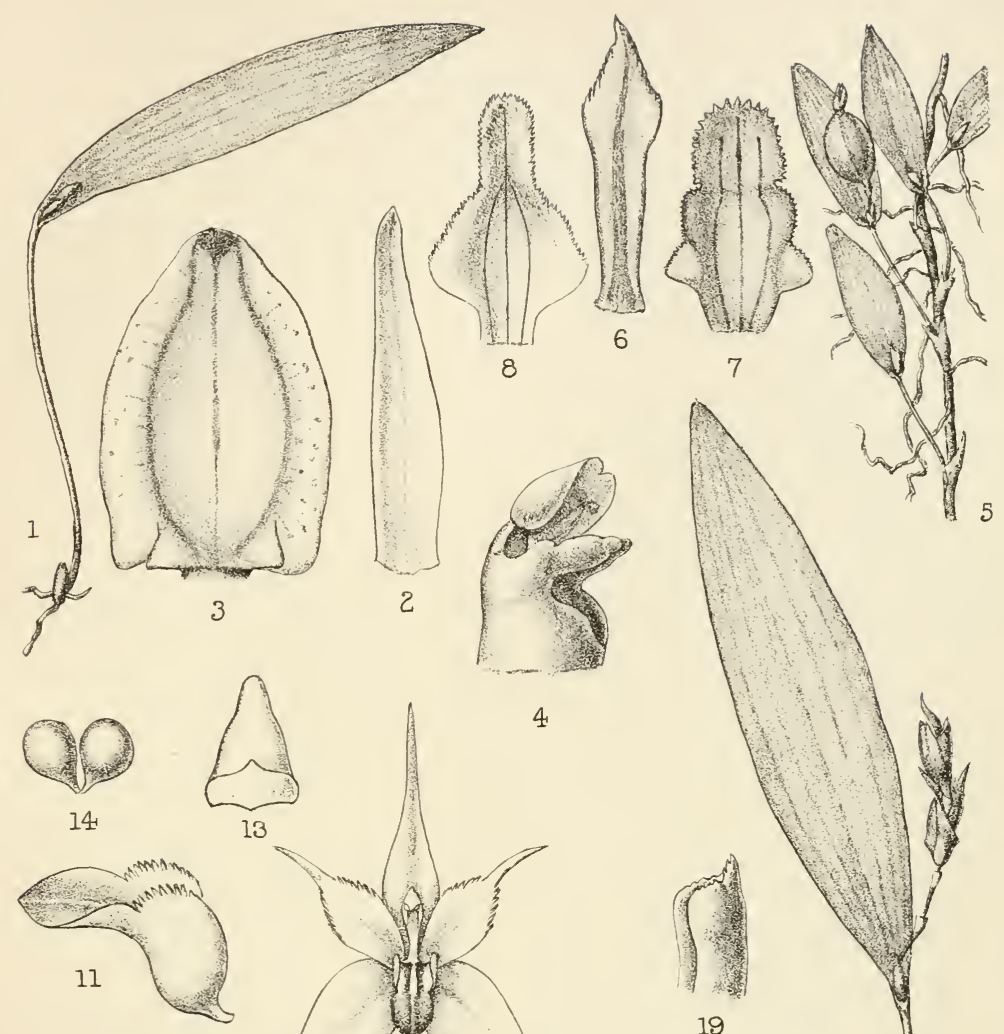

2
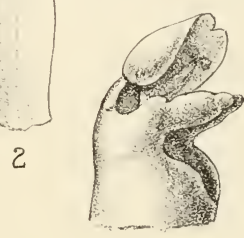



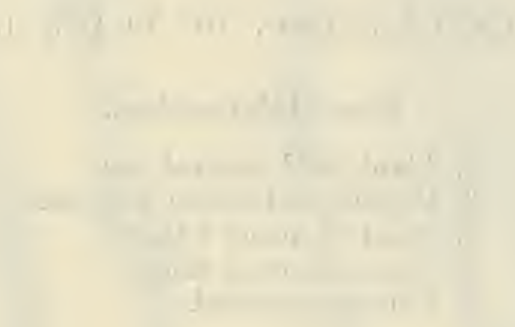




\section{EXPLANATION OF PLATE 10}

\section{Pleurothallis uncinata}

1. Plant, half natural size.

2. Capsule and flower, nat. size.

3 . Petal $\times$ about 4 times.

4. Lip $\times$ about 4 times.

5. Column enlarged. 


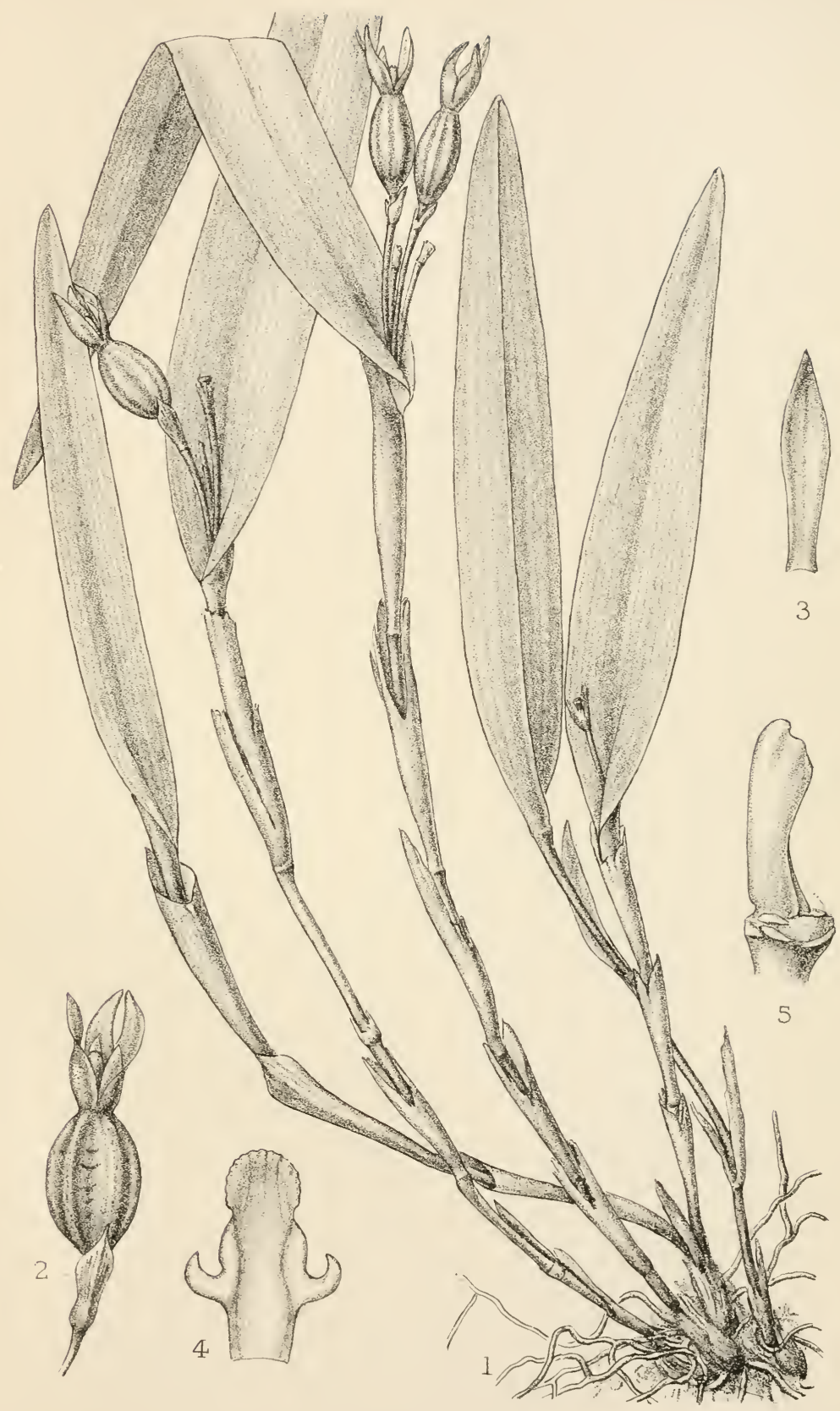





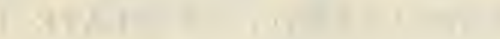
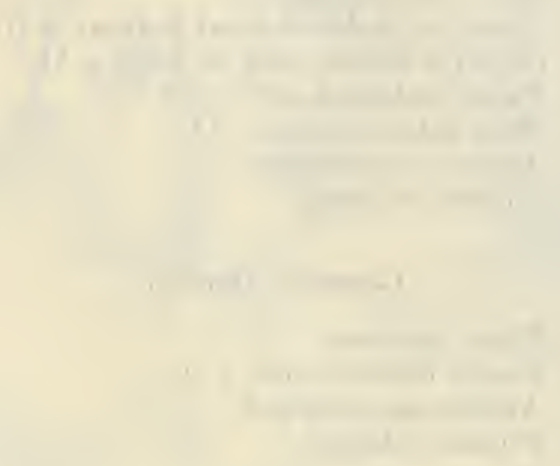
EXPLANATION OF PLATE 11

Lepanthes arcuata

1. Plant, natural size.

2. Flower with dorsal sepal in front $\times 11$.

3. Do. with lateral sepal in front $\times 11$.

4. Nlower flattened out $\times 13$,

5. Petal flattened out $\times 14$.

6. Anther case enlarged,

7. Pollinia enlarged.

\section{Lepanthes Harrisii}

8. Plant, nat. size.

9. Flower flattened out $\times 9$.

10. Anther case enlarged.

11. Pollinia enlarged.

\section{Lepanthes Woodiana}

12 \& 13. Plant nat. size.

14. Flower flattened out $\times 12$.

15. Capsule enlarged.

16. Anther case enlarged.

17. Pollinia enlarged.

Lepanthes elliptica

18. Plant, nat. size.

19. Flower flattened out $\times 5$.

20. Petals and column enlarged.

21. Lip enlarged.

\section{Lepanthes brevipetala}

22. Plant, nat. size.

23 . Flower flattened out $\times 12$. 

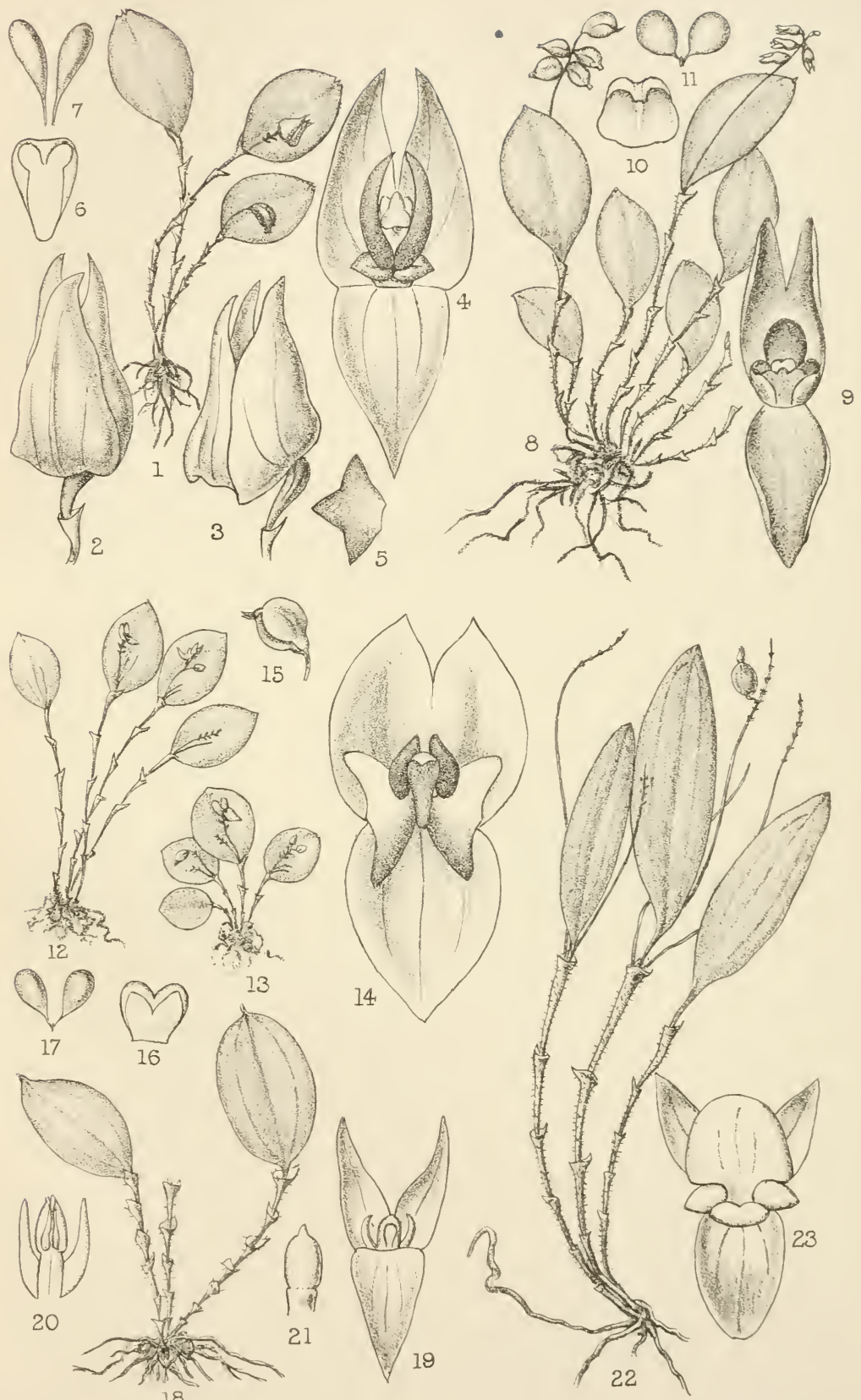

1-7 Lepanthes arcuata: 8-11 L.Harrisil:

12-17 L. Woodiana: 18-21 L. elliptıca: 22.23 L brevipetala 




\section{EXPLANATION OF PLATE 12}

\section{Brachionidium Sherringii}

1. Plant, natural size.

2. Leaf showing position of sheaths $\times 2$.

3 . Flower $\times 1 \frac{1}{2}$, from front.

4. Do. from back.

5. Dorsal sepal $\times$ about 2 .

6. Lateral sepals $\times$ about 2 .

7. Petal $\times$ about 2 .

8. Lip and column $\times 17$, side view.

9. Do. back view.

10. Anther case enlarged.

11. Pollinia enlarged. 


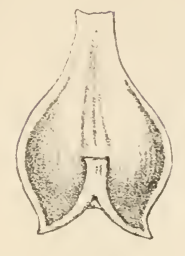

10

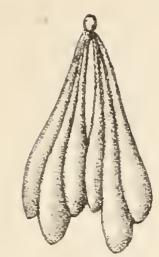

11
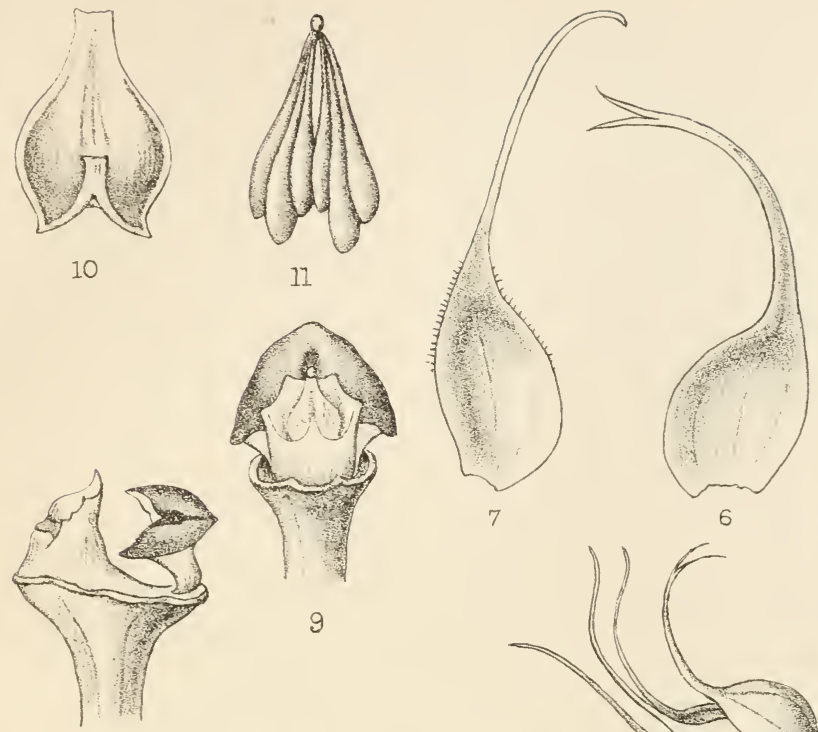

6

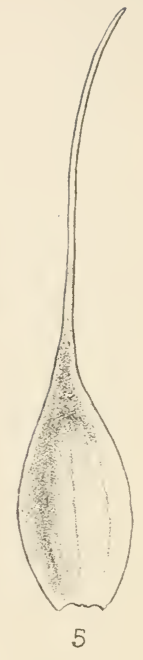

8

9
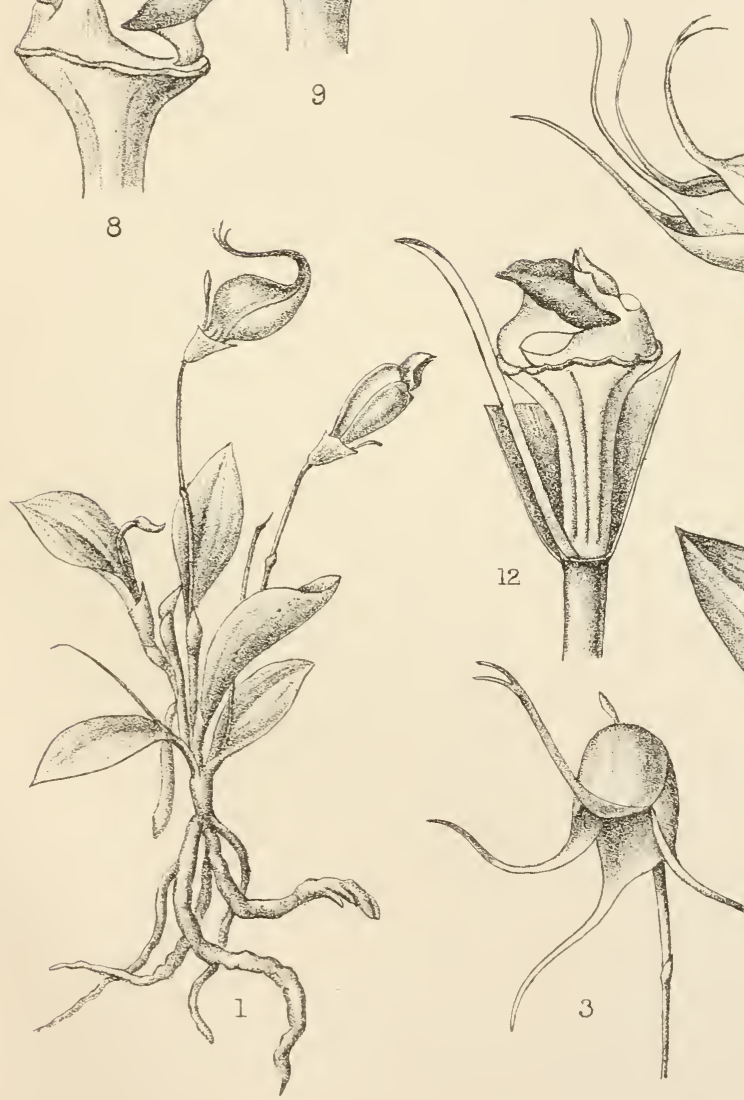

5
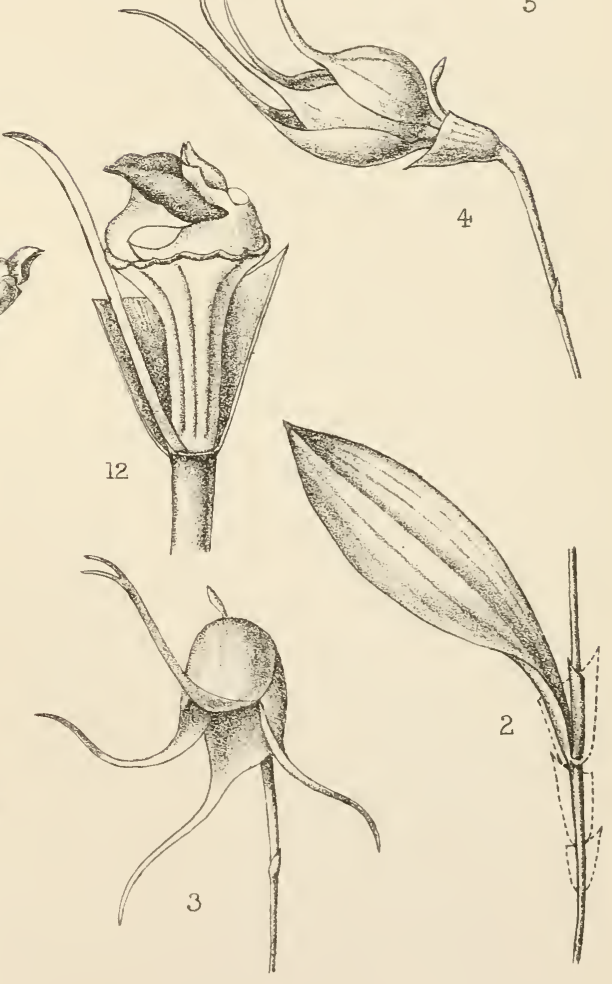

H A WOOD DEL 




\section{EXPLANATION OF PLATE 13}

\section{Coelia triptera}

1. Plant, half natural size.

2. Flower with dorsal sepal held down $\times 2$.

3. Flower with sepals and petals removed $\times 2$.

4. Do. from one side $\times 2$.

5. Column enlarged.

6. Anther enlarged.

7. Pollinia enlarged.

\section{Isochilus linearis}

8. Plant, half nat. size.

9. Flower $\times$ nearly 2 .

10. Flower, with half the sepals and one petal removed, $\times 3$.

11. Lip $\times 3$.

12. Anther enlarged

13. Pollinia enlarged. 


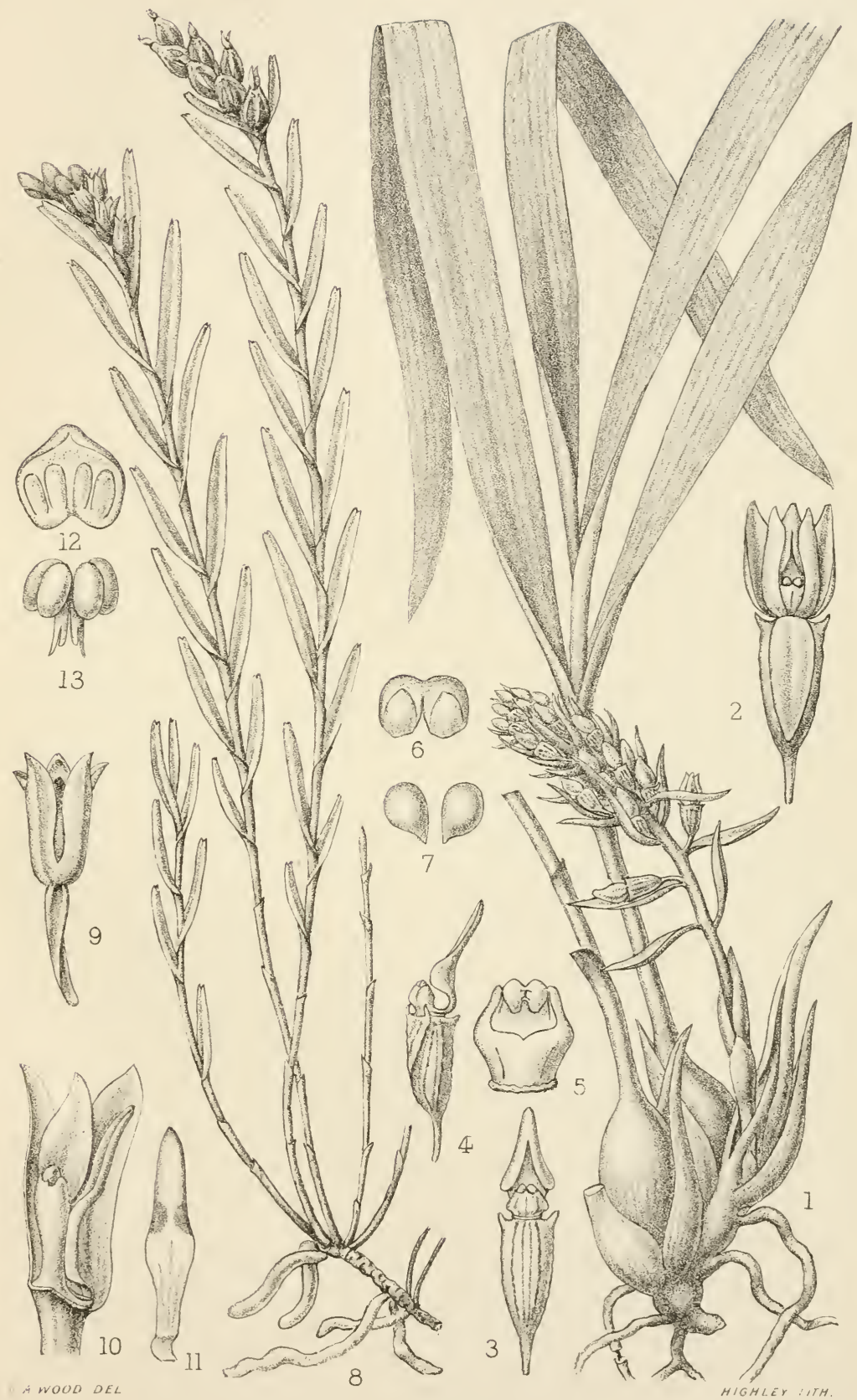

1-7 Cœlia triptera; 8-13 Is ochilus linearis. 




\title{
FIPLANATION OF PIATE 14
}

\author{
Srraphyta riffusa \\ 1. Flower $\times$ about 3 . \\ 2. Anther enlarged. \\ 3. Pollinia enlarged. \\ Arpophyllum giganteum \\ 4. Upper portion of spike, natural size. \\ 5. Flower $\times 2$. \\ 6. Lip and column $\times 2$. \\ 7. Do, with lip depressed. \\ 8. Anther enlarged. \\ 9. Pollinia enlarged.
}

\section{Broughtonia sanguinea}

10. Flower, with one sepal and one half and one petal removed, nat. size.

11. Lip slightly enlarged.

12. Column $\times$ about 2 .

13. Anther enlarged.

14. Pollinia enlarged.

\section{Broughtonia domingensis}

15. Upper portion of spike, nat. size.

16. Lip, nat. size.

17. Column $\times$ about 2 .

18. Anther enlargerl.

19. Pollinia enlarged. 


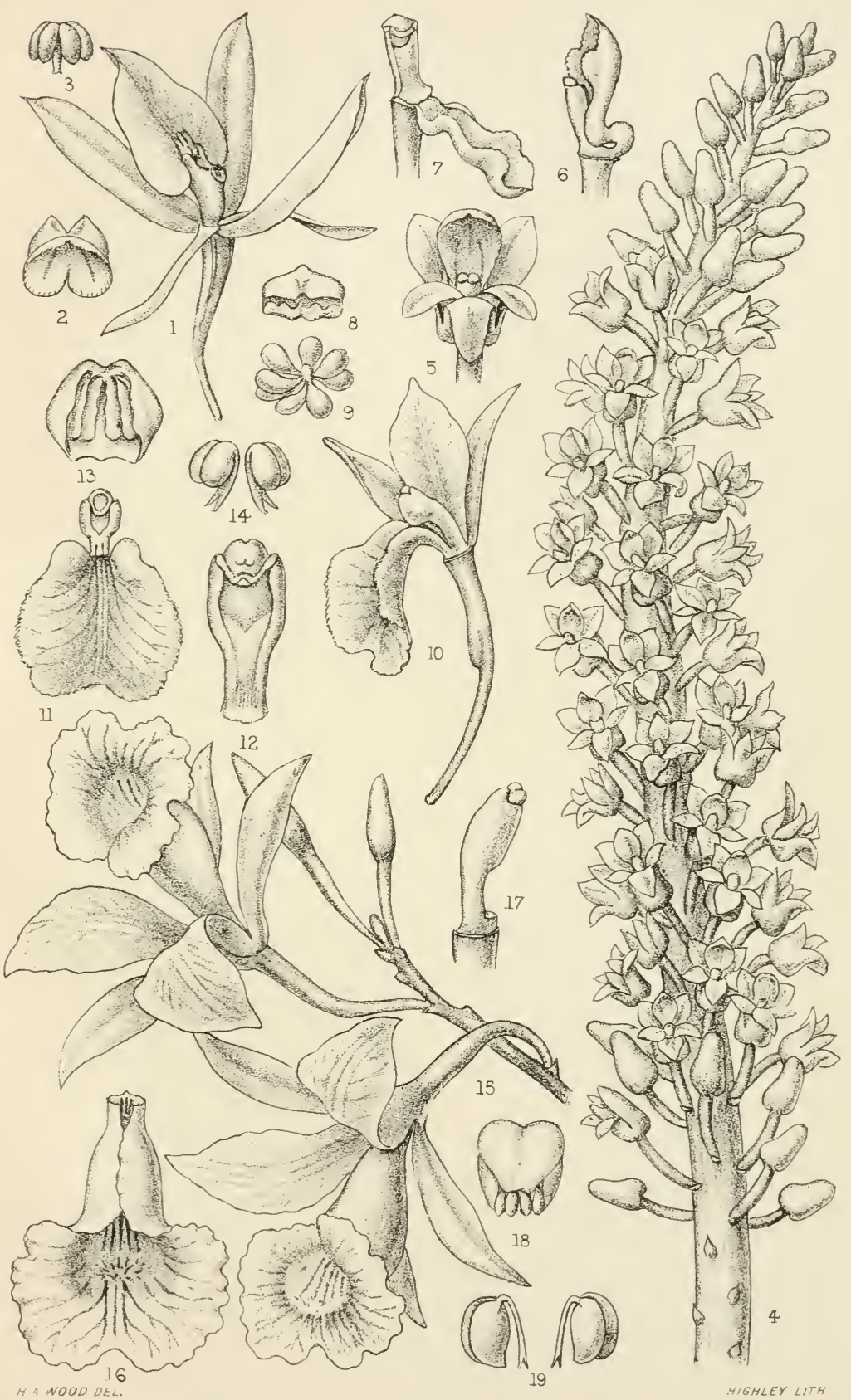

13 Seraphyta diffusa: 4-9 Arpophyllum giganteum; 10-14. Broughtonia sanguinea, 15-19 B domingensis 


FAPLANATION OF PLATE 15

Evidendrum angustilobum

1. Flower, natural size.

Epridendrum nocturmum

$\therefore$ Lip and eolumn, nat. size.

Epidendrum difforme

:. Hlower $\times$ ?.

\section{Epidendrum serrulatum.}

4. Flower with lateral sepal and petal removed $\times$.).

Epidendrum mitans

ร. Flower $\times 1 \frac{1}{2}$.

Epidendrum bifarium

6. Flower $\times 6$.

Epidendrum rivulare

๘. Flower slightly enlarged.

Epidendrum Ottonis

․ Flower $\times 4$.

Epidentrum imbricatum

9. Flower $\times 3$.

Epidendrum anceps

10. Flower slightly enlarged.

Epidendrum verrucosum

11. Flower slightly enlarged.

Epidendrum ramosum

12. Lip and column $\times 4$. 


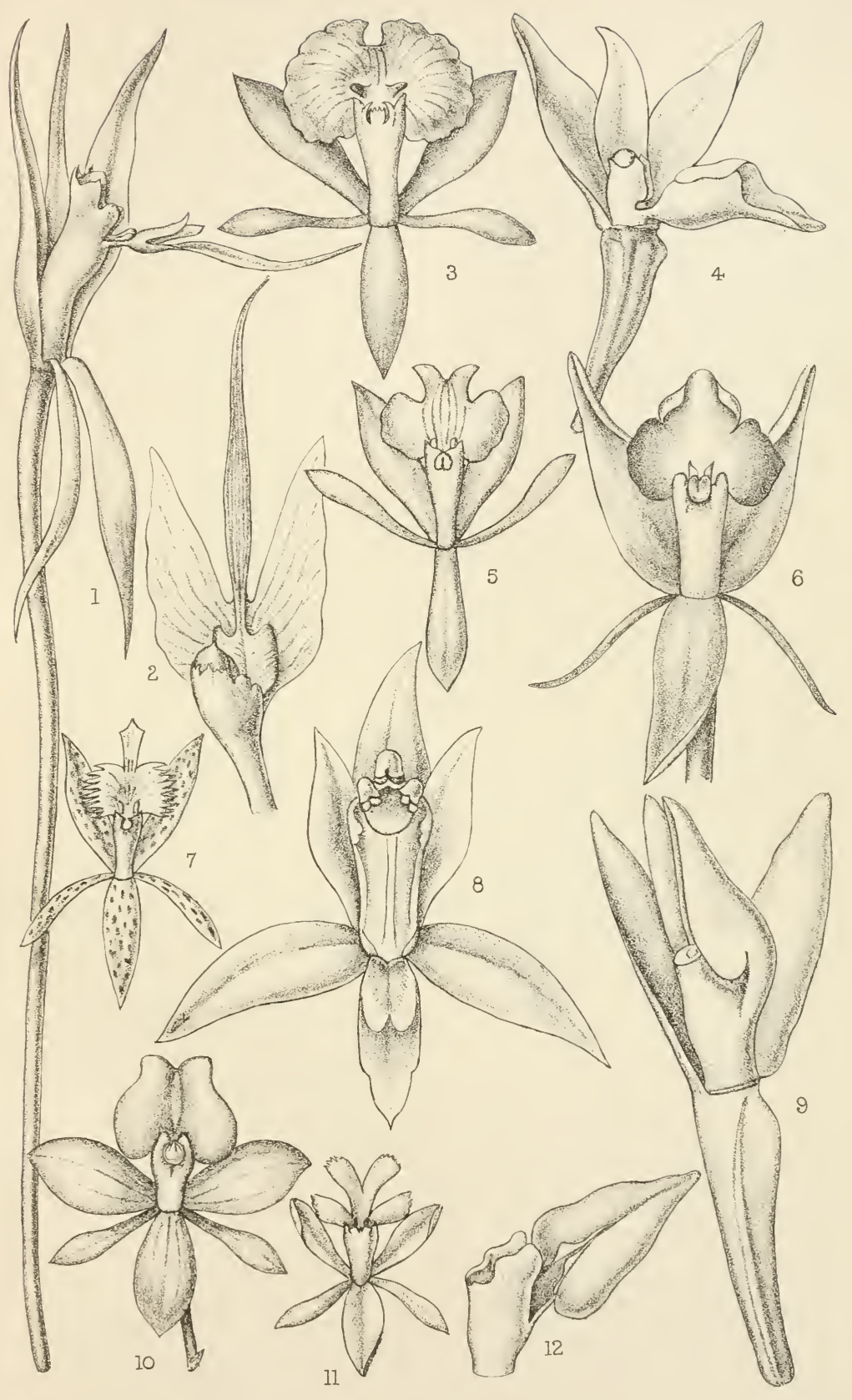




EXPLANATION OF PLATE 16

Epidendrum monticolum

1. Plant, natural size.

2. Flower $\times 1 \frac{1}{2}$.

3. Petal $\times 2 \frac{1}{2}$.

4. $\operatorname{Lip} \times 2 \frac{1}{2}$.

\section{Epidendrum parvilobum}

5. Plant, lower part, with leaf, nat. size.

6. Petal $\times 3$.

7. Lip $\times 3$.

\section{Epidendrum belvederense}

8. Petal $\times 3$.

9. Lip $\times 3$.

10. Capsule, nat. size, 


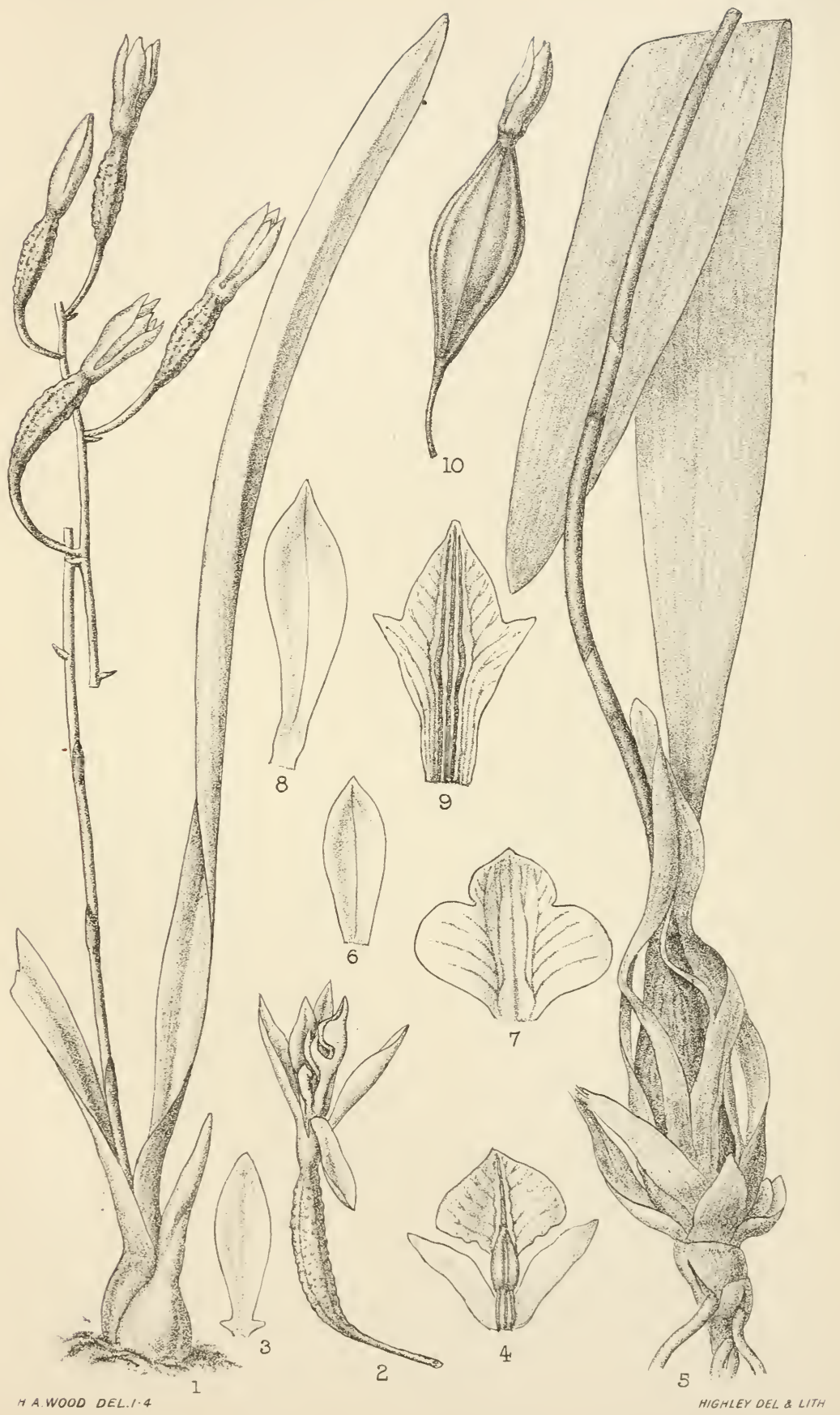

1-4 Epidendrum monticolum: 5-7 E parvilobum; 8-10 E belvederense. 



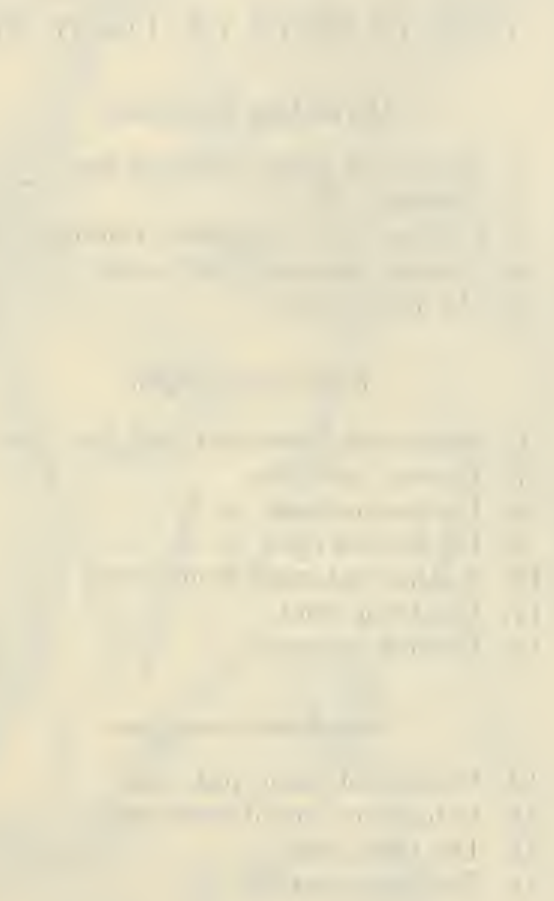




\title{
EXPLANATION OF PLATE 17
}

\author{
Hormidium tripterum
}

1. Portion of plant, natural size.

2. Flower $\times 3$.

3. Column and lip, anther removed $\times$ about 7 .

4. Anther enlarged, side view.

5. Do. front view.

\section{Lælia monoplyylla}

6. Stem with roots and leaf, nat. size.

7. Flower, nat. size.

8. Lip and column $\times 4$.

9. Lip spread open $\times 4$.

10. Anther enlarged from back.

11. Do. from front.

12. Pollinia enlarged.

\section{Octadesmia montana}

13. Portion of stem, nat. size.

14. Column enlarged front view.

15. Do. back view.

16. Pollinia enlarged. 


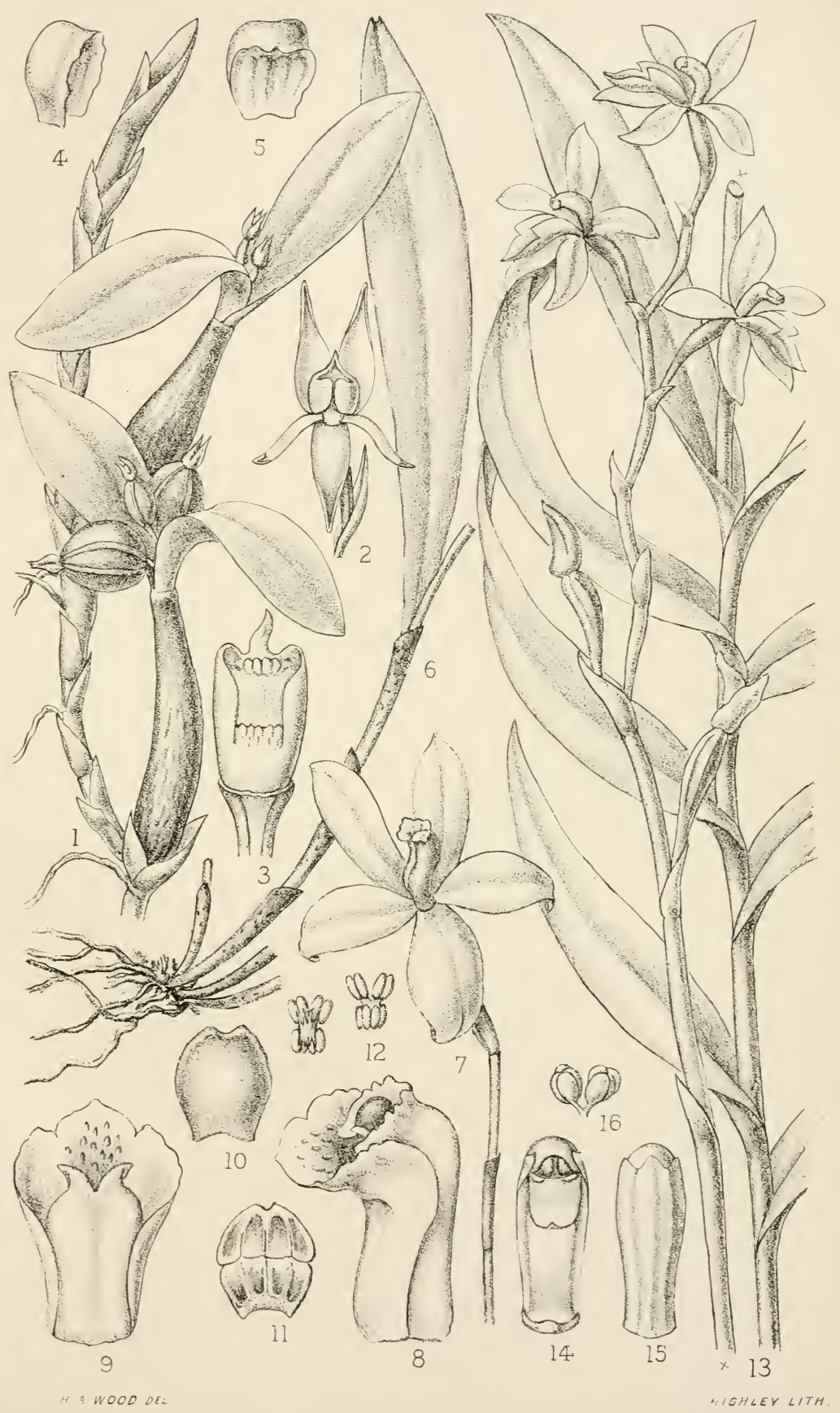




EXPLANATION OF PLATE 18

Homalopetalum vomeriforme (H. jamaicense)

1. Plant, natural size.

2. Column and $\operatorname{lip} \times 3$.

3. Lip flattened $\times 3$.

4. Anther with pollinia, enlarged.

5. Pollinia enlarged.

6. Do. spread out.

Tetramicra parviflora

7. Plant, nat. size.

8. Flower $x$ about 3 .

9. Anther with pollinia, enlarged.

10. Pollinia enlarged, 


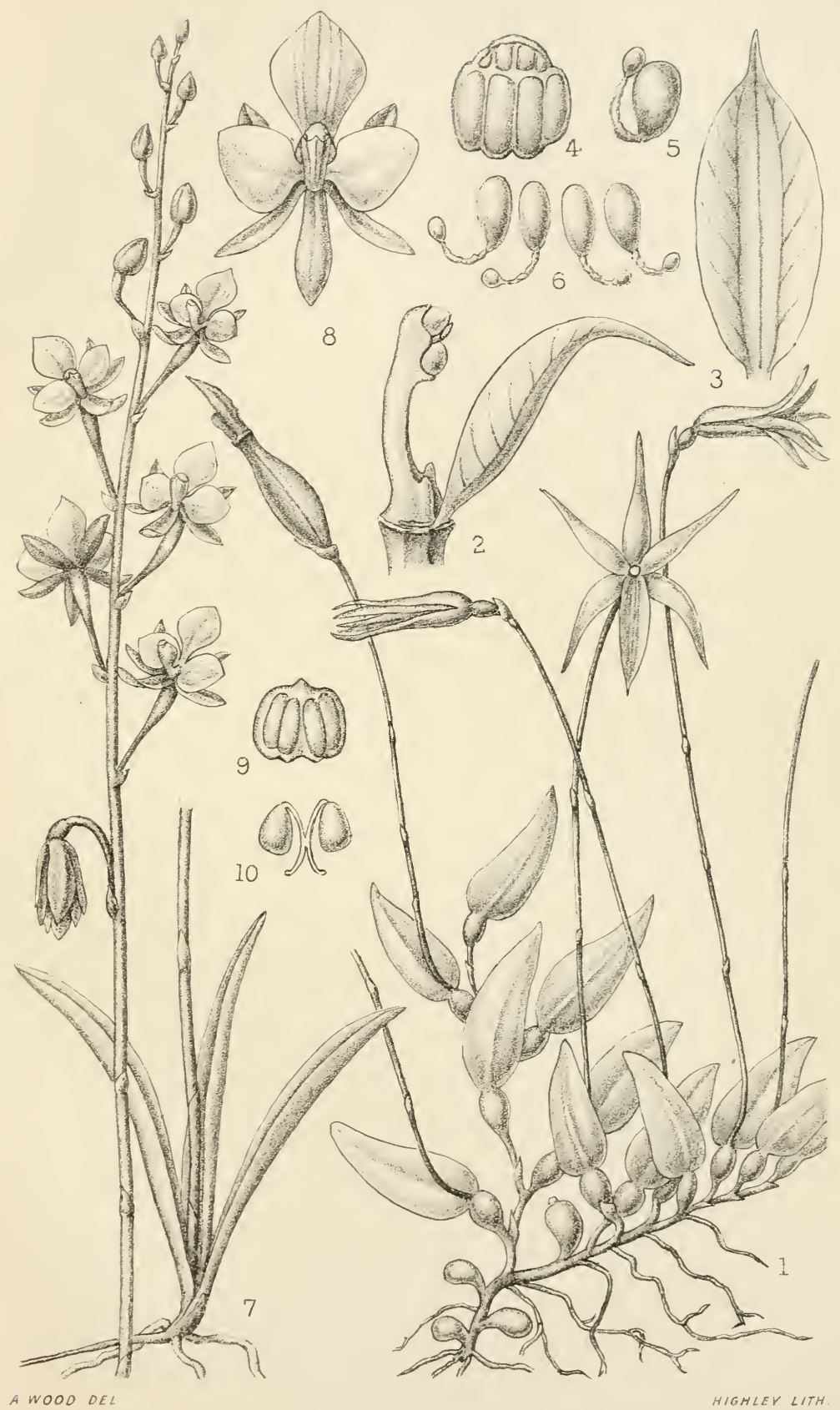

1-6 Homalopetalum jamaicense: 7-10 Tetramicra parviflora. 



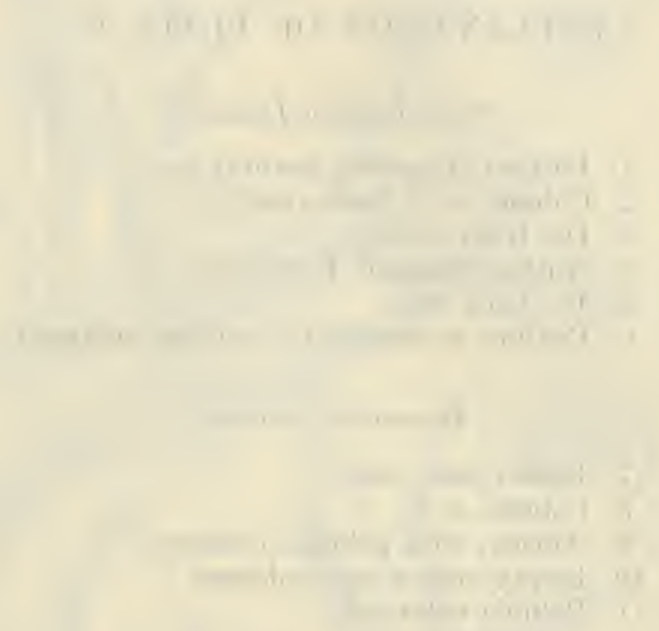




\section{EXPLANATION OF PLATE 19}

\section{Schomburglia Lyonsii}

1. Portion of raceme, natural size.

2. Column $\times 2$, back view.

3. Do. front view.

4. Anther enlarged, front view.

5. Do. back view.

6. Pollinia, as attached to stigma, enlarged.

\section{Brassavola cordata}

¡. Flower, nat. size.

8. Column $\times 3$.

9. Anther, with pollinia, enlarged.

10. Empty anther case enlarged.

11. Pollinia enlarged. 


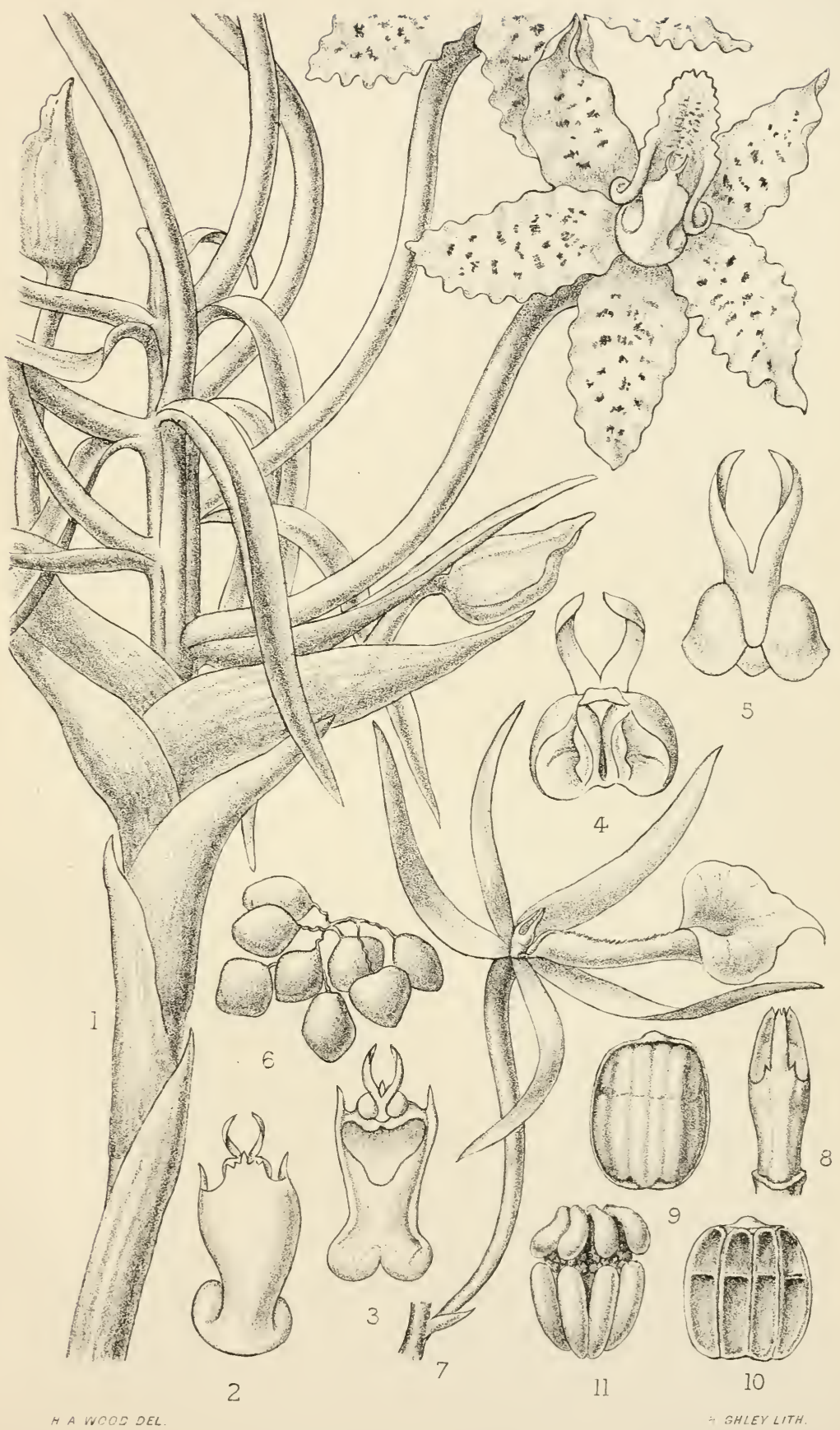

1-6 Schomburgkıa Lyonsii; 7-11 Brassavola cordata. 




\section{EXPTANATION OF PIATE 20}

\section{Elleanthus capitatus}

1. Apex of stem with head of flowers, natural size.

2. Flowers, nat. size, from back.

3. Do. from side.

4. Column $\times$ about 2, partly front view.

5. Do. from side.

6. Anther enlarged.

i. Pollinia enlarged.

\section{Elleanthus longibracteatus}

8. Flower with bract $\times 2$.

9. Column and lip $\times 2$.

10. Do., lip thrown back, $\times 2 \frac{1}{2}$.

11. Lip $\times 2 \frac{1}{2}$.

12. Pollinia enlarged.

Phaius Tancarvilleæ (P. grandifolius)

13. Flower $\times$ about $\frac{1}{2}$.

14. Column slightly enlarged from side.

15. Do. from front.

16. Anther enlarged.

17. Pollinia enlarged.

\section{Calanthe mexicana}

18. Raceme, nat. size.

19. Flower, with one sepal and one half and one petal removed, $\times 21$.

20. Lip flattened $\times 3$.

21. Anther enlarged.

22. Pollinia enlarged. 


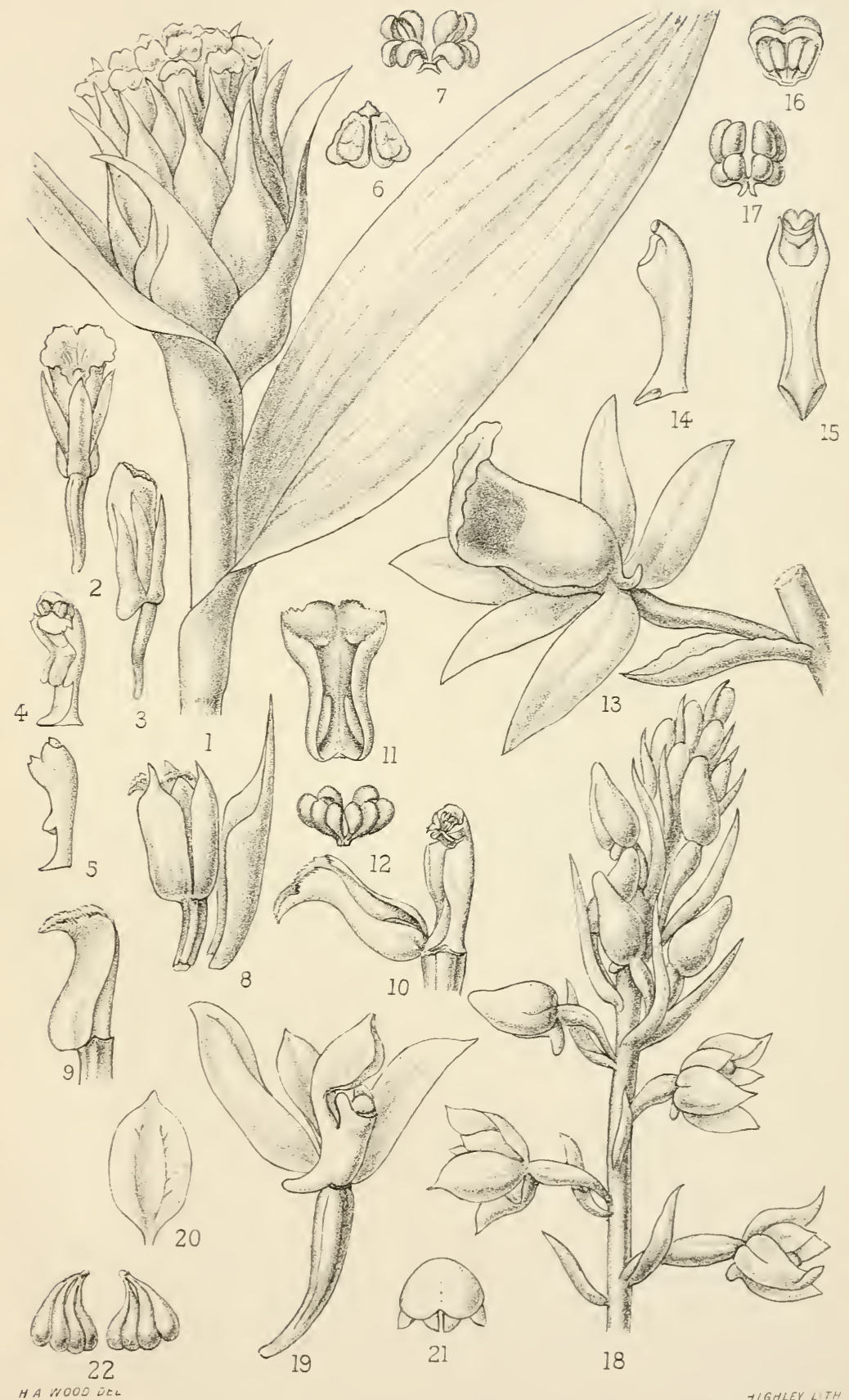

1-7 Elleanthus capitatus; 8-12 E. longibracteatus;

13-17 Phalus grandifolius: 18-22 Calanthe mexicana 



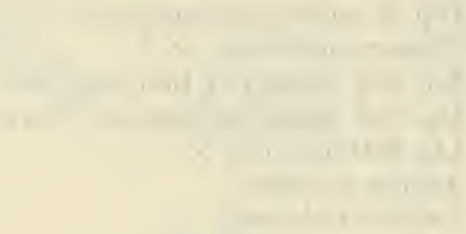

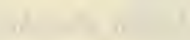

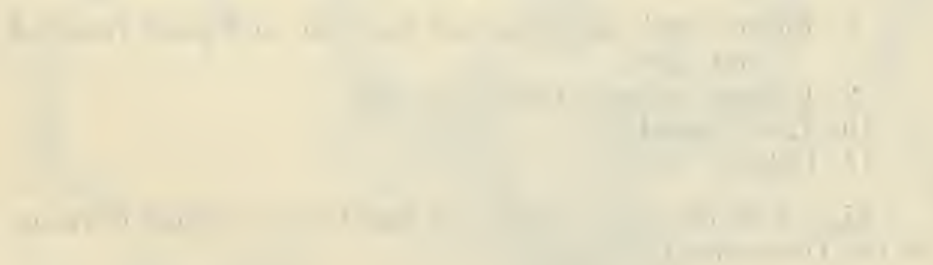




\section{EXPLANATION OF PLATE 21}

\section{Bletia purpurea (B. alta)}

1. Top of raceme, natural size.

2. Flower spread out $\times 2$.

3. Lip and column of bud, nat. size.

4. Lip and column of opening flower $\times 2$.

5. Lip flattened out $\times 2$.

6. Anther enlarged.

7. Pollinia enlarged.

\section{Bletia florida}

8. Flower, with one sepal and one half and petal removed, nat. size.

9. Lip and column of bud, nat. size.

10. Lip $\times$ nearly 2 .

11. Column $\times 2$.

Figs. 3, 9, 10, 11 are copies of Salisbury's original drawings in the Department of Botany. 


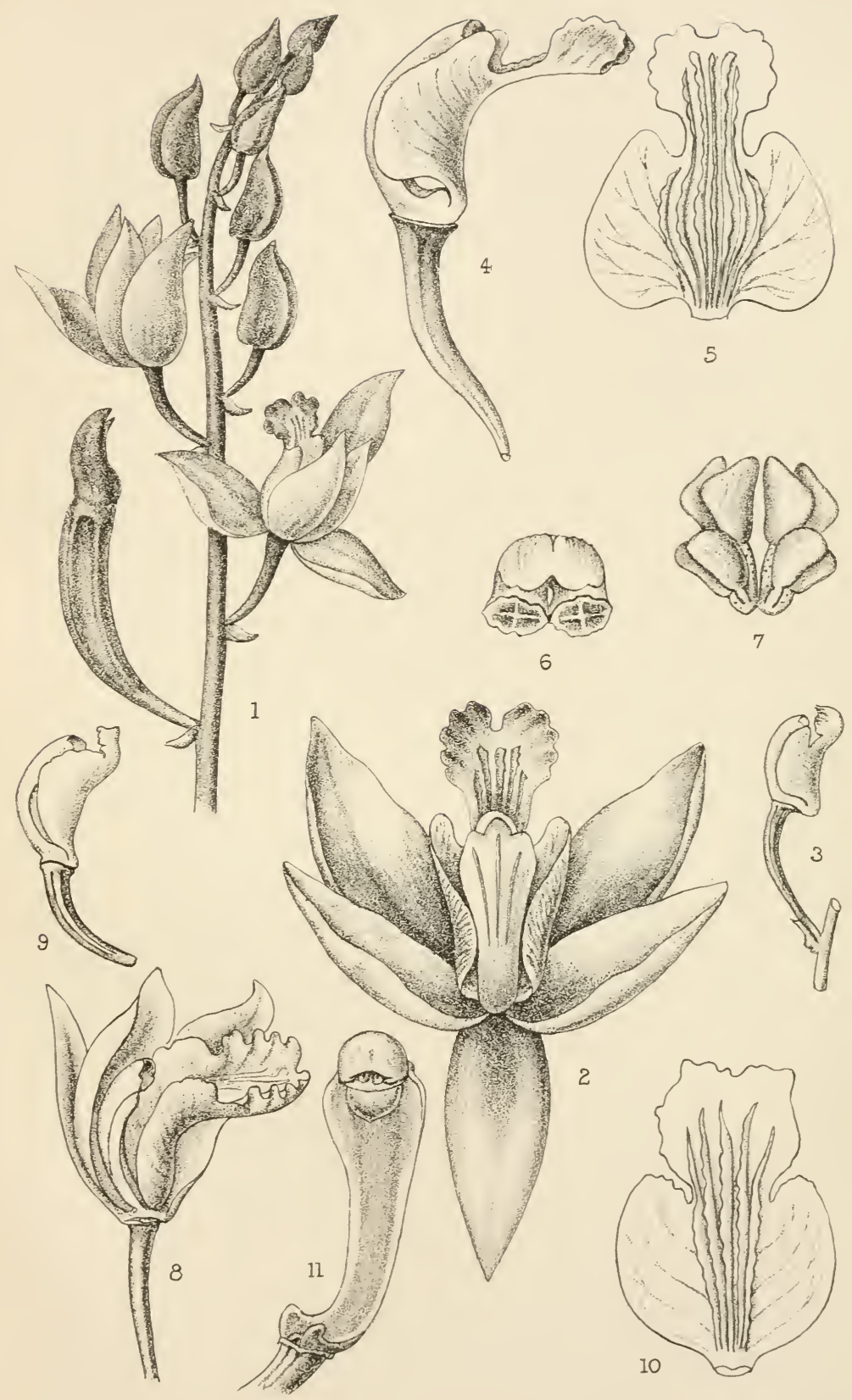





\section{EXPLANATION OF PLATE 22}

\section{Govenia utriculata}

1. Lower portion of stem, about natural size.

2. Upper portion of raceme slightly enlarged.

3. Flower slightly enlarged.

\section{Eulophia alta (by error longifolia)}

4. Raceme, nat. size.

5. Flower with lip removed, nat. size.

6. Lip, nat. size.

7. Anther enlarged.

8. Pollinia enlarged. 


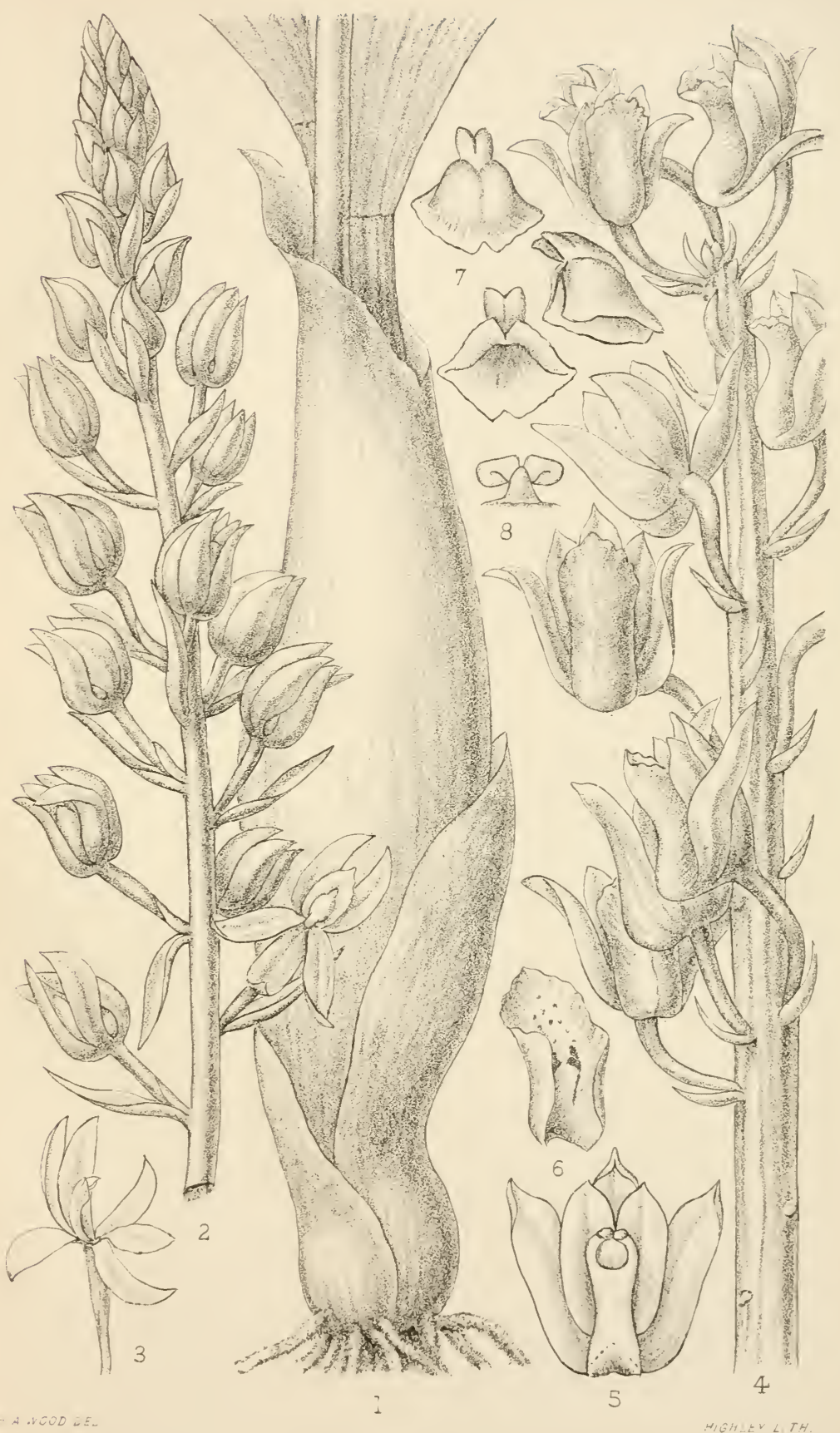

1-3 Govenua utriculata : -8 Eulophia longifolıa 




\section{EXPLANATION OF PLATE 23}

\section{Lycaste Barringtonix}

1. Seapes and pseudobulb, with sepals and petals removed in one flower, half natural size.

2. Anther enlarged.

3. Pollinia enlarged.

\section{Xylobium palmifolium}

4. Scape and pseudobulb, halî nat. size.

5. Flower with perianth removed, except one sepal and one petal, slightly enlarged.

6. Anther enlarged.

7. Pollinia enlarged.

\section{Bulbophyllum jamaicense}

8. Stem and pseudobulb, nat. size.

9. Flower $\times 3$.

10. Flower, sepals and one petal removed $\times 6$.

11. Column and lip $\times 6$.

12. Anther enlarged, from front.

13. Do. from back.

14. Pollinia enlarged.

\section{Bulbophyllum pachyrrhachis}

15. Upper portion of stem, nat. size. 16. Flower, sepals removed, $\times 7$.

\section{Zygopetalum flabelliforme (Z. cochleare)}

17. Lower portion of plant, nat. size.

18. Anther enlarged.

19. Pollinia enlarged. 


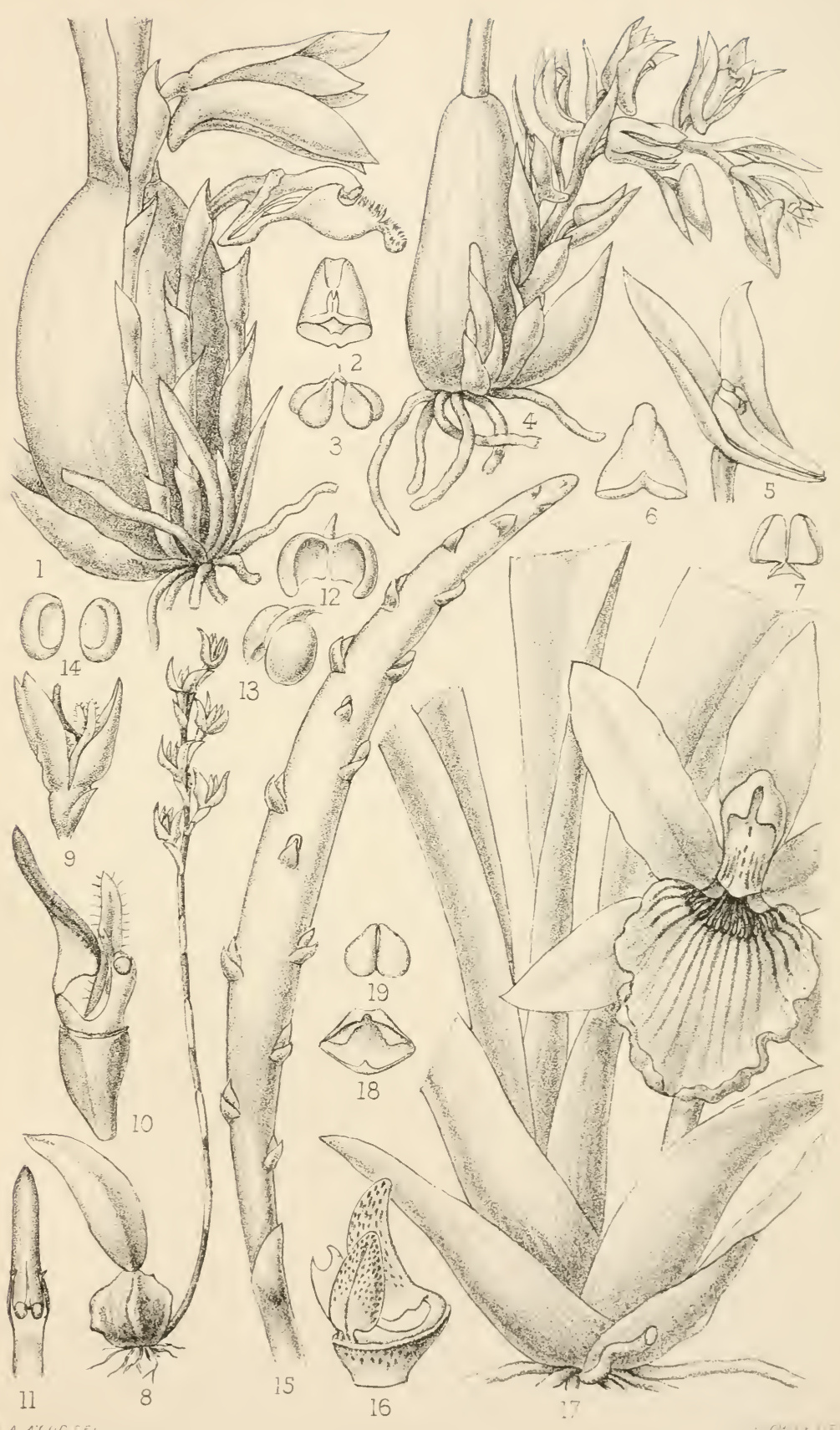

1-3 Lycaste Barringtonize: 4-7 Xyiobium palmifoilum. 8-14 Bulbophyllum jama cense; 15,16 B pachyrrhachs, 



\section{EXPLANATION OF PLATE 24}

Neo-urbania adendrobium

1. Plant, half natural size, lower part.

2. Do. upper part.

3 . Flower and peduncle with bracts $\times 3$.

4. Flower, half the sepals and one petal removed $\times 7$.

5. Lip from side $\times 7$.

6. Lip $\times 7$.

7. Column $\times$ about 8 .

8. Anther enlarged, from above.

9. Do. from below.

10. Pollinia enlarged. 


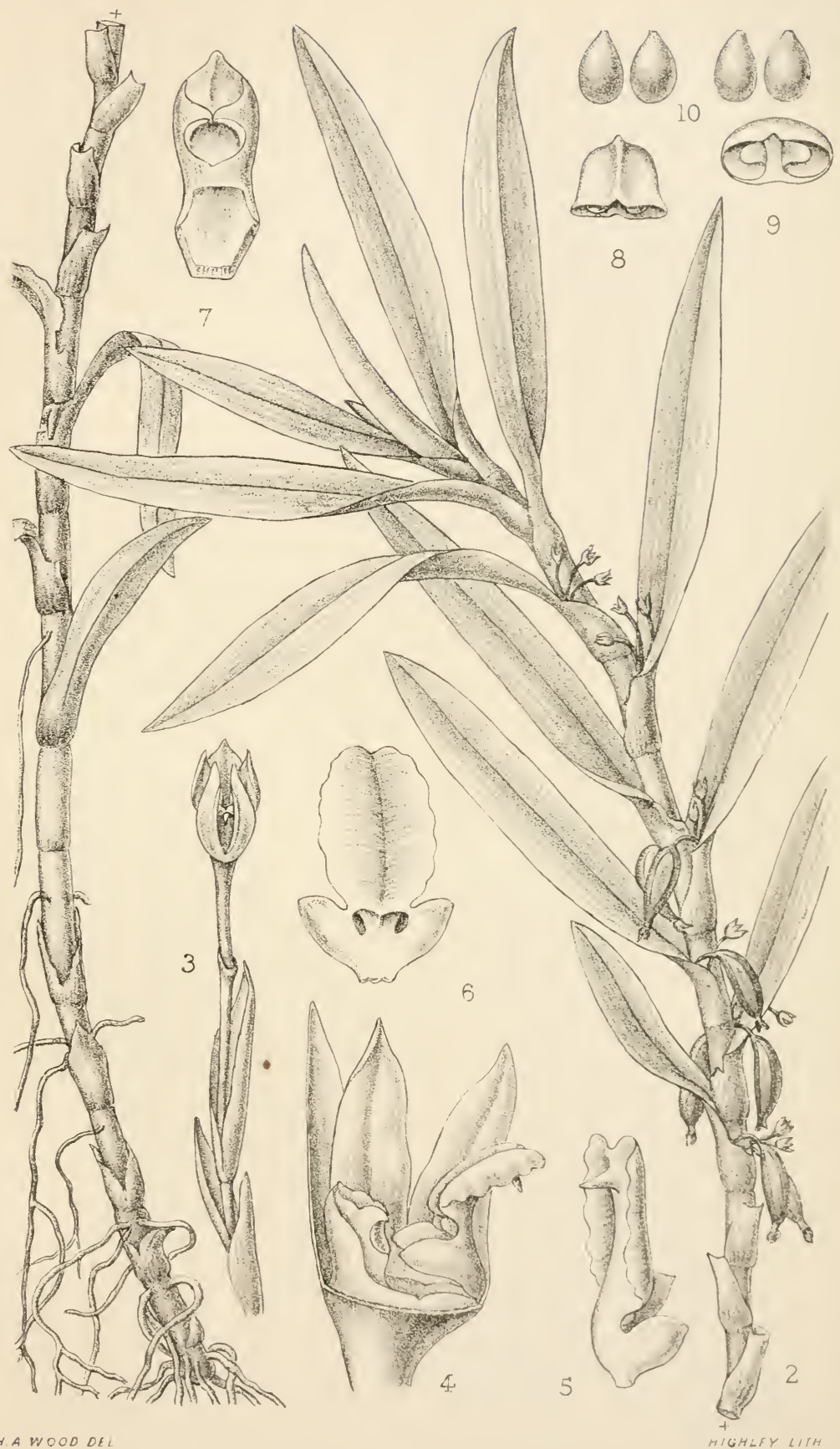

Neo-urbania adendrobium. 




\section{Maxillaria alba}

1. Plant, half natural size.

2. Flower, nat. size.

3. Lip and column slightly enlarged.

4. Lip flattened slightly enlarged.

5. Anther enlarged.।

6. Pollinia enlarged.

\section{Maxillaria sessilis}

7. Tip of leaf nat. size.

8. Flower nat. size.

9. Lip flattened nat. size.

10. Column enlarged.

11. Anther enlarged.

12. Pollinia enlarged.

\section{Maxillaria rufescens}

13. Plant, half nat. size.

14. Lip flattened $\times 1 \frac{1}{2}$.

15. Anther enlarged.

16. Pollinia enlarged.

Maxillaria rufescens var minor.

17. Flower, nat. size.

18. Lip flattened slightly enlarged.

19. Column, nat. size. 


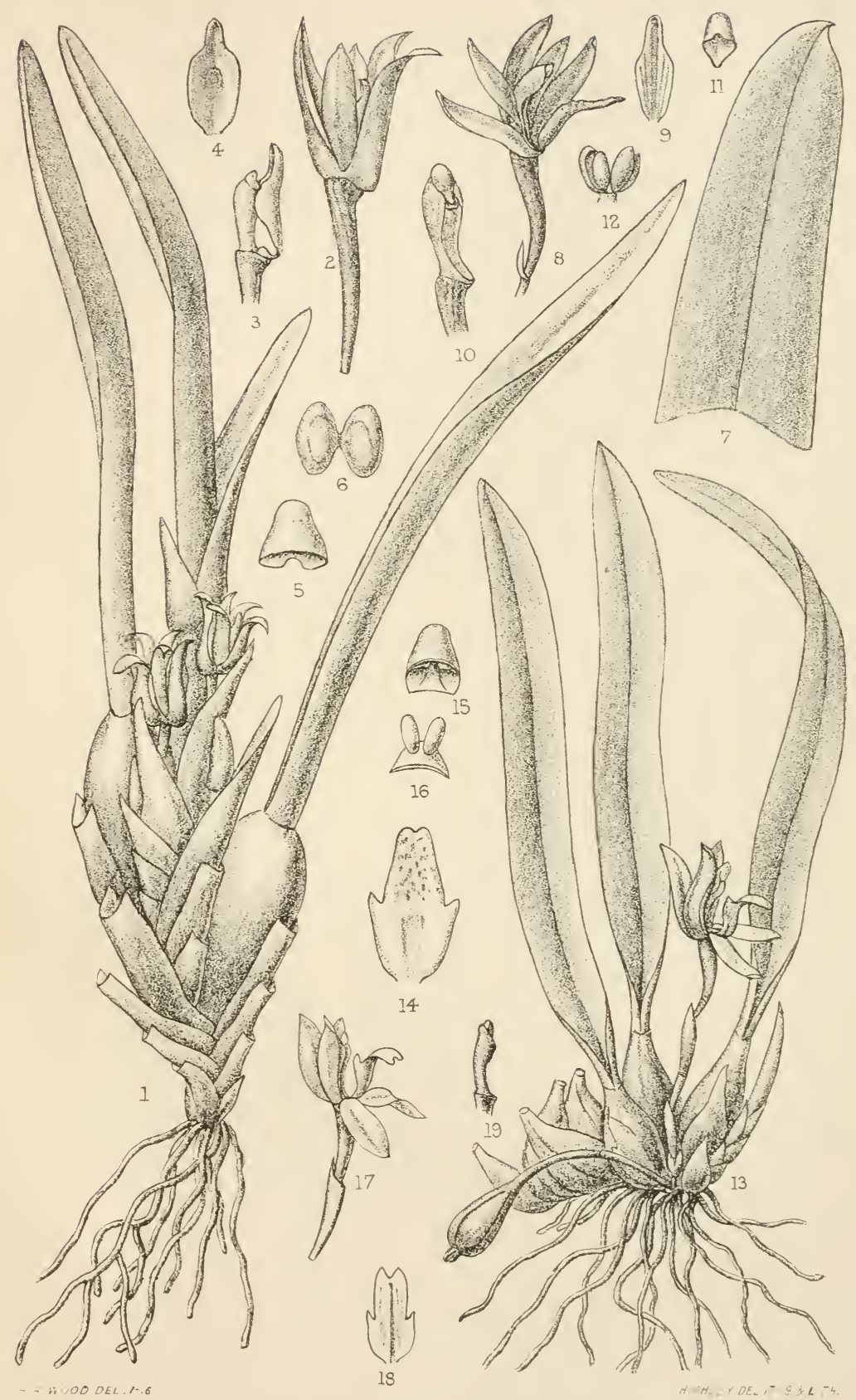

1-6 Maxillaria alba; 7-12 M sessilis: 13-16 M rufescers: 



\section{EXPLANATION OF PLATE 26}

\section{Ornithidium vestitum}

1. Portion of plant, natural size.

2. Flower, with one sepal and one half and one petal removed $\times 5$.

3. Anther enlarged.

4. Pollinia enlarged.

\section{Ornithidium proliferum}

5. Portion of plant, nat. size.

6. Flower $x$ about 2.

7. Lip flattener $\times$ about 2 . 


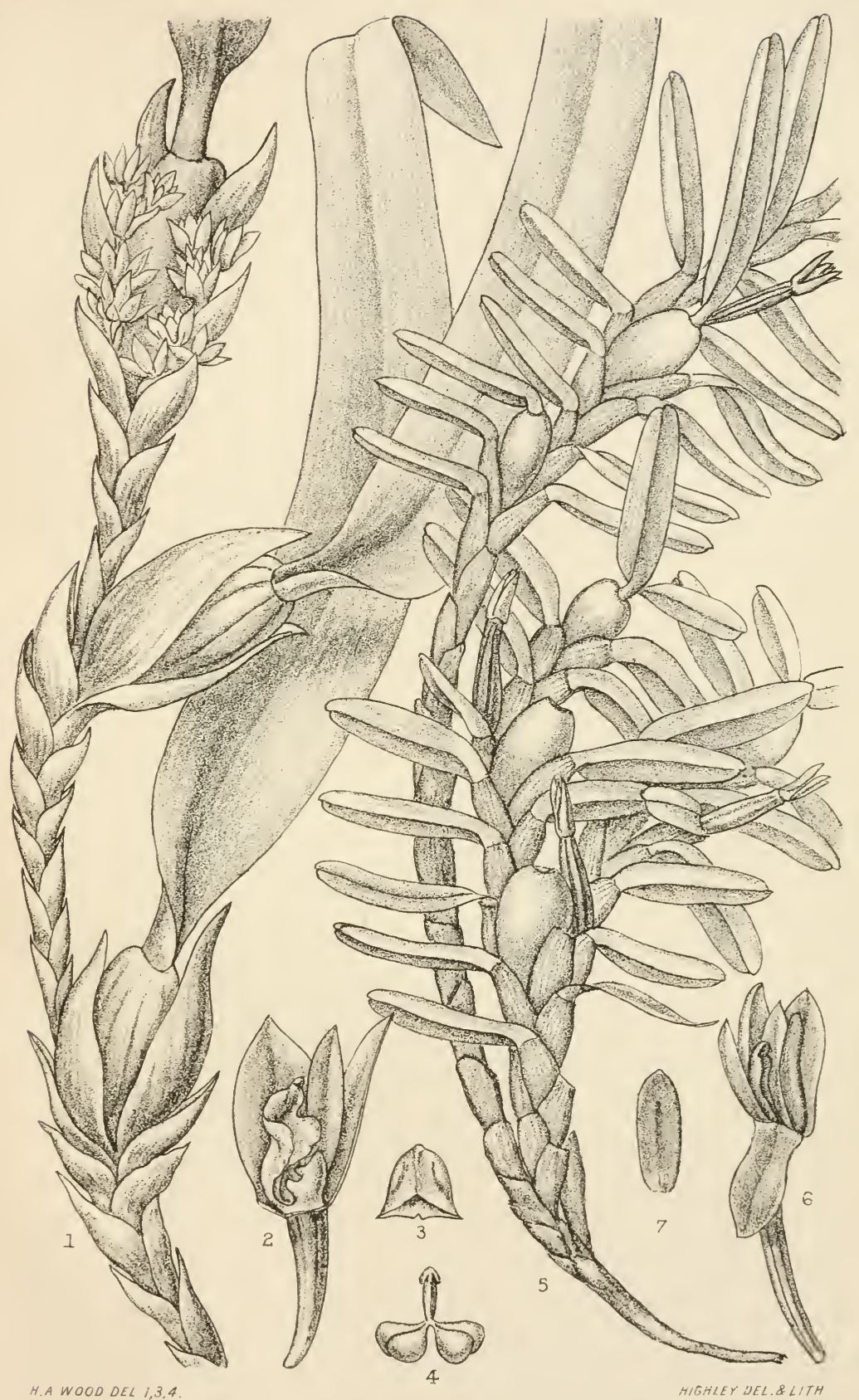

1-4 Ornithidium vestitum; 5-7 0 prollferum 

$+2+2$

$1+100$

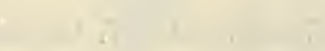

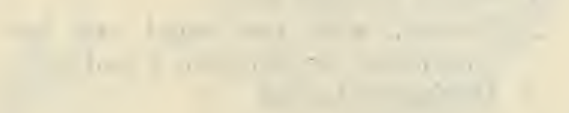

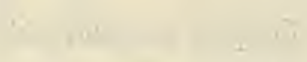

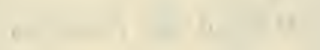




\section{EXPLANATION OF PLATE 27}

Ionopsis satyrioides (I. testiculata)

1. Plant, natural size.

2. Flower, with one sepal and one half and one petal removed, $x$ between 3 and 4 .

3. Pollinia enlarged.

\section{Ionopsis utricularioides}

4. Portion of panicle, nat. size.

5. Flower, with half perianth removed, slightly enlarged.

6. Pollinia enlarged.

\section{Macradenia lutescens}

7. Plant, nat. size.

8. Flower, with sepals and petals removerl, $\times$ about 2 .

9. Pollinia enlarged, from side.

10. Do, from back. 


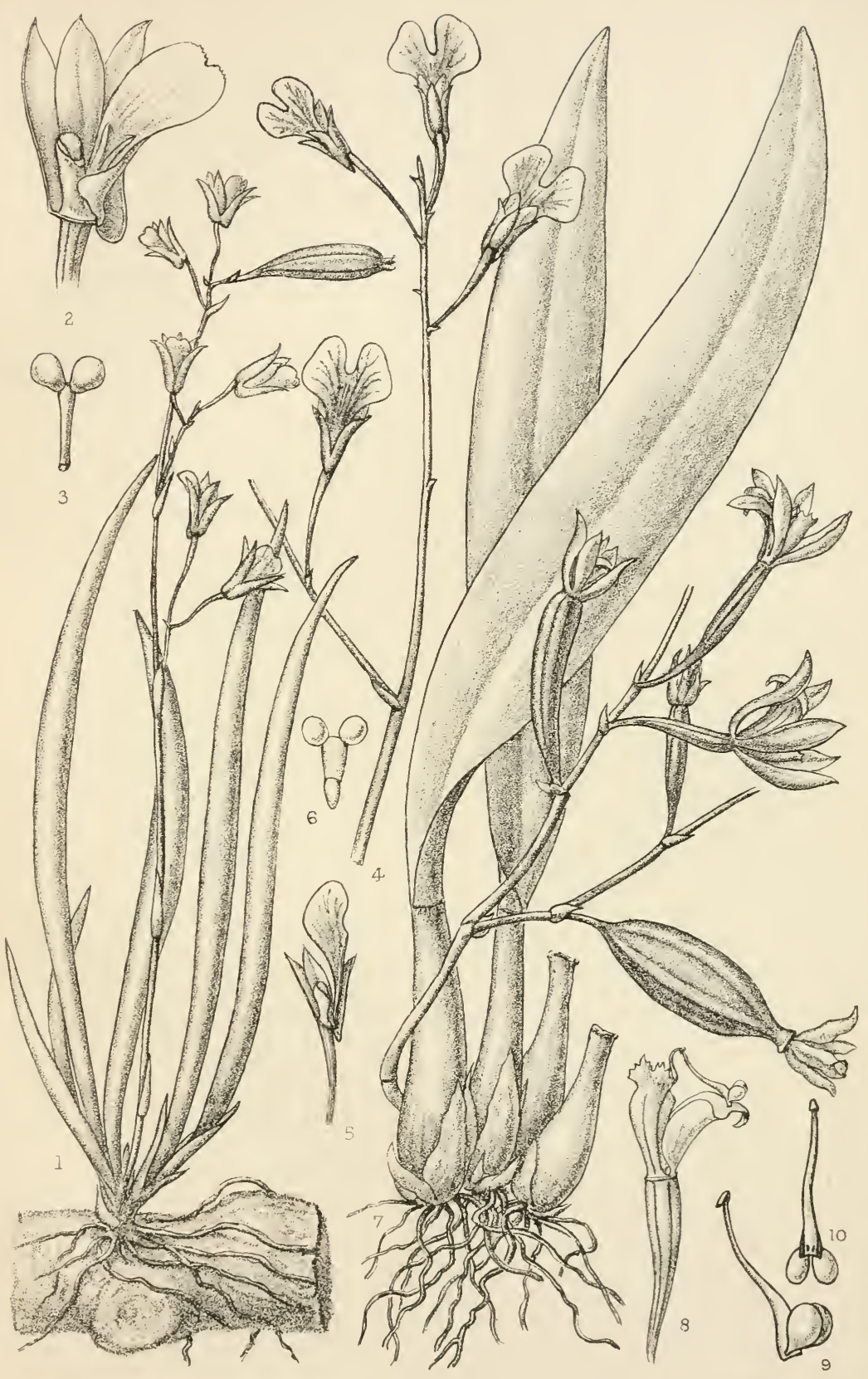

1030 . 0.4

1-3 Ionopsis testiculata; 4 I utricularıoıdes: 710 Macradema 




\section{BXPLANATION OF PIATE 2S}

\section{Brassin maculata}

1. Portion of plant, half natural size.

2. Portion of raceme, half nat. size.

3. Column $\times 4$, from side.

4. Do. from front.

5. Anther enlarged.

6. Pollinia enlargerl.

\section{Brassia caudata}

7. Flower, with one sepal and one petal removed, nat. size.

8. Anther enlarged.

9. Pollinia enlarged.

\section{Comparettia falcata}

10. Plant, half nat. size.

11. Flower, with sepals and one petal removed, slightly enlarged.

12. Sepals and ovary, slightly enlarged.

13. Column $\times 3$.

14. Anther enlarged.

15. Pollinia enlarged. 


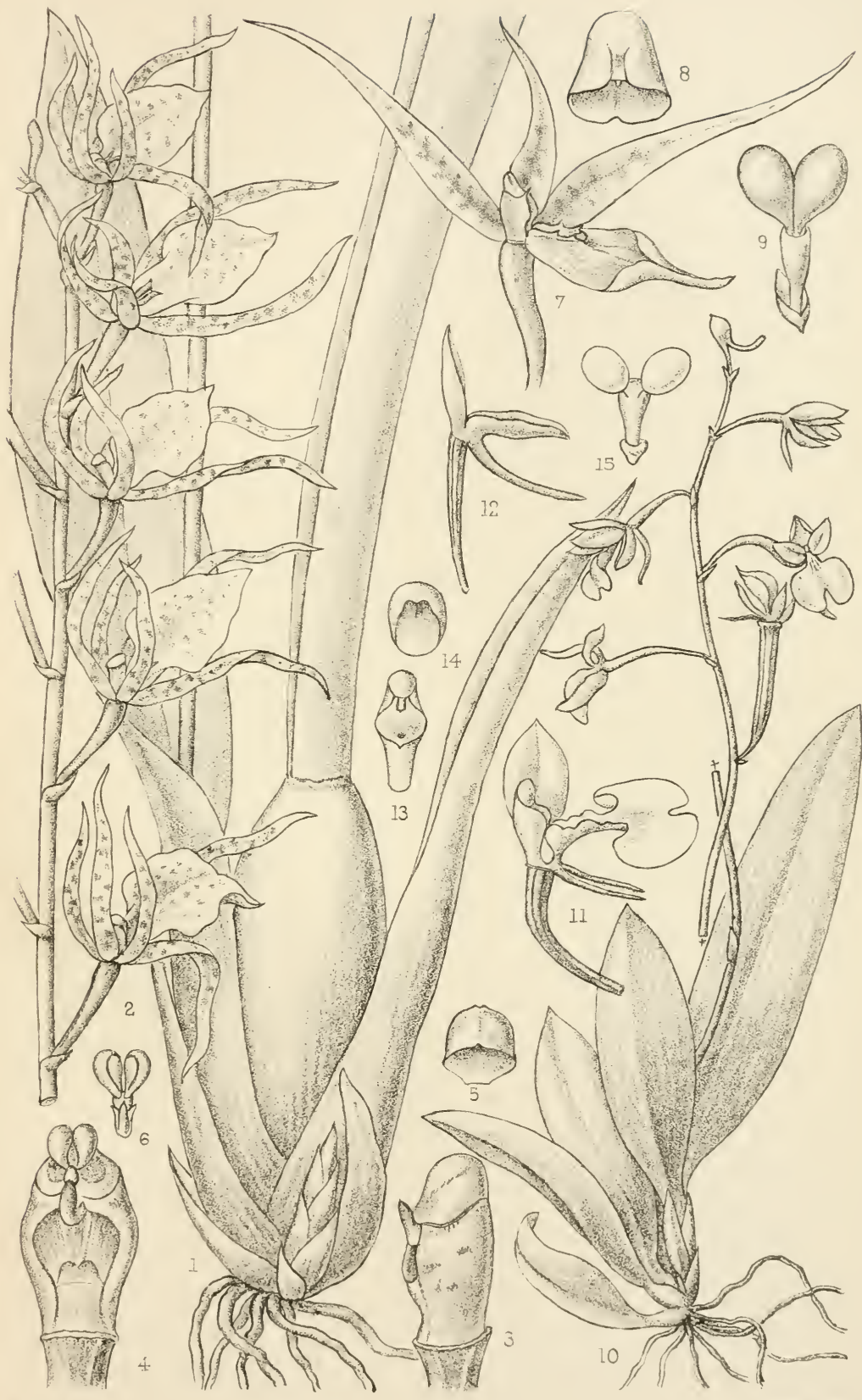

1-6 Brassia maculata, 7-9 B.caudata.10-15 Comparettı falcata 


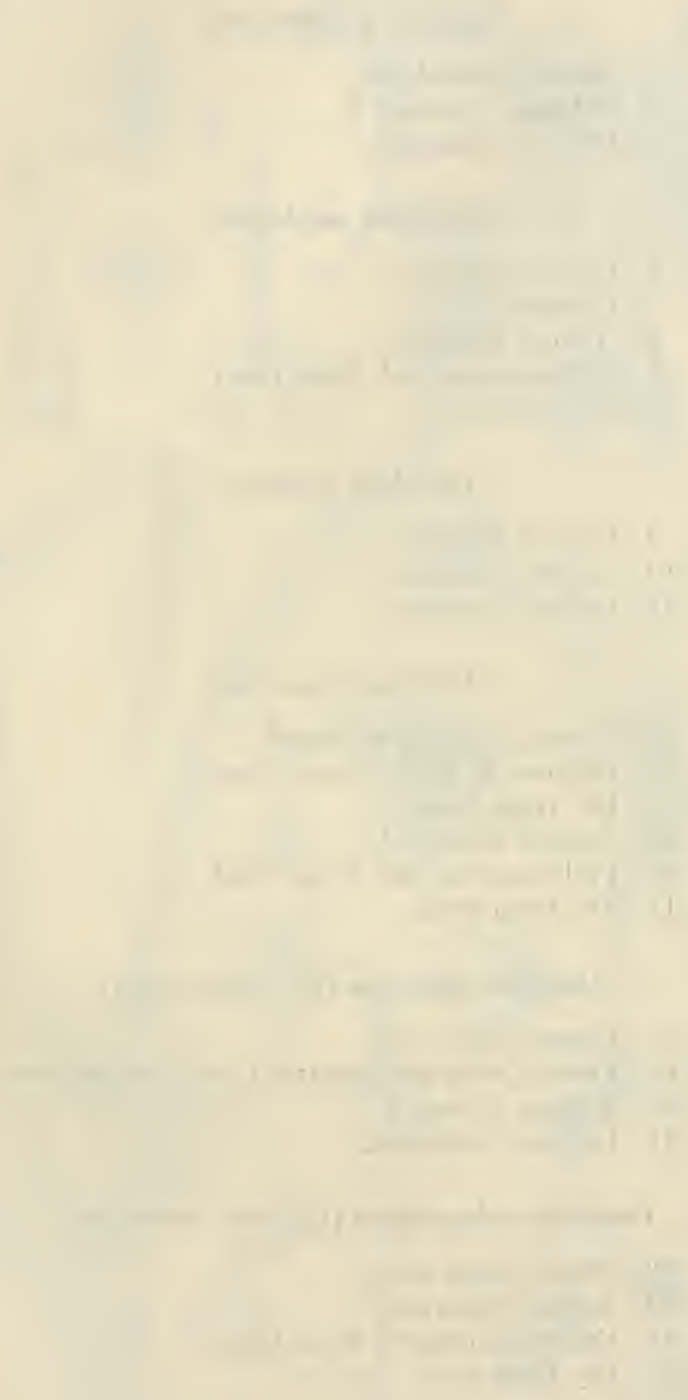


\section{Trichopilia jamaicensis}

1. Plant, natural size.

2. Column $\times$ about 3 .

3. Pollinia enlarged.

\section{Oncidium pulchellum}

4. Flower, nat. size.

5. Column $\times 6$.

6. Anther enlarged.

. Pollinia enlarged, from front.

\&. Do. from side.

\section{Oncidium luridum}

9. Flower, nat. size.

10. Anther enlarged.

11. Pollinia enlarged.

\section{Oncidium triquetrum}

12. Flower, slightly enlarged.

13. Column $\times 4$ or 5 , from front.

14. Do. from back.

15. Anther enlarged.

16. Pollinia enlarged, from front.

17. Do. from back.

\section{Oncidium guttatum (O. tetray, stalum)}

18. Flower, nat. size.

19. Flower, with one sepal and one petal removed, $\times 2 \frac{1}{2}$.

20. Anther enlarged.

21. Pollinia enlarged.

Oncidium sphacelatum (by error altissimum)

22. Flower, nat. size.

23. Anther enlarged.

24. Pollinia enlarged, from front.

25. Do. from side. 


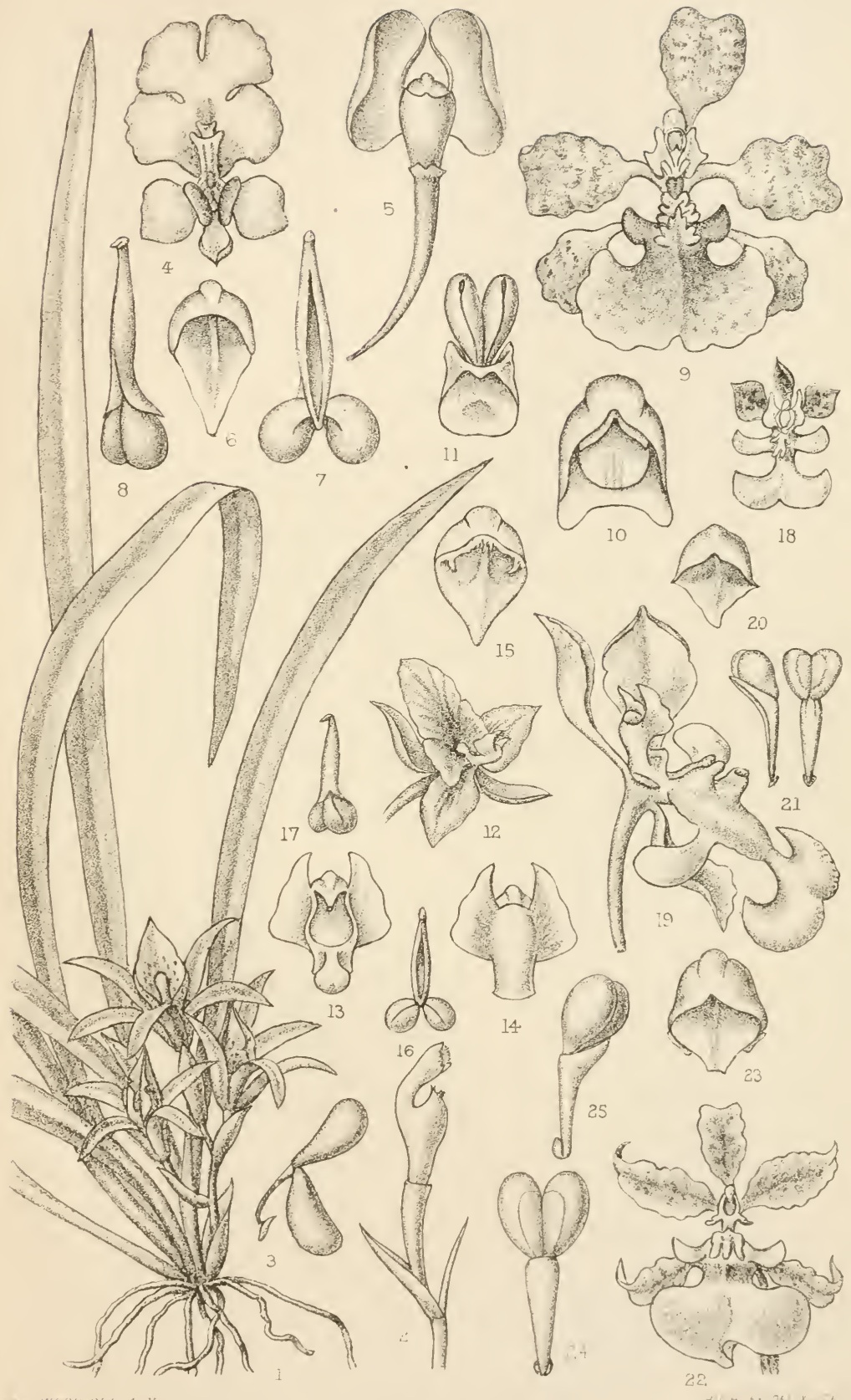

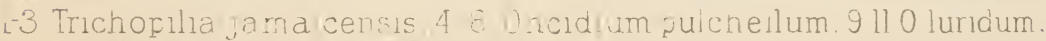

$12-170$ inquetrum, $18-2 ! 0$ terapetalum $22-250$ altissimum 


EXPLANATION OF PLATE 30

\section{Leochilus Tabiatus (L. cochlearis)}

1. Plant, natural size.

¿. Flower, with one sepal and one half and one petal removed $x$ about 4 .

3. Lateral sepals $\times$ about 4 .

4. Column $\times$ about 9 .

5. Pollinia enlarged.

\section{Cryptarrhena lunata}

6. Flower $x$ about 4 .

7. Jip $\times$ about 4 .

Dichæa graminoides

8. Plant, half nat. size.

9. Lateral sepal $\times 3$.

10. Median sepal $\times 3$.

11. Petal $\times 3$.

. 12. Lip $\times 3$.

\section{Dichæa glan'a}

13. Lateral sepal $\times 3$.

14. Median sepal $\times$ :3.

15. Petal $\times 3$.

16. Lip $\times 3$.

\section{Dichæe trichocarpa}

17. Lateral sepal $\times 3$.

18. Median sepal $\times$ :3.

19. Petal $\times 3$.

20. Lip $\times 3$.

21. Hairs from capsule $\times 3$.

Dichæa muricata

22. Sepal $\times 3$.

23. Petal $\times 3$.

24. Lip $\times 3$.

25. Hairs from capsule $\times 3$.

\section{Dichra echinocarpa}

26. Lateral sepal $\times$ ?.

27. Median sepal $\times 3$.

28. Petal $\times 3$.

29. Lip $\times 3$.

30. Hairs from capsule $\times$ :?.

\section{Dichæa Morrisii}

31. Lateral sepal, nat. size. 32. Median sepal, nat. size.

33. Petal, nat. size.

34. Lip and column $\times 3$.

35. Lip $\times 3$.

36. Hairs from capsule $\times 3$. 


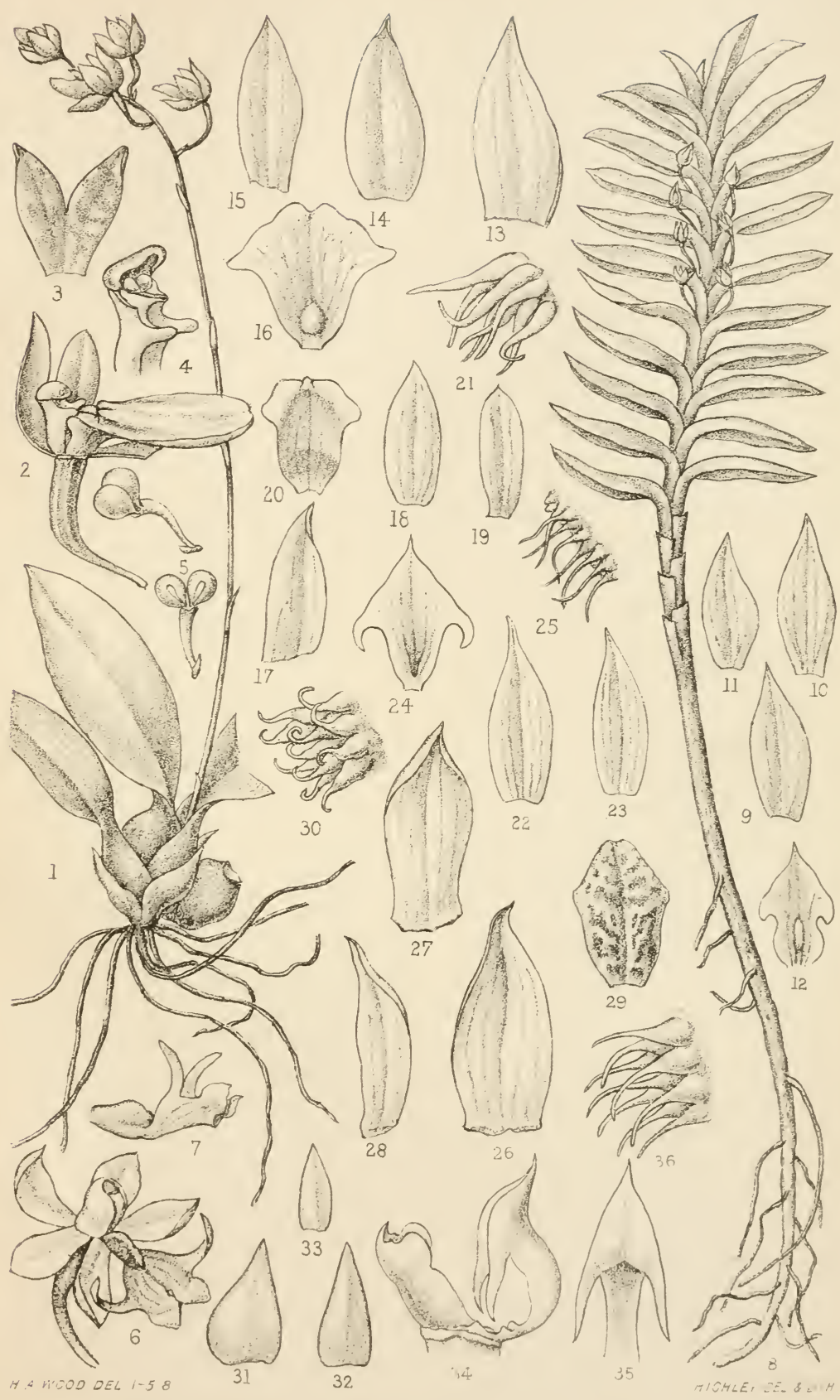

1-5 Leochilus cochlearis, 6.7 Cryptarrhena lunata; 8-12 Dichra

graminoldes: 13-16 D. glauca, 17-2] D irichccarpa: 22-25 D. muricata, 26-30 D echinocarpa;31-35 D Morrisii. 




\section{EXPLANATION OF PLATE : 11}

\section{Campylocentrum Sullivanii}

1. Plant, natural size.

2. Flower $\times 11$ times.

3. Flower, with sepal and petal removerl, $\times 11$ times.

4. Lip $\times 11$ times.

\section{Campylocentrum mims}

5. Leaf and spike, nat. size.

6. Flower $\times 10$.

7. Flower, lateral sepals removed, and lip held down, $\times 10$.

8. $\operatorname{Lip} \times 10$.

\section{Campylocentrum Barrettice}

9. Plant, nat. size.

10. Flower $\times 5$.

11. Lip, spur, column and ovary $\times 8$.

12. Lip $\times 8$.

13. Anther, enlarged, from side.

14. Do. from front.

15. Pollinia enlarged.

\section{Harrisella porvecta}

16. Plant, nat. size.

17. Flower $\times 8$.

18. Flower, with sepals and petals removed, $\times 8$.

19. Anther, enlarged, from front.

20. Do. from back.

21. Pollinia enlarged. 

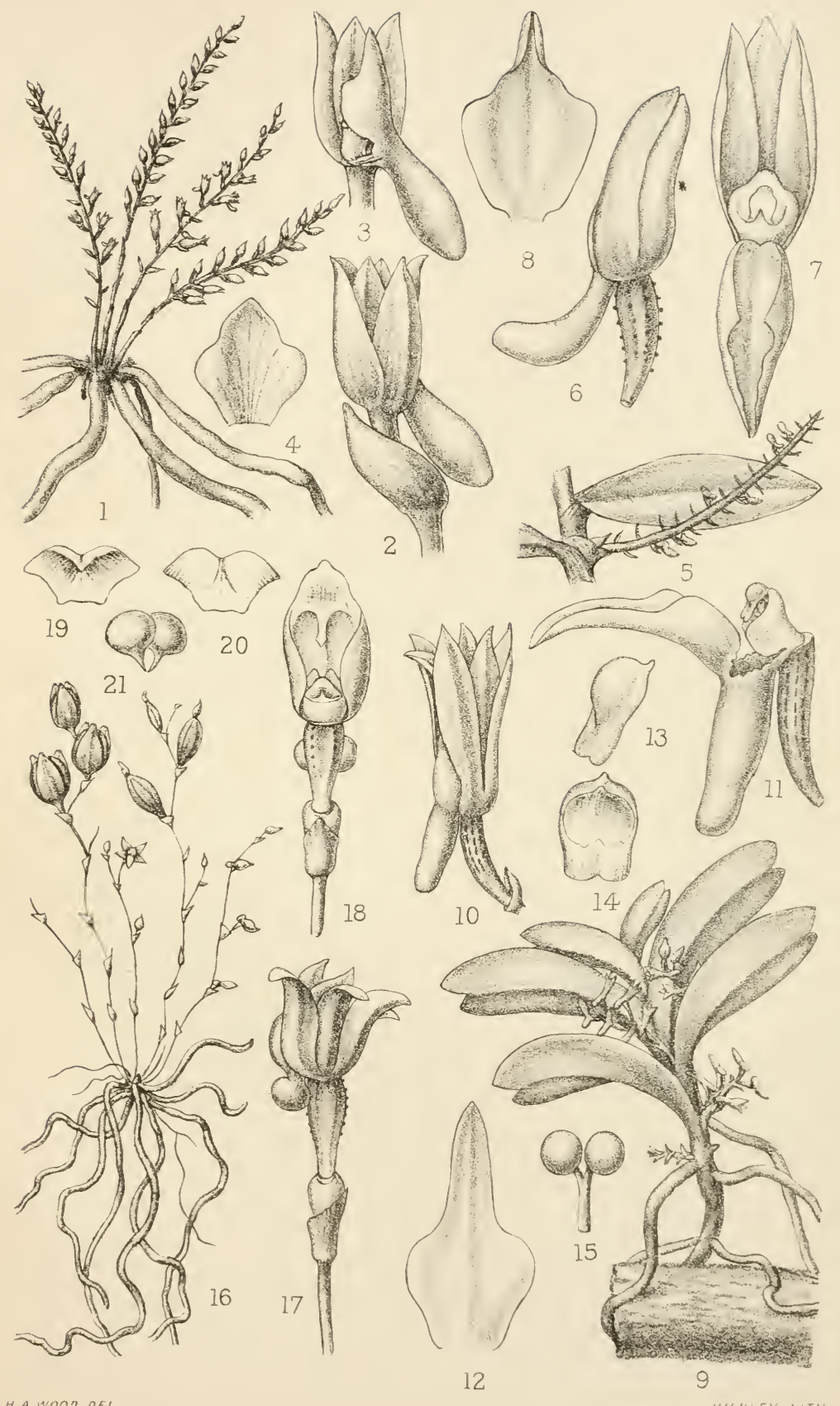

1-4 Campylocentrum Sullivani1; 5-8 C minus: 9-15 C.Barrettıæ; 16-21 Harrisella porrecta. 



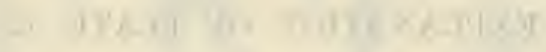

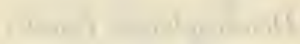

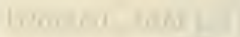

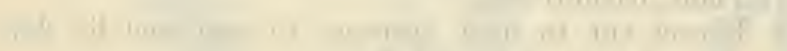

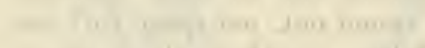

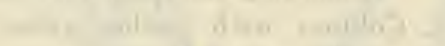

$$
\begin{aligned}
& -\ln 1+1,1+1,
\end{aligned}
$$

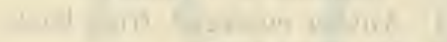

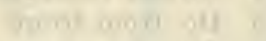

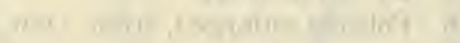

$$
\begin{aligned}
& \text { n. } 19+110=
\end{aligned}
$$




\section{EXPLANATION OF PLATE 32}

\section{Dendrophylax funalis}

1. Plant, natural size.

2. Flower cut to show entrance to spur and lip flattened out, not quite full size.

3. Column with anther raiser to show position of pollinia $\times 3$ times.

4. Anther enlarged, from back.

5. Do. from front.

6. Pollinia enlarged, front view.

7. Do, side view. 


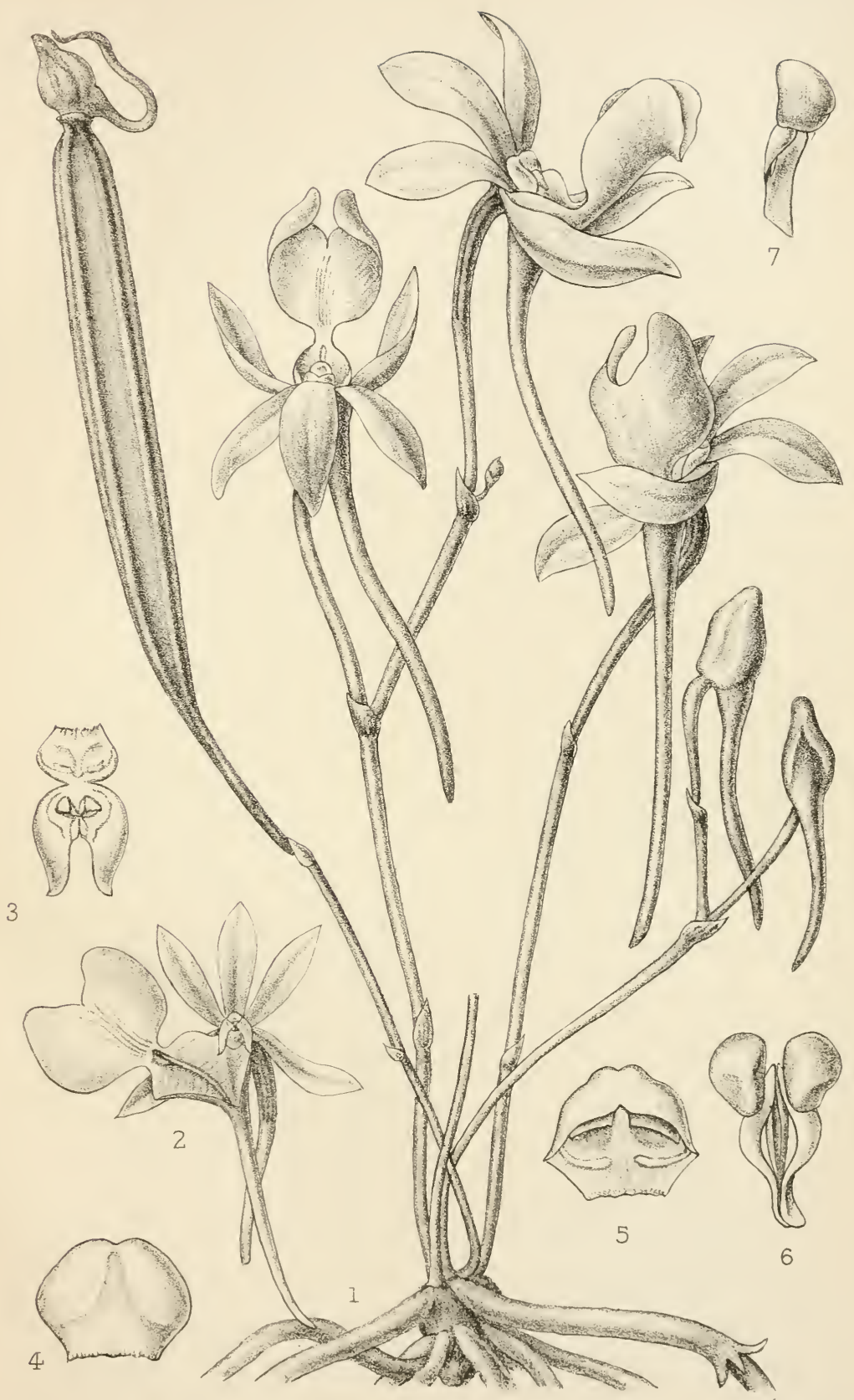

H A WOOD DEL.

Dendrophylax funalis 



\section{NATURAL HISTORY PUBLICATIONS \\ OF THE TRUSTEES OF THE BRITISH MUSEUM.}

The following publications can be purchased through the Agency of Messrs. Longuans \& Co., 39, Paternoster Row, London, E.C.; Mr. QUARITCH, 11, Grafton Street, New Bond Street, $W_{\text {, }}$; and Messr's. Dulau \& Co., Ltd., 37, Soho Square, $W . ;$ or at the Natural History MUSEUM, Cromwell Road, London, S.W.

The History of the Collections contained in the Natural History Departments of the British Museum :-

Vol. I. Libraries; Botany; Geology ; Minerals. Pp. xvii., 442. 1904, 8vo. 1ว́s.

Vol. II. Separate historical accounts of the several collections included in the Department of Zoology. Pp. 782. 1906, 8vo. 1l.10s.

Catalogue of the Books, Manuscripts, Maps, and Drawings in the British Museum (Natural Histor'y). Compiled by B. B. Woodward, Assistant in charge of the General Library, with some clerical assistance :-

Vol. I. A-D. Pp. viii., 500. 1903, 4to. $1 l$.

Vol. II. E-K. Pp. 501-1038. 1904, 4to. 1 .

Catalogue of the Specimens and Drawings of Mammals, Birds, Reptiles, and Fishes of Nepal and Tibet. Presented by B. H. Hodgson, Esq., to the British Museum. 2nd edition. By John Edward Gray. Pp. xii., 90. [With an account of the Collection by Mr. Hodgson.] 1563, $12 \mathrm{mo.}$ 2s. $3 d$. 
Report on the Zoological Collections made in the IndoPacific Ocean during the voyage of H.M.S. "Alert," 1881-2. Pp. xxv., 684. 54 Plates. 1854, 8vo. 1l. 10s.

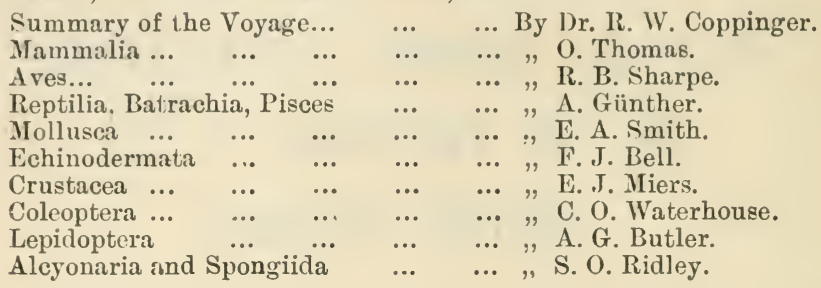

Report on the Collections of Natural History made in the Antarctic Regions during the Voyage of the "Southern Cross." Pp. ix., 344. 53 Plates. 1902, Royal 8vo. $2 l$.

Mammalia ... ... ... By Capt. G. E. H. Barrett-Hamilton.

Notes on Antarctic Seals ... , E. A. Wilson, M.B.

Extracts from the "Diary" of the late Nicolai Hanson.

\begin{tabular}{|c|c|c|c|c|c|}
\hline Aves ... & ... & $\cdots$ & $\cdots$ & $"$ & Dr. R. Bowdler Sharpe. \\
\hline Pisces... & $\ldots$ & $\ldots$ & $\ldots$ & $"$ & G. A. Boulenger, F.R.S. \\
\hline Tunicata & $\cdots$ & $\cdots$ & $\cdots$ & ," & Prof. W. A. Herdman, F.R.S. \\
\hline Mollusca & & $\cdots$ & $\cdots$ & $"$ & E. A. Smith. \\
\hline Echinoderm & & $\cdots$ & $\cdots$ & $"$ & Prof. F. J. Bell. \\
\hline Insecta & $\ldots$ & ... & $\cdots$ & $"$ & $\begin{array}{l}\text { G. H. Carpenter and Hon. N. C } \\
\text { Rothschild. }\end{array}$ \\
\hline rachnida & ... & $\cdots$ & $\cdots$ & $"$ & Dr. E. L. Trouessart. \\
\hline $\begin{array}{l}\text { cea } \\
\text { lata }\end{array}$ & ... & $\cdots$ & $\cdots$ & $"$ & T. V. Hod \\
\hline æta & $\cdots$ & $\cdots$ & $\cdots$ & $"$ & Dr. A. Will \\
\hline Nematoda & $\cdots$ & $\cdots$ & $\dddot{\jmath}$ & $"$ & A. E. Shipley. \\
\hline Cestoda & $\cdots$ & ... & \} & $"$ & Dr. von Linstow. \\
\hline $\begin{array}{l}\text { Polyzoa } \\
\text { Porifera }\end{array}$ & $\begin{array}{l}\ldots \\
\ldots\end{array}$ & $\cdots$ & \} & & R. Kirkpatrick. \\
\hline Anthozoa & $\cdots$ & $\cdots$ & ( & $"$ & $\begin{array}{l}\text { Dr. L. Roule and S. J. Hickson, } \\
\text { F.R.S. }\end{array}$ \\
\hline Actin & ... & $\cdots$ & ‥ & $"$ & J. A. Clubb. \\
\hline $\begin{array}{l}\text { Hydrozoa } \\
\text { Cryptogan }\end{array}$ & ... & $\cdots$ & $\cdots$ & $"$ & E. T. Browne. \\
\hline Cryptogamia & & ... & $\cdots$ & , & $\begin{array}{l}\text { A. Gepp, V. H. Blackman, } \\
\text { Miss E. S. Barton. }\end{array}$ \\
\hline & & & $\cdots$ & & T. Prior. \\
\hline
\end{tabular}

National Antarctic Expedition, 1901-1904. [Discovery Report.] Natural History :-

Vol.I. Geology (Field-Geology: Petrography). Pp. xii., 160 : 10 plates, 72 text-figures, 2 maps. [With Index.] 1907, 4to. 1l. 10 s.

Field-Geology $\quad$... ... By H. T. Ferrar, M.A., F.G.S.

Rock-Specimens $\quad \ldots \quad$... $"$ G. T. Prior, M.A., D.Sc., F.G.S.

Vol. II. Zoology (Vertebrata : Mollusca : Crustacea). Pp. xiv., 355 : 33 plates (17 coloured), 146 text-figures, 1 map. 1907,4 to. $3 l$.

Mammalia (pp. 69: 5 pls. [3 col.], 36 figs.)

Aves (pp. $121: 13$ pls. col., 46 figs.)

Anatomy of Penguins (pp. $28: 1 \mathrm{pl}$., "W. P. Pycraft. 8 figs.) 
National Antarctic Expedition, 1901-1904-continued. Vol. II-continued.

Fishes (pp. $5 ; 2$ pls.) $\quad \ldots \quad \ldots \quad \ldots \quad$ By G.A. Boulenger, F.R.S. Cephalodiscus (pp. $67: \ddot{7}$ pls. $[\ddot{1}$ col. $]$,,$W . G$. Ridewood, D.Sc. 17 figs.)

Mollusca. I.-Cephalopoda (pp. 2 : "W. E. Hoyle, D.Sc. 1 fig.) $\begin{gathered}\text { II.-Gastropoda } \\ \text { III.-Amphineura }\end{gathered}\left\{\begin{array}{c}(p p .12,1: \\ 2 \text { pls.) }\end{array}\right\}$, E. A. Snsith, I.S.O. IV.-Nudibranchiata (pp. 23: , Sir Chas. Eliot, 1 pl., 30 figs.)

V.-Lamellibranchiata (pp. 7: ) $1 \mathrm{pl}$.)

$\left.\begin{array}{cc}1 \text { pl.) } & \\ \text { Brachiopoda (pp. } 2: 4 \text { figs.) } & \ldots \\ \text { Crustacea I._Decapoda (pp. 7) } & \ldots\end{array}\right\} "$ E. A. Smith, I.S.O. K.C.M.G., LI.D. " II.-Cumacea (pp. 6: 1 pl., $\}$ t figs.)

Vol. III. Zoology and Botany (Invertebrata: Marine Algæ, Musci). Pp. vi., 273: 51 plates, 8 text-figures, and 1 chart. 1907, 4to. 2l. 10 s.

On Collecting in Antarctic Seas (pp.10) By T. V. Hodgson, F.L.S.

Mollusca. VI.-P'teropoda (pp. 15: "Sir Charles Eliot, 2 pls.)

Crustacea.III.-Amphipoda (pp. 39 : 13 pls.)

K.C.M.G., LL.D.

"A. O. Walker, F.L.S.

IV.-Leptostraca 2 figs.)

V.-Ostracoda (pp. $9: 3$ pls.)

VI.-Cirripedia (pp. $4: 1$ pl.)

Pycnogonida (pp. $72: 10$ pls.) ... $\quad \ldots$

Acari (pp. $6: 1$ pl.) $\quad \ldots, \quad \ldots \quad \ldots$

,Dr. E. L. Trouessart.

Chætognatha (pp. $6: 1$ chart) $\ldots \quad \ldots \quad$, ... Dr.G.H.Fowler,F.L.S.

$\begin{array}{llll}\text { Nematoda (pp. 4: } 1 \text { pl.) } & \ldots & \text {... } & \text { "Dr. O. von Linstow. }\end{array}$

Cestoda (pp. $6: 1$ pl.) $\quad \ldots \quad \ldots \quad \ldots \quad \ldots$ A. E. Shipley, F.R.S.

Coelentera. I.-Alcyonaria (pp. 15: " Prof. S. J. Hickson, 2 pls.)

II.-Hydroid Zoophytes (pp. $34: 4$ pls.)

" III.-Tentacles of a Siphonophore(pp. $3: 5$ figs.)

Porifera. I.-Hexactinellida (pp. 25 : $\checkmark \mathrm{pls}$.)

Marine Algæ. I.-Phæophyceæ and Florider (pp. 15 : 4 pls.) F.R.S.

"Prof S. J. Hickson, F.R.S., and F. İ. Gravely.

"Dr. J. Rennie.

, R. Kirkpatrick.

„A. Gepp and MIrs. E. S. Gepp.

, Mr. Faslie. 1 fig.)

Musci (pp. $6: 2$ pls.) $\quad \ldots \quad \ldots \quad \ldots \quad$,J. Cardot.

Vol. IV. Zoology (various Invertebrata). Pp. iv., 281:

65 plates, 1 text-figure. 1908, 4to. 1l. 15 s.

Mullusca. VII,-Solenogastres (pp. 13 : By Dr. II. F. Nierstrasz. $2 \mathrm{pls}$.

Insecta.-Aptera (pp. 5: 1 pl.) ‥ " G. H. Carpenter, B.Sc.,

Crustacea. VII.-Schizopoda (pp. 42: "W. I. Tattersall, M.Sc. 8 pls.)

VIII._Copepoda (pp. 44: "R. Norris Wolfenden,

$\quad \quad$ VIII._Copepoda (pp. 4t: 7 pls.)
R. NI.D. 
National Antarctic Expedition, 1901-190i-continuel. Vol. IV-continued.

Echinoderma (pp. 16 : j pls.) ... $\quad \ldots \quad$ By F. Jeffrey Bell, M.A.

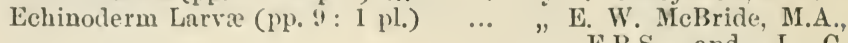
F.R.S., and J. C. Simpson, B.Sc.

Myzostomida (pp. $26: 1$ pl, and 1 figure) Dr. Rudolf Ritter von

Sipunculoidea (pp. 6) Stummer-Traunfels. Coelentera. IV.-Actinia (pp. 12 : 3 pls.) , J. A. Clubb, M.Sc.

Porifera. II.-Tetraxonida (pp. 56: , R. Kirkpatrick.

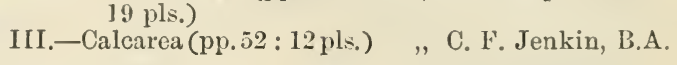

Vol. V. Zoology and Botany. Pp. ix., 212 : 28 plates, and 19 text-tigures. [With a Summary of the Contents of Vols. II.-V.] 1910, 4to. 17. 10..

Vertebrata. IA.-Mammalia (Seal-Embryos) (pp. $21: 2$ pls., 1 text-figure)

Tunicata (pp. $26: 7$ pls., 2 text-figures)

Crustacea. IX.-Isopoda (pp. $77: 10$ pls)

Nemertinea (pp. 15: 1 pl., 16 textfigures)

Coelentera. V.-Medusa (pp. $62: 7$ pls.)

By Dr. H. W. Marett Tims.

" Prof. W.A. Herdman, D.Sc., F.R.S.

, T. V. Hodgson, F.L.S.

" Prof. L. Joubin.

Lichenes (pp. $11: 1$ pl.)...

Edward T. Browne.

" Dr. O. V. Darbishire.

A Monograph of Christmas Island (Indian Ocean) : Physical Features and Geology by C. W. Andrews, B.A., B.Sc., F.G.S., with descriptions of the Fauna and Flora by numerous contributors. Pp. xv.,337: 22 plates (7 coloured), a map, and 27 illustrations in text. [With Index.] 1900, Svo. 17.

First Report on Economic Zoology. By Fred. V. Theobald, M.A., \&c. [With an Introduction, containing a Classification of Animals from the point of view of Economic Zoology, by Prof. E. Ray Lankester, LL.D., F.R.S.] Pp. xxxir., 192. 18 Woodeuts. 1903, Roy. Svo. 6s.

Second Report on Economic Zoology. By Fred. V. Theobald, M.A., \&c. Pp. x., 197. 29 Illustrations. 1904, Roy. Svo. $6 s$.

\section{MAMMALS.}

Catalogue of the Bones of Mammalia in the Collection of the British Museum. By Edward Gerrard. Pp. iv., 296. 1862, 8vo. $5 s$.

Catalogue of Monkeys, Lemurs, and Fruit-eating Bats "in the Collection of the British Museum. By Dr. J."E. Gray, F.R.s., \&c. Pp. viii., 137. 21. Woodcuts. 1870, Svo. 4s.

Catalogue of Carnivorous, Pachydermatous, ancl Edentate Mammalia in the British Museum. By John Edward Gray, F.R.S., \&c. Pp. vii., 398. 47 Woodcuts. 1869, 8vo. 6s. 6d. 
Catalogue of Seals and Whales in the British Museum. By John Edward Gray, F.R.S., \&c. 2nd Edition. Pp. vii., 402. 101 Woodeuts. 1866,8 ro. $8 s$.

Supplement. By John Edward Gray, F.R.S., \&c., Pp. vi., 103. 11 Woodcuts. 1371, 8vo. 2s. 6d.

List of the Specimens of Cetacea in the Zoological Depart. ment of the British Niseum. By William Henry Flower, LL.D., F.R.S., \&c. [With Systematic and Alphabetical Indexes.] Pp. iv., 36. 1885, 3vo. 1s. 6d.

Catalogue of Ruminant Mammalia (Pecora, Linnæus) in the British Museum. By John Edward Gray, F.R.S., \&c. Pp. viii., 102. 4 Plates. 1872, Svo. 3s. 6d.

Catalogue of the Marsupialia and Monotremata in the Collection of the British Museum. By Oldfield Thomas. Pp. xiii., 401. 4 Coloured and 24 plain Plates. [With Systematic and Alphabetical Indexes.] 1888, Sิvo. 11. $8 s$.

\section{BIRDS.}

Catalogue of the Birls in the British Nuseum :-

Vol. VII. Catalogue of the Passeriformes, or Perching Birds, in the Collection of the British IIuseum. Cichlomorphce : Part IV., containing the concluding portion of the family Timeliidæ (Babbling Thrushes). By R. Bowdler Sharpe. Pp. xvi.,698. Woodcuts and 15 coloured Plates. [With Systematic and Alphabetical Indexes.] 1883,8 ro. $1 . l_{0} 6 s$.

Vol. VIII. Catalogue of the Passeriformes, or Perching Birds, in the Collection of the British IIuseum. Cichlomorphce: Part V., containing the families Paridæ and Laniirlæ (Titmice and Shrikes); anil Certhiomorphce (Creepers and Nuthatches). By Hans Gadow, M.A., Ph.D. Pp. xiii., 386. Woodeuts anci 9 coloured Plates. [With Srstematic and Alphabetical Indexes.] 1853, 8г0. $17 \mathrm{~s}$.

Vol. X. Catalogue of the Passeriformes, or Perching Birds, in the Collection of the British IIuseum. Fringilliformes: Part I., containing the families Dicæidæ, Hirundinidæ, Ampelidæ, Mniotiltidæ, and Motacillidæ. By R. Bowdler Sharpe. Pp. xiii., 682. Woodcuts and 12 coloured Plates. [With Systematic and Alphabetical Indexes.] 1885, Svo. 17. $2 \mathrm{~s}$.

Vol. XI. Catalogue of the Passeriformes, or Perching Birds, in the Collection of the British Nuseum. Fringilliformes: Part II., containing the families Cœrebidæ, Tanagridæ, and Icteridæ. By Philip Lutley Sclater, M.A., F.R.S. Pp. xvii., 431. Woodcuts and 18 coloured Plates. [With Systematic and Alphabetical Indexes.] 1856, 8ro. 11. 
Catalogne of the Birds in the British Museum-continued.

Vol. XII. Catalogue of the Passeriformes, or Perching Birds, in the Collection of the British Museum. Fringilliformes: Part IIJ., containing the family Fringillidx. By R. Bowdler Sharpe. Pp. xv., 871. Woodcuts and 16 coloured Plates. [With Systematic and Alphabetical Indexes.] 18s8, Svo. 1l. $8 s$.

Vol. XIII. Catalogue of the Passeriformes, or Perching Birds, in the Collection of the British Museum. Sturniformes, containing the families Artamidæ, Sturnidæe, Ploceidæ, and Alaudidæ. Also the families Atrichiidæ and Menuridæ. By R. Bowdler Sharpe. Pp. xvi., 701. Woodcuts and 15 coloured Plates. [With Systematic and Alphabetical Indexes.] 1890, Sิvo. 17. 8s.

Vol. XIV. Catalogue of the Passeriformes, or Perching Birds, in the Collection of the British Museum. Oligomyoda, or the families Tyrannidze, Oxyrhamphidæ, Pipridæ, Cotingidæ, Phytotomidæ, Philepittidæ, Pittidæ, Xenicidæ, and Eurylæmidæ. By Philip Lutley Sclater, M.A., F.R.S. Pp. xix., 494. Woodcuts and 26 coloured Plates. [With Systematic and Alphabetical Indexes.] 1888, 8ro. 17. 4 s.

Vol. XV. Catalogue of the Passeriformes, or Perching Birds, in the Collection of the British Museum. Tracheophonce, or the families Dendrocolaptidæ, Formicariidæ, Conopophagidæ, and Pteroptochidæ. By Philip Lutley Sclater, M.A., F.R.S. Pp. xvii., 371. Woodcuts and 20 coloured Plates. [With Systematic and Alphabetical Indexes.] 1890, Svo. 17.

Tol. XVI. Catalogue of the Picariæ in the Collection of the British Museum. Upupce and Trochili, by Osbert Salvin. Coracice, of the families Cypselidæ, Caprimulgidæ, Podargidæ, and Steatornithidæ, by Ernst Hartert. Pp. xvi., 703. Woodcuts and 14 coloured Plates. [With Systematic and Alphabetical Indexes.] 1892, 8vo, 1l. 16s.

Vol. XVII. Catalogue of the Picariæ in the Collection of the British Museum. Coracice (contin.) and Halcyones, with the families Leptosomatidæ, Coraciidæ, Meropidæ, Alcedinidæ, Momotidæ, Totidæ and Coliidæ, by R. Bowdler Sharpe. Bucerotes and Trogones, by W. R. Ogilvie Grant. Pp. xi., 522. Woodcuts and 17 coloured Plates. [With Systematic and Alphabetical Indexes.] 1892, 8vo. 1l.10s. 


\section{Catalogue of the Birds in the British Museum-continued.}

Vol. XVIII. Catalogue of the Picariæ in the Collection of the British Museum. Scansores, containing the family Picidæ. By Edward Hargitt. Pp. xv., 597. Woodcuts and 15 coloured Plates. WWith Systematic and Alphabetical Indexes.] 1890, 8vo. 17.6s.

Vol. XIX. Catalogue of the Picariæ in the Collection of the British Museum. Scansores and Coccyges : containing the families Rhamphastidæ, Galbulidæ, and Bucconidæ, by P. L. Sclater ; and the families Indicatoridæ, Capitonidæ, Cuculidæ, and Musophagidæ, by G. F. Shelley. Pp. xii., 484: 13 coloured Plates. [With Systematic and Alphabetical Indexes.] 1891, Sro. 1l. วs.

Vol. XX. Catalogue of the Psittaci, or Parrots, in the Collection of the British Museum. By T. Salvadori. Pp. xvii., 658. Woodcuts and 18 coloured Plates. [With Systematic and Alphabetical Indexes.] 1891, 8vo. $1 l .10 \mathrm{~s}$.

Vol. XXI. Catalogue of the Columbæ, or Pigeons, in the Collection of the British Museum. By T. Salvadori. Pp. xvii.,676. 15 coloured Plates. [With Systematic and Alphabetical Indexes.] 1893, Sro. 1l.10s.

Vol. XXII. Catalogue of the Game Birds (Pterocletes, Gallince, Opisthocomi, Hemipodii) in the Collection of the British Nuseum. By W. R. Ogilvie Grant. Pp. xvi., 585. \& coloured Plates. [With Systematic and Alphabetical Indexes.] 1893, 8vo. 1l.6s.

Vol. XXIII. Catalogue of the Fulicariæ (Rallidæ and Heliornithidæ) and Alectorides (Aramidæ, Eurypy gidæ, Mesitidæ, Rhinochetidæ, Gruidæ, Psophiidæ, and Otididæ) in the Collection of the British Museum. By R. Bowdler Sharpe. Pp. xiii., 353. 9 coloured Plates. [With Systematic and Alphabetical Indexes.] 1894, 8ro. 17.

Vol. XXIV. Catalogue of the Limicolæ in the Collection of the British Museum. By R. Bowdler Sharpe. Pp.xii., 794. Woodcuts and 7 coloured Plates. [With Systematic and Alphabetical Indexes.] 1896, 8vo. $1 i .5 s$.

Vol. XXV. Catalogue of the Gaviæ and Tubinares in the Collection of the British II useum. Gaviæ (Terns, Gulls, and Skuas), by Howard Saunders. Tubinares (Petrels and Albatrosses), by Osbert Salvin. Pp. xv., 475. Woodcuts and 8 coloured Plates. [With Systematic and Alphabetical Indexes.] 1896, 8vo. 11.1s. 


\section{Catalogue of Birds in British Museum-contimued.}

Vol. XXVI. Catalogue of the Platalere, Herodiones, Steganopodes, Pygopodes, Alcr, and Impennes in the Collection of the British Nuseum. Platalese (Ibises and Spoonbills) and Herodiones (Herons and Storks), by R. Bowdler Sharpe. Steganopodes (Cormorants, Gannets, Frigate-birds, Tropic-birds, and Pelicans), Pygopodes (Divers and Grebes), Alcæ (Auks), and Impennes (Penguins), by W. R. Ogilvie-Grant. Pp. xvii., 687. Woodents and 14 coloured Plates. [With Systematic and Alphabetical Indexes.] 1898, 8vo. 1l. 53,

Vol. XXVII. Catalogue of the Chenomorphre (Palamedeæ, Phoenicopteri, Anseres), Crypturi, and Ratitæ in the Collection of the British Museum. By T. Salvadori. Pp. xv., 636. 19 coloured Plates. [Witr. Systematic and Alphabetical Indexes.] 1895, 8vo. 11. $12 \mathrm{~s}$.

A Hand-list of the Genera and Species of Birds. [Nomenclator Arium tum Fossilium tum Viventium.] By R. Bowdler Sharpe, LL.D. :-

Vol. II. Pp. xv., 312. [With Systematic Index, and an Alphabetical Index to Vols. I. and II.] 1900, Svo. 10 s.

Yol. III. Pp. xii., 367. [With Systematic and Alphabetical Indexes.] 1901, 8vo. 10s.

Vol. IV. Pp. xii., 391. [With Systematic and Alphabetical Indexes.] 1903, 8ro. 10 s.

Vol. T. Pp. xx., 678. [With Systematic and Alpha-

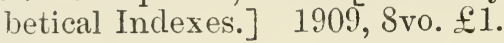

List of the Specimens of Birds in the Collection of the British Museum. By George Robert Gray :-

Part III., Sections III. and IV. Capitonidæ and Picidæ. Pp. 137. [With Index.] 1868, 12mo. 1s.6d.

Part IV. Columbæ. Pp. 73. [With Index.] 1856, 12mo. 1 s. 9 d.

Part V. Gallinæ. Pp. iv., 120. [With an Alphabetical Index.] 1867, 12mo. 1s. 6 d.

Catalogue of the Birds of the Tropical Islands of the Pacific Ocean in the Collection of the British Museum. By George Robert Gray, F.L.S., \&c. Pp. 72. [With an Alphabetical Index.] 1859,8 vo. 1s. $6 d$. 
Catalogue of the Collection of Birds' Eggs in the British Museum (Natural History) :-

Vol. I. Ratitæ. Carinatæ (Tinamiformes-Lariformes). By Eugene W. Oates. Pp. xxiii., 252. 18 Coloured Plates. [With Systematic and Alphabetical Indexes.] 1901, 8ro. 17. 10s.

Vol. II. Carinatæ (Charadriiformes-Strigiformes). By Eugene W. Oates. Pp. xx., 400. 15 Coloured Plates. [With Systematic and Alphabetical Indexes.] 1902, 8vo. 1l. 10s.

Vol. III. Carinatæ (Psittaciformes - Passeriformes). By Engene W. Oates and Capt. Savile G. Reid. Pp. xxiii., 349. 10 Coloured Plates. [With Systematic and Alphabetical Indexes.] 1903, 8vo. 1l. 5s.

Vol. IV. Carinatæ (Passeriformes continued). By Eugene W. Oates, assisted by Capt. Savile G. Reid. Pp. xviii., 352. 14 Coloured Plates. [With Systematic and Alphabetical Indexes.] 1905, 8vo. 1l. 10s.

\section{REPTILES.}

Catalogue of the Tortoises, Crocodiles, and Amphisbænians in the Collection of the British Museum. By Dr. J. E. Gray, F.R.S., \&c. Pp. viii., 80. [With an Alphabetical Index.] 1844, 12mo. $1 s$.

Catalogue of Shield Reptiles in the Collection of the British Museum. By John Edward Gray, F.R.S., \&c.:-

Appendix. Pp. 28. 1872, 4to. 2s. 6d.

Part II. Emydosaurians, Rhynchocephalia, and Amphisbænians. Pp. vi., 41. 25 Woodcuts. 1872, 4to. $3 s .6 d$.

Hand-List of the Specimens of Shield Reptiles in the British Museum. By Dr. J. E. Gray, F.R.S., F.L.S., \&c. Pp. iv., 124. [With an Alphabetical Index.] 1873, 8vo. $4 s$.

Catalogue of the Chelonians, Rhynchocephalians, and Crocodiles in the British Museum (Natural History). New Edition. By George Albert Boulenger. Pp. x., 311. 73 Woodcuts and 6 Plates. [With Systematic and Alphabetical Indexes.] 1889, Sro. 15 s. 
Catalogue of the Lizards in the British Museum (Natural History). Second Edition. By George Albert Boulenger :-

Vol. I. Geckonidx, Eublepharidr, Uroplatidx, Pygopodidx, Agamidr. Pp. xii., 436. 32 Plates. [With Systematic and Alphabetical Indexes.] 1885, Svo. $1 l$.

Vol. II. Iguanidæ, Xenosauridæ, Zonuridæ, Anguidie, Anniellidæ, Helodermatidx, Varmidie, Xantusiidæe, Teiidr, Amphisbenide. Pp. xiii., 497. 24 Plates. [With Systematic and Alphabetical Indexes.] 1885, Sัro. 17.

Vol. 11I. Iacertidæ, Gerrhosauridæ, Scincidæ, Anelytropidæ, Dibamidæ, Chamæleontidæ. Pp. xii., 575. 40 Plates. [With a Systematic Index and an Alphabetical Index to the three volumes.] 1887, 8vo. 1l. 6s.

Catalogue of the Snakes in the British Museum (Natural History). By George Albert Boulenger, F.R.S., \&c. :-

Vol. I., containing the families Typhlopidæ, Glauconiidæ, Boidæ, Ilysiidæ, Uropeltidæ, Xenopeltidæ, and Colubridæ aglyphæ (part). Pp. xiii., 448 : 26 Woodcuts and 28 Plates. [With Systematic and Alphabetical Indexes.] 1893, 8vo. 1l. 1s.

Vol. II., containing the conclusion of the Colubridæ aglyphæ. Pp. xi., 382 : 25 Woodcuts and 20 Plates. [With Systematic and Alphabetical Indexes.] 1894, Svo. $17 \mathrm{~s} .6 \mathrm{~d}$.

Vol. III., containing the Colubridæ (Opisthoglyphæ and Proteroglyphæ), Amblycephalidæ, and Viperidæ. Pp. xiv., 727 : 37 Woodents and 25 Plates. [With Systematic Index, and Alphabetical Index to the 3 volumes.] 1896, 8vo. 17. 6s.

Catalogue of Colubrine Snakes in the Collection of the British Museum. By Dr. Albert Günther. Pp. xvi., 281. [With Geographic, Systematic, and Alphabetical Indexes.] $1858,12 \mathrm{mo} .4 s$.

\section{BATRACHIANS.}

Catalogue of the Batrachia Salientia in the Collection of the British Museum. By Dr. Albert Güinther. Pp. xvi., 160. 12 Plates. [With Systematic, Geographic, and Alphabetical Indexes.] 1858, 8vo. $6 s$.

\section{FISHES.}

Catalogue of the Fishes in the British Museum. Second edition. Vol. I. Catalogue of the Perciform Fishes in the British Museum. Vol. I. Containing the Centrarchidæ, 
Catalogue of Fishes in the British Nuseum-continued.

Percidæ, and Serranidæ (part). By George Albert Boulenger, F.R.S. ' Pp.xix., 394. Woodcuts and 15 Plates. [With Systematic and Alphabetical Indexes.] 1895, 8vo. $15 s$.

Catalogue of Fish collected and described by Laurence Theodore Gronow, now in the British Museum. Pp. vii., 196. [With a Systematic Index.] 1854, 12mo. $3 s .6 d$.

Catalogue of Lophobranchiate Fish in the Collection of the British Museum. By J. J. Kaup, Ph.D., \&c. Pp. iv., 80. 4 Plates. [With an Alphabetical Index.] 1856, 12mo.2s.

Catalogue of the Fresh-water Fishes of Africa in the British Museum (Natural History). Vol. I. By G. A. Boulenger, F.R.S. Pp. xi., 373 : 270 text-figures. [With Systematic and Alphabetical Indexes.] 1909, imp. Sro. $£ 112 s .6 d$.

\section{MOLLUSCA.}

Guide to the Systematic Distribution of Nollusca in the British Museum. Part I. By John Edward Gray, Ph.D., F.R.S., \&c. Pp. xii., 230. 121 Woodcuts. 1857, \&vo. วัs.

Catalogue of the Collection of Mazatlan Shells in the British Nuseum, collected by Frederick Reigen. Described by Philip P. Carpenter. Pp. xvi., 552. 1857, 12mo. 8s.

Catalogue of Pulmonata, or Air Breathing Mollusca, in the Collection of the British Museum. Part I. By Dr. Louis Pfeiffer. Pp. iv., 192. Woodcuts. 1855, 12mo. 2s.6d.

Catalogue of the Auriculidæ, Proserpinidæ, and Truncatellidæ in the Collection of the British Museum. By Dr. Louis Pfeiffer. Pp. iv., 150. Woodcuts. 1857, 12mo. 1s. 9d.

List of the Mollusca in the Collection of the British Museum. By John Edward Gray, Ph.D., F.R.S., \&c. :-

Part II. Olividæ. Pp. 41. 1865, 12mo. 1s.

Catalogue of the Conchifera, or Bivalve Shells, in the Collection of the British Museum. By M. Deshayes :-

Part I. Veneridæ, Cyprinidæ, Glauconomidæ, and Petricoladæ. Pp. iv., 216. 1853, 12mo. 3s.

Part II. Petricoladæ (concluded); Corbiculadæ. Pp. 217-292. [With an Alphalsetical Index to the two parts.] $1854,12 \mathrm{mo} .6 d$. 


\section{BRACHIOPODA.}

Catalogue of Brachiopoda Ancylopoda or Lamp Shells in the Collection of the British Museum. [Issued as "Catalogue of the Mollusca, Part IV."] Pp. iv., 128. 25 Woodents. [With an Alphabetical Index.] 1853, 12mo. 3s.

\section{POLYZOA.}

Catalogue of Marine Polyzoa in the Collection of the British Museum. Part III. Cyclostomata. By George Busk, F.R.S. Pp. viii., 39. 38 Plates. [With a Systematic Index.] 1875, Sro. 5s.

\section{CRUSTACEA.}

Catalogue of the Specimens of Amphipodous Crustacea in the Collection of the British Museum. By C. Spence Bate, F.R.S., \&c. Pp. iv., 399. 58 Plates. [With an Alphabetical Index.] 1862, 8vo. 1l.5s.

\section{ARACHNIDA.}

Descriptive Catalogue of the Spiders of Burma, based upon the Collection made by Eugene W. Oates and preserved in the British Museum. By T. Thorell. Pp. xxxvi., 406. [With Systematic List and Alphabetical Index.] 1895, Sro. 10 s. $6 d$.

\section{INSECTS.}

\section{Coleopterous Insects.}

Nomenclature of Coleopterous Insects in the Collection of the British Museum :-

Part VII. Longicornia, I. By Adam White. Pp. iv., 174. 4 Plates. 1853, 12mo. 2s. $6 d$.

Part VIII. Longicornia, II. By Adam White. Pp. 237. 6 Plates. $1855,12 \mathrm{mo} .3 s .6 d$.

Illustrations of Typical Specimens of Coleoptera in the Collection of the British Museum. Part I. Jycidæ. By Charles Owen Waterhouse. Pp. x., 83. 18 Coloured Plates. [With Systematic and Alphabetical Indexes.] 1879, Svo. 16 s.

Catalogue of the Coleopterous Insects of Madeira in the Collection of the British Museum. By T. Vernon Wollaston, M.A., F.L.S. Pp. xvi., 234: 1 Plate. [With a Topographical Catalogue and an Alphabetical Index.] 1857, 8vo. З3s. 
Catalogue of the Coleopterous Insects of the Canaries in the Collection of the British Museum. By T. Vernon Wollaston, M.A., F.L.S. Pp. xiii., 648. [With Topographical and Alphabetical Indexes.] 1864, Svo. 10s. $6 d$.

Catalogue of Halticidæ in the Collection of the British Musenm. By the Rev. Hamlet Clark, M.A., F.L.S. Physapodes and Edipodes. Part I. Pp. xii., 301. Frontispiece and 9 Plates. 1860, 8vo. $7 s$.

Catalogue of Hispidæ in the Collection of the British Museum. By Joseph S. Baly, M.E.S., \&c. Part I. Pp. x., 172. 9 Plates. [With an Alphabetical Index.] 1858, Svo. 6s.

\section{Hymenopterous Insects.}

Catalogue of Hymenopterous Insects in the Collection of the British Nuseum. By Frederick Smith. 12mo. :-

Part I. Andrenidæ and Apidæ. Pp. 197. 6 Plates. 18533, 2s. $6 d$.

Part II. Apidæ. Pp. 199-465. 6 Plates. [With an Alphabetical Index.] 1854. $6 s$.

Part III. Mutillidæ and Pompilidæ. Pp.206. 6 Plates. 1855. $6 s$

Part IV. Sphegidæ, Larridæ, and Crabronidæ. Pp. 207497. 6 Plates. [With an Alphabetical Index.] 1856. $6 s$.

Part V. Vespidæ. Pp. 147. 6 Plates. [With an Alphabetical Index.] 1857. bs.

Part VI. Formicidæ. Pp. 216. 14 Plates. [With an Alphabetical Index.] 1858. 6s.

Part VII. Dorylidæ and Thynnidæ. Pp. 76. 3 Plates. [With an Alphabetical Index.] 1859. 2s.

List of Hymenoptera, with descriptions and figures of the Typical Specimens in the British IIuseum. Vol. I., Tenthredinidæ and Siricidæ. By W. F. Kirby. Pp. xxviii., 450. 16 Coloured Plates. [With Systematic and Alphabetical Indexes.] 1882, 8vo. $1 l .18 s$.

\section{Dipterous Insects.}

A Monograph of the Culicidæ, or Mosquitoes. Mainly compiled from the Collections received at the British Museum from various parts of the world in connection with the 
Investigation into the cause of Malaria conducted by the Colonial Ofrice and the Royal Society. By Fred. V. 'Theobald, M.A., \&c. :-

Vol. III. Pp. xvii., 359: 17 plates, 1 diagram, and 193 illustrations in text. 1903,8 ro. $1 / .1 \mathrm{~s}$.

Vol. IT. Pp. xix., 639: 16 plates and 297 text-figures. [With Index.] 1907, Bvo. 1l. 12s.6d.

A Monograph of the Tsetse-Flies (Genus Glossina, Westwood), based on the Collection in the British Museum. By Ernest Edward Austen. With a chapter on Mouth-parts by H. J. Hansen, Phil. Doc. Pp. ix., 319: 9 plates (7 coloured), 16 woodeuts, 1 map. 1903, Roy. 8ro. $15 s$.

Illustrations of African Blood-sucking Flies other than Mosquitoes and 'Tsetse-Flies. By Ernest Edward Austen, with coloured figures by Grace Edwards. Pp. xv., 221: 1:) coloured plates, 3 text-figures. 1909 , roy. 8 vo. $£ 17$ s. $6 d$.

\section{Lepidopterous Insects.}

Catalogue of the Lepidoptera Phalænæ in the British Nuseum. By Sir George F. Hampson, Bart. :-

Vol. I. Catalogue of the Syntomidx in the Collection of the British Museum. Pp. xxi., 559 : 285 woodeuts. [With Systematic and Alphabetical Indexes.] 1898, 3ัo. 1 อ̃s.

—Atlas of 17 Coloured Plates, 8vo. $15 s$.

Vol. II. Catalogue of the Arctiadæ (Nolinæ, Lithosianæ) in the Collection of the British Museum. Pp. xx., 589 : 411 woodcuts. [With Systematic and Alphabetical Indexes.] 1900, 8vo.18s.

-Atlas of 18 Coloured Plates (xviii.-xxxv.), 8vo. $15 s$.

Vol. III. Catalogue of the Arctiadæ (Arctianæ) and Agaristidre in the Collection of the British Museum. Pp. xix., 690: 294 woodcuts. [With Systematic and Alphabetical Indexes.] 1901, 8vo. 15s.

-Atlas of 19 Coloured Plates (xxxvi-liv.), 8vo. $16 s$.

Vol. IV. Catalogue of the Noctuidæ [Agrotinæ]. Pp. xx., 689: 125 woodcuts. [With Systematic and Alphabetical Indexes.] 1903, 8vo. 15s.

-Atlas of 23 Coloured Plates (lv.-lxxvii), 8vo. 16s.

Vol. V. Catalogue of the Noctuidæ [Hadeninæ]. Pp. xvi., 634: 172 woodcuts. [With Systematic and Alphabetical Indexes.] 1905, Svo. 15s.

_-Atlas of 18 Coloured Plates (lxxviii.-xev.), 8vo. 15 s. 
Catalogue of Lepidoptera Phalænæ-continued.

Vol. VI. Catalogue of the Noctuidæ [Cucullianæ]. Pp. xiv., 532: 172 woodcuts. [With Systematic and Alphabetical Indexes.] 1906, Sro. $15 s$.

- Atlas of 12 Coloured Plates (xcri.-crii.), Sro. $10 s$.

Vol. VII. Catalogue of the Noctuidæ [Acronyctinæ]. Pp. xv., 709: 184 woodcuts. [With Systematic and Alphabetical Indexes.| 1908, 8vo. $17 \mathrm{~s}$.

-Atlas of 15 Coloured Plates (cviii.-cxxii.), 8vo. $13 \mathrm{~s}$.

Vol. VIII. Catalogue of the Noctuidæ [A cronyctinæ, II.]. Pp. xiv., 583: 162 woodcuts. [With table of the Phylogeny of the Acronyctinæ, and Systematic and Alphabetical Indexes.] 1909, 8vo. 15 s. $12 \mathrm{~s}$.

Vol. IX. Catalogue of the Noctuidæ [A cronyctinæ, III.] Pp. xv., 55\%. 247 Woodcuts. [With Table of the Phylogeny of the Acronyctinæ, and Systematic and Alphabetical Indexes.] 1910, 8ro. $15 s$. $12 s$.

Illustrations of Typical Specimens of Lepidoptera Heterocera in the Collection of the British Museum:-

Part V. By Arthur Gardiner Butler. Pp. xii., 74. 78-100 Coloured Plates. [With a Systematic Index.] 1881, 4to. 2l. 10 s.

Part VI. By Arthur Gardiner Butler. Pp. xv., 89. 101-120 Coloured Plates. [With a Systematic Index.] 1856,4 to. $2 l .4 s$.

Part VII. By Arthur Gardiner Butler. Pp. iv., 124. 121-135 Coloured Plates. [With a Systematic List.] 1889, 4to. $2 l$.

Part VIII. The Lepidoptera Heterocera of the Nilgiri District. By George Francis Hampson. Pp. iv., 144. 139-156 Coloured Plates. [With a Systematic List.] 1891, 4to. $2 l$.

Part IX. The Nacrolepidoptera Heterocera of Ceylon. By George Francis Hampson. Pp. v., 182. 157-176 Coloured Plates. [With a General Systematic List of Species collected in, or recorded from, Ceylon.] 1893, 4to. $2 l .2 s$. 
Catalogue of the Collection of Palæarctic Butterflies formed by the late John Henry Leech, and presented to the Trustees of the British Museum by his Mother, Mrs. Eliza Leech. By Richard South, F.E.S. Pp. vi., 228. '2 Coloured Plates. With a Portrait and Biographical Memoir of Mr. Leech. 1902, 4to. 17 .

Calalugue of Diurnal Lepidoptera described by Fabricius in the Collection of the British Museum. By Arthur Gardiner Butler, F.L.S., \&c. Pp. iv., 303. 3 Plates. 1869, 8vo. 7 s. 6 d.

List of the Specimens of Lepidopterons Insects in the Collection of the British Musenm. By Francis Walker. 12mo. :-

Part XXIlI. Geometrites. Pp. 756-1020. 1861. 3s. 6d. Part XXV. - - Pp. 1281-1477. 1862. 3s.

Part XXVI. —— Pp. 1478-1796. [With an Alphabetical Index to Parts XX.-XXVI.] 1862. 4s.6d. Part XXVII. Crambites and Tortricites. Pp. 1-286. 1S63. $4 s$.

Part XXVIII. Tortricites and Tineites. Pp. 287-561. 1863. $4 s$.

Part XXIX. Tineites. Pp. 562-835. 1864. $4 s$.

Part XXX. — Pp. 836-1096. [With an Alphabetical Index to Parts XXVII.-XXX.] 1864. $4 s$.

Part XXXI. Supplement. Pp. 1-321. 1864. 5s.

Part XXXIII.— Part 3. Pp. 707-1120. 1865. $6 s$.

Part XXXIV.—_ Part 4. Pp. 1121-1533. 1865. 5s. $6 d$.

\section{Neuropterous Insects.}

Catalogue of the Specimens of Neuropterous Insects in the Collection of the British Museum. By Dr. H. Hagen. Part I. Termitiua. Pp. 34. 1858, 12mo. 6d.

\section{Orthopterous Insects.}

Catalogue of Orthopterous Insects in the Collection of the British Museum. Part I. Phasmidæ. By John Obadiah Westwoud, F.L.S., \&c. Pp. 195. 48 Plates. [With an Alphabetical Index.] 1859, 4to. $3 l$.

Catalogue of the Specimens of Blattariæ in the Collection of the British Museum. By Francis Walker, F.L.S., \&c. Pp. 239. [With an Alphabetical Index.] 1868, 8vo. 5s. $6 d$. 
Catalogue of the Specimens of Dermaptera Saltatoria in the Collection of the British Museum. By Francis Walker, F.L.S., \&c. :-

Part 1I. Locustidæ (continued). Pp. 225-423. [With an Alphabetical Index.] 1869, 8vo. 4s. 6d.

Part III. Locustidæ (continued).-Acrididæ. Pp. 425604. [With an Alphabetical Index.] 1870, Svo. $4 s$.

Part IV. Acrididæ (continued). Pp. 605-809. an Alphabetical Index.] 1870, 8vo. 6s.

Part V. Tettigidæ.-Supplement to the Catalogue of Blattariæ.-Supplement to the Catalogue of Dermaptera Saltatoria (with remarks on the Geographical Distribution of Dermaptera). Pp. 811-850; $43 ; 116$. [With Alphabetical Indexes.] 1870, 8vo. $6 s$.

Synonymic Catalogue of Orthoptera. By W. F. Kirby :-

Vol. I. Orthoptera Euplexoptera, Cursoria, et Gressoria. (Forficulidæ, Hemimeridæ, Blattidæ, Nantidæ, Phasmidæ.) Pp. x., 501. [With Index.] 1904, Svo. $10 s$.

Vol. II. Orthoptera Saltatoria, Part I. (Achetidæ et Phasgonuridæ.) Pp. viii., 562. [With Index.] 1906, Sro. $15 s$.

Vol. III. Orthoptera Saltatoria, Part II. (Locustidæ vel Acridiidæ.) Pp. vii., 674. [With Index.] 1910,

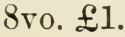

\section{Hemipterous Insects.}

Catalogue of the Specimens of Heteropterous Hemiptera in the Collection of the British Museum. By Francis Walker, F.L.S., \&c. 8vo. :-

Part VI. Pp.210. [With Alphabetical Index.] 1873. 5s.

Part ViI. Pp. 213. [With Alphabetical Index.] 1S73. 6s.

Part VIII. Pp. 220. [With Alphabetical Index.] 1873.

[6s. $6 d$.

\section{Homopterous Insects.}

A Synonymic Catalogue of Homoptera. Part I. Cicadidæ. By W. L. Distant. Pp. 207. [Index.] 1906, 8vo. วs. 


\section{VERMES.}

Catalogue of the Species of Entozoa, or Intestinal Worms, contained in the Collection of the British Mnseum. By Dr. Baird. Pp. iv., 132. 2 Plates. [With an Index of the Animals in which the Entozoa mentioned in the Catalogue are found, and an Index of Genera and Species.] 1853, 12mo. $2 s$.

\section{ANTHOZOA.}

Catalogue of Sea-pens or Pennatulariidx in the Collection of the British Museum. By J. E. Gray, F.R.S., \&c. Pp. iv., 40. 2 Woodcuts. 1870, S'vo. 1s. 6d.

Catalogue of Jithophytes or Stony Corals in the Collection of the British Museum. By J. E. Gray, F.R.S., \&c. Pp. iv., 51. 14 Woodents. 1870, Svo. 3s.

Catalogue of the Madreporarian Corals in the British. Museum (Natural History) :-

Tol. I. The Genus Madrepora. By George Brook. Pp. xi., 212. 35 Collotype Plates. [With Systematic and Alphabetical Indexes, and Explanation of the Plates.] 1893, 4to. 1l. 4 s.

Vol. II. The Genus Turbinaria ; the Genus Astræopora. By Henry M. Bernard, M.A. Cantab., F.L.S., F.Z.S. Pp. iv., 106. 30 Collotype and 3 Lithographic Plates. [With Index of Generic and Specific Names, and Explanation of the Plates.] 1896, 4to. 18 s.

Vol. III. The Genus Montipora; the Genus Anacropora. By Henry M. Bernard, M.A., \&c. Pp. vii., 192. 30 Collotype and 4 Lithographic Plates. [With Systematic Index, Index of Generic and Specific Names, and Explanation of the Plates.] 1897,4 to. 1l. $4 s$.

Vol. IV. The Family Poritidæ. I.-The Genus Goniopora. By Henry M. Bernard, M.A. Pp. viii., 206. 12 Collotype and 4 Lithographic Plates. [With Index of Generic and Specific Names, and Explanation of the Plates.] 1903, 4to. $1 l$.

Vol. V. The Family Poritidæ. II.-The Genus Porites. Part I.-Porites of the Indo-Pacific Region. By Henry M. Bernard, M.A. Pp. vi., 303. 35 Plates. [With Index of Generic and Specific Names and Explanation of the Plates.] 1905, 4to. $£ 115 \mathrm{~s}$.

Vol. VI. The Family Poritidæ. II.-The Genus Porites. Part II.--Porites of the Atlantic and West Indies, with the European Fossil Forms. The Genus Goniopora, a supplement to Vol. IV. By Henry M. Bernard, M.A. Pp. vi., 173. 16 Collotype and 1 Lithographic Plates. [With Index of Generic and Specific Names, and Explanation of the Plates.] 1906, 4to. $£ 1$. 


\section{BRITISH ANIMALS.}

Catalogue of British Birds in the Collection of the British Museum. By George Robert Gray, F.L.S., F.Z.S., \&c. Pp. xii., 248. [With a List of Species.] 1863, Svo.3s. $6 d$.

Catalogue of British Hymenoptera in the Collection of the British Museum. Second edition. Part I. Andrenidæ and Apidæ. By Frederick Smith, M.E.S. New issue. Pp. xi., 236. 11 Plates. [With Systematic and Alphabetical Index. 1891, Svo. 6s.

Catalogue of British Fossorial Hymenoptera, Formicidæ, and Vespidre in the Collection of the British MIuseum. By Frederick Smith, V.P.E.S. Pp. 236. 6 Plates. [With an Alphabetical Index.] 1858, 12mo. 6s.

Catalogue of British Hymenoptera of the Family Chalcididæ. By Claude Morley, F.Z.S., F.E.S. Pp. 74 . [Index.] 1910,8 vo. $3 s .6 d$.

Illustrations of British Blood-sucking Flies, with notes by Ernest Edward Austen, Assistant, Department of Zoology, British Museum (N.H.). Pp. 74. 34 Coloured Plates. 1906, roy. Svo. £1 5 s.

A Catalogue of the British Non-parasitical Worms in the Collection of the British Museum. By George Johnston, M.D., Edin., F.R.C.L., Ed., Lu.D., Narischal Coll., Aberdeen, \&c. Pp. 365. Woodcuts and 24 Plates. [With an Alphabetical Index.] 1S65, 8vo. $7 \mathrm{~s}$.

Catalogue of the British Echinoderms in the British Museum (Natural History). By F. Jeffrey Bell, M.A. Pp. xvii., 202. Woodcuts and 16 Plates (2 Coloured). [With Table of Contents, Tables of Distribution, Alphabetical Index, Description of the Plates, \&c.] 1892, Svo. 12s. $6 d$.

List of the Specimens of British Animals in the Collection of the British Museum; with Synonyma and References to figures. 12mo.:-

Part V. Lepidoptera. By J. F. Stephens. 2nd Edition. Revised by H. T. Stainton and E. Shepherd. Pp. ir., 224. 1856. 1s. $9 d$.

Part VI. Hymenoptera. By F. Smith. Pp. 134. 1851. $2 s$.

Part VII. Mollusca, Acephala and Brachiopoda. BJ Dr. J. E. Gray. Pp. iv., 167. 1851. 3s. 6d.

Part VIII. Fish. By Adam White. Pp. xxiii., 164. (With Index and List of Donors.) 1851. 3s. $6 d$. 
List of the Specimens of British Animals in the Collection of the British Museum-continued.

Part IX. Eggs of British Birds. By George Robert Gray. Pp. 143. 1852. 2s. 6d.

Part XI. Anoplura, or Parasitic Insects. By H. Denny. Pp. iv., 51. 1852. $1 s$.

Part XII. Lepidoptera (continued). By James F. Stephens. Pp. iv., 54. 1852. 9d.

Part XIII. Nomenclature of Hymenoptera. By Frederick Smith. Pp. iv., 74. 1853. 1s. $4 d$.

Part XIV. Nomenclature of Neuroptera. By Adam White. Pp. iv., 16. 1853. 6d.

Part XV. Nomenclature of Diptera, I. By Adam White. Pp. iv., 42. 1853. 1s.

Part XVI. Lepidoptera (completed). By H. T. Stainton. Pp. 199. [With an Index.] 1854. 3s.

\section{PLÁNTS.}

Illustrations of Australian Plants collected in 1770 during Captain Cook's Voyage round the World in H.M.S. "Endeavour." By the Right Hon. Sir Joseph Banks, Bart., K.B., P.R.S., and Dr. Daniel Solander, F.R.S. [Being a series of Iithographic reproductions of copperplates engraved after paintings by F. P. Nodder, James Miller, J. F. Miller, and John Cleveley.] With Introduction and Determinations by Jámes Britten, F.L.S., Senior Assistant, Department of Botany, British Museum :-

Part I.-101 Plates, with 31 pages of descriptive text. 1900, fol. $£ 15 s$.

Part II.-142 Plates (pls. 101-243), with 41 pages of descriptive text (pp. 35-75). 1901, fol. $₫ 115 s$.

Part III.-77 Plates (pls. 244-318, 45 A, and 122), with 26 pages of descriptive text, including Index to the whole work (pp. 77-102), and 3 maps. 1905, fol. $£ 15 s$.

Catalogue of the African Plants collected by Dr. Friedrich Welwitsch in 1853-61 :

Vol. I. Dicotyledons. By William Philip Hiern, M.A., F.L.S., \&.c. :-

Part I. [Ranunculaceæ to Rhizophoraceæ.] Pd. xxvi., 336. [With Portrait of Dr. Welwitsch. Introduction, Bibliography, and Index of Genera.] 1896. 8vo. 7 s. $6 d$. 
Catalogue of the African Plants collected by Dr. Friedrich Welwitsch in 1853-61-continued.

Vol. I.-continued.

Part II. Combretaceæ to Rubiaceæ. Pp. 337-510. [With Index of Genera.] 1898, 8vo. 4s.

Part III. Dipsaceæ to Scrophulariaceæ. Pp. 511784. [With Index of Genera.] 1898, 8ro. $5 s$.

Part IV. Lentibulariaceæ to Ceratophylleæ. Pp. 7851035. [With Index.] 1900, Sro. 5 s.

Vol. II. Monocotyledons, Gymnosperms, and Cryptogams :-

Part I. Monocotyledons and Gymnosperms. Br Alfred Barton Rendle, M.A., D.Sc., F.L.S., Assistant, Department of Botany. Pp. 260. [With Index of Genera.] 1899, Svo. 6s.

Part II. Cryptogamia. Pp. 261-566. [With Table of Errata, and General Index to the whole work.] 1901, 8ro. 6s.

\begin{tabular}{|c|c|c|c|c|}
\hline \multicolumn{3}{|c|}{ Vascular Cryptogams } & $\ldots \mathrm{By}$ & William Carruthers, F.R.S. \\
\hline Mosses & $\ldots$ & $\ldots$ & ... , & Antony Gepp, M.A., F.L.S. \\
\hline Hepatics & $\ldots$ & ... & $\ldots$ & F. Stephani. \\
\hline Marine Al & gæ & $\ldots$ & $\ldots$ & Ethel S. Barton. \\
\hline Freshwate & Algæ & $\ldots$ & $\ldots$ & $\begin{array}{l}\text { W. West, F.L.S., and G. S. } \\
\text { West, B.A. }\end{array}$ \\
\hline Diatomace & & $\ldots$ & $\ldots$ & Thomas Comber, F.L.S. \\
\hline Lichenes & $\ldots$ & $\ldots$ & $\ldots$ & E. A. Wainio. \\
\hline Fungi & $\ldots$ & $\ldots$ & . & Annie Lorrain Smith. \\
\hline Mycetozoa & $\ldots$ & $\ldots$ & $\ldots$ & Arthur Lister, F.R.S. \\
\hline
\end{tabular}

Synopsis of the British Basidiomycetes: a Descriptive Catalogue of the Drawings and Specimens in the Department of Botany, British Museum. By Worthington George Smith, F.L.S. Pp. 531. 5 Plates and 145 Figures in Text. [With Index.] 1908, Svo. 10s.

A Monograph of Lichens found in Britain : being a Descriptive Catalogue of the Species in the Herbarium of the British Museum. By the Rev. James M. Crombie, M.A., F.L.S., F.G.S., \&c. Part I. Pp. viii., 519 : 74 Woodents. [With Glossiry, Synopsis, Tabular Conspectus, and Index.] 1894, Sro. $16 s$.

List of British Diatomacer in the Collection of the British Museum. By the Rev. W. Smith, F.L.S., \&c. Pp. iv., 55. $1859,12 \mathrm{mo} .1 s$. 


\section{FOSSILS.}

Catalogue of the Fossil Mammalia in the British Museum (Natural History). By Richard Iydekker, B.A., F.G.S.:-

Part I. Containing the Orders Primates, Chiroptera, Insectivora, Carnivora, and Rodentia. Pp. xxx., 268. 33 Woodcuts. [With Systematic and Alphabetical Indexes.] 1855, 8vo. 5s.

Part II. Containing the Order Unqulata, Suborder Artiodactyla. Pp. xxii., 324. 39 Woodcuts. [With Systematic and Alphabetical Indexes.] 1885, Svo. $6 s$.

Part III. Containing the Order Ungulata, Suborders Perissodactyla, Toxodontia, Cond ylarthra, and Amblypoda. Pp. xvi., 186. 30 Woodcuts. [With Systematic Index, and Alphabetical Index of Genera and Species. including Synonyms.] 1886, 8vo. $4 s$.

Part IV. Containing the Order Ungulata, Suborder Proboscidea. Pp. xxiv., 235. 33 Woodcuts. [With Systematic Index, and Alphabetical Index of Genera and Species, including Synonyms.] 1886, 8vo. 5 s.

Part V. Containing the Group Tillodontia, the Orders Sirenia, Cetacea, Edentata, Marsupialia, Monotremata, and Supplement. Pp. xxxv., 345. 55 Woodcuts. [With Systematic Index, and Alphabetical Index of Genera and Species, including Synonyms.] 1887, Svo. $6 s$.

Catalogue of the Fossil Birds in the British Museum (Natural History). By Richard Lydekker, B.A. Pp. xxvii., 368. 75 Woodcuts. [With Systematic Index, and Alphabetical Index of Genera and Species, including Synonyms.] 1891, 8vo. 10 s. 6 d.

Catalogue of the Fossil Reptilia and Amphibia in the Britisl: Museum (Natural History). By Richard Lydekker, B.A., F.G.S. :-

Part I. Containing the Orders Ornithosauria, Crocodilia, Dinosauria, Squamata, Rhynchocephalia, and Proterosauria. Pp. xxviii., 309. 69 Woodeuts. [With Systematic Index, and Alphabetical Index of Genera and Species, including Synonyms.] 1888, 8vo. 7s. $6 d$.

Part II. Containing the Orders Ichthyopterygia and Sauropterygia. Pp. xxi., 307. 85 Woodeuts. [With Systematic Index, and Alphabetical Index of Genera and Species, including Synonyms.] 1889, 8vo. 7s.6d.

Part III. Containing the Order Chelonia. Pp. xviii., 239. 53 Woodcuts. [With Systematic Index, and Alphabetical Index of Genera and Species, including Synonyms.] 1889, 8vo. 7s. 6d. 
Catalogue of the Fossil Reptilia and Amphibia in the British Museum-continued.

Part IV. Containing the Orders Anomodontia, Ecaudata, Caudata, and Labjrinthodontia; and Supplement. Pp. xxiii., 295. 66 Woodcuts. [With Systematic Index, Alphabetical Index of Genera and Species, including Synonyms, and Alphabetical Index of Genera and Species to the entire work.] 1890, 8vo. $7 s .6 d$.

Catalogue of the Fossil Fishes in the British Museum (Natural History). BJ Arthur Smith Woodward, LI.D., F.R.S., F.G.S., \&c. :-

Part I. Containing the Elasmobranchii. Pp. xlvii., 474. 13 Woodcuts and 17 Plates. [With Alphabetical Index, and Systematic Index of Genera and Species.] 1889, 8vo. 1l. $1 \mathrm{~s}$.

Part II. Containing the Elasmobranchii (Acanthodii), Holocephali, Ichthyodorulites, Ostracodermi, Dipnoi, and Teleostomi (Crossopterygii and Chondrostean Actinopterygii). Pp. xliv., 567. 58 Woodcuts and 16 Plates. [With Alphabetical Index, and Systematic Index of Genera and Species.] 1891, 8vo. 1l. $1 \mathrm{~s}$.

Part III. Containing the Actinopterygian Teleostomi of the Orders Chondrostei (concluded), Protospondyli, Aetheospondyli, and Isospondyli (in part). Pp. xlii., 544. 45 Woodcuts and 18 Plates. [With Alphabetical Index, and Systematic Index of Genera and Species.] 1895, 8vo. 1l. 1 s.

Part IV. Containing the Actinopterygian Teleostomi of: the Suborders Isospondyli (in part), Ostariophysi, Apodes, Percesoces, Hemibranchii, Acanthopterygii, and Anacanthini. Pp. xxxix., 636. 22 Wondcuts and 19 Plates. [With Alphajetical Index, ancl Systematic Index of Genera and Species.] 1901, Svo. 1l. $1 \mathrm{~s}$.

A descriptive Catalogue of the Tertiary Vertebrata of the Fayîm, Fgypt. Based on the Collection of the Egyptian Government in the Geological Museum, Cairo, and on the Collection in the British Museum (Natural Historr), London. By C. W. Andrews, D.Sc. Pp. xxxrii., 324: 98 Text Figures and 26 Plates. [With Systematic and Alphabetical Indexes.] 1906, 4to. 1l. $15 \mathrm{~s}$.

Systematic List of the Edwards Collection of British Oligocene and Eocene Mollusca in the British Museum (Natural History), with references to the type-specimens from similar horizons contained in other collections belonging 
to the Geological Department of the Museum. By Richard Bullen Newton, F.G.S. Pp. xxviii., 365. [With table of Families and Genera, Bibliography, Correlation-table, Appendix, and Alphabetical Index.] 1891, 8vo. $6 s$.

Catalogue of Tertiary Mollusca in the Department of Geology, British Museum (Natural History). Part I. 'The Australasian Tertiary Mollusca. By George F. Harris, F.G.S., \&c. Pp. xxvi., 407. \& Plates. [With Table of Families, Genera, and Sub-Genera, and Index.] 1897, Svo. 10 s.

Catalogue of the Fossil Cephalopoda in the British Museum (Natural History) :-

Part I. Containing part of the Suborder Nautiloidea, consisting of the families Orthoceratidæ, Endoceratidæ, Actinoceratidæ, Gomphoceratidæ, Ascoceratidæ, Poterioceratidæ, Cyrtoceratidæ, and Supplement. By Arthur H. Foord, F.G.S. Pp. xxxi., 344. 51 Woodcuts. [With Systematic Index, and Alphabetical Index of Genera and Species, including Synonyms.] 1888, Sro. 10 s. $6 d$.

Part II. Containing the remainder of the Suborder Nautiloidea, consisting of the families Lituitidæ, Trochoceratidæ, Nautilidæ, and Supplement. By Arthur H. Foord, F.G.S. Pp. xxriii., 407. 86 Woodcuts. [With Systematic Index, and Alphabetical Index of Genera and Species, including Synonyms.] 1891, 8vo. 15̌s.

Part III. Containing the Bactritidæ, and part of the Suborder Ammonoidea. By Arthur H. Foord, Ph.D., F.G.S., and George Charles Crick, A.R.S.M., F.G.S. Pp. xxxiii., 303. 146 Woodcuts. [With Systematic Index of Genera and Species, and Alphabetical Index.] 1897, Svo. $12 s .6 d$.

List of theTypes and Figured Specimens of Fossil Cephalopoda in the British Museum (Natural History). By G. C. Crick, F.G.S. Pp. 103. [With Index.] 1898, 8vo. 2s. 6d.

A Catalogue of British Fossil Crustacea, with their Synonyms and the Range in Time of each Genus and Order. By Henry Woodward, F.R.S. Pp. xii., 1.55. [With an Alphabetical Index.] 1877, 8vo. 5s.

Uatalogue of the Fossil Bryozoa in the Department of Geology, British Museum (Natural History):-

The Jurassic Bryozoa. By J. W. Gregory, D.Sc., F.G.S., F.Z.S. Pp. [viii.,] 239 : 22 Woodeuts and 11 Plates. [With List of Species and Distribution, Bibliography, Index, and Explanation of Plates.] 1896, 8vo. 10 s. 
Catalogue of the Fossil Bryozoa in the British Museum-cont. The Cretaceous Bryozoa. By J. W. Gregory, D.Sc., F.R.S., \&c. :-

Vol. I. Pp. xiv., 457 : 64 Woodeuts and 17 Plates. [With Index and Explanation of Plates.] 1899, 8vo. $16 s$.

Tol. II. Pp. xlviii., 346. 75 Woodeuts and 9 Plates. [With List of Localities, Bibliography, Subject and Systematic Indexes, and Explanation of Plates.] 1909, Svo. 13s.

Catalogue of the Blastoidea in the Geological Department of the British Museum (Natural History), with an account of the morphology and systematic position of the group, and a revision of the genera and species. By Robert Etheridge, jun., of the Department of Geology, British Museum (Natural History), and P. Herbert Carpenter, D.Sc., F.R.S., F.L.S. (of Eton College). Pp.xv., 322. 20 Plates. [With Preface by Dr. H. Woodward, Table of Contents, General Index, Explanations of the Plates, \&c.] 1886, 4to. 1l. 5s.

The Genera and Species of Blastoidea, with a List of the Specimens in the British Nuseum (Natural History). By F. A. Bather, M.A., F.G.S., of the Geological Department. Pp. x., 70. 1 Woodeut. 1899, 8vo. 3s.

Catalogue of the Palæozoic Plants in the Department of Geology and Palæontology, British Museum (Natural History). By Robert Kidston, F.G.S. Pp. viii., 288. [With a list of works quoted, and an Index.] 1886, 8 vo. $5 s$.

Catalogue of the Mesozoic Plants in the Department of Geology, British Museum (Natural History). By A. C. Seward, M.A., F.R.S., F.G.S., University Lecturer in Botany and Fellow of Emanuel College, Cambridge :-

Part I. The Wealden Flora. Part I. ThallophytaPteridophyta. Pp. xxxviii., 179. 17 Woodeuts and 11 Plates. [With Alphabetical Index, Explanations of the Plates, \&c.] 1894, 8vo. $10 s$.

Part II. The Wealden Flora. Part II. Grmnospermæ. Pp. viii., 259. 9 Woodeuts and 20 Plates. [With Alphabetical Index, Explanations of the Plates, \&c.] 1895,8 vo. $15 s$.

Part III. The Jurassic Flora. Part I. The Yorkshire Coast. Pp. xii., 341. 53 Woodeuts and 21 Plates. [With Alphabetical Index, Explanations of the Plates, \&c.] 1900,8 vo. 17 . 
Catalogue of the Mesozoic Plants in the Department of Geology, British Nuseum-continued.

Part IV. The Jurassic Flora. II.-Liassic and Oolitic Floras of England (excluding the Inferior Oolite Plants of the Yorkshire Coast). Pp. xv., 192. 20 Woodeuts and 13 Plates. [With Alphabetical Index, Explanations of the Plates, \&c.] 1904, 8vo.10s.

Catalogue of the Fossil Plants of the Glossopteris Flora in the Department of Geology, British Museum (Natural History). Being a Monograph of the Permo-carboniferous Flora of India and the Southern Hemisphere. By E. A. Newell Arber, M.A., F.L.S., F.G.S. Pp. lxxiv., 255 : 51 Text-Figures and $\delta$ Plates. [With Bibliography and Alphabetical Index.] 1905, 8vo. 12s. $6 d$.

\section{GUIDE-BOOKS, ETC.}

A General Guide to the British Museum (Natural History), Cromwell Road, London, S.W. Twelfth Edition. With 59 woodcuts, 2 plans, 2 views of the building, and an illustrated cover. Pp. x., 117. 1909, 8vo. 3d.

Guide to the Specimens illustrating the Races of Mankind (Anthropology), exhibited in the Department of Zoology, British Museum (Natural History). [By R. Lydekker, F.R.S.] Illustrated by 16 Figures. Pp.31. 1908, 8vo. 4d.

Guide to the Galleries of Mammals (other than Ungulates) in the Department of Zoology of the British Museum (Natural History). Eighth Edition. Pp. 101. 52 Woodcuts and 4 plans. [Index.] 1906, 8vo.6d.

Guide to the Great Game Animals (Ungulata) in the Department of Zoology, British Museum (Natural History). Pp. 93. 53 Text and other figures. With list of Horns, Antlers and Tusks, and Index. 1907, 8vo. 1s.

Guide to the Elephants (Recent and Fossil) exhibited in the Department of Geology and Palæontology in the British Museum (Natural History). [By Dr. C. W. Andrews, F.R.S.] Illustrated by 31 text-figures. Pp. 46.1908 , 8vo. $6 d$.

Guide to the Specimens of the Horse Family (Equidx) exhibited in the Department of Zoology, British Museum (Natural History). [By R. Lydekker, F.R.S.] Pp. 42 26 Figures. 1907, 8vo. 1s.

Guide to the Domesticated Animals (other than Horses) exhibited in the Central and North Halls of the British Museum (Natural History). [By R. Lydekker, F.R.S.] Illustrated by 24 Figures. Pp. 55. [With table of Contents, List of Illustrations, and Index.] 1908, 8vo. 6d. 
Guide to the Whales, Porpoises, and Dolphins (order Cetacea) exhibited in the Department of Zoologr, British Museum (Natural History). [By R. Lydekker, F.R.S.] Illustrated by 33 Figures. Pp. 47. [With Index.] 1909, 8vo. 4d.

Guide to the Gallery of Birds in the Department of Zoology, British Museum (Natural Historry). [By W. R. Ogilvie Grant.] Second Edition. Pp. iv., 228. 25 Plates, and 7 Illustrations in text. [With Index.] 1910, 4to. 2s. $6 d$.

Guide to the Gallery of Birds in the Department of Zoology, British Museum (Natural History). [By W. R. Ogilvie Grant.] :-

Part I. General Series. Pp. 149. [With Index.] 1905, 4to. 6d.

Part II. Nesting Series of British Birds. Second Edition. Pp. 62. 4 Plates. [Index.] 1909, 4to. $4 d$.

Guide to the Gallery of Reptilia and Amphibia in the Department of Zoology of the British Museum (Natural History). [By R. Lydekker, F.R.S.] Illustrated by 76 text and other Figures. Pp. iv., 75. [With Table of Contents.] 1906, 8vo. 6d.

Guide to the Gallery of Fishes in the Department of Zoolngy of the British Museum (Natural History). [By Dr. W. G. Ridewood.] Illustrated by 96 Figures. Pp. T.. 209. [With Preface by Sir E. Ray Lankester, Table of Classification, and lndex.] 1908, Sro. 1 s.

Guide to the British Vertebrates Exhibited in the Department of Zoology, British Mruseum (Natural History). [By W. P. Pycraft.] Pp. iv., 116. 26 Text-Figures, 1 Plan. 1910, ơvo. 1.s.

Guide to the exhibited series of Insects in the Department of Zoology, British Museum (Natural History). By C. O. Thaterhonse. Second Edition. Pp. 65: 62 text- and fullpage Illustrations. [With Table of Contents and Index.] 1909, Sro. $1 \mathrm{~s}$.

Guide to the Crustacea, Arachnida, Onschophorit and Myriopoda exhibited in the Department of Zoology. British Museum (Natural History). (Br W. T. Calman, D.Sc., A. S. Hirst, and F. J. Bell.) Pp. 133 : ?0 Text-Figures. [With Table of Contents and Index.] 1910, Sro. $1 s$.

Guide to the Shell and Starfish Galleries (Mollusca, Polyzoa, Brachiopoda, Tunicata, Echinoderma, and Torms). Department of Zoology, British Museum (Natural Histor's). Fifth Edition. Pp. iv., 133. 125 Woorleuts, Plan and Indexes. 1908, Sro. 6d.

Guide to the Coral Gallery (Protozoa, Porifera or Sponges, Hydrozoa, and Anthozoa) in the Department of Zoology, British Museum (Natural History). Second Edition. Pp. [iv., 8] 73. 90 Illustrations, Plan and Index. 1907, Svo. 1s. 
A Guide to the Fossil Mammals and Birds in the Department of Geology and Palrontology in the British Museum (Natural History). Ninth Edition. [By A. S. Woodward, I.T.D., F.R.S.] Pp. xvi., 100. 6 Plates, 88 Woorleuts. [With List of Illustrations, Table of Stratified Rocks, and Index.] 1909, Sro. lid.

A Guide to the Fossil Reptiles, Amphibians, and Fishes in the Department of Creology and Palreontology in the British Musemm (Natural History). Eighth Edition. [By A. S. Woodward, LL.D., F.R.S.] Pp. xviii., 110. \& Plates and 116 'lext-Figures. [With List of Illustrations, Genlogical Time-Scale and Index.] 1905, šo. 6d.

A Guide to the Fossil Invertebrate Animals in the Department of Geology and Palæontology in the British Museum (Natural History). [By F. A. Bather, D.Se.] Pp. ix., 18\%. 7 Plates and 96 'Text-Figures. [With List of Illustrations, Geological Time-scale, and Index.] 1907, Evo. 1 s.

List of British Seed-plants and Ferns exhibited in the Department of Botany, British Museum (Natural History). [By A. B. Rendle, D.Sc., F.R.S., and J. Britten, F.L.S.] With table of Sequence of Orders, and Index of Genera Pp. 44. 1907, 8vo. 4d.

Guide to Sowerby's Models of British Fungi in the Department of Botany, British Museum (Natural History). Second Edition, revised. By Worthington G. Smith, F.L.S. Pp. 85. 91. Woodeuts. With Table of Diagnostic Characters, Glossary, and Index. 1908, 8vo. $4 d$.

Guide to the British Mycetozoa exhibited in the Department of Botany, British Museum (Natural History). [By Arthur Lister, F.R.S.] Third Edition, revised. Pp. 49. $46^{\circ}$ Woodcuts. Index. 1909, 8vo. 3d.

A Guide to the Mineral Gallery of the British Museum (Natural History). Tenth Edition. [By L. Fletcher, M.A., F.R.S.] Pp. 32. Plan. 1908, 8vo. 1d.

The Student's Index to the Collection of Minerals, British Iuseum (Natural History). Twenty-third Edition. [By L. Fletcher, M.A., F.R.S.] Pp. 36. With a Plan of the Nineral Gallery. 1908, 8vo. $2 d$.

An Introduction to the Study of Minerals, with a Guide to the Mineral Gallery of the British Museum (Natural History). By L. Fletcher, M.A., F.R.S. Thirteenth Edition. Pp. 123. 41 Woodcuts. With Plan of the Mineral Gallery and Index. 1910, Svo. 6d. 
An Introduction to the Study of Rocks and Guide to the Museum Collection. Fourth Edition. By L. Fletcher, M.A., F.R.S. Pp. 155. [With Plan of the Mineral Gallery, 'Table of Contents, and Index.] 1909, Sro. $1 s$.

An Introduction to the Study of Meteorites, with a List of the Meteorites represented in the Collection. Br L. Fletcher, II.A., F.R.S., \&c. Tenth Edition. Pp. 120. [With a Plan of the Mineral Gallery, and an Index to the Meteorites represented in the Collection.] 1908, 8 ro. bैd.

\section{SPECIAL Guides.}

No. 2.-Books and Portraits illustrating the Histors of Plant Classification exhibited in the Department of Botany. Second Edition. [By A. B. Kendle, M.A., D.Sc., F.R.S.] Pp. 19. 4 Plates. 1909, 8vo. $4 d$.

No.3.-Memorials of Linnæus: a collection of Portraits, Manuscripts, Specimens, and Books exhibited to commemorate the Bicentenary of his Birth. [By A. B. Rendle, M.A., D.Sc.] Pp. 16. 2 Plates. 1907, 8vo. $3 d$.

No. 4.-Memorials of Charles Darwin : a Collection of Manuscripts, Portraits, Medals, Books, and Natural History Specimens to commemorate the Centenary of his Birth and the Fiftieth Anniversary of the Publication of "The Origin of Species." (Second Edition.) |By W. G. Ridewood, D.Sc.] Pp. vi., 50. 2 Plates. 1910, 8ro. 6d.

\section{INSTRUCTIONS FOR COLLECTORS.}

Handbook of Instructions for Collectors, issued by the British Museum (Natural History). With Illustrations. Third Edition. Pp. 144. Index. 1906, 8vo. 1s. 6r.

Instructions for Collector's :-

No. 1.-Mammals. Third Edition. Pp. 12. Text illust. 1905,8 ro. $3 d$.

No. 2.-Birds. Fourth Edition. Pp. 10. 5 figures in text. $1908,8 v 0.3 d$.

No. 3.-Reptiles, Batrachians, and Fishes. [Third Edition.] Pp. 12. 1903, 8ro. 4 \%.

No. 4.-Insects. Fourth Edition. Pp. 11. Text illust. 1907, 8vo. 3d.

No. 5.-Diptera (Two-winged Flies). Third Edition. Pp. 16. 'Text illust. 1908, Sro. 3d. 
No. 6.-Mosquitoes (Culicide). [Third Edition.] Pp. ^. 1 Plate, 1 figure in text. $190 \cdot 4$, svo. $3 d$.

No. 7.-Blood-sucking Flies, Ticks, \&c. By E. F. Austen. Third Edition. Pp. 24: 1:3 figures in text. 1907, 8ro. 3d.

No. 8.-Spiders, Centipedes, \&c. Second Edition. Pp. 4. 1906, sro. 3d.

No. 9.-Soft-bodied and other Invertebrate Animals ; Shells of Molluses. Third Edition. Pp. 1S. 1909, Svo. 3d.

No.10.-Plants. Fourth Edition. Pp. 10 : 3 figures in text. 1909, Svo. 3d.

No. 11.-Fossils and Minerals. Third Edition. Pp. \$. 1906, Svo. 3d.

British Museum (Natural History),

Cromwell Road, London, S.W.

Мay, 1910. 


Fawcett, William/Flora of Jamaica, conta

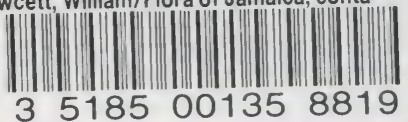




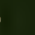

